Digitized by the Internet Archive in 2007 with funding from Microsoft Corporation 




\section{YALE}

\section{HISTORICAL PUBLICATIONS}

\section{MISCELLANY}

\section{VI}

PUBLISHED UNDER THE DIRECTION OF

THE DEPARTMENT OF HISTORY

FROM THE INCOME OF

THE FREDERICK JOHN KINGSBLRY

MEMORIAL FUND 



\title{
THE QUIT-RENT SYSTEM
}

\section{IN 'THE}

\section{AMERICAN COLONIES}

\author{
BY \\ BEVERLi W. BOND, JR. \\ ASSOC! "OFESSOR OF HISTORY \\ UUE UNIVERSITY
}

WITH AN INTRODUCTION

BY

CHARLES M. ANDREWS

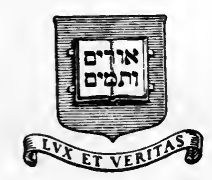

NEW HAVEN: YALE UNIVERSITY PRESS

LONDON : HUMPHREY MILFORD

OXFORD UNIVERSITY PRESS

MDGCCCXIX 



\section{PREFACE}

The first work undertaken by the author on the subject of quit-rents was a study of "The History of Clergy Taxes and Quit Rents in Maryland," completed in 1909 under the auspices of the Department of Economics and Sociology of the Carnegie Institution of Washington, a portion of which was published in the Maryland Historical Magazine for December, 1910. Professor Charles M. Andrews, who was then at the Johns Hopkins University, pointed out the need of an extensive study of the quitrent system in all the American colonies and with his assistance the author prepared a preliminary paper on the subject, which was printed in the American Historical Review for April, 1912. Since that time, and after extensive additional research in the various sources of American colonial history, here and abroad, the present study has been written.

One of the greatest pleasures which the author has enjoyed in the preparation of this work has come from numerous visits to historical libraries both in the United States and in England, and from the many delightful acquaintances formed thereby. Especial acknowledgment is due to the officials in charge of the Public Record Office in London, and to Mr. Gaillard Hunt and his assistants in the Manuscript Division of the Library of Congress in America. At the New York State Library, at the libraries of the Pennsylvania Historical Society, the Maryland Historical Society, and the Virginia Historical Society also, much time was spent and aid received, while in numerous other libraries the author found hearty co- 
operation and courteous attention. In addition, Professor W. M. Hepburn of the Purdue University Library has greatly facilitated the progress of the work by securing through the Library Exchange many needed reference books.

From the beginning to the end of the undertaking, Professor Andrews has extended aid without which the present study would have been impossible. He has not only contributed information and made valuable suggestions as to sources, but has also read and criticized the manuscript and proof. Professor W. T. Root of the University of Wisconsin and Professor C. P. Gould of the College of Wooster have also made a number of critical and suggestive comments. To these gentlemen, as well as to numerous others, the author would acknowledge his indebtedness for the help they have so generously furnished.

Purdue University,

Beverley W. Bond, Jr.

June 14, 1918. 


\section{CONTENTS}

PAGE

Preface

Introduction . . . . . 11

Chapter I. The Origin of the Quit-Rents .

Chapter II. Colonies in which there were no Quit-Rents

Chapter III. Proprietary Quit - Rents: in Crown Colonies

Chapter IV. Proprietary Quit-Rents: under Proprietary followed by Royal Government .

Chapter V. Proprietary Quit-Rents: in Proprieties surrendered to the Crown .

Chapter VI. Proprietary Quit-Rents : in Proprieties not surrendered to the Crown, Pennsylvania and the Lower Counties

Chapter VII. Proprietary Quit-Rents : in Proprieties not surrendered to the Crown, Maryland .

Chapter VIII. Royal Quit-Rents : in Virginia . 219

Chapter IX. Royal Quit-Rents: in New York 254

Chapter X. Royal Quit-Rents: in North Carolina . . . . 286

Chapter XI. Royal Quit-Rents: in South Carolina 
Chapter XII. Royal Quit-Rents: in Georgia .

PAGE

Chapter XIII. Royal Quit-Rents : in Other Brit-

ish Colonies in America .

Chapter XIV. British Control of the Royal Quit-Rents . . . . 388

Chapter XV. The Significance of the QuitRents . . . . . 439

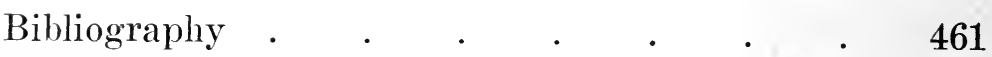

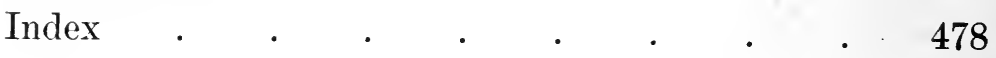




\section{INTRODUCTION}

Is this introductory statement, I wish to write briefly of the character and importance of the quit-rent, without trespassing more than can be helped upon the subject of Professor Bond's volume. His volume deals with the quit-rent system in all the British colonies in America before the Revolution and discloses the long-continued and wide-spread influence of this seemingly trivial detail of the colonial land system. It gives to the quit-rent for the first time its proper place not only as a feature of colonial land tenure and legislation, but as a contributory cause also to the discontent which brought on the Revolution. This little incident of men's daily lives, probably unfamiliar to a majority of those to-day who are versed in colonial history, involved a principle quite as fundamental as that of no taxation without representation and one that probably had more actual influence in bringing about independence than had some of the widely heralded political and constitutional doctrines of the pre-Revolutionary period. It is, therefore, of the meaning and significance of this somewhat obscure payment, badge of an inferior title to the soil and relic of feudalism and the past, that I would say something here. The subject involves more than an incident of land tenure, it raises the question of the treatment of history as well.

When we consider the liking which every American has for his "heritage of freedom," it is not surprising that the aristocratic and feudal characteristics of our colonial beginnings should have been either overlooked entirely by writers on our early history, or if discussed at all 
regarded in the light of fossils from a bygone age, negligible survivals of medievalism, or outworn parts of the social organism that having ceased to perform any vital function or serve any useful purpose deserve to be ignored as meaningless curiosities.

This disregard of well-defined features of our colonial history is largely due to the absorbing interest which scholars and the reading public have taken in the origin and growth of American political ideas. Such an interest is wholesome when it betokens a desire to know something of the conditions under which have developed those institutions that we now recognize as characteristically American, but it is positively harmful when it leads to false assumptions and mistaken interpretations. Some writers, in their enthusiastic search for origins, have spent much time and printer's ink upon certain supposititious institutions of our primitive ancestors-folkmoots, for example-in the effort to show the antiquity of what we like to call the free institutions of the Anglo-Saxon race, while others have indulged in grave distortions of fact regarding colonial thought and opinion and have treated every indication of colonial self-assertiveness and independence as if it were a manifestation of modern ideas concerning liberty and democracy.

But happily as knowledge of colonial conditions increases, the customs and thoughts of our forefathers are being better understood, and it is realized that the "privileges and franchises" guaranteed by our early charters conveyed no more rights and advantages than these words implied to the men in England who drafted the instruments, and that thousands of those who came from England to America, particularly in the years after 1689, were similar in type to the Englishmen who remained at home, bold spirits often, but less dissatisfied and opinion- 
ated than were the earlier refugees. England of the seventeenth and eighteenth centuries was not in the remotest sense of the term a democratic country and the average Englishman of that time was restricted in his thoughts and activities by the feudal customs, class rights, and constitutional limitations of his day. Furthermore, throughout the entire colonial period, the government at home enforced in America principles of law and methods of control that were at bottom monarchical, aristocratic, and feudal. Naturally such principles and methods did not take permanent root in the free soil of America, among colonists often radical in temperament, but they survived their transplanting and appeared for many years as features of the law, government, and even social relations of the American seaboard.

We cannot ignore or condemn these aspects of colonial history because they do not happen to coincide with our present notions of how government and society ought to be constituted or pretend that they were unimportant factors in colonial life. In viewing the past we are apt to sympathize with and overstress the contemporary importance of the liberalizing movements, just as in dealing with the present we are much given to deprecating radical changes and justifying things as they are. Most people are more or less inconsistent in that they glorify revolution in the past and abhor it in the present; and in consequence are inclined to center their attention on the progressive aspects of history and to dismiss as of minor consequence that resisting power of conservatism, by means of which alone the dynamic, liberal energies can be measured. Many fail to realize that on our own soil, as elsewhere, democracy, free government, and a more just, equable, and humane system of law and order have evolved slowly though steadily from a state of 
society in which the royal prerogative, aristocratic distinctions, and some of the rules of feudal law were living realities to a large proportion of the population.

In no single particular have the customs of the past been more tenacious and persistent than in the domain of real property, for even to-day the laws governing descent, contract, conveyance, and tenure bear the marks of their feudal origin. It is hardly surprising, therefore, that in colonial times in America, landholding should have been essentially tenurial in character. Except in the corporate colonies of Massachusetts, Rhode Island, and Connecticut, the formula held good, mulle terre sans seigneur, for every acre of land was held of a lord, either the king himself, or some landed proprietor or proprietors to whom a grant had been made by the crown. Even in those colonies, though there was nothing tenurial about the way the towns distributed their lands among their own inhabitants, for the Puritans were vehemently opposed to the distinction between lord and tenant and were determined to be "supreme lords of their own lands," equal before God and the law, there was much that was tenurial in the higher relations of town and colony with the crown. The corporations held their lands of the king by a socage tenure, and though no rent was demanded by their charters, because the latter were in origin the instruments of trading companies and not of feudal lords, they might have paid such a rent had it been demanded, as Massachusetts thought of doing in 1681, when threatened with the loss of her charter. The Connecticut towns acknowledged their legal status as tenants in socage of the crown, when in 1685 and 1686 they took out formal patents of confirmation to protect their lands from reverting into the king's hands at the time of the Andros 
government. Thus the feudal ${ }^{1}$ landed relationship, which was so widely prevalent elsewhere, had a place even in these self-governing Puritan colonies, ${ }^{2}$ and it is incumbent on us to know something of the origin and character of a tenure by which so large a portion of the colonial lands was held.

This tenure was commonly styled free and common socage or tenure in fee-simple, ${ }^{3}$ the terms of which were fealty and a fixed rent. Feudally speaking, fealty was the bond between lord and man, which survived only in the oath of allegiance to the crown; rent was the bond between the lord and the land, the symbol of territorial ownership, and was usually called the quit-rent, or sometimes-and there is an instance of this in the "Fundamental Constitutions" of Carolina-the chief rent. In

1 Throughout this work, the word 'feudal' is used, not in its restricted, technical meaning but in the broader connotation of medieval tenure in general. In the narrower sense of the word, neither socage tenure nor quitrent was feudal.

2 See note at the end of this introduction.

3 Lands thus held, though subject to the payment of a quit-rent, were 'free' because they were alienable and heritable. When in Massachusetts a grantor desired (as was almost always the case) to free the land from all its tenurial burdens, and so to make the transfer an outright gift or an absolute sale, he generally stated the fact in the deed. The usual phrases were, "to be held forever in fee without any incumbrance whatever," "free from all and every claim or future pretence or demand," "a good perfect and absolute estate of inheritance in Fee Simple without any manner of condition reversion or limitation whatsoever.' Suffolk Deeds, passim. In Connecticut, where it was taken for granted that no quit-rents were to be paid, there are but few instances in which the attempt was made to guard against such a payment. The following would appear, howerer, to represent such an attempt: "That the town doth grant all those lands that have been already granted to be free and clear according to the most free tenure of East Greenwich in the county of King [Kent], in the Realm of England.', Larned, History of Windham County, I, 223. Legally speaking, these words could not have accomplished the desired end, for at this time not even the freest tenure on the king's manor of East Greenwich ereated an absolute ownership. Such ownership was unknown to the English common law. 
addition there were other incidents, such as alienation fines and escheats. The quit-rent was originally a commutation in money of certain medieval villein obligations, such as laboring for the lord of the manor a number of days in the week and paying to him a portion of the produce of the villein's land and stock. In very early times in England, the payment of a money rent seems to have been the privilege of the class of sokemen (whence the name of the tenure), the free peasantry, who in considerable numbers survived the Norman Conquest, and as a commutation to have been applied first to those of the unfree who held "uncertainly" or at the will of the lord, that is, the future copyholders as contrasted with the freeholders. But later the quit-rent was used to designate any form of payment, which absolved or made quit the tenant, whether vassal, freeholder, copyholder, or leaseholder, in respect of personal service or other similar obligation to the lord. The tenure thus evolved became the "freest", of all the English land tenures, and because of its easy adaptability to a changing land system, which was gradually throwing off its medieval fetters, was widely employed to meet the need of a simpler and more flexible method of acquiring landed property. The strictly feudal tenures, knight's service, frankalmoin, grand serjeanty, and petty serjeanty, had become formal and rare by the seventeenth century and the first named was becoming obsolete long before its abolition by the Restoration Parliament in 1661, so that socage tenure was all but universal in the British world during our colonial period. ${ }^{1}$ As there were no copyholds in America,

1 "'Thus socage begins to swallow up the other tenures, and preparation is already made for the day when all, or practically all, tenants will hold by the once humble tenure of the sokemanni." Pollock and Maitland, History of English Law (2d ed.), I, 356. 
it applied only to freeholds and leaseholds, the prevailing types of land in the colonies, and unless payment of the rent were waived, as in the case of the corporate colonies, all colonial freeholders and leaseholders were under obligation to recognize in one form or another the higher title of some landed proprietor. The payment in no way hampered the freeholder in the control of his land, for though actual ownership remained elsewhere, he was free to alienate or bequeath his real estate according to the law of his colony and to exercise all the rights of possession, provided he conformed to the terms of his tenure.

Quit-rents were either real or nominal, either an actual sum of money or a mere token of lordship, the rendering of which was evidence of the freeholder's inferior title. Proprietors, such as the Baltimores, the Penns, the Duke of York, or the corporation of the city of Albany, tendered Indian arrows or beaver skins, and occasionally those lower in the scale made similar payments, as of a red rose for a manor in Pennsylvania or a silver shilling for a whole barony in South Carolina. ${ }^{1}$ But more often the quit-rents had a real money value and were a source of income to those who owned the land. The proprietors of the Jerseys and the Carolinas paid or should have paid (for they were generally in arrears) a goodly number of marks or nobles; while the settlers who occupied the soil met their obligations in sums ranging from a penny an acre to as low as two shillings and six pence a hundred acres and sometimes less. In no case was the quit-rent a heavy financial burden to the colonist though the requirement, often imposed, that the pay-

1 Quit-rents of this character were similar to the services due from petty serjeanties. Even in the fifteenth century Littleton could say that petty serjeanty was but "socage in effect." Pollock and Maitland, History of English Law (2d ed.), I, 282-283, 291, 323, 355-356. 
ment be made in silver rather than produce, was difficult to meet, owing to the scarcity of hard money. It was not a rent, as we define the term, bearing a value proportionate to the worth of the land; it was a compounding for service, the rendering of a fixed annual sum, which remained the same whether the price of land rose or fell. Many a farmer, in Virginia, for example, who was a leaseholder not a freeholder, a tenant, that is, possessing no fee of the soil, paid a rent to his landlord as well as a quit-rent to the king. The total amounts received from the quit-rents were often considerable, as they were bound to be in a country where land was plentiful and grants in fee were many, and they added appreciably to the revenues of the Baltimores, the Penns, Lord Fairfax, and Lord Granville. The quit-rents of Virginia were sufficiently large to find a place in the estimates of the British Exchequer. But the sums were always affected by the refusal of the colonist to pay, by the difficulties of collection, and by the large outstanding arrears that everywhere accumulated. The proprietors of the soil in New Hampshire and the Jerseys had almost nothing to show for their titles, and the crown in New York netted very meager returns from the quit-rents of that province. Taking the British colonies as a whole, there were many instances in which the system worked so badly that the obligation to pay remained little more than a dead letter.

But there is no doubt that the quit-rent as a source of revenue influenced the nobility of the seventeenth and early eighteenth centuries in seeking lands in America. We have probably never fully appreciated the part which the feudal class of England and Scotland played in our early history from the time of Gilbert and Raleigh until well on in the eighteenth century. For more than a 
century and a half, lords and gentlemen of rank tried to obtain a footing on American soil and to introduce there the feudal rights and privileges which they exercised upon their own franchises at home. Had they succeeded they might have fastened upon the colonies feudal obligations that the New World would have found it difficult to shake off, as was the case with Canada under the French régime. We treat often with ill-disguised impatience what seem to us the fantasies of Locke's "Fundamental Constitutions" and fail perhaps to understand that they were but a philosopher's elaboration of a feudal order of society that was still real to many of those who sought lands in America. Even as late as 1728, the Duke of Montagu was authorized to divide the island of Tobago into counties and towns, to grant fairs and markets, and. to erect manors and seigniories. In England these seigniorial rights continued to exist because they had a financial value; and it was apparently easy for the manorial lord at home to believe that he could recoup his failing resources in a similar manner from lands granted to him in America.

Of all the seigniorial rights the collecting of a quitrent was the most important. The value of the quit-rent as a source of revenue was uppermost in the minds of those who received grants from the New England Couneil in the early seventeenth century, if we may judge from the demands made after the Restoration by the Duchess of Hamilton, the Mason and Gorges heirs, and the various persons representing the Stirling claims. Its value was recognized in the Arlington and Culpeper grant of the lands of Virginia, a part of which was afterwards inherited by Lord Fairfax, and it influenced the proprietors of the Jerseys to retain their rights to the soil and the Earl of Carteret, later Lord Granville, to hold on to 
his eighth share of the lands of the Carolinas, after the government of these proprietary colonies had been surrendered to the crown. Because of their belief in the financial value of the quit-rent, the Earl of Doncaster and others tried to obtain landed estates in various parts of America, and in 1717 Sir Robert Montgomery, prompted by a desire for revenue from that source, secured from the Carolina proprietors his well-known grant of Azalia, lying between the Savannah and the Altamaha rivers. Had plans for the settlement of this grant ever been carried out, there would have come into existence the most remarkable feudal estate within the colonial area, in which the settlers would have held of Montgomery, Montgomery of the Carolina proprietors, and they of the king, three rungs of the feudal ladder. Even though most of these feudal efforts failed and all feudal institutions withered in the uncongenial atmosphere of the wilderness and the frontier, their introduction and struggle for existence had an appreciable effect on the life of the colonists.

The quit-rent continued to be collected within the territory of the thirteen colonies until the very eve of the Revolution and traces of its influence can be seen long after all feudal incidents were abolished by the first state constitutions. Although not permanently in force in Barbadoes and the Leeward Islands during the colonial period, because other forms of payment were substituted therefor, it was introduced into Canada and the Ceded Islands soon after their acquisition in 1763 , in the form of leases with fines and quit-rents and fee-simple grants at small quit-rents, "according to the familiar plan in early colonization," and persisted there in some measure after it had passed away among the thirteen colonies. In England it remained into the nineteenth century (and 
here and there still exists), chiefly as a rent-charge payable to private landlords, for all crown lands were surrendered by George III on his accession in 1760 . Some features of it lingered on until 1835 in the English municipalities, where many a messuage held in a burgage tenure bore a quit-rent-a peppercorn, a rose, gloves, spurs, etc.-betokening the desire of the owner of the soil, whether manorial lord or town corporation, to grant the fee of a tenement while retaining the lordship over it. It was present in Ireland in the nineteenth century, where the crown possessed as its only interest in the Irish lands, the leases and quit-rents from the estates forfeited in 1641 and 1688, in the counties of Ulster, Munster, Leinster, and Connaught, which were looked after by an auditor-general and a clerk of the quit-rents, in much the same manner as had been the quit-rents due the crown from the American colonies in the years before 1774 . Thus as an incident of land tenure and a source of income from the ownership of the soil, the quit-rent has been a factor of no little importance in the agrarian history of the British empire.

Professor Bond's account of the quit-rent in America is an exceedingly valuable contribution to our knowledge of colonial history, because in bringing together in orderly and intelligent fashion a large amount of information, widely scattered and often difficult of access and never before used except in part and by Professor Bond himself, it opens a new chapter of colonial life and throws light upon a little-known phase of the struggle which took place in America to get rid of an outside control that was hampering colonial progress. The quitrent in the domain of real property, like the royal prerogative in the field of government and the navigation acts in the field of commerce, was an obstacle to complete 
colonial independence, and a check upon the ability of a people to utilize its own resources for its own benefit and advantage.

Charles M. Andrews.

Note. Some additions may be made to what Professor Bond has written of the tenurial situation in New England, outside of New Hampshire, for there were perhaps more individuals than we realize holding lands in socage tenure with a quit-rent.

The Maine tenures were feudal, at least on paper. For example, Capt. Thomas Camock held Black Point first of the New England Council and later of Gorges at a quit-rent of $12 d$ per 100 acres (Cal. State Pap. Col. 1574-1660, p. 137 ; York Deeds, II, ff. 84-88). Vines Ellacot first held Hogg Island of the king at a quit-rent of $10 \mathrm{~s}$; later he sold it to William Stoughton of Boston and then took it back on lease, paying a rent to Stoughton and a quit-rent to the king ( ork Deeds, VIII, f. 217). Richard Wharton, merchant of Boston, applied for land upon which to erect a manor at Pejebscot to be held of the king at $2 \mathrm{~s}$ per 100 acres, and he promised, if he obtained it, to confirm John Parker in possession of a part to be holden of himself at a quit-rent of fish (N. E. Gen. \& Hist. Reg., VI, 375; Maine Hist. \& Gen. Rec., IX, 6; Cal. State Pap. Col. 1685-1688, \$155). The evidence contained in the York Deeds is of considerable importance.

Elsewhere, Plymouth's payment of beaver skins for the lands of Mount Hope was a quit-rent (Mass. Hist. Soc. Col., 4th series, V, 66, 126; and below, p. 403, note 1); and Samuel Shrimpton's payment of $40 \mathrm{~s}$ for Noddle's Island (East Boston) was the same (Mass. Col. Rec., V, 413). Richard Wharton in 1687 received a large grant of land in the Narragansett Country, for which he was to render 10 s quit-rent per annum (Cal: State Pap. Col. 1685-1688, $\$ 1319)$. Fitz-John Winthrop, Wharton's brother-inlaw, held Fishers Island of the Duke of York by the yearly payment of a lamb (Mass. Hist. Soc. Col., 6th series, III, 463). Lion Gardiner ("a God-fearing Puritan"') and his sons held Gardiners Island of the Earl of Stirling as a manor for a quit-rent of $£ 5$; after 1664 they held it of the Duke of York, first for $£ 5$ a year and then for the yearly rendering of a lamb; the holding was confirmed by Governor Dongan as a manor in 1686, and quit-rents in money continued to be paid, except for the period of the Revolution, until 1789 (C. C. Gardiner, Lion Gardiner and his Descendants, pp. 58-59, 69, 87). In Connecticut there were Belcher's farm near Meriden, sometimes called a "'manor,', Lonetown Manor near Redding, and Mortlake Manor near Fomfret, but they seem to have had no tenurial significance. In at least one case, a Connecticut man petitioned the Andros council in Poston for a confirmation of his title, offering to pay a quit-rent. This was James Pendleton who held land near Stonington, which had been originally granted by the General Court of the colony. The petition is in the Massachusetts Archives, 127, f. 248. 
The town of Boston was a landed proprietor and before 1660 disposed of its lands either in particular allotments or on lease for a term of years at a money rental; after 1660 it introduced, in a few instances, what appears to be a faint survival of a burgage tenure, granting privileges (rather than land as such) on payment of " an honorarium," " an acknowledgement of the Towne propriety,' a peppercorn, in one instance, and a quit-rent in proprio nomine, in another (Boston Town Records, 1660-1701, pp. 19, 21, 50, 155; Suffolk Deeds, XIII, 174, 175, 243, 244, "'and paying therefore unto the Treasurer of the Towne of Boston the sume of two shillings and two pence per annum forever as a Quitt-Rent for the use of the sd Towne"'). Other payments of small sums per annum "forever" seem very like quitrents. Such tenures were, however, rare. Boston at this time was not an incorporated town, though it wanted to be (Boston Town Records, 1660-1701, p. 111), and I cannot discover any grant to it of the lands it allotted, leased, or sublet; nor do I know of any tenurial grants of lands or privileges in the colony outside of Boston, or in Connecticut or Rhode Island other than those mentioned above.

Regarding the attitude of Massachusetts men toward the quit-rent during the administration of Andros, it is interesting to note that in the charges brought against John West and John Palmer concerning the Pemaquid grants, which had been made under a supposed commission from Governor Dongan of New York, the grievance was not the quit-rent but the heavy fees and the way the business was transacted (Andros Tracts, I, 164, 166).

Felt in his History of Massachusetts Currency, p. 44, leaves the impression that the colony actually instructed its agents in 1681 to offer a quit-rent to the king. This is not true as in the original manuscript the clause in question is marked "Not agreed to." It is noteworthy, however, that the committee which drafted the instructions should have inserted such a clause, showing that there were those in the colony who had no objection to paying a quit-rent. 



\section{CHAPTER I}

\section{THE ORIGIN OF THE QUIT-RENTS}

To the student of colonial history, the quit-rent is a familiar incident of the land system, and one that frequently survived until the Revolution. The significance of such a charge, the various measures taken to enforce it, its failures and its successes are topics closely intertwined with the history of the American colonies. Like other fundamental features of the land system, the quitrent was a customary institution in England, which was transplanted to America. Essentially it constituted a feudal due, originating from the commutation into a fixed money equivalent of the food and labor payments exacted by the lord of the manor. The very name is significant, for by the payment of the quit-rent the tenant was quit, i.e. free from all other annual feudal charges. ${ }^{1}$ Payable at first to proprietaries and later, in many instances, to the crown, the quit-rent emphasized the feudal dependence of the American colonies, and was the visible token of such a relation.

The full significance of the quit-rent, as it was reserved in the colonies, cannot be appreciated without tracing its gradual development in England, where it was an outgrowth of the movement to transform the peasantry of

1 The nature of the quit-rent is emphasized by the designation "white," i.e. silver rent, in contrast with the "black" rent due in work, grain or baser money. Palgrave, Dictionary of Political Economy, III, 249; Blackstone, Commentaries, II, 42. There are those who believe, however, that "white" is merely a corruption of "quit," and not a term designating silver money. 
England, free tenants and villeins, into freeholders and copylolders paying to their lords a fixed money rent. The old customary obligations, which had consisted of labor and payments in kind, were wasteful, clumsy, and inefficient, and a source of constant trouble. between lord and tenants. As the supply of coin increased, as new industrial activities in the towns and seaports attracted the agriculturists, and as men became available for hire at a money wage, the old manorial organization broke down, the open fields began to be enclosed, and the tillers of the soil little by little passed out of a state of bondage into a higher and more stable economic and legal status. ${ }^{1}$ The free tenants, freemen and sokemen, who performed few labor services, were the earliest to commute their obligations and to render to their lords what soon became the main incidents of a socage tenure, fealty and a fixed rent; while the lower ranks of the peasantry, the villeins or customary tenants, who held their lands on uncertain tenure at the will of the lord and were accustomed to perform heavy labor services on the lord's demesne and to furnish for his use a great variety of agricultural products, were slower to resolve into money their works and obligations.

Though commutation began at an early date, it was nowhere a regular or continuous process, following a uniform course, but, particularly among the villeins, was uncertain and fluctuating, influenced by a great variety of motives that were operating in different degrees in different places and at different times. In some cases

1 Vinogradoff, Villainage in England, 288, 297, 302, 307. The literature of the subject is extensive, though generally inadequate in its discussion of the later history of the quit-rent. The best brief account of the whole subject is in E. Lipson, An Introduction to the Economic History of England, I, The Middle Ages, chs. III, IV. See also E. Jenks, Modern Land Law, chs. II-V. 
the commutation was only apparent, as when services were entered on the manor rolls in terms of money merely as a convenient form of reckoning; in others it was only temporary, as when the lords found opportunities to return to the old system after commutation had proved or seemed to have proved disadvantageous; still again it often became permanent only in part, as when the villein paid in both labor and money. ${ }^{1}$ But in the long run the change was inevitable. The older natural economy of labor service and payments in kind could not be maintained in the presence of a growing industry and trade. It was suited only for a self-contained agricultural life free from competition with the world outside. Though no fixed dates can be given, the movement toward money payments, which was earlier in England than on the Continent, began before the Black Death and was fairly complete by the middle of the fifteenth century. ${ }^{2}$ Even in the next century, fifty years before the settlement of America, manorial tenants were here and there performing labor services. Whatever traces lingered on into the seventeenth century had no economic significance, as they merely exhibited the persistence of legal claims on the part of the landowners to fines and incidents that still might be due, technically speaking, from tenants who, in the eyes of the law, had not entirely emancipated themselves from a state of bondage.

Of special interest is the transition from labor dues to quit-rents in the palatinate of Durham, for the proprietaries, under whom quit-rents were reserved in many of the colonies, received territorial rights copied after those

1 For typical instances of the gradual transformation of the various forms of rent into a money payment, see the Victoria History of the Counties of England; Berkshire, II, 173, 180-188, 192 ; Essex, II, 316-317 ; Lincoln, II, 301; Rutland, I, 215.

2 Vinogradoff, Villainage in England, pp. 297, 307-312, 329. 
held by the bishop there. As early as the thirteenth century there was a steady increase in Durham of copyholders who paid only a small reserved rent. This movement was accelerated in the fourteenth century by the opposition of the villeins to the required work, and the resulting difficulty that arose in enforcing the bishop's rights. After the Black Death the enforcement of the labor dues proved to be practically impossible, though the collection of the money rents was a scarcely easier task. A new village officer, the collector, was appointed, but his work was neither pleasant nor popular. Often the men of Durham refused to accept the office, or to serve upon the juries that heard the cases of delinquent tenants. ${ }^{1}$ The bishop partly relieved the situation by abolishing the local collectors, and by making all rents payable at Durham. As a result, by the fifteenth century the quit-rents were accepted as an essential feature of the land system in the palatinate. ${ }^{2}$ Following the example of the bishop, the proprietaries incorporated the quit-rents into the land systems of their American colonies as a customary charge. Like the bishop, they experienced much difficulty in enforcing their rights.

With the evolution of the quit-rent went a corresponding development of common law principles which fixed the status of this feudal due. At first the agreement to pay a quit-rent depended upon custom rather than a written contract. Such an anomalous situation was the natural outcome of the gradual substitution of fixed money payments for customary feudal dues. Few of the

1 This opposition to the payment of the quit-rents seems to have been partly due to poverty. So serious did the situation become that in June, 1350 , no tenants appeared in person for their leases, and the bishop, in order to let his lands, was obliged to grant large remissions of the quit-rents for the current year. Victoria History; Durham, II, 183, 201-223.

2 Victoria History; Durham, II, 183, 204, 219-226, 231. 
tenants could show, as the basis of their rights, any other title than the custom of the manor entered upon the roll of the court baron, an entry which the courts deemed a sufficient proof of tenure. ${ }^{1}$ Further uncertainty was removed by the Statute of Frauds in 1678 which required that all perpetual leases be in writing. Even where this act was not observed, judicial decision held that the payment of rents for forty or more years established a quitrent. ${ }^{2}$ Thus the principle of the common law was finally fixed that the evidence of a quit-rent which was perpetual established the right of the tenant to the soil, and of the lord to the rent. ${ }^{3}$

Of equal importance was the development of legal means for the enforcement of the quit-rents. According to the English common law, the quit-rent was due upon the land from which it issued, unless the original agreement specified otherwise. Where these rents were due the crown, they were payable either at the exchequer, or to the royal receiver in the county, and in either case payment must be tendered before sunset on the anniversary of the original reservation. ${ }^{4}$ If the tenant failed to meet

1 Blackstone, Commentaries, II, 94-96; Finlayson, History of the Tenures of Land in England and Ireland, p. $47^{\circ}$.

2 The Statute of Frauds was anticipated in the colonies by the custom of fixing the agreement between the tenant and the lord in the form of a written contract. Finlayson, History of the Tenures of Land in England and Ireland, pp. 57-59.

3 This doctrine was illustrated in 1828 in the ease of Whitlock vs. Johnson in which suit was brought to eject a tenant from two parcels of land. The defendant proved that for forty years he had paid an unvaried rent on each tract, and the court held that such payments created a presumption that the rent constituted a quit-rent. The suit was therefore dismissed. Gow's Reports, 173-174. It should be noted, however, that even with the payment of quit-rents the lord still retained the feudal right to exact alienation or descent fines. Finlayson, History of the Tenures of Land in England and Ireland, p. 47.

4 Blackstone, Commentaries, II, 42. 
his obligation, the usual method was to enforce payment by distress upon his personal property, although by the Statute of Gloucester an action of cessavit per biennium could be brought by the lord when a tenant, holding by rent or other services, neglected for two years to pay his dues. ${ }^{1} \quad$ Yet preferring the usual method of collection by distress, the law provided that if the arrears of rent and all damages were tendered before final judgment had been entered, and if security were given for future payments, the process for forfeiture should cease and the tenant would retain his land. Injustice in distraint was prevented by a clause in Magna Carta which prohibited the lord from levying more distress than was actually due. $^{2}$

The quit-rent, with the common law principles which had grown up about it, fitted in logically with the feudal theory upon which the colonial land system was based. As the original proprietor of the soil in all the British dominions, the crown possessed the sole power to make grants of vacant land. ${ }^{3}$ At first it made these grants to proprietaries who in turn, by a process of subinfeudation, reserved a quit-rent, as the customary feudal due, in the patents which they issued to their tenants. Therefore the quit-rent, as it was first transplanted to the colonies, was really a feudal payment from freeholders whose tenure was in free and common socage. Although payable in the beginning to proprietaries, later it became due in many colonies directly to the crown, and thus constituted in either instance the visible sign in the colonial land system of the royal feudal supremacy.

1 Pollock and Maitland, History of English Law (2d ed.), I, 353.

2 Blackstone, Commentaries, II, 230-233; Pollock and Maitland, History of English Law (2d ed.), I, 352-355.

3 Blackstone, Commentaries, II, 51. 
Usually the charters which transferred the royal rights in the soil did not specifically confer the power to reserve quit-rents. Indeed, at first the territorial rights of the proprietaries were vague, as in John Cabot's patent of 1496 which merely fixed the general standing of the patentees as tenants of the crown. ${ }^{1}$ The patents to Sir Humphrey Gilbert in 1578 and to Sir Walter Raleigh in 1584 were more explicit, including two features found in most subsequent charters. First, the patentees received full rights in the soil, together with ample power to dispose of it subject to the laws of England. Secondly, they were required to swear allegiance to the crown, thus acknowledging their obligation of fealty. ${ }^{2}$ Though the right to reserve a quit-rent was not specifically named, the territorial powers conferred were held to permit such feudal charges, and Sir Humphrey Gilbert set an important precedent when he included a quit-rent of $10 \mathrm{~s}$ per 100 acres in his proposals for settlement. ${ }^{3}$

In later charters, the right to reserve a quit-rent was more clearly specified. By investing the proprietary with full power as exercised by the Bishop of Durham, the charter to Sir Robert Heath unquestionably sanctioned such a feudal due. This precedent was followed in the charters for Maryland, Maine, and Carolina but not in that for Pennsylvania, although Penn's right to reserve quit-rents was never questioned. The feudal character of these proprietary grants, as seen in the right of subinfeudation, was further emphasized by an explicit waiving

1 Thorpe, Constitutions and Charters, I, 46.

2 These patents required that a fraction, generally one-fifth of all gold and silver ore, should be given to the crown, a condition that was repeated in all subsequent charters. In later charters, some further additional acknowledgment of a nominal value was required. Thorpe, Constitutions and Charters, 1, 49-50 and 54 and passim.

3 Osgood, American Colonies in the 17th Century, I, 10. 
of the statute, Quia Emptores Terrarum. ${ }^{1}$ In the proprietary charters of 1664 and 1674 to the Duke of York the right to reserve quit-rents is mentioned, but such specific reference is unique. ${ }^{2}$ Only by implication were quit-rents recognized in the charters of the original corporate colonies. The provisions of the patent of 1606 which gave the Virginia companies of London and Plymouth full power to determine the conditions of settlement were practically identical with those contained in the London Company's charter of 1609 and in that of the New England Council of 1620. Following the precedent set by Sir Humphrey Gilbert, the last two charters were interpreted as conferring the right to reserve a quit-rent. ${ }^{3}$ In the charter to the trustees of Georgia in 1732 the crown reserved a quit-rent of $4 \mathrm{~s}$ per 100 acres as a royal revenue and a sign of overlordship. ${ }^{4}$ Thus, under the territorial rights conferred by these original charters, a quit-rent was invariably included as the usual sign of a free and common socage tenure, with the crown as the lord of the soil.

The quit-rent was established with varying success in all the American colonies except those of New England. Throughout the colonial era the proprietaries retained the right to reserve such dues in the Jerseys, in Pennsylvania including the Lower Counties, and in Maryland. The crown collected the quit-rents in New York after the Duke of York became king, in Virginia after the charter was annulled in 1624, in the Carolinas after the purchase from the proprietaries in 1729, and in Georgia after the surrender by the trustees in 3037 .

1 Thorpe, Constitutions and Charters, 1, 70; 3, 1627, 1633, 1679; 5, 2744,

\footnotetext{
2 Ibid., 3, 1638, 1641-1642.

3 Ibid., 3, 1834; 7, 3789, 3796.

4 Ibid., 2, 771.
} 
1752. In the West Indies, too, the crown either granted the soil to proprietaries, or retained it in its own hands. In either case there was a reservation of quit-rents, except in Barbadoes and the Leeward Islands, where they were waived in favor of the more productive four and a half per cent. export duty. A quit-rent was reserved also in Nova Scotia after the conquest from the French, and the proclamation of 1763 specifically required that such a feudal due to the crown should be included in all grants in Quebec, in East and West Florida, and in Grenada. ${ }^{1}$ Reserved therefore in by far the majority of the colonies both royal and proprietary, the quit-rent became an important feature of the land system in the American colonies.

The transfer to the colonies of such a land charge as the quit-rent, necessarily gave rise to much controversy. In England landholders at first gladly accepted the quitrent as a commutation of irksome services and payments in kind and gradually became accustomed to it through long usage. But in the colonies the quit-rent had no significance as a welcome release from undefined obligations and was usually construed as an arbitrary charge upon the land. Sacrifices borne and expenses incurred by the founder of a colony were soon forgotten, especially where the quit-rent was paid to an absentee proprietary, and the people opposed the payment of it as an obligation for which they got nothing in return. Even where the quit-rents were paid to the crown, trouble in one form or another was bound to ensue. While the common law principles that had been built up around the quit-rent in England were theoretically transplanted to America, actually they were not universally accepted. It was not always possible, at such a distance, to enforce legal rules 1 Annual Register, 1763, pp. 208-212. 
that had been developed in the mother country, and it became necessary to determine anew in each colony such questions as the amount, the place and medium of payment, and the means for the enforcement of the quit-rent. The establishment of this land charge in the American colonies was, therefore, in reality an attempt to transfer a feudal relationship and a feudal obligation from the Old World, where it had a meaning, to the New where it had none.

In order to understand the many problems created and the antipathies aroused by the establishment of the British quit-rent in the American colonies, it is necessary to trace in detail the history of this feudal charge wherever it occurred. For this purpose we may divide the colonies into three groups. The first includes the corporate colonies of New England in which all attempts to establish quit-rents ended in complete failure; the second, the colonies, some of which afterwards became royal, in which the quit-rents were paid to proprietaries; and the third, the royal colonies, in which the crown administered both the quit-rents and the government. The history of the quit-rents in the last group is marked by an increasing appreciation of the importance of these feudal dues on the part of the British government, and by the gradual evolution of a unified system of control. 


\section{CHAPTER II}

\section{COLONIES IN WHICH THERE WERE NO QUIT- RENTS}

Tнолgн quit-rents were originally proposed as a feature of the land system in New England, they were never actually established in the colonies of Massachusetts Bay, Plymouth, Connecticut, or Rhode Island. Sir Ferdinando Gorges included a quit-rent in his elaborate scheme for the government of Maine, and John Mason contemplated such a feudal charge in New Hampshire also. The outcome of these attempts to reserve quit-rents, together with the claims set up by the heirs of Gorges and Mason, will be considered in connection with the other proprieties. In the four New England colonies that remained, the absence of quit-rents, practically from the beginning of settlement, is a unique feature of the colonial land systems, and had an influence upon the radical political theories held in the four colonies. Determined to assert as complete an independence of external control as possible, the inhabitants bitterly opposed such a charge as the quit-rent, deeming it a sign of vassalage and an arbitrary limitation of their rights as lords of their own land.

Responsibility for the failure to establish the quit-rent in the leading colonies of New England can be traced in the first instance to the wavering and inconsistent policy of the New England Council. Though this body planned to reserve such dues in all grants, ${ }^{1}$ it did not issue imme-

1 The charter of 1620 granted the New England Council the land between $40^{\circ}$ and $48^{\circ}$ north latitude, with the right to issue patents under such "con- 
diately, as did other proprietaries, definite conditions to induce individuals to take up its lands. Rather did it try to secure settlement by private bodies, such as the Plymouth Company and the Massachusetts Associators, though the free and common socage tenure by which their lands were to be held was not always defined in specific terms. In the beginning, however, it was understood that every man desiring to have "any possession of land in the said territories"' was to pay a quit-rent of two shillings for every hundred acres that he received, and this rate is mentioned in the first Plymouth patent of 1621. Later, lands were granted at the rate of twelve pence per 100 acres. $^{2}$ Though there is no evidence of any attempt to collect these rents, the council did not abandon at any time its policy of reserving such a charge. The final plan for the division of its territories contemplated a quit-rent on the third of the land that was set aside for the support of the government. From the two-thirds assigned to individual members, each free-

ditions, reservations and agreements"' as it should direct. The council held that these powers included the one of reserving quit-rents. Thorpe, Constitutions and Charters, 3, 1832; Minutes, New England Council, July 24, 1622, and March 18, 1623, Am. Antiq. Soc. Proc. 1867, pp. 63, 90.

1 'Articles and Orders concluded on by the President and Counsell for the Affairs of New England"' (about September, 1621), American Historical Review, IV, 686-690, No. 29; Bradford, History of Plymouth Plantation (Ford, ed.), I, 248. The form of patent agreed upon in 1622 does not mention the form of quit-rent required. A resolution passed by the council in 1623 , which determined some of the conditions of settlement, also fails to mention a definite quit-rent. Later patents show great inconsistencies in this regard. Minutes, New England Council, November 2, 30, 1622, and March 25, 1623, Am. Antiq. Soc. Proc. 1867, pp. 68, 77, 93.

2 Ibid., December 1, 1631, p. 99. Typical patents, issued February 12, 1630, granted lands on the Saco River, with a quit-rent of $12 \mathrm{~d}$ per 100 acres payable annually to the rent-gatherer of the New England Council. A number of other patents issued in 1631 and 1632 reserved a quit-rent of either $12 \mathrm{~d}$ or, in some instances, $2 \mathrm{~s}$ per 100 acres. Maine Hist. Soc. Col., $2 \mathrm{~d}$ series, VII, 117-125; Am. Antiq. Soc. Proc. 1867, pp. 98-99, 100-105. 
holder was to give a small acknowledgment to the proprietary under whom he held. ${ }^{1}$ The failure to carry out this elaborate scheme of division put an end to the proposed quit-rents. ${ }^{2}$

By transferring all rights in the soil to the people of Plymouth the council set a precedent that was destined to prove fatal to the quit-rent system in New England. The first patent to Plymouth in 1621 reserved an annual quit-rent of $2 \mathrm{~s}$ per 100 acres, payable after seven years, ${ }^{3}$ but in 1622 John Peirce took advantage of his position as trustee to obtain, without the knowledge of his fellow colonists, a second grant which really empowered him to create a propriety. When the facts were laid before the council, it promptly set aside this second patent and made the Plymouth colonists again directly dependent upon itself. ${ }^{4}$ Finally, by the patent of 1628 , the council transferred to William Bradford and his associates all rights in the lands at Plymouth and on the Kennebec. As this grant was confirmed by the crown, ${ }^{5}$ the title to the land became vested in Bradford and the others, acting as trustees for the colony, and the records show no inclination on the part of the latter to impose at any time a

1 Minutes, New England Council, February 3, 1635, Am. Antiq. Soc. Proc. 1867, p. 118; Gorges Papers, I, 236.

2 Minutes, New England Council, April 26, 1635, Am. Antiq. Soc. Proc. 1867, pp. 119-120.

3 This patent, from the New England Council to John Peirce and his associates, granted the lands upon condition of the payment of "the yearly rent of two shillings at the feast of St. Michaell Tharchaungall to the hand of the rent-gatherer of the said President and Council and their successors forever, the first payment to begin after the expiration of the first seren years next after the date hereof.', Patent, June 21, 1621, Mass. Hist. Soc. Col., 4th series, II, 158-163.

4 Minutes, New England Council, March 25, 1623, Am. Antiq. Soc. Proc. 1867, pp. 91-93.

5 Maine Hist. Soc. Col., 2d series, VII, 109-116; Thorpe, Constitutions and Charters, 3, 1843-1844. 
charge upon those to whom it granted land. The colony itself was never required to pay a quit-rent other than the nominal fraction of gold and silver that might be discovered within its borders, the inclusion of which as a substitute for a more specific quit-rent is characteristic of the charters to corporate bodies. ${ }^{1}$

The case of Massachusetts is similar to that of Plymouth, since the patent of 1628, confirmed by the crown in 1629, transferred to the grantees all rights of the New England Council in the soil, in free and common socage, saving only the fraction of gold and silver as in the case of Plymouth. Under its patent the Massachusetts Bay Company had the right to reserve quit-rents at its pleasure. ${ }^{2}$ But the situation was altered from that of other corporate companies, when the company with its charter removed to New England and became a body politic, in which was vested all rights to the soil. Even there it might have granted lands with a quit-rent attached had not such a form of tenure been wholly foreign to Puritan ideas. The matter was settled by the Body of Liberties in 1641 which forbade any such charge as a quit-rent except by order of the General Court. This regulation proved effective. ${ }^{3}$ The free tenure of land in Plymouth and Massachusetts Bay had important results. It saved the New England colonies from the struggles which so frequently arose elsewhere over the enforcement of this unpopular form of tenure, and it strengthened the habit, already well established among the Puritan settlers, of self-assertion in matters

1 Professor Osgood calls attention to a tract of land at Pocasset which was leased to Capt. Philip Church in 1679 for a rent of 50s. This lease was limited to one year, however, and cannot therefore be termed a quit-rent. Osgood, American Colonies, I, 428.

2 Thorpe, Constitutions and Charters, 3, 1851-1852.

3 Colonial Laws of Massachusetts, Reprint, pp. 33, 35. 
of government. To a certain extent it served as an example to other colonies, for wherever the Massachusetts settlers went they carried with them this idea of the ownership of the soil, which took root at once in Connecticut, Rhode Island, and New Haven, and in the end won out in New Hampshire where it had to compete with the older notion of the quit-rent.

This Puritan idea of a land tenure free of all feudal incidents and restraints completely controlled the Connecticut people from the beginning. In 1643, George Fenwick, one of the English lords and gentlemen who were planning to find a refuge in Saybrook in case affairs in England went against the Puritans, having failed to sell to the Connecticut colony the rights of the patentees, proposed to levy a quit-rent on every acre of improved land, but found that the occupiers of the soil would not listen to the suggestion, for, as he ironically complained, "we must all here be independent and supreme lords of our own land." A year later, despairing of raising a revenue from a quit-rent, he disposed of the lands controlled by the patentees at the mouth of the river for a certain sum of money, to be paid in the form of dues that he was to collect for the ensuing ten years. These dues $^{2}$ were probably much heavier than a quit-rent would have been, and much less easily evaded, and show that to Connecticut the issue was not one of money but of tenure-a tenure free from the obligations that rested on

1 George Fenwick to Thomas Barrington, Norember 10, 1642, Brit. Mus., Egerton MSS. 2648, f. 1.

2 The dues were: $2 d$ per bushel of corn and $6 \mathrm{~d}$ per hundred weight of biscuit passing out of the mouth of the river; 12d per annum for every milch cow or mare, three years old and over, in any town or farm on the river; 12d for every hog killed in the same jurisdiction; 20s per hogshead of beaver sent down the river and out of the colony; and $2 d$ per pound of beaver traded on the river, except in the general Indian trade. "Articles of Agreement,"' December 5, 1644. Conn. Col. Rec., I, 268-269. 
freehold and copyhold at home. This free tenure of land was assured the colony by the Connecticut Code of 1650 which forbade all feudal incidents, ${ }^{1}$ and by the charter of 1662 , which vested all rights to the soil in the governor and company for the benefit of the freemen. ${ }^{2}$ In similar fashion the charter of Rhode Island in 1663 reflected the influence of the Massachusetts land system in preventing the establishment of quit-rents in neighboring colonies. ${ }^{3}$

In answer to the proprietary claims of Anne, Duchess of Hamilton, over lands in Connecticut, Fitz-John Winthrop in 1698 admirably expressed the deep-seated prejudice against such feudal dues as quit-rents. While he had not been able to bring the Hamilton claims to the attention of the assembly, Winthrop represented that a number of landowners had expressed themselves with regard to the matter, considering it "hard and unprecedented in any age" that, after sixty years' possession, they should become tenants on lands that had been purchased from the Indians and confirmed to them by Charles II. With biting sarcasm Winthrop noted the honor of being placed under the patronage of the son of the duchess, the Earl of Arran, asserting that the people of Connecticut, as strangers to the customs and usages of England, had a "strange notion and fright of the word, quit-rent." . . . "Being the successors to the first planters who so long time since ventured their lives, and spent considerable estates for which they have yet no fitting compensation," they "do think it the hardest thing in the world to have any difficulty laid upon their lands so dearly purchased." He himself, he declared, knew well the difficulties under which the planters had

1 Conn. Col. Rec., I, 536-537.

2 Thorpe, Constitutions and Charters, 1, 536.

3 Ibid., 6, 3221. 
labored in settling up the country, and the great toil necessary to procure subsistence, "and, besides, how all mankind in this country think themselves happy in that one undertaking, that they have a just and firm title to their lands by purchase from the natives, and supported by the king's precious charter." This statement, revealing as it does a full appreciation of the feudal principle involved in the quit-rent, clearly shows that the chief reason for this hostile attitude was dislike of a feudal control of the land by an external power rather than the mere monetary loss involved. As long as the

1 Fitz-John Winthrop to Andrew Hamilton, June 9, 1698, Mass. Hist. Soc. Col., 5th series, IX, 193-195.

The Hamilton claim is interesting from many points of view. It was based on a grant by the New England Council, April 22, 1635, to James, Marquis of Hamilton, who, it was claimed, sent over an agent to view the territory, but "was prevented from settling it by the rebellion." His daughter, Anne, duchess in her own right (1643), was a minor at the time, but after the Restoration, she and her husband, William, Marquis of Douglas, who was ereated Duke of Hamilton in 1660 , petitioned that the territory, which embraced the Narragansett Country, be restored to them as a propriety. "The duchess begged that "I be established in my right to the said land and that the inhabitants pay me such quit-rents as you think best." The case dragged along for many years and is typical of the attempts of the colonizing seigniors to recover grants made before the Civil War, which they had been unable to occupy on account of the disturbances of the time. The Gorges, Mason, and Stirling claims are in the same class. The final petition was made by the son of Anne, James Douglas (1658-1712), whose 'style' or title was the Earl of Arran (he is ealled 'Lord Arran' by Winthrop), and was presented to the crown in 1697. The case was referred to the Board of Trade, which reported, giving a full history of the claim from the beginning, and recommending that nothing be done by the crown, on the ground that "the revival of all the dormant titles under the grants of the Council of Plymouth would lead to unspeakable disturbance and confusion.", It was manifestly the intention of the Stuarts that the territory, called the 'King's Province' in 1664, should remain in the hands of the crown and that settlers there should pay a quit-rent of $2 \mathrm{~s} 6 \mathrm{~d}$ a hundred acres. Whether because of its peculiar history or for other reasons, the Narragansett territory had distinctive features of its own in colonial times, and showed some of the characteristies of an artistocracy. Quit-rents would not have seemed out of place there. c. M. A. 
ownership of the soil was vested in the body of freemen, the quit-rent, as the mark of feudal supremacy, was eliminated entirely.

The relaxed control exercised by the British government during the Puritan Revolution and the period of the Commonwealth and Protectorate greatly strengthened the system of free tenure of land in New England. With the downfall of the proprietary claims in Maine and New Hampshire, both colonies passed temporarily under the jurisdiction of Massachusetts and thus seemed secure from proprietary control. But after the Restoration, when efforts were made to revive many of the earlier seigniorial grants, in order to increase the incomes not only of the crown but of members of the nobility also, there was some reason to fear lest quit-rents be established in parts of New England. The only serious danger came from the effort to revive the claims of Mason and Gorges. The proprietary rights set up by the heirs of the former proved a source of much controversy in New Hampshire, while those of the latter were purchased by Massachusetts in 1678. With Maine finally included in Massachusetts and all other proprietary claims dismissed by the crown, the quit-rents were banished from all New England except New Hampshire. Clearly, if the proprietary rights of the crown were to be asserted in the New England colonies, the system of land tenure free from the usual feudal charge, the quit-rent, must first be attacked in its chief stronghold, Massachusetts.

The first suggestion for a system of quit-rents in Massachusetts seems to have been made by Edward Randolph in 1677, when he characterized the inhabitants of the colony as usurpers who possessed no legal right either to the land or to the government of any part of New England. They had formed themselves into a 
commonwealth, he asserted, "denying any appeals to England, and do not take the oath of allegiance," but they might be overawed by royal forces. The most refractory cases could then be subdued by the promise of a general pardon coupled with a royal declaration, "confirming unto the inhabitants the land and houses they now possess upon payment of an easy quit-rent." Nor did Randolph ignore the revenue value of the quit-rents. In 1686 he complained that the people of Massachusetts were very "cold and backward" toward his proposal for raising by quit-rents and import duties a royal revenue, which, if Rhode Island and Connecticut were added, should bring in $£ 4,000$ annually. Yet Randolph was not at all optimistic regarding the success of this attempt to establish quit-rents in Massachusetts. Richard Wharton, the president of Dudley's council, and several other persons who had engrossed large tracts in the Narragansett Country, he asserted, had foreseen the possibility of a quit-rent, and had presented every obstacle to his attempts to discover their estates, creating at the same time great popular prejudice against himself. ${ }^{2}$

The representations of Randolph in 1686 were not necessarily made to impress upon the British government the importance of a quit-rent in New England, for already the imposition of this feudal due had become an important feature of the policy adopted to compel these colonies to submit to the royal authority. The commission to Sir Edmund Andros in 1686 directed him to grant such lands "as are or hereafter shall be" at the disposal of the

1 Memoir of Edward Randolph, May 6, 1677, Toppan, Edward Randolph, I, 77-78. Randolph's suggestion was partly followed in the instructions to Colonel Kirke, see p. 44, note 1 .

2 Randolph to Lord Treasurer, and to Board of Trade, August 23, 1686, Toppan, Randolph, IV, 113-115, 118; ef. Cal. State Pap. Col. 1685-1688, \$91. 
crown, "under such moderate quit-rents" as should be appointed. This general order might be interpreted as requiring quit-rents merely in grants of unoccupied lands. That it was intended to apply to occupied lands also was clearly shown when the instructions to Andros called attention as well to the existence of vast tracts in New England still at the disposal of the crown, which were to be granted with a quit-rent of not less than $2 \mathrm{~s} 6 \mathrm{~d}$ per 100 acres, and to other lands for which the royal confirmation might be wanting upon which Andros was to "reserve such acknowledgments" . . . "as you shall think most equitable and conducive to our service." "The only possible interpretation of this statement is that settled lands, titles to which had been rendered doubtful by the annulment of the Massachusetts charter, were also to be included. Evidently Andros was required to make a quitrent a condition of confirmation for all lands held in Massachusetts, and after other charters in New England had been annulled to establish quit-rents in similar fashion elsewhere.

The quit-rent was not revived in New England merely to secure an outward token of the crown's proprietary supremacy. There is abundant evidence to show that its revenue value was also considered. Andros upon his appointment was granted a salary of $£ 1,200$, to be paid from the royal exchequer until sufficient revenue should be obtained from the colonies. ${ }^{2}$ While the source of this

1 Commission and Instructions to Sir Edmund Andros, May 25, 1686, and September 12, 1686, C. O. 5: 904, pp. 279, 284 ; Publications of the Colonial Society of Massachusetts, II, 53. On December 23, 1684, the Lords of Trade "recommended an instruction to Colonel Kirke the intended Governor of Massachusetts, to confirm all titles of land quietly possessed, reserving a quit-rent of $2 \mathrm{~s}$ 6d for every hundred acres." Cal. State Pap. Col. 1681-1685, $\$ 1953 ; 1696-1697$, p. 578 .

2 Memorandum, Board of Trade, June 3, 1686, Cal. State Pap. Col. 1685 1688 , p. 203. 
allowance was not specified, the quit-rent, as a royal revenue wholly free from local control, was admirably suited to afford a salary for a governor whose mission was bound to cause irritation if not actual outbreaks. Randolph had not failed to note the importance of the quit-rent as a producer of revenue, and it is significant that the orders already given regarding the quit-rents were repeated in the instructions and commission of 1688 which added New York and the Jerseys to the Dominion of New England. ${ }^{1}$ We must conclude, therefore, that the quit-rent, as a sign of proprietorship and as a means of raising revenue, was to be made a definite feature of the land system of the Dominion of New England.

In carrying out this purpose, the representatives of the crown first attacked the free tenure of land that had been developed in Massachusetts. Soon after his arrival in Boston, Andros gave public notice that the annulment of the charter had invalidated all land titles in Massachusetts, and that confirmations in the future must include a quit-rent. This declaration caused the utmost consternation. A few landholders, chiefly officers under the crown, or persons closely connected with the royal administration, sought confirmation of their lands under the new conditions, but by far the greater number of inhabitants of Massachusetts refused to accede to the governor's demands, ${ }^{2}$ and indignantly resented what they construed as a high-handed attempt to saddle upon their lands feudal dues from which they had always been free. The popular outcry was voiced by Increase Mather, who vigorously protested against the attempt to compel the inhabitants of Massachusetts to pay quit-rents for

1 Instructions to Sir Edmund Andros, April 16, 1688, N. Y. Col. Docs., III, 541-542, 545; Publications, Col. Soc. Mass., II, 66.

2 Andros Tracts, I, 143 ; Palfrey, History of New England, III, 529. 
"houses which their own hands have built, and the lands which at vast charges in subduing a wilderness they have for many years had as rightful possession of, as ever any people in the world have or can have." Mather accused Andros of irregularities in measuring out the lands of certain persons in Charlestown, in order to bestow them upon his favorites, and in issuing arbitrary writs of intrusion in many cases. Moreover, the commons belonging to several towns, Mather asserted, had been given over to members of the council; "to the impoverishing, if not utter ruining" of whole townships. Especially did he complain of the injustice with which an island belonging to Plymouth was petitioned away by Nathaniel Clark, "whom Sir Edmund Andros made his property," and he declared that when the agents of the town secured subscriptions to uphold their title by law, they were compelled for their presumption to journey from their own colony to Boston in order to answer as criminals. ${ }^{1}$

Probably the accusations brought by Mather were not altogether unfounded. The patents taken out by royal officials naturally aroused prejudice, and it would have been the wiser policy to have ignored some of the applications for land in face of the already disturbed state of public opinion. $^{2}$ A petition that aroused much popular wrath was one filed by Edward Randolph for five hundred acres on Nahant Neck for which, in spite of the claims of the town to vacant lands, the petitioner offered to pay whatever quit-rent the governor deemed proper. ${ }^{3}$

Besides such instances of favoritism toward royal officials, the vexations and delays incident to the readjust-

\footnotetext{
1 Increase Mather's "Narrative of the Miseries of New England," Andros Tracts, II, 3-8.

2 Palfrey, History of New England, III, 529.

3 Petition of Edward Randolph, October 1, 1687, Toppan, Randolph, IV, 171.
} 
ment of titles were very annoying. An illustration was the case of Joseph Lynde who petitioned for his estate as a whole, but was informed he must have a separate patent for each county, if not each town, in which he owned a parcel of land. When he delayed to secure these separate patents, each of them involving considerable outlay, a writ of intrusion was issued against one of his tracts. This writ seems to have been held over Lynde in order to club him into submission, and he was even threatened with similar procedure against other parcels of his land. ${ }^{1}$ Though such high-handed methods were often employed to force quit-rents upon the landholders of Massachusetts, the actual amount demanded was moderate, varying from $1 \mathrm{~s}$ to $2 \mathrm{~s}$ per 100 acres. $^{2}$ The monetary charge therefore was probably the least important of the motives that led to the outcry against this attempt to reserve quit-rents. Rather, it was the principle of having these feudal dues so suddenly and so arbitrarily thrust upon them that aroused the militant indignation of the Massachusetts Puritans.

Nowhere was the popular attitude toward the efforts to establish quit-rents better set forth than by the Rev. Mr. Higginson at a crowded hearing held when the governor and council happened to pass through Salem. Boldly stating his views regarding the ownership of the soil, the minister acknowledged that the people of Massachusetts had secured their powers of government through the charter, but he denied what was the very cornerstone of the quit-rent system, the rights of the crown as feudal

1 The suit was moved in illegal fashion from court to court, even though Lynde had paid $£ 3$ to have it dropped, and had promised $£ 10$ additional when the new patent was made out. Andros Tracts, I, 92-93; Osgood, American Colonies, III, 408-409.

2 Palfrey, History of New England,.III, 529, note; Toppan, Randolph, II, 33. 
proprietary of colonial soil. The title to the land of Massachusetts, he asserted, was derived by the people from God, "according to His grand charter to the sons of Adam and Noah, and with the consent of the native inhabitants." When the governor upheld the rights of the crown in the soil, the minister advanced as a standing principle, "nil dat qui non habet." Therefore, he declared, as the crown had no claim to the American lands before the English came, it could not subsequently confer any right to them. The only argument that could justify a contrary opinion, he held, was the popish principle that Christians had a right to the lands of the heathen. Upon this basis the pope had given the West Indies to the Spanish, but it was a principle that all Protestants abhorred. Such reasoning was adroitly framed to arouse the prejudice of a New England audience, ardently detesting as they did anything that savored of Romanism. In answer to these arguments the adherents of the governor stoutly maintained that the king had acquired a right in the land, after his subjects came over and took possession. At last Sir Edmund Andros, impatient at these bold utterances so publicly made, exclaimed, "Either you are subjects, or you are rebels!" intimating, in the words of the minister, "according to the whole scope and tendency of his speeches and actions, that if we would not yield all the land of New England to be the king's, so as to take patents for our land, and to pay rents for the same, then we should not be accounted subjects, but rebels, and treated accordingly." "1

In these words the Puritan minister at Salem stoutly upheld the general hostility toward feudal dues. Nor did the people of Massachusetts long tolerate the efforts of Andros to force them to pay quit-rents upon lands which 1“"The Revolution in New England justified," Andros Tracts, I, 90. 
for so many years they had held free of such charges. A mass of contemporary evidence, including especially the numerous tracts to justify the revolution in Massachusetts, shows that Andros's land policy was one of the chief causes of his overthrow. These pamphlets contain scathing denunciations of the attempt to revive quitrents, and of the means adopted. In one of them the gist of the entire controversy is pithily stated: "What people," the author asks, "that had the spirit of Englishmen, could endure this?" Having possessed their estates for forty to sixty years, no people would allow "a parcel of strangers" to come in and seize what they "and their fathers before them had labored for." The popular belief, according to this tract, was that the entire attempt to establish quit-rents was a scheme to seize their lands and distribute them among favored officials. ${ }^{1}$ The overthrow of James II and of Andros afforded the people of Massachusetts an opportunity to lay these matters before William and Mary, and especially to represent how the governor had sought to turn them out of their lands and possessions, "upon which, under God, they had their dependency for a necessary livelihood.", Their grievances were recognized in the charter of 1691 which vested the original title to the soil of Massachusetts in the body of inhabitants and confirmed all patents that had been issued by the general court. ${ }^{3}$ This charter marked the doom of the quit-rent system in New England, for with

1 "The Revolution in New England justified," Andros Tracts, I, 87.

Upon Randolph was fixed the responsibility for the scheme. It was even alleged that he had purposely had himself made secretary, and had made false representations in order to secure the overthrow of the charter as a means of carrying out his designs upon the lands of Massachusetts. Answer to Randolph, 1690, Toppan, Randolph, V, 46-47.

2 Instructions to Agents of Mass. Bay, January 24, 1690, Andros Tracts, III, 59-60.

3 Thorpe, Constitutions and Charters, 3, 1877. 
a free tenure of land established in Massachusetts, feudal dues elsewhere in these colonies were impossible.

In view of the persistent opposition that had already been shown, any future attempt to establish quit-rents on lands claimed by Massachusetts was foredoomed to failure. This situation was forcibly illustrated when Colonel Dunbar in 1729 attempted to settle a group of Irish Catholics in his new colony of 'Georgia' on the east bank of the Kennebec. A large part of this region had already been taken up under patents from the New England Council, confirmed by deeds from the Indians. But representing that these lands were under the jurisdiction of Nova Scotia and the titles were therefore void, Dunbar offered to confirm them with a quit-rent of 1d sterling per acre, and many patentees took advantage of his offer. ${ }^{1}$ Though Dunbar had been granted permission to issue patents for his colony, Massachusetts quickly protested, asserting her own rights over the entire region between the Kennebec and the St. Croix. In face of this protest the Privy Council recalled its former order, and the effort to reserve a quit-rent on any part of the soil of Massachusetts failed. ${ }^{2}$ This outcome of the struggle was not without its effect in other colonies, notably in East Jersey where the determined opposition of the Puritan settlers of Elizabethtown was one of the chief factors in the downfall of the quit-rents there. Probably, too, the opposition to quit-rents in New England had its influence upon New York, and even to some extent upon other colonies.

1 Acts, Privy Coun. Col., III, 185; Colonel Dunbar to Secretary Popple, December 10, 1729, Maine Hist. Soc. Col., $2 \mathrm{~d}$ series, X, 455.

2 Acts, Privy Coun. Col., III, 188, 282. 


\section{CHAPTER III}

\section{PROPRIETARY QUIT-RENTS: IN CROWN COLONIES}

Tнолgн quit-rents never became a feature of the land system in Massachusetts Bay, Plymouth, Connecticut, and Rhode Island, they were reserved either nominally or as an actual charge in most of the other American colonies. They were established with the greatest degree of success where either a proprietary or the crown held, at the same time, both the rights in the soil and those of government. But in several crown colonies an altogether illogical situation arose because of proprietary claims by private individuals, in spite of the feudal theory that the function of local administration and the ownership of the land should be vested in the same overlord. The chief instances in which this principle was violated were those of Mason in New Hampshire, Fairfax in Virginia, Granville in North Carolina, and the proprietors of the soil in the Jerseys. The case of Maine, too, probably falls in the same category, for, though Maine was originally organized as a proprietary province, the colony was virtually under royal control until it was taken over by Massachusetts. The very shadowy rights of Gorges may be considered more readily in connection with the Mason claims in New Hampshire.

Following the usual policy, the New England Council transferred full rights in the soil to Captain John Mason and Sir Ferdinando Gorges, who later divided their joint 
holdings. ${ }^{1}$ After the dissolution of the council, Gorges received full power from the crown to establish a propriety, while Mason's rights in the soil were confirmed. ${ }^{2}$ Although he announced that he would reserve a quit-rent upon his lands, Mason does not seem to have taken any definite steps to carry out his plans, and he soon complained that he had not enjoyed any returns from the large sum spent on his colony. ${ }^{3}$ Gorges, much more active, at least on paper, proposed a quit-rent of $6 \mathrm{~d}$ per acre as a feature of his elaborate scheme for the settlement of his province of Maine. But he failed to provide an effective method of collection, and the quit-rents vanished in the general collapse of his government. ${ }^{4}$ Probably, too, the example of Massachusetts in abandoning quit-rents greatly aided in the defeat of the proprietary schemes of both Gorges and Mason. ${ }^{5}$

But these claims were not allowed to lapse without protest, and with the revival of royal control after the Restoration, the heirs of Mason and Gorges attempted to reëstablish their authority. The crown's attorney up-

1 In most of these grants, Mason and Gorges were required to give some small annual acknowledgment to the New England Council, thus putting them in the position of vassals. Thorpe, Constitutions and Charters, 3, 1623, 4, 2438-2440, 2444; Maine Hist. Soc. Col., 2 d series, VII, 96-107, 143-150.

2 Thorpe, Constitutions and Charters, 3, 1627 et seq.

3 Mason Papers, 74; Belknap, History of New Hampshire, p. 428.

4 Williamson, History of Maine, I, 282. An illustration of the poliey of Gorges was a grant for lands around Casco Bay made in 1637 to George Cleeve. The lease, limited to 2,000 years, reserved an annual rent of $2 \mathrm{~s}$ per 100 acres, to be levied by distress or otherwise, according to the laws of England, "used and approved," . . . "for tenants of like nature." Maine Hist. Soc. Col., 2d series, VII, 214-218.

5 Belknap holds that the attempts to reserve quit-rents in Maine and New Hampshire constituted one of the chief causes of the complete failure of the schemes of Mason and Gorges. In such close contact with the free and more fertile lands of Massachusetts, a quit-rent system was, he considers, an impossibility. Belknap, History of New Hampshire, pp. 16-17. 
held the petition of Ferdinando Gorges for the restoration of his grandfather's rights. ${ }^{1}$ His report set forth that, as the elder Ferdinando Gorges had supported the king, his commissioners had been forced to flee from Maine, and although he had expended $£ 20,000$ upon his province, his tenants had placed themselves under the protection of Massachusetts. ${ }^{2}$ Accepting this report, the king issued a proclamation ordering the people of Maine forthwith to recognize these rights, ${ }^{3}$ and Gorges energetically undertook to enforce them, appointing deputy collectors, whom he instructed to secure rent rolls as soon as possible, and to ascertain what quit-rents the landholders were willing to pay in order to secure the confirmation of their titles. But a mere royal proclamation was not sufficient to induce the settlers in far-away Maine to accede to feudal claims over their lands, and these conciliatory measures proved futile. ${ }^{*}$ When Massachusetts asserted her jurisdiction over Maine, the colonists sided with her as a champion of free tenure of land against Gorges and his proprietary claims. Gorges, himself, showed little disposition to enter upon the weary struggle which he knew was inevitable if he were to secure even a slight acknowledgment of his title, ${ }^{5}$ and in 1678 he sold his proprietary rights to Massachusetts for $£ 1,250 .^{\circ}$ After the revocation of the charter of Massachusetts he claimed that the title to Maine had reverted

1 Petition of Ferdinando Gorges, April 4, 1661, Gorges Papers, II, 195-197.

2 Report of J. Palmer, June 3, 1664, Gorges Papers, II, 201-203.

3 Royal Proclamation, June 11, 1664, Gorges Papers, II, 206.

4 Commission to Fran. Champermann, Henry Jossilyn and others, June 21, 1664, Gorges Papers, III, 309-310.

5 Acts, Privy Coun. Col., I, 690, 725-726.

6 Maine Hist. Soc. Col., 2d series, VII, 343-350, 351-356. Already, in 1676, Gorges had offered to sell his rights to the crown for $£ 1,000$ cash and $£ 10,000$ in five annual payments. Gorges Papers, II, 213. 
to himself. ${ }^{1}$ No attention was paid to this petition by those who drafted the charter of 1691 , which, by including Maine in the territories assigned to Massachusetts, definitely put an end to any attempts to reserve quit-rents in this region. ${ }^{2}$

The claims of Robert Mason, the heir of Captain John Mason, in New Hampshire were not so easily disposed of. With much greater persistence than Gorges he attempted to revive these proprietary rights, but only to meet ultimate defeat because of the hostile attitude of the New Hampshire settlers toward feudal dues. The struggle began in 1661 when Robert Mason secured a decree that upheld his title to all vacant tracts in New Hampshire, and permitted him to secure by suits an adjustment of his claims to settled lands. ${ }^{3}$ No immediate steps were taken to enforce this decree, though the king included an investigation of Mason's claims in the instructions to the commission sent to New England in 1664. Mason continued to press his claims, but definite action was delayed, chiefly owing to the determined opposition of Massachusetts. Finally in 1674 the crown's attorneys, after a careful examination, reported in favor of Mason's proprietary rights in New Hampshire."

The enforcement of Mason's claim now came into conflict with the attempt of Massachusetts to extend its jurisdiction over New Hampshire, an attempt which Mason naturally resisted, since its success would have ended all his rights in the colony. The crown adopted a just policy, calling the attention of the people of Massa-

1 Petition of Ferdinando Gorges, July 30, 1691, Gorges Papers, II, 217 221; Thorpe, Constitutions and Charters, 3, 1876-1877.

2 The charter of 1691 of course ended the attempts of New York to reserve quit-rents in Pemaquid. See p. 112.

3 Mason Papers, p. 49.

4 Ibid. 
chusetts to the revival of Mason's claims, and asking that someone be sent to England to represent the popular side. ${ }^{1}$ No effort seems to have been made to act upon this suggestion, and the organization of New Hampshire as a separate royal colony in 1679 marked the definite triumph of Mason. The instructions to John Cutt, president of the council, in 1680 ordered him to aid in enforcing Mason's claims, but forbade any arbitrary or oppressive measures. Mason agreed to waive all arrears of quitrents up to June 24,1679 , and to confirm all titles, provided the patentees promised to pay a quit-rent of $6 \mathrm{~d}$ in the pound on the yearly value of all improvements and cultivated lands. For vacant lands Mason was permitted to propose such conditions as he saw fit. Should the inhabitants of New Hampshire, however, refuse to come to an agreement with his agents, and should the governor and council fail to secure a settlement, the dispute was to be referred to the crown for final adjustment. ${ }^{2}$ This last restriction, especially, was not very scrupulously observed by Mason who came himself as secretary of the province in 1680, and impatiently began to push his elaims. By their demands for the quit-rents his agents caused great uneasiness in the province, for they ignored the restrictions imposed by the crown, and threatened to sell the houses of persons who would not settle promptly with the proprietary. The council refused to countenance such action and appealed to the king. ${ }^{3}$

In order to enforce his rights Mason now attempted to coerce the officials of the royal government, a course in which he was greatly aided by the death of Cutt and the

1 King to Corporation of Boston, December 18, 1774, and March 10, 1676, Gorges Papers, II, 210-213; C. O. 324: 18, pp. 282-283.

2 Acts, Priv. Coun. Col., I, 854-855; Thorpe, Constitutions and Charters, 4, 2450-2451.

3 Mason Papers, p. 111. 
removal from office of a number of the members of the council. With the appointment of Cranfield as governor in 1682, the stage was set for a high-handed effort to compel the inhabitants of New Hampshire to pay their quit-rents. Cranfield, whose help was assured by an allowance of one-fifth of the quit-rents in part payment of his salary, gave Mason ample aid in whatever measures were necessary, ${ }^{1}$ but the people of New Hampshire, like their fellow colonists in Massachusetts under the Andros government, sturdily opposed this aggressive policy. Their attitude was voiced by Elias Stilemon who, in answer to a demand that he should pay quit-rents and take out a deed from Mason, asserted that he had bought his land and had enjoyed undisturbed possession of it for fifty years, and, being himself in possession, would contest the right of anyone else, by trial "upon the place," according to statute law. Moreover, as he pointed out, if Mason's claims were upheld, the latter would even gain possession of the town commons, which had always been used to pasture cattle and to procure timber and firewood. There was, he added, no justification for these proprietary claims in the allegation that Mason's grandfather had spent large sums of money in founding the colony inasmuch as, if he had come at all, it had been merely on a fishing expedition or to secure the beaver trade. Rather than pay quit-rents upon the basis of

1 Council Minutes, January 2, 1684, N. H. Prov. Papers, I, 555; Palfrey, History of New England, III, 407-408. Mason's intention to make of his proprietary claims a valuable source of income is illustrated by a deed, October 2, 1683, for 256 acres to George Broughton, Richard Otis, and James Chadbourne. A quit-rent of $10 \mathrm{~s}$, or approximately $4 \mathrm{~s}$ per 100 acres, was reserved and an additional rent of $1 \mathrm{~s}$ was to be paid for each dwelling, over four, on the property. Also, Mason reserved all pine trees which at ten feet from the ground were thirty-four inches in diameter and were fit for masts. N. H. Prov. Papers, I, 470-471. 
such a claim, Stilemon stoutly maintained that he would appeal to the crown. ${ }^{1}$

Meanwhile, the efforts of Mason, supported by Cranfield, seem to have been to overawe the colonists. In utter disdain of the appeal allowed to the crown in case no settlement could be secured, he instituted numerous lawsuits against landholders, including one against Major Waldron who, as president of the council, had been superseded by Cranfield. ${ }^{\circ}$ By a passive attitude, offering no evidence and asserting no title in reply, the defendants virtually denied the legality of these proceedings. Under such conditions judgment was invariably in Mason's favor, and from seven to twelve cases were disposed of in a single day. But when the officers attempted to carry out the court's orders, the real spirit of resistance manifested itself. In the few instances where they levied executions they could neither give possession, nor find purchasers, and the lands remained in control of their owners. At Dover several officers, who had been driven off while attempting to levy an execution, returned on the Sabbath armed with warrants for the arrest of the rioters. The tumult that ensued was ended by a young girl who promptly knocked down one of the officers with her Bible. ${ }^{2}$ Faced by such forcible manifestations of popular hostility, even Cranfield declared that the thirty or forty executions which Mason had secured were useless, and that to enforce them by a posse might "bring blood and confusion.", Moreover, Cranfield found that "through the perverse obstinacy of the most part of the inhabitants," his own share in the quit-rents had failed

1 Answer of Elias Stilemon, November 15, 1682. N. H. Prov. Papers, I, 509 et seq.

2 N. H. Prov. Papers, I, 514-515.

3 Palfrey, History of New England, III, 415-416, note. 
to materialize. ${ }^{1}$ Mason, too, acknowledging that the effort to enforce the quit-rents by arbitrary acts had failed completely, was willing finally to refer all disputes to the crown according to his agreement. ${ }^{2}$

Already the people of New Hampshire, by their agent, Nathaniel Weare, had appealed to the crown against the arbitrary conduct of Mason and Cranfield. ${ }^{3}$ In his representation of grievances Weare pointed out that the efforts to force quit-rents upon New Hampshire had not deceived the people, for Cranfield had failed to observe the royal order to refer Mason's claims to the crown if an agreement could not be reached, and, with a personal interest in enforcing these rights, had "made courts whereof both judges and jury have agreed with Mason for their own lands and some of them have even taken grants from Mason of other men's lands.' The judges also, he declared, ignoring several pleas, had refused to read certain statutes, and under color of this show of legality had awarded Mason damages in suits against forty persons. The execution of these judgments, Weare continued, had turned a number of persons out of their lands, and had led to encroachments upon the rights even of those who had yielded and had taken out new titles with quit-rents. ${ }^{4}$ Weare's representation of the illegal proceedings instituted in New Hampshire resulted in an order by the Lords of Trade that Cranfield should suspend all suits to enforce Mason's rights. At the same time they administered a severe reprimand to Cranfield for his unlawful conduct in permitting titles to be sued out in court

1 Council Minutes, January 2, 1684, N. H. Prov. Papers, I, 555.

2 Proposals of Robert Mason, October 15, 1683, and Proclamation of Cranfield, February 17, 1684, N. H. Prov. Papers, I, 475, 476.

3 Palfrey, History of New England, III, 415.

4 Complaint of Nathaniel Weare to Crown, 1684, N. H. Prov. Papers, I, 516-519; Belknap, History of New Hampshire, Appendix, pp. 505-506. 
and judgments to be enforced without an appeal to the crown, as the agreement with Mason required. Such a rebuke put an end to Mason's high-handed attempt to use the royal government in New Hampshire as a means of coercing the inhabitants into an acknowledgment of his rights. ${ }^{1}$

As the resistance of the people in New Hampshire, which culminated in the overthrow of Cranfield, plainly showed the futility of attempting to enforce proprietary rights, Mason in 1690 sold his claims to Samuel Allen, a merchant of London, ${ }^{2}$ who seems to have believed that he might realize some substantial rewards from his purchase, a belief in which he was encouraged by the failure of the charter of 1691 to include New Hampshire in Massachusetts. ${ }^{3}$ But such optimistic views were doomed to a swift disappointment, for even the continuance of New Hampshire as a separate royal colony made no provisions for the reservation of quit-rents. Though the Privy Council sent orders to ensure Allen's rights a fair trial in court, it must have realized that little consideration for claims to proprietary dues was to be expected from a New Hampshire jury. ${ }^{4}$ Nor could the governor hope, without a great display of force, to carry out any decision that was in Allen's favor. That the use of force was no part of the policy of the British government appears from the fact that the Privy Council in 1705 refused to reopen a suit that had been appealed from New Hampshire. ${ }^{5}$ Ultimately, Allen's claims were sold

1 Board of Trade to Cranfield, April 29, 1685, N. H. Prov. Papers, I, 572-573.

2 Mason Papers, pp. 51-52.

3 The failure to include New Hampshire in the bounds of Massachusetts was probably due to Allen's influence. Channing, History of the United States, II, 285-286.

4 Acts, Privy Coun. Col., II, 366-367, 423-424.

5 Ibid., II, 367. 
to a number of proprietors who after making numerous grants, all of them without quit-rents, ${ }^{1}$ offered in 1746 to sell their remaining shadowy rights to the assembly. The prompt shelving of this offer by the committee to whom it was referred marked the final downfall of efforts to revive the proprietary claims of Captain John Mason. ${ }^{2}$

But the reservation of quit-rents in New Hampshire was not wholly abandoned, for in 1741 such a charge had been included in the conditions governing the settlement of lands west of Mason's claims, which were added to the colony at that time. In fixing the rate the British government did not wholly ignore the opposition that had arisen to Mason's claims. The Board of Trade wished to reserve $4 \mathrm{~s}$ per 100 acres, but the Privy Council held that, as the land in the neighboring province of Massachusetts was altogether free of such dues, so high a quit-rent would discourage intending settlers, and it instructed Governor Wentworth to reserve but $12 \mathrm{~d}$ per 100 acres on these frontier holdings. ${ }^{3}$ This quit-rent was collected in part at least by Governor Wentworth and the proceeds were employed for public purposes." As no attempt was made to extend the charge to the older parts of the colony where Mason's claims lay, we see that the Massachusetts land system, with its characteristic freedom from all

1 Belknap, History of New Hampshire, pp. 297, 299.

2 Letter from Proprietors of Mason Claims, September 4, 1746, N. $H$. Prov. Papers, V, 834, 835.

3 Acts, Privy Coun. Col., III, 696-697; Abstract, Instructions to Governor Wentworth, August 7, 1741, Brit. Mus., Addit. MSS. 30372, f. 57. On a few grants after 1727, probably by the proprietors who had purchased Allen's rights, there were such nominal acknowledgments as an ear of Indian corn, or a grain of flaxseed, but only on grants west of Mason's claim was there a quit-rent of 1 s per 100 acres reserved after 1741. Grants to Townships in New Hampshire, 1764, C. O. $5: 929$, f. 3.

4 By 1772 Governor Wentworth had expended $£ 500$ from the quit-rents in building roads. Treasury to Hillsborough, July 16, 1772, C. O. 5: 145, p. 20 . 
feudal dues, finally prevailed through all New England. As far as it eoncerned the province of New Hampshire, the reason for this is clear. As long as Robert Mason enjoyed the close coöperation of Governor Cranfield, he was able to compel the people of the colony to listen to his proprietary claims, but with the loss of his official influence he became merely a private person, seeking to enforce unpopular demands and receiving from the royal administration only a lukewarm support.

The proprietors of the Northern Neck in Virginia and of the Granville Grant in North Carolina were more successful in building up their estates as private colonial proprieties. Their success was partly due to the difference in local conditions and a more favorable atmosphere. In New Hampshire Robert Mason and his successors undertook to establish long dormant claims and to collect for their personal profit a charge which the people had never before paid. But in Virginia and North Carolina quit-rents had been reserved since the earliest settlements, ${ }^{1}$ and the chief innovation introduced when these proprietary grants were made was the transfer of the payments from the crown to private proprietors. There was no outside exemplar like Massachusetts to arouse hostility to the quit-rents. Yet even under such satisfactory conditions these proprieties were unpopular and the people of Virginia and North Carolina, like those of New Hampshire, opposed the paying of quit-rents to private individuals as something out of keeping with a

1 In a petition of Henry Horsey to the king, September 2, 1639, the quit-rent in Virginia is stated to be $12 \mathrm{~d}$ on every 50 acres, but the petitioner added that it had never been paid. Cal. State Pap. Col. 1574-1660, p. 302. Bruce, very erroneously, calls the quit-rent a tax. Bruce, Institutional History, II, 575. In 1637 Jerome Hawley, brother of the governor of Barbadoes, was appointed treasurer of Virginia and instructed to receive the quit-rents in the province. Maryland Fund Publications, 28, p. 153. 
country where life was free and land was cheap and plentiful. In North Carolina, especially, there was a noticeable lack of coöperation between the proprietary agents and the royal officials, although the former were obliged to depend on the latter for the enforcement of their demands.

In Virginia much of the opposition to this transfer of proprietary control from the crown to a private person was due in part to the careless way in which the quitrents had been collected from the beginning, and in part to the custom prevailing in Virginia of spending what little was received for purposes of local administration. A proprietary would probably enforce collections much more rigidly and of course appropriate the income to his own private needs. When, therefore, in 1672, the king granted the quit-rents of all Virginia for thirty-one years, including all arrears since 1669, to Lord Culpeper and the Earl of Arlington, the colony took alarm. ${ }^{1}$ It deemed the grant "contrary to his Majesties service and destructive to their peace and welfare," for the new proprietors, in addition to issuing patents and collecting the quit-rents in specie for thirty-one years, were authorized to name the sheriffs and other local officers. ${ }^{2}$ The assembly promptly appointed commissioners to go to London, in order to represent "the grievous pressures likely to grow upon us," to seek an annulment of the grants, and to ask for a new charter which would remove

1 Already in 1649, Charles II had issued to Lord Culpeper and his associates a grant, which, renewed in 1669 , conveyed full proprietary rights except those of government in the region between the Potomac and Rappahannock rivers, commonly known as the Northern Neck. This grant had never been acted on. Osgood, American Colonies, III, 248-249; Grant made at St. Germain, August 16, 1649, to Lord Culpeper and his associates, Brit. Mus., Addit. MSS. 37047, f. 25.

2 Hening, Statutes at Large, II, 427-428. 
all fears of being taken "from His Majestie's immediate protection." For the expenses of this commission heavy taxes were levied ${ }^{1}$ which, together with the general hostility against a propriety, helped to swell the discontent that culminated in Bacon's Rebellion. ${ }^{2}$

Soon after their arrival, the commissioners reached an agreement with the proprietaries that the assembly should sanction the rights of the latter to collect quit-rents and assume escheats. As the rate at which tobacco would be received proved a knotty problem, the proprietaries proposed that the colony of Virginia should purchase their rights in the Northern Neck. This solution was accepted, and it was agreed that each claimant should receive $£ 400$ for his rights. ${ }^{3}$ Next the commissioners drew up a charter the terms of which permitted the purchase of the Northern Neck, and guaranteed that quit-rents from the remaining lands of Virginia should be paid directly to the crown. This charter revoked the grant of 1672 and forbade "surreptitious proprietary grants" in the future, ${ }^{4}$ but though favorably reported on by the Lords of Trade and twice ordered to pass under the great seal, the news of Bacon's Rebellion stopped its further prog-

1 For the next two years, a levy of $70 \mathrm{lbs}$. of tobacco was made upon every cause in the general court, and $50 \mathrm{lbs}$. in the county courts. Also, there was a poll tax of $50 \mathrm{lbs}$. of tobacco. Act, September, 1674, Hening, Statutes at Large, II, 311-314.

2 Andrews, Narratives of the Insurrections, p. 107; Beverley, History of Virginia, p. 61. The fear that the quit-rents would be more energetically collected under private ownership seems to have been the chief canse of the opposition to a propriety. Beer, Old Colonial System, Part I, I, 194-195.

3 This deed included only the Northern Neck, the grant to which does not seem to have been disputed. Burk, History of Virginia, II, Appendix, xxxv, xli-xliv, liii-liv.

4 There was an express provision that the governor and council must be consulted before any further proprietary grants could be made. Hening, Statutes at Large, II, 523-524. 
ress. ${ }^{1}$ It is possible that if Virginia had been permitted to purchase the quit-rents of the Northern Neck, a land system similar to that of Massachusetts would have come into being, for in all probability the quit-rents of the rest of Virginia would ultimately have been taken over by the colony, thus establishing virtually free tenure of land. That the British government foresaw this result is a possible deduction from the fact that the charter which finally passed contained no reference to the troublesome proprietary grants. ${ }^{2}$

Though the violence of Bacon's Rebellion soon quieted down, the people of Virginia did not abate their opposition to a private propriety in the province. Collections of the quit-rents were small, and in 1679 a petition was sent the crown for a release from the burden of arrears. ${ }^{3}$ Another petition in 1683 asked that the crown purchase the quit-rents of all but the Northern Neck, since there was no other fund "for the least emergent occasion." Ignoring such evidences of the popular attitude Lord Culpeper, who was now sole proprietary, ordered the sheriffs to collect the quit-rents, and "to require the light"' of every person's patent. ${ }^{5}$ That compliance with these orders was a difficult matter became evident when the burgesses were asked to repay 98,000 pounds of tobacco which Lord Culpeper had advanced out of the quit-rents for military purposes. Considering this sum

1 Hening, Statutes at Large, II, 527-531.

2 The commissioners from Virginia were expressly forbidden to expend, without permission, the money raised from the special levies. This order of course prevented them from carrying out the proposed purchase of the Northern Neck. Hening, Statutes at Large, II, 431-432, 531-532; Beverley, History of Virginia, p. 61.

3 Bruce, Institutional History of Virginia, II, 576.

4 Address, Council of Virginia, May 4, 1683, C. O. $5: 1356$, ff. 184-185.

5 Sainsbury Abstracts, XVIII, 75; Cal. State Pap. Col., 1681-1685, p. 361; Hening, Statutes at Large, II, 521; Va. Mag. of Hist., XVIII, 362. 
as "well paid, being for the public use," the burgesses, "after serious debate and consideration," reported that, "no good and rightful power doth appear for the receiving of the quit-rents by His Lordship." Therefore, in an address to the king they prayed that the quit-rents be used solely "for the defense and other public uses of this your Majesty's Dominion." When the governor, Lord Howard, undertook to uphold Lord Culpeper's claims, the burgesses stoutly asserted that his demand for this repayment of advances from the quit-rents conflicted with the charter of 1676 , which guaranteed direct dependence upon the crown. Even in face of the governor's threat to collect all arrears of quit-rents by force, they refused to make a levy which would settle Lord Culpeper's claims. The controversy was finally ended by a resolution that the 98,000 pounds of tobacco should be paid by the counties in which it had been disbursed, an order which probably never was, and had not been intended to be carried out. ${ }^{2}$

Aroused by the discord thus created, the British government renewed negotiations to resume the proprietary grants ${ }^{3}$ in Virginia, and in 1684 purchased all of these rights excepting those of Culpeper in the Northern Neck. ${ }^{4}$ This measure settled in part the vexatious problem of a propriety in Virginia, but the opposition

1 Proc. Va. House of Burgesses, May 4 and 18, 1684, C. O. 5: 1407, ff. 161$162,185$.

2 Proc. Va. House of Burgesses, May 18 to 21, 1684, C. O. $5: 1407$, ff. 186 197, 203-204.

3 King to Lord Culpeper, August 4, 1680, and Minute of Privy Council, 'August 17, 1681, Blathwayt's Journal, I, 56-58, 122-123.

4 Culpeper received $£ 700$ in cash, and $£ 600$ annually in payment of the remaining twenty-one years of his grant and of the arrears of his salary as governor. Royal Warrant, June 24, 1684, and Culpeper's Surrender, May 27, 1684, Blathwayt's Journal, I, 179-183, 188. The $£ 600$ was paid from the funds appropriated for the military establishment in England, as an annuity payable for twenty-one years. Andrews, Guide, II, 287. 
that had been aroused created such an impression that, upon the recommendation of the Lords of Trade, the Privy Council decided to prohibit for the future any private grants of the quit-rents in the American colonies. Its future policy, the council declared, would be to reserve such dues for purposes of local government, "as they were originally intended." This important declaration meant that the principle of direct dependence upon the crown would be upheld, and that henceforth the quitrents of settled colonies, instead of being parcelled out in arbitrary fashion to private beneficiaries, royal officials or adherents in England, were to be conserved as an essential part of the royal revenue. The one important exception to this rule was the Granville Grant in North Carolina, and this exception was made to settle an existing and vexatious proprietary claim.

As the British government had not included the Northern Neck in the purchase of Culpeper's claims, the House of Burgesses petitioned that the inhabitants of this section might be allowed to hold their lands in direct dependence upon the crown, as was the custom elsewhere in Virginia. $^{2}$ That this petition represented popular sentiment became evident when many persons in the Northern Neck refused to pay their quit-rents, upon the pretext that a confirmatory patent issued to Lord Culpeper by James II in 1688 was not valid. Culpeper's heirs intimated that this refusal was upheld by the governor and council, and they secured a royal order requiring all papers relating to their rights to be for-

1 Acts, Privy Coun. Col., II, 21-22; Board of Trade Journal, August 10, 1681, Cal. State Pap. Col. 1681-1685, p. 100.

2 Proc. Va. House of Burgesses, April 26, 1684, and May 21, 1691, C. O. 5: 1407, ff. 134-136, 771-773: Spence to William Blathwayt, June 18, 1685, and Representation of Council of Virginia, April 21, 1685, C. O. 5: 1356, ff. 331-334. 
warded to Virginia for an investigation. ${ }^{1}$ Thereupon the governor and council instructed the proprietary agent to transcribe all the records in his office and at the same time directed the landholders of the Northern Neck to hand in copiès of their grants. Such unwarranted requirements so alarmed the people of the Northern Neck that many of them refused to pay their quit-rents and displayed much irritation. Judging from the previous attitude of the governor and council, this was the very situation they desired to create in order to force the crown to take over the proprietary rights in the Northern Neck. If such were their aims, they failed completely, for after the British attorney-general had upheld the patent of 1688, the king issued another order declaring that Culpeper's heirs should enjoy, unmolested, the exercise of their proprietary rights. ${ }^{2}$ Determined to put an end to these rights, the burgesses presented another petition maintaining that inasmuch as Culpeper had incurred no expense in the settlement of the Northern Neck, his heirs had no valid claim upon the quit-rents. Therefore, they asked, "in the name of ourselves and of the whole country" for a settlement of these claims, ${ }^{3}$ but this petition like the others proved fruitless.

Except for the natural objection which the colonists had to dependence upon a proprietary rather than the crown, there was no valid reason for setting aside the patent to the Northern Neck. Lord Fairfax, who by his

1 Petition of Margaret, Lady Culpeper, Thomas, Lord Fairfax and his wife Katharine, and Alexander Culpeper, about 1691, and Orders of Privy Council, May 21 and July 30, 1691, Wilmington Papers, 1675-1736.

2 Petition of Culpeper heirs (see above) about 1692, Orders of Privy Council, December 8, 1692, to January 26, 1693, and Report of Attorneygeneral, January 11, 1693, Wilmington Papers, 1675-1736.

3 Proc. Va. House of Burgesses, April 20, 1692, and May 10, 1695, C. O. 5: 1407, ff. $871,887,1261-1266$. 
marriage with Lord Culpeper's daughter came into control of the propriety, administered it with great moderation. $^{1}$ He retained the quit-rent usual in Virginia, while demanding purchase money that was in most cases less and never more than that charged for crown lands. ${ }^{2}$ The measures which he adopted for collecting the quit-rents did not differ essentially from those that were customary elsewhere in Virginia, although he employed special collectors, rather than the sheriffs, and assigned to each either one or a number of counties. ${ }^{3}$ So tactful an administration gradually quieted the opposition that had at first arisen, and caused the propriety of the Northern Neck to be accepted as a settled institution. Nevertheless, to the crown the extinction of these private rights was desirable, in view of the material reduction they made in the quit-rent revenue from Virginia. An opportunity to bring this about was offered in 1709 when Lord Fairfax proposed to exchange the Northern Neck for an estate in England. Though the auditor-general, William Blathwayt, recommended this settlement as one that would allay discontent and increase the royal revenues, the British government did not see fit to adopt his suggestion. ${ }^{4}$

As settlement gradually spread westward, a controversy arose between Lord Fairfax and the royal government in Virginia over the exact boundaries of the

1 Va. Mag. of Hist., I, 223.

2 The purchase money for tracts under 600 acres was 5 s per 100 acres, or half the rate usual after 1705 on erown-lands in Virginia. On large tracts the rate was 10 s per 100 acres. Bruce, Economic History of Virginia, I, 568-569.

3 Estate of Thomas, Lord Fairfax, Executors' Accounts, 1781-1798.

4 The estate for which the Northern Neck was to be exchanged comprised the lott and cope and the office of burgomaster in the wapentake of Werkesworth in Derbyshire. Blathwayt's report, January 22, 1709, Blathwayt's Journal, II, 544-548. 


\section{PROPRIETARY QUIT-RENTS}

Northern Neck. The patent of 1688 conferred upon Culpeper proprietary rights over all lands between Chesapeake Bay and the Rappahannock and Potomac rivers from their sources. ${ }^{1}$ The first difficulty was whether the north or the south branch of the Rappahannock, the latter usually called the Rapidan, was the source of that river. In 1686 Lord Culpeper granted 30,000 acres within the disputed area, and when the governor of Virginia likewise issued patents in this region the proprietary heirs protested against such infringement upon their rights. Though commissioners, appointed in 1706 to adjust the boundary, reported that both branches of the Rappahannock were of an "equal magnitude," the governor of Virginia continued to make grants within the lands in dispute. When settlement began in the Shenandoah Valley, the source of the Potomac became the subject of an additional controversy involving the acknowledgment of the proprietary rights over the region west of the Blue Ridge. Finally, in 1733, the younger Thomas, Lord Fairfax, who had succeeded to the rights of his grandfather, Lord Culpeper, petitioned the crown for the appointment of a commission to ascertain the exact boundaries of the Northern Neck, and for a royal order restraining the governor of Virginia from making grants in the disputed area. This petition was granted, but before the royal order was received in Virginia, the governor made a number of grants contrary to its terms. ${ }^{2}$

Armed with the royal order, Lord Fairfax came to Virginia in 1735. His representatives met those of Vir-

1 This patent from James II granted the lands between the "first heads or springs" of the Rappahannock and Potomac rivers, and Chesapeake Bay, together with the rivers themselves and their islands, "as they are commonly called and known by the inhabitants and descriptions of these parts.', Copy of Report of Board of Trade, July 27, 1739, Fairfax Papers, 1739-1751.

2 Acts, Privy Coun. Col., III, 385-386. 
ginia, September 26, 1736, but the two commissions could not agree. The commissioners for Virginia contended that the north branch of the Rappahannock was wider at its mouth than the south branch, while the representatives of Fairfax asserted that the latter was the larger stream. Furthermore, the proprietary commissioners secured affidavits to prove that twenty years before, Governor Spotswood had changed the name of the south branch to Rapidan, although it had previously been known as the southern fork of the Rappahannock. The two commissions disagreed likewise as to the source of the Potomac. ${ }^{1}$ In their final report the commissioners for Virginia held that the boundary line between the Northern Neck and the crown lands was marked on the north by the northern branch of the Rappahannock and on the west by a straight line from the head of this stream to the confluence of the Shenandoah and the Potomac. As the Potomac above this point was known to the Indians as Cahongaronton, the commissioners held that the confluence with the Shenandoah was its true source. On the other hand, the commissioners for Lord Fairfax maintained that as the south branch was the actual source of the Rappahannock, the boundary should run from the headwaters of this stream in a straight line to those of the Potomac. ${ }^{2}$ After a full consideration of

1 The representatives of Fairfax pointed out that the commissioners for Virginia had measured the mouth of the south branch from an island, and had omitted an additional stream which was over thirty feet wide. Minutes, Commissioners relative to Lord Fairfax's claim to the Northern Neck, September 26-November 17, 1736. Virginia MSS., Library of Congress.

2 The land between the boundaries proposed by the two commissions comprised roughly a part of Stafford and Culpeper counties and most of the Shenandoah Valley below the Massanutten Range. It should be noted that the commissioners for Fairfax accepted the south branch of the Potomac as its source. Copy of Report of Board of Trade, July 27, 1739, Fairfax Papers, 1739-1751. 
the two reports, the Privy Council in 1745 accepted the boundary that was fixed by the commissioners for Lord Fairfax. A royal order was then issued forbidding the governor of Virginia to make further grants within this region, and directing Lord Fairfax to exercise his full rights over these lands. Fairfax for his part agreed to recognize all grants which had been made by the governor in the disputed area and to give up all claims to the arrears, provided the quit-rents were paid him in the future. ${ }^{1}$ These terms were embodied in an act passed by the assembly in 1748 to safeguard titles in this section. ${ }^{2}$ A further evidence of the good feeling with which this controversy ended was the issue of a royal warrant for $£ 1,23516$ s 11d from the quit-rents in payment of the survey to fix the boundaries of the Northern Neck.

The prolonged controversy over the boundary of the Northern Neck was the origin of a suit against Lord Fairfax filed in 1749 by Joist Hite, one of the pioneers of the Shenandoah Valley, and his associates. Hite, it seems, in 1730 bought out the claims of Isaac and John Vanmeter to 40,000 acres for which they had secured an order in Council. Later Hite obtained a similar order for 100,000 additional acres upon condition that within two years he should settle one hundred families upon the tract. Relying upon the good faith of the government of Virginia, he left his home near Philadelphia, with a number of families whom he induced to accompany him, and settled in the Shenandoah Valley. Though subjected to much inconvenience by conflicting grants from Fairfax, by 1734 Hite had complied with the conditions for the settlement of the Vanmeter tract. At this time the

1 Acts, Privy Coun. Col., III, 388-391.

12 Act, October, 1748, Hening, Statutes at Large, VI, 198-199. 
council extended the limit for settling the 100,000 acres, but in 1736 Lord Fairfax filed a caveat against the issue to Hite of grants for these lands. Hite, who had given bonds for several thousand pounds to ensure a safe title to the settlers who came with him, immediately applied to Fairfax for a confirmation, and Fairfax informed him that as the question was merely one of the quit-rents, he would confirm all grants if these dues were paid. To this arrangement Hite agreed, but after the final settlement of the boundary controversy in 1745, which showed that almost all of the 140,000 acres was included in the Northern Neck, Fairfax delayed doing his part, although Hite stood ready to pay the quit-rents and any other charges demanded.

Meanwhile Fairfax began to issue patents to other persons for land within the 140,000 acres claimed by Hite, asserting that the act passed in 1748 was intended to confirm only the grants that had actually been made in the name of the crown. This act, Hite maintained, had been secured in a surreptitious fashion by Fairfax's agents in order to bar his own claims. As he could not secure a confirmation from Fairfax, he was unable in his turn to confirm the titles of the settlers on his lands, and they refused to release him from his bonds. Though Hite sent a list of these settlers, Fairfax ignored his rights by posting a public notice that all persons who desired grants might apply at the proprietary land-office. In view of these proceedings, Hite prayed that Lord Fairfax should be compelled to issue patents to him and his associates for the 140,000 acres, and that all persons who had taken out grants in this tract under Fairfax patents should be compelled to deed their lands back to him. If the court agreed to these terms, Hite promised to pay Lord Fair- 
fax the same quit-rents as were due elsewhere in Virginia, together with any other charges for the land. ${ }^{1}$

In answer to these representations Lord Fairfax asserted that, although Hite had fulfilled the conditions for the Vanmeter tract, the order in Council had been secured after he himself had refused a patent owing to a prior grant. The order for the 100,000 acres, he declared, had not been in accordance with the laws of Virginia for granting land, nor had Hite complied with the conditions that had been arbitrarily fixed. Moreover, Fairfax complained, Hite had sold lands to the highest bidder, and had allowed surveys to be run in such a fashion as to include only the most valuable and wellwatered land. Consequently, what was left was for the most part worthless. Asserting that he had given Hite ample opportunity to appear and protect his claims, Fairfax repudiated the charge that he had used underhand methods in order to secure the act passed in 1748. This act, he pointed out, confirmed actual grants by the crown, and not claims, like that of Hite, which were based upon mere orders in Council. As proof that he desired to come to an understanding with Hite, he cited similar cases of questionable claims that he had settled in an amicable fashion, and denied that he had issued grants, except to waste lands, in the tract claimed by the defendant. ${ }^{2}$

The hearing of this suit was greatly delayed, chiefly owing to a caveat filed by Fairfax against all orders in Council and patents from the crown for lands in his propriety. Finally, in 1771, the general court issued a decree which held that Hite and his associates were en-

1 Bill filed by Hite and MeCoy before Court of Chancery (about 1749), Fairfax MSS.; Cartmell, History of Frederick County, pp. 6-7, 12-13, 518.

2 Answer of Thomas, Lord Fairfax, to Bill of Complaint of Joist Hite and others, filed in Frederick Co., March 22, 1750, Fairfax MSS. 
titled to the 40,000 acres included in the Vanmeter claim, and to 54,000 of the additional 100,000 acres. The decree required all persons who had purchased land from Hite, but secured deeds from Fairfax, to pay the former the balance of their purchase money and to release him from the bonds guaranteeing their titles. Other persons who had received grants from Fairfax within the tract awarded to Hite were to pay the latter $£ 3$ per 100 acres purchase money with interest. For the remaining lands, the decree required Lord Fairfax to give deeds to Hite and his associates who should then pay the usual proprietary quit-rents. ${ }^{1}$ As the decree allowed an appeal to the Privy Council its execution was delayed, and in 1786 the court confirmed the claims of Hite and his associates, provided they complied with an order to retain their surveys. Numerous suits for ejectment which had been filed by Fairfax were dismissed by a decision that his heir had no claim upon lands west of the Blue Ridge, for which grants had been issued prior to 1738 . The importance of these proceedings is evident from the number of settlers, over 500, whose titles were involved. ${ }^{2}$

The long delay in settling Hite's suit caused great losses in the quit-rents from the valuable section of the Northern Neck that was included in his claims. In fact, throughout the entire Fairfax propriety the quit-rents were very indifferently collected, owing to the neglect of the receivers, and in consequence a considerable sum in arrears accumulated. The situation became so bad that in 1771 Lord Fairfax ordered the receivers to levy the quit-rents by distress, if necessary, unless the landholders paid their charges more promptly. In case there

1 Copy of Decree of General Court held at Williamsburg, October 15, 1771, in Case of Hite vs. Fairfax, Fairfax MSS.

2 Cartmell, History of Frederick County, p. 518. 
was no distress available, he required the receivers to demand the quit-rents either from the owner or from his attorney, according to a carefully prescribed procedure. Collections were to be made either in sterling, or in current money of Virginia at an exchange of 25 per cent. advance, or else in tobacco at the rate of thirty pounds per 100 acres. In addition, the instructions contained provisions designed to secure exact accounting and to prevent such careless practices as the receipt by a receiver of the quit-rents upon land which was not included in his district. ${ }^{1}$

The absence during the later colonial period of ill feeling toward the collection of quit-rents in the Northern Neck was shown in 1777 when the assembly abolished Fairfax's propriety. In order to equalize burdens throughout the state, this act of assembly allowed the landholders of the Northern Neck a deduction of $2 \mathrm{~s} 6 \mathrm{~d}$ current money per 100 acres from their taxes. This deduction, according to the act, was to be assessed upon the Fairfax estate, ${ }^{2}$ an arrangement which secured the rights of Lord Fairfax, a resident of Virginia since about 1746, and lasted until his death, March 12, 1782. As he willed his estate in Virginia to his nephew, Rev. Denny Martin Fairfax, a British citizen, the assembly directed the landholders of the Northern Neck to retain the arrears of their quit-rents as a part of the sequestered estate of an alien, and to pay these dues in the future into the public treasury. ${ }^{3}$ Seven months later another act removed this sequestration, so far as it concerned the arrears of quit-rents due at the death of Lord Fairfax. ${ }^{4}$ In

1 Instructions to Collectors of Quit-Rents, from Thos. Benj. Martin, April 19, 1771, William Allason's Letter Book, 1770-1789, pp. 64-65.

2 Act, October, 1777, Hening, Statutes at Large, IX, 359.

3 Act, October, 1782, Ibid., XI, 128.

4 Act, May, 1783, Ibid., 289. 
1785 another act finally abolished the quit-rents in the Northern Neck and placed the landholders of this section upon the same basis as those in the remaining part of Virginia. ${ }^{1}$ That this act did not hinder the collection of the arrears due at the death of Lord Fairfax is shown by the large sum from this source which was paid to his executors. As the greater part of these arrears were collected from lands in the Piedmont region and in the Shenandoah Valley, it is probable that the inhabitants of the counties in the tidewater, which had first been settled, were accustomed to pay their quit-rents much more regularly than the residents of the back country. ${ }^{2}$

The conservatism displayed by the assembly in dealing with the quit-rents in the Northern Neck is a proof of the tact with which this propriety had been administered. This conclusion is strengthened by the lack of any violent opposition, after it became clear that the British government would take no steps to annul the patent to Lord Culpeper. The boundary controversy had been amicably adjusted, and the animosities arising from the Hite suit had been confined to that section of the Northern Neck which lay within the Shenandoah Valley. Altogether, the Northern Neck stands unique as a propriety that was administered with comparative success under a royal government.

In strong contrast with the peaceful history of the Northern Neck stands the disorderly record of the Granville Grant in North Carolina. This grant was made to Lord Carteret, who became Earl Granville, October 18,

1 Act, October, 1785, Hening, Statutes at Large, XII, 113.

2 Between 1783 and 1797 inclusive, the executors of Lord Fairfax collected $£ 5,9167 \mathrm{~s} 21 / 2 \mathrm{~d}$, probably for the most part in payment of the arrears of quit-rents due when he died. Part of this sum seems to have been secured by suits that were filed against delinquent landholders, Estate of Thomas, Lord Fairfax, Executors' Accounts, 1781-1798. 
1744, to compensate him for the eighth part of the soil of Georgia and the Carolinas, which he had refused to sell at the time the Carolinas were surrendered to the crown. It included all of North Carolina between 35 degrees 34 minutes and the Virginia boundary, and formed a strip at least sixty miles wide, taking up more than half the colony, on which were settled fully two-thirds of its population. ${ }^{1}$ From every standpoint the British government made a grave mistake in settling with Carteret in this fashion rather than by an outright purchase of his claims. Already the region thus granted had become the scene of much discord, because the inhabitants claimed that under the Grand Deed to Albemarle (northern North Carolina) they should pay a lesser quit-rent than the one reserved elsewhere in the province. ${ }^{2}$ Another source of trouble was the hostility with which the landholders of this section, like those of the Northern Neck, looked upon the transfer from a position of dependence upon the crown to one of feudal subjection to a private individual. Moreover, the province of North Carolina suffered greatly by the grant to Granville, both from the loss of needed revenue and from the introduction of a new element of discord into its already troubled politics. ${ }^{3}$ One of the really serious results of the Granville grant was the opposition which the inhabitants of the propriety displayed, through their representatives in the assembly, to the enactment of the necessary laws for the collection of

1 The grant included all arrears of quit-rent and other debts due the crown in this region, and it conferred full proprietary rights except those of government. Grant to Earl Granville, October 26, 1744, C. O. 5: 370, ff. 5-20; Deed, with map, George II to Lord Carteret, September 12, 1744, Granville Papers.

2 See pp. 113-114.

3 Henry MeCulloh to Henry Pelham, November 8, 1752, N. C. Hist. Com. MSS.; Raper, North Carolina, p. 111. 
the quit-rents that were still due the crown. To pass acts that applied to only a part of the colony was a grave administrative error, yet the people of the Granville Grant bitterly opposed quit-rent laws that applied to their own lands. The agents of Granville also usually objected to such laws. ${ }^{1}$

Granville's administration of his propriety did not tend to allay the discontent that the grant aroused. At first the proprietor showed considerable interest in his new possessions and established a land-office at Edenton, from which his agents were authorized to issue grants with the reservation of either $3 \mathrm{~s}$ sterling or $4 \mathrm{~s}$ proclamation money per 100 acres, the rate established in North Carolina under the royal government. Unfortunately Granville's interest soon waned, and he entrusted the management of his propriety to agents who usually carried on their work in very slipshod fashion. They failed to make out complete rent rolls, or to keep satisfactory accounts, and were frequently charged with such irregular practices as demands for unwarranted fees and extortionate rents. Granville himself seems to have suffered considerable losses from their dishonest and careless methods. ${ }^{2}$

The arbitrary acts of Granville's agents led a committee of the assembly to report in 1755 that there had been much abuse in the granting of land, that unwarranted fees had been exacted, and that the general

1 See pp. 299, 302-303.

2 One cause of the extortion practised by these agents was the custom of allowing them a commission of 10 per cent. on all collections, with an additional 10 per cent. on all remittances to Lord Granville. This arrangement naturally led to excessive demands in order to increase collections, and to many dishonest practices. The situation was somewhat relieved in 1752 by a reduction of the commissions to 5 per cent., and by a salary of $£ 200$ for each proprietary agent (usually there were two). Coulter, The Granville District, pp. 39, 44. 
maladministration of the propriety greatly retarded settlement in that section. ${ }^{1}$ No action seems to have been taken upon this report, and as a result in 1758 a number of landholders in the Granville Grant presented to the assembly a petition which complained of the grievances they had suffered at the hands of the proprietary agents. ${ }^{2}$ After an investigation, another committee reported to the lower house that these alleged exactions, most of them in the form of unwarranted fees, had been made, not by the proprietary agents but by their deputies. The instances cited in this report showed not so much flagrant abuses as petty annoyances; consequently the petitioners voluntarily withdrew all complaints as far as the quitrents were concerned, ${ }^{3}$ and again the assembly took no action. About a month later, a number of Granville's tenants went to the house of Francis Corbin, one of the accused agents, near Edenton, and compelled him to give bond that he would surrender all the fees that he had collected unjustly. ${ }^{4}$ This incident is typical of the turmoil aroused by the alleged illegal acts of Corbin. Beside receiving extortionate fees, he was accused of having insisted upon the payment of the quit-rents in gold and silver rather than in the commodities to which the people were accustomed. There were also frequent controversies over boundaries and disputes between the different governors and Corbin. As a result many persons paid no quit-rents at all. ${ }^{5}$

Another source of trouble was a controversy between

1 Report of Committee of Assembly, N. C., January 9, 1755, N. C. Col. Rec., V, 299-300.

. 2 Council and Lower House Journals, November 25, 1758, N. C. Col. Rec., V, 1016-1017, 1042-1043.

3 Report of Committee, December 21, 1758, N. C. Col. Rec., V, 1088-1094.

4 N. C. Col. Rec., V; lvii; Raper, North Carolina, p. 113.

5 Coulter, The Granville District, pp. 44, 46, 50. 
Granville and Henry McCulloh, ${ }^{1}$ which illustrates the complications that were likely to arise from the existence of a propriety in a region where the crown had already made numerous grants. In $1737 \mathrm{McCulloh}$ received a patent for 1,200,000 acres, of which at least 475,000 acres lay in the territory that was afterwards granted to Granville. A dispute that arose over these lands was settled in 1755 by an agreement according to which McCulloh, in view of the surrender of Granville's rights over this land, agreed to pay him annually $£ 400$ in lieu of quitrents for the three years from 1757 to 1760 . After 1760 McCulloh undertook to pay the customary quit-rent, 3s sterling or $4 \mathrm{~s}$ proclamation money per 100 acres, to register in Granville's land-office all grants he made, and to surrender after a fixed time all land on which there was not an average of one settler for each two hundred acres. This agreement does not seem to have been carried out, since McCulloh later sued Francis Corbin for $£ 8,000$ of quit-rents which, he alleged, had been wrongfully collected. ${ }^{2}$ By a new agreement in 1761 , McCulloh promised to pay within six months the balance of the quit-rents due before 1760 , as a discharge of all arrears up to the date of this second settlement. For the next two years McCulloh agreed to pay $£ 400$ annually, and $\$ 450$ each year thereafter, until two years after the close of the Cherokee War. On this last date he was to retain only the land, not exceeding 300,000 acres, which he had taken up, and on it he agreed to pay the usual $3 \mathrm{~s}$ or $4 \mathrm{~s}$ per 100 acres according to the agreement made in $1755 .^{3}$

1 For McCulloh, a noteworthy figure in colonial history, see below, pp. 296-299, 331-341, 396-397.

2 Coulter, The Granville District, pp. 48-50.

3 Agreement between John, Earl Granville, and Henry MeCulloh, April 17, 1761. N. C. Col. Rec., VI, 573-574. 
In view of the confused state into which the Granville Grant soon fell it is likely that the agreement with McCulloh was not enforced. After the death in 1763 of John, Lord Granville, his son, who inherited his claims, greatly neglected his propriety. In 1766 the land-office was closed, and many persons, unable to secure titles, merely settled as squatters. ${ }^{1}$ Possessing no legal title to their lands, they refused to pay either taxes or quit-rents, and became a perennial source of trouble. ${ }^{2}$ The slightest rumor that Granville was planning to assert his rights aroused these people, who declared that they "would perish in resistance" rather than leave their lands. The only remedy for the situation, according to Governor Martin, was the purchase by the crown of Granville's interests. Such a measure, he believed, would appease the people, establish a uniform quit-rent throughout the province, and increase the royal revenues by the addition of the proprietary quit-rents, which were estimated in 1766 as worth $£ 6,000$ annually if collected. ${ }^{3}$ Had not the Revolution intervened, it is probable that the British government would have followed this advice as the only means of allaying the discontent, which was one of the chief sources of the continual disorder in North Carolina. After the outbreak of the Revolution a clause in the

1 In contrast with the settlement with MeCulloh, was the failure to attempt any agreement with Richard Henderson whose colony of Transylrania lay partly within the Granville Grant. Coulter, The Granville District, pp. 48, 52-53.

2 Governor Tryon to the Earl of Shelburne, July 18, 1767, and to Lord Hillsborough, April 2, 1770; Governor Martin to Lord Hillsborough, November 10, 1771, N. C. Col. Rec., VII, 513-514; VIII, 195; IX, 49.

3 Granville valued his propriety at $£ 60,000$ to $£ 70,000$, but even at this price, Governor Martin estimated that after two years' possession, the crown should realize 10 per cent. on the investment. Governor Martin to Lord Hillsborough, March 6, 1772, and to Lord Dartmouth, November 28, 1772, N. C. Col. Rec., IX, 261, 355. 
North Carolina Declaration of Rights, which was incorporated in the state constitution, asserted that the property in the soil belonged to the people. This declaration was followed by the prohibition of perpetuities and the dismissal of all suits for quit-rents and arrears "said to be due" from lands held of the king." Though these acts did not specifically mention Granville's claims, the popular interpretation was that they abolished the quitrents in his propriety, and the British Commission on American Loyalist Claims awarded his heirs a large sum in payment of their losses from this source. In 1801, however, the Earl of Coventry, who had inherited the Granville title, brought action for ejectment against persons who had received grants from the state of North Carolina for lands that had been included in the propriety. But the suit, in which no attempt was made to reëstablish the right to collect the quit-rents, was finally lost upon an appeal to the United States Supreme Court. ${ }^{2}$

The history of the Granville Grant illustrates the diffculty of enforcing private proprietary rights in a royal colony. This propriety caused disorder that was in striking contrast with the peaceful development of the Fairfax estate in Virginia. The difference was due primarily to the tactful proprietary policy of Fairfax and his agents and the consequent absence of the many irritating incidents that stirred up trouble in North Carolina. ${ }^{3}$ The proprieties established in Virginia and North Carolina, like those of Maine and New Hampshire,

i N. C. Col. Rec., X, 1004-1006, 1013; N. C. State Rec., XXIV, 62.

2 H. G. Connor, "The Granville Estate and North Carolina,"' in University of Pennsylvania Law Review, October, 1914, pp. 671-697.

3 Some consideration ought probably to be given to the fact that Lord Fairfax was a resident of the colony, living at Greenway Court, in Frederick County, while Granville nerer came to America, leaving his propriety to be managed entirely by agents. 


\section{PROPRIETARY QUIT-RENTS}

showed that a quit-rent system subject to private ownership was an inherently weak organization in a crown colony, and could not be successfully enforced except under the most favorable circumstances, because if quitrents were to be paid the inhabitants preferred to hold their lands of the crown, which controlled the government, rather than of a proprietary whose status was that of a mere private individual. 


\section{CHAPTER IV}

\section{PROPRIETARY QUIT-RENTS: UNDER PROPRIE-}

TARY FOLLOWED BY ROYAL GOVERNMENT

The transition in the Jerseys from a proprietary to a royal form of government is an important event in the history of the quit-rent system in that province. Elsewhere the proprietaries usually surrendered to the crown their rights in the soil as well as those of government, since without the latter it was almost impossible to enforce the former, but in the Jerseys they attempted to retain the ownership of the land after they had given up all control of the government. The situation thus created was one cause of the failure of the quit-rent system there, but it was not the only cause. Even more important was the fact that the inhabitants had an ineradicable objection to the system in all its details. To East Jersey had come a large number of immigrants from New England, who brought with them the Puritan doctrine of a land tenure free from all proprietary charges. The Calvinistic settlers from England and Scotland also rallied to the support of a movement that had as its object the elimination of a landlord, while the Quaker inhabitants of West Jersey, with their democratic form of organization, were naturally predisposed in favor of a popular control of the soil. Amid such surroundings and with a wavering though grasping proprietary policy, the quit-rent system in the Jerseys inevitably collapsed.

Trouble arose soon after Berkeley and Carteret in their concessions had ordered that a quit-rent of a penny 
or half-penny an acre, according to the value of the land, be reserved in all grants. The first payment was to be made on March 1, 1670, to constables who should report to the receiver-general, unless the assembly devised some other method by which the rents might be collected "without charge or trouble" to the proprietaries." These seemingly mild conditions of landholding were by no means acceptable to the Puritans from Rhode Island and Connecticut who had settled at Monmouth and Elizabethtown. Unaccustomed to quit-rents in their New England homes, they now sought to evade them upon the pretext that their lands were held by purchase from the Indians, confirmed by patents from Governor Nicolls of New York. ${ }^{2}$ But objection to feudal dues was not the sole reason for this attitude of opposition, since the patents from Governor Nicolls also reserved the quitrent "customary in the Duke's dominions." This 'customary' quit-rent was but $2 \mathrm{~s} 6 \mathrm{~d}$ per 100 acres, the usual rate in New York, or a little more than half of what must be paid if new grants were taken out under Berkeley and Carteret. ${ }^{3}$ This dispute between the settlers from New England and the proprietaries came to a head in 1670 when payment of the quit-rents was demanded. In Monmouth and a number of other towns the landholders were

1 These conditions exempted from the rents, lands used for wharres, quays and harbors, for streets and highways not over 100 feet broad, for public houses, and 200 acres in each parish for the use of the minister. Instructions 'to Governor Carteret, February 10, 1665, N.J.Archives, 1st series, I, 41-42; Concessions and Agreements, 17-25.

2 Yard; Old Times in Old Monmouth, pp. 1-2; Answer to Bill in Chancery, 7-15; N. J. Archives, 1st series, I, 19, 45.

3 Professor Tanner considers the actual title to the land the real cause of the controversy between the people of Monmouth and Elizabethtown, and the proprietaries. In view of the origin of these settlers and the strong opposition already shown to these feudal dues in New England, it would seem logical to conclude that evasion of the quit-rents was equally important as a cause of this dispute. Tanner, Province of New Jersey, pp. 26, 58-59. 
soon induced to take out new patents under the terms prescribed by the proprietaries. ${ }^{1}$ The more determined associates of Elizabethtown, supported by most of their neighbors, refused either to pay quit-rents or to take out new patents. By their failure to enforce collections at this juncture the proprietary agents increased the ill feeling, and after the disaffected element had held unauthorized assemblies, the entire matter was referred to England. ${ }^{2}$

Meantime the proprietaries vigorously undertook to bring the Elizabethtown people to terms. Declaring that all grants not derived from them were null and void, they directed the constables to distrain for the quit-rents which remained unpaid and ordered the marshal of the province, in case this measure dịd not prove effective, to collect all arrears. ${ }^{3}$ To the obstinate settlers of Elizabethtown and their neighbors, they gave three years in which to pay the arrears of their quit-rents at the full rate of a half-penny an acre. ${ }^{4}$ These proprietary demands were strengthened by a personal letter from Charles II, which reminded all "turbulent and disaffected" persons in New Jersey that Berkeley and Carteret had sole power to dispose of their land, "upon such

1 Tanner, Province of New Jersey, pp. 62-63. Among these agreements was one entered upon, July 1, 1669, with the people of Woodbridge. For seven years a third of the quit-rents was remitted, but after that the full $1 / 2 \mathrm{~d}$ per acre must be paid. Bill in Chancery, p. $31 ; N . J$. Archives, 1st series, I, 105.

2 Tanner, Province of New Jersey, pp. 39-41, 69 et seq.; Whitehead, East Jersey under the Proprietors, pp. 54-58.

3 As a slight concession, payment was allowed in "such merchantable pay" as the country produced, "at merchant's price," rather than in the lawful money that was reserved in the grants. Declaration of Proprietors, December 6, 1672, Concessions and Agreements, p. 36.

4 Instructions to Governor and Council, December 6, 1672, Concessions and Agreements, p. 37. 
terms and conditions as they shall think fit." In face of these vigorous measures, open opposition to the quitrents temporarily ceased, but it is not probable that collection was actually enforced at this time.

The division of New Jersey in 1676 was of special importance as far as the quit-rents were concerned. At first the Quakers who controlled West Jersey planned to reserve such feudal dues, including in their concessions a rather complicated quit-rent which varied from three farthings to half a penny an acre, according to the date of the grant and the situation of the land. Collection of these quit-rents was provided for in a brief proprietary order which ealled upon the constables to perform this duty. ${ }^{2}$ But after the division of 1676, the reservation of a quit-rent became optional with each proprietary, a situation which finally brought about the virtual abandonment of the whole system by the democratic Quakers of West Jersey. ${ }^{3}$ Even the West Jersey Society, which was not Quaker in its controlling influences and was organized for profit, made no apparent effort to collect quit-rents, ${ }^{4}$ and after the organization of

1 Charles II to Captain John Berry, December 9, 1672, Concessions and Agreements, pp. 38-39.

2 Tanner, Province of New Jersey, pp. 12-16. For settlers coming before April, 1677, the quit-rent was $1 d$ and $1 / 2 \bar{d}$ per acre for town and country land respectively; for those coming before April, 1678, it was $1 \mathrm{~d}$ if and $3 / 4 \mathrm{f}$; and for those coming before $1679,11 / 2 \mathrm{~d}$ and $1 \mathrm{~d}$ per acre. West Jersey Concessions, March 3, 1676, N. J. Archives, 1st series, I, 245-246; Concessions and Agreements, p. 392.

3 In most deeds there was a nominal quit-rent, such as two capons, and a proportionate share of the 20 nobles annually due the erown, if it should ever be demanded. For example, see patent from the West Jersey Society to Thomas Crowell for 226 acres at Cape May, dated April 22, 1695, which reserved the proportion of the annual dues to the crown and two fat capons or hens annually. West Jersey Records, Liber B, Part 2, 462 and passim.

4 Accounts of Lewis Morris, May 15, 1704, to July 23, 1730, N. J. Hist. Soc. MSS. 
the council of proprietors for West Jersey, lands continued to be granted upon purchase or by proprietary rights, but without any quit-rents. ${ }^{1}$ This early abandonment of the quit-rent system in West Jersey cannot be ignored in tracing the causes of the bitter disputes that later arose in East Jersey over the attempts to enforce the proprietary claims.

After Carteret became sole proprietary, he undertook to enforce his rights in East Jersey. Denying that the patents from Governor Nicolls were valid, he offered those holding under them a year's respite within which to obtain a confirmation of their titles with a quit-rent of a half-penny an acre. Should they refuse this offer, Carteret threatened to eject them from their lands. For all future grants he ordered the reservation of a quitrent of a half-penny an acre, which might be paid in local commodities. ${ }^{2}$ These peremptory orders were sufficient to induce the settlers of Elizabethtown, in part at least, to sacrifice their principles and to offer to pay an annual quit-rent of $£ 20$ provided their titles were confirmed to a township of eight miles square. This compromise, which would probably have ended the opposition to quitrents in East Jersey, the governor and council refused to accept. ${ }^{3}$ For a time active hostility to the quit-rents seems to have ceased, for almost all of the Elizabethtown claimants secured surveys and a few of them took out patents; but opposition was merely slumbering, ready to revive if any really decided attempt was made to enforce payments."

1 Minutes, Council of Proprietors, West Jersey, 1688-1782, passim.

2 Proprietary Instructions, and Commission of Governor Carteret. July 31, 1674, Concessions and Agreements, pp. 51-54, 59.

3 Hatfield, History of Elizabeth, p. 181.

4 Tanner, Province of New Jersey, p. 74; Answer to Bill in Chancery, p. 48 . 
In contrast with the owners of West Jersey, the twenty-four proprietaries who purchased East Jersey of Carteret's heirs in 1682 were evidently determined to make of their province a profitable investment. Accordingly, they offered to issue grants with an advanced quitrent of $2 d$ per acre, or $6 d$ per 100 acres if a purchase price of $£ 10$ per 100 acres were paid. ${ }^{1}$ These dues upon the land were more than a merely nominal charge, for a clause in the new form of patents provided that, if the quit-rents were not paid within ten days after March 25, the proprietary agents would forthwith proceed to distrain. ${ }^{2}$ Under these terms a number of grants were made, some of the grantees paying purchase money and others the higher quit-rent. Then the proprietaries adopted measures to collect their quit-rents and issued a commission in 1682 to Samuel Groome as receiver-general. ${ }^{3}$ They also gave instructions that patents must be registered, after a careful survey of each tract had been made, in order to prevent all holdings of surplus land, demanded that satisfactory assurances be given for the payment of arrears, "to which we have just right," and of the quitrents in the future, and provided that in case anyone wished to surrender a part of his lands, he might settle his arrears in the same fashion. Finally, they directed that an inquiry be made into the legal standing of the

1 This commutation, which was offered also to all landholders who wished to buy up their quit-rents, was based upon a twelve years' purchase at $2 \mathrm{~d}$ per acre. Tanner, Province of New Jersey, p. 44; Proprietary Instructions, July 3, 1685, N. J. Archives, 1st series, I, 493.

2 The proprietary policy does not appear to have been always consistent, as some grants were issued at this time with a quit-rent of $1 / 2 \mathrm{~d}$ per acre, while on others only $3 \frac{1}{2} \mathrm{~d}$ per acre seems to have been paid in purchase money. Miscellaneous Papers, East Jersey, Liber A, passim; East Jersey Deeds, Liber D, passim.

3 Commission to Samuel Groome, September 16, 1682, N. J. Archives, 1st series, I, 378; XIII, 54. 
patents issued by Governor Nicolls. ${ }^{1}$ These instructions, had they been carried out, would have greatly helped in enforcing the quit-rents. In 1684, as a further means of aiding enforcement, the proprietaries organized a board or committee of their own to act in all matters that concerned the proprietary interests. The board soon took up the quit-rent problem, and instructed Governor Lawrie to collect the large arrears that were due. ${ }^{2}$

The measures adopted by the new proprietaries to straighten out the tangled land situation in East Jersey and to enforce the quit-rents, naturally revived the question of the Elizabethtown patents. In 1683 Governor Rudyard, in an attempt to compromise, met representatives of the people of Elizabethtown and "Navesinkes." This conference proved fruitless, owing to the uncertain powers of the committees representing the people and the very evident disinclination of the latter to pay anything except nominal quit-rents. ${ }^{3}$ The board of proprietors adopted an equally uncompromising attitude. Refusing to enter into "any treaty" with the men of Elizabethtown, Neversink, or any other planters who claimed to hold under patents issued by Governor Nicolls and characterizing such pretensions as "both an affront to the government here, and of evil consequence to make things to be put off by delays, and thereby hinder the settlement of our affairs in the province," they demanded that in all future patents the terms which had already been issued should be strictly observed." For

1 Instructions to Governor Lawrie, July 25 and December 21, 1683, N. J. Archives, 1st series, I, 173, 179.

2 Instructions to Governor Lawrie, August 1, 1684, N. J. Archives, 1st series, I, 461; Whitehead, East Jersey under the Proprietors, p. 101.

3 Council Journal, May 18, 1683, N. J. Archives, 1st series, XIII, 72-74; Tanner, Province of New Jersey, p. 75.

4 Instructions to Governor Lawrie, November 13, 1684, and Order of Board, July 1, 1685, N. J. Archives, 1st series, I, 477, 493. 
a time the efforts of the board were successful. By 1688 at least $£ 2409 \mathrm{~s} 31 / 2 \mathrm{~d}$ in bonds had been collected from the quit-rents, though the ultimate payment of some of these obligations is uncertain. ${ }^{1}$ Encouraged by such success the board issued further instructions in 1692, requiring a rent roll to be made out for each county that would include the name of the owner, the number of acres, and the date and situation of each patent, and ordering that after the roll had been drawn up, the receiver-general should collect the arrears of quit-rents, making distraint or bringing suit when necessary. To prevent the frequent misunderstandings that had arisen as to the value of the commodities that were offered in payment of the quit-rents, the board allowed a discount of fifteen and a half per cent. to all tenants who settled promptly in gold or silver. ${ }^{2}$

The proprietors soon discovered that there was a wide gap between the issue and the enforcement of these orders, and began to see that the general inefficiency of their government was having its effect upon the payment of quit-rents. They dismissed at least one governor for dishonesty in making collections, ${ }^{3}$ and made frequent changes in the office of receiver-general. As one of these latter officials, William Dockra, did not even come to the province, Governor Hamilton administered the office for four years, and from 1698 until after the surrender of

1 Some of the items were comparatively large, as in the case of Major John Berry whose bond was for $£ 70$. This payment was probably for the arrears on the tract known as New Barbadoes which Berry and his associates had taken up, and which extended "six miles into the country." But the account is very fragmentary, and does not specify the period for which payments were made. Quit Rent Accounts, Norember 10, 1688, N. J. Col. Doc., Liber D, p. 37 ; Tanner, Province of New Jersey, p. 43.

2 Instructions to Governor Hamilton, April 9, 1692, N.J. Archives, 1st series, II, 84-86.

3 Proprietary Order, May 3, 1687, N. J. Archives, ]st series, I, 531-532. 
the province to the crown in 1702 , there was no regularly commissioned receiver-general in East Jersey. ${ }^{1}$ Meantime, the board of proprietors assumed charge of the quit-rents, but was unable to maintain any adequate control because of internal dissensions. ${ }^{2}$ The land policy of the board tended further to complicate the quit-rent situation. Part of their holdings the proprietors divided among themselves, and on these tracts, just as in West Jersey, the reservation of a quit-rent was left to the individual proprietary. On the remaining land, which the board held as the joint property of the proprietaries, a quit-rent was reserved. ${ }^{3}$ Thus, there came into existence a twofold tenure of land, under which a part of the settlers paid no quit-rents, while the remainder were charged a high rate. Such a situation was bound to cause trouble, especially when quit-rents were demanded from settlers who had not been accustomed to pay these charges in their New England homes.

Opposition to the quit-rents in East Jersey appeared in 1695 when Governor Hamilton attempted to secure an act to enforce them. Representing that these dues constituted a real grievance, the speaker of the assembly proposed that they should be bought up, but the governor intimated that the proprietaries would not consent to this plan, unless the assembly at the same time provided a fund for the support of government. After considerable wrangling, the speaker of the lower house showed the council a letter that he had been authorized to write to the proprietaries in response to their demand for money to defend the frontier and to clear the ports. Pointing out the large arrears of the quit-rents that

1 Tanner, Province of New Jersey, p. 49.

2 Ibid., pp. 22-24.

3 Ibid., p. 54. 
were due, the letter represented that as the people had paid these charges, or "are to pay them," there would be a sufficient fund for all purposes without imposing additional taxation. The insincerity of this statement was evident in the final refusal of the assembly to enact the necessary bill for collection. ${ }^{1}$

The refusal of the assembly to pass an act for collecting the quit-rent, and the evident hostility of the people in East Jersey toward such a charge finally had an effect upon the proprietaries. They now made an attempt at conciliation, and in Newark at least made a compromise with many of the original settlers and granted them patents for their lands. ${ }^{2}$ In 1697 some of them, after resolving "to gather in their quit-rents," proposed to sell them off, and sent George Willocks to make this offer to the people of East Jersey. The conditions of purchase prescribed that after all arrears had been settled, the quit-rents might be sold for twenty times their annual value, but that the landholders must still pay annually a half-penny an acre. No purchases were to be valid until at least $£ 133$ in annual quit-rents had been sold. ${ }^{3}$ These terms were not liberal, and as only a part of the proprietaries agreed to the offer, any purchases of the quit-rents would have been of doubtful legal validity. ${ }^{4}$

1 Council Journal, July 27 and August 3, 1695. N. J. Archives, 1st series, XIII, 218, 223-224.

2 The people of Newark had already taken out patents for 8,134 acres with a quit-rent of $1 / 2 \mathrm{~d}$ per acre. They now agreed that each of the original settlers should have an additional 100 acres with a quit-rent of $6 \mathrm{~d}$. This agreement was made February 28, 1692, and was ratified by the town meeting. Claims of the Inhabitants of Newark, pp. 6-7.

3 Commission and Instructions to George Willocks, December 1, 1697, N. J. Archives, 1st series, II, 186-193.

4 It was proposed that, after one-half of the quit-rents were sold, a law should be passed which would secure purchasers against the claims of the proprietaries who had not signed Willocks's commission. Instructions to Governor Basse, April 14, 1698, Concessions and Agreements, p. 219. 
Willocks failed to secure the coöperation of the governor, and his presence only increased the prevailing discontent. $^{1} \quad$ The incident illustrates the general inefficiency of the proprietary administration which in 1702 culminated in the surrender of the government to the crown. ${ }^{2}$

It was scarcely to be expected that feudal claims which had been largely nominal during the proprietary régime could be enforced under a royal administration. Yet this plainly impossible course was followed by the crown. To add to the general confusion, the title to both the Jerseys was rendered doubtful by the failure of the proprietaries to pay the twenty nobles that were due the crown as an annual acknowledgment. William Blathwayt, the auditor-general, repeatedly called the attention of the proprietary representatives to this obligation, and finally threatened legal proceedings unless it was promptly met. ${ }^{3}$ This pressure on the part of the auditorgeneral, immediately after the surrender of the government by the proprietaries, would seem to indicate that

1 Concessions and Agreements, pp. 220-222; Tanner, Province of New Jersey, pp. 54-55, 78.

2 Tanner, Province of New Jersey, pp. 30-38. A petition from the people of Elizabethtown complained that the inhabitants had received arbitrary orders either to pay their quit-rents or to surrender their lands. Finally, in 1693 , the proprietors set up courts, without royal commissions to the judges, in order to try the suits for ejectment. Even a packed jury gave a verdict for the defendants, which the judges promptly set aside, though their decision was reversed by the crown. So, "groaning under these and other great oppressions," and fearful that their lands would be taken from them by arbitrary methods, the petitioners prayed that either the civil government should be placed under the jurisdiction of New York, or else different judges should be appointed to administer justice between them and the "pretended proprietors" of East Jersey. Petition to King from Freeholders of Elizabethtown and adjoining regions, about 1701-1702, Concessions and Agreements, pp. 688-691.

3 Blathwayt's report, March 22, 1703, Treas. 1: 85, no. 73; Blathwayt to William Dominique, July 20, 1703, and October 31, 1704, Blathwayt's Journal, II, 189, 295; Blathwayt's report, 1704, Treas. 1: 93, no. 127. 
the crown proposed to take over the soil as well as the government of the province, but nothing further was done and the proprietary debt to the crown remained unpaid throughout the colonial period. ${ }^{1}$ As in the similar case of the Penns in the Lower Counties, this failure to fulfill the conditions of their grant greatly weakened the position of the proprietaries in demanding quit-rents in East Jersey.

Scarcely had the royal régime been inaugurated when lack of coöperation, if not open hostility, developed between the proprietary officials and those of the crown. The instructions to the governor, Lord Cornbury, ordered him to secure an act that would confirm the rights of the proprietaries, especially to the quit-rents, and give adequate assistance to their authorized agents. ${ }^{2}$ Following these orders, Cornbury induced the assembly to pass a measure prohibiting purchases of land from the Indians, except by the proprietaries, and requiring all claimants under such titles to take out patents within six months. ${ }^{3}$ Any uncertainty as to the meaning of this act was removed by the "Long Bill" which, declaring that all grants made by Governor Nicolls were invalid, expressly nullified the Elizabethtown patents, and authorized the proprietaries and their agents to levy distress for the non-payment of the quit-rents. Unfortunately this bill was lost because of political quarrels between Cornbury and the assembly. ${ }^{4}$

The slight assistance that Lord Cornbury had rendered the proprietary interests was now withdrawn, for the

1 Gorernor Franklin to Earl of Shelburne, February 21, 1767, C. O. 5: 112, ff. 99-100.

2 Instruetions to Lord Cornbury, November 16, 1702, N. J. Archives, 1st series, II, 51.

3 Nevill, Laws of New Jersey, I, 1-2.

4 Tanner, Province of New Jersey, pp. 606-608. 
governor from corrupt motives threw himself altogether into the hands of the popular party. ${ }^{1}$ This changed attitude was openly taken in 1706 when, upon the pretext that the board of proprietors had not taken the oath required of public officials, Cornbury prohibited any further exercise of their powers. Aroused by this arbitrary act, the assembly reminded the governor that the proprietaries still retained their rights in the soil, but Cornbury, denying that his action had been dictated by a desire to get rid of the quit-rents, cited as proof his repeated attempts to secure laws for their enforcement. The assembly, however, insisted that as mere attorneys for private individuals the board should not be obliged to take the oath required of public officials. ${ }^{2}$ In view of the consistent opposition of the assembly to the quitrents, we can only explain their attitude as a pretext to pick a quarrel with Cornbury, rather than a sincere effort to uphold proprietary rights. Whatever the motive, the assembly's stand failed to revive the board of proprietors which entered upon a period of somnolent existence during which the quit-rents greatly suffered.

Controversies now arose among the proprietaries themselves, in which Cornbury took an active part. $\mathrm{He}$ was especially hostile toward John Barclay, who was appointed by one faction as receiver-general in 1704 . When Peter Sonmans appeared a year later armed with a similar commission from a smaller group of proprietaries who resided near London, Cornbury promptly recognized this second appointee. Later, Barclay produced another commission, superseding that of Sonmans. This commission, he claimed, was "most unjustly and

1 Cornbury's change of front was secured by a bribe of $£ 700$ to $£ 800$. Tanner, Province of New Jersey, pp. 608-609.

2 Mulford, History of New Jersey, pp. 296-299. 
malitionsly" kept from him by order of the governor and council. Moreover, he was not admitted to his office, though his first commission had been approved by a greater number of proprietaries than the one presented by Sonmans. The controversy was finally settled when Sonmans fled from the province after a somewhat spectacular career, and Barclay was reinstated as receivergeneral. ${ }^{1}$ Upon the appointment of James Alexander in 1716, a quarrel, similar to that between Cornbury and Barclay, was forestalled by a royal order to give "countenance" to the new receiver-general. Alexander was authorized to use every possible means to collect the quitrents, now estimated as worth $£ 350$ sterling annually. He was to remind the people that even though they were unaccustomed to these charges, they still had to pay them, and that if a "corrupt jury" would not give a favorable verdict in enforcing proprietary rights, he should appeal to the crown. ${ }^{2}$ But because of the inefficiency of his predecessors, and the general hostility to the quit-rents, he had little prospect of carrying out his instructions.

Meanwhile the quit-rent as an actual charge was practically abandoned, for with divisions among themselves, the proprietaries could not cope with the determined opposition led by the settlers of Elizabethtown. The strength of the anti-proprietary party was forcibly

1 Statement of John Barclay (1710), N. Y. Col. MSS., 54, p. 117 ; Tanner, Province of New Jersey, pp. 616-618.

2 The commission displayed a partial appreciation of the situation, advising the new receiver-general that, "we hope you will not tread in the corrupt paths of your predecessors in this post, but in a faithful honest discharge of the trust committed to you, pursue those methods that will most tend to our interest, to be diligent in recovering what money you can, of such as are both willing and able to pay." Commission from Charles Dunster and Jas. Ormston to Jas. Alexander, April, 1716, N. J. Archives, 1st series, IV, 241-242. 
shown in 1709 when, by order of the assembly, bills were introduced to confirm the proprietary claims in East and West Jersey. ${ }^{1}$ One Lawrence, a member of the committee to whom the bill relating to East Jersey was referred, blotted out the entire draft, afterwards informing the assembly that this "was the best amendment they could make to it." While this astounding procedure was taking place, Gershom Mott, another member of the committee, forcibly detained the chairman when the latter would have "departed the room." After an investigation into this affair, the assembly held that both Lawrence and Mott were guilty of contempt, and administered a severe reprimand. That the conduct of the two members was not unpopular was shown by the assembly's refusal to permit the introduction of another bill to confirm the proprietary rights in East Jersey. Even the bill for West Jersey, where quit-rents had been abandoned, was finally lost by the failure of the lower house to agree upon amendments. The fate of both bills clearly demonstrates the unpopularity of proprietary claims throughout the Jerseys. $^{2}$

In spite of the discouraging outcome of these efforts, renewed attempts to enforce the quit-rents marked the reorganization of the board of proprietors of East Jersey in 1725. In place of James Alexander, who had resigned, the board appointed Richard Ashfield receiver-general, and conferred upon him full powers to collect the quitrents and all other dues owed to the proprietaries. ${ }^{3}$ They succinctly outlined their general policy in a resolution

1 Journal, N. J. Assembly, December 8 and 13, 1709, Journal, 1703-1709, pp. 224, 226.

2 Journal, N. J. Assembly, January 2-12, Journal, 1703-1709, pp. 243-254.

3 Ashfield was to receive 10 per cent. on all collections, in addition to reasonable traveling expenses. Minutes, Council of Proprietors, East Jersey, September 30, 1725, Vol. A, p. 4. 
that the new receiver-general should apply himself "with all proper diligence" to this work. ${ }^{1}$ Any question as to his authority they met by public advertisements stating that Ashfield alone had power to receive the quit-rents, and that his receipt was a sufficient release. ${ }^{2}$ These measures should have been aided by the harmony that now prevailed with the royal government, especially as the governor called upon all public officials to assist the receiver-general in his work. ${ }^{3}$ But though armed with extensive powers and supported by the royal government, Ashfield seems to have entered upon his office with considerable misgiving. Very wisely he decided to take with him, in making collections, a discreet person, "to be an assistant to him in talking with the people, as also to be an evidence of what passed in case there should be an occasion for it." " The actual results of his work cannot be estimated with much accuracy, although there is evidence that he collected a considerable amount of money from the quit-rents during the first few years under the reorganized board of proprietors. But as active opposition increased, collections probably diminished to a merely nominal sum. ${ }^{5}$ Despite these discourag-

1 Minutes, Council of Proprietors, East Jersey, October 2, 1725, A, p. 6.

2 Minutes, Council of Proprietors, East Jersey, October 4, 1725, A, p. 7. These advertisements were intended to meet the pretensions of Sonmans who had returned to East Jersey and still claimed to have power to collect the quit-rents. Tanner, Province of New Jersey, 653-655. The board of proprietors ordered a bill in chancery filed against Sonmans, in order to compel him to pay over the money he had already collected from the quit-rents. Minutes, Council of Proprietors, East Jersey, July 15, 1726, A, p. 10.

3 Minutes, Council of Proprietors, East Jersey, July 7, 1729, and August 8, 1737, A, pp. 29-30, 51.

4 Minutes, Council of Proprietors, East Jersey, July 13, 1726, A, p. 10.

5 Minutes, Council of Proprietors, East Jersey, 1725-1764, especially 1725. 1750, Vol. A. In 1726 Ashfield reported collections of $£ 401$ 16s 3d, part of which probably was for quit-rents. Other items appear from time to time in the minutes, but there is no attempt to show the specific purpose for 
ing circumstances, the board of proprietors still continued to reserve a quit-rent, usually 10 s per 100 acres, in all grants. ${ }^{1}$ A scheme proposed in 1746 for the division of the quit-rents among the different proprietaries would have created a land system similar to that first proposed in West Jersey but there is no record of any actual steps being taken to carry out the plan. ${ }^{2}$

Meantime, the vigorous efforts of the board of proprietors to enforce its rights led to serious trouble. Beginning in 1741, it brought numerous suits for trespass against claimants under the Elizabethtown patent, and secured in every instance a decision in favor of the proprietary interests. These suits became the signal for an outbreak which was especially serious at Newark, where mobs actually broke into the jails and released the prisoners. Only with the greatest difficulty was the governor able to secure an act from the assembly to end these proceedings, and even then he tried in vain to enforce order. ${ }^{3}$ Thoroughly alarmed, the board of proprietors appealed to the council and assembly for the protection of its rights, representing that by "false tales and insinuations" many of the "poor, ignorant people", of the province had banded together and acted in an exceedingly riotous manner. "Like a torrent bearing all before them," they had trampled upon all law and authority. If the local officials failed to end these riots,

which they were received. Some of these receipts were probably for quitrents, but the greater part were from sales of land. Minutes, Council of Proprietors, East Jersey, July 13, 1726, et seq., A, p. 10, passim.

1 Minutes, Council of Proprietors, East Jersey, A, passim, and especially pp. 133, 210-211, 212-213.

2 Minutes, Council of Proprietors, East Jersey, September 3, 1744, A, p. 283.

3 For details of these riotous proceedings see: Fisher, New Jersey as a Royal Province, pp. 186-197; Hatfield, History of Elizabeth, pp. 367-369; Mulford, History of New Jersey, pp. 349-356. 
the board threatened to call upon parliament for aid, and forthwith made an appeal to the crown. ${ }^{1}$ After an investigation of the board's petition, and of the counter assertions of the anti-proprietary party, the Board of Trade made a report in 1751 which censured the assembly for not aiding the governor and council in the maintenance of order, and recommended the appointment of a commission to investigate fully the situation in New Jersey. But the commission failed to materialize, and with the gradual cessation of the riots, the royal government seems to have recognized the futility of attempting to enforce shadowy proprietary claims in the face of such determined opposition. ${ }^{2}$

Of the suits which caused the riots, the most important was one begun by the board of proprietors in 1745, who filed a bill in chancery against the associates of Elizabethtown. Denying the validity of the Indian deeds, or the subsequent confirmation by Governor Nicolls, this bill set forth that in spite of frequent notifications, the defendants had consistently refused to pay their quit-rents; that many persons had had their patents surveyed in the Elizabethtown tract, "in hopes to avoid the payment of the quit-rents," while "privately and often by moonlight" causing lines to be run into the proprietary lands "six times" farther to the westward than the original settlers ever claimed; and that the associates, by inducing many proprietary tenants to join with them and by selling land to other persons at greatly reduced rates, had secured many supporters in their refusal to pay the quit-rents. The bill therefore prayed that the deeds from

1 Memorial, Council of Proprietors to Council and Assembly, December 1, 1748, N. J. Archives, 1st series, XVI, 15-19; Petition to the Crown, December 23, 1748, Paris Papers, Elizabethtown, Vol. R.

2 Fisher, New Jersey as a Royal Province, pp. 201-206; Mulford, History of New Jersey, pp. 349-350; Acts, Privy Coun. Col., IV, 76-80. 
the Indians, together with the patents from Nicolls and all claims under them, should be declared void, that patentees for whom surveys had been made in the disputed area should be required to pay their arrears with interest from 1670, and that all persons who held proprietary patents for these lands should be forced to pay whatever quit-rents they owed. ${ }^{1}$

In their answer to the bill, the Elizabethtown associates, or the Clinker Lot Men, as they were popularly called, ${ }^{2}$ upheld the validity of their claims and denied the right of the proprietaries of East Jersey to collect quitrents from them. ${ }^{3}$ Probably the position thus assumed by the defendants would not have been upheld in any case, but before Governor Morris could hear the suit, he was succeeded by Governor Belcher, who was supposed to favor the anti-proprietary party. The hearing of the suit was delayed from time to time, until finally it was permitted to lapse. ${ }^{4}$ This was the only politic manner of disposing of such a test case, ${ }^{5}$ for had it been pressed to a successful issue, the proprietaries would probably

1 Bill in Chancery, especially pp. 26-27, 35, 44, 46-47, 65-67.

2 The term, "Clinker Lot," originated from the division of the public lands by the Elizabethtown town meeting in 1699 . This was known as the Clinker Lot Division and hence the Associates were nicknamed, "Clinker Lot Men.' Tanner, Province of New Jersey, pp. 79-80.

3 The answer clearly stated the issue, asserting: ",and these defendants do further admit that there might have been receivers-general of the quitrents of the proprietors: and that these defendants have refused to pay to the said receivers-general, to the said complainants, or to those under whom they claim, quit-rents for the lands in controversy, without that there is any other matter, cause or thing material or necessary for these complainants to make answer unto.", Answer to Bill in Chancery, especially p. 48.

4 Hatfield, History of Elizabeth, pp. 370-372.

5 The proprietaries claimed that they had brought this suit by agreement with the assembly in order to test their property rights. Broadside, March 25, 1747, Paris Papers, Elizabethtown, Vol. R. 
have asserted their rights triumphantly throughout East Jersey. According to their estimate, $£ 15,000$ in arrears would then have been due, and many long-established tenures of land have become void. ${ }^{1}$ Such a situation was undoubtedly contrary to the public interest, for experience had already shown that disorders always accompanied all attempts to enforce the proprietary claims, and the royal government was in no position to bring about a rebellion in order to collect quit-rents, the enforcement of which had virtually been abandoned.

The filing of the suit against the associates of Elizabethtown was attended with a veritable shower of broadsides and newspaper articles, in which the views of the proprietary and anti-proprietary parties were set forth in vigorous fashion. A pamphlet issued by the board of . proprietors defended its right to collect the quit-rents, and sarcastically scored the members of the anti-proprietary party who, "for a few bottles of rum bestowed for Indian deeds," thought they would be discharged of all quit-rents and purchase money. In order to answer attacks that had appeared in the New York Post Boy, five hundred copies of this pamphlet were printed, chiefly for distribution to all public officials. ${ }^{2}$ The proprietary right to collect the quit-rents was upheld in the assembly by Samuel Nevill, who characterized as foolish the claim that such charges were contrary to the patents. Merely because the proprietaries had not enforced the quit-rents for a number of years, he asserted, was no reason to assume that these charges were not due after they had been expressly reserved in the patents. ${ }^{3}$ Analyzing the

1 Appendix, Bill in Chancery, p. 6.

2 Defense of Council of Proprietors, February 17, 1746, and Broadside, March 25, 1747, Paris Papers, Elizabethtown, Vol. O.

3 Extract, New York Post Boy, May 19, 1746, Paris Papers, Elizabethtown, Vol. O. 
Newark deeds and the titles held by purchase from the Indians, the author of one pamphet, evidently a member of the board of proprietors, denied any possible rights in these lands under the Elizabethtown patent. As only a few persons had stirred up the opposition, he called upon the people of Newark, "who have a due regard to the general peace and real interest of the town," to. acknowledge the claims of the board of proprietors. ${ }^{1}$

In answer to the assertions of the proprietary partisans, a committee representing the anti-proprietary party published a broadside, of which the dominant note was an unrelenting hostility toward any feudal impositions that was reminiscent of similar protests in New England against the efforts of Governor Andros to revive the quit-rents there. In support of the theory that government merely exists for protection, the author declared that when property is lost, "this bond is broken and the society is in danger of running into disorder and confusion." As to the questions at issue in East Jersey, he maintained that the Indian purchases had been made in good faith, and that upon these lands the planters had paid "all dues, duties, rates and taxes, . . . for even more than twenty, thirty or forty years." . . "And now we have spent our time and strength thereon to get a poor living for our families, we must (forsooth) be outed by them who never had any title, but only a grant or liberty to make one by purchase." Strikingly similar to the arguments used by Increase Mather in opposing quit-rents in Massachusetts is the query of this author, "Can any rational man think our predecessors (or indeed any men in their wits) would expose themselves to so great fatigues and costs to bring themselves and their

1 Claims of the Inhabitants of the Town of Newark. 
posterity into bondage by being the tributaries of, and to the proprietors?",

Many other authors sprang forward to defend the antiproprietary party. The views expressed by one anonymous theorist are decidedly socialistic as regards the ownership of land. "No man," he asserts, "is naturally entitled to a greater proportion of the earth than another; but tho' it was made for the equal use of all, it may nevertheless be appropriated by every individual." To prevent the confusion from every man's "being his own carver," governors were appointed by the crown to parcel out the land among its subjects. "But the mischief of it is, that the best parts and most commodiously situated have been granted to a few particulars, in such quantities that the rest of the subjects have been obliged to buy it for their own use at an extravagant price, a hardship that seems as great as if they had been put under the necessity of buying the waters of the rivers.",

Equally typical of these anti-proprietary pamphlets is a quaint tract by Griffith Jenkins, in which a long rambling defense of the popular cause is inserted between religious verses intended to "soften the reader's heart." In a spirit that is reminiscent of similar utterances by John Wyckliffe and his Poor Priests, Jenkins advises the proprietaries to beware of the sin of covetousness, and to cultivate brotherly love. Turning to the grievances of the people, he tells how, "under pretense of proprietors," many persons have "sold land to poor people without giving any title but a quit-claim, as they call it." The ignorant man, he continues, believed this was a sufficient title until, "after a little time another comes to demand

1 Broadside, Answer to Council of Proprietors.

2 Extract, New York Post Boy, June 9, 1746, N. J. Archives, 1st series, XII, 308-309. 
pay for the land, or else to prison he must go." In their covetousness, Jenkins declares, the proprietaries have robbed the poor of their habitations, and have even "induced certain ministers to preach sermons in your defense." But, adds the author, the congregations were greatly displeased with the ministers for "preaching such lectures. . . . And methinks such preaching was nothing but a mocking of God's word." Finally, denying the proprietary claims, Jenkins favored an appeal to the crown as the one means of settling the dispute. ${ }^{1}$ In other tracts in favor of the anti-proprietary party there are little touches of religious fervor that emphasize the strength of the Puritan element in East Jersey. Of such a nature is the statement ascribed to one of the prisoners who had been released during the Newark riots in 1748 that "a strong northwest wind blew the door off the hinges" and he "walk'd out of prison as Paul and Silas did.",

In face of the bitter hostility displayed in these pamphlets, the failure to secure a favorable decision of the test case against the Clinker Lot Men was fatal to the quitrents in East Jersey, and the defendants won a virtual victory. Yet the board of proprietors, still asserting its claim, publicly denied in 1754 a rumor that it had made an agreement with the people of Elizabethtown. ${ }^{3}$ Though the board continued to reserve quit-rents in all grants and caused a rent roll to be drawn up in 1752 , it paid little attention to actual collection. ${ }^{4}$ While there may have been a few scattered payments of the quit-rents after the

1 A Brief Vindication of the "Purchassors"' against the Proprietors, by Griffith Jenkins, Paris Papers, Elizabethtown, Vol. P.

2 Extract, Pennsylvania Journal, December 13, 1748, N. J. Archives, 1st series, XII, 507.

3 Extract, New York Post Boy, September 2, 1754, N. J. Archives, ${ }^{\circ}$ st series, XIX, 403-405.

4 Minutes, Council of Proprietors, East Jersey, 1746-1776, especially A, pp. 419, 539-541; B, p. 112. 
filing of the suit against the Elizabethtown associates, there is no positive evidence to prove that any systematic collection was attempted. ${ }^{1}$

The outbreak of the Revolution put an end to all hope of enforcing the quit-rents in East Jersey, although, as the proprietary rights to vacant lands remained undisturbed, theoretically all feudal charges upon settled lands continued also. Indeed, by the terms of the original patents, quit-rents are still legally due on many tracts of land in East Jersey. ${ }^{2}$ This failure formally to abolish the quit-rents in the Jerseys shows that for all practical purposes these feudal dues had entirely disappeared long before the close of the colonial period. In their first concessions, the proprietaries made a serious mistake in demanding an excessive quit-rent. Had they been willing to reserve only the moderate rate that was customary in New York, they might have avoided the fatal controversy with the Elizabethtown settlers, for these determined opponents of the quit-rents would then have been without any possible legal pretext to support their claims. Later, the proprietaries by their refusal to compromise aroused these settlers, with New England traditions, to make the persistent defiance that ended in a virtual victory. Other factors that helped to defeat the efforts to enforce the quit-rents in East Jersey were: the numerous changes in and the large number of the proprietaries, their wavering policy, and the abandonment of feudal dues in West Jersey. Under such conditions the proprietaries in East Jersey completely failed to establish their quit-rents even while they controlled the government. After they had

1 Minutes, Council of Proprietors, East Jersey, 1746-1794, A and B, passim.

2 Many persons who are familiar with the East Jersey records maintain that the quit-rents are still due, and that until they are extinguished by legislative action they constitute a blot upon many land titles. 
surrendered their administrative powers to the crown, their attempt to enforce their rights became still more hopeless. The mass of controversial literature and the riots aroused by the measures adopted to enforce the quit-rents during this later period afford a sufficient demonstration of the impossibility of such a course. Altogether, the controversy over quit-rents in East Jersey during the eighteenth century illustrates the principle that in face of a persistent and united public opinion legal right must give place to social needs. 


\section{CHAPTER V}

\section{PROPRIETARY QUIT-RENTS : IN PROPRIE-}

TIES SURRENDERED TO THE

CROWN

UnLIKE the proprietaries of East Jersey, the patentees of other American proprieties usually surrendered their rights over the soil when they handed back to the crown their powers of government, and in consequence the transition from a propriety to a crown colony naturally divides the history of the quit-rents in those cases into two periods: the first, under proprietary; the second, under royal control. A detailed study of the evolution of the quit-rents in the various colonies during the first period illustrates in striking fashion the difficulties that confronted proprietaries, even though they controlled the government, when they attempted to enforce such dues. With the exception of Georgia, all of these temporary proprieties were founded in the seventeenth century, and in accordance with the general movement to strengthen royal control over the American colonies, practically all of them were surrendered to the crown before the middle of the eighteenth century.

In Virginia, the first colony under private control that was actually set up in America, there were no quit-rents during the first few years when all property was held in common. But after the division of the land, the London Company reserved $2 \mathrm{~s}$ per 100 acres as the usual sign of proprietary ownership. Since this quit-rent was not pay- 
able until seven years after a patent had been issued, it did not become due before 1624, when the crown took over the rights of the London Company. ${ }^{1}$ Throughout the greater part of their history, therefore, the quit-rents of Virginia were enforced as feudal dues payable to the crown rather than to proprietaries.

The next propriety established for a limited period was that of New York, which was administered under the Duke of York from the British conquest in 1664 until the succession of the proprietor to the throne, in 1685, merged his feudal rights with those of the crown. During this proprietary period the quit-rents in New York suffered, as was usual in such instances, from the neglect of the overlord and his agents. Their importance as a source of revenue was entirely overlooked, and apparently they were merely reserved as the customary form of feudal dues. Consequently the administrative policy with respect to these dues was marked by many errors, which afterwards became the source of serious embarrassment when the colony came under royal control.

The first conditions under which land was granted in New York were not favorable to the collecting of quitrents. The Duke's Laws required the reservation of a quit-rent in future patents but, by confirming all Dutch grants under the original terms, they permanently waived feudal dues on the lands that were already settled. ${ }^{2}$

1 Instructions to Governor Yeardley, Norember 18, 1618, Va. Mag. of Hist., II, 157-165.

${ }_{2}$ N. Y. Col. Laws, I, 44, 81. See especially New York Patent Books, 2 and 3, 1667-1772, and Translations of Dutch Patents 1630-1674. None of the Dutch patents reserve a charge similar to the quit-rent. For example, Jan Jansen Damen was granted Calck Hook on Manhattan Island, March 15, 1646. In the deed the patentee acknowledged the authority of the States General and their deputies. Also, he was required to submit to such taxation and imposts as the Dutch West India Company might lay. Later Dutch patents retained these terms, and added clauses that ensured loyalty to the 
This measure was perhaps necessary in order to induce the Dutch settlers peaceably to accept British rule, but by creating a twofold form of land tenure in New York, it sowed the seeds of much future discord. According to its terms the part of the land which was held under the Dutch patents was free from feudal charges, while the remainder, which alone was available for grants, was liable to a quit-rent. Naturally the holders of patents under these latter conditions would not look with favor upon a system of quit-rents from which their fellow settlers under Dutch rights were exempt. The existence of such an antagonistic feeling partly explains the persistence with which the assembly opposed the adoption of measures that were necessary if the payments were to be enforced.

The quit-rent system in New York also suffered during the proprietary period from the need of a more vigorous policy in determining the rate to be paid, and in establishing a suitable system of collection. The Duke's Laws required the reservation of $2 \mathrm{~s} 6 \mathrm{~d}$ per 100 acres, ${ }^{1}$ but in most grants the quit-rent clause was an indefinite one and the actual rate not stated. Where the annual acknowledgment was fixed, there was often a merely nominal charge, such as a peppercorn, while on other tracts more valuable rents were reserved, as a lamb or a barrel of merchantable cod. ${ }^{2}$ The necessity of a fixed and uniform quit-rent was not recognized even after the

West India Company. Translations of Dutch Patents, 1630-1674, 323-324 and passim.

1 N. Y. Col. Laws, I, 44, 81.

2 Grants of Land, New York, 1666-1755, C. O. 5: 1134. These indefinite patents specified merely the payment of a quit-rent, "according to the customary rate" in the dominions of the Duke of York, or else "such acknowledgements and duties" as should be fixed by the Duke of York and his heirs, or by the governor, New York Patent Books 1-4, 1664-1674. 
re-conquest from the Dutch when, if ever, a more enlightened policy might have been expected. The administration of the quit-rents continued to be without system, for the governors were merely directed to reserve these dues in every grant and to determine the amount in each case with the aid of the council. ${ }^{1}$ The measures taken for the enforcement of the quit-rents were equally ineffective. Usually the patents failed to designate the place of payment, and during the earlier part of the proprietary régime there was no official whose duty it was to collect the quit-rents. ${ }^{2}$ In 1673 a receiver-general was appointed, but a second commission from the Duke of York, after the re-conquest from the Dutch, failed to mention the quitrents as one of the proprietary revenues. ${ }^{3}$ In spite of this seeming indifference, in 1677 when Andros seized Pemaquid in the name of the Duke of York, he reserved a quit-rent of $1 \mathrm{~s}$ per 100 acres, and appointed collectors. The royal order in 1683 that annexed Pemaquid to Massachusetts closed the incident, but it illustrates the general fact that the grant of a propriety in America carried with it the right to impose a quit-rent as a source of revenue for the grantee. ${ }^{4}$

The small amount of attention that was bestowed upon the quit-rents during the proprietary régime in New York prepared the way for much future trouble in collecting these dues after the province came under royal control. As lands held under Dutch rights were exempt from such charges, the enforcement of the quit-rents reserved on other grants was inevitably attended with

\footnotetext{
1 Instructions to Governor Andros, July 1, 1674, and to Governor Dongan, January 27, 1683, N. Y. Col. Docs., III, 216-217, 331-334.

2 New York Patent Books, 1 - 5, 1664-1686.

3 N. Y. Calendar of Hist. MSS., II, 11; N. Y. Col. Docs., III, 221-222.

* Maine Hist. Soc. Col., 1st series, V, 74-75, 80, 105, 107, 130-131, 260-261; Hough, Papers relating to Pemaquid, pp. 80 et seq.
} 
much opposition, even under the most favorable conditions. With such added drawbacks as the varying rate and the lack of a well-organized system of enforcement, the quit-rents became a mere nominal charge under the administration of the Duke of York, and there is no evidence that any active steps were taken to collect them.

The lax administration of the quit-rents under proprietary rule in New York was duplicated in large measure in the Carolinas, the next proprieties to be temporarily established in America. In many respects the history of the quit-rents is similar in North and South Carolina, since the two colonies were controlled by the same proprietaries, who neglected in each case to establish the quit-rents upon a firm basis. But so diverse were the problems in each colony that the quit-rent systems there must be considered separately in detail. In their first conditions of settlement the proprietaries displayed a singular lack of tact in reserving a half-penny an acre in North Carolina, although grants had already been made there with a quit-rent of 2 s per 100 acres, the usual rate in Virginia. ${ }^{1}$ This arbitrary attempt to increase the quit-rents aroused such loud protests that the proprietaries finally assured the settlers along the northern border that their lands would be granted under the same conditions as in Virginia. This concession, popularly known as the Grand Deed to Albemarle, later became a source of much dispute, since the people asserted that it was irrevocable and included all of North Carolina, while the proprietaries insisted that it might be withdrawn at their pleasure and that it extended only to Albemarle County. ${ }^{2}$ Later, attempts were made to increase the

1 Proprietary Proposals, August 25, 1663, N. C. Col. Rec., I, 44, 51, 60 et seq.; Instructions to Sir William Berkeley, about 1663, C. O. 5 : 286.

2 Proprietary Instructions, May 1, 1668, N. C. Col. Rec., I, 175-176; C. O. 5: 286 , f. 29. 
quit-rents to a penny an acre, but the temper of the people was so plainly hostile that these attempts were abandoned, ${ }^{1}$ and the usual rate in North Carolina during the proprietary period became, for "rented" land, 2s per 100 acres, and for "purchase" land, $6 \mathrm{~d}$ or $1 \mathrm{~s}$, with purchase money of $£ 2$ or $£ 1$ per 100 acres. $^{2}$ Under these conditions quit-rents were reserved upon practically all grants. $^{3}$

The necessity of meeting local conditions compelled the proprietaries to modify their demands regarding the medium of payment. At first they made the quit-rents payable in "lawful English money," but specie was so scarce in these early days that ultimately they accepted commodities instead. ${ }^{5}$ In 1714 when the assembly made the quit-rents payable in bills of credit, the proprietaries absolutely refused to accept them. ${ }^{6}$ Thereupon, the assembly assumed the initiative and passed a law in 1715 which named the commodities that were to be received, at fixed prices, in payment of all public dues. As the quality of these commodities was to be established by the sworn statement of "two substantial freeholders

1 See various instructions, $1669-1681, N$. C. Col. Rec., I, passim, especially 237-238, 335-336. One of the chief causes of Culpeper's Rebellion in 1677 was a rumor that the quit-rents would be increased. Representation to Proprietors, about December, 1679, N. C. Col. Rec., I, 256.

2 Instructions, 1694-1708, N. C. Col. Rec., I, 390-391, C. O. 5 : 289, f. 159 ; 292, ff. 51-52; Accounts of Daniel Richardson, 1714, N. C. Col. Rec., II, 169 ; North Carolina Land Grants, 1707-1768, C. O. 5: 319.

3 No quit-rents were reserved on lands used for highways and streets not orer 100 feet broad, for ehurches, forts and quays. Proprietary Instructions, 1685, N. C. Col. Rec., I, 92.

4 Proprietary Conditions, 1665 and 1667, N. C. Col. Rec., I, 91, 164.

5 The value of these commodities was to be ascertained by three or more deputies, appointed by the governor. Instructions, January 5, 1679, and August 31, 1694, C. O. 5: 286, f. 137; N. C. Col. Rec., I, 390.

6 Proprietors to Council and Assembly, August 1, 1716, N. C. Col. Rec., II, 235 ; N. C. State Rec., XXV, 157-158. 
indifferently chosen," this law was scarcely fair to the proprietaries. Nevertheless, they seem to have given their assent, and the law remained the basis for collecting the quit-rents. ${ }^{1}$

At first the quit-rents were collected in North Carolina by a receiver-general who came annually to Edenton and Bathtown to receive payments from all landholders. This method was probably ineffective, for few people cared to take so long and tedious a journey merely to pay such unpopular dues as the quit-rents. ${ }^{2}$ The one means of enforcing payment was distraint according to the English common law, but this remedy was useless on the great stretches of vacant lands held by speculators. ${ }^{3}$ Later, this means of enforcement was strengthened by the appointment of a number of collectors, to each of whom a district was assigned in which he should go to every landholder and collect the quit-rents that were due. Where lands had been held without a patent for six years or more, these collectors were to demand payment of the quit-rents and to inform the claimants to such tracts that they could have their titles confirmed. From settlers who held under patents, the collectors were to demand the quit-rents, and whenever payment was refused to levy distress. ${ }^{4}$ The enforcement of these orders was some-

1 The commodities included tobaceo at 10 s per ewt, Indian corn and wheat at $1 \mathrm{~s} 8 \mathrm{~d}$ and $3 \mathrm{~s} 6 \mathrm{~d}$ per bu, tallow at $5 \mathrm{~d}$ per $\mathrm{lb}$, leather at $8 \mathrm{~d}$ per $\mathrm{lb}$, beaver and other skins at $2 \mathrm{~s} 6 \mathrm{~d}$ per $\mathrm{lb}$, wild cat skins at $1 \mathrm{~s}$ each, butter and cheese at $6 \mathrm{~d}$ and $4 \mathrm{~d}$ per $\mathrm{lb}$, raw buck and doe skins at $9 \mathrm{~d}$, and dressed at $2 \mathrm{~s} 6 \mathrm{~d}$ per lb, feathers at 1 s $4 d$ per $1 b$, pitch, whale oil, pork and beef at $£ 1, £ 110$ s, $£ 25 \mathrm{~s}$ and $£ 110$ s per barrel. Rice and turpentine were added in 1723 . N. C. Col. Rec., IV, 293-294; N. C. State Rec., XXIII, 54-55.

2 The receiver-general was allowed a 10 per cent. commission. Instructions to Robert Holden, February 19, 1679, and to Governor Tynte, March 24, 1709, C. O. 5 : 286, ff. 133-134; N. C. Col. Rec., I, 707.

3 Proprietary Instructions, 1670, and Council Journal, November 5, 1713, N. C. Col. Rec., I, 183; II, 70 et seq.

4 Commission to John Anderson, November 5, 1701, and Instructions to 
what obstructed by an act for distraint, passed in 1715, which deprived the proprietary agents of the power to value goods that had been seized for the quit-rents. Though this act was unfavorable to effective collection, it was renewed in 1749 , and remained the basis of distraint throughout the colonial period. ${ }^{1}$ Such piecemeal legislation was to be deplored, for a really comprehensive law, sanctioned by the assembly, was needed to include all details relating to the reservation and collection of the quit-rents. Though the governor received instructions in 1726 to secure such a measure, he took no steps to carry them out at this time. ${ }^{2}$

A prime necessity, if the quit-rents were to be collected, was a rent roll, but such a guide could not be drawn up until the many questionable land titles had been confirmed. That such titles existed was due to the confused and wavering policy of the proprietaries. Though the latter revoked the so-called Grand Deed to Albemarle, their agents continued to issue grants that reserved only 2 s per 100 acres. To end such irregularities the proprietaries closed their land-office in 1712, but this only increased the confusion, for grants had now to be secured in England. ${ }^{3}$ Inasmuch as many persons had purchased land but had not taken out patents before these instructions arrived, the council confirmed their titles. ${ }^{4}$ Thus, a large number of questionable titles to land arose, while, to add to the confusion, many persons

Collectors of the Quit-Rents from the President and Council, undated. N.C. Hist. and Gen. Register, III, 78, 144.

1 Valuation was determined by two representatives each of the owner and the purchaser of the distrained goods. Where no agreement could be reached, three of these representatives might agree upon an umpire. N. C. State Rec., XXIII, 22-23, 333.

2 Proprietary Instructions, about 1726, C. O. 5: 292, f. 154.

3 Instructions to Governor Hyde, January 29, 1712, N. C. Col. Rec., I, 832.

4 Council Journal, May 8, 1713, N. C. Col. Rec., II, 41. 
began to leave North Carolina and others simply took possession of land as squatters. ${ }^{1}$ The organization of the quit-rents was further affected by the numerous disturbances that took place in North Carolina during the proprietary period. The Culpeper rising in 1677, Carey's Rebellion, 1708-1711, and the struggles with the Indians made collection a matter of great difficulty, especially in the face of the generally turbulent disposition of the North Carolina settlers. ${ }^{2}$ There was also a boundary dispute between the authorities of North Carolina and those of Virginia, during the continuance of which the settlers on the border seem to have escaped in large measure from the payment of quit-rents in either colony. ${ }^{3}$ As an aftermath of this dispute came the problem created by the blank patents for 400,000 acres, which Sir Richard Everard was induced to sign in 1728 in order to pay the expenses of a boundary commission. ${ }^{4}$

Notwithstanding these local disturbances, the collection of the proprietary quit-rents was not wholly neglected and a number of instances can be cited to show that the local officials were accustomed to make use of such legal means as were available in order to force delinquent tenants to pay their arrears. ${ }^{5}$ Occasionally these officials were unnecessarily harsh in levying dis-

1 Council Journal, April 15, 1724, N. C. Col. Rec., II, 528-529.

2 N. C. Col. Rec., I, xxvii-xxxi ; Raper, North Carolina, pp. 6, 14.

3 See N.C. Col. Rec., I, 307, 343, 352, 357, 372 ; also below, p. 250.

4 The validity of these patents afterwards became a very serious question. See Opinion of the Solicitor-General and Attorney-General of England, February 11, 1738, N. C. Col. Rec., IV, 319.

5 One notable incident was the suit brought against the estate of Governor Seth Sothell, which had not paid any quit-rents for the nine years from September 29, 1680, to September 29, 1689. At 2s per 100 acres, the arrears of quit-rents for the entire estate of 4,000 acres were estimated at $£ 36$. Suit was not filed until after repeated demands had been made upon the executors to pay these quit-rents. N. C. Hist. and Gen. Register,'III, 30-31, 93-94. 
traint, as when a horse belonging to one petitioner was seized, despite his offer to make full satisfaction for the quit-rents. ${ }^{1}$ Such instances were, however, not frequent, and the collectors managed to secure the payment of at least a part of the quit-rents. ${ }^{2}$ An exact estimate of these payments cannot be made from the few confused records still extant, but they were probably so completely absorbed by the salaries of the local officials and the expenses of collection that the proprietaries received few if any returns from their quit-rents in North Carolina. ${ }^{3} \mathrm{~A}$ striking proof of this was given when, in the final sale of the Carolinas, the quit-rents from North Carolina were virtually ignored. ${ }^{4}$

The comparative failure of the proprietary quit-rents in North Carolina was duplicated, though in somewhat modified form, in South Carolina. Here, too, an initial mistake was made in proposing too exorbitant a quit-rent, and the rate first ordered, a penny and a half an acre, was soon reduced to a penny an acre, ${ }^{5}$ although much land

1 Petition of Cornelius Lairly, undated, N. C. Hist. and Gen. Register, III, 83-84.

2 For example, Edward Southwick paid 2,078 lbs. of " good sound fait clean drest neat poarke" for the four years' quit-rents due upon his farm of about 1,300 acres. See bill signed by Edward Southwick, February 9, 1697, N. C. Hist. and Gen. Register, III, 90.

3 The governor was allowed $£ 300$ annually from the quit-rents. The president of the council, the secretary, the chief justice, and the attorneygeneral also received allowances from this source. The receiver-general was to have a commission of 10 per cent. and the special collectors, in two precinets, 12 per cent. additional. In $1713 £ 482101 / 2 \mathrm{~d}$ was received for quitrents and $£ 6207 \mathrm{~s}$ for purchase money. All of this revenue, except $£ 16916 \mathrm{~s}$ $111 / 2 \mathrm{~d}$, was absorbed by salaries and charges. Account of Daniel Richardson, February 11, 1714, N. C. Col. Rec., II, 169-170; Proprietary Instruetions, August 13, 1713, C. O. 5 : 290, f. 68.

4 See p. 125 , note 4 .

5 Proposals for Settlement, August 25, 1663, and Instructions, July 26, 1669 , C. O. $5: 286$, ff. 3,45 . 
was sold with merely a peppercorn as the nominal rental. ${ }^{1}$ After 1694 the usual terms were $£ 2$ per 100 acres for purchase money and $1 \mathrm{~s}$ for quit-rent. ${ }^{2}$ Some form of acknowledgment was reserved in practically all grants, ${ }^{3}$ although occasionally the quit-rents were waived on the frontier in order to secure settlement as a protection from the Indians. ${ }^{*}$ Thus, in South Carolina, there was a wide variation in the amount of the quit-rent reserved on different tracts which inevitably caused much confusion in making collections.

The measures at first adopted by the proprietaries in order to enforce the quit-rents in South Carolina were exceedingly arbitrary. Ignoring the optional payment in commodities which they had already allowed, they gave orders in 1682 that all rents must be settled in "lawful money of England," ${ }_{5}$ and that grants must be made out in the form of an indenture rather than a deed. ${ }^{6}$ Aroused by so sudden a change in policy, the assembly represented that the people had been "extremely hard dealt with," but the proprietaries refused to retract, and

1 Instructions, May 10, 1682, C. O. 5: 286, ff. 178, 193 . See also C. O. 5 : 288 , ff. 70 et seq.

2 Instructions, August 21, 1694 and years following, N. C. Col. Rec., I, 390 et seq.

3 The quit-rents were waived on land used for highways, streets not over 100 feet broad, churches, forts, wharves, harbors, and public houses, and on 100 acres in each parish for the use of the minister. Proprietary Conditions, 1665, N. C. Col. Rec., I, 91-92. On town lots there was a quit-rent of either $1 \mathrm{~d}$ or $1 / 2 \mathrm{~d}$ each, but the amount of these charges was so insignificant that they were soon ignored. S. C. Land Grants 1674-1765, C. O. 5 : 398.

4 Proprietary Instructions, February 2, 1710, and March 3, 1716, C. O. 5: 289 , f. $238 ; 290$, f. 92.

5 Proprietary Instructions, July 26, 1669, C. O. 5 : 286, f. 45.

6 The new form of indenture, which was to be countersigned by the patentee, required yearly payment of the quit-rents at "Charlestown." If the rent was thirty days in arrears, distress could be levied, and after six months, reëntry was allowed. Proprietary Instructions, November 10, 1682, C. O. 5 : 288 , f. 2. 
haughtily asserted that their regulations had been framed to meet the arguments of men who "instilled fancies', into the people's heads in order to avoid the payment of the quit-rents. ${ }^{1} \quad$ Eventually they permitted commodity payments. ${ }^{2}$ This concession did not satisfy the assembly, which complained that the frequent changes in the conditions of landholding had "occasioned heart burnings and discontents" and forced many persons to leave the colony, and that the collection of arrears would "endanger the ruin" of the greater part of the planters. In reply to these assertions Governor Archdale indicated a willingness to come to terms, provided the assembly passed certain acts that were desired by the proprietaries. ${ }^{3}$ This hint bore fruit in a series of acts $^{4}$ which ordered that patents should be made out in a prescribed form of deed that might not be altered for five years and permitted the payment of rents of $1 \mathrm{~d}$ per acre in commodities, but required the settlement of those of $1 \mathrm{~s}$ per 100 acres in current money. ${ }^{5}$ These acts also made ample provision for distress, or for forfeiture where the quitrents were not paid for a number of years, and in view of the large expenditures for fortifications at Charleston, remitted all arrears for three years. Lastly, the acts gave persons on whose lands a quit-rent of $1 \mathrm{~d}$ per acre was reserved the right to change to $1 \mathrm{~s}$ per 100 acres, provided they paid $£ 2$ per 100 acres as purchase money to

1 Address of Assembly to Governor Sothell, about 1685, and Proprietary Instructions, June 3, 1684, C. O. 5: 287, ff. 155-158; 288, ff. 31-32.

2 Proprietary Instructions, October 18, 1690, and February 6, 1692, C. O. 5: 288, ff. 167-168, 216.

3 Journal of Commons, February 5 and 6,1696 , pp. 16-19.

4 Ibid., February 29 - March 4, 1696, pp. 28-33.

5 The commodities allowed were indigo, cotton, silk, rice, beef, pork, and English peas. Prices were to be fixed annually by six commissioners; three to be appointed by the governor and council, and three by the assembly. S. C. Statutes at Large, II, 97. 
the receiver-general. All of the acts contained clauses to prevent repeal. ${ }^{1}$ In allowing such marked control by the assembly over their revenue, the proprietaries virtually conceded the failure of their original arbitrary policy in dealing with the quit-rents.

Meantime the proprietaries failed to enforce the payment of the quit-rents. Although they created the office of receiver-general with its duties confined to South Carolina, a kaleidoscopic succession of incumbents gave scant courtesy to their numerous instructions. One official was described as "too hard and too soft" with respect to the quit-rents. ${ }^{2}$ Often the proprietaries failed to agree upon an appointment to this important office, ${ }^{3}$ and they even made no protest against the nepotism displayed by Governor Archdale who appointed his sonin-law as receiver-general. Though their instructions received little attention, the proprietaries persistently continued their efforts to enforce the quit-rents. ${ }^{4}$ Finally, they secured in Colonel Rhett a receiver-general who at least kept excellent accounts ${ }^{5}$ and even made attempts to secure an adequate rent roll, but like his predecessors, Rhett soon became dilatory in the conduct of his office. ${ }^{6}$ In truth, the proprietaries in South Carolina had become so impotent that their wishes had little weight, and the consistent neglect of their instructions made a really

1 S. C. Statutes at Large, II, 97-103, 133-134.

2 See .various Proprietary Commissions, Instructions, ete., 1679-1693, C. O. 5: 286, 288, passim.

3 Journal of Commons, January 18 and September 20, 1693, pp. 17, 35.

4 Proprietary Instructions, 1697-1702, C. O. 5: 289, ff. 37-38, 42-43, 52, 94-99.

5 Proprietary Entry Book, January 31, 1713, C. O. 5: 292, f. 62; Proprietary. Instructions, September 3, 1709, C. O. 5: 289, ff. 227-228; Proprietors to Governor Glenn, March 23, 1713, C. O. 5 : 290, f. 65.

- Proprietary Instructions, September 12, 1718, and Proprietary Entry Book, February 27, 1719, C. O. 5: 290, ff. 123-127; 292, f. 117. 
accurate rent roll an impossibility. ${ }^{1} \quad$ In 1710 they closed their land-office in South Carolina but intending settlers suffered so many hardships as a result that they reopened it in 1713 , only to shut it up again in $1718 .^{2}$ Meantime, as in North Carolina under similar conditions, so many questionable claims arose that great popular opposition would have been aroused had a scrutiny of titles been undertaken such as the drawing up of a quit-rent roll would have made necessary. Full collections of the quitrents, therefore, became an impossibility.

A striking proof of the weakness of the proprietary quit-rent system in South Carolina is afforded by the insignificant revenue produced, especially in the eighteenth century. This revenue was used chiefly to pay the salaries of the proprietary officials, but it probably was never sufficient to meet all their demands. This deficiency had important results, since the failure to provide a sufficient compensation for the local officials was one of the chief causes of the generally weak administration of the proprietaries in the colony. ${ }^{3}$ Other allowances were made from the quit-rents for such public purposes as the expenses of the courts and the upkeep of charitable and religious institutions, ${ }^{4}$ but the proprietaries

1 In 1699 the proprietaries ordered that no more than 500 acres should be granted to one person, an instruction that was consistently ignored. Smith, South Carolina as a Royal Province, p. 31.

2 Smith, South Carolina as a Royal Province, pp. 31-32.

3 These allowances, which were made to all the principal officers except the governor, included $£ 80$ to the chief justice, $£ 50$ to the secretary, $£ 50$ to the attorney-general, $£ 40$ to the naval officer, and to the receiver-general 10 per cent. of all receipts, with $£ 20$ annually for clerical aid. Governor Johnson to Board of Trade, January 31, 1733, C. O. 5: 364.

4 Included in court expenses was $£ 5$ to the minister who preached the sermon at the general sessions. Five hundred pounds was appropriated to build a church at Charleston, while to the rector $£ 100$ annually was allowed in recognition of his activity to secure the "peace, unity and tranquillity" of 
received little if any private income from their rent in South Carolina. ${ }^{1}$ Eventually, popular opinion seems to have regarded the quit-rents as merely a local revenue, and in passing a bill in 1719 for collecting these charges, the assembly coolly appropriated the expected funds for four years in order to build a state house, a gaol, and a parish house in Charleston. ${ }^{2}$ Though the act was promptly vetoed, it is significant as disclosing the general attitude toward the quit-rents. ${ }^{3}$

The chief opposition to the proprietary quit-rents in South Carolina arose from the fear lest the large amount of arrears which had accumulated, especially upon lands held for speculation, might be collected. The desire to evade payment of these arrears was undoubtedly one of the motives that led to the overthrow of proprietary rule, although such an aim was dissembled. Pretending that the proprietaries had employed all the revenue from the quit-rents for their own profit, the assembly categorically denied that the large arrears had influenced the rebellion, ${ }^{4}$ while Governor Nicholson represented that the appointment of a properly authorized receiver was the one necessity in order to secure collection. ${ }^{5}$ The proprietaries, on the other hand, asserted that all these statements were merely hypocritical pretenses, and that the governor had thrown every hindrance in the way of col-

the church in South Carolina. Proprietors to Colonel Rhett, September 8, 1714, April 11, 1715, and April 17, 1719, C. O. 5: 290, ff. 83, 85, 138.

1 Proprietary Entry Book, November 3, 1716, C. O. 5: 292, f. 93.

2 S. C. Statutes at Large, III, 44-49.

3 Proprietors to Governor and Council, July 24, 1719, C. O. 5: 290, ff. 150-152.

4 Remarks on Colonel Rhett's Letter, December 21, 1719, C. O. 5: 387, f. 35 and passim; C. O. 5: 387, f. 35; Petition of Assembly, Brit. Mus., Addit. MSS. 35909, f. 9.

5 Governor Nicholson (prohably) to Proprietors, January 14, 1722, C. O. $5: 387$, f. 46. 
lecting the quit-rents. Furthermore, they were well assured that the "occasion" of "the late disturbances was by the means of such persons as were greatly in arrears to the proprietors" for their quit-rents. Unless, as proprietaries, they were again permitted to appoint the governor, they would be deprived of their quit-rents, which "are set with ease" and for the "encouragement of the inhabitants."

The people of South Carolina were determined neither to restore the weak rule of the proprietaries nor to pay arrears, and the assembly called attention to the undoubted right of these overlords to sue for their quitrents in the courts. ${ }^{2}$ Other evidence shows the insincerity of this statement, since the assembly was determined to retain popular control of the courts, fearing that otherwise the proprietaries might attempt to collect their arrears, and that many people might be ousted from their lands. $^{3}$ The real purpose of the South Carolina landholders was revealed in the instructions given their agents in London to represent to the crown the necessity of taking over the property rights of the proprietaries as well as their government, in order to encourage settlement on the frontiers. The agents were also to ask that the arrears should be taken over as well, and that in the future the quit-rents should be devoted exclusively to purposes of government as in Virginia. ${ }^{4}$ At first the proprietaries met this menace to their claims by opposing

1 Proprietary Memorial, about 1726, C. O. 5: 383, ff. 61-62. The proprietary secretary asked that no offices be filled in South Carolina without due notice to him. See Petitions of Richard Sheldon, about 1726, C. O. 5: 290 , f. 177 ; 385 , f. 59.

2 Memorial, Assembly of South Carolina, May 21, 1726, C. O. 5: 383, ff. 71-74.

3 Middleton Correspondence, 1726, C. O. 5 : 387. 358.

4 Instructions to Francis Young and John Floyd, May 9, 1722, C. O. 5: 


\section{PROPRIETARY QUIT-RENTS}

the reappointment of Governor Johnson, upon the pretext that, as he and his relatives owed large arrears of quit-rents, little justice could be expected from him. ${ }^{1}$ Though this charge was afterward shown to be true, the British authorities accepted Johnson's indignant denial and reappointed him. ${ }^{2}$ Under such conditions, any further effort to uphold their rights was hopeless, and the proprietaries proposed in 1728 that the crown take over the soil, as well as the government of the Carolinas, together with all the arrears. ${ }^{3}$. This was the only feasible solution of the matter. The utter impossibility of enforcing their claims had been proven by their failure for nineteen years to collect any quit-rents in South Carolina, and with the exception of Lord Granville, the proprietaries gladly seized the chance to sell their unprofitable and uncertain rights. ${ }^{4}$

The quit-rent system in both the Carolinas became a virtual failure during the proprietary period, chiefly because of the desultory and neglectful policy with which it was administered. In their first conditions of settle-

1 Board of Proprietors to Privy Council, October 12, 1727, C. O. 5: 290, ff. $182-184$.

2 Answer of Robert Johnson, 1727, Proprietary Entry Book, July 1, 1727, and January 21, 1725, C. O. 5: 290, f. 168 ; 292, f. 159 ; 387, f. 154.

3 Petition, Proprietors to the Crown, March 5, 1728, and Memorial of Thomas Lowndes, February 16, 1729, C. O. 5: 290, ff. 257-258; 361.

4 For the ten years preceding 1719 the proprietaries estimated the annual arrears of South Carolina at $£ 600$, and for the nine years, 1719-1728, at $£ 800$. The total arrears were therefore $£ 13,200$. The accounts showed $\mathfrak{f 4 , 8 2 4} 7 \mathrm{~s} 1 \mathrm{~d}$ still due the proprietary officers. The erown assumed these debts, and also allowed the proprietaries $£ 5,000$ in settlement of the arrears. In addition, each of the seven proprietaries received $£ 2,500$ in payment of their property rights. The ultimate settlement with Granville for the remaining one-eighth finally established the sole rights of the crown in South Carolina. See above, pp. 76-77. Also see Proprietary Memorials, ete., 1728, C. O. 5 : 290, ff. 267-269; Treas. 1 : 266, ff. 284-287; N. C. Col. Rec., III, 38, 47. 
ment the proprietaries demanded that exorbitant quitrents should be collected in an arbitrary fashion, but in the face of popular demands they were compelled to recede from so high-handed a policy. In North Carolina they recognized the influence of the Virginia quit-rents by accepting a material reduction in the rate, while in South Carolina, by permitting the passage of laws that were notably partial to their tenants, they virtually allowed the assembly to prescribe the terms upon which their feudal dues should be paid. In both instances such confessions of the weakness of the proprietary position were not conducive to a general compliance with the demands for the payment of quit-rents. Moreover, the utter confusion in the land systems of both North and South Carolina made impossible the drawing up of the rent rolls that were necessary for adequate collections. As the officials in charge of collections were usually far from conscientious in the discharge of their duties, the arrears of quit-rents accumulated to such an extent that, in South Carolina, the general fear that these debts might be collected was one of the chief causes of the overthrow of proprietary power. Then, too, the failure to collect the quit-rents had a bad effect upon local administration, for this revenue was the one source from which the salaries of proprietary officials were paid, and in neither colony did it suffice for this purpose. Thus, after the crown purchased the Carolinas, one of the chief problems that faced the royal government was to bring order out of the chaos into which the quit-rents had been plunged during the period of proprietary control.

The failure of the quit-rents in the Carolinas was reproduced in Georgia under the trustees, for here too there was the same grasping and narrow policy that so frequently controlled a propriety. Upon all lands taken 
up by the trustees, the charter of Georgia reserved a quit-rent of $4 \mathrm{~s}$ per 100 acres, which, after ten years of actual settlement, was to become payable to the crown in proclamation money. ${ }^{1}$ In order to provide for the support of the colonial administration, the trustees increased this quit-rent to the extortionate rate of 20 s per 100 acres, payable in sterling ten years after the date of the grant, ${ }^{2}$ but upon town lots they reserved only $2 \mathrm{~s}$ sterling per 50 acres with a purchase price of $5 \mathrm{~s}$ proclamation money. Usually the trustees consistently adhered to these conditions in making grants, although occasionally on large estates they reduced the quit-rent to 10 s per 100 acres. The conditions for payment were equally arbitrary, as the terms of the grant provided that the quit-rents should be paid to "such persons and at such places in the said province of Georgia as by the said Common Council from time to time shall be appointed." Even more drastic was the condition that the land should be forfeited if the quit-rents remained unpaid for six months. ${ }^{3}$

In order to foster settlement, the trustees allowed occasional variations from their exorbitant charges upon the land, and reserved only $4 \mathrm{~s}$ per 100 acres upon one large tract of 5,000 acres. ${ }^{4}$ But they included some form of quit-rent in practically all grants, excepting a few tracts that were devoted to public, charitable, or religious purposes. ${ }^{5}$ Occasionally they attempted to establish a com-

1 Thorpe, Constitutions and Charters, 2, 771; Acts, Privy Coun. Col., III, 301-302.

2 Ga. Col. Rec., III, 412.

3 Settlers in towns received a lot 60 by 90 feet, with 50 acres in the country. Instructions, 1735, Ga. Col. Rec., III, Appendix, 409-410; Entry Book, 1732-1740, C. O. 5: 670, passim.

4 Grant, Oetober 26, 1735, Entry Book, 1732-1740, C. O. 5: 670, p. 9.

5 March 31, 1736, a grant was made in trust to Thomas Cranston, first bailiff, Henry Parker, second sheriff, and Thomas Christie, recorder of 
plicated leasehold system, as in a grant made in 1740 of 200 acres on the Savannah River, on which the patentee had already spent $£ 60$ in improvements. This patent, which was limited to twenty-one years, reserved a quitrent of $12 \mathrm{~s}$ after the first ten years. Upon its expiration, the patent was to be renewed for another twenty-one years, but the tenant must pay a fine of $16 \mathrm{~s}$ and one pound of raw silk, the produce of the colony, with a quitrent of $40 \mathrm{~s}$. Thereafter, the lease was to be renewed every twenty-one years, the fine being doubled each time, though the quit-rent was not increased. ${ }^{1}$ Such complicated terms were reproduced in other grants, notably in one of 1,200 acres that was made in 1732 to John Solman and his eleven associates in order to enable them to carry on the "pot ash" trade. After the first seven years they were to pay for three years a quit-rent of $5 \mathrm{~s}$ British money per 100 acres, and then 10 s per 100 acres annually. ${ }^{2}$

These excessive quit-rents, together with the complicated and onerous terms of landholding, were among the chief economic causes that interfered with the rapid development of the colony, and after 1740 the trustees adopted a policy of reducing the charges upon the soil. A move in this direction was a petition from the trustees that the crown should waive all quit-rents upon "pine barren" lands." When the Georgia House of Commons in 1742 held that further encouragement was needed, the

Savannah. The 300 acres were to be used for public religious purposes, and no quit-rent was reserved. Entry Book, 1732-1740, C. O. 5: 670, pp. 281-283. A quit-rent of $£ 3$, with the usual ten years' exemption, was reserved upon a grant of 500 acres in trust to Rev. George Whitefield. A quit-rent was also reserved on a grant of 300 acres to Rev. John McLeod, missionary to Georgia, and his successors. Entry Book, 1732-1740, C. O. 5: 670, pp. 393 $397,421-424$.

1 Minutes, Common Council, December 1, 1740, Ga. Col. Rec., II, 352-353.

2 Grant, Ga. Col. Rec., II, 12, 13.

3 Journal of the Trustees, December 5, 1741, Ga. Col. Rec., I, 390. 
trustees proposed the release of the quit-rents due the crown, in order that they might grant the land upon more liberal terms. ${ }^{1}$ The assembly even went so far as to petition that its members and their successors should be discharged entirely from "the payment of all rents reserved on all the grants already made and hereafter to be made of lands within the colony." "2 The Board of Trade, to whom these petitions were referred, favored a reduction in the quit-rents due the crown from $4 \mathrm{~s}$ to $2 \mathrm{~s}$, and the trustees drew up an act which embodied this change. ${ }^{3}$ Besides providing for the remission of all arrears of rent, and the abolition of former conditions of landholding, this act ordered that new patents should be issued for all grants with a quit-rent of only 2s per 100 acres, payable within ten years. As Lord Granville still held an eighth interest in the soil, there was a further provision that three-fourths of the revenue should go to the crown and one-fourth to satisfy his claims. This act, which would have straightened out the quit-rent system in Georgia, seems to have been passed by the assembly, but was probably not confirmed by the crown, since there is no evidence that it was ever put in force. ${ }^{4}$

Upon the expiration of the ten years' exemption, the trustees undertook to collect the quit-rents that had become due in Georgia. In 1745 they recommended that lists of all lands upon which the quit-rents had become

1 Journal of the Trustees, July 14, 1742, Ga. Col. Rec., I, 400.

2 Acts, Privy Coun. Col., III, Appendix, 843.

3 Acts, Privy Coun. Col., III, 729; Journal of the Trustees, November 6, 1742, Ga. Col. Rec., I, 406-407.

4 Journal of the Trustees, November 30 and December 21, 1742, and December 5, 1743, Ga. Col. Rec., I, 408, 410, 433. The claims of Lord Granville, as one of the proprietaries of the Carolinas, to an eighth interest in Georgia, were finally settled by the trustees, by purchase, before the surrender to the crown. Journal of the Trustees, June 23, 1752, Ga. Col. Rec., I, 578. 
payable should be sent to the president and assistants, together with a copy of the clause in the charter that required such dues, and that these officers should appoint receivers. ${ }^{1}$ The president and his assistants seem to have paid little attention to these orders, although Auditor-General Walpole twice asked for the quit-rent accounts. $^{2}$ But actual enforcement of the quit-rents was almost impossible, in view of the doubtful legality of the tenure of land in Georgia and the local opposition that the onerous conditions of settlement had aroused. ${ }^{3}$ Finally, in 1749, all trust-grants were held to be invalid, and possessors of fifty-acre tracts had nothing to show for their claims. ${ }^{4}$ With the confirmation of all these doubtful titles in 1750, and the order that all land tenures should henceforth be in fee-simple, the path was cleared for a final adjustment of the quit-rents. ${ }^{5}$ There is no evidence of any persistent effort toward this end before the surrender of the propriety to the crown in 1752. Such neglect was characteristic of the enfeebled administration of the trustees, under which the quit-rents in Georgia became merely a nominal charge reserved in all grants.

In addition to those established on the American mainland, a number of proprieties were at first founded in the West Indies and the outlying islands that were under British control. Here too quit-rents might naturally have been levied as the usual sign of a propriety, but even where they were proposed by the proprietaries, they were less successful than on the mainland. The uncertain powers of these absolute lords and the general weakness

1 Journal of the Trustees, April 12, 1745, Ga. Col. Rec., I, 467. 534.

2 Ibid., December 21, 1747, and June 22, 1749, Ga. Col. Rec., I, 503-504,

3 Banks, Economics of Land Tenure in Georgia, p. 13.

4 Minutes of Common Council, May 29, 1747, Ga. Col. Rec., II, 497.

5 Minutes of Common Council, May 19, 1750, Ga. Col. Rec., II, 500. 
of their administration precluded any effective collection of these feudal dues. The crown created the first of these proprieties in 1629 by granting Barbadoes and the neighboring islands to the Earl of Carlisle. ${ }^{1}$ In these islands the quit-rents were soon abolished by an agreement with the earl that the inhabitants should hold their lands in free and common socage with an annual acknowledgment of one peppercorn for each grant. ${ }^{2}$ Likewise in Bermuda, the London Company to whom the island was granted apparently made no attempt to reserve quitrents. ${ }^{3}$ The proprietaries of the Bahamas, the Earl of Shaftesbury and his associates, reserved a quit-rent of $1 d$ per acre which they later increased to $3 d$ per acre. Actual collections, however, were meager, if they were made at all, and the quit-rents do not appear ever to have become more than a nominal charge in these islands. ${ }^{4}$

While the quit-rents failed most completely in the island proprieties that were later surrendered to the crown, nowhere may they be regarded as unqualifiedly successful. The loose organization under the proprietaries, due to distance, numbers, and conflicting claims, was a bar to any vigorous administration, and made impossible the establishment of such a consistent policy as was essential in the development of a really efficient quit-

1 Geographically, the term Barbadoes was used at this time with rather an elastic limit. Besides Barbadoes proper, this grant included the British part of St. Christopher, St. Vincent, St. Lucia, and the small contiguous islands. As an acknowledgment, the Earl of Carlisle was required to pay an annual rent of $£ 100$ and.a white horse whenever the king should come to the island. Grant, July 2, 1627, and King to the Governor of Barbadoes, 1629, Cal. State Pap. Col., 1574-1660, pp. 85-86, 98.

2 Petition from President and Council of Barbadoes, July 10, 1661, Cal. State Pap. Col., 1661-1668, pp. 45-46.

3 See various documents, 1615-1684: Cal. State Pap. Col., 1574-1660, p. 17 ; 1681-1685, 664-665, 789 .

4 See various documents, 1670-1697: Cal. State Pap. Col., 1669-1674, 122-123, 207 ; Acts, Privy Coun. Col., III, 374-375; C. O. 5: 288. 
rent system. This wavering and weak management of the quit-rents was typical of proprietary administration generally in the West Indies, and in the final surrender to the crown it was necessary to include the rights over the soil as well as those over the government. In practically every such instance the period of proprietary control left, as a legacy to the royal régime, a system of quitrents which was only partly enforced if at all, and which might easily become a source of great local discord. 


\section{CHAPTER VI}

\section{PROPRIETARY QUIT-RENTS: IN PROPRIETIES NOT SURRENDERED TO THE CROWN}

\section{Pennsylvania and the Lower Counties}

Among all the proprieties, Pennsylvania, including the Lower Counties, and Maryland, presented the most favorable conditions for the successful management of the quitrent system. The fact that each propriety was under the control of a single family made possible a unified and well-ordered policy. In each the proprietary established an administration that was sufficiently strong to enable him to retain control of his governmental powers until the Revolution. Except for a few patentees in the Lower Counties, whose claims were speedily adjusted, there were no previous settlers, as in New York and the Jerseys, to be reckoned with, and as neither colony suffered from the disturbances that usually marked the transition to royal control, the management of its quit-rents should have been conducted in a consistent and orderly fashion. But, in fact, the administration of the system by the Penns was in decided contrast to that by the Calverts in Maryland. The policy adopted by the latter was broad-minded and intelligently adapted to local conditions and needs, that of the former seldom considered the necessity of conciliating public opinion or was governed by the same businesslike efficiency. This narrow spirit characterized the supervision of their proprietary rights in both Pennsylvania and the Lower Counties, but owing to the administrative division and the difficult problems that arose in the two sections, it is 
necessary to consider separately the detailed history of the quit-rents in each.

In Pennsylvania the first mistake was the failure to establish and adhere to a uniform rate of payment. The first grants reserved 1d per acre on "rented," and 1s per 100 acres on "purchase" land, with an initial price of $£ 5$ per 100 acres on the latter. These terms were not strictly adhered to, and many early patents paid only a half-penny per acre. ${ }^{1}$ In 1719 , in accordance with a policy of securing the largest possible profits from this source, the purchase price was raised to $£ 10$ and the quit-rent to $2 \mathrm{~s}$ per 100 acres. There was another increase in 1732 when the purchase price was fixed at $£ 15$ 10 s currency per 100 acres and the quit-rent at a halfpenny per acre. Finally, in 1765, the purchase money was reduced to $£ 5$ per 100 acres, though the quit-rent was increased to a penny. ${ }^{2}$ In addition to these official quit-rents, the proprietaries reserved on many tracts merely nominal acknowledgments such as an Indian corn, a red rose, or a beaver skin. ${ }^{3}$ The earlier rents at

1 Shepherd, Proprietary Government in Pennsylvania, pp. 17-18; Penn. Archives, 2d series, XIX, 47 et seq., 192.

2 Shepherd, Proprietary Government in Pennsylvania, p. 34.

3 The following table shows the annual value and the variations in the quit-rents in 1776:

\begin{tabular}{|c|c|c|c|c|}
\hline 12,000 & acres@one beaver skin per 12,000 acres & 0 & $6 \mathrm{~s}$ & 0 \\
\hline 45,951 & acres@two beaver skins per 60,000 acres & & $9 \mathrm{~s}$ & $21 / 4 \mathrm{~d}$ \\
\hline $856,8951 / 4$ & 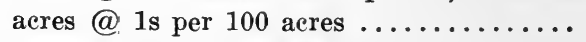 & 428 & $8 \mathrm{~s}$ & 11 \\
\hline 176,760 & acres@1s per 1,000 acres. & 8 & $16 \mathrm{~s}$ & 9 \\
\hline $93 / 4$ & acres@1/2d per acre..... & 2,885 & $17 \mathrm{~s}$ & $53 / 4 d$ \\
\hline 629,279 & acres@1d per acre & 6,788 & $13 \mathrm{~s}$ & \\
\hline $37,0371 / 2$ & acres@1 bushel of wheat per 100 acres & 55 & $11 \mathrm{~s}$ & \\
\hline $4,5713 / 4$ & es@4 & 9 & $2 \mathrm{~s}$ & 101 \\
\hline $46,511 \% / 4$ & res@various rents & 26 & $15 \mathrm{~s}$ & \\
\hline 100,000 & Indian corn & & & \\
\hline 40,000 & Rose per 10 & & & \\
\hline
\end{tabular}




\section{PROPRIETARY QUIT-RENTS}

a penny or a half-penny an acre were often converted by purchase into an annual charge of 1s per 100 acres, which became the common rate in the older counties of Philadelphia, Chester, and Bucks. On later patents in Lancaster, York, and Cumberland counties the quit-rent was usually a half-penny or a penny an acre. ${ }^{1}$ This wide variation in the rate extended also to town lots, on which an almost prohibitive rent was often reserved. By 1776 some lots in Philadelphia were paying annually $£ 50$ each with an average of from $£ 2$ to $£ 5$, and in other towns the amounts ranged from 11s $6 \mathrm{~d}$ up to $£ 10$ on each holding. ${ }^{2} \quad$ Such excessively high quit-rents formed a real hindrance to the building of towns, while the variations in the rate on these lots, as well as on country grants, became the source of much confusion in the rent rolls. If a uniform and fixed rate for the quit-rents had been reserved in all grants, the task of collecting these dues would have been a less complex and therefore a much easier matter.

See Account of Penn. Land Grants, 1681-1776, Penn MSS., II, 113, Friends' Library; Land Grants, probably 1681-1776, Penn-Physick MSS., IV, 95.

1 Accounts of Quit-Rents, 1701-1776, Penn-Physick MSS.

2 Lots on the "Bank of Philadelphia" facing the Delaware paid $5 \mathrm{~s}$ per 50 feet. In less desirable localities the quit-rent was smaller, with a minimum of 1s per 60 feet. Gov. John Blackwell's "List of Philadelphia Quit Rents," 1684-1689, Logan Papers. In Carlisle, the quit-rents varied from 11 s $6 d$ to $£ 7$ per lot, with an average of $£ 3$. In Reading, the average quitrent was between $£ 5$ and $£ 7$, though on one lot there was an $£ 11$ quit-rent. In York Town, these dues varied from $£ 4$ to $£ 10$, and in Easton from $£ 3$ to $£ 7$, but the one quit-rent noted in Bedford was $£ 413 \mathrm{~s} 2 \mathrm{~d}$. As the usual medium for paying these quit-rents was provincial currency, the apparently large amount is partly explained. The size of the lots is not given, nor from the confused records is it possible to say whether all the rents in each town were included. Consequently, any very exact deductions from these accounts cannot be made, although it may safely be concluded that the normal quitrent on each town lot was very high. Quit-Rent Accounts, 1701-1776, PennPhysick MSS. 
Practically no exemptions from the quit-rents were allowed, and even Penn's children paid some form of acknowledgment yearly for their private estates. ${ }^{1}$ This strict rule was broken once only, in 1755 , when, in order to promote settlement on the frontier, grants were authorized in this region with a quit-rent of either a halfpenny or a farthing per acre, but with an exemption from payment until $1786 .^{2}$ Had such concessions been more frequent, the proprietaries would probably have been more successful in opening up the rich valleys of western Pennsylvania.

This short-sighted policy was accompanied by great negligence in the method of collection. Unwilling to bear the expense of an effective force of collectors, the proprietaries suffered great loss in their revenues from the assumption that the quit-rents of a province could be managed as easily and in the same fashion as those of an English private estate. In the earlier patents Penn reserved a quit-rent that was due in silver or the equivalent, and was payable either in Philadelphia or in the chief town of the county, but he failed to fix a penalty for delinquency. ${ }^{3}$ The collection of these dues under the general supervision of a Board of Property, he assigned to his steward.* As this method did not prove satisfactory, the provincial court ordered the sheriffs to col-

1 The only exemption noted was in favor of land that was used for streets and roads. Thorpe, Constitutions and Charters, 5, 3045; Shepherd, Proprietary Government in Pennsylvania, p. 36.

2 Shepherd, Proprietary Government in Pennsylvania, pp. 52-53.

3 These patents were mere contracts, granting the land upon the condition of, "yielding and paying therefor to the proprietor and his heirs, at and upon the first day of the first month (March 1st) in every year, at the town of Philadelphia, one English silver shilling, or the value thereof in current money of the province, to such person or persons as shall be from time to time appointed for that purpose." Patent Book A, nos. 2, 3, etc.

4 Minutes, Board of Property, May 13, 1687, Penn. Archives, 2d series, $\mathrm{XIX}, 7$. 
lect the quit-rents, using distraint if necessary on seizing the real estate of the delinquent where there was no available distress. ${ }^{1}$ After 1689 the sheriffs were made responsible to the receiver-general, though the Board of Property continued to exercise a general supervision, especially over all accounts of the quit-rents. ${ }^{2}$

For a time the Board of Property conscientiously watched over the quit-rents. Making the payment of all arrears a condition for the confirmation of patents, they held the new owners in alienations responsible for whatever quit-rents were due. ${ }^{3}$ Often the board made detailed investigations in order to determine the exact amount of arrears and devoted much of its time to collections. ${ }^{4}$ But the actual results were meager, and the board, busy with the more important affair of granting lands, gradually abandoned its policy of close supervision. Eventually the quit-rents came almost wholly under the care of the receiver-general, James Logan, who, now that the sheriffs no longer made collections, undertook annual trips to each county in order to receive them. ${ }^{5}$ This system, too, proved very ineffective, for the work of collecting the quit-rents, which were usually paid in wheat, was altogether too great a task for one official. ${ }^{6}$

1 Proceedings, Provincial Court, September 24, 1687, Penn Archives, 1st series, I, 99-100.

2 Instructions to Governor Blackwell, May 25, 1689, and Minutes, Board of Property, April 16, 1689, Penn. Archives, 4th series, I, 106-107, and 2d series, XIX, 22.

3 Minutes, Board of Property, 1691, et seq., Penn. Archives, 2d series, XIX, passim.

4 Minutes, Board of Property, May 9, 1691, and June 6, 1692, Penn. Archives, 2d series, XIX, 68, 70 et seq.

5 James Logan to Isaac Taylor, December 5, 1704, Taylor Papers, 14, 2783.

6 To Bucks County, at least two trips had to be made annually by the receiver-general in order to collect the rents. Jas. Logan to Isaac Taylor, March 5, 1705, Taylor Papers, 14, 2785. 
These many changes in the methods of collection soon resulted in a heavy accumulation of arrears, which constituted a "grievous burden" upon the province." Penn's financial difficulties inculcated an exceedingly grasping spirit, which insisted upon the payment of even doubtful amounts and inevitably aroused violent opposition to his policy. ${ }^{2}$ This opposition showed itself openly in 1701 when the assembly petitioned that landholders should be allowed to buy up their quit-rents according to Penn's promise, as they claimed. When Penn refused to grant this request, the assembly intimated that the quit-rents had originally been levied for purposes of government. This claim it revived in 1705, although Governor Evans characterized it as a "groundless assertion.", The truth seems to be that the assembly was merely using this claim as a pretext in order to rid the province of the system entirely. With the development of the proprietary and the anti-proprietary parties, this attitude of opposition to the quit-rent was greatly strengthened. ${ }^{*}$

In 1705, laying aside for the time being its attitude of hostility, the assembly passed an act that included ample provisions for the collection of the quit-rents. According to the terms of this act, the receiver-general or his deputy was required to attend in each county, after ten days' public notice, at some time in March in order to receive

1 Penn. Statutes at Large, II, 223.

2 An instance of this grasping policy was the ease of the Welsh tract in Chester County. The settlers, who laid claim to 40,000 acres, asserted that quit-rents were due only after the final deeds had been passed. Penn insisted that they were due from the date of the original grant. The difference in arrears was about $£ 100$. As outsiders were ultimately given grants in the tract, the Welsh settlers became much disgruntled. Browning, Welsh Settlement of Pennsylvania, pp. 34-35, 333-334, 380-385.

3 Shepherd, Proprietary Government in Pennsylvania, p. 67; Governor Evans to Assembly, June 20, 1705, Penn. Archives, 4th series, I, 213.

4 Shepherd, Proprietary Government in Pennsylvania, pp. 549 ct seq. 
the payments, which, if made in wheat, must be delivered, of good merchantable quality, at some convenient mill within a mile of navigable water. To prevent extortion the act provided that the quit-rent originally reserved in the patent "shall not be multiplied" and that where small tracts were alienated, the original owner should be held responsible for the entire arrears. ${ }^{1}$ If the quit-rents were not promptly paid, the law empowered the collectors to levy distress after six months' notice, or if there were no personal property, to bring suit in the county court as in an action for debt. Any injustice in collections was guarded against by the requirement that accounts of all quit-rents should be filed in the office of the receiver-general in Philadelphia where tenants would be free to inspect them. Moreover, in case of disputed payments where no receipts were produced, the act provided that the suit should be tried by a jury before any distraint could be made, and that the tenant should be allowed to "make affirmation" as to his payments, backed up by "probable circumstances."

The act of 1705 , which authorized the enforcement of the quit-rents during the remainder of the colonial period, made possible a much more efficient system of collection, but the unsettled state of proprietary affairs prevented any reorganization along the lines laid down.

1 No person was to be charged with the quit-rent on tracts he had alienated, provided that on land sold after March 25, 1706, the total quit-rent was at least $12 \mathrm{~d}$ or one bushel of wheat. On lands alienated before that date, the quit-rent must be not less than $3 \mathrm{~d}$ or one peck of wheat. This clause meant that where the quit-rent on an alienated tract was less than these minimum amounts, the original owner remained responsible for the payment. Such a limitation complicated collections, but as small lots of land were probably rare in colonial Pennsylvania, the general effect of the law was to determine definitely the person responsible for the quit-rents. Penn. Statutes at Large, II, 223-228.

2 Penn. Statutes at Large, $\Pi, 223-228$. 
The financial difficulties of Pemn were followed by the negotiations for the surrender of the province, which were terminated by his insanity and death, ${ }^{1}$ and later the lawsuits brought by his heirs rendered it impossible to initiate the energetic proprietary policy that was necessary if the quit-rents were to be enforced. James Logan, the receiver-general, urged the necessity of strong measures, ${ }^{2}$ but when he returned to Pennsylvania in 1712 after a prolonged absence, he alleged, it was too late in the spring to act. The early harvests prevented his taking up the matter during the summer and in the autumn sickness interfered with his work, but he wrote that he hoped to proceed with the "utmost diligence" the following spring. ${ }^{3}$ In 1714 he handed over the greater part of his duties as receiver-general to a deputy, James Steele. ${ }^{4}$

Though Steele suffered many petty annoyances, especially in the adjustment of disputed arrears, ${ }^{5}$ he vigorously undertook the collection of the quit-rent, and sent numerous notices, including one to Isaac.Taylor, surveyor of Chester County, "to be posted at such public places as thou think most popular." ${ }^{\prime}$ But actual returns were far from satisfactory, and the arrears continued to be so large ${ }^{7}$ that in 1725 , when the Penns proposed to

1 Cal. Treas. Papers, V, 41-42; VI, 14, 55.

2 Trustees of William Penn to James Logan, November 10, 1711, Penn. Archives, 2d series, VII, 27-28. One brother Quaker even complained to the "meeting", when Logan insisted upon the payment of quit-rents that had long been due. Logan to Isaac Taylor, May 3, 1712, Taylor Papers, 14, 2800.

3 Logan to Penn, February 26, 1713, Penn. Archives, 2d series, VII, 32.

4 Logan to S. Clement, May 13, 1719, Penn. Archives, $2 d$ series, VII, 64.

5 J. Steele to A. Adams, March 11, 1717, James Steele's Letter Book, Appendix.

6 James Steele to Isaac Taylor, February 22, 1718, James Steele's Letter Book, Appendix.

7 Taylor Papers, 14, 2913 et seq. 
surrender the government of Pennsylvania to the crown, Logan advised the insertion in the agreement of an express provision reserving the proprietary rights, as otherwise he believed it would be impossible to enforce them. ${ }^{1}$ He pointed out that if the quit-rents were to be collected, the chief necessity was a larger allowance to the receiver-general, who thus far had received only $£ 50$ Pennsylvania currency, with a commission of two and a half per cent., a meager allowance which had never been promptly paid. He thought that the situation could not be remedied until some one person was appointed on "terms more encouraging," for " 'tis a most invidious as well as troublesome business," and a receiver-general should receive a commission of at least seven and a half per cent. and be obliged to report either annually or semiannually to commissioners who themselves should have adequate salaries. In this way, he said, a receivergeneral might be secured who would give his entire time to the work of collection, and who would be under proper supervision. ${ }^{2}$ This plan received scant consideration, and collection of the quit-rents continued to be made in the same dilatory fashion as before.

In the meantime the rights of the proprietors were again under popular attack. The first move was in the form of a petition in $\mathbf{1 7 2 5}$ which complained that, in addition to the high price of land in Pennsylvania, the quitrents were greater than in neighboring provinces. The answer of the proprietary officials was not convincing. The persistent increases in the purchase money and the quit-rent seem to have been at least in part responsible

1 Logan to John Penn, November 24, 1725, Penn MSS., Official Correspondence, I, 207.

2 Logan to John Penn, November 25, 1727, and to John, Thomas and Richard Penn, November 17, 1729, Penn. Archives, 2d series, VII, 99, 122. 
for much of the emigration from Pennsylvania, ${ }^{1}$ while the resulting discontent, which was doubtless increased by the practical exemption of the settlers in the near-by Jerseys from payment of the quit-rents, manifested itself in a controversy over the medium in which the rents were to be paid. An act passed in 1723 declared that all debts were payable in paper money, ${ }^{2}$ but when a second issue was proposed in 1729 , the governor endeavored to secure an express provision that the quit-rents should be payable in sterling. The assembly refused to make this exception, though in an address to the proprietary family it disavowed any intention of making the quit-rents payable otherwise than in an English shilling or its equivalent, as was specified in the patents. Because of this explanation the act was allowed, ${ }^{3}$ but the people still insisted upon paying their quit-rents in paper money. ${ }^{4}$ Finally, owing to the great arrears, the proprietaries agreed to accept bills of credit, but in order to cover the cost of remission to London they demanded an exchange of $18 \mathrm{~d}$ for a shilling, though the legal rate in Pennsyl-

1 The usual quit-rent in Pennsylvania, before 1732, was one-fourth of the similar charge in Maryland, and one-half of the amount paid in Virginia. But after 1732 the quit-rent reserved on new grants was practically quadrupled, and the purchase money became three times what was paid in Maryland, and seven times what was paid in Virginia. However, the difference was not so great, in view of the fact that both the quit-rents and the purchase money were not promptly paid at this time in Pennsylvania, and whaterer payments were made were in paper money. In Maryland and Virginia they were usually settled promptly in specie. Shepherd, Proprietary Government in Pennsylvania, pp. 34-35, 70; also see below, pp. 198-199.

2 The act was explicit, making all forms of contract, "already made or hereafter," whether in sterling or other forms of money, payable in the paper money, which was to constitute as effective a payment as if current gold or silver had been tendered. Penn. Statutes at Large, III, 329.

3 Minutes, Prov. Coun., March 10 to May 6, 1729, and January 17, 1739, Penn. Col. Rec., III, 367-380 ; IV, 329 ; Penn. Statutes at Large, IV, 103-104.

4 Shepherd, Proprietary Government in Pennsylvania, p. 70. 
vania was only $16 \mathrm{~d} .{ }^{1}$ This action aroused much protest. The dispute was finally referred to the crown lawyers, who supported in part the proprietary position. They held that as the quit-rents were neither due in England nor payable in English money, they should be accepted in the equivalent in Pennsylvania of bills of credit, and that the proprietaries should bear the cost of exchange. ${ }^{3}$

Meanwhile, efforts to enforce the payment of quitrents were prosecuted with new vigor. James Steele, who had served since 1714 as deputy for James Logan, was commissioned in $\mathbf{1 7 3 4}$ as receiver-general, with full power to receive and collect by all "lawful ways and means" the quit-rents and other money due the proprietaries. He received authority to appoint deputies, although, in keeping with the usually parsimonious policy of the Penns, he was granted no additional allowance for the purpose. ${ }^{4}$ New forms of patents were adopted, by which payment of the quit-rents was specified at the current rate of exchange between London and Pennsylvania, and these new patents gave the proprietary

1 James Logan to Proprietors, April 28, 1736, Penn. Archives, 2d series, VII, 196-197.

2 The people of Chester County alleged that they had assembled to pay their rents, but refused to accept the exorbitant terms demanded. Therefore, they petitioned that orders should be given the receiver-general to accept the exchange that had been legally established. These Chester County farmers employed language in their petition that was unmistakable, asserting that their plea should be granted, since "the doing whereof we have reason to believe will encourage the people to pay their arrearages due and very much tend to the credit of the currency as also to the satisfaction of the people in general." . . " So with all due submission we subseribe ourselves thy real friends and hearty well wishers." Remonstrance of Several Inhabitants of Chester County to Thomas Penn, March 7, 1733, Miscellaneous Papers, Chester County, 95.

3 Opinion of $J$. Wittes, October 7, 1734, Miscellaneous Proprietary Papers, Land Office MSS.

4 Commission to J. Steele, October 15, 1734, Penn. Archives, $2 \mathrm{~d}$ series, VIII, 34-35. 
agents the right of reëntry until all arrears and charges were settled, in case the quit-rents remained unpaid for ninety days. ${ }^{1}$ In addition a requirement was imposed that all arrears must be settled before any new patents, conveyances, or settlements could become valid. ${ }^{2}$ This order, in addition to the new form for patents, should have greatly increased collections, but unfortunately the Board of Property did not'see fit to grant definite compensations to the deputy collectors. Boundary disputes, uncertainty as to the right to grant many tracts, and the failure to take out patents, even for lands that had long been under cultivation, proved effective obstacles to the collection of the quit-rents, and there was little improvement. ${ }^{3}$

The question of the medium of exchange was revived in 1739 by the proposal to pass an act for.another issue of paper money. James Logan pointed out that the passage of this measure would afford an opportunity to secure some fixed rule with regard to the tender of the provincial currency. In his opinion, the proprietaries should call the attention of the speaker to the failure to live up to the address of the assembly, which had promised that there would be no loss in the quit-rents due to the bills of credit. As the people had, nevertheless, insisted upon the payment of the rents in paper money at a very low rate of exchange, the assembly should make good its promise in positive fashion. ${ }^{4}$ Acting upon this advice

1 See sample grant to William Blackfan for 200 acres in Bucks County, Patent Book A, no. 6. See also ibid., succeeding volumes, passim, in Land Office Records.

2 Minutes, Board of Property, July 25, 1734, Penn. Archives, 3d series, I, 40 et seq.

3 Proclamation of Richard Peters, November 23, 1738, Penn MSS., 9, p. 78; Shepherd, Proprietary Government in Pennsylvania, pp. 50-51.

4 James Logan to Proprietors, April 28, 1736, Penn. Archives, $2 \mathrm{~d}$ series, VII, 196-197. 
from Logan, the governor in a message to the assembly called attention to the increasing depreciation of the paper money, and to the resulting loss if sterling debts and the quit-rents were made payable in that medium. In view of these conditions, he declared that he would not consent to the proposed paper money bill unless it contained a clause for the payment of all' sterling debts, including the quit-rents, at the current rate of exchange between Philadelphia and London. ${ }^{1}$

The governor's message was the first move in a prolonged conflict between that official and the assembly. The latter claimed that the proposed clause would greatly injure the credit of the paper money and would prevent the collection of the quit-rents then due. In order to compromise, the governor held a conference, but the representatives of the assembly, after vaguely dwelling upon the suffering that the proposed clause would bring upon widows and orphans, asserted that to make the current rate of exchange, which was likely to fluctuate greatly, the standard of payment would render the payment of the quit-rents "very precarious and uncertain" and subject to the "caprice, artifice, or design of evil men." A deadlock ensued. The governor maintained that his instructions compelled him to insist upon the special clause, to which the representatives of the assembly answered that his instructions were unreasonable and of such a kind that he was not bound to follow them. Two diametrically opposite points of view were evident throughout the controversy. The governor was determined that the quit-rents should be paid in the actual value they represented, while the assembly was equally determined that they should be paid in bills of credit and was unwilling to make any exceptions in favor

1 Minutes, Prov. Coun., January 17, 1739, Penn. Col. Rec., IV, 319-320. 
of the proprietaries. From this it appears that the assembly made the declaration of 1729 in order to secure the proprietary assent to the paper money bill, and had drawn it up with full knowledge that it would prove worthless. ${ }^{1}$

At the next session the governor informed the assembly that though he had no authority to recede from his former stand, he would suggest the offer of some com- pensation to the proprietaries in return for the payment of their rents in paper money. ${ }^{2}$ After an exchange of friendly platitudes between the governor and the assembly, the following compromise was arranged. ${ }^{3}$ On all grants after 1732 the quit-rent was to be payable according to the terms of the patent, ${ }^{4}$ but if paper money were accepted for the quit-rents on earlier patents, issued at "the rate the same as made by law," then the assembly was to pay the proprietaries a lump sum of $£ 1,200$, together with $£ 130$ annually as long as bills of credit were in circulation. As a further evidence of its good will, the assembly enacted a bill giving the receiver-general power to collect the quit-rents from delinquents either by distress, or by suit where there was no personal property. ${ }^{5}$

The receiver-general soon issued a proclamation in which he called attention to the new conditions of pay-

1 Minutes, Prov. Coun., January 20, 1739, Penn. Col. Rec., IV, 321-328.

2 Ibid., May 8, 1739, Penn. Col. Rec., IV, 329.

3 Ibid., May 12 and 18, 1739, Penn. Col. Rec., IV, 330-334.

4 On grants after 1732 the quit-rents were due, under the terms of the form of patent adopted at that time, in English silver or the equivalent in current exchange between Philadelphia and London. See Patent Book A, no. 6 , etc.

5 If there were no distress, or if the delinquent were a non-resident, $a$ summons must be delivered ten days before the session of the court, either to the owner of the land or to a member of his family, or else it must be left upon the land provided no one resided there. If no defense were made, judgment for the quit-rents due should then be entered. Penn. Statutes at Large, IV, 322-326. 
ment in paper money, and gave warning that if the quitrents were not promptly settled, he would distrain. ${ }^{1}$ Though this proclamation seems to have had little immediate effect, the appointment of Lynford Lardner in 1741 as co-receiver-general and, after the death of James Steele, the sole incumbent of this important office, promised a more efficient system of collection for the future. But the promise was not fulfilled. Continuing the usual custom of going to the different counties in order to receive the quit-rents, ${ }^{2}$ Lardner found the journeys very difficult, especially as the tenants in the frontier counties increased, and complained that the keeping of books on horseback was extremely injurious to his accounts. ${ }^{3}$ Most of his receipts were for arrears of several years' standing, and his accounts show that customarily the quitrents were only paid in order to secure a legal title in making transfers. In short, the work of collection in addition to the other duties of his office proved too burdensome for one receiver-general and Lardner merely accepted whatever quit-rents were paid, without making any systematic effort to enforce collections. ${ }^{4}$ The meddlesome disposition frequently displayed by the assembly also increased his difficulties, ${ }^{5}$ until completely dis-

1 The usual places of attendance, as fixed at this time, were Philadelphia for Philadelphia City and County, until October 10; Chester for Chester County, October 11 to 20; Pennsbury for Bucks County, October 23 to November 3; and Lancaster for Lancaster County, November 7 to 17 . Note the special fall attendance to collect arrears under the terms of the new law. See Broadside, probably about September, 1739, Penn MSS., 9, p. 79.

2 Lardner paid a bill of $£ 206 \mathrm{~s} 6 \mathrm{~d}$ to the estate of Andrew Bradford, printer of the Pennsylvania Gazette, for quit-rent advertisements, 1717-1741. See Receipt, November 23, 1743, Penn MSS., Accounts, I, 63.

3 Lynford Lardner to Thomas Penn', May 10, 1748, Penn MSS., Official Correspondence, IV, 109.

4 Lynford Lardner's Receipt Book, 1743-1750, Logan Papers.

5 An instance was the requirement that the trustees of the bills of credit must see that, before any of the paper money was lent out on a mortgage, 
couraged, he surrendered his commission in $1753 .^{1}$ Even then his troubles did not cease, for as late as 1772 he was still trying to secure the arrears of salary due him. ${ }^{2}$ Such delays in paying even this meager allowance, in addition to the disagreeable features of the office, served to repel competent men from undertaking the work.

To succeed Lardner two receivers-general, Richard Hockley and Edmund Physick, were appointed in the hope that by dividing the burden, the work of collection would be made easier. ${ }^{3}$ The new receivers industriously began to collect the quit-rents, and for a time they were successful. Though they kept their office in Philadelphia open from seven to one in the morning and from two to six in the afternoon they were unable to accommodate all those who thronged their doors. Despite this promptitude, Hockley did not feel justified in attempting to carry out a proprietary order to seize property for arrears, inasmuch as the approaching meeting of the assembly was certain to bring up a number of political problems." Yet he hoped to increase collections, if "persuasion" and a "frequent repetition" to all persons who came to his office could secure prompt payments. ${ }^{5}$ The

the quit-rents on the land were paid. These payments were to be made to the trustees rather than to the receiver-general, and in at least one case the latter found it practically impossible to collect arrears that had been paid in this manner. Penn MSS., Official Correspondence, IV, 15.

1 Richard Hockley to Thomas Penn, February 24, 1753, Penn MSS., Official Correspondence, V, 17.

2 Lynford Lardner to one of the Penns, October 9, 1772, Penn-Physick MSS., Correspondence, I, 37.

3 Commissions to Hockley and Physick, January 1, 1753, Penn. Archives, $3 d$ series, IX, 12-14.

4 Richard Hockley to Thomas and Richard Penn, May 11, 1753, Penn MSS., Official Correspondence, VI, 59.

5 Richard Hockley to Thomas and Richard Penn, November 5, 1753, Penn MSS., Official Correspondence, VI, 119. 


\section{PROPRIETARY QUIT-RENTS}

co-receivers warned delinquent tenants that unless the quit-rents were paid they would adopt disagreeable measures. ${ }^{1}$ They continued to attend in March in the different counties in order to receive the rents, giving notice of the exact time and place in the Pennsylvania Gazette and by means of posted advertisements. ${ }^{2}$ But the small degree of success that followed these vigorous measures showed the necessity for deputy collectors who, by devoting more time to the work, could enforce the payment of arrears.

One cause of indifference to the payment of quit-rents was the increasing hostility displayed by the antiproprietary party toward these feudal charges. This. hostility was strikingly shown during the struggles between the governor and the assembly over the taxation of the proprietary estates, including the quit-rents. ${ }^{3}$ The trouble first began when the proprietaries, in accordance with a decision of the Board of Trade in 1748, denied the right of the assembly to tax their estates at all, though later they intimated that they were willing to contribute to the defense of the province. ${ }^{4}$ The question was allowed to slumber until 1755 , when the assembly proposed to raise $£ 50,000$ for the French and Indian War by a tax of $12 \mathrm{~d}$ in the pound upon all property, both real and

1 Richard Hockley to Thomas and Richard Penn, April 17, 1754, Penn MSS., Official Correspondence, VI, 175.

2 See Pennsylvania Gazette, files for 1752 et seq. A typical advertisement was one dated February 4, 1755, to the effect that all persons who were indebted to the proprietaries for quit-rents should pay what they owed, either to Richard Hockley or to Edmund Physick. Attendance would be given in Philadelphia, March 1-8, in Chester, March 10-15, in Pennsbury, March 17-22, and in Lancaster, March 25-29. Pennsylvania Gazette, February 4, 11 and 18, and March 18, 1755.

3 For a complete account of this struggle, see Shepherd, Proprietary Government in Pennsylvania, pp. 435-494.

4 Shepherd, Proprietary Government in Pennsylvania, p. 441. 
personal, from which the proprietary quit-rents were not to be exempt. ${ }^{1}$

Anticipating opposition, the assembly defended this inclusion of the estates of the proprietaries as "perfectly just and equitable" in face of the common danger. The governor, however, pointed out that his commission forbade any such tax, and proposed, instead, to give the soldiers lands west of the Alleghanies with exemption for fifteen years from purchase money and quit-rents. ${ }^{2}$ In the numerous messages that passed between the governor and the assembly the broad question of taxing the entire proprietary estate was considered, but for our . purpose interest centers only on the attitude that was taken with regard to the quit-rents. Maintaining that the proprietaries were being taxed as fellow subjects, landholders, and the possessors of estates in Pennsylvania, the assembly cited as a justification of the nonexemption of their quit-rents, the case of crown tenants in England who were required to deduct taxes from their rents. It also undertook to enlighten the governor upon the nature of the quit-rents, claiming that when the first settlers objected to these feudal dues as an unreasonable charge, Penn replied that they were intended as "the most easy and equal tax,' as in Virginia. Furthermore, it said, the proprietaries having gone to England still claimed their quit-rents, which were their "first support," as their private estate, while the people were compelled to pay a salary to a lieutenant-governor. In asking for exemption from taxation, the proprietaries "claim more than king, lords, or commons who all contribute to defense. They go beyond their royal charter in their injustice and severity in not allowing the people to raise

1 Minutes, Prov. Coun., August 1, 1755, Penn. Col. Rec., VI, 510-511.

2 Minutes, Prov. Coun., August 5 and 6, 1755, Penn. Col. Rec., VI, 525-526. 
money for their own defense," and they would stir up great ill will against themselves if they persisted in their refusal to bear a part in the common defense. ${ }^{1}$ These arguments by the assembly were framed with a masterly skill that placed the proprietaries in an awkward dilemma. Either they would be obliged to recede from their claims as absolute owners of the soil of Pennsylvania and concede the right of the assembly to tax the quit-rents, the sign of their proprietary right, or else they would come into direct conflict with the interests of the crown, and thus probably lose their province. ${ }^{2}$

In his reply to the skillful arguments of the assembly, the governor avoided the question of the origin of the quit-rents and asserted his unqualified right to veto money bills. The assembly, he declared, really wished to make itself independent of the proprietaries and the governor, "a plan you would not fail to carry into execution were your power equal to your inclinations." The proprietaries, he maintained, did not object to the amount of the tax, but rather to the principle, for they were determined to preserve "the rights of their station which, if they give up whenever demanded, as claims will never be wanting, they will very soon be stript of everything they have the right to enjoy, both power and

1 Minutes, Prov. Coun., August 15-20, 1755, Penn. Col. Rec., VI, 524-586, passim.

2 Richard Hockley, one of the receivers-general, who was in the assembly, characterized the assertion that the quit-rents were intended for the support of government as an "obsolete tale." To his neighbors in the assembly, he scored the message of that house as intended to disgust all respectable people and to irritate the populace. These neighbors, however, who were hostile to the proprietaries, accused Hockley of being a "downright courtier."' This incident illustrates the gulf fixed between the official class in Pennsylvania, and the representatives of the people. Richard Hockley to Thomas Penn, August 25, 1755, Penn MSS., Official Correspondence, VII, 113. 
property." Though in this reply he stated clearly the gist of the controversy, the assembly showed no sign of yielding. ${ }^{1}$ Their failure to pass the supply bill before adjournment, in the face of the threatened French and Indian invasion, aroused much apprehension, and several gentlemen of Philadelphia, fearful lest the troops would not receive the proper support, offered sufficient security to cover the tax on the proprietary estates. ${ }^{2}$ After the failure of this appeal the assembly adjourned.

The assembly met again after an interim of about three weeks. ${ }^{3}$ Still determined to uphold its views, it passed an act to issue $£ 60,000$ in bills of credit for the king's service and to provide a sinking fund by a tax upon all personal and real property. When this bill was presented to the governor, the latter, who was "under a great concern of mind at the ill temper of the assembly in raising a dispute about the proprietary tax at such a critical time," refused his assent." A deadlock ensued, which was broken by Thomas Penn, who sent an order upon the receiver-general for $£ 5,000$ to be paid out of the quit-rents, "as a free gift from us to the public," in case the assembly exempted the proprietary estates from the proposed tax. This gift was prompted by criticism in England of the apparent unwillingness of the Penn. family to contribute to the common defense, and by Thomas Penn's fear of an investigation by parliament with consequent danger to the continuance of proprietary control. $^{5}$ The governor promptly notified the assembly

1 Minutes, Prov. Coun., August 12-14, 1755, Penn. Col. Rec., VI, 537-546.

2 Ibid., August 20, 1755, Penn. Col. Rec., VI, 586; ibid., August 28, 1755, Penn. Col. Rec., VI, 597-598.

3 Ibid., September 24 and 29, 1755, Penn. Col. Rec., VI, 617-637.

4 Ibid., November 8-24, 1755, Penn. Col. Rec., VI, 682-729.

5 Thomas Penn to Governor Morris, October 4, 1755, Penn. Col. Rec., VI, 730-731. 
of the proprietary gift, beseeching it to lay aside all disputes in face of the common danger, and to grant suffcient supplies for the defense of the province. This message, which was supported by a remonstrance of the same tenor from the mayor, the aldermen, and the council of Philadelphia, was effectual. ${ }^{1}$ The assembly, accepting the terms of what was essentially a compromise, exempted the proprietary estate from taxation. ${ }^{2}$

The controversy was revived a year later by a bill which proposed to raise $£ 100,000$ by a tax upon all property, "the estates of the proprietors not excepted." When Governor Denny vetoed this bill upon the plea that it was contrary to his instructions, the assembly boldly asserted that, "proprietary instructions are by no means laws in this province," and it again accused Penn's heirs of failure to uphold the interests of the crown. ${ }^{3}$ The bill was revived the next year, but this time the proprietaries were not disposed to resist. The governor consented to a tax upon their estates if certain exemptions were made, including especially the quitrents and the purchase money that was due. Not satisfied with this concession, the assembly in pointed language accused the governor of standing between the people and the crown, to whom he must answer for the consequences of his refusal to grant the necessary aid. The climax of the controversy was reached when the assembly asked, "Must the country be destroyed and the whole lost rather than these instructions be departed

1 Minutes, Prov. Coun., November 24, 1755, Penn. Col. Rec., VI, 733-735.

2 The bills of credit issued under this act were to be current until January 1, 1760, and were declared valid for all manner of debts. This declaration made them legal tender for the quit-rents, although no attempt was made to contest this point. Minutes, Prov. Coun., November 26, 1755, Penn. Col. Rec., VI, 737-738; Penn. Statutes at Large, V, 201-212.

3 Penn. Statutes at Large, V, 597-598, 607-608. 
from? So it seems.", Finally, the Earl of Loudoun informed the governor that pay for six months was due the troops, and that a part of them refused to march until their demands were met. In view of this serious situation the governor waived all objections and signed the bill as it was presented by the assembly. ${ }^{2}$ This surrender was of the utmost significance, for it marked the final defeat of the proprietary effort to obtain exemption of their quit-rents, and constituted a denial of their absolute feudal rights in Pennsylvania.

When an additional grant of $£ 100,000$ was proposed in 1759 for the service of the crown, the governor consented to the taxation even of the quit-rents, but insisted that the proprietary interests should have at least a voice in the appointment of assessors. This demand was the cause of another series of messages between the governor and the assembly, and again military necessity became the determining factor. Urged by the representations of the Earl of Amherst, the governor waived all proprietary instructions, ${ }^{3}$ and signed an act to issue the $£ 100,000$ in bills of eredit, and to provide a sinking fund of $18 \mathrm{~d}$ in the pound by a tax on the annual value of all property, including the quit-rents. The act, which permitted the deduction of the $£ 5,000$ already paid by the proprietaries from the total amount of their tax, required the annual election of assessors by the freeholders

1 Minutes, Prov. Coun., January 28, February 22 and 23, 1757, Penn. Col. Rec., VII, 402, 417-429.

2 Earl of Loudoun to Governor Denny, March 21, 1757, Penn. Col. Rec., VII, 454 .

3 Minutes, Prov. Coun., March 29 to April 13, 1759, and Earl of Amherst to Governor Denny, April 11, 1759, Penn. Col. Rec., VIII, 303-332. Governor Denny, who had already showed marked inclinations to favor the popular rather than the proprietary cause, was probably bribed to assent to this law. Shepherd, Proprietary Government in Pennsylvania, p. 460. 
of every township, borough, and ward. ${ }^{1}$ When this bill was sent to London, the Privy Council at first disallowed it, chiefly because of the tax upon the proprietary estate, but finally confirmed it upon the promise of Benjamin Franklin and Robert Charles, the agents of Pennsylvania, that its most objectionable features would be amended. ${ }^{2}$ Needless to say, the assembly refused to pass the proposed amendments, but the fear that the assessments would be unfair to the proprietary interests, upon which the Privy Council based its action, does not seem to have been generally realized. The one apparently unfair assessment, that of the proprietary estate in Cumberland County, was due to the very unbusinesslike conduct of the land-office rather than to any intentional injustice. ${ }^{3}$ Yet the burden of the tax was not light, especially as the quit-rents were usually collected in the depreciated paper money. Moreover, the final unconditional surrender by the governor upon the principle of taxation of the quit-rents gave these dues, which were essentially feudal, the status of a private debt. ${ }^{4}$

1 Penn. Statutes at Large, V, 379-396.

2 Minutes, Prov. Coun., January 28 and March 14, 1761, Penn. Col. Rec., VIII, 554-555, 584-585; Shepherd, Proprietary Government in Pennsylvania, pp. 462-466; Acts, Privy Coun. Col., IV, pp. 441-442.

3 Although only 34,013 acres had been patented in Cumberland County, quit-rents at $1 / 2 \mathrm{~d}$ sterling per acre were assessed upon 171,315 acres. As the quit-rents could not be collected until the land was patented, the proprietary agents protested against this assessment of unpatented land. Moreover, owing to the distressed condition of the inhabitants on the frontier of Cumberland County, their quit-rents had been remitted, and if the full assessment stood, it was intimated that this favor might be withdrawn. Minutes, Prov. Coun., April 3, 1760, Penn. Col. Rec., VIII, 472-475; Shepherd, Proprietary Government in Pennsylvania, pp. 465-466.

4 The unfairness of the assembly in dealing with the quit-rents was illustrated in Chester County. The total quit-rents of this county were estimated in 1776 at approximately $£ 330$ sterling. and 73 bushels of wheat. The tax upon these quit-rents amounted in 1760 to $£ 822 \mathrm{~s} 5 \frac{1}{4} \mathrm{~d}$, payable of course in paper money. In sterling, the tax, at $18 \mathrm{~d}$ advance on the pound, would 
The same determination that underlay the acts to tax the proprietary estate was manifest in a bill passed in June, 1759 , to issue $£ 36,650$, which omitted the annual compensation of $£ 130$ for receiving the quit-rents in paper money. The provincial council held that this omission was a "piece of downright injustice," but in reply the assembly sent a laconic message stating that it "peremptorily rejected" any amendments. ${ }^{2}$ After the final decision of the governor to assent to this bill, the council angrily accused him of having bargained with the assembly for the omission of the usual compensation. ${ }^{3}$ When the act reached England, it was disallowed, chiefly upon the ground that though the quit-rents were to be paid in paper money the compensation was refused. ${ }^{4}$

During the long controversies between the governor and the assembly the receipts from the quit-rents did not improve, and in view of the opposition so plainly voiced by the assembly, the need of a better organized system of collection was manifest. In 1756 the proprietaries proposed to employ deputy-receivers on the frontier, with eight or ten townships assigned to each one in order to insure a sufficient compensation. ${ }^{5}$ But the dissent of Richard Hockley, who did not believe that competent men could be secured, was sufficient to defeat this

have been $f 44$ 2s 6 d. Evidently the assessors made full allowance for the depreciated paper money in which the tax was paid, by allowing exchange of nearly twice the sterling value. At the same time the assembly insisted upon the payment of the quit-rents in paper money at an exchange of $16 \mathrm{~d}$ currency for 1s sterling. Quit-Rent Accounts, 1701-1776, Penn-Physick MSS.; Penn. Archives, $2 \mathrm{~d}$ series, VII, 268-269.

1 Minutes, Prov. Coun., June 13, 1759, Penn. Col. Rec., VIII, 350, 352.

2 Ibid., June 16, 1759, Penn. Col. Rec., VIII, 353-354.

3 Ibid., June 18, 1759, Penn. Col. Rec., VIII, 357-360; Penn. Statutes at Large, $\mathrm{V}, 426-433$. 553.

4 Minutes, Prov. Coun., January 28, 1761, Penn. Col. Rec., VIII, 537-538,

5 Shepherd, Proprietary Government in Pennsylvania, pp. 40-41. 
scheme. ${ }^{1}$ Equally unsuccessful were a number of attempts to secure a rent roll which would serve as a basis for collections. Finally, in 1757, the proprietaries proposed a general roll similar to that customary in Maryland, which should include full particulars of every tract, and from which separate books might be drawn up for each collector. The inauguration of such a roll, so long after the original grants had been made, proved to be a difficult task, and in only a few instances were any serious attempts made to carry out this plan. ${ }^{2}$ The need of such a roll was clearly stated by Governor John Penn, who, in 1767, showed that the confusion existing in the earlier quit-rent rolls made a full estimate of the arrears almost impossible. ${ }^{3}$

Meanwhile, the task of collecting the quit-rents became more and more difficult. In 1757 Richard Hockley called the attention of landholders to the need of money with which to pay the remainder of the $£ 5,000$ donated by the proprietaries. ${ }^{4}$ As his appeal secured only a meager response, he planned to collect this balance from the quitrents by going personally to the houses of landowners, "dunning them as it is called," and "making my just complaints to everyone of consequence." Tersely summing up the situation, he declared that the tenants "are for making the most of everything, let the manner of doing it be ever so mean, I had almost said unjust." "5 He pointed out that in Lancaster County many people refused to pay their rents upon the pretext that as their

1 Richard Hockley to Thomas and Richard Penn, January 28, 1757, Penn MSS., Official Correspondence, VIII, 229.

2 Shepherd, Proprietary Government in Pennsylvania, pp. 41-43.

3 Gov. John Penn to Earl of Shelburne, April 24, 1767, Penn. Col. Rec., IX, 379-380.

4 Pennsylvania Gazette, February 9 and 23, 1758.

5 Richard Hockley to Thomas and Richard Penn, February 23, 1756, Penn MSS., Additional Miscellaneous Letters, I, 94. 
lands would soon become the frontier, they would be driven from their homes by the enemy. Perhaps this excuse was really justifiable, since the "back counties" were almost depopulated, and those who remained were distressed by intestine broils and fear of the Indians. ${ }^{1}$ But the inhabitants of the more thickly settled and better organized parts of the province also displayed a decided disinclination to pay their quit-rents. ${ }^{2}$ Nevertheless, the receivers-general continued to advertise their attendance, although they met with little encouragement. ${ }^{3}$ The difficulties they encountered were greatly increased by the general neglect to take out patents even for lands that had long been occupied, ${ }^{4}$ while the commotion stirred up by the Stamp Act soon added to their other troubles. ${ }^{5}$

1 Richard Hockley to Thomas Penn, April 3, 1756, Penn MSS., Official Correspondence, VIII, 69.

2 An example of the intention to evade the payment of both quit-rents and purchase money was that of the people of "Donigall"' in Lancaster County who had come in 1720. They paid neither charge, and in 1733 an attempt was made to settle with them. They were offered, in view of their poverty, three and a half years in which to pay their purchase money together with a quit-rent of $1 \mathrm{~s}$ or $2 \mathrm{~s}$ per 100 acres, or else $1 \mathrm{~d}$ per acre. The purchase money was to be proportioned according to the quit-rent they accepted. They made no move to acknowledge this proposed settlement, nor did they pay their quit-rents or purchase money, and in 1763 they petitioned Thomas Penn, protesting against any grants of their lands to other persons. Owing to their porerty, however, they prayed that they might be allowed to have their lands at less quit-rents and purchase money than was paid by tenants who were nearer the market, and whose lands were more productive. Thomas Penn to Secretary Logan, January 23 and 24, 1733, Penn. Archives, 2d series, VII, 161-162; petition to Thomas Penn, June 29, 1763, Penn-Physick MSS., VI, 29.

3 Pennsylvania Gazette, February 12, 1761, et seq.; Richard Hockley to Thomas and Richard Penn, January 28, 1757, Penn MSS., Official Correspondence, VIII, 229.

4 Richard Hockley to Thomas Penn, March 31, 1759, Penn MSS., Official Correspondence, IX, 83; Pennsylvania Gazette, February 9, 1764.

5 Richard Hockley to Proprietors, March 1, 1766, Penn MSS., Additional Miscellaneous Letters, II, 5. 
An important step was taken when Edmund Physick became sole receiver-general and Richard Hockley was appointed auditor-general. ${ }^{1}$ This separation of the two most important offices concerned with the collection of proprietary charges should have had good results, especially as Physick had already drawn up an excellent scheme for the enforcement of the quit-rents which had been put into effect in a modified form. Continuing the practice of attendance at the chief towns in March, Physick undertook a thorough revision of the rent rolls in order to secure a basis for effective collections. ${ }^{2}$ Though the confused land situation presented a formidable obstacle, he persistently worked upon a rent roll, and used every possible means to make collections. ${ }^{3}$ The general situation he regarded as very unsatisfactory, since the entire amount due for the quit-rents and purchase money was in excess of the total value of the former, capitalized at twenty-four years' annual value. ${ }^{4}$ These conditions he found it was impossible to improve during the few troubled years that preceded the Revolution, although in $\mathbf{1 7 7 5}$ he still gave notice of his accus-

1 Commissions to Edmund Physick and Richard Hockley, January 1, 1769, Penn. Archives, 3d series, X, 377-381.

2 Richard Hockley to Proprietors, November 12, 1766, and to Thomas Penn, May 20, 1768, Penn MSS., Additional Miscellaneous Letters, II, 9; Official Correspondence, X, 146. Besides Philadelphia, Chester, Pennsbury and Lancaster, the receiver-general now included York in his itinerary, and thus made payments more convenient for settlers in the back country. Pennsylvaria Gazette, February 15, 1770, et seq.

3 Among the difficulties he encountered was the desire of owners of large tracts to have one patent for the entire holding. To comply, Physick pointed out, would necessitate many transfers upon the rent roll, and as small tracts were less liable to subdivision he considered that the rents from them were easier to collect. Usually, a separate patent seems to have been issued for each 300 acres. Physick to Thomas Penn, April 1, 1769, Penn-Physick MSS., Letter Book; III, 1.

4 Physick to Thomas Penn, September 28, 1769, Penn-Physick MSS., Letter Book, III, 31. 
tomed attendance at the usual places in each county in order to collect the quit-rents. ${ }^{1}$

With the overthrow of British control, the popular opposition to the quit-rents reached its climax. Chief Justice McKean, in an opinion he delivered to a committee of the assembly, denied that these charges had been reserved for the support of the government. Just as in other American proprieties, he held, the quit-rents of Pennsylvania originated under the rights of the mesne lord, William Penn, and were, therefore, feudal dues at the absolute disposal of the proprietary. ${ }^{2}$ After the receipt of this opinion, the committee reported that the feudal rights of Penn's heirs should not be allowed, and in the divesting act the assembly clearly distinguished between these rights and the private property of the proprietaries. The former, represented by the quit-rents and the purchase money, they summarily abolished, at the same time relieving all lands of any arrears, but the latter, including the reserved manors and the manorial rents, they confirmed. With a sense of justice that was unique at this time, the assembly compensated the Penn family for the loss of their proprietary rights by a gift of $£ 130,000$ "in remembrance of the enterprising spirit of the founder, and of the expectations and dependence of his successors."

1 Pennsylvania Gazette, February 22, 1775.

2 Cadwalader, Law of Ground Rents in Pennsylvania, pp. 45-46.

3 The report of the committee asserted that the quit-rents were " utterly subservient of the rights, safety, and happiness of the good people of this state and dangerous to civil liberty in general, as evidently tending to revive and confirm an unwarrantable aristocratical power and influence within this state, inconsistent with its true interests and therefore not to be admitted in a government founded upon equal liberty and the authority of the people." Cadwalader, Law of Ground Rents in Pennsylvania, pp. 46-47.

4 Shepherd, Proprietary Government in Pennsylvania, p. 91; Penn. Statutes at Large, $\mathrm{X}, 33-39$. By some authorities the ground rents in Pennsylvania 
this compensation, the proprietary claimants secured an excellent bargain, for the actual returns from their quitrents in Pennsylvania were by no means satisfactory. The rent roll had kept pace with the increase in settlement, until in 1776 it represented an annual value of. $£ 10,20473 / 4 \mathrm{~d}$, but collections had amounted to little more than a third of what was due. ${ }^{1}$ As the total arrears, excluding interest, amounted by 1779 to $£ 118,5694 \mathrm{~s} 61 / 2 \mathrm{~d}$, the quit-rent system in Pennsylvania may scarcely be considered a success, even though it had been inaugurated under favorable conditions. ${ }^{2}$

In the Lower Counties, later organized as Delaware, the proprietary quit-rents were even less lucrative than in Pennsylvania. The failure of the system there was not, however, without justification, for Penn's claim to this region was based upon deeds issued by the Duke of York before he received his final grant. 'Even if these deeds were valid, they required, as far as Newcastle and the circuit of twelve miles were concerned, an annual

have been identified as quit-rents. The chief point of similarity is the right of distraint upon delinquent tenants, but the nature of the two charges is essentially different. The ground rent is a contract limited in duration; the quit-rent was a perpetual feudal charge. Cadwalader, Law of Ground Rents in Pennsylvania, pp. 62, 214-215.

1 The following table shows the steady increase in the nominal amount of the annual quit-rents and profits, of which the former was the chief item.

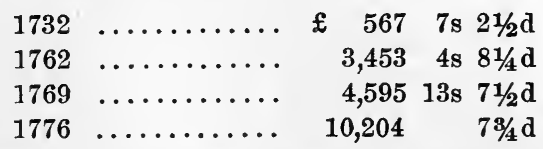

See sworn statement of Edmund Physick, 1779, Penn-Physick MSS., IV, 91.92.

2 Physick estimated that the total sum due on the quit-rents, 1700-1779, was $£ 182,24812 \mathrm{~s} 10 \mathrm{~d}$ sterling. Altogether, there had been paid $£ 63,679$ $8 \mathrm{~s} 31 / 2 \mathrm{~d}$, leaving still due a balance of $£ 118,5694 \mathrm{~s} 61 / 2 \mathrm{~d}$. See Account of Quit-Rents, 1700-1779, Penn MSS., II, 113, in Friends' Library. 
acknowledgment of $5 \mathrm{~s}$, and for the remainder of the peninsula, the yearly payment of one-half of all proprietary profits and quit-rents. ${ }^{1}$ As this latter condition, if unfulfilled, carried with it the penalty of distraint or forfeiture after seven years, Penn's failure to carry out these terms made his already questionable title even more uncertain. Under these conditions landholders could scarcely be expected to pay their quit-rents. Boundary disputes with Lord Baltimore and the demands of an administration separate from Pennsylvania still further complicated the task of enforcing the quit-rents in the Lower Counties.

Had not these uncertainties of title and jurisdiction intervened, the enforcement of the quit-rents in the Lower Counties might not have proved a difficult task, for even before the issue of the deeds to Penn, a precedent of reserving such charges had been set. The Duke's Laws had confirmed grants in the Lower Counties under the Swedes or the Dutch, with a quit-rent, which was usually one bushel of wheat for 100 acres or for each "tract," and the governor of New York had appointed deputies to collect these charges. ${ }^{3}$ Penn made no change in the rate until early in the eighteenth century when he increased it to a penny an acre for all new grants. ${ }^{4}$ Meanwhile, a number of landholders, most of them of

1 Deeds, Duke of York to William Penn, August 24, 1682, Franklin, Laws of Delaware, pp. 3-8.

2 Conditions of Queen Christina, January 24, 1640, Penn. Archives, 2d series, V, 779-780; Instructions to Governor Lovelace, July 1, 1669, and numerous grants, 1669, et seq. Penn. Archives, 2d series, V, 577-578 et seq.

3 Penn. Archives, 2d series, V, 580, 620-621, 683 et seq.

4 Occasionally there were special rates on "marsh" land, but usually the quit-rent was one bushel of wheat per 100 acres, or later $1 \mathrm{~d}$ per acre. After 1736 there was a nominal alienation fine, but there is no evidence that it was enforced. Abstract of Land Warrants, 1706-1735, and Proprietary Warrants, 1736, Penn MSS., Papers relating to the Three Lower Counties, pp. 179-241. 
Swedish origin, denied Penn's right to collect the quitrents and protested that the transfer to proprietary authority subjected them to much injustice. The Board of Property abruptly dismissed their petition, with a sharp reminder that under no excuse or "pretense whatsoever" would they be relieved from the payment of their rents. ${ }^{1}$

Unfortunately this firm policy was not maintained. The proprietary agents did not specify the place of payment, though they appointed a receiver in each county, ${ }^{2}$ who made meager collections and was often compelled to accept bonds for the large arrears that had accumulated. The accounts, too, of these receivers were carelessly kept and contained many petty personal details with regard to the circumstances of each landholder. ${ }^{3}$ After the first decade of the eighteenth century they secured few payments of the quit-rents, and these were usually made in the form of personal bonds which were of very doubtful value. ${ }^{4}$

One of the chief causes of the failure to collect the quit-rents in the Lower Counties was the interminable

1 Minutes, Board of Property, September 14, 1709, Penn. Archices, 2d series, XIX, 501.

2 Petition, probably from Neweastle County about 1700, Miscellaneous Papers, Three Lower Counties, p. 5; Commission to Maj. John Donaldson, March 3, 1700, Miscellaneous Papers, Three Lower Counties, p. 83; Bond of George Dakeyne, February 28, 1712, Penn-Physick MSS., VI, 8, 18; Minutes, Prov. Coun., Oetober 27, 1712, and January 7, 1713, Penn. Archives, 2d series, XIX; 537, 543.

3 For example, on one estate in Newcastle County, the arrears of the quitrents due were 99 bushels and 2 pecks of wheat. But Logan noted, "the whole family is poor and therefore I have taken one bushel and one-half.", For the remainder he accepted a bond which probably was never paid. This item is typical. Logan Papers: Quit-Rent Accounts, 1711-1713, Three Lower Counties, pp. 1-34; Quit-Rent Accounts, Neweastle County, 1701, pp. 20-24; Kent County, 1712-1713, pp. 34-53; Sussex County, 1701-1706, p. 59.

4 George Dakeyne's Account Book, 1709-1714, Penn MSS., Accounts, I. 
boundary dispute with Lord Baltimore. In 1713 James Logan declared that with "pathetick" language he had continually called attention to the necessity of establishing a boundary line between Maryland and Pennsylvania, in order that grants might be made for much desirable land in the disputed region, and that thousands of pounds of quit-rents and purchase money might be collected. ${ }^{1}$ Again, in 1719, Logan declared that although the quitrents of the Lower Counties had considerably increased, the people refused to pay them, and collections could not be enforced until these boundary disputes were settled, "without an armed force," unless their arrears, "which are great," were remitted. ${ }^{2}$ Still another hindrance to collection was the continued failure to carry out the conditions of the original grant from the Duke of York. In 1701 the Treasury and the auditor-general, William Blathwayt, reminded Penn that one-half of all rents and profits from the Lower Counties had not been paid. ${ }^{3}$ But this reminder had no effect for no steps were taken to fulfill this obligation, which by 1711 amounted, with arrears to $£ 8,700$. The British government did not press the matter during the negotiations with Penn for the surrender of the government, and the deed of transfer expressly reserved his rights in the soil of the Lower Counties. ${ }^{4}$ Penn's insanity and death prevented the

1 James Logan to William Penn, February 26, 1713, Penn. Archives, 2d series, VII, 32.

2 James Logan to S. Clement, May 13, 1719, Penn. Archives, 2d series, VII, 65.

3 Treasury Board to William Penn, March 27, 1701, Blathwayt's Journal, II, 73-75.

4 Report of John Povey, August 28, 1701, and reports of William Blathwayt, August 9 and March 2, 1703, Blathwayt's Journal, II, 88-89, 141-142, 205. In connection with these continued arrears, Oliver Hill petitioned with regard to his alleged discovery. See below, pp. 403-404. This estimate of 
ratification of this deed, but his heirs continued to claim their rights in the Lower Counties, notwithstanding their failure to make the annual payments which the original patents called for. ${ }^{1}$

The uncertain status of the Penn title led the Earl of. Sutherland in 1716 to petition for a grant of the Lower Counties in payment of certain claims he held against the crown. After considering this petition and the answer of Penn's creditors, the crown's attorneys held that there were grants in the Lower Counties under Penn on which improvements had been made, while many original claims under the Dutch and Swedes had been confirmed by the governor of New York. Furthermore, they considered that Penn's deeds were valid, while Lord Baltimore's grant was already void, and that the entire question of proprietary rights in the Lower Counties should be submitted to a court of chancery. If the court should decide that the province might be regranted, all patents to improved lands should be protected, but if it should uphold Penn's rights there was no reason to prevent the collection of the half of all the quit-rents and profits that were due. ${ }^{2}$ Had this advice been followed, the status of the proprietary claims would have been finally settled and the quit-rents in the Lower Counties could have been organized upon a definite basis. But nothing was done, and in 1725 the Earl of Sutherland again petitioned for a grant of the Lower Counties,

arrears was based upon an annual average revenue of $£ 300$ from August 24, 1682 , to August 24, 1711, twenty-nine years, a total of $£ 8,700$. See Blathwayt's report, October 1, 1711, Blathwayt's Journal, III, 89.

1 Report of Attorney-General Northey, February 25, 1712, Treas. 1: 144, f. 97.

2 Report of Edward Northey and Wm. Thompson, October 21, 1717, Penn MSS., Papers relating to the Lower Counties, p. 85. 
asserting that he stood ready to confirm the titles of all grants. $^{1}$

The refusal of the people of the Lower Counties to pay their quit-rents while the proprietary title was in doubt led to an accumulation of very large arrears, and forced upon the landowners an unpleasant dilemma. If the proprietary title should be confirmed, they would probably be forced to pay these arrears. On the other hand, if Lord Baltimore's claims should be confirmed or the province granted to a new proprietary, there would be great confusion in land titles. Sir William Keith proposed the one possible solution when he drew up an act in 1718 for the release of the "poor people" from the burden of the arrears, "which is become impracticable for them to pay without ruining and depopulating the whole country." This act, which was conditioned upon the consent of the crown and provided for the remission of all arrears of quit-rents and profits, would have secured the proprietary title in the Lower Counties. ${ }^{2}$ But the Board of Property, failing to grasp the situation, refused to allow the bill, and certain of the proprietary officials accused Sir William Keith of having made such a proposal in order to ingratiate himself with the people. The narrow point of view displayed in this charge had a. bad effect, for the people of the Lower Counties, fearing that the quit-rents might be collected, now began to plan for a government that would be altogether separate from that of Pennsylvania, and for an appeal to the crown with respect to the quit-rents. ${ }^{3}$ James Logan,

1 Neweastle to Board of Trade, November 18, 1725, Miscellaneous Papers, Three Lower Counties, pp. 139-143.

2 Scheme drawn up in 1718 by Sir William Keith, Penn MSS., Papers relating to Three Lower Counties, pp. 87 et seq.

3 Gordon to John Penn, October 22, 1726, Penn MSS., Official Correspondence, I, 247. 
however, vigorously upheld the proprietary rights, considering that there could be no real settlement of the quit-rents until the boundary dispute with Lord Baltimore was adjusted. ${ }^{1}$ Though by 1725 actual collections had practically been given up in the Lower Counties, ${ }^{2}$ he declared that the arrears were amply sufficient to pay the one-half of all profits to the crown if it should be demanded. In Logan's opinion the notion, which had been "artfully" fostered by Sir William Keith, that these arrears should be remitted had caused much discontent which it would be difficult to overcome. ${ }^{3}$

That the fear of being forced to pay the arrears of quit-rent was a real influence in the Lower Counties is shown in an address of the assembly to the proprietary family in 1726. Ostensibly, the address was drawn up in order to emphasize the loyalty of the assembly to the claims of the Penns in opposition to those of Lord Baltimore. The uncertainty of title due to these claims, the address alleged, was the chief cause of the failure to pay the rents. Now, owing to an "indifferent" soil, and the fact that the "inhabitants are but low in their circumstances," it would be impossible to pay the arrears if the proprietary rights were established. Great trouble had been caused by the encroachments of Lord Baltimore upon their lands, and the assembly did not believe that the proprietaries wished to distress the people further by insisting upon the enforcement of claims that they were unable to satisfy. While emphasizing in this

1 James Logan to Simon Clement, November 1, 1718, and Simon Clement to James Logan, May 30, 1720, Penn MSS., Official Correspondence, I, 79, 93.

2 James Logan to John Penn, November 24, 1725, Penn MSS., Official Correspondence, I, 207.

3 James Logan to Thomas Penn, April 17, 1726, and to John Penn, July 24, 1726, Penn MSS., Official Correspondence, I, 217, 231. 
fashion the kindly feeling toward the Penn family throughout the Lower Counties, the address pointed out that the fear lest the arrears be collected had made many persons "uneasy," and had been used as a "handle" by "designing people" in order to alienate the landholders from the proprietary interests. The former peace could only be restored if the Penns would signify to the governor or to the assembly their willingness to make a reasonable abatement of these arrears. The address concluded, "and we beg you to believe that this request does not altogether proceed from the consideration of the uncertainty of our titles, but also from the inability of great numbers of the inhabitants, whose lands, were they to be disposed of, would scarce sell for money enough" to discharge the arrears of rent. ${ }^{1}$

The strong sentiment in favor of the confirmation of the proprietary title to the Lower Counties, provided the arrears were remitted, was shown also in an address from the Protestant and Quaker inhabitants. The petitioners set forth that their ancestors had settled in the Lower Counties with a "full expectation" of the same "freedom and liberties" that were enjoyed in Pennsylvania, but they were now, it was rumored, to be handed over to "new masters" to the overthrow of both their civil and religious rights. Therefore, they prayed that the crown would take no advantage of the "honest improvers" owing to a "pretended defect" in the original title, but would confirm the proprietary claim. ${ }^{2}$ In another petition, very similar in tone, which was never presented to the crown, the Delaware assembly asked

1 Representation of Assembly of Lower Counties to Hannah and Springer Penn, 1726, Miscellaneous Papers, Three Lower Counties, p. 151.

2 Address of Protestant and Quaker Inhabitants of Newcastle, Kent, and Sussex counties, October 17, 1726, from their half year's meeting held in Kent County, Miscellaneous Papers, Three Lower Counties, p. 149. 
that the people of the Lower Counties should not be handed over to another proprietary. Inasmuch as such a change might alter the laws and liberties these people had enjoyed under Penn, it too petitioned that the rights of his heirs should be confirmed. ${ }^{1}$ In 1735 the assembly again drew up a petition to the crown which seems to have been actually presented. Again protesting against the claims of Lord Baltimore, it favored the confirmation of the Penn rights. ${ }^{2}$

The continued failure of the proprietaries to promise some abatement of the arrears of quit-rent furnished the anti-proprietary party with an ample pretext for the spread of their propaganda. Especially was this true after the final agreement had been reached between Lord Baltimore and the Penn family in 1750 which greatly strengthened the claims of the latter. The arguments of the anti-proprietary party were illustrated in a paper, said to have been written by the sheriff of Sussex County, which was circulated through the Lower Counties in 1754, evidently with a design of aiding the cause of certain claimants to a proprietary grant of the province. The Quakers, the paper insinuated, were supporting the union of the Lower Counties to Pennsylvania because they had been promised an abatement of their own quit-rents, although a "terrific burden of arrears" would thereby be fixed upon the province. The paper analyzed and denied the validity of the proprietary title to the Lower Counties, and asserted that if it should be established, and the Lower Counties should be united to Pennsylvania, laws would be passed for distraint, and the back quit-rents would all be collected. These rents, the paper

1 Address of Lower House of Delaware to Crown, March 15, 1727, Penn MSS., Papers relating to the Three Lower Counties, p. 139.

2 Petition of Assembly of Lower Counties to Crown, April 19, 1735, Penn MSS., Papers relating to Three Lower Counties, pp. 159-160. 
claimed, were void by all the laws of equity. If the province should be granted to another proprietary, no such claims for arrears would be made, and better terms for the future might be secured than from the proprietary family. But the "honorable and generous proposals" lately made by Sir William Keith, to represent the situation to the crown, had been slighted by the assembly, which "ignored all the interests of the people they represented,' ' if they were against those of Penn. ${ }^{1}$

This last paper clearly represented the real motive in the continued opposition to the quit-rents in the Lower Counties, for until some settlement was made of the large arrears that had accumulated, landholders were bound to feel more or less insecure. The proprietaries should have come to some agreement with the crown for the remission of these arrears, especially in view of the boundary dispute with Lord Baltimore. But failing to grasp the situation, they merely exercised a nominal control, and included quit-rents, which could not be enforced, in all grants. ${ }^{2}$ In 1774 a more vigorous policy was promised by a proclamation from Governor John Penn, which notified the people of the Lower Counties that the boundary line had finally been established by an agreement between Lord Baltimore and the Penn family, and that speedy steps would be taken to confirm all grants. The enforcement of this proclamation would have made possible the collection of the quit-rents, had not the Revolution intervened and put an end to a system

1 Copy of Paper handed about in Lower Counties, and "said to be wrote by one, Rodney, Sheriff of Kent County,', about 1754, Miscellaneous Papers, Three Lower Counties, p. 246.

2 Between March 1, 1742, and December 31, 1776, quit-rents aggregating $£ 5608 \mathrm{~s} 4 \mathrm{~d}$ in currency were reserved in the Lower Counties. Probably none of them was erer collected. See Quit-Rent Accounts, 1701-1776, PennPhysick MSS. 
of proprietary quit-rents which had failed even more signally than in Pennsylvania. ${ }^{1}$ The merely nominal character of these claims was forcibly illustrated when, upon the Declaration of Independence, the people of Delaware, like their neighbors in the Jerseys, took no steps to abolish the quit-rents. ${ }^{2}$

In the Lower Counties, as well as in Pennsylvania, the Penns failed to establish the quit-rent system upon a really firm basis. Though they controlled the government in both provinces, they could plead less justification for their failure in Pennsylvania, since there, every condition would seem to have been favorable to the quitrent system. Possessing an unquestioned title, the proprietaries had at hand abundant and well-kept records of patents and alienations, from which to make out a complete rent roll in Pennsylvania. ${ }^{3}$ Furthermore, the provincial laws, in addition to the terms of the patents, were adequate for the purpose. In the Lower Counties conditions were not so favorable, as here the proprietary title itself was questionable, and there was a long continued boundary controversy with Lord Baltimore. The records of the Lower Counties were not as well kept as those of Pennsylvania, and there was no provincial law specially drawn for the purpose of enforcing payment. On the other hand, as there was but one change in the rate, the varied assortment of quit-rents that confused the Pennsylvania rolls was not found in the Lower Counties. In both provinces the chief trouble seems

1 Proclamation of Gov. John Penn, September 15, 1774, Penn MSS., Papers relating to the Lower Counties, p. 284.

2 Thorpe, Constitutions and Charters, I, 562-570; Laws of Delaware, 1700-1797, passim.

3 The quit-rent accounts show that the land records had been kept up. Statement of Edmund Physick, 1779, Penn-Physick MSS., IV, 91-92; Accounts of Quit-Rents, 1700-1779, Penn MSS., II, 113, Friends' Library; Land Grants of Philadelphia County, Penn MSS., 7, 13. 
to have been the inability of the proprietaries to grasp the real difficulties of their quit-rent system. According to the opinion of one keen-sighted critic, Penn's heirs were men of narrow views who were so economical in the management of their province that, following an old adage, "they lost a sheep for a pennyworth of tar." Instead of efficient persons with adequate allowances, they appointed one receiver-general, with a salary of $£ 400$, who was accustomed annually to ride to each county in Pennsylvania in order to collect whatever quit-rents the tenants chose to pay. ${ }^{1}$ The system of collection was little better in the Lower Counties where the proprietaries appointed a receiver in each county, but failed to provide for any definite system of supervision. Consequently, the receivers were usually left to their own devices, and they collected the quit-rents in a very careless fashion.

The unbusinesslike management of the Penns led to the accumulation of large arrears in both of their provinces. ${ }^{2}$ Although these arrears did not arouse any marked discontent in Pennsylvania, they constituted a cloud upon most of the land titles. In the Lower Counties, on the other hand, the fear that the arrears would be collected was the main cause of opposition to proprietary control. In their usual blundering fashion the Penns made no effort to place their quit-rents in the Lower Counties on a firm basis, by negotiating an agreement with the crown for the remission of the arrears. Their policy was one

1 Estimate of the Estate of the Proprietaries in Pennsylvania, probably 1767, C. O. 5 : 1233.

2 In Pennsylvania, as the value of the land was usually greater than the quit-rents plus the purchase money, the proprietaries allowed large arrears to accumulate, upon which they received 6 per cent. interest. They seem to have been confident that the principal would be collected whenever it was wanted, as otherwise a clear title could not be secured. Estimate of the Estate of the Proprietaries of Pennsylvania, probably 1767, C. O. 5: 1233. 
of expediency, which postponed any definite action as long as possible, and ended in the general weakening of their authority. Such dilatory tactics were partly responsible for the rise in Pennsylvania of the popular claim that the revenues from the quit-rents should be appropriated to public rather than private purposes, and for the attempts of the assembly to force payments of the quit-rents in paper money and to tax these feudal dues. The success of both these efforts strikingly illustrates the weakness of proprietary control in Pennsylvania. Indeed, the entire history of the quit-rent system in Pennsylvania shows that even under the most favorable conditions, a firm and far-sighted policy was necessary if these dues were to be enforced in a propriety. 


\section{CHAPTER VII}

\section{PROPRIETARY QUIT-RENTS: IN PROPRIETIES NOT SURRENDERED TO THE CROWN}

\section{Maryland}

As proprietaries of Maryland, the Calverts developed a quit-rent system that was in decided contrast to the one founded by William Penn in Pennsylvania and the Lower Counties. The favorable conditions that attended the establishment of such feudal dues in these proprieties have already been mentioned, but the success of the quit-rents in Maryland, as compared with their virtual failure in the neighboring colonies, was due primarily to the tactful and broad-minded policy of the Baltimore proprietaries. Under their careful supervision, a system of quit-rents was established and enforced in Maryland, which was more successful in its actual results than any similar organization in the American colonies either proprietary or royal. The history of the quit-rents in Maryland, therefore, illustrates the possibility, even in America, of establishing this feudal charge upon the land, provided it were ably and firmly administered. The Maryland case presents an illuminating and interesting illustration of the successful maintenance of a feudal institution in the colonial period. The details fall into three well-defined periods, the first from 1634 to 1671, the second from 1671 to 1733 , and the third from 1733 until the Revolution.

In the period of establishment, 1634 to 1671 , the first 
necessity was to fix a precedent for the quit-rent and determine its rate. Upon all grants prior to 1635 , Lord Baltimore reserved $10 \mathrm{lbs}$. of wheat per 50 acres, and for those of later date he established a quit-rent of $1 \mathrm{~s}$ per 50 acres, "to be paid in commodities of the country.", These conditions were repeated in $1641,{ }^{2}$ but an attempt in 1648 to reserve a much higher and more complex rent was soon abandoned on account of the necessity of encouraging settlement. ${ }^{3}$ Such an increase in the quit-rent was a doubtful policy in view of the disturbances that attended the Puritan Revolution. ${ }^{4}$ Although proprietary rights in the soil were maintained under the Commonwealth, the passage of a bill, "concerning rights of land," which upheld the right of all persons who came to Maryland to take up land disclosed a determination to prevent any arbitrary exercise of proprietary powers. The bill did not specifically mention the quit-rents, but clearly asserted that the rights of the settlers, as well as those of the proprietary, must be respected. ${ }^{5}$ When Lord Baltimore resumed control after the overthrow of the Protectorate, he inaugurated a more vigorous policy and issued orders to increase the quit-rents to $4 \mathrm{~s}$ per 100 acres. Local conditions prevented the enforcement of these orders until 1669, when the quit-rent, reserved in

1 Conditions of Settlement, 1636, Md. Archives, III, 47-48.

2 Conditions of Settlement, November 10, 1641, Md. Archives, III, 99.

3 According to these conditions, for the first seven years the quit-rent was to be $1 \mathrm{~s}$ per 50 acres payable in commodities, for the next fourteen years $3 \mathrm{~s}$ or one bushel of wheat per 50 acres, and then either one-twentieth the annual yield, or else, for manors of 2,000 acres, $£ 10$, and on smaller tracts, 20 s per 50 acres. The medium in which this final rent would be paid was to be at the option of the proprietary. There was also to be an elaborate system of fines to enforce collections. Conditions of Plantation, 1648, and July 2, 1649, Md. Archives, III, 223-228, 231-235.

4 Council Proceedings, March 29, 1652, Md. Archives, III, 271.

5 Kilty, Landholder's Assistant, p. 255; Assembly Proceedings, October 20, 1654, Md. Archives, I, 348. 
all new grants, was fixed at 4 s per 100 acres. ${ }^{1}$ Except for a brief period, 1733 to 1738 , this rate remained in force until the Revolution. Either $2 \mathrm{~s}$ or, after 1669, $4 \mathrm{~s}$ per 100 acres was reserved in practically all grants, ${ }^{2}$ although the proprietary offered settlers on Delaware Bay, who claimed to hold under grants from the governor of New York, a rate of $1 \mathrm{~s}$ per 50 acres, in order to induce them to accept his authority. ${ }^{3}$ Lord Baltimore required only nominal rents from the Indians of the Eastern Shore." With these unimportant exceptions, the quit-rent rate was a uniform one, and consequently the confusion that marked the rent rolls of Pennsylvania was avoided in Maryland.

During the first period, 1634 to 1671 , the system of collection was not very well organized in Maryland. At first the governor received semi-annual payments at St. Mary's, ${ }^{5}$ but after the council appointed two receivers

1 An alienation fine was also imposed at this time, but the charge never seems to have been enforced to any great extent. Declaration of Lord Baltimore, October 4, 1660, Md. Archives, III, 458-459; Mereness, Maryland as a Proprietary Province, pp. 86-87; Council Proceedings, March 20, 1670, Md. Archives, V, 63-64. There was also a purchase price, commonly known as "caution"' money. This was first required in 1683 and was then $200 \mathrm{lbs}$. of tobacco per 100 acres. The following year it was increased to $240 \mathrm{lbs}$. and in 1704 to $480 \mathrm{lbs}$. In 1717 the purchase price was made $40 \mathrm{~s}$ and in 1738 $£ 5$ per 100 acres. Mereness, Maryland as a Proprietary Province, pp. 62, 77.

2 The only exception shown in the records was an offer of ten acres to every "ffirst", adventurer, and to later ones five acres, to be free of quitrents in either case, in the town and field of "St. Maries." Conditions of Settlement, 1636, Md. Archives, III, 47-48.

3 Lord Baltimore to Charles Calvert, July 28, 1669, Md. Archives, V, 54-55; Council Proceedings, December 23, 1670, and June 24, 1677, Md. Archives, V, 79; XV, 133.

4 In 1669 the Indians on the Choptank River agreed to pay six beaver skins annually as a sign of allegiance. Similar agreements were made in 1752 with the chiefs of the Indian River, the Assateague, the Pocomoke, and the Chicacoan Indians. Assembly Proceedings, 1669, Md. Archives, II, 200 ; Council Proceedings, July 24, 1752, Md. Archives, XXVIII, 584 et seq.

5 Kilty, Landholder's Assistant, p. 257. 
in 1642 , a yearly settlement became customary. ${ }^{1}$ When the population began to spread over a larger area, the sheriffs collected the quit-rents from their respective counties, and reported to the receivers at St. Mary's. ${ }^{2}$ Meanwhile, the proprietary agents undertook to enforce the quit-rents by distraint, if it proved necessary. ${ }^{3}$ This policy was greatly aided by the passage of a series of measures which, in order to prevent speculative holding of lands, provided that all owners of large tracts who had not paid their quit-rents would forfeit their lands unless they paid the arrears within a year. In the future, lands would be forfeited if the quit-rents were left unpaid for three years. ${ }^{4}$ Another important measure, which made every debt due Lord Baltimore a prior lien upon the land, ${ }^{5}$ was supplemented by a ruling of the provincial court, that the proprietary officers should have the power to levy rents and arrears upon "any goods chattels or debts" on lands for which the quit-rents had not been paid. But where there were no distrainable goods, the delinquent tenant might be detained in custody until he paid his due. The act also carefully regulated the fees of the officers, and the conditions under which distress might be levied. ${ }^{\circ}$ Notwithstanding these laws,

1 Council Proceedings, November 18, and later, 1643, Md. Archives, III, $142,147$.

2 Kilty, Landholder's Assistant, p. 257; Council Proceedings, March 20, 1652, and June 13, 1666, Md. Archives, III, 267-268; XV, 119.

3 The first notable instance of enforcement involved the land elaimed by Captain William Claiborne on Kent Island. All persons who took up lands there were required to pay a quit-rent of $2 \mathrm{~s}$ per 100 acres, with arrears from the date of any "pretended" grant from Claiborne, under penalty of distraint upon their lands, goods, and chattels. A receiver was appointed to enforce this order. Council Proceedings, December 7, 1640, and Provincial Court Proceedings, January 27, 1646, Md. Archives, III, 95; IV, 308-309.

4 Assembly Proceedings, 1650, Md. Archives, I, 288-289.

5 Ibid., Md. Archives, I, 304.

6 The fees allowed for distraint illustrate the difficulties attending the 
the enforcement of the quit-rents was often obstructed by the failure to take out patents for lands that had been surveyed. Consequently, as these lands were not entered upon the patent rolls, they escaped the quit-rents. The governors issued a number of proclamations threatening to employ drastic measures against persons who sought to evade their quit-rents in this fashion, while the proprietary sent instructions ordering complete rent rolls to be made out and annual courts of inquiry and survey to be held in each county in order to examine the quitrent accounts. ${ }^{1}$

The proprietary policy with respect to the medium of payment was exceedingly liberal. Specie payments were impossible, and as the conditions of settlement allowed an equivalent, tobacco was usually received, although other commodities were occasionally permitted. Thus, in 1640, the assembly, in prohibiting the exportation of corn, declared that it should be accepted in all tobacco payments. $^{2}$ In 1662 in order to secure a variation in crops, it provided that a variety of grains should be accepted at fixed prices in payment of the quit-rents and other public dues. ${ }^{3}$ As tobacco remained the chief medium of payment, in spite of these attempts to pro-

enforcement of the quit-rents in the sparse settlements of early Maryland. To levy distraint the officer must make a personal visit to the land of the delinquent tenant. If the trip were made without the loss of more than a day, the fee was 30 pounds of tobacco and a cask, but if a boat and helpers were necessary, the allowance was doubled. If more than a day were required, the fee was in proportion to the distance from St. Mary's; for the first ten miles by water, 10 pounds of tobaceo and a cask were allowed, and proportionately for greater distances. Provincial Court Proceedings, January 20, 1651, Md. Archives, X, 124-125.

1 Council Proceedings, 1649-1671, Md. Archives, III, V, passim.

2 Assembly Proceedings, October, 1640, Md. Archives, I, 96.

3 The grains, of which the cultivation was encouraged, were wheat to be received at $5 \mathrm{~s}$, barley and English peas at $3 \mathrm{~s}$, rye at $4 \mathrm{~s}$, and oats at $2 \mathrm{~s} 6 \mathrm{~d}$ per bushel. Assembly Proceedings, 1662, Md. Archives, I, 445. 
mote diversified farming, the quit-rents became involved in the frantic efforts to halt the rapid drop in the price of Maryland's leading crop. At first, the council arbitrarily fixed the exchange value from time to time, ${ }^{1}$ but in 1662 the assembly undertook to establish a legal rate of two pence per pound. ${ }^{2}$ The climax was reached in 1669 , when, owing to the scarcity of specie, the assembly declared all debts payable in tobacco at three and a half pence per pound. ${ }^{3}$ With a market price of only about one penny per pound, this valuation would have made the quit-rents practically worthless, and there was little possibility that the act would be accepted. Finally, the assembly passed a compromise measure which laid an export duty of two shillings upon every hogshead of tobacco, one-half to compensate the proprietary for receiving the quit-rents and alienation fines in tobacco at two pence per pound, the other half to be used for the expenses of government. ${ }^{4}$ This act, which was to be continued during the lifetime of Charles Calvert and that of his heir, marked the close of the first period of the quitrents. ${ }^{5}$ During this time these charges were established as a customary due, a system of collecting was organized, and laws for enforcement were passed.

The quit-rent system of Maryland now entered upon a second period of development, 1671 to 1733 , which was marked at first by partial and finally by complete commu-

1 Thus, the council directed the sheriff of Kent Island to accept tobacco at $3 \mathrm{~d}$ per pound and wheat at $12 \mathrm{~d}$ per peck, in payment of the quit-rents. Council Proceedings, December 7, 1640, Md. Archives, III, 95.

2 Assembly Proceedings, 1662, Md. Archives, I, 445.

3 Ibid., 1669, Md. Archives, II, 220-221.

4 The analogy between this duty and the $2 \mathrm{~s}$ per hogshead that was levied in Virginia for the support of government, is a striking one. Assembly Proceedings, 1671, Md. Archives, II, 256 et seq., 284 et seq.

5 Assembly Proceedings, 1674 and 1676, Md. Archives, II, 386-387, 515517. 
tation for the compensatory duty of two shillings upon every hogshead of tobacco exported. That there was no intention of giving up the quit-rents entirely became evident, when an act that was passed in 1683 for laying out a town in each county reserved a penny on each lot, not excepting public commons. ${ }^{1}$ Collection, too, was vigorously pushed, and the sheriffs received instructions to distrain whenever the rents were not promptly paid. ${ }^{2}$ This order produced so much friction that the assembly subjected sheriffs, who seized a greater amount of tobacco than was owed for the quit-rents, to a fine of $£ 2,000 .^{3}$ It also passed an act imposing heavy penalties upon landholders who disposed of tobacco that had already been seized for the quit-rents. ${ }^{4}$

Occasionally the proprietary officials did not adhere to the compensatory agreement of 1671 , and a quaint petition to the crown sent by the assembly in 1688 asks that inasmuch as there was no gold or silver in the province, Lord Baltimore should continue to receive his rents in tobacco at two pence per pound. ${ }^{5}$ The assembly complained also that collectors refused to accept tobacco and exacted sterling money in payment of the rents, "to the great grievance and oppression of the people of this province." The governor promised speedy relief from such exaction, ${ }^{6}$ but the charge was repeated in articles of complaint that were filed just before the crown as-

1 Assembly Proceedings, 1683, 1694 and 1696, Md. Archives, VII, 613; $\mathrm{XIX}, 110-113,501$ et seq.

2 Council Proceedings, November 24, 1675, Md. Archives, XV, 62.

3 Assembly Proceedings, 1676 and 1692, Md. Archives, II, 520-521; XIII, 484-485.

4 Assembly Proceedings, 1678, Md. Archives, VII, 77.

5 The quaintness of this petition is indicated by the title, "A complaint from Heaven with a Hue and Crye and Petition out of Virginia and Maryland,' about 1671, Md. Archives, V, 134-149.

6 Assembly Proceedings, November 22, 1688, Md. Archives, XIII, 171-173. 
sumed the government of Maryland. ${ }^{1}$ That Lord Baltimore was not wholly satisfied with the agreement became apparent when the council proposed, in 1689, that the two shillings duty should be reduced by one-third and the quit-rents paid in sterling. As the lower house refused to concur, the compensatory duty remained unchanged. ${ }^{2}$ After the crown took over the government of Maryland in 1691, the assembly appropriated one-half of the two shillings duty for the support of the royal administration, but continued to give the remaining one shilling to the proprietary in return for the receipt of tobaceo at two pence per pound. ${ }^{3}$ Lord Baltimore probably received little profit from his quit-rents at this time, and in 1699 he leased them to Richard Heath and James Bennett for eight years. The lessees did not push their claims, "through tenderness and mildness," they alleged, but probably because, in reality, tobacco was of such little value that the quit-rents were scarcely worth the trouble of collection. ${ }^{4}$ For the first fifteen years of the eighteenth century, the shilling a hogshead on exported tobacco seems to have been the chief return to the proprietary from the quit-rents.

Upon the death of Charles, Lord Baltimore, in 1715, the assembly offered to renew the agreement made in 1671. But as the proprietary had now reassumed his governmental rights, he was in an excellent strategic position to drive a bargain with the assembly over the quit-rents. Alleging the uncertain state of the tobacco

1 Council Proceedings, November, 1690, Md. Archives, VIII, 216 et seq.

2 Council to Lord Baltimore, January 16, 1688, and December 5, 1690, Md. Archives, VIII, 63, 220 et seq.

3 Council Proceedings, February 27, 1690, Md. Archives, VIII, 234-235. This allowance to the proprietary of $1 \mathrm{~s}$ per hogshead for receiving the quitrents at $2 d$ per pound of tobaceo, was renewed in 1704. Assembly Proceedings, 1704, Md. Archives, XXVI, 312-313.

4 Assembly Proceedings, 1707, Md. Archives, XXVII, 154-157. 
market, he refused to continue the agreement. But the assembly persisted, offering to increase the compensatory duty to eighteen pence in view of the increased size of a hogshead. Unfortunately, before the act containing these terms reached England, the proprietary died, and it became necessary to make a new bargain with Lord Guilford, guardian of Lord Baltimore's heir.' Governor Hart recommended for the consideration of the lower house an agreement, to which he had secured Lord Guilford's assent, to levy a duty of two shillings per hogshead in full commutation of all quit-rents and alienation fines. ${ }^{2}$ But his arguments did not prevail, inasmuch as Lord Guilford had already intimated that he would accept the eighteen pence duty for his youthful ward. As the acceptance of this offer meant that the quit-rents, being paid in tobacco at two pence per pound, would become practically a nominal charge, the assembly adhered to its former plan. ${ }^{3}$

Evidently the assembly had not appreciated the dangers that would arise if a proprietary who controlled the government wished to enforce the quit-rents. Charles Carroll forcibly aroused it from this lethargy, informing the council that Henry Darnall had offered to lease the quit-rents from the proprietary. As proof of his assertion, he produced a lease from Lord Guilford by which Darnall was given the right to collect the quitrents for six years beginning with September 25, 1714, in consideration of an annual payment of $£ 300$ sterling

1 Account of Maryland Revenue Laws, Miscellaneous Papers, Portfolio, $2 \mathrm{~b}$; Acts of the Assembly, 1715, Md. Archives, XXX, 348 et seq.

2 Council Proceedings, April 24 and 25, 1716, Md. Archives, XXV, 337, 339.

3 Account of Maryland Revenue Lawis, Miscellaneous Papers, Portfolio, 2b; Upper House Journal, July 20, 1716, and April 30 and May 10, 1718, Liber 31, pp. 168-169, 443-504. 
and 67,000 pounds of tobacco to certain of the proprietary officials. Darnall, however, refused the lease, and Carroll tore it up in the presence of the council. This rather dramatic scene, which Carroll had probably staged on purpose, had the desired effect. Reminded of the absolute proprietary control of the rents, the lower house consented to the passage of a measure which offered the two shillings duty in payment of all quit-rents and alienation fines. ${ }^{1}$ This act seems to have been rejected for some reason, and at the next session the governor addressed the assembly with regard to the best terms that could be secured for the payment of the quit-rents. After pointing out that the latter were now due in sterling money, a form of payment that would bring great hardships upon the people and might retard the settlement of the back-lands, Governor Hart proposed a possible compromise. As the size of tobacco casks had been increased, and the rent rolls had grown, the proprietary, he announced, would accept a three shilling three pence duty, of which three pence would be used to maintain forts and magazines, one shilling to support the government, and two shillings to compensate for all quit-rents and alienation fines. This settlement the council recommended, but the lower house insisted that the bill should state explicitly that only the two shillings, and not the entire three shillings three pence, was in-

1 Carroll estimated that at the prevailing price of tobaceo, $1 \mathrm{~d}$ sterling per pound, the 67,000 pounds received from the proposed lease of the quitrents would bring in $£ 2793 \mathrm{~s} 4 \mathrm{~d}$. This sum was necessary to pay allowances to different officials. As the lessee would pay an additional $£ 300$, the $2 \mathrm{~s}$ duty proposed by the house must pay, altogether, $55793 \mathrm{~s} 4 \mathrm{~d}$, unless the proprietary was to suffer loss. Incidentally, this estimate gives an insight into the actual value of the quit-rents at this time. Account of Maryland Revenue Laws, Miscellaneous Papers, Portfolio, 2b; Upper House Journal and Lower House Journal, July 24, 1716, and Acts of the Assembly, 1716, Md. Archives, XXX, 397-399, 503-504, 626-627. 
tended as a commutation of the quit-rents and alienation fines. If, it asserted, the act implied that the entire duty was merely an easy way to pay the quit-rents, "we are unjust stewards to the country in raising so much in lieu of rents beyond their values." ${ }^{2}$ With such restricting clauses the assembly finally passed the act in 1717, and regularly renewed its provisions until $1730 .^{2}$ As this arrangement shifted the burden of the quit-rents from the land, it was believed that collections would prove less vexatious than under the old system.

At first the agreement met the approval of the proprietary and of the general public. In recommending a renewal of the duty in 1720, Governor Hart declared that all the former inconveniences in collecting the rents were now obviated, that the proprietary received a larger net income than before, and that the people had never been better pleased or easier in their possessions. In reply, the council expressed the hope that the arrangement would continue, and the lower house concurred in this mutual exchange of courtesies. Lord Guilford, too, in adding his testimony to this general approval, noted the aid that the act had given in settling up the back-lands. ${ }^{3}$ But by 1726 a strong antagonism had arisen to the compensatory duty, probably as a result of Lord Baltimore's attempt to secure the entire three shillings three pence duty for his personal use. Governor Calvert, uncle of the proprietary, prevented any really hostile action at this session. In a conciliatory address to the lower house, he pointed out that under the existing arrangement the proprietary received only about half of what he would

1 Upper House Journal, June 5 and 7, 1717, Liber 31, pp. 351-354, 368-369.

2 Bacon, Laws of Maryland, May-June, 1717; Kilty, Landholder's Assistant, p. 226.

3 Upper House Journal, April 5, 8, 11 and 21, 1720, Liber 31, pp. 612-613, $639,643,708$. 
realize if the rents and alienation fines were collected in sterling. But Lord Baltimore accepted this agreement, the governor asserted, from "tender regard" for his tenants, and authorized a renewal for three years, "which is an instance His Lordship prefers the interests of the country to his own, and which I do not doubt you are sensible of."'

In 1729 , when the time came to renew the agreement, public sentiment against the compensatory duty had greatly increased. Lord Baltimore, also, had begun to think that the quit-rents would be more valuable than the duty, especially as efforts were being made to reduce by law the amount of tobacco that was planted. ${ }^{2}$ But he finally gave his consent to a renewal of the agreement, chiefly upon the representations of his brother, Governor Benedict Calvert, who made a keen analysis of the situation. The people of Maryland, Governor Calvert said, complained that the proprietary had too good a bargain, while Lord Baltimore considered that the quit-rents were greatly in excess of the equivalent he received from the duty. Both were in error, for in no other fashion could the tenants so easily pay their quit-rents. Under the existing arrangement, the governor pointed out, the burden was borne by the traders rather than the poorer farmers. As the traders held the "whip hand" of the planters in furnishing necessary supplies, and as their profits were often excessive, the duty was, therefore, a just one. From the proprietary standpoint, also, Governor Calvert considered that the commutation of the quitrents presented great advantages. It would be almost impossible, 'he believed, to collect the quit-rents on the rent rolls, amounting to almost $£ 6,000$, without very great

1 Lower House Journal, July 14, 1726, Md. Archives, XXXV, 537-538.

2 Gould, Land System in Maryland, 1720-1765, p. 38. 
losses and charges. As there was not enough money in the province to pay them in specie, the proprietary officers would be obliged to accept tobacco, corn, beef, wheat, and other products of the country in payment of the quit-rents. The conversion of these commodities into cash would be the source of great losses, and would cause endless vexation and inconvenience. In conclusion, he added, "I shall say no more at present, but pray for the continuance of this agreement.",

For a time Governor Calvert's arguments prevailed, and when the assembly passed a law in 1730 to limit the number of tobacco plants, they provided for the resulting loss in the compensatory duty by an additional three pence per hogshead. ${ }^{2}$ In 1732 the opponents of the agreement won a partial victory, for the two shillings duty was renewed, but without this extra allowance. ${ }^{3}$ Finally, in 1733, the lower house refused to continue the two shillings duty, although the council still favored this means of settling the quit-rents. Apparently Lord Baltimore, who was in Maryland, made no effort to have the duty renewed. ${ }^{4}$ The motives for the action taken by the lower house, as far as they appear in the scanty records, give an interesting insight into the political and economic situation in Maryland at this time. Undoubtedly there was a widespread popular feeling that the proprietary was getting the better of the bargain. Moreover, the

1 Benedict Calvert to Lord Baltimore, October 20, 1729, Calvert Papers.

2 For the past nine years the average return from the $3 \mathrm{~s}$ duty per hogshead had been annually $£ 4,2838 \mathrm{~s}$, of which one-third had been used to meet the expenses of government, and two-thirds to commute all quitrents and alienation fines. The loss due to a decrease in the planting of tobacco was to be made good by the extra 3d duty. Bacon, Laws of Maryland, May, 1730.

3 Bacon, Laws of Maryland, July, 1732.

4 Lower House Journal, June 3, 1733, Jiber 45; Upper House Journal, April 10, 1733, Liber 35. 
incidence of the duty had aroused the hostility of two influential classes: the large planters, who shipped their tobacco by the hogshead, and were unable to evade the duty; and the traders, who usually bought their tobacco in odd lots, and found that it was impossible to shift the charge. As grain, rather than tobacco, had now become the principal crop of the Eastern Shore, the planters of the Western Shore objected to paying, by a tax on their own tobacco, the quit-rents of their neighbors across the bay. An analysis of the votes in 1732 and 1733 upon the compensatory duty shows the strength of this opposition, since most of the negatives in each case came from the tobacco-raising Western Shore. ${ }^{1}$

From the proprietary standpoint also, a continuance of the duty was considered equally undesirable. Many representations had been made to the proprietary of the actual loss involved in the compensatory duty, and there was grave danger that if this method of paying off the quit-rents was continued, the latter charges might eventually become obsolete. As no collections were being made, the organization for this purpose had been allowed to lapse, and the rent rolls, not being kept up, had fallen into much confusion. ${ }^{2}$ At the same time there was eva-

1 Gould, Land System in Maryland, 1720-1765, pp. 35-39.

2 For the year 1690 , the 1 s per hogshead netted $£ 1,3453 \mathrm{~s} 71 / 2 \mathrm{~d}$, and the rent roll was not more than $£ 5,000$. As the quit-rents under the agreement were accepted in tobacco at $2 d$ per pound, although the actual value was only $1 \mathrm{~d}$, they did not bring in over $£ 2,500$ in 1690 , and probably the receipts were far less. That is, the total revenue in 1690 from both the compensatory duty and the quit-rents was not over $£ 3,845$, or scarcely more than half of the apparent rent roll was realized. Assembly Proceedings, June, 1692, Md. Archives, VIII, 205; XIII, 532-533. With the complete commutation of the quit-rents by a compensatory duty, the fiscal situation did not improve. For the seven years preceding 1730 , the 2 s duty averaged $£ 2,855$, but the total amount of the rent roll by 1724 was at least $£ 5,22513 \mathrm{~s}$, or only a little over half the apparent value of the quit-rents was realized. Bacon, Laws of Maryland, 1730; Lord Baltimore's Account Books and Rent Rolls, 
sion of the conditions of settlement, and many persons, settling upon land without warrants, practically denied the proprietary authority. ${ }^{1}$ Now that the quit-rents were no longer collected, speculators were able to take up great tracts of uninhabited land without any attempt at settlement, while many persons held large quantities of surplus land above the number of acres in the original grant. ${ }^{2}$ All these abuses show that the abandonment of the direct collection of the quit-rents was leading to a general confusion in the land system, which would inevitably result in much loss in revenue and the general weakening of proprietary authority. These facts were probably fully ascertained by Lord Baltimore during his stay in Maryland and doubtless influenced his decision to abandon the compensatory duty. ${ }^{3}$

The resumption of direct collection in 1733 marks the beginning of the third period of the quit-rent system in Maryland, which lasted until the Revolution. The most notable feature of this period was the successful organization of the system of collection, under the able and vigorous administrations of Governors Ogle, Sharpe, and Eden. Gradually the rent rolls increased until a large revenue was received from this source, while such opposition as arose was smoothed away by a policy both tactful and forcible. Occasional mistakes were made, as when Lord Baltimore arbitrarily increased the quit-rents reserved in new grants to 10 s per 100 acres, except upon frontier or surplus land. ${ }^{4}$ As a result the number of

Calvert Papers; Calvert to Governor Sharpe, October 8, 1761, Md. Archives, IX, 542-543.

1 Governor Ogle to Lord Baltimore, January 10, 1731, Calvert Papers.

2 Gould, Land System in Maryland, 1720-1765, pp. 36-37.

3 Mereness, Maryland as a Proprietary Province, p. 82.

4 Conditions of Plantation, June 20, 1733, Md. Archives, XXVIII, 45-46; Kilty, Landholder's Assistant, p. 232. 
land warrants that were taken out decreased almost ninety per cent., and settlement was so greatly retarded that the former four shillings rate was restored in $1738 .{ }^{1}$ Trouble was caused also by proprietary instructions in 1735 which attempted to fix an extortionate rate of exchange for the foreign gold and silver that had become the usual medium for paying the quit-rents. But after the lower house had passed a resolution protesting vigorously against such an exaction, Lord Baltimore consented to a more reasonable rate. ${ }^{2}$ Both of these incidents might have made serious trouble, had not the proprietary sensibly recognized the limitations that were imposed by local conditions.

Soon after the two shillings compensatory duty was given up, an effective system of collection was organized. According to this scheme the quit-rents were collected either by private persons, popularly known as farmers of the rent, at a discount of from twenty to twenty-five per cent., or else by receivers, usually the sheriffs, who were appointed in each of the counties involved and received a commission of ten per cent. The large discount allowed in the counties that were farmed out was necessary, on account of the confusion into which the rent rolls had fallen. Adequate security was required from both the farmers and the receivers of the rent, and all of them were subject to the direct supervision of two rent roll keepers; one in charge of the Eastern, and the other of

1 Gould, Land System in Maryland, 1720-1765, pp. 56-57; Lower House Journal, May 25, 1744, Liber 46.

2 The usual rate of exchange for foreign gold in Maryland in 1735 was $£ 42 \mathrm{~s} 6 \mathrm{~d}$ per ounce. The proprietary instructions fixed exchange at $£ 310 \mathrm{~s}$, a rate which was sufficient to cover the expense of transferring funds to England. This arbitrary action was elearly illegal, and ultimately the rate of exchange for payments of the quit-rents was made $£ 317 \mathrm{~s} 6 \mathrm{~d}$ per ounce for gold, and 5s 3d for silver. Gould, Land System in Maryland, 1720-1765, p. 42 . 
the Western Shore. These last two officials, who were appointed by the governor and were under his general direction, received a commission of five per cent. on all collections in their respective districts, and in addition to the receipts from the quit-rents, which they transmitted to the proprietary steward, they kept rent rolls of each of the counties under their control. From these rolls they annually made out debt books for the receiver or the farmer of the rents in each county, and these lists afforded a basis for collections. ${ }^{1}$ This scheme, which with only slight alterations remained in force until the Revolution, was by far the most effective method of collecting the quit-rents that had been employed in any colony. Its most distinctive features were the direct control exercised by the governor and the organization of an official force whose chief duty was to receive the quit-rents. After he had put this effective system of collection in force, Governor Ogle reported much grumbling and complaint from persons who had not paid any quitrents for many years; but no real trouble arose. ${ }^{2}$

This unmistakable determination on the part of the proprietary to collect the quit-rents, and the scarcity of coin, in which medium they were to be paid, had its effect upon the lower house, which now made a number of per-

1 Instructions to Governor Ogle, June 18, 1733, Md. Archives, XXVIII, 67-68; Lower House Journal, September 10, 1745, Liber 46.

2 Governor Ogle displayed great determination in enforeing the quit-rents, asserting that he would see justice done by the tenants with respect to the proprietary rights, "without the least regard to what any of them may say or think about it." It is interesting to contrast this determined stand and the excellent results that followed from it in Maryland, with the policy in South Carolina after the crown bought the colony, and the attempt that was made in a half-hearted fashion, at least as far as the local officials were concerned, to enforce the quit-rents. Governor Ogle to Lord Baltimore, August 23, 1733, Calvert Papers ; Upper House Journal, September 10, 1745, Liber 35; Proclamation of Governor Ogle, January 29, 1734, Md. Archives, XXVIII, 54. 
sistent efforts to secure a new agreement. The proprietary, however, displayed no eagerness to accept any compensation for his quit-rents, and met all overtures with an independent attitude that was a proof of the strength of his position in Maryland. The first effort to secure an agreement was a proposal made by the lower house, in 1735, to send a joint address asking for some means of discharging the quit-rents. The council, in reply, blamed the lower house for the discontinuance of the former duty and proposed the offer of a definite equivalent. ${ }^{1}$ This last hint failed to bear fruit, owing to the opposition of the tobacco-growing counties to another tax upon their product, $^{2}$ but in a joint address the assembly acknowledged in repentant fashion the great mistake it had made by its refusal to continue the former agreement. Owing to the scarcity of money, it said, the present method of collection "will prove very detrimental if not ruinous to many of the inhabitants of this province." Therefore, it besought the proprietary to "commiserate" the unhappy situation of his tenants, and to give instructions to the governor regarding a sum of money, to be raised in the easiest fashion, in lieu of the quit-rents and alienation fines. ${ }^{3}$ This complete change of heart on the part of the lower house, in contrast to its rather haughty refusal only two years before to renew the agreement, was a striking tribute to the firm policy that attended the direct collection of the quit-rents.

The proprietary's reply to the assembly's address expressed, in general terms, a willingness to accept an equivalent for the quit-rents that did not impose too great a burden upon trade. ${ }^{4}$ By a vote of twenty-seven

1 Upper House Journal, April 15 and 16, 1735, Liber 35.

2 Gould, Land System in Maryland, 1720-1765, p. 45.

3 Upper House Journal, April 23, 1735, Liber 35.

4 Ibid., April 20, 1736. 
to six, the lower house bore testimony to the general sentiment in favor of some agreement, but when the time came for a definite offer, the old fear lest the proprietary get the better of the bargain was revived. The lower house insisted upon a duty of two shillings six pence per hogshead of tobacco, while the council proposed one of three shillings. ${ }^{1}$ After much wrangling between the two houses, they finally agreed upon a joint address which offered in lieu of the quit-rents and alienation fines a lump sum of $£ 4,000$ sterling, to be raised chiefly by duties on tobacco, negroes, rum, wine, and spirits. The assembly also proposed that the provincial officials should collect the quitrents in paper money, and use the proceeds as the chief source from which to reimburse the traders who paid the proposed duties. ${ }^{2}$ Had it been accepted in its entirety, the quit-rents would have come wholly under the control of the assembly, and, paid in paper money, would eventually have been converted into a merely nominal charge. Daniel Dulany, the proprietary agent, pointed out the inadequacy of the equivalent that was offered. The total rent roll he estimated at $£ 8,000$, and as it was bound to increase, any proposed agreement should consider this future growth and be limited in time. Dulany called attention to the inevitable demoralization of the rent rolls if an equivalent should be accepted, for many persons, he said, were already backward in paying their rents, hoping that some such agreement would be reached. ${ }^{3}$ In the end, though the proprietary did not altogether refuse an equivalent, he implied that he would not

1 Lower House Journal, April 26 and 29, and May 4, 1736, Liber 45.

2 Lower House Journal, May 4, 5 and 6, 1736, Liber 45; for a full account of this rather elaborate scheme of colonial finance, see Gould, Land System in Maryland, 1720-1765, pp. 45-47. f. 3 .

3 Daniel Dulany to Lord Baltimore, September 7, 1736, Dulany Papers, 2, 
accept the scheme proposed by the assembly or look with encouragement upon similar proposals in the future. ${ }^{1}$

In 1739 the governor aptly expressed the popular sentiment in favor of an equivalent for the quit-rents, when he proposed to the assembly that some means be devised to pay these charges in paper money. If such a measure were impossible for the entire province, he said, at least it might be practicable to adopt it for the settlers in the back country. Emphasizing the general principle of an agreement, he called attention to the changed attitude of the members of the lower house who had opposed his efforts to continue the former compensatory duty. "At present," he declared, "few are so partial as not to acknowledge that the government was then acting for the general benefit and advantage of the people whose interest was greatly mistaken by their own representatives."2 This appeal produced no immediate results, but in $\mathbf{1 7 4 2}$ the lower house asked the governor for a statement of the annual value of the quit-rents and alienation fines. ${ }^{3}$ Although this inquiry met with little encouragement, even from the council, the lower house persisted in its effort to secure some method of discharging the quit-rents. A committee drew up an address to the proprietary whch proposed, in lieu of the quit-rents, a tax, the amount of which was to be determined later. Unless the proprietary consented to this proposal, and to a levy for purposes of government, the assembly intimated that it would be under the "disagreeable necessity" of applying to the crown for the redress of certain grievances. The rejection of this bold address from the lower house by a vote of only twenty to nineteen showed

1 Upper House Journal, April 26, 1737, Liber 35.

2 Lower House Journal, May 1, 1739, Liber 45.

3 Lower House Journal, October 21, 1742, Liber 46. 
the strength of the opposition to proprietary authority at this time in Maryland.' 'The committee then drew up a much more conciliatory address which the lower house accepted. This address proposed to raise an equivalent for' the quit-rents, but left the amount and the'manner of collection to be determined by agreement." The proprietary, however, seems to have paid no attention to this proposal.

In 1744 the assembly proposed a duty of two shillings six pence per hogshead for not over seven years, as an equivalent for the quit-rents. Urging the acceptance of this duty, it laid stress upon the great difficulties involved in the payment of the quit-rents in sterling money, and the necessity of promoting settlement in the back country as a barrier against the French. ${ }^{3}$ But Dulany considered all such schemes for an equivalent worthless, unless a law should be passed at the same time for the proper inspection of tobacco. Edmund Jennings and Benjamin 'Tasker, also, strongly urged Lord Baltimore not to accept the proposed duty. A definite sum well secured, they believed, would be a far better device, and one that would not restrict trade as much as a duty. ${ }^{5}$ The proprietary followed the advice of these agents, although he informed the assembly that he had authorized the governor to accept a composition which would be mutually beneficial."

1 The anger of the assembly had been aroused especially by the proprietary attempt to collect a duty of $12 \mathrm{~d}$ por hogshead, which was levied under an act of $\mathbf{1 7 0 4}$ for the support of government. This act, the assembly claimed, had now expired. Lower House Journal, October 25, 1742, Liber 46.

2 Iower House Journal, October 28, 1742, Liber 46.

3 The chief opposition to this duty, as to similar taxes on tobacco, came from the Western Shore. Lower House Journal, May 26 and 29, 1744, Liber 46.

4 Daniel Dulany to Lord Baltimore, about 1744, Dulany Papers, 2, f. 17.

5 Edmund Jennings to Lord Baltimore, June 12, 1744, and Benjamin Tasker to Lord Baltinore, December 3, 1744, Calvert Papers.

- Lower House Journal, August 28, 1745, Liber 46. 
At once the lower house asked for an exact statement of the sum that would be accepted, together with details as to the value of the quit-rents. ${ }^{1}$ Complying with both requests, the governor answered that $£ 5,000$ was the least amount that would be accepted, and that this would be done only to promote the "good agreement" which had always existed between the proprietary and the people of Maryland. The actual net returns of the quit-rents, he pointed out, were not over $£ 5,000$, but with the contemplated improvements in the system of collection, the rent rolls ought soon greatly to exceed the proposed equivalent. $^{2}$

Upon receiving the governor's message, the lower house determined to offer $£ 5,000$ annually in commutation of the quit-rents. It did not agree as easily upon the manner of raising this sum, since sectional differences again arose between the tobacco planters of the Western Shore and the grain farmers of the Eastern Shore, but finally, by the deciding vote of the speaker, it passed a resolution agreeing to raise the equivalent for the quitrents by a duty upon other commodities than tobacco. After rejecting a duty on flour and wheat, throngh the influence of the grain producers on the Eastern Shore, it passed a bill laying export duties on tobacco, staves, and shingles, and import duties on negroes, servants,

1 Upper House Journal, September 3, 1745, Liber 35.

2 Deducting the expenses of collection, the actual net returns from the quit-rents had been $£ 4,50815 \mathrm{~s} 4 \mathrm{~d}$ at the last collection, although the gross receipts had been $£ 5,36911 \mathrm{~s} 3 \mathrm{~d}$. By placing the sheriffs in charge of all collections on a commission. of 5 per cent., Governor Bladen estimated that the quit-rents would have netted $£ 5,1012 \mathrm{~s} 2 \mathrm{~d}$. As the gross amount had increased at least $£ 400$ in five years, the revenue would be much larger in the future: This account shows that the proprietary would not have gained by the equivalent. Lower House Journal, September 5 and 10, 1745, Liber 46. 
spirits, and wine. ${ }^{1}$ Unfortunately this act never became a law, and for the following reason. Though the proprietary, in order to promote harmony, was willing to give his consent to the quit-rent act and other measures that the people desired, he considered that in return the militia bill also should be passed. To refuse to pass this bill, the governor said, "can have no other interpretation but that you are desirous that those bills which have taken up so much of our time should be lost, which must be the case." Despite this threat, the lower house refused to be coerced into passing the militia bill, and the proprietary would not give his consent to the act offering an equivalent for the quit-rents. ${ }^{2}$

The persistent efforts of the lower house to secure a commutation of the quit-rents are significant. The landholders of Maryland, aroused by the vigorous manner in which the rents were collected, naturally wished to shift the burden, but their attempts to agree upon a commutation were always thwarted by the economic jealousies existing between the Eastern and the Western Shores, together with the fear lest the proprietary get the better of any bargain that might be made. Taking advantage of this legislative difficulty, the proprietary took a firm stand, refusing to permit a virtual surrender of his quitrents in order to still popular clamor. In the end he was

1 In addition to the duty of $2 \mathrm{~s} 9 \mathrm{~d}$ per hogshead on tobacco, there were to be export duties of $5 \mathrm{~s}, 2 \mathrm{~s} 6 \mathrm{~d}, 1 \mathrm{~s} 6 \mathrm{~d}$, and $6 \mathrm{~d}$ per 1,000 , respectively, on pipe, hogshead, and barrel staves, and on shingles. Also, there were to be import duties of 20 s per head on negro slaves, $5 \mathrm{~s}$ per gallon on rum and spirits, and $5 \mathrm{~s}$ per pipe on wine. As there was no tax upon either wheat or flour, there seems to have been little opposition to these duties. By a special vote, alienation fines were not included in the agreement, probably because they constituted only a nominal charge. Upper House Journal, September 20, 1745, Liber 34; Lower House Journal, September 11 to 16, 1745, Liber 46; Gould, Land System in Maryland, 1720-1765, p. 49.

2 Lower House Journal, September 24, 1745, Liber 46; Gould, Land System in Maryland, 1720-1765, pp. 49-50. 
successful, for after 1745 the movement for commuting the quit-rents ceased, since with the growth of trade specie became more abundant in Maryland, and the burden of these feudal dues ceased to be felt to any appreciable extent.

The general policy of enforcing the quit-rents favored the frontier rather than the settled portions of the province. In all the acts that were passed during the eighteenth century for the laying out of towns, the proprietary reserved a quit-rent of a penny upon each lot, not even excepting town commons. An instance in point was the act that founded Charlestown, as a muchneeded port at the head of the Northeast River. According to the provisions of this act, 200 acres were to be laid out in as many lots, and an additional 300 acres were to be set aside as a town commons. As an offset to any possible loss in revenue from these public lands, the act required the reservation of two pence on each town lot. But such excessive quit-rents, in comparison with those on country lands, gave little encouragement to the growth of towns. ${ }^{1}$ In decided contrast were offers in 1732 and 1735 to give settlers on the frontier exemption from the quit-rents for from three to five years. ${ }^{2}$ These measures, which were taken in order to erect a barrier against the French and Indians and to afford an outlet from the more fertile and accessible tidewater regions, produced such excellent results that a large

1 Proprietary greed was shown especially in the case of Princess Anne. All lots in the town, it was claimed, had escheated. In order to reëstablish titles, each lot-holder was required to pay $20 \mathrm{~s}$, and the county commissioners 20 s for the town commons. As the act carrying out this agreement failed to specify the quit-rent, the proprietary compelled the assembly to rectify the mistake before he would sign the bill. Acts of the Assembly, 1742 and 1751 ; Council Proceedings, October 17, 1753, Liber 19, p. 15.

2 Proprietary Instructions, March 22, 1733, Md. Archives, XXVIII, 25; Mereness, Maryland as a Proprietary Province, pp. 122-123. 
number of German settlers moved into the back country. In calling attention to this desirable immigration, Daniel Dulany pointed out the need of further inducements, in order to secure recognition of the proprietary claim that the south branch of the Potomac formed the southern boundary of Maryland. ${ }^{1}$ In accordance with this advice Lord Baltimore offered exemption from the quit-rents for three years to settlers on these frontier lands. ${ }^{2}$ This liberal land policy greatly aided settlement on the frontier, especially in the Monocacy Valley, and at least 2,800 immigrants came in between 1748 and $1756 .^{3}$

The peaceful operation of the quit-rent system was threatened by the narrow-minded policy of Frederick, Lord Baltimore, who succeeded to the propriety in 1751. Soon after his accession, he proposed to increase the quit-rents to 10 s per 100 acres, though this rate would have placed landholders virtually in the same position as the tenants on his manors. ${ }^{4}$ With a clearer insight into the situation, Governor Sharpe intervened in favor of the people of Maryland, informing the proprietary that so high a quit-rent was wholly impracticable. The proprietaries of Pennsylvania, he acknowledged, had successfully advanced both the quit-rents and the purchase money, but a similar policy was impossible in Maryland. ${ }^{5}$ In Pennsylvania there was a large population and land could always be rented, while in Maryland there were not enough inhabitants to furnish tenants, and

1 Daniel Dulany to Lord Baltimore, July 21, 1744, and April 8, 1745, Dulany Papers, ff. 26, 33.

2 Proprietary Instructions, 1749, Proprietary Papers.

3 Council Proceedings, August 23, 1756, Liber 19, p. 119.

4 On the proprietary manors the usual rent was 10 s per 100 acres. Had this become the rate for the quit-rents, the only advantage of the latter form of tenure would have been its permanency. Gould, Land System in Maryland, 1720-1765, pp. 92-93.

5 Governor Sharpe to Calvert, February 10, 1754, Md. Archives, VI, 37. 
the demand for agricultural products was far smaller. Yet in spite of these unfavorable comparisons, the quitrent, he said, was already higher in Maryland than in Pennsylvania, although the purchase money was less. Furthermore, the higher purchase money in Pennsylvania was offset by the clergy tax in Maryland, and there were no alienation fines in the other colony. In Virginia the land was more fertile, but both the quit-rent and the purchase money were less than in Maryland. Under such conditions, he thought that if the purchase money should be increased, there would inevitably be a decrease in the revenue from land warrants. ${ }^{1}$ This statement clearly shows the intercolonial effect of a higher quitrent, in turning intending settlers from Maryland either to Pennsylvania or to Virginia. Lord Baltimore very sensibly heeded Governor Sharpe's advice and gave up the proposed increase in the rate. But after the boundary line had been run between Maryland and Pennsylvania, he suggested a quit-rent of $8 \mathrm{~s}$ per 100 acres upon lands west of the Susquehanna. This plan, also, he abandoned in face of the governor's decided opposition. ${ }^{2}$

1 The clergy tax in Maryland was 40 pounds of tobaceo for each taxable, or else the money equivalent. The difference between the various charges in Maryland and Pennsylvania was estimated as follows by Governor Sharpe: Per 110 acres, Pennsylvania, purchase money $£ 8$ 11s 6d; quit-rent, $4 \mathrm{~s} 2 \mathrm{~d}$; total $£ 815 \mathrm{~s} 8$ d. Per 110 acres, Maryland, purchase money $£ 510 \mathrm{~s}$; quit-rent, $4 \mathrm{~s} 5 \mathrm{~d}$; total $£ 514 \mathrm{~s} 5 \mathrm{~d}$. Add the clergy tax of Maryland, estimated on 100 acres as $5 \mathrm{~s} 6 \mathrm{~d}$; total Maryland $£ 519 \mathrm{~s} 11 \mathrm{~d}$. The disadvantage of Maryland in the annual taxes was $5 \mathrm{~s} 9 \mathrm{~d}$, but there was an advantage in the purchase money, paid once for all, of $£ 3$ 1s $6 \mathrm{~d}$. Per 100 acres, Virginia, purchase money £2; quit-rents 2s. Per 100 acres, Maryland, purchase money £5; quit-rents $4 \mathrm{~s}$. Disadvantage of Maryland in comparison with Virginia $£ 3$ purchase money, and 2s quit-rent. Memorandum, Governor Sharpe and others, about 1757-1758, Calvert Papers.

2 Owing to the boundary controversies, most of these lands had been held without patents. The owners must now sue out patents, and were therefore at the mercy of the proprietary of Maryland. Governor Sharpe to Lord 
Although opposing any increase in the rate, Governor Sharpe by the exercise of a firm control placed the quitrent system upon a thoroughly businesslike basis. One problem to which he gave his attention was that of the heavy expenses of collection. On the Eastern Shore the sheriffs carried on this work with a commission of ten per cent., but on the Western Shore the farmers of the rents were usually allowed a discount of twenty per cent. ${ }^{1}$ Governor Sharpe wished to reduce this discount to fifteen per cent., but Lord Baltimore insisted that the sheriffs should make all collections of the quit-rents with a commission of ten per cent. ${ }^{2}$ Although Governor Sharpe believed that it would be impossible to secure a sufficient bond from each sheriff, the proprietary insisted upon this change in the method of collection. ${ }^{3}$ The new plan did not prove at all satisfactory, and when a still further reduction in the commission was proposed, Governor Sharpe wrote that he doubted if anyone could be found to collect the quit-rents under such unfavorable conditions, for even with the ten per cent. commission, the collection of quit-rents had been a great burden upon the sheriffs. The previous year the sheriff of Frederick County had resigned on account of the quit-rents, and as he could not find a responsible person in Frederick County to undertake this work, he had been obliged to appoint a man

Baltimore, and Hammersley to Governor Sharpe, March 1 and July 20, 1767, Md. Archives, XIV, 373 et seq., and 403.

1 The accounts are somewhat inadequate with regard to the details of collection, but on the Western Shore the usual discount allowed the farmers of the quit-rents was 20 per cent., except in Prince George County where it was 15 per cent. Lord Baltimore's Account Book, 1753. Calvert Papers.

2 Lord Baltimore's Account Book, 1754, Calvert Papers; Governor Sharpe to Lord Baltimore, October 2, 1753, and Calvert to Governor Sharpe, January 5, 1754, Md. Archives, VI, 8, 30.

3 Governor Sharpe to Calvert, and to Lord Baltimore, May 2, 1754, and October 21, 1755, Md. Archives, VI, 54-55, and Calvert Papers. 
from a neighboring county. This situation soon became general, he said, since in most counties the total collections of the quit-rents were less than $£ 500$, and the entire commission was not over $£ 50$, which was a smaller amount than a clerk would ask for similar work. If the proprietary insisted upon a further reduction, he suggested that perhaps two or more counties might be farmed out on an eight per cent. commission to one person, thus increasing the profit to each collector. In the end the governor's advice was accepted, and most of the quit-rents were farmed out at a discount of ten per cent. to collectors, each of whom was responsible for several counties. ${ }^{1}$ In supervising the work of these collectors, Sharpe so framed their contracts that they had ample powers to collect the quit-rents and at the same time were held fully responsible for all receipts. As he could now offer an adequate compensation, he was able to induce men of standing to act as collectors. ${ }^{2}$

The proprietary's representative and agent in London also exercised considerable control over the officials connected with the quit-rent system. In 1753 he gave instructions that the rent rolls of each county should be made out annually in detail and sent to England, and that the judges of the land-office should compare the receipts

1 Governor Sharpe to Lord Baltimore, August 15, 1765, and March, 1767, and Hammersley to Governor Sharpe, July 20, 1767, Md. Archives, XIV, 213-216, 375 et seq., 403.

2 The contract of each farmer was detailed, and gave him power to sue, distrain, or implead, in the name of the proprietary, for any arrears that were not paid. Undue exactions were prevented by a requirement that the farmer must follow his instructions as to the rate at which he should receive either paper money, gold, or silver. Twice a year, June 25 and December 29, he must pay the receiver-general the full amount due, less a discount of 10 per cent. These provisions were enforced by a properly secured bond. See specimen contract between Governor Sharpe and Allen Davis of Charles County, September 28, 1759, Calvert Papers; Governor Sharpe to Lord Baltimore, May 23, 1760, Md. Archives, IX, 403-405. 
from the quit-rents with the total amount reserved in the patents. ${ }^{1}$ By such means he was able to keep a close watch over the quit-rents, and to bring numerous discrepancies in the accounts to the attention of the receivergeneral, Edward Lloyd. He called Lloyd's attention especially to the great arrears on the Eastern Shore. Since the farmers of the rents in this section were accustomed to use the money that they collected for their own purposes, he directed Lloyd to bring such practices to an end by requiring prompt payment of all receipts. The abuses that had arisen were largely due to the neglect of the rent roll keeper of the Eastern Shore, Tilghman, who claimed in extenuation that he had been building a house and also had a suit in chancery; a very shallow excuse, the proprietary secretary sententiously observed. ${ }^{2}$ Other instances of official delinquency, either in keeping the accounts or making out the rent rolls, were discovered in England and brought to the attention of the local officials, though the reproofs that followed the discoveries did not always produce the desired results. ${ }^{3}$ The real difficulty in enforcing proprietary instructions, Governor Sharpe asserted, lay largely in official incompetency and jealousies, for "those whose duty it is to settle and manage Your Lordship's pecuniary affairs are perpetually blaming each other and endeavoring to vindicate their own conduct." Probably in making this statement Governor Sharpe had in mind especially the receiver-general, Colonel Lloyd, who, despite numerous remonstrances, had steadfastly refused to remove the incompetent rent

1 Cecilius Calvert to Benjamin Tasker, May 15, 1752, Calvert Papers, 2, ff. 140-145.

2 Cecilius Calvert to Edward Lloyd, December 10, 1754, Calvert Papers.

3 Examination of Accounts, March 7, 1755, Calvert Papers; Calvert to Governor Sharpe, 1755, Md. Archives, VI, 371. 
roll keeper for the Eastern Shore. ${ }^{1}$ As Lloyd continued to exercise only a loose supervision over his subordinates, and to ignore the admonitions of Governor Sharpe, Lord Baltimore finally wrote that either he must become more efficient or else he must quit his office of receiver-general. ${ }^{2}$

But as the returns from the Eastern Shore did not materially improve, the proprietary agent directed Governor Sharpe to hold Colonel Lloyd "to the mark" regardless of his complaints, ${ }^{3}$ and consented to the appointment of a new rent roll keeper for the Eastern Shore, suggesting that if Lloyd resigned, there should be a receiver-general for each shore. ${ }^{4}$ In his reply Governor Sharpe gave an interesting description of the administrative difficulties caused by the physical configuration of Maryland. He said that the keeper of the rent rolls for the Eastern Shore could reside with advantage on the Western Shore, since the sheriffs, who were in charge of the details of collection, were compelled to come to Annapolis at least three or four times each year $;^{5}$ that the appointment of a receiver-general for each shore would be a needless expense and an exceedingly inconvenient arrangement unless the land-office also was divided; and, finally, that the receiver-general should not be a man of large private interests, or a

1 Governor Sharpe to Lord Baltimore, July 13, 1756, and to Calvert, August 20, 1756, Md. Archives, VI, 449, 453, 463.

2 Governor Sharpe to Calvert, October 16, 1756, Md. Archives, VI, 499; Cecilius Calvert to Governor Sharpe, December 23, 1765, Calvert Papers.

3 Calvert to Governor Sharpe, December 16, 1756, Md. Archives, VI, 514515.

4 Calvert to Governor Sharpe, April 7, 1757, Md. Archives, VI, 538.

5 Governor Sharpe stated clearly the position of the rent roll keepers, asserting that it was not their "duty to ride about and look after the several tracts of land, the rent whereof may at any time be disputed. That is the duty of the farmer, who may be charged with the rents and whose interest it is to recover them.' Sharpe to Calvert, December 26, 1757, Md. Archives, IX, 116-117. 
lawyer with an extensive practice, but rather a person who could devote his entire time to the office. This excellent advice was not followed, for Colonel Lloyd, in spite of his negligence, continued to hold his office. ${ }^{1}$

As one feature of his policy to enforce the quit-rents, Governor Sharpe planned to bring all lands in Maryland upon the rent rolls. Although most of the richer surplus land had been patented, many persons, he found, still held far larger areas than their grants called for. ${ }^{2}$ To such individuals he offered patents for their surplus land at the quit-rent stipulated in the original grant. ${ }^{3}$ This offer was necessary, inasmuch as many persons refused to have their grants resurveyed, fearing lest they might be held accountable for all the accrued arrears on their surplus land. If they could be assured that only the original quit-rent, as it became due in the future, would be required, the governor believed that they would consent to a resurvey, ${ }^{4}$ and he proposed to increase the rolls by a resurvey of one or two of the smaller counties, where there was the largest proportional amount of cultivated surplus land. ${ }^{5}$ This suggestion was only partly carried out in an offer made in 1756, permitting the survey of surplus land within two years and waiving all arrears, provided the quit-rents were paid in the future at the rate reserved in the original grants. ${ }^{6}$ But no surveys

1 Governor Sharpe to Lord Baltimore, May 23, 1760, Md. Archives, IX, 403-415.

2 This surplus land arose chiefly from the careless methods of surveyors who frequently included in a grant a much larger acreage than the warrant of survey actually called for. Mereness, Maryland as a Proprietary Province, p. 55 .

3 Council Proceedings, August 12, 1741, Md. Archives, XXVIII, 256.

4 Governor Sharpe to Calvert, August 8, 1754, Md. Archives, VI, 92-93.

5 Ibid., May 3, 1754, Md. Archives, VI, 58.

${ }^{6}$ Council Proceedings, January 17, 1756, Liber 19, pp. 83-84. 
were attempted on a large scale, and the question of surplus land soon became one of minor importance.

Though the collection of the quit-rents in Maryland was singularly free from serious friction, there were occasional complaints of exactions by the proprietary officials. For example, in 1737, a committee of the lower house reported that the farmers of the quit-rents in Baltimore and Anne Arundel counties were demanding a higher rate of exchange for foreign coins than was permitted by their instructions, and that the sheriffs and the receiver-general had divided between them large amounts of tobacco which they had extorted from tenants in arrears. The committee further reported that the farmer of the rent in Baltimore County had given instructions to his deputies which were illegal and unnecessarily severe. ${ }^{1}$ After hearing this report, the lower house asked the governor to prosecute the officials guilty of these extortions which were not warranted by law, and "are such as may tend to alienate the minds of His Lordship's tenants from his dominion and government." There is no record that any positive action was taken in this case, and soon the receiver of Baltimore County was again accused of extortion. This time, he was charged with having distrained, before making any demand for quit-rent, for twelve shillings upon "one bed, one chest and one spinning wheel," the property of Jacob Hall. Later, the sheriff and the receiver made a second distress upon the much-persecuted Hall, taking his plow horse, which they sold for only $£ 410$ s currency, although it was appraised at $£ 4$ sterling. After an investigation of these charges, a committee of the lower house scored such actions as "against common reason as well as common

1 Lower House Journal, May 12, 1737, Liber 45; Gould, Land System in Maryland, 1720-1765, p. 43.

2 Lower House Journal, May 19, 1737, Liber 45. 
right and the laws of the land.' 'The lower house then ordered that the offending receiver should pay the expenses of the hearing, and added $£ 45$ s to compensate Hall for his seven days' attendance "on his complaint.", This penalty had little apparent effect, and later the same receiver was again accused of similar extortions. ${ }^{3}$

Other instances of petty persecutions in the enforcement of the quit-rents were reported from time to time. In 1747 the farmer of the rents and the sheriff of Charles County were reproved at the bar of the lower house for distraining upon a plow horse whose owner had already tendered the money for his quit-rents. ${ }^{4}$ Another typical instance of extortion was the complaint of Roger Hooper that Thomas Muir, receiver for Dorchester County, had forced him to pay an excessive and questionable sum of arrears for a period previous to the date of his patent. Upon an investigation of this complaint, the lower house held that quit-rents could not be collected prior to the issue of a patent, and that Muir had "illegally and oppressively" extorted the arrears in question from Hooper. Also, it resolved to petition the governor to prosecute Muir as an example, in order that other proprietary officials might be deterred from like practices in the future. ${ }^{5}$ A type of extortion that threatened really serious results was charged in a petition in 1748 from the "back country." This petition alleged that the sheriff and the farmer of the rents in Frederick County had appointed deputies to receive the quit-rents "in the woods." The landholders in this region were accustomed to entrust the money for these receivers to their neigh-

\footnotetext{
1 Lower House Journal, June 13 and 16, 1749, Liber 46.

2 Ibid., June 23 and 24, 1749, Liber 46.

3 Ibid., December 20, 1754, Liber 48.

4 Ibid., June 9, 1747, Liber 46.

5 Ibid., October 24 and November 1, 1754, Liber 47.
} 
bors, who often failed to turn it in. Consequently, the petition set forth, "black lists" had been prepared of those who failed to settle for their rents, and the delinquents had been compelled to pay a commission of ten per cent. with other illegal fees, even though their arrears were not of more than half a year's standing. As a result of these extortions, many of these people, most of whom were Germans, had left the province, and others were preparing to go. In response to these representations, the council sharply reproved the officials who were responsible for such extortionate demands. ${ }^{1}$ But complaints of irregular practices in the collection of the quitrents soon ceased, for after the receiver-general had fixed a definite rate of exchange in $\mathbf{1 7 5 4}$, the chief source of extortion was removed. ${ }^{2}$ Moreover, the promptness with which the lower house and the council dealt with complaints undoubtedly. curbed any tendency toward irregular practices.

Even the conciliatory policy of Governor Sharpe could not prevent a certain amount of opposition to the proprietary rights. This opposition was directed especially against an attempt to tax the quit-rents. The first move was the imposition of a tax of 1 s per 100 acres, which was levied in 1756 in order to raise $£ 40,000$ for the protection of the frontier. In reality this tax was an addition to the quit-rents, since it was collected by the same officers and by the same methods. ${ }^{3}$ The next move was a proposal in

1 Many of these petitioners had been summoned to Frederick, and most of them had preferred to pay the unjust charges demanded by the receivers, rather than suffer worse consequences. Memorial, with Depositions, 1748, Md. Archives, XXVIII, 420-424.

2 Secretary Calvert to Edward Lloyd, December 10, 1754, Calvert Papers, 2, f. 34 ; Governor Sharpe to Lord Baltimore, August 15, 1756, Md. Archives, XIV, 213.

3 The tax was to be collected by receivers who accounted to the rent roll keepers, the latter receiving a commission of $2 \frac{1}{2}$ per cent. Of course 
1758 from the lower house to raise $£ 30,000$ for the service of the crown by a general land tax, which did not exempt the proprietary estate and permitted landholders to deduct a part of their quit-rents from this levy. After the council had rejected this measure, the session was prorogued. ${ }^{1}$ When the assembly met again the lower house proposed to collect $£ 45,000$ for the service of the crown by a tax upon all personal and real property. This bill, also, the council rejected, upon the ground that by taxing the quit-rents it established a precedent which Lord Baltimore undoubtedly would not allow. ${ }^{2}$ In a lengthy reply to the council's objections, the lower house followed the example of the assembly in Pennsylvania and attempted to throw upon the proprietary the responsibility, if he rejected the bill, of sacrificing the needs of the crown in favor of his own private interests. It was the "almost universal opinion", in Pennsylvania, the assembly pointed out, that the proprietary estates should bear their share of the burden of defense. The proprietary of Maryland as well as the people, they asserted, should aid in the common defense of the crown's interests. In this and similar arguments, the lower house showed in noteworthy fashion the influence of the struggle that was taking place at this time in Pennsylvania to tax the proprietary estate, and especially the quit-rents. ${ }^{3}$

the debt books formed the basis of collection. The act, which continued for five years, provided that Roman Catholies should pay a double tax and that their names should be kept in a separate list. Acts of the Assembly, May, 1756 .

1 Lower House Journal, March 8, 1758, Liber 50.

2 Ibid., March 31 and April 18, 1758, Liber 50.

3 Of special significance was the stand taken by the lower house that "the quit-rent, together with the caution or purchase money, was no doubt originally thought to be a render proportionate to the value of the land; and it is sufficiently oppressive that after our ancestors were enticed, by moderate terms of taking up land, to transport themselves, families, and fortunes thither, their children should have new terms imposed upon them, 
In its reply the council conceded the obligation of Lord Baltimore to contribute to the common defense, but held that the quit-rents constituted a special form of his estate which should be exempted. If the quit-rents were taxed, there was no doubt that he would reject the supply bill. But the lower house, maintaining its position, passed a series of resolutions which were even bolder than its previous utterances. Again it asserted that the quit-rents, together with other parts of the proprietary estate, should bear a proportionate share of the common defense. Any wish of the proprietary to have so large a portion of his estate exempted would show an inclination to oppress his tenants by loading upon them an expense that he himself ought to bear. By his unwillingness to bear his just burden in opposing the encroachments of the common enemy, he would "betray a want of zeal and loyalty to his emost gracious sovereign." In spite of the efforts of the council to secure a compromise, the lower house persisted in its refusal to recede from this position, and the supply bill was finally dropped. ${ }^{1}$

That the entire controversy had been purposely stirred up in order to discredit the proprietary, is the conclusion to be drawn from a series of articles that appeared about this time in the London Chronicle. The first asserted that the chief cause of the failure in Maryland of the act to extend aid to the crown was the insistence by the assembly that the proprietary estates should be taxed. Denying this charge, as a "malicious insinuation void of truth," another article asserted that the estate of the proprietary bore an equal burden of taxation. This statement was answered by a clever author who sar-

both as to purchase money and quit-rents.", Lower House Journal, April 27, 1758, Liber 50 .

1 Lower House Journal, May 4, 7 and 13, 1758, Liber 50. 
castically called attention to the very small sum that the proprietary estates in Maryland paid in taxes, and who pointed out that the governor and the council, who were dependent upon the proprietary, were the ones who had rejected the supply bill. As the lower house had passed the measure by a vote of forty to ten, it was clear that the veto in the upper house did not represent popular opinion. Therefore, the writer concluded, it was evident that the proprietary, through his agents, had acted against the wishes of the people of Maryland, and the interests of the crown, and such proceedings might well lead to an inquiry into the general conduct of the proprietary government. ${ }^{1}$

There is no doubt that Lord Baltimore fully appreciated the real purpose underlying this attempt to tax his quit-rents. Through his agent, he declared that these charges upon the land were not an ordinary rent, but constituted a recognition of the proprietary rights in the soil of Maryland. Therefore he denied absolutely the power of the assembly to tax them, for they were "rights he cannot, and with resolution just, will not part with or suffer to be infringed, or be deviated from, or be purloined from him." For their "just defense" of these rights from "injury, perplexity and confusion" he expressed his thanks to the council. ${ }^{2}$ As Lord Baltimore was sufficiently powerful in Maryland to maintain this position, in contrast with the surrender by the Penns in Pennsylvania, this attempt to tax his quit-rents was not renewed.

In spite of such occasional manifestations of an antiproprietary sentiment, these charges continued to be col-

\footnotetext{
1 Extract from the London Chronicle, about September, 1758, Miscellaneous Papers.

2 Cecilius Calvert to Governor Sharpe, November 27, 1758, and March 17, 1759, Md. Archives, XXXI, 506-507, 509-510.
} 
lected in Maryland in an orderly fashion. In the end the revenue became so large that the work of supervision, in addition to his other duties, imposed too heavy a burden upon the governor, and in 1761 tentative plans were made for a board of revenue; but under the dilatory administration of Edward Lloyd as receiver-general these plans came to naught. ${ }^{1}$ At length, in 1706 , the proprietary sent instructions ordering all accounts of the receiver-general to be audited by a board composed of the governor, the commissary-general, the secretary, and the judges of the land court. Later, this Board of Revenue, to whom a general oversight of the quit-rent system was assigned, was required to report to a supervisor who directly represented the proprietary. ${ }^{2}$

From its first meeting, April 5, 1768, the board exercised a close supervision over the quit-rents, but made only a few changes in the details of collection. It ordered that if a farmer of the rent refused to settle at the specified time, the attorney-general should immediately bring suit against the delinquent's bond; it held also that tenants were bound by their patents to make semi-annual payments, and that farmers of the rent must file at least a third of their accounts by July $25 ;^{3}$ and in addition, it required that all rent roll keepers and farmers of the rents should give an acceptable bond. ${ }^{*}$ In other instructions of the same detailed and businesslike character, it worked for greater efficiency in the system of collection, especially in urging rent roll keepers to make out debt

\footnotetext{
1 Proprietary Instructions, October 8, 1761, Md. Archives, XXXII, 391 394.

2 Lord Baltimore to Governor Sharpe, February 21 and March 22, 1766, Md. Archives, XXXII, 395-396; Kilty, Landholder's Assistant, p. 262.

3 Instructions to Receiver General, June 30, 1768, Md. Archives, XXXII, 402-407.

4 Proceedings, Board of Revenue, September 1, 1768, Md. Archives, XXXII, 408.
} 
books with full details and to keep a close watch upon the accounts of the local collectors. ${ }^{1}$ To the farmers of the rents it gave full power to inspect the necessary records and to employ all lawful means to enforce the quit-rents. ${ }^{2}$

The board exercised a general control also over the officers in charge of the quit-rents, appointing farmers of the rents in Frederick and Prince George counties, securing the confirmation of Daniel of St. Thomas Jenifer as receiver-general, in place of the notorious Rev. Bennett Allen, ${ }^{3}$ and adjusting numerous questions regarding the details of actual collection. Its policy was conciliatory yet firm, and always designed to promote the best interests of the proprietary estate in Maryland. ${ }^{4}$ An instance of the board's energy and vigor was given when certain farmers of the rents on the Eastern Shore failed to settle promptly their accounts for 1769. At once, it ordered that unless these receivers settled immediately, suits would be brought against their bonds. But when the farmers of the rents in Talbot and Dorchester counties refused to renew their contracts, it took pains to explain to them how impossible it was to avoid a number of seemingly unreasonable conditions. ${ }^{5}$ Again, when the receiver-general declared that he could not close his

1 Proceedings, Board of Revenue, December 5, 1768, Md. Archives, XXXII, 420-428.

2 Proceedings, Board of Revenue, December 5, 1768, Md. Archives, XXXII, 422-428.

3 Proceedings, Board of Revenue, October 26 and November 25, 1768, Md. Archives, XXXII, 409, 413.

4 Proceedings, Board of Revenue, 1768-1775, Md. Archives, XXXII, passim. The work of the board was greatly aided by a clause, which was inserted in all new patents, to the effect that the quit-rents must be paid within thirty days after they became due, or else the land would be subject to reëntry. Governor Sharpe to Judges of the Land Office, February 28, 1767, in Kilty, Landholder's Assistant, p. 245.

5 Proceedings, Board of Revenue, February 21, 1770, Md. Archives, XXXII, 460-462. 
accounts by March 25, "by reason of the inclemency of the weather," the board fixed September 29 as the date on which he should make his annual settlement. ${ }^{1}$

But the board did not find the actual enforcement of the quit-rents an easy matter during the troubled years that preceded the Revolution. The large tracts of uncultivated land on the frontier that were held by nonresidents for speculative purposes presented an especially difficult problem. As large arrears were due on much of this land, the board ordered its clerk to threaten the owners with legal proceedings unless their quit-rents were paid. ${ }^{2}$ These orders produced few if ans results, as far as non-residents were concerned, and eren resident landholders so often failed to pay their quit-rents that, in 1770 , the receiver for Frederick County sent in a long list of arrears for almost $£ 500$ that had been due for six months. Acting with its usual energy, the board referred the names of these delinquents to the attorner-general, with instructions to institute suits. ${ }^{3}$ Toward the close of the colonial period it became difficult to enforce parments even in the more thickly settled sections of Marryland, and not until 1775 was the receiver-general able to make up the accounts of the quit-rents for the period, 1771 to 1773. His explanation that this delay was due to a reduction of the commission to ten per cent., led the board to authorize an increased allowance whenerer efficient receivers could not otherwise be secured. ${ }^{*}$ This increase was typical of the enlightened policy observed by the

1 Proceedings, Board of Rerenue, June 6, 1771, Md. Archices, XXXII, 469-470.

2 Proceedings, Board of Rerenue, February 20, 1769, Md. Archives, XXXII, 443.

3 Proceedings, Board of Rerenue, February 21, 1770, Md. Archives, XXXII, 460.

4 Proceedings, Board of Rerenue, January 11, 1775, Md. Archives, XXXII, $488-489$. 
board in supervising a quit-rent system which, at the outbreak of the Revolution, was organized upon a thoroughly practical and businesslike basis.

With the declaration of independence from British control, the opposition to the quit-rents, which as we have seen had already manifested itself on several occasions, broke forth into open hostility. The act of 1780, which abolished the quit-rents as incompatible with the sovereignty of an independent state, disclosed the fact that the payment of such a charge, aside from the mere financial consideration, had been galling to the pride of Marylanders, inasmuch as it constituted a sign of dependence upon an absentee landlord. It also disclosed the additional fact that in the view of the assembly the quit-rent had become an outgrown feudal charge. ${ }^{1}$ This attitude was taken in a message sent to the lower house by the senate in 1783, with reference to the claims of Henry Harford, the proprietary heir. The quit-rents, the senate declared, could not be held by an alien, nor could "any power on earth place the free people of Maryland in the degraded position of tenants to a superior lord, a foreigner and a British subject." The assembly, it held, had acted wisely in declaring that the payment of the

1 The act was unmistakable in its attitude toward the quit-rents, declaring in part, "whereas it appears to this general assembly highly improper for, and derogatory to the eitizens of this sovereign and independent state to pay quit-rents as a tribute to the subject of a foreign prince, and that their honor and dignity as well as their safety requires that no subject of an enemy should draw a revenue from this state; and whereas since the present glorious revolution the payment of quit-rent has ceased throughout the United States, and sound policy demands that the citizens of this state should hold their lands on equal terms with the eitizens of the other states; and whereas the payment of quit-rent, from the declaration of independence, both ceased and of right ought to cease, being an acknowledgement of seigniory incompatible with the independent sovereignty of this free state," the assembly abolished the quit-rents, and relieved all persons from the payment of arrears. Acts of the Assembly, March, 1780. 
quit-rent, even to the state government, should not be permitted, and that the people of Maryland should hold their lands on the same terms as the citizens of other states. ${ }^{1}$ When these resolutions reached the lower house, that body so unanimously upheld the stand taken in the abolition of the quit-rents that it took no further action, either upon this communication or the claims of Henry Harford. ${ }^{2}$

The opposition to the quit-rents in Maryland was due in part to the fact that they constituted a real charge upon the land. The vigorous policy of the proprietaries, after the reorganization of the system of collection in 1733, greatly increased the returns from this revenue. One important factor in this increase was the improvement in the rent rolls, which had fallen into great confusion owing to the internal disturbances in the seventeenth century, and had been largely neglected during the period of the compensatory duty. By systematic supervision these rolls were perfected to such an extent that, by 1767 , practically all lands were entered upon them. ${ }^{3}$ The degree of improvement is shown by a comparison of the gross value

1 Votes and Proceedings of the Maryland Senate, December 19 and 21, 1785.

2 Some authorities hold that the system of ground rents in Baltimore is a survival of the quit-rents. As in the case of similar rents in Pennsylvania, this statement is incorrect. The ground rent in Maryland is merely an ordinary rent that is limited in time, even though there may be a clause for renewal, while the quit-rent was a perpetual feudal charge due the overlord. Mayer, Ground Rents in Maryland, p. 48.

3 By 1767 land grants in Maryland included 4,578,511 acres. If the $4 \mathrm{~s}$ quit-rent rate had been reserved upon all this land, the total rent roll would have been $£ 9,1576$ d. Actually, there were a large number of grants after 1671 , as well as before, at the $2 \mathrm{~s}$ rate, while a few of the earlier ones were payable in wheat. These seventeenth-century grants account for the gross value of the quit-rents at this time, which was $£ 7,98410$ s 6 d. Thus, practically all land grants had been brought upon the rent rolls. Governor Sharpe to Board of Trade, May 14, 1767, C. O. 5: 112, f. 155. 
and the net returns from the quit-rents during the period from 1733 to the Revolution. In 1745 the gross value of the rents was $£ 5,369 \mathrm{11s} 3 \mathrm{~d}$, and the net returns $£ 4,508$ $15 \mathrm{~s} 4 \mathrm{~d}$, a loss in collection of less than one-fifth. ${ }^{1} \mathrm{By}$ 1755 the gross value was $£ 6,85910$ s $91 / 4 \mathrm{~d}$, and the net returns $£ 5,1262 \mathrm{~s} 4 \mathrm{~d}$, a loss of a little over one-seventh. During the next five years the net revenue was still further increased by the collection of large arrears from the Eastern Shore and Frederick County, the two regions most inaccessible to Annapolis. According to the proprietary estimate, the total value of the quit-rents in 1774 was $£ 8,5186 \mathrm{~s} 2 \mathrm{~d}$. The statistics for the net returns during these years are not available, but except for trifling arrears, the entire rent roll was collected at this time with a commission of ten per cent. to the farmers of the rents, and of five per cent. to the rent roll keepers. ${ }^{2}$

At the outbreak of the Revolution, the revenue from

1 Lower House Journal, September 10, 1745, Liber 46.

2 The following table shows the steady growth in the value of the quitrents :

Year Annual net returns

$1753 \ldots . \ldots 5,752 \quad 4 \mathrm{~s} \quad 81 / 4 \mathrm{~d}$

Year Annual gross value

$1754 \ldots . .5,325 \quad 12 \mathrm{~s} \quad 91 / 4 \mathrm{~d}$

$1722-1724 \ldots . £ 5,22513 \mathrm{~s} \quad 1 / 2 \mathrm{~d}$

$1755 \ldots . .5,126 \quad 2 \mathrm{~s} \quad 4 \quad \mathrm{~d}$

$1756 \ldots . .5,121 \quad 3 \mathrm{~s} 113 / 4 \mathrm{~d}$

$1758 \ldots . .8,593 \quad 16 \mathrm{~s} \quad 4 \quad \mathrm{~d}$

$1759 \ldots . .9,273 \quad 16 \mathrm{~s} \quad 41 / 2 \mathrm{~d}$

$1760 \ldots 6,093 \quad 19 \mathrm{~s} \quad 73 / 4 \mathrm{~d}$

$1761 \ldots . .8,383 \quad 5 \mathrm{~s} 111 / 2 \mathrm{~d}$

$1750-1755 \ldots . .6,859 \quad 10$ s $\quad 91 / 4 d$

$1760-1765 \ldots . .7,398 \quad 17 \mathrm{~s} \quad 31 / 4 \mathrm{~d}$

$1770 \ldots \ldots \ldots \quad 8,297$ 6s $113 / 4 \mathrm{~d}$

$1774 \ldots \ldots \ldots 8,518$ 6s 2 d

Alienation fines varied from $£ 137$ in 1748 , to $£ 250$ in 1761 . Although they were usually included in the returns from the quit-rents, their amount was so small that for practical purposes they can be ignored. The effective work of Governor Sharpe in organizing the system of collection is shown by the remarkable increase in the net returns, 1758-1761, when at times they even exceeded the gross value as shown in the rent rolls. Lord Baltimore's Account Books, also Rent Rolls and Debt Books, Calvert Papers and Land Office Records. Governor Sharpe to Board of Trade, May 14, 1767, C. O. 5: 112, f. 155; Senate Proceedings, December 21, 1785. 
the quit-rents of Maryland was fully twice as large as the returns from this source in any other colony. This result, which was a tribute to the able management of the proprietaries and their officials, had been secured by a consistent and moderate policy. In the beginnings of settlement the proprietary of Maryland had established for all grants a uniform quit-rent that was increased only once. Consequently, the exorbitant and confusing rates found on the Pennsylvania rolls were avoided. Moreover, unlike the Penns, the Calverts developed an excellent system of collection, being sufficiently broad-minded to see the necessity of ample allowances in order to secure a force of competent collectors. Other excellent features of the general proprietary administration of the quitrents in Maryland were the readiness with which exemptions or special rates were granted and the general disposition to be moderate in the method of enforcement and the medium of payment.

It is significant that even so well managed a system of feudal charges as that of the quit-rents in Maryland did not altogether escape popular opposition. The ready acceptance of the compensatory duty shows that the people were very glad to get rid of a charge which was really an additional tax upon their lands, while their persistent efforts to renew this arrangement afford a sufficient proof that the quit-rents were by no means mere nominal dues in Maryland. The attempt to tax the proprietary estate, and especially the quit-rents, was the outcome of a growing desire among the landholders to rid themselves of the incidents of feudal control. But such manifestations of ill will were not general, and the quit-rents were paid with less opposition in Maryland than in any other colony, with the possible exception of Virginia. This situation is a tribute to the moderation 
with which these charges were administered. Yet the opposition of the land speculators was always to be reckoned with. The enforcement of the quit-rents rendered unprofitable in Maryland the holding for an indefinite period of such large unsettled tracts as were taken up in New York, and thus promoted the division of the land into small holdings. On the other hand, the higher quit-rents in Maryland probably kept out emigrants from Virginia. Those intending to come from Pennsylvania were doubtless somewhat discouraged, also, by the more rigid enforcement of these feudal dues in Maryland than in the neighboring province. ${ }^{1}$ From such causes, added to the usual desire to be rid of any form of taxation, a spirit of opposition arose that brought about the abolition of the quit-rents in Maryland at the outbreak of the Revolution.

1 Professor C. P. Gould, in a painstaking and valuable study of the average size of landholdings in Maryland, shows the decrease in the number of acres in single holdings that attended the enforcement of the quit-rents. Professor Gould also considers that possibly the higher rents in Maryland, as contrasted with those of Virginia, tended to turn settlers to the latter colony. Gould, Land System in Maryland, 1720-1768, pp. 57-59. 


\section{CHAPTER VIII}

\section{ROYAL QUIT-RENTS: IN VIRGINIA}

SuPERficially considered, the colonies in which the quitrents were paid to the crown seem to present a much more favorable environment for the establishment of these dues than was afforded by the proprieties. In the royal colonies both the government and the soil were under the control of the crown, and the full weight of British authority was available to enforce the quit-rents. In the proprieties, although the overlord controlled the administration, his tenure of power was always subject to the revocation of his charter. Consequently, in taking the necessary steps to deal firmly with the quit-rents, the proprietary was likely to encounter the active intrigues of an opposition party, such as marked the struggle over taxation in Pennsylvania. The situation in the crown colonies was altogether different, for up to the very outbreak of the Revolution, the continuance of the royal authority was not questioned, and ample instructions might always be given for the enforcement of the quitrents. Moreover, there was a clear distinction in the popular mind between the payment of quit-rents to a proprietary, who used this revenue for his own private purposes, and to the crown, in whose name the income was expended, at least in part, for local needs. This attitude of the public explains the absence in the royal colonies of such attempts to deny the right to reserve quit-rents as were made in East Jersey and Pennsylvania. The patentees who held under the crown tried 
to evade or reduce the quit-rents, or else to assert the control of the assembly over the revenue from this source; they never denied the right of the king to impose them.

In certain respects the proprieties offered more favorable conditions than did the royal colonies for the establishment of the quit-rents, for in them the proprietaries were able to give that close supervision which was necessary if enforcement were to be successful. The example of Maryland shows the results that could be obtained under a firm and tactful proprietary administration that considered the problems of only one colony. Such direct control was impossible under the crown, inasmuch as the quit-rents constituted but one of a large number of royal revenues which were to be enforced in several colonies. With so wide an extension of their duties, the royal officials were often unable to compel the governor and the local authorities to enforce instructions and there was a general laxity in obeying their orders. Then, too, the quit-rents frequently became involved in the intrigues that were so often carried on by the official hierarchy in the royal colonies, while in a propriety the authority of the overlord, if it were exerted, was direct, and if he were a forceful ruler, he could quickly counteract the machinations of a group of selfserving local politicians. Another advantage enjoyed by the proprietary was the opportunity to reserve quit-rents from the very first settlement of the colony, as he was seldom confronted with problems that had been handed down from a preceding régime. If discord arose and the quit-rents were not fully enforced, the fault lay in his tactless or dilatory policy. This was not true in the crown colonies, since the royal authorities either took over a proprietary system of quit-rents which had proved a signal failure, as in the Carolinas, or else they at- 
tempted, as in New York, to establish these feudal dues, which were customary in England, among an alien people who had already lived under a different system of land tenure. In either case the enforcement of the quitrents inevitably aroused much local opposition. The sole exceptions to these unfavorable conditions were Jamaica and Virginia, the two colonies in which the crown controlled the quit-rents practically throughout their entire history.

The earliest and most successful of the quit-rent systems under the crown was established in Virginia and this colony illustrates in an interesting fashion the various problems that confronted the royal authorities everywhere in enforcing these feudal dues. The $2 \mathrm{~s}$ per 100 acres that was reserved by the London Company in 1618 did not become payable until 1625 , a year after the colony came under the royal control. ${ }^{1}$ As a result, virtually the entire administration of the quit-rents in Virginia was carried on under royal control. The history of this administration may be divided into three distinct periods; the first from 1624 to 1684 , the second from 1684 to 1720 , and the third from 1720 to the Revolution. During the first period the quit-rents were reserved in Virginia as a customary charge upon the land, but the British government paid little attention to collection, and allowed these feudal dues to come under local control. The rate established by the London Company was retained, although one penny per acre was proposed, in order to "moderate" the "excessive engrossing" of land and to provide a "publique stocke." Practically no exemptions or special rates were allowed, ${ }^{3}$

1 Sée above, pp. 109-110.

2 Report of the Governor and Council, May 17, 1626, Va. Mag. of Hist., II, 50 .

3 Town lots paid the usual rate, except that the quit-rents were waived 
and even the Indian tribes were obliged to render some small acknowledgment for their lands. ${ }^{1}$. Just as in Maryland, this reservation in all grants of a uniform quit-rent, which was never increased, was one of the chief factors in the ultimate success of the system in Virginia.

No definite steps toward collection seem to have been taken before 1638 when Jerome Hawley, one of the "gentlemen servers" to the queen, went to Virginia as treasurer with definite instructions to collect the quitrents. ${ }^{2}$ This new official doubtless found these feudal dues in a chaotic condition, since four years later the Privy Council granted the petition of the assembly that all arrears of quit-rents should be remitted, "in regard scarce the hundredth part of the sayde land hath been planted and manured, being taken up more to keep the clayme on foot, than for any benefit made thereof.", Future collections should have been helped by Virginia laws which required annual payments of the quit-rents at some convenient place in each county, and permitted the treasurer to levy distress upon delinquents. ${ }^{4}$ The assembly placed all expenditures from the quit-rent revenue under its own direction, and provided that pay-

on "land built out into the water" for the aid of shipping. Act, October, 1705, Hening, Statutes at Large, III, 412.

1 Articles of Peace with Indians, May 29, 1677, Acts, Privy Coun. Col., I, 735 .

2 Hawley accomplished little, and died without giving any account, "in regard to his great charges and trouble because of the wildness of the plantation.' King to Governor and Council, January 5, 1636, and Petition of Howard Horsey, September 20, 1639, Va. Mag. of Hist., IX, 43; XIII, 377 378. On Hawley, who was a brother of Henry Hawley, governor of Barbadoes, see Steiner, "'Beginnings of Maryland,'” J. H. U. Studies, 1903, p. 16, note.

3 Acts, Privy Coun. Col., I, 287-288.

4 Acts, January, 1640, March, 1643, and November, 1647, Hening, Statutes at Large, I, 228, 280, 351; Bruce, Economic History of Virginia, I, 559 . 
ments should be accepted in tobacco at three pence per pound. ${ }^{1}$ This local control continued for many years, although the British government, awakening to the value of this form of revenue, instructed Sir William Berkeley in 1662 to have the treasurer levy the quit-rents, and "no longer forbear.",

Continuing the local control of the quit-rents, the assembly in that year ordered the sheriffs to carry on the work of collection. As the rents were due in money, "which wee being destitute of coyne cannot provide," it authorized payments in tobacco at two shillings per pound, and released the arrears due from persons who paid double quit-rents for the next two years. ${ }^{3}$ In 1666 when the assembly prohibited the planting of tobaceo for a year, it undertook to determine the commodities in which quit-rents and other public dues might be paid at specified prices. ${ }^{4}$ Thus, the quit-rents, which by 1665 were worth nearly $£ 950$ annually according to the roll, were at this time controlled by the assembly, ${ }^{5}$ and as collections were not being made in a systematic fashion,

1 Acts, November, 1645, and March, 1646, Hening, Statutes at Large, I, 306-307, 316.

2 Instructions to Sir William Berkeley, 1662, Va. Mag. of Hist., III, 19.

3 Act, March, 1662, Hening, Statutes at Large, II, 83, 99.

4 The commodities were: wheat, garravances, and English peas at $4 \mathrm{~s}$ per bushel; Indian corn, shelled, at $2 \mathrm{~s}$ per bushel; barley at $3 \mathrm{~s} 6 \mathrm{~d}$ per bushel; "wound silke", 20 s per pound; Indian peas at $3 \mathrm{~s} 6 \mathrm{~d}$ per bushel; "oates" at $3 \mathrm{~s}$ per bushel; and "noe rates sett upon flax by reason of the uncertainty of the quality, nor beife and porke, but both these left to valuation according to the condition and goodness,' Act, June, 1666, Hening, Statutes at Large, II, 233.

5 Usually the quit-rents of Virginia were under the care of the sheriffs, although in 1665 the counties seem to have been laid off in groups of two or three, each group being in charge of a collector. Altogether, in 1665, the rolls listed 941,667 acres that produced an annual quit-rent, if it had all been paid, of 113,000 pounds of tobacco. Virginia Quit Rent Roll, 16631665, Va. Mag. of Hist., III, 42-47. 
they were rapidly becoming a merely nominal charge. ${ }^{1}$ But the inhabitants were soon awakened from their complacency by a royal grant in 1672 which handed over the colony to two proprietaries, the Earl of Arlington and Lord Culpeper. The struggle that ensued plainly shows how intense was the opposition in Virginia to proprietary rights, and ended in the return of the entire colony, with the exception of the Northern Neck, to a position of direct dependence upon the crown. ${ }^{2}$ Though this separation of the Northern Neck materially reduced the rent roll, it still left a very substantial revenue to be collected for the crown from the remaining section of Virginia.

The second period in the history of the quit-rent in Virginia began with the purchase of Culpeper's rights in 1684, and ended with the act passed in 1720 which represented the climax of the reforms instituted by Governor Spotswood in the management of this revenue. During this period the careful supervision of the auditor-general, William Blathwayt, assisted by the two governors, Nicholson and Spotswood, converted a system of quitrents that had previously been administered in an exceedingly careless fashion into an important source of revenue. The control of this revenue gave rise to a struggle between the assembly and the royal government that ended in a complete vindication of the right of the crown to dispose of this income as it pleased.

An important question that arose at the beginning of this second period concerned the medium of payment. The king directed that the quit-rents should be paid in specie according to the terms of the grants, although in "special cases" tobacco might be accepted." But as

1 Lords of Treasury to Colonel Norwood, November 17, 1681, Blathwayt's Journal, I, 126-128.

2 See above, pp. 62-66.

3 In the instructions to be made public, the governor was directed to 
there was little money in the colony, the only feasible medium of payment was tobacco. ${ }^{1}$ In a forcible representation of the situation to the governor, the burgesses demanded that payments should be accepted in tobaceo at two pence per pound, the rate that had been fixed by law in $1662 .{ }^{2}$ In reply the governor denied the right of the assembly to regulate the payment of the quit-rents, but in view of the lack of money, he consented to accept tobacco at a penny per pound. This position he maintained despite repeated protests, and the king finally repealed by proclamation the act of $1662 .{ }^{3}$ Although the burgesses protested, no attention was paid to their complaints, and a penny a pound became the usual basis for payments of the quit-rents in tobacco until the middle of the eighteenth century. ${ }^{4}$ Thus, the first struggle for the control of the quit-rents, which the assembly had hitherto exercised, ended in favor of the crown.

Another important problem was how to provide an effective system of collection. Colonel Henry Norwood, who had been appointed treasurer in 1650 , had not taken the trouble even to hand in accounts of the quit-rents he

accept payment in English or Spanish money alone, and "not in tobacco or any other commodity.', In a private letter, the receipt of tobacco was permitted when it was impossible to secure money. Letters of King to Lord Howard, July 25, 1684, Blathwayt's Journal, I, 190-192.

1 Lord Howard to Blathwayt, June 21, 1685, 'Blathwayt's Journal, I, 278-284.

2 Proceedings, House of Burgesses, November 18, 1685, C. O. 5: 1407, ff. 279-280.

3 Proceedings, House of Burgesses, November 20, 1685, C. O. 5: 1407, ff. 280-284.

4 Bruce, Economic History of Virginia, I, 562; Proceedings, House of Burgesses, November 2 and 8, 1686, C. O. 5: 1407, ff. 346, 356-357. As tobacco was not worth more than $1 / 2 \mathrm{~d}$ per pound in Virginia in 1685 , the refusal to receive the rents at the old rate of $2 d$ per pound was not unfair. Wertenbaker, Virginia under the Stuarts, pp. 245-246. 
received. ${ }^{1}$ Later the auditor, Nathaniel Bacon, was appointed treasurer, receiving from his two offices a commission of seven and a half per cent. on all public funds. ${ }^{2}$ But apparently the British government did not yet appreciate the importance of these offices, for in 1678 a court favorite, Robert Ayleway, was made auditor of Virginia. Protesting against such an appointment, the assembly, backed by the governor, declared that the office should be held by a resident of Virginia, and Ayleway's grant was annulled. ${ }^{3}$ In 1680 Bacon was appointed a deputy auditor under Blathwayt, and in 1687 the combined offices of deputy auditor and treasurer, or receiver-general as the latter was afterwards called, were combined when Nathaniel Bacon, owing to "his age and great indisposition of health," surrendered his commission, and William Byrd was appointed his successor." But this combination of the offices of deputy auditor and receiver-general concentrated too much power in one person. The Privy Council held that to combine the two "seems incongruous," and Governor Nicholson recommended that they should be separated. ${ }^{5}$ Blathwayt did not approve such a move, fearing added expense, ${ }^{6}$ but after the death of William Byrd, in 1705, the two offices were permanently separated. William Byrd, II, was made receiver-general

1 Lords of Treasury to Colonel Norwood, November 17, 1681, Blathwayt's Journal, I, 128-129.

2 Blathwayt's report, February 11, 1701, Blathwayt's Journal, II, 65-67.

3 Proceedings, House of Burgesses, July 7, 1680, C. O. 5: 1376, f. 358.

4 Byrd was required to give a bond of $£ 5,000$ to the governor and council for the faithful performance of his duties, and Ayleway made over all his own rights to the office. Order of Treasury Board, December 4, 1687, and Blathwayt's report, February 11, 1701, Blathwayt's Journal, I, 472-473; II, 65-68; Robert Ayleway to William Byrd, March 10, 1692, Va. Mag. of Hist., XIII, 227-231.

5 Lord Justices to Governor Nicholson about 1700, and Governor Nicholson to the Treasury, August 24, 1700, Blathwayt's Journal, II, 58-61.

6 Blathwayt's report, February 11, 1701, Blathwayt's Journal, II, 69. 
with a commission of three per cent., which was later increased to five per cent., and at the same time Dudley Diggs was appointed deputy auditor with a commission of five per cent. ${ }^{1}$

Actual collections were made by the sheriffs who usually received a commission of ten per cent. ${ }^{2}$ Yet as this was only one of the many duties of these officials, they frequently paid little attention to the collection of the quit-rents. Indeed, the entire system of collection in Virginia, as in the other crown colonies, suffered from a lack of adequate supervision and consequent inefficiency. The receiver-general was appointed by the crown, the deputy auditor by the auditor-general, and the authority of the governor over both of these officials was exceedingly shadowy and uncertain. On the other hand, as the sheriffs held their commissions under the governor and council, they could not be called strictly to account by either the receiver-general or the deputy auditor. The result was a loose organization which afforded little opportunity to fix responsibility, but much for graft. The most glaring instance of official peculation during this second period was the custom of selling the tobaceo, received in payment of the quit-rents, to the members of the council by "inch of candle."

1 Byrd was required to give security in England for $£ 6,000$, and for an equal amount in Virginia. Commission to William Byrd, October 19, 1705, Treas. 52: 22, ff. 500-501; Blathwayt's report, January 8, 1709, and Royal Warrant, January 25, 1710, Blathwayt's Journal, II, 541-542; III, 22-25; Deputation to Dudley Diggs, October 16, 1705, Blathwayt's Journal, II, 396-397.

2 The sheriffs were appointed by the governor with the consent of the council, nominally for twelve months, though customarily their term was an indefinite one. Bruce, Institutional History of Virginia, I, 594-595, 599.

3 In 1699 the quit-rent tobaceo was sold to the council for only $4 \mathrm{~s}$ to $6 \mathrm{~s}$ per hundredweight, although the usual price was 20 s per hundredweight. Even considering the inferior quality of the tobacco that was usually paid for the quit-rents, such prices forcibly illustrated the large profits to the 
Closely connected with the problem of enforcement was that of breaking up the vast areas of land which were held for speculative purposes. These uncultivated tracts, which were a menace to the colony because they interfered with settlement on the frontier, were usually secured by flagrant disregard of the land-laws. In direct violation of the conditions of settlement, head rights had been bought for three or four shillings, or even for half-acrown apiece. Colonel Ludwell, a member of the council, originally held 2,000 acres by forty "head"' rights, but by adding a cipher to each figure in his patent, he had received 20,000 acres. Although the enforcement of the quit-rents would have made unprofitable the holding of these great tracts, it was almost impossible to bring this about. As there was no personal property upon these vacant lands, distraint, the usual means of forcing collections, was out of the question, and the only other possible measure, forfeiture of the land, could not be employed in face of the popular opposition it was certain to provoke. Yet the situation was an intolerable one, and in one county alone the sheriff returned 30,000 acres for which the owners were not accustomed to pay the quit-rents. ${ }^{1}$ Naturally these patentees, many of whom belonged to the officeholding class, strenuously resisted all attempts to break up their speculative holdings, and

office-holding class under the sales by "inch of candle." Bassett, Writings of Colonel William Byrd, p. xxvi; Henry Hartwell and others, Account of the present state and government of Virginia, October 20, 1697, Cal. State Pap. Col. 1696-1697, p. 660; Bruce, Economic History of Virginia, I, 562563.

1 Representations of Dr. Blair, Major Wilson, and Edward Chilton, Board of Trade Journal, September 24, 1697, C. O. 391: 10, pp. 205 et seq.; Bruce, Economic History of Virginia, I, 564; Bruce, Institutional History of Virginia, II, 577 . 
used their influence to block the efforts of a governor who proposed to adopt more effective measures for the enforcement of the law.

Undeterred by the powerful influences that were arrayed against him, Governor Nicholson twice attempted to have a rent roll drawn up as the first step in enforcing the quit-rents and reforming the land system. Neither of these efforts proved successful, but he finally secured an equally important reform in the substitution of public sale in place of the private auction, by "inch of candle," of the tobacco that was received for the quit-rents." Although experience had proved that this latter custom was a source of much loss in revenue, the crown twice ordered that it should be reëstablished. But on each occasion the council decided that public sale of the quitrent tobacco should continue. ${ }^{2}$ The persistence of Governor Nicholson was finally rewarded by an order from the Treasury in England that a rent roll should be made out with lists of all patents by counties, and that the sheriffs should report all lands for which the quit-rents were not being paid. ${ }^{3}$ But even after this order, Governor Nicholson seems to have made little real progress with his proposed reforms. ${ }^{4}$

1 Minute, Va. Council, June 22, 1699, Cal. State Pap. Col., Addenda, 1621 1698, p. 294; Bruce, Economic History of Virginia, I, 564; Bruce, Institutional History of Virginia, II, 577. A survey of the province was also proposed. See Discourse of E. Randolph, August 31, 1696, Sainsbury Abstracts, V, 262; Va. Mag. of Hist., XX, 115; XXIII, 37.

2 Council Minute, October 18, 1705, and July 25, 1710, C. O. 5: 1316, f. 419 .

3 Lord Treasurer to Governor of Virginia, April 2, 1705, Blathwayt's Journal, II, 347-350.

4. One forward step, as far as the land situation was concerned, was an act in 1705 which provided that land might be acquired by purchase at $5 \mathrm{~s}$ per 50 acres, as well as by "'head rights." Act, October, 1705, Hening, Statutes at Large, III, 304-305. 
The next series of reforms in the quit-rent system of Virginia was instituted by Governor Spotswood. Under his influence the assembly passed an act in 1710 which provided that surplus land might be taken up by any discoverer after a year's notice to the original claimant, and that patents to uncultivated lands should lapse if the quit-rents that were due upon them were not paid for three years. ${ }^{1}$ Another act a few years later made the quit-rents payable at public warehouses in inspected tobacco, rather than in the miserable trash that had hitherto been offered. ${ }^{2}$ Next Governor Spotswood proposed to reform the system of collection. The sheriffs, he found, assumed little responsibility for the quit-rents, and employed deputy collectors who were not under bond, and who often appropriated to their own uses a large part of their receipts. ${ }^{3}$ For the future, he proposed that the sheriffs, whose commission he would reduce to five per cent., should be required personally to attend at designated places in order to receive the quit-rents, and should make their payments, if possible, directly to the receiver-general. In addition he advised that a complete rent roll should be made out, that the sheriffs should pass their accounts at Williamsburg on April 11, and that the quit-rent tobacco should be publicly sold to the highest bidder. ${ }^{4}$ This plan, which Spotswood drew up in order

1 Act, October, 1710, Hening, Statutes at Large, III, 526, 529. Though this law was subsequently declared retroactive, within a year after its passage 10,000 acres of surplus land were added to the rent rolls. Spotswood to Treasury Board, July 25, 1711, and January 27, 1715, Spotswood Letters, I, 89-90; II, 101-103; Hening, Statutes at Large, IV, 41.

2 Spotswood to William Blathwayt, March 13, 1713, and to the Lord High Treasurer, May 11, 1714, Spotswood Letters, II, 61-62, 67-69.

3 Governor Spotswood to William Blathwayt, June 2, 1713, Spotsuood Letters, II, 20-21.

4 Minutes, Va. Council, December 8, 1715, Ludwell MSS., II, no. 15. 
to put the quit-rent system upon a businesslike foundation, encountered at first the violent opposition of the council. But when the governor asked the members for their objections in writing, only the receiver-general, William Byrd, responded, presenting a counter scheme for the appointment of four deputy collectors who would be wholly under his own charge. Byrd also offered a number of criticisms of the governor's plans, which were answered in such vigorous fashion that the council quickly passed Spotswood's entire scheme for the collection of the quit-rents. ${ }^{1}$

The immediate result of Governor Spotswood's reforms was a marked improvement in collections. ${ }^{2}$ But the opposition of the official classes, who saw their control of the quit-rent system threatened, was soon aroused, and Spotswood bitterly complained of the difficulties that confronted a governor who, with "no other assistance than his own hearty inclinations," struggled against the "general bent" of a "whole country.", The central figures in the opposition were the receiver-general, William Byrd, II, and the deputy auditor, Thomas Ludwell. Ludwell especially, Spotswood asserted, had coolly ignored the changes that had been made in the method of collection, had stirred up the people against the governor, and had encouraged the assembly in an attempt to secure complete local control of the quit-rents, and was par-

1 Governor Spotswood to Board of Trade, December 1, 1714, Spotswood Letters, II, 81 et seq.; Bassett, Writings of Colonel William Byrd, pp. Ivi, lviii.

2 For the two years, 1714-1715, the average annual amount of collections was nearly. $£ 2,000$. Observations of Governor Spotswood, May 24, 1716, Spotswood Letters, II, 181.

3 Governor Spotswood to Treasury Board, January 27, 1715, Treas. 1: 187, ff. $172-173$. 
ticularly ill-qualified to exercise an effective check upon accounts because of his relationship to Byrd. In view of all these circumstances Governor Spotswood summarily removed Ludwell from his office. ${ }^{1}$ As William Byrd, whose commission had just expired, was applying for reappointment, an excellent opportunity was presented to remove the chief obstacles in the way of the reform of the quit-rents and to sustain the governor. Although influence was brought to bear in Byrd's behalf, ${ }^{2}$ the British authorities showed an appreciation of the situation by appointing James Roscow as receiver-general, and John Grymes as deputy auditor. ${ }^{3}$ These two appointments finally established the authority of the governor over the receiver-general and the deputy auditor and proved of great assistance in securing more adequate control of the quit-rents.

The mere removal from office of the leaders of the opposition did not secure a complete reform of the quitrent system in Virginia. With nearly 3,000,000 acres already patented, the actual returns from the quit-rents were far short of what was due, and though these charges were not paid on thousands of acres, every effort to secure an adequate rent roll proved a signal failure. Many of the old abuses continued, and the new scheme for collection was practically ignored. The one remedy, Spotswood considered, was to put an end to the collection by the sheriffs, and to appoint special agents for this work. Yet such a move would, he feared, inevitably arouse the politicians, since it would create too great an exactness

1 Governor Spotswood to Treasury Board, May 23, 1716, Treas. 1: 199, ff. $76-80$.

2 Petition from Micajah Perry, March 17, 1715; Treas. 1: 189, ff. 15, 16.

3 Patent to James Roseow, April 21, 1716, and Deputation to John Grymes, July 2, 1716, Blathwayt's Journal, III, 141-145. 
in collections, and would increase the governor's powers. ${ }^{1}$ Like many another colonial governor, Spotswood was compelled to compromise. He secured an act in 1720 which recognized local prejudices by retaining the sheriffs as collectors of the quit-rents, but gave the governor much ampler powers of supervision. It required every sheriff, at the November court, to divide his county into precincts, and to fix in each of these subdivisions a place at which he would attend before February 20 , in order to receive the quit-rents either in money, or in tobacco at a penny a pound. It ordered the county courts to see that the sheriffs performed these duties and promptly turned over all collections to the receivergeneral, and it continued distraint as the penalty for delinquent landholders. ${ }^{2}$ Although the act was a great aid to the proper enforcement of the quit-rent system in Virginia, it would have secured far better results if, ignoring local prejudices, it had required collection by special deputies as was customary in Maryland. Its passage marked the close of the second period under consideration.

The opposition that Governor Spotswood had encountered to his plans for the reform of the quit-rents was probably due in part to the repeated attempts of the assembly to retain its former control over the revenue from this source. But the representatives of the crown had learned from the lesson of Bacon's Rebellion the

1 Governor Spotswood to Board of Trade, March 7, 1718, Spotswood Letters, II, 265-269.

2 The act clearly showed the popular opposition to forfeiture of the land, declaring that this penalty would not be permitted for failure to pay the quit-rents, "notwithstanding a proviso in the patent or any other law whatsoever." . The penalty of double quit-rents was of only doubtful value as after events showed, for it could only be collected after the land had been improved. Also, it constituted a cloud on the title in case of alienations. Act, Norember, 1720, Hening, Statutes at Large, IV, 79-80. 
necessity for a fund, not controlled by the assembly, which might be employed "for preventing and suppressing all intestine seditions." 1 Accordingly, after the purchase of all proprietary rights in Virginia, except those over the Northern Neck, the king explicitly forbade any expenditures from the quit-rents without a royal order, although he made an indefinite promise to employ this revenue for public purposes. ${ }^{2}$ Nevertheless, the income was for a time expended in Virginia, and the change in the status of the quit-rents from a revenue under local to one under royal control does not seem to have been at first fully appreciated. ${ }^{3}$ Usually the British government permitted the accumulation in Virginia of a large balance from the quit-rent fund upon which warrants could be drawn, either for the general service of the crown, or for objects for which the assembly was unwilling or unable to make appropriations. Thus, henceforth, the quit-rents provided the royal government in Virginia with a fund that was free from popular control, and was available for any special emergency.

The returns from the quit-rents steadily increased after the purchase of Lord Culpeper's rights; and during the period from 1684 to 1715 , the income from this source

1 Acts, Privy Coun. Col. I, 810. The regular revenue for the support of government, an export duty of $2 \mathrm{~s}$ per hogshead of tobacco, was first levied in 1661. As the assembly controlled this fund, the importance of the royal control of the quit-rents is obvious. Ripley, Financial History of Virginia, pp. 58-59.

2 King to Lord Howard, July 25, 1684, Lord Treasurer to Lord Howard, December 21, 1685, and Blathwayt's report, September 13, 1711, Blathwayt's Journal, I, 190-191, 286-287 ; III, 64; Hening, Statutes at Large, II, 521 522.

3 Minutes, Council of Virginia, April 26, 1686, Blathwayt's Journal, I, 348-349. By 1692, out of $£ 4,375$ collected from the quit-rents in six years, all but $£ 1,985$ had been expended for the public service in Virginia. Memorial, July, 1692, Cal. State Pap. Col. 1689-1692, p. 672. 
was more than quadrupled. ${ }^{1}$ An annual allowance from this fund of $£ 1,000$ to the governor soon ceased, ${ }^{2}$ and the regular charges allowed yearly up to 1720 included $£ 100$ to the commissary of the Bishop of London, $£ 60$ to the attorney-general, ${ }^{3}$ and the regular expenses of collection. ${ }^{4}$ Occasionally there were warrants in favor of specified expenditures in Virginia. Of special interest is a petition from the assembly in 1691 asking that the balance on hand from the quit-rents should be granted to aid in founding a "colledge" in Virginia, and begging that in the future this revenue should be employed to pay a commissary, and to make a "comfortable augmentation" of the meager stipends that were paid the clergy of the colony. ${ }^{5}$ The Treasury opposed both requests, believing

1 The increase in the quit-rent revenue is shown by the following table:

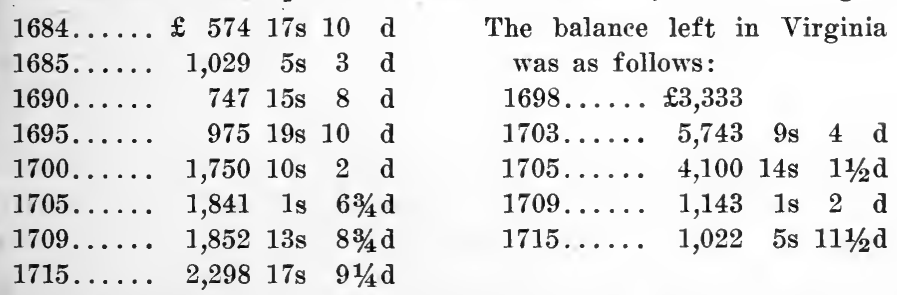

Blathwayt's Journal, II, 23, 224, 292, 356, 403 ; III, 93, 94; Treas. 1: 185, no. 24 ; 192 , no. 36 .

With the exception of one small item, entered 1720-1728, the quit-rents of Virginia were not carried in the general account of the British revenue as was done with the $41 / 2$ per cent. from Barbadoes, Brit. Mus., Stowe MSS. 317, Addit. MSS. 36731-36734.

2 W. Popple to W. Lowndes, June 22, 1698, Treas. 1: 54, f. 19.

3 Minute, Privy Council, September 1, 1692, and Royal Warrants, May 19, 1703, and March 6, 1704, Blathwayt's Journal, I, 597; II, 178-179, 244 ; Treas. 1: 13-192, passim.

4 These charges included a commission of 5 per cent. each to the receivergeneral and the auditor, and of 10 per cent. to 14 per cent. to the sheriffs, Virginia Quit-Rent Account, April 25, 1713-April 25, 1714, Treas. 1: 187, f. 14 .

5 The "colledge" was to be called the "Colledge of King William and Queen Mary", and was to include "A Grammar School for teaching the Latin and Greek tongues, a Philosophy School, for Philosophy and Mathe- 
that to concede them would establish a precedent which would stir up the clergy of all the other colonies to come begging for allowances out of the quit-rents in order to found colleges. ${ }^{1}$ But Dr. Blair and the other supporters of the petition were persistent. There were already, they asserted, sufficient revenues in the colony for ordinary purposes and these revenues would be continued as long as the governor called the assembly together. If the governor should fail to do this, they intimated, "it will need a much larger sum than that now asked for the college to defend the country.",2 Despite this last rather significant statement, the petitioners won. The crown granted the balance of the quit-rents on hand, $£ 1,98314 \mathrm{~s} 10 \mathrm{~d}$, to found the college of. William and Mary. In addition, it set aside the entire quit-rent revenue for the next three years, less fixed charges, to give the commissary a salary of $£ 100$ annually, and to support in part the Virginia clergy. ${ }^{3}$

The liberality displayed toward the new college in Virginia was unusual, since most of the expenditures from the quit-rents were for military needs which the usual revenues of the colony were unable to meet. The crown issued warrants for such purposes as to maintain a war sloop, to build a fort at Jamestown, and to pay for military supplies that had been shipped to Virginia. ${ }^{4}$ It matics, and a Divinity School.', Petition, Virginia Assembly, 1691, Blathwayt's Journal, I, 574-581.

1 Blathwayt's report, February 22, 1692, and Treasury to the King, July 15, 1692, Blathwayt's Journal, I, 582, 588-591.

2 Unsigned Memorial, July, 1692, Cal. State Pap. Col. 1689-1692, pp. 6ז2674.

3 Minute, Privy Council, September 1, 1692, Blathwayt's Journal, I, 597. When the college buildings were burned, an additional $£ 1,000$ was granted from the quit-rents, Royal Warrants, March 21, 1709, and April 8, 1710, Blathwayt's Journal, II, 561-564; III, 38-39.

4 In 1698 there was a deficit in the $2 \mathrm{~s}$ duty for the support of the government of $£ 2,9559 \mathrm{~s} 81 / 4 \mathrm{~d}$, due to the purchase of military supplies. This sum 
also issued a warrant of $£ 250$ to defray the expenses of the commission to adjust the boundary line between Virginia and North Carolina. ${ }^{1}$ It allowed other warrants for purposes for which the assembly would not have made appropriations. For example, Colonel Robert Hunter, who was captured at sea while on his way to act as governor of Virginia, was given an allowance from the quitrents to pay for the loss of his baggage and for his salary for four years. ${ }^{2}$ But after the seventeenth century, by far the larger part of the revenue from the quit-rents was spent outside of Virginia, and was used altogether at the discretion of the British government as a fund wholly at the disposal of the crown. ${ }^{3}$

The assembly did not permit the conversion of the quit-rents from a local into a royal revenue to pass unnoticed. When they were asked to aid New York during the struggles with the French and Indians, in 1688, they flatly refused upon the pretext that the financial condition of Virginia would not permit an appropriation for this purpose. ${ }^{4}$ The crown then set a precedent by drawing upon the quit-rents for the immediate needs of New

was replaced from the quit-rents. Blathwayt's Journal, I, 684-685, 698-699; II, 224; Palmer, Calendar of Virginia State Papers, I, 58-59; Account, Virginia Quit-Rents, 1702, Blathwayt's Journal, II, 224.

1 Royal Warrant, March 25, 1714, Blathwayt's Journal, III, 131-133. The disputes as to jurisdiction between the two colonies resulted in much loss to the Virginia quit-rents, since many settlers on the border refused to take out patents. Report of Board of Trade, January 7, 1709, Blathwayt's Journal, II, 549-555.

2 Royal Warrants, April 28, 1708, and January 25, 1710, Blathwayt's Journal, II, 535-538; III, 20-21.

3 Out of a balance in Virginia in 1703 of $£ 5,7439$ s $4 \mathrm{~d}, £ 3,000$ was drawn out for the royal exchequer. In 1707 the entire balance, $£ 2,06012 \mathrm{~s} 43 / 4 \mathrm{~d}$, was used in the same fashion. Other large amounts were withdrawn from time to time. Royal Warrants, April 2, 1705, and August 18, 1707, Blathwayt's Journal, II, 346-347, 491.

4 Proceedings, House of Burgesses, May 1 and 2, 1788, C. O. 5: 1407, ff. $440-444$. 
York. ${ }^{1}$ In 1693 the Treasury directed the governor of Virginia to agree with the governors of neighboring colonies as to the quota of troops and money that each of them was to furnish for the aid of New York. This request, too, the burgesses refused, on the ground that Virginia could not afford to defend New York, and that such appropriations should come from the quit-rents. ${ }^{2}$ Two years later the burgesses reluctantly consented to raise $£ 500$ to aid New York, ${ }^{3}$ although they met at least three later requests for aid with a flat refusal. Finally they sent an address to the crown, in which they represented that Virginia could not spare for the benefit of New York either the money or the men that were needed for her own defense. ${ }^{4}$ There was a very evident feeling of resentment among the burgesses that with the quit-rent fund available, the royal government should ask for such additional expenditures. ${ }^{5}$ This attitude compelled the crown to dip into the quit-rents upon several occasions in order to relieve the necessities of New York. ${ }^{6}$ The

1 Altogether, $£ 70215 \mathrm{~s} 9 \mathrm{~d}$ was sent New York from the Virginia quitrents, 1691-1693. King to Sir Edmund Andros, March 5, 1693, Blathwayt's Journal, I, 655-656.

2 Proceedings, House of Burgesses, November 7-13, 1693, C. O. 5: 1407, ff. 1-7.

3 Ibid., April 11-May 16, 1695, C. O. 5: 1407, ff. 9-18.

4 Ibid., April 29, 1696, September 16-30, 1701, and April 2-9, 1703, C. O. 5 : 1408, ff. $262-263 ; 1411$, ff. $185-188 ; 1413$.

5 This attitude was shown especially when aid was asked for South Carolina. Proceedings, House of Burgesses, August 4 and 9, 1715, C. O. 5 : 1416. See also, Proceedings, December 10, 1710, C. O. 5: 1414, and Governor Spotswood to Board of Trade, May 8, 1712, Spotswood Letters, I, 151.

6 In 1712 an order for $£ 3,000$, to be transmitted to the royal exchequer, could not be honored owing to the large grants already made to supply troops sent against Canada, Spotswood to Lord Treasurer, May 8, 1712, Spotswood Letters, I, 154-158. Later, a warrant of $£ 917$ 7s $3 d$ was allowed for the troops sent to Canada. Va. Quit-Rent Accounts, 1713-1714, Ludwell MSS., II, no. 14. When the revenues of New York were unable to provide $£ 32414 \mathrm{~s} 8 \mathrm{~d}$ for presents to the chiefs of the Five Nations in 1719, the 
sentiment of the burgesses toward the quit-rent was also shown in 1685 when a house was proposed for the governor. Readily consenting to this expenditure, the burgesses coolly asserted that the cost could easily be met from the quit-rents. The governor sharply rebuked such freedom with regard to the royal revenue, ${ }^{1}$ but the burgesses stoutly maintained their position. In 1699, and again in 1700 , they took the same stand, ${ }^{2}$ and not until 1706 did they finally consent to an appropriation of $£ 3,000$ to build the governor's mansion. ${ }^{3}$

Meantime the burgesses persistently attempted to recover their former control over expenditures from the quit-rents. In 1691 and again in 1701 they petitioned that this fund should be employed for the benefit of the colony. ${ }^{4}$ They did not act hastily, and refused to interfere when grievances were presented with reference to the quit-rents, ${ }^{5}$ but in 1701 they resolved that a law was necessary which would name the charges to be met out of the "publick" and out of the "royal" revenues."

Virginia quit-rents were drawn upon. Report of the Auditor-General, July 20, 1719, Cal. Treas. Papers, V, 471.

1 Proceedings, House of Burgesses, December 2 and 3, 1685, C. O. 5: 1407, ff. 292-297.

2 Proceedings, House of Burgesses, May 3 and 22, 1699, and December 17 and 24,1700 , C. O. 5 : 1408, ff. 72, 105; 1411, ff. 358, 428.

3 Proceedings, House of Burgesses, April 30, 1706, C. O. 5: 1413.

4 Among the objects for which allowances were asked from the quitrents were the following: to build a capitol, to provide a house for the governor, and to draw up a revision of the laws of the colony. All of them, it may be noted, were extra expenditures. Proceedings, House of Burgesses, May 7, 1691, and December 27, 1700, C. O. 5 : 1407, f. 731; 1408, ff. 116-119.

5 From Gloucester County came a request that the quit-rents should be received either in tobacco at $2 d$ per pound or in Spanish coins. The landholders in Isle of Wight and Nansemond counties complained that their quit-rents were too high. Proceedings, House of Burgesses, May 10, 1699, C. O. 5 : 1411 , f. 391 .

6 Proceedings, House of Burgesses, September 12, 1701, C. O. 5: 1408, f. 255 . 
Finally, in 1714, both houses of the assembly united in a joint address to the crown, praying that, in view of the large deficit in the two shillings duty, the quit-rents should be employed, as formerly, to make good all deficiencies in the regular revenue. Subject to a strict accounting to the crown, they asked that the governor, with the consent of the council, should be permitted to use the quit-rents in any sudden emergency. ${ }^{1}$

Governor Spotswood supported the petition of the assembly, although he did not approve the "improper request" that the crown hand over the entire revenue from the quit-rents. Representing the necessity of a grant from this source in order to replace the current deficit of $£ 1,0709 \mathrm{~s} 11 \frac{1}{2} \mathrm{~d}$ in the two shillings per hogshead, he emphasized the need of an emergency fund for the colonial government, and reminded the Board of Trade that the lack of $£ 1,000$ at the disposal of the governor had made possible Bacon's Rebellion. ${ }^{2}$ In even more vigorous language the receiver-general, William Byrd, II, personally championed the petition of the assembly, ${ }^{3}$ and even the Board of Trade favored it, calling attention to the fact that the quit-rent revenue was being forwarded to the royal exchequer "as fast as it could be raised." Asserting that the two shillings duty did not bring in sufficient revenue, and that the governor had no fund to draw upon in an emergency, the board pointed out that in no other colony were the quit-rents diverted for making good local deficiencies. But the Treasury opposed any grants from this fund except upon

1 Joint Address to Crown, December 17, 1714, C. O. 5 : 1414.

2 Governor Spotswood to Board of Trade, January 27 and July 15, 1715, Treas. 1: 187, ff. 172-173; 192, ff. 34-35.

3 Memorial of William Byrd, August 11, 1715, Sainsbury Abstracts, III, 456. 
royal warrants. ${ }^{1}$ Eventually the crown permitted the deficit in the revenues of Virginia to be made up from the quit-rents, but refused to allow the local control of the fund which was the most important feature of the petition. ${ }^{2}$ This episode marked the last effort to restore the Virginia quit-rents to their former position as a local revenue. By the end of the second period of their history, the quit-rents were established in Virginia as a revenue collected in a fairly effective fashion, and expended wholly under the direction of the crown.

The third period in the history of the quit-rent system in Virginia, from 1720 to the Revolution, saw the gradual establishment of these charges upon a more businesslike basis. One of the chief problems of the period was to secure effective work from the officials in charge of collections. The county courts, to which the supervision of these officials was usually assigned, were dominated by the landholding class, and were naturally disinclined to compel the sheriffs to collect the quit-rents. ${ }^{3}$ In at least two instances the council was obliged to warn delinquent sheriffs that unless they submitted their accounts promptly, the attorney-general would bring suit against their sureties. ${ }^{*}$ The sheriffs had little excuse for such neglect, as they had full powers of distraint upon all "slaves, goods or chattels," and could even compel tenants to pay the quit-rents for lands which they rented. ${ }^{5}$

1 The report of the Board of Trade was endorsed, doubtless by the Treasury to whom it was referred; "of opinion revenue appropriated to Civil List not to be employed for public purposes. Let accounts of the revenue of Virginia be transmitted to the Crown for consideration." Report, Board of Trade, September 1-2, 1715, Treas. 1: 192, ff. 30-32.

2 Cal. Treas. Papers, V, 159; Ripley, Financial History of Virginia, p. 55.

3 Royal Warrant, March 6, 1734, Cal. Treas. Papers, VIII, 536; Ripley, Financial History of Virgiria, p. 53.

4 Va. Mag. of History, XIV, 32, 116, 339, 444.

5 Acts, August, 1736, and October, 1748, Hening, Statutes at Large, IV, $491 ; \mathrm{V}, 424$. 
Furthermore, they were aided in their work by an act of 1748 which allowed a discount of from ten to thirty per cent. on all tobacco received for the quit-rents that was delivered to public warehouses by April 10, though the act also provided that if these charges were not settled within the specified time, they should be paid in money. ${ }^{1}$

Official neglect continued to be the chief cause of meager and dilatory collections. Richard Corbin reported that when he assumed office as receiver-general, he found that his predecessor, John Grymes, still owed $£ 18,338$ on account of the quit-rents, and there was little prospect that this debt would ever be paid. ${ }^{2}$ Probably the greater part of this sum had never been actually collected, for, owing to the custom of leaving a large balance of the fund in Virginia, the receiver-general had not demanded prompt payments by the sheriffs. The bad effect of such a practice was evident when Corbin wrote on July 29, 1762, that not a single sheriff had handed in his account, although all of them should have reported in April. ${ }^{3}$ As repeated demands secured few results, Corbin was obliged to allow the sheriffs from six to twelve months' credit on their accounts. ${ }^{4}$ Careless bookkeeping by the sheriffs was another cause of trouble. Often the accounts were so badly kept that it was impossible to estimate the arrears due on a given tract, especially as the rent rolls were in an equally unsatisfactory condi-

1 Act, October, 1748, Hening, Statutes at Large, VI, 168-171.

2 Richard Corbin to Auditor-General Cholmondeley, November 7, 1763, Richard Corbin's Letter Book, II, 36. This large balance was offset by a bond of only $£ 6,000$. Cal. Treas. Papers, VII, 475 .

3 Corbin estimated the profits from his office for one year at $£ 3206 \mathrm{~s}$, all of which had been swallowed up in the hire of a clerk and miscellaneous expenses. Corbin to John Roberts, July 29 and December 1, 1762, Richard Corbin's Letter Book, II, 9-11, 19-20.

4 Corbin to Roberts, December 15, 1767, Richard Corbin's Letter Book, II, 93-94. 
tion. As transfers were usually not entered on these rolls, the quit-rents on alienated lands were often not collected, while the many irregularities in the land system increased the general confusion. The deputy auditor passed the quit-rent accounts according to the best information he could secure from the sheriffs, but the numerous errors in bookkeeping, and the generally unsatisfactory condition of the rent rolls, undoubtedly enabled much land to escape payments altogether. An attempt was made in 1767 to improve the situation by drawing up, in a "clear manner," an exact rent roll for each county and a further reform was promised by an instruction to Lord Dunmore, in 1771, to have a survey made of the entire colony, and to see that every patent was entered upon the rent rolls. ${ }^{2}$ If these orders had been carried out, the quit-rents, and incidentally the land system of Virginia, would have been placed upon a much more satisfactory basis, but the Revolution came too soon to permit this result.

Besides the negligence of the officers, the careless methods of the land-office also caused much loss in revenue. Though there were occasional resurveys, many persons were permitted to hold surplus land for which they never pretended to pay the quit-rents. ${ }^{3}$ In one typical instance the rent rolls listed only 1,000 acres, although a resurvey showed that the tract actually contained 5,000 acres. ${ }^{4}$ Even greater loss arose from the failure to take

1 Report of John Blair, May 20, 1768, C. O. 5 : 112, ff. 194-195.

2 Instructions to Lord Dunmore, February 7, 1771, Mass. Hist. Soc. Col., 4 th series, $X, 653-654$.

3 The lax methods employed are illustrated by the petition of one landholder from Gloucester County. Upon the plea that he had "discovered" it himself, he asked for permission to take out a patent for the 800 acres of surplus land that he held, and for the remission of all arrears of quit-rents upon the tract. $\nabla a$. Mag. of Hist., XV, 233-234.

4 Report of John Blair, May 20, 1768, C. O. 5 : 112, ff. 194-195. 
out patents for lands that had been surveyed. Governor Dinwiddie estimated that by this custom the owners of fully 1,000,000 acres escaped any payment of the quitrents. By vigorous efforts he induced these landholders to take out patents for 294,755 acres, but his activity soon brought an outcry from interested persons and was, he believed, the real cause of the controversy over the demand he made for a pistole as a fee when the seal was affixed to a patent. ${ }^{1}$ Finally the Board of Trade sent instructions that patents should be issued immediately after the return of the surveys. This order should have greatly swelled the rent rolls. ${ }^{2}$

The general disposition to evade the quit-rents was shown after the British government offered special conditions in order to secure settlement in the back country. In 1723 the Privy Council granted settlers in the frontier counties of Spottsylvania and New Brunswick an exemption for seven years from both the purchase money and the quit-rents. ${ }^{3}$ In anticipation of this concession, the land speculators had displayed great activity. The boundaries of Spottsylvania County had been enlarged to include 120,000 acres that had been surveyed but not patented, and grants of 20,000 to 40,000 acres each had been made. ${ }^{4}$ As Governor Spotswood was among the prominent men involved in these schemes to evade the quit-rents, official influence was largely responsible for

1 Governor Dinwiddie to Treasury Board, December 29, 1753, Treas. 1: 353, ff. 240-241 ; Acts, Privy Coun. Col., IV, \$227.

2 Board of Trade to Robert Dinwiddie, January, 1755, Treas. 1: 360, ff. $82-85$.

3 These grants were limited to 1,000 acres each, a condition that later led to much confusion. Persons who took up land here were required to give security for the payment of the quit-rents that were due on tracts they already held in the older parts of the colony. Acts, Privy Coun. Col., III, 23.

4 Governor Drysdale to Board of Trade, June 6, 1724, Sainsbury Abstracts, IX, 131-132. 
the leniency displayed by the Privy Council in dealing with these very questionable grants. ${ }^{1}$ The policy of offering special conditions was extended to the lands west of the Alleghanies by a grant of 500,000 acres in 1749 to the Ohio Company, which waived the quit-rents for ten years after active settlement. ${ }^{2}$ Later, a general order was issued granting all lands west of the Alleghanies upon these terms. ${ }^{3}$ To the soldiers who took part in the expedition against the French 200,000 acres of western lands were assigned with an exemption from the quit-rents for fifteen years. ${ }^{4}$ Though these concessions were an attempt to assert the jurisdiction of Virginia, it is not probable that the quit-rents ever became of actual value in these distant regions. Many of the settlers positively refused to pay them, and apparently there was no wellorganized system of collection. ${ }^{5}$ The conflicting claims of Pennsylvania and the Transylvania Company regarding jurisdiction finally ended all efforts to enforce the payment of the quit-rents for the lands along the Ohio. ${ }^{6}$

Another important problem that arose during the third period of the quit-rent system in Virginia concerned the medium of payment. As tobacco was gradually super-

1 Altogether, Governor Spotswood and his associates had taken up 85,027 acres before the exemption order was issued in 1723. As numerous improvements had been made upon this land, the quit-rents were remitted to 1728 , provided the purchase money was paid on 59,766 acres to which the title was uncertain. To other landholders equally liberal terms were offered, and titles were confirmed for 60,547 acres that had been taken up previous to 1723. Though the purchase money was remitted, the quit-rents were to be paid, and single tracts were limited to 6,000 acres. Acts, Privy Coun. Col., III, 168-171, 244, 247.

2 Acts, Privy Coun. Col., IV, 55-58.

3 Ibid., IV, 237-238.

4 Governor Dinwiddie to Secretary Holdernesse, March 12, 1754, Dinwiddie Papers, I, 96.

5 Report of John Blair, May 20, 1768, C. O. 5: 112, f. 194.

6 Filson Club Publications, 27, pp. 36-37; Va. Mag. of Hist., XVII, 388389 . 
seded by the Spanish silver that was in general use in Virginia, the exchange at which these coins would be accepted became a matter of much importance. ${ }^{1}$ The usual rate was at first nineteen pennyweight, and later seventeen and one-half pennyweight of foreign silver for five shillings English money, but after 1733 Spanish money depreciated in value, and the receiver-general was permitted to deduct five and three-eighths per cent. to cover the cost of transmitting the quit-rent revenue to England. ${ }^{2}$ The exchange rate continued to soar until, in sending the receipts for the years 1745 and 1746, the receiver-general followed the advice of the governor and council, and increased this allowance to twelve and a half per cent. ${ }^{3}$ This act roused the wrath of Auditor-General Walpole in England, who held that the receiver-general should not have sent the quit-rents with so large a discount until he had received definite permission from the Treasury. Walpole believed that the delegation of such arbitrary power to the governor and council might prove of "bad consequence" to the interests of the crown in the future. ${ }^{*}$ The Privy Council attempted to settle the matter by an order that if Spanish coins were offered in payment of the quit-rents, the sheriffs should demand full value in English sterling, and receive tobacco at three farthings per pound. For the years 1745-1748 the Privy Council

1 The accounts do not elearly distinguish between payments in money and those in tobacco, but gradually Spanish silver seems to have become the usual medium. Virginia Quit-Rent Accounts, 1720-1747, C. O. 5: 13191326, passim.

2 Report of Auditor-General Walpole, August 22, 1748, Treas. 1: 330, ff. $50-51$.

3 The governor signed a certificate which set forth the facts in the case. Only in view of the excessive rate of exchange, he asserted, and the failure to receive specific instructions, would the receiver-general have adopted such a course. Petition of John Grymes, October 20, 1747, Treas. 1: 328, no. 96.

4 Report of Auditor-General Walpole, August 22, 1748, Treas. 1: 330, ff. $51-52$. 
allowed the discount of twelve and a half per cent., but in the future, it required that the revenue from the quitrents should be transmitted to England without any deductions for exchange. ${ }^{1}$ This order was only partly carried out. For the years 1749 and 1750 an exchange of six and two-thirds per cent. was allowed, but later it was reduced to the nominal rate of half of one per cent. ${ }^{2}$

Ultimately the arbitrary orders of the Privy Council proved powerless in face of the chaotic economic situation in Virginia. Though the paper money first issued in 1755 was not made'legal tender for the quit-rents, the receiver-general found that he was obliged to accept it. ${ }^{3}$ So rapidly did this colonial currency depreciate that any fixed exchange proved impossible, and in 1762, from this source alone, fully $£ 1,000$ was lost in the quit-rent revenue. ${ }^{4}$ As the rapid depreciation in the value of tobacco made considerable inroads also into this fund and as Spanish money had practically disappeared from the colony, paper money became the one available means of settling the quit-rents. ${ }^{5}$ The value of this currency had so decreased by 1765 that some new regulation was necessary, unless great losses in the quit-rents were to

1 In practice, 19 pennyweight was accepted in Spanish coins, under the terms of this order, for $5 \mathrm{~s}$ sterling. As this rate was about 22 per cent. in excess of the current exchange in Virginia, it should have provided for all expenses of remittance. Acts, Privy Coun. Col., IV, 104-107.

2 Virginia Quit-Rent Accounts, 1749-1757, C. O. 5: 1327-1329, passim.

3 This paper money was issued in 1755 , primarily in order to aid Braddock's expedition. While the act passed in 1755 did not make the quitrents legally payable in this medium, a similar exception was not made in those passed in 1769, 1771 and 1773. Hening, Statutes at Large, VI, 467, 528-529; VIII, 347, 502, 648-649.

4 Richard Corbin to John Roberts, July 29 and September 2, 1762, Richard Corbin's Letter Book, II, 9-11, 14-15.

5 Richard Corbin to R. Tunstall, February 25, 1763, and to Treasury Board, December 17, 1764, Richard Corbin's Letter Book, II, 22, 52; Va. Committee of Council to Agent, June 16, 1763, Va. Mag. of Hist., XI, 348. 
be incurred. But in view of the disorders that followed the passage of the Stamp Act, collection of the quit-rents was at best uncertain, and the receiver-general wisely concluded not to add to the general irritation by arbitrary orders regarding the medium of payment. ${ }^{1}$

In spite of many hindrances, a fairly satisfactory revenue was secured from the quit-rents after the reforms instituted by Governor Spotswood were put in force. From about 1730 the average net annual returns in the eighteenth century varied usually between $£ 3,500$ and $£ 4,000$. Large arrears accumulated as a result of the dilatory conduct of the sheriffs, but as they were eventually collected, this average was steadily maintained. ${ }^{2}$ Though a part of the revenue from the quit-rents was left in Virginia, probably the bulk of the fund, after 1720, was remitted to the royal exchequer in London, and between 1731 and 1745 fully $£ 22,500$ was placed at the disposal of the crown. ${ }^{3}$ Toward the close of the colonial period little if any balance was left in Virginia, as much as $£ 7,420$ being sent to England in $1775 .^{4}$ Warrants were

1 Richard Corbin to James Abercrombie, May 30, 1765, and to John Roberts, May 20, 1765, and February 8, 1766, Richard Corbin's Letter Book, II, 58-59, 69-70.

2 The following table shows the net returns, above the regular expenses of collection, and also the amount of arrears in the respective years.

\begin{tabular}{|c|c|c|c|c|}
\hline Year & Returns & Arrears & Balance on & hand \\
\hline 1739 & $£ 3,604 \quad 4 \mathrm{~s} 51 / 2 \mathrm{~d}$ & $£ 1,145 \quad 19$ s 5 d & $£ 5,44712 \mathrm{~s}$ & \\
\hline 1745 & $3,817 \quad 16 \mathrm{~s} \quad 1 \quad \mathrm{~d}$ & $1,520 \quad 2 \mathrm{~s} \quad 51 / 4 \mathrm{~d}$ & 6,759 & $21 / 4 d$ \\
\hline 1751 & $\begin{array}{llll}5,230 & 6 s & 3 & d\end{array}$ & $\begin{array}{llll}1,679 & 9 \mathrm{~s} & 1 & \mathrm{~d}\end{array}$ & $8,08318 \mathrm{~s}$ & 5 \\
\hline 1755 & $3,693 \quad 17 \mathrm{~s} \quad 2 \quad \mathrm{~d}$ & $1,793 \quad 5 \mathrm{~s} 1$ & $9,50715 \mathrm{~s}$ & 8 \\
\hline 1757 & $4,914 \quad 19 \mathrm{~s} \quad 6 \quad \mathrm{~d}$ & 1,77510 s 9 d & $12,226 \quad 2 \mathrm{~s}$ & 9 \\
\hline 1771 & $3,88516 \mathrm{~s}$ & $\begin{array}{llll}3,954 & 8 \mathrm{~s} & 4 & d\end{array}$ & $14,86319 \mathrm{~s}$ & 10 \\
\hline
\end{tabular}

To and including 1773 , the balance was $£ 8,06819 \mathrm{~s} 10 \mathrm{~d}$. To April 25, 1775, the balance was $£ 2,316$ 6s. See Various Accounts, Virginia Quit-Rents, Treas. 1 : 303, ff. 205, $206 ; 323$, ff. 90-92; 348, ff. 253-254; 376, ff. 214-215; 379 , ff. $125-126$; 503, ff. 114,117 ; 525, f. 87.

3 Cal. Treas. Papers, VIII, 166, 502; IX, 265; XI, 604.

4 Treas. 1 : 348 , f. 254 ; 376 , f. 215 ; 379 , f. 126 ; 503 , f. 114 ; 525 , f. 87 . 
issued for such general purposes of the British government as "for services to be performed in the West Indies" by Woodes Rogers, governor of the Bahamas, and to pay the cost of the signet and seals that were made for the American colonies after the accession of George II. ${ }^{1}$ The crown even drew upon the quit-rents of Virginia to pay for the enlargement of the gateway that led to the parliament house in London. ${ }^{2}$

From the balance of the quit-rent revenue that was left in Virginia, a number of annual allowances were made to royal officials, including, during the period 1720 to the Revolution, $£ 100$ to the commissary, $£ 70$ to the attorney-general in the colony, and $£ 150$ to the auditor-general in England. These allowances had originally been paid out of the two shillings per hogshead fund that constituted the regular support of the government of Virginia. In the latter part of the eighteenth century the quit-rent fund was used to pay a salary of $£ 200$ to the agent who represented Virginia in London. ${ }^{3}$ In 1727 there were allowances from the quit-rents to the governor, the members of the council, and a number of other officials whose salaries were usually paid from the two shillings per hogshead fund, but such allowances were unusual. ${ }^{4}$ In

1 Royal Warrants, March 11 and December 15, 1729, Cal. Treas. Papers, VII, 30, 235.

2 Royal Warrant, March 22, 1729, Cal. Treas. Papers, VII, 36.

3 See various accounts, Virginia Quit-Rents, especially Treas. 1: 303, f. 205 ; 503, f. 114 . Owing to the greatly increased work of this officer, Governor Gooch asked that the customary allowance of $£ 60$ to the attorneygeneral should be increased to $£ 100$. The grant of only $£ 10$ additional showed how carefully expenditures from the quit-rent fund were guarded. Governor Gooch to Treasury Board, July 16, 1732, Treas. 1: 279, ff. 98-99.

4 For the year, April 25, 1727, to April 25, 1728, the allowances from the quit-rents to local officials included $£ 2,000$ to the governor, $£ 350$ to the council, $£ 200$ to the judges and other officers of the court of oyer and terminer, $£ 100$ to the auditor, $£ 100$ to the solicitor, $£ 40$ to the attorneygeneral, $£ 100$ to the clerk of the council, $£ 12$ to the armorer, and $£ 40$ to the 
addition to the regular charges upon the quit-rents, there were of course the usual costs of collection, and occasionally local expenses for which warrants were drawn. ${ }^{1}$ For example, the fund was used to meet the disbursements of the commissions appointed to adjust the boundary line between the crown lands in Virginia and the Fairfax propriety of the Northern Neck, and between Virginia and North Carolina. ${ }^{2}$ On the other hand, when Governor Gooch proposed in 1732 to make out a cómplete map of Virginia, the Treasury apparently did not see fit to recommend a grant from the quit-rents for this purpose. $^{3}$ It exhibited more regard for the interests of the colony in 1745 when it induced the king to issue a warrant to purchase presents for the chiefs of the Six Nations, and to pay the expenses of the commissioners who made the difficult journey from Virginia to Lancaster, Pennsylvania, in order to negotiate a treaty with the Indians.* Occasional allowances were made also to royal officials in Virginia who were especially deserving of such bounty. A typical instance was an allowance of $£ 300$ to a local magistrate, Thomas Lee, "towards lessen-

gunners of batteries. Va. Quit-Rent Accounts, April 25, 1727, to April 25, 1728, C. O. 5: 1321, ff. 39, 102.

1 The expenses of collection, after 1720, included commissions of 5 per cent. to the receiver-general, and 10 per cent., or rarely 14 per cent., to the sheriffs. After 1742 all the sheriffs received only 10 per cent. Va. QuitRent Accounts, 1720-1757, C. O. 5: 1319-1329, passim.

2 Altogether, $£ 1,9733 \mathrm{~s} 1 \mathrm{~d}$ was expended in order to adjust the boundary with North Carolina, and $£ 1,23516 \mathrm{~s} 1 \mathrm{~d}$ for the one with the Northern Neck, Quit-Rent Accounts, Virginia, 1739 and 1751, Treas. 1: 303, f. 205; 348, f. 254; Governor Gooch to Treasury, March 26, 1729, Treas. 1: 271, f. 190; Order, Treasury Board, June 6, 1729, Cal. Treas. Papers, VII, 85.

3 Governor Gooch to Treasury Board, July 16, 1732, Treas. 1: 279, ff. 98-99.

4 Royal Sign Manual, Mareh 22, 1745, Cal. Treas. Papers, XI; 677. Another grant was asked for in 1752 in order to provide presents for the Indians, and it was probably made. Governor Dinwiddie to Peter Leheup, December 10, 1752, Treas. 1: 348, f. 230. 
ing the loss of his dwelling house, outhouses and goods" which had been burned by transported felons in revenge for the arrest of one of their number. ${ }^{1}$ Usually, however, the Treasury discouraged expenditures from the quitrents for local needs, and did not favor the issue of warrants for such purposes.

Though after 1720 the expenditure of the quit-rent fund outside of Virginia did not arouse any noteworthy hostility, there was a very general belief that this revenue, whenever possible, should be employed at home. In 1757 Governor Dinwiddie represented that, owing to the "growing absolutely necessary" expenses in a time of war, the two shillings per hogshead fund was wholly insufficient to support the local government, and as the quit-rent balance was $£ 9,50715 \mathrm{~s} 8 \mathrm{~d}$, he asked permission to draw upon this fund in an emergency. ${ }^{2}$ This request does not seem to have been granted, even though over $£ 3,000$ had been taken from the two shillings per hogshead fund between 1744 and 1756, in order to replace deficiencies in the quit-rent fund. ${ }^{3}$ As expenses continued to increase, public opinion naturally favored the quit-rents as a fund from which to meet the need for additional revenue, but the Treasury paid scant attention to requests for such grants. ${ }^{4}$ However in 1766 , when, as a result of the agitation over the Stamp Act, the two shillings fund decreased to a mere pittance, the board recommended a warrant upon the quit-rents for $£ 1,255$

1 Report of Board of Trade, June 4, 1729, Treas. 1: 271, ff. 186, 188.

2 Governor Dinwiddie to Treasury Board, January 4, 1757, Treas. 1: 379, f. 129 .

3 Most of these payments were to cover exchange and for various contingencies for which, owing to the constant drains upon the royal exchequer, there were no funds. Report of Auditor, Treas. 1: 372, f. 142.

144 Memorials, Governor and Council of Virginia to Treasury, January 3 and July 23, 1759, Treas. 1: 372, f. 142. 
in order to pay the salaries of royal officials in Virginia. ${ }^{1}$ This decision was a convincing proof of the emergency value of the quit-rents, to which Blathwayt had so frequently called attention. Hoping to save this revenue, in the closing days of his power, Lord Dunmore called upon the people of Virginia to retain their quit-rents, unless collected by properly authorized officials, ${ }^{2}$ but this order had no effect in the presence of the popular determination to put an end to a feudal charge which had been used for the most part outside the colony. By an act passed in 1776 the assembly transferred from the crown to the commonwealth of Virginia the right to reserve quit-rents, $^{3}$ and in 1779 summarily abolished these charges upon the lands which once were but were now no longer in the demesne of the crown. ${ }^{4}$

During the colonial period the quit-rent system in Virginia was for the most part successful, and illustrates how much could be done with a charge of this kind when once it had got firmly established in a crown colony. From the first reservation local conditions in Virginia were favorable to the quit-rents, inasmuch as they were established and developed under a royal administration which did not inherit any troublesome problems handed down from a proprietary régime, as was the case in New York and the Carolinas. In Virginia the crown retained without change throughout the colonial period a rate that was reasonable and uniform in all grants. Thus, the keeping of rent rolls became a mere matter of routine

1 Entry, May 3, 1766, Richard Corbin's Letter Book, II, 72.

2 Instructions to Lord Dunmore, February 7, 1771, Mass. Hist. Soc. Col., 4th series, X, 654-655; Proclamation by Lord Dunmore, November 7, 1775, N. C. Col. Rec., X, 309.

3 Act, May, 1776, Hening, Statutes at Large, IX, 127-128.

4 Act, May, 1779, Hening, Statutes at Large, X, 64-65. For an account of the series of acts by which the proprietary quit-rents in the Northern Neck were abolished, see above, pp. 75-76. 
and of business efficiency. Then, too, there were adequate laws in Virginia to enforce the quit-rents on settled lands, and there were no serious manifestations of popular hostility toward their enforcement. The one important controversy, which was aroused by the proprietary grant in 1672, quickly subsided when the inhabitants of the greater part of Virginia were allowed to resume the payment of their quit-rents to the crown.

Yet a number of mistakes were made in organizing the quit-rent system of Virginia, especially in the method of collection. While the situation underwent a notable improvement after the inauguration of Governor Spotswood's reforms, the custom of entrusting collection to sheriffs, who had little sense of responsibility, was far inferior to the admirable organization for enforcement that was built up in Maryland. The lack of an effective method of supervision, which resulted in much official negligence, led to the accumulation of great arrears in the quit-rents, while the failure of the land-office to carry out the conditions of settlement encouraged a widespread land speculation from which the royal officials were not altogether free. Despite these drawbacks, the crown enjoyed a very considerable income from the quit-rents of Virginia, and succeeded in upholding its control, notwithstanding the efforts of the assembly to secure the quit-rent fund for local needs. The comparatively large revenue that the royal exchequer derived in this way from the quit-rents in Virginia is a proof of their value to the crown, and had they been enforced as effectively in the other royal colonies they would have proved of the utmost importance in the struggles with the assemblies that arose just prior to the outbreak of the Revolution. 


\section{CHAPTER IX}

\section{ROYAL QUIT-RENTS: IN NEW YORK}

Chronologically speaking, New York is the colony, next after Virginia, in which the crown gained greatest control of the quit-rents, yet there is a decided contrast between the two in the conditions under which the rights in the soil were taken over. In Virginia the royal government established and organized the quit-rent system, after the London Company had done no more than make the preliminary arrangements, but in New York the crown inherited the system after twenty years of ineffective proprietary control. One of the worst mistakes that it made at the start was its confirmation of the Dutch grants which, by exempting many patentees from the payment of the quit-rents, created a twofold form of land tenure in the province. Morever, the many and varied forms in which the quit-rents had been reserved under the Duke of York greatly complicated the work of keeping up the rent rolls, and often proved a great boon to land speculators, while the fact that no effective system of collection had been established during the proprietary period caused the quit-rents to appear as merely nominal charges which were not expected to be paid. In the face of such general disorganization, the royal government found the task of enforcing the quit-rent system in New York one of great difficulty.

Unfortunately the British government did not appreciate the necessity of firm, constructive measures at the outset in dealing with the system. The same unsettled 
policy toward the quit-rent rate that had characterized the proprietary period was continued almost to the close of the seventeenth century. The governors received general instructions to reserve a quit-rent, and to determine with the advice of the council the amount to be charged in each grant. ${ }^{1}$ Consequently, on many large tracts a merely nominal acknowledgment was required, although it became customary to fix the rate for new grants at one bushel of wheat per 100 acres. When specie became more plentiful, the usual quit-rent was $4 \mathrm{~s}$ per 100 acres in "currant" money which was the equivalent of two shillings six pence in sterling. ${ }^{2}$ In 1698 Governor Bellomont received definite orders that he should not grant land with a quit-rent of less than two shillings six pence sterling, ${ }^{3}$ and from that time on, with the exception of a few grants which reserved one bushel of wheat, $2 \mathrm{~s}$ $6 \mathrm{~d}$ per 100 acres became the usual rate for the quit-rent until $1774,{ }^{4}$ when for new patents the amount was fixed at a half-penny an acre. ${ }^{5}$

The royal government, like that of the proprietary, reserved without exception a quit-rent in all grants, not even exempting lands that were to be used for public purposes, such as town commons and churchyards. Thus, a quit-rent was reserved in a grant that was issued in 1705 for "Trinity Church burying ground and the land thereunto belonging" in "York City." ${ }_{6}$ Also, "for the

1 Commissions to Benjamin Fletcher, March 18, 1692, and to the Earl of Bellomont, June 18, 1697, N. Y. Col. Docs., III, 827-832; IV, 266-293.

2 N. Y. Patent Books, 5-7, 1680-1698; N. Y. Land Grants, 1666-1755,

C. O. 5: 1134; Report of Thos. Weaver, September 27, 1698, C. O. 391: 11.

3 Representation to the King by Board of Trade, September 26, 1722,

N. Y. Col. Docs., V, 650.

4 N. Y. Patent Books, 7-16, 1696-1775; N. Y. Land Grants, 1666-1755, C. 0.5 : 1134 .

5 A purchase price of at least $6 \mathrm{~d}$ per acre was also required. N. Y. Col. Docs., VIII, 11.

6 This grant, which was made upon the representation of the Bishop of 
good of the college and the province," a quit-rent was reserved upon a tract of 20,000 acres that was granted in 1765 to King's College, for the benefit of that "most laudable institution" for the encouragement of religion and useful learning. ${ }^{1}$ Occasionally, exemptions from the quit-rents were allowed for a limited period. Thus, in 1760 the Privy Council waived the quit-rents for ten years in favor of settlers in the vicinity of Lake Champlain, and made a similar exemption in the case of soldiers who had fought in the French and Indian War. ${ }^{2}$ But the usual policy, after the crown assumed control of the quit-rents in New York, was to reserve these charges in all grants as a sign of feudal supremacy. ${ }^{3}$

London that it was desired by "the Governor there, Lord Cornbury, and all the inhabitants,' included a small farm worth $£ 200$, and half an acre of waste land. The quit rent was 3s. N. Y. Land Grants, 1666-1755, C. O. 5: 1134, New York City, 75; William Lowndes to William Blathwayt, April 13, 1703, and Blathwayt's report, January 27, 1704, Blathwayt's Journal, II, 166-167, 236-237.

1 Acts, Privy Coun. Col., IV, 682.

2 Acts, Privy Coun. Col., IV, 459. Under these terms a number of patents were taken out in Albany County but it should be noted that the exemption from quit-rents was not a perpetual one. N. Y. Land Grants, 1761-1764, C. O. 5: 1134 .

3 The position of the city of Albany as feudal tenant and proprietor is of considerable interest. The city was incorporated July 22, 1686, by Gorernor Dongan acting on the king's behalf, and for its land paid annually to the crown, on March 25 (Lady Day) of each year, one beaver skin as quit-rent (apparently later commuted for a money equivalent), which was collected either by a special receiver of quit-rents for the city or by the collector of quit-rents at New York. The land thus held included the city site and the patents of "Schaaghtecogue and Tionnondorogue," which the corporation held in full possession as lord and proprietor, with the right to sell or sublet the lands as it pleased. This it did, at yearly quit-rents, which with the purchase money in case of sale were frequently rendered in stipples of wheat. As late as 1767, the Common Council resolved "that the several lots sold at Public Vendue bear a quit-rent of four shillings a lot forever." Collections of the History of Albany, I, 120, 123, 125, 177, 179, 186, 225; Munsell, Annals of Albany, IV, 156, 158, 160, 167-168 (a quit-rent suit, 1703), 
The many varieties of quit-rents reserved under the Duke of York and at first under the crown, gave rise to abuses, and greatly increased the difficulties encountered in settling the land system. Naturally landholders preferred to pay a merely nominal acknowledgment if possible, especially as the enforcement of the quit-rents with a rate of $2 \mathrm{~s} 6 \mathrm{~d}$ per 100 acres would put an end to the custom of holding great tracts for speculative purposes. One very difficult problem that confronted the royal government was how to impose an exact annual rent upon early proprietary grants in which an indefinite obligation had been specified. In 1713 the crown's attorney-general decided that these grants with a "customary" quit-rent should pay the full $2 \mathrm{~s} 6 \mathrm{~d}$ per 100 acres, although arrears could not be collected for the period previous to an explicit declaration regarding the rate. ${ }^{1}$ For a time no steps were taken to enforce this opinion, but in 1724 the receiver-general, Archibald Kennedy, represented to the council that it was exceedingly important to determine by legislative authority the exact quit-rents that were due on these old indefinite grants. ${ }^{2} \mathrm{~A}$ bill for this purpose was prepared and presented to the council, but action upon it was deferred. Two years later the bill was revived, but only to meet the same fate. Finally, in 1727, the measure was passed by the council, but failed in the assembly. ${ }^{3}$ As a result, the $2 \mathrm{~s} 6 \mathrm{~d}$ per 100 acres could never be collected from patents in which the quit-rent was indefinite, and the failure of the assembly to adopt this

VIII, 273, X, 94. The charter is printed in Albany Bicentennial, pp. 431454. C. M. A.

1 N. Y. Col. Docs., V, 179-180.

2 Journal, N. Y. Legislative Council, June 23, 1724, I, 509.

3 Journal, N. Y. Legislative Council, June 29 and July 16, 1724, November 2, 1726, October 18 and 26 and November 2, 1727, I, 510, 513, 546, $556,557,559$. 
measure shows the political strength of the interested landowners.

The vagueness of the quit-rent rate during the early period was responsible for a number of grants, chiefly during the administration of Governor Fletcher, 16921698, upon which a merely nominal acknowledgment was reserved. The most notorious of these patents was that issued to Dellius, the Dutch minister at Albany, and his associates for 620,000 acres, with an annual quit-rent of a racoon's skin. ${ }^{1}$ Such preposterous grants ceased after the rate for the quit-rents was definitely fixed, but those already made threatened a serious loss to the revenue. Of even greater moment was the effect of such grants upon settlement. Governor Bellomont, in explaining the situation, pointed out that these great tracts of vacant lands were driving from New York many settlers who preferred to go into neighboring colonies rather than become subtenants of the owners of these patents. The chief remedy, he considered, was to annul all the extravagant grants under Governor Fletcher, of which the greater number had been secured under questionable conditions, and to reserve in all future patents a quit-rent of $2 \mathrm{~s} 6 \mathrm{~d}$ per 100 acres. $^{2}$

1 Dellius, it was claimed, had fraudulently obtained these lands from the Indians, with the connivance of Governor Fletcher. A deposition before Lord Bellomont in 1698 by two Indians gave a typical instance of the manner in which these great tracts, paying merely nominal quit-rents, had been obtained. Three years before, the Indians testified, while they were fighting the French, an agent of Col. Nicholas Bayard had secured from six drunken people of the "Moquase", the title to a large tract, "Skohere," which was of so vast extent that a young man had enough to do to run over it in one day's time. The purchase price was the value of thirty beaver skins in rum and other goods, but Governor Fleteher confirmed the grant with only a trifling quit-rent. Letter from Lord Bellomont, September 14, 1698, Cal. Treas. Papers, II, 206, 208; Report of Agent for New York, 1700, N. Y. Col. Docs., V, 11.

2 Letters from Earl of Bellomont, October 22 and 27, 1698, Cal. Treas. Papers, II, 229, 235. 
At first the lower house proved amenable to Governor Bellomont's suggestion and summoned Dellius and his associates before it to answer the charge of having fraudulently secured their claims from the Indians. The assembly then passed an act in 1699 which vacated eight of these Fletcher grants, including two that had been issued to Dellius and his associates. ${ }^{1}$ Unfortunately, a delay in the royal confirmation of this act afforded the land speculators an opportunity to employ their political influence so effectively that the assembly finally repealed the act, together with a number of others, upon the plea -that all had been passed by persons who were "unqualified by right or law" to act in a legislative capacity, and were not "the choice of the people." 2 But the crown refused to allow this repeal, and confirmed the act of 1699 , issuing at the same time an instruction to the governor to the effect that lands forfeited under the provisions of the act should be regranted with a quit-rent of $2 \mathrm{~s} 6 \mathrm{~d}$ per 100 acres. $^{3}$

This tardy and rather questionable confirmation of the act of 1699 did not put an end to the custom of holding great tracts of vacant lands upon which a merely annual acknowledgment was reserved. In order to solve this difficult problem, Governor Hunter in 1710 urged that parliament establish a quit-rent of $2 \mathrm{~s} 6 \mathrm{~d}$ per 100 acres for all landholdings in New York. This measure, he believed, would render altogether unprofitable the ownership of great unimproved tracts, and would tend to encourage small holdings. ${ }^{4}$ So drastic a. measure was impossible,

1 Journal, N. Y. Assembly, April 13, 1699, I, 101; N. Y. Col. Laws, I, 412-416.

2 N. Y. Col. Laws, I, 524.

3 Instructions to Governor Hunter, December 27, 1709, N. Y. Col. Docs., V, 141.

4 Governor Hunter to Board of Trade, November 14, 1710, N. Y. Col. Docs., V, 179-180. 
especially as signs were not wanting that the owners of these speculative holdings would resist the surrender of their patents. A bill passed about 1722, supposedly to aid the collection of the quit-rents, was really drawn up, the surveyor-general believed, to secure the confirmation of large tracts held under a nominal quit-rent, of which the titles were uncertain. Governor Burnet refused to sign the act, but the problem of enforcing the quit-rents on these lands still continued to be a difficult one. Although the original deeds had been fraudulently'obtained from the Indians, it was clearly impossible to secure a jury in New York that could be depended upon to annul them. The only remedy, according to the Board of Trade, was to secure an act of the assembly similar to that of 1699. ${ }^{1}$ But the governor made no effort to carry out this recommendation, probably because he was aware that in a move to establish the royal rights over the lands of New York, no more dependence could be placed upon an assembly than upon a jury.

But it was possible to discourage further grants of vast tracts with inadequate quit-rents and to prevent the reëstablishment of doubtful claims. In the interest of such a policy, the claims of the Earl of Stirling and other heirs of the rights of William, Lord Alexander, in Long Island were quietly ignored ${ }^{2}$ the Treasury and Auditor-

1 On eight of these patents, on a basis of $2 \mathrm{~s} 6 \mathrm{~d}$ per 100 acres the quitrents should have produced $£ 4,176$ annually. Actually they brought in $£ 17$ 17s 6 d. Representation of the Board of Trade to the King, September 26, 1722, N. Y. Col. Docs., V, 650-654.

2 Long Island had been granted to William, Lord Alexander, son of the first Earl of Stirling, April 22, 1635, as his share in the lands of the New England Council. As a number of patents had been issued to lands there, through James Farrett, Lord Alexander's agent, the claim was not without justification. In 1697, however, the Board of Trade, reviewing all the claims based on grants from the New England Council decided adversely to them. Report of William Blathwayt and Order of the Privy Council, Blath- 


\section{ROYAL QUIT-RENTS}

General Blathwayt stoutly opposed a request of Governor Dongan for a grant of Staten Island in payment for expenditures that he claimed he had made in the public service $;^{1}$ and a petition from George Evans in 1742 for a confirmation of certain lands which had been granted to his uncle in 1694 and lost under the act of 1699 was rejected in $1744 . .^{2}$ But though it was possible to prevent in this fashion further losses, the continued existence of great vacant tracts on which the quit-rents could not be collected, was a formidable obstacle to the maintenance of these feudal dues.

In addition to the numerous abuses in the land system, the quit-rents in New York suffered from the failure of the government to organize an effective system of collection. Under the Duke of York few if any of the quitrents were paid, but in 1683 a receiver-general was appointed, to whom the oversight of these charges was specifically assigned. ${ }^{3}$ This office was of course continued under the royal government, and a deputy auditor was appointed by Blathwayt in $1687 . .^{4}$ As the time of these two officials was almost wholly taken up with the enforcement of the customs and excise duties, little attention could be spared for the quit-rents, though the council endeavored to exercise some supervision. ${ }^{5}$

wayt's Journal, I, 359-362, 526; Acts, Privy Coun. Col., II, 317 ; Cal. State Pap. Col. 1696-1697, 1234.

1 Treasury to John Povey, and Povey's report, May 17 and June 11, 1693, Treasury to Blathwayt, September, 1694, and Blathwayt's report, 1695, Blathwayt's Journal, I, 653-655, 707-709.

2 Acts, Privy Coun. Col., III, 734-735, C. O. 5: 1126, pp. 265-268. The case is interesting. The tracts lay along the Hudson and had been erected into a manor, to be held at a yearly quit-rent of 20 s and a buck. Evans wanted a sort of proprietary estate, with subtenants paying him a quit-rent.

3 Commission to Lucas Santen, February 17, 1683, N. Y. Col. Docs., III, 335.

4 Blathwayt's Journal, I, 446-452, 460, 492-493.

5 Executive Council Minutes, December 14, 1685, 5, ff. 144 et seq. 
Under the royal government the actual collection of the quit-rents was at first one of the numerous duties of the sheriffs. ${ }^{1}$ In 1691 the council issued elaborate instructions requiring these officials to compel all persons to pay their quit-rents at the appointed place in each county, to report all those who should "be failing therein," and to make out "perfect accounts" of what was due. ${ }^{2}$ These orders remained chiefly on paper, for the sheriffs, having other duties, proved very dilatory as collectors. Finally, the receiver-general endeavored to appoint deputy receivers, but no responsible person was willing to accept the umpleasant task of collecting quit-rents from unwilling landholders, who feared that they would be called upon to pay large arrears. When the office was offered to the sheriffs, all of them refused to undertake a duty that might cost them their lives, according to Governor Bellomont, among a "lawless unruly people." ${ }^{3}$ None of the various expedients for collections that were then adopted proved successful in face of the local opposition, ${ }^{4}$ and the receiver-general and his deputies found that "with the utmost diligence," they could not put an end to the accumulation of a large sum in arrears. Finally, it became necessary to return to the original system, with the sheriffs in charge of all col-

1 Executive Couneil Minutes, June 10, 1686, 5, ff. 156-157.

2 Ibid., April 22, 1691, 6, f. 18.

3 Ibid., August 24, 1693, 7, f. 8; N. Y. Col. Docs., IV, 254.

4 Governor Bellomont had accepted the offer of a Captain Clark to collect the quit-rents from New York, Orange, Westchester, and Richmond counties. As Clark failed to enter upon his office, Bellomont believed that his offer had been a hypocritical one that was intended to seare the people into a belief that their arrears would be collected, and thus to "sower" them against the governor. Bellomont to Board of Trade, May 15, 1699, N. Y. Col. Docs., IV, 519 ; Executive Council Minutes, December 29, 1697, 8, Part 1, f. 25 . 
lections. ${ }^{1}$ Such frequent changes in the method of collection were specially unfortunate, in view of the generally unsatisfactory condition of the quit-rent system in New York. Aside from the loss in revenue, the failure to enforce these charges during the first few critical years of royal control was a great error in policy.

The difficulties encountered in collecting the quit-rents were increased by the unsatisfactory character of the receivers-general and the deputy auditors, and their constant quarrels with the governors. The offices of deputy auditor and receiver-general were held by a succession of incumbents, most of whom were either unable or unwilling to coöperate with others in authority. ${ }^{2}$ This friction continued during the first two decades of the eighteenth century, and in consequence at least two receiversgeneral were dismissed from office. The failure of the British government to uphold the governor in one of these controversies, that with Thomas Byerley, practically put an end to the control of the council over the receiver-general. ${ }^{3}$ Even where these officials were charged with shortage in their accounts, little real attempt seems to have been made to force a settlement. ${ }^{4}$ With the appointment of Thomas Dixon in 1717, matters were somewhat improved, but not until 1722, when Archibald Kennedy was made receiver-general, was the work

1 N. Y. Cal. of Hist. MSS., II, 526; Memorial of Archibald Kennedy, about February, 1733, C. O. 324 : 36, ff. 387-389; Governor Cosby to Treasury, December 15, 1733, Treas. 1: 284, f. 146.

2 Blathwayt's Journal, I, 492-493 et seq.

3 Blathwayt's report, January 31, 1705, Treas. 1: 93, ff. 125-126; Letters from Lord Cornbury, June 13, 1705, and March 26, 1707, Treas. 1: 93, f. 389, and Cal. Treas. Papers, III, 497.

4 As an example of the bonds given by the receiver-general, see the certificate, dated July 5, 1706, that Thomas Byerley and Robert Byerley, of Yorkshire, had each given bond for $£ 1,000$ for the faithful performance by the former of his duties as collector and receiver-general of New York. N. Y. Col. MSS., 51, f. 153a. 
of the office administered by a really capable official. Meantime, the failure to secure effective supervision over the work of collection, while the quit-rents were first being established, under the crown, resulted in a general laxity which proved impossible to overcome later.

During the period preceding 1722 , when, as we have seen, the office of receiver-general was usually administered in an incompetent fashion, the governor and the council exercised a certain degree of supervision over the quit-rents. In 1685 they assumed the powers of a court of exchequer, planning to meet monthly and to have full authority to "hear, try and determine" all matters and disputes regarding the royal revenue. ${ }^{1}$ The need of such a court was shown in the case of Staten Island where, up to 1681 , the people had paid no rent "because (they say) it hath not been demanded.", Finding that many landholders neither paid nor owed any annual acknowledgment, Governor Dongan called in all patents, and renewed many of them with the reservation of a quit-rent. ${ }^{3}$ The council adopted other measures to enforce the rents, ordering many persons who were notoriously in arrears to settle their debts, and directing the sheriffs to compel payment. ${ }^{4}$ That these orders were not wholly fruitless became evident when the representa-

1 Executive Council Minutes, December 14, 1685, 5, f. 144.

2 Lewin's Report on the Government of New York, about 1681, N. Y. Col. Docs., III, 303-304.

3 Governor Dongan's Report, February 22, 1687, N. Y. Col. Docs., III, 412.

4 See Executive Council Minutes, Vols. 5-6, 1683-1693. A case in point was that of Prevoost John Trompeet and his partners, who were ordered to pay the quit-rent on their lands in Albany County, amounting to 100 bushels of wheat, together with arrears for three years. The council ordered the sheriff to enforce this decision. Executive Council Minutes, October 8, 1687, 5, f. 208; N. Y. Cal. of Council Minutes, 55. 
tives of a number of towns came to treat with the council regarding their indebtedness. ${ }^{1}$

The council followed a policy that was conservative and fair, and made a number of adjustments in cases where the quit-rents were considered excessive or indefinite. ${ }^{2}$ Thus, in 1693 the freeholders of Ulster County petitioned for the remission of their arrears, which, they represented, were due to the constant frontier struggles. ${ }^{3}$ Upon investigation the council found that these arrears amounted to 184 bushels of wheat, or to the entire quitrents for nine years. ${ }^{4}$ Apparently it was not convinced that the petition was justified, for there is no record that it was granted. But when a number of settlers in Albany County complained of various irregularities in collections, the council ordered the sheriff to discontinue the collection of the quit-rent until the exact arrears could be determined. ${ }^{5}$ In spite of so fair a policy, the council found that arrears continued to accumulate, and that many persons had not paid their quit-rents for sixteen to eighteen years. Fears lest the arrears would be collected aroused much opposition to the drawing up of a rent roll, but such a measure was necessary if the quitrents were ever to be collected. ${ }^{6}$ The council, therefore,

1 Executive Council Minutes, April 19 and 25, 1684, 5, ff. 72, 79.

2 For example, George Cummins and Louis Lockman of Staten Island represented that Governor Andros had promised to reduce the quit-rents of 2 bushels of wheat on their respective holdings. The council ordered that a new patent should be made out for each of them with the usual quit-rent of 1 bushel of wheat. Executive Council Minutes, March 20, 1683, 5, ff. 59-60 et seq.

3 Petition of Freeholders of Ulster County, September 8, 1693, N. Y. Land Papers, IV, 79.

4 Executive Council Minutes, June 21, 1697, and April 22, 1703, 8, Part 1, f. $4 ; 9$, f. 218 .

5 Executive Council Minutes, March 25, 1697, 7, f. 229.

6 Thomas Byerley to Lord Treasurer, November 30, 1703, Cal. Treas. Papers, III, 210-211; Bellomont to Board of Trade, November 7, 1698, N. Y. Col. Docs., IV, 419. 
required the attorney-general to bring suit against all persons who failed to produce their patents within three months, and ordered the secretary to draw up, "with all convenient speed," full lists of the quit-rents that were due. ${ }^{1} \quad$ By these means a rent roll was finally secured, which though far from satisfactory was of use as a basis for collections. ${ }^{2}$

Under the direction of Governor Hunter, who arrived in 1710, the collection of the quit-rents was pushed much more vigorously. The governor found that previous neglect had produced a general indifference to the whole matter. Many persons acknowledged that they had no idea of paying their quit-rents, and others openly bragged that no New York jury would award a verdict for the crown in a suit for arrears. This defiant attitude Governor Hunter met by subpœnas to a court of chancery, a method which proved so effective that a large sum in arrears was paid. ${ }^{3}$ But the improvement was only temporary, and by 1718 the returns from the quit-rents had fallen so low as to be scarcely worth the cost of collection. Even where they were paid, great loss occurred from the wide variety of commodities that were offered. ${ }^{4}$ Thomas

1 Executive Council Minutes, August 8, 1703, 9, f. 313.

2 This roll was planned to give exact information regarding each tract, but many items were left blank. Moreover, the roll was by no means a complete one, although even from the scanty information it gave, great arrears appeared. For one tract in Orange County, upon which the quit-rent was only 16 bushels of wheat, the arrears amounted to $£ 4416 \mathrm{~s}$. On another tract of 228 acres the arrears were $£ 12$ 1s 6 d. N. Y. Quit-Rent Roll, about 1705, Treas. 1: 87, ff. 556-563.

3 Governor Hunter to Board of Trade, March 14 and July 30, 1713, and January 20, 1718, N. Y. Col. Docs., V, 358, 368-371, 499.

4 Affording an interesting insight into the different commodities produced in New York at the time, Thomas Dixon testified that "some pay in money, others in grain, a deer, otter, beaver, bear, or such skin; some (large grants) a peppercorn and some nothing, to the envy of those that do pay more reasonably.' Thomas Dixon to Treasury Board, June 2, 1718, Treas. 1: 214, ff. 97-98. 
Dixon, the receiver-general, held that any actual increase in the quit-rent returns could be assured only by calling in all patents for registration. Such an inquiry, he asserted, would be paid for by the resulting improvement in the rents, "and [neither] hurt nor offend (except unreasonable men) the proprietors as I have already hinted." Later events proved this statement to be somewhat optimistic, for although the council again called upon the people of New York to pay their quit-rents and to produce their patents to the receiver-general, ${ }^{2}$ there is nothing to show that this order, any more than the others, was obeyed.

Archibald Kennedy, who was appointed receivergeneral in 1722 , administered his office with vigor, and worked in harmony with the governor and council to a greater extent than had been shown by previous incumbents. Finding that several test suits for quit-rents were depending in the chancery court, he induced the council to engage the services of Andrew Hamilton, a lawyer of Philadelphia ${ }^{3}$ whose determined and successful prosecution of these suits had an excellent effect. Kennedy warned the owners of several islands in the Sound and to the eastward (probably including Nantucket) that they must pay their quit-rents or incur the heavy charges of similar suits, ${ }^{4}$ but when he attempted to secure a rent roll, he found himself balked by the interested local oppo-

1 Thomas Dixon to Treasury Board, June 2, 1718, Treas. 1: 214, ff. 97-98.

2 Executive Council Minutes, August 23, 1718, and April 30, 1719, 11, ff. 510,587 .

3 Altogether, the council allowed $£ 100$ for this important legal aid in enforeing the quit-rents. Executive Council Minutes, April 18 and 19, 1723, 14, ff. 142, 147 ; N. Y. Cal. of Council Minutes, p. 286.

4 Executive Council Minutes, April 18 and 19, 1723, 14, ff. 142-143, 144-145. 
sition that so frequently thwarted measures of decided advantage to the crown. ${ }^{1}$

Meanwhile, the unsatisfactory condition of the quitrent situation in New York was brought to the attention of the British government by a report of Auditor-General Walpole in 1719. In order to better conditions, the report proposed that Thomas Dixon, the former receivergeneral, should be authorized to undertake the work of improvement. ${ }^{2}$ Three years later the Board of Trade urged the assembly to pass an act readjusting the whole system, saying that if such a measure could not be secured, it might be necessary to refer the matter to parliament. $^{3}$ Again, in 1730, the board proposed a thorough inquiry into land grants in New York, as a step preliminary to a complete reorganization of the quit-rent system. ${ }^{4}$ But the British government, busy with other important problems in the administration of New York, did not see fit to act upon these proposals.

Governor Burnet, whose administration lasted from 1720 to 1728 , effected a temporary improvement in the quit-rent system. By means of a chancery court which assumed the powers of a court of exchequer, he secured a number of decrees for the collection of arrears. ${ }^{5}$ But these arbitrary proceedings provoked a vigorous re-

1 For example, when a general survey was about to be made of Staten Island, Kennedy induced the council to order that the people should show their patents, with the amount of the quit-rents, to the surveyor-general. This order provoked such a popular outery that the survey was indefinitely postponed. Executive Council Minutes, December 7, 1722, 14, f. 63; N. Y. Cal. of Hist. MSS., II, 476.

2 H. Walpole to Treasury Board, June 9, 1719, Treas. 1: 221, f. 191.

3 Statement of Gorernor Hunter, August 29, 1721, and Board of Trade to the King, September 26, 1722, N. Y. Col. Docs., V, 561, 653-654.

4 Report of Board of Trade, December 10, 1730, Treas. 1: 266, f. 111.

5 Instructions to Governor Burnet, June 3, 1720, C. O. 5: 1124, pp. 196197, 226-227; Governor Burnet to Board of Trade, December 21, 1727, N. Y. Col. Docs., V, 848. 
monstrance, and the chancery court became exceedingly unpopular. So strong was the outery that Burnet's successor, Montgomerie, was reported to have refused either to hold the court or to concern himself with the quit-rents. After Montgomerie's death, Van Dam, president of the council and acting governor, adopted a similar attitude, but the Board of Trade peremptorily ordered him to hold the chancery court and to assist the collection of the quitrents by every lawful means. ${ }^{1}$ Cosby, who became governor in 1732, entered vigorously upon the work of enforcement; the sheriffs were compelled to make collections and the chancery court was continued as a means of enforcing the payment of arrears. To hasten the hearing of suits, Cosby recommended that the judges of the supreme court should open a court of equity. But the judges, taking the popular side, not only denied their power to try these cases but questioned the right of the crown to erect a court of this type. Finally, Governor Cosby dismissed Chief Justice Morris, whom he charged with having inveighed against the proposed court, "with that heat and bitterness as showed him rather an advocate for sedition than the chief judge for a province." But even these vigorous methods secured only a temporary improvement in the collection of the quit-rents. ${ }^{2}$

As arbitrary enforcement by royal officials failed, the only alternative was an act of the assembly. But the many efforts to secure such a measure only resulted in long-drawn-out wrangles between the council, which represented the interests of the crown, and the assembly, which favored popular rights, for though it was neces-

1 Board of Trade to Rip Van Dam, February 4, 1732, N. Y. Col. Docs., $\mathrm{V}, 931$.

2 Governor Cosby to Treasury, December 15, 1733, Treas. 1: 284, f. 146; Governor Cosby to Board of Trade, June 19, 1734, N. Y. Col. Docs., VI, 4-5; N. Y. Quit-Rent Accounts, 1730-1733, Treas. 1: 284, ff. 148-155. 
sary to secure the consent of the assembly to any quitrent act, the crown would make no concession by surrendering any of its prerogatives as feudal overlord. In its turn, the assembly opposed any effective collection of the quit-rents which might force the payment of arrears and thus endanger many land titles. Moreover, the political influence of the owners of large unimproved tracts was inevitably directed against any measure, which by forcing payment might compel them to break up their great speculative holdings. Besides these particular efforts at obstruction, there was general opposition to any act which seemed to favor the interests of the crown as against the supposed advantage of the people. The history of the different quit-rent acts everywhere illustrates the working of these antagonistic factors.

In the early years of royal control in New York the opposition to the feudal rights of the crown had gathered little strength, and, in 1685, the assembly passed an act for "the better asserting, collecting, and levying His Majestie's quit-rents', in New York, but the governor refused to sign it. ${ }^{1}$ Another act, passed in 1701, required the owners of unimproved lands in.Albany, Westchester, Richmond, and Orange counties to pay their quit-rents, ${ }^{2}$ and a third in 1703 provided that these feudal dues should be assessed and collected as any "public and necessary charge." "The favorable attitude shown in these

1 Legislative Council Journal, I, p. xv.

2 The owners of these unimproved tracts had refused to pay their quitrents, upon the plea that they received no income from their lands. As there was no personal property, distraint could not be employed in these instances. The act provided that owners of such lands in Orange County might be sued before a justice of the peace. In the other counties, when the quit-rent was not paid, the inhabitants were authorized to enter upon, and cut wood and timber from uninclosed lands, as if they were public commons. N. Y. Col. Laws, I, 473-474.

${ }^{3}$ N. Y. Col. Laws, I, 542. 
acts was not long maintained. In 1704, the attorneygeneral, acting on an order from the council, prepared a quit-rent bill, which provided that all patents should be produced before commissioners who were to be appointed in each county; and that a rent roll should then be made out to serve as a basis of collection, compelling all persons either to pay their quit-rents or suffer prosecution. ${ }^{1}$ The council passed the bill, but the lower house insisted upon a number of amendments which, they claimed, were necessary to prevent any arbitrary administration of the quit-rents. Although a conference was held, the two houses failed to agree, and the bill was lost. ${ }^{2}$

As a quit-rent act was a necessity, the council, in 1711, passed another bill, which had been drawn up in accordance with the governor's recommendations. But the lower house failed to act upon this measure, even though the council passed it again at its next session. ${ }^{3}$ Not until 1742 did the two houses agree upon the details of a bill which the governor would sign. ${ }^{4}$ One of the most important features of this act of 1742 was a provision that lands held in common might be partitioned in order to aid the collection of the quit-rents. The rents were to be paid annually on March 25, or within six months thereafter, either to the receiver-general at New York or to a collector in each county, but should the receiver-general

1 Report, Committee of Council, May 28, 1704, N. Y. Col. MSS., 49, f. 85.

2 Among the amendments favored by the lower house was an additional clause that the act should not be construed to alter any tenure, or to impose any burdens in addition to those that had already been established by law. Also, it wished to strike out the elauses that imposed summary punishment for failure to pay the quit-rents, and obliged the commissioners who were appointed by the governor to serve. Legislative Council Journal, May 19 to June 22, 1704, I, 212-220 ; N. Y. Col. MSS., 49, ff. 110-112, 119, 122.

3 Legislative Council Journal, October 17 to November 5, 1711, and June 7 to 19,1712, I, 322-323, 336-340.

4 Assembly Proceedings, April 30 to May 22, 1742, I, 828-830. 
fail to appoint a collector, no persons in that particular county might be sued for the quit-rents. The act also required the assessment and collection of such proportion of the quit-rents as was due from each freeholder in towns and other tracts held in common. If these assessments were not paid, they were to be levied by distress, and where there was no personal property the proportion due from the delinquent was to be paid by the remaining joint holders, who were to be reimbursed after five years from the lands in arrears. For the payment of arrears on joint holdings the procedure was the same, except that the sheriff was empowered, within six months, to sell enough of the delinquent's land to satisfy the claim. Another important clause of the bill required that all suits for quit-rents and other dues to the crown should be prosecuted only in the supreme court. ${ }^{1}$

From the standpoint of the crown, there were two important objections to this act. The first was directed against the clause suspending forced collections until the receiver-general should appoint a collector, for if such a limitation were permitted, it was feared that the difficulty of securing competent collectors would result in the accumulation of large arrears. The second objection was made to the provision that all suits for arrears must be heard in the supreme court, a provision which seemed to constitute an encroachment upon the prerogative of the crown to sue in chancery or in any other court that was suitable. This latter objection was well founded, since the judges of the supreme court in New York had already shown a decided disinclination to compel the collection of quit-rents. Moreover, if the attempt of the assembly at this time to control judges should succeed, there was danger lest the enforcement of the quit-rents under this

1 N. Y. Col. Laws, III, 209-212. 
act should become completely subject to local control. In view of these considerations the Privy Council disallowed the act. ${ }^{1}$ Even from the popular standpoint the measure was not entirely satisfactory, for the requirement that tenants on joint holdings should be responsible for their fellow landholders' quit-rents found little favor. Though the defects in the act were generally appreciated, yet two years later, when it was proposed to amend the section relating to the partition of lands and the receivergeneral insisted upon a revision of the quit-rent provisions also, the assembly refused to comply. ${ }^{2}$

In 1754 another quit-rent act was drawn up under the guidance of the receiver-general and the deputy auditor. The assembly at its next session in 1755 passed this measure without amendment. ${ }^{3}$ In most of its essential features the act was similar to the one that had been passed in 1742, although it omitted the objectionable clause suspending enforced collections where a collector had not been appointed. Another important change empowered the sheriff, after the quit-rents had been due for three or more years, to secure a decree from the justices of the supreme court, sitting as a court of exchequer, authorizing him to sell sufficient land of the delinquent in order to pay whatever arrears were due. This clause delayed collections, but it partly overcame the objection that suits for arrears could be brought only in the supreme court. ${ }^{4}$ Probably owing to these changes, which

1 Acts, Privy Coun. Col., IV, 5-6.

2 N. Y. Col. Laws, III, 400-402; Legislative Council Journal, September 4-21, 1744, II, 857-874.

3 Legislative Council Journal, October 30 and November 20, 1754, and May 28 to 'July 5, 1755, II, 1168, 1174-1175, 1197-1207; De Lancey to Board of Trade, March 16, 1759, N. Y. Col. Docs., VI, 369 .

4 N. Y. Col. Laws, III, 1107-1121. 
met the chief objections that had been raised to the quitrent act of 1742, the Privy Council confirmed the measure. Yet the Board of Trade roundly scored Lieutenant Governor De Lancey for having given his assent to so important a law without a suspending clause awaiting the crown's pleasure. In his own defense De Lancey replied that since the royal officials who were specially interested had drawn up the act, he had regarded it as a "beneficial"' one."

That even the limited concessions allowed the crown in the act of 1755 did not meet with unanimous approval, was shown by the protest of William Smith, a prominent member of the council and one of the most influential men in New York at this time, who, having refused to approve the act, was permitted to enter his objections upon the council minutes. ${ }^{2}$ He based his opposition upon three provisions of the act. First, contrary to Magna Carta, the act made it possible to dispossess a man of his freehold by a mere official certificate that a debt was owed, without a verdict of his "equals" or due process of law. Secondly, it deprived debtors to the crown of all pleas and defense. Thirdly, it took away from the subject any common law action or defense when distress was levied for the crown's rents. Finally, said Smith, it "seems contrary to natural justice and equity in that it will subject the lands of a freeholder to sale, tho' the king be indebted to him in a greater sum than is due for quit-rents, and leaves him no remedy either in law or equity in such a case.",3 This declaration, spread on the minutes of the council, was of great importance,

1 Board of Trade to De Lancey, December 19, 1758, and De Lancey's reply, March 16, 1759, N. Y. Col. Docs., VI, 354, 369.

2 Legislative Council Journal, June 11, 1755, II, 1199.

3 N. Y. Col. MSS., 81, f. 18. 
for it reflected the public resentment against any measures that might sanction the claims of the crown to an arbitrary right of enforcement of the quit-rents and the arrears. ${ }^{1}$ Despite Smith's opposition, however, the act was renewed in 1762 and 1768, and gave legal warrant for enforcing the payment of quit-rents throughout the remainder of the colonial period. ${ }^{2}$ While it by no means fully met all the perplexities of the quit-rent system in New York, it did improve collections to a noticeable extent. Especially serviceable was the clause that permitted the sale of the lands of delinquents in order to collect the quit-rents and arrears. ${ }^{3}$

After the passage of a quit-rent law, the next obvious need was the drawing up of a really adequate rent roll as a basis for collections. Before this step could be taken, the land situation in New York had to be cleared up, although such a move was bound to encounter widespread and influential opposition. Great tracts of land, which for the most part were unimproved, continued to be held under questionable titles and with nominal quitrents. Three of these tracts, according to the owners' claims, included at least 1,000,000 acres apiece, and there were several others of over 200,000 acres. With their uncertain boundaries, these huge unimproved tracts greatly hindered the development of the province, but if the two shillings six pence quit-rent could be collected

1 William Smith was one of the notable champions of popular rights, at this time, in New York. He was a republican and a Calyinist, a combination that would easily explain the fearlessness of the position he assumed with regard to the quit-rent act. In 1751 he was made attorney-general of New York, and served for a year, although his appointment was not confirmed by the crown. He was a member of the council, 1753 to 1767 .

2 N. Y. Col. Laws, IV, 589-590, 1036-1038.

3 Governor Moore to Earl of Shelburne, February 20, 1767, N. Y. Col. Docs., VII, 901. 
upon them, their owners would be compelled either to surrender or to sell their claims. ${ }^{1}$ As a preliminary step to this end, Lieutenant Governor Colden proposed that a map of all grants in the province should be made out. This work was undertaken and had been completed for grants issued before 1708, when suddenly the auditorgeneral stopped the necessary allowance from the quitrents. Colden ascribed this unexpected move to the influence of persons interested in large grants which in many cases they had secured by fraud. This explanation was probably the true one. ${ }^{2}$ Even upon the basis of the incomplete survey Colden was able to force a number of persons to take out patents and to pay their quit-rents. ${ }^{3}$ Ultimately, in spite of the opposition of the landholders, he secured a rent roll which though far from ideal was of much aid in collecting the quit-rents. ${ }^{4}$

As collections of the quit-rents continued to be unsatisfactory, Governor Moore in 1766 followed the example of Governor Burnet in an attempt to secure a map that would show the exact boundaries of each tract of land in

1 Lieutenant Governor Colden to Earl of Egremont, September 14, 1763, and to Board of Trade, September 20, 1764, Colden Papers, I, 230-231, 363.

2 Colden to Board of Trade, October 13, 1764, Colden Papers, I, 388.

3 Upon the return of the surveys, Lieutenant Governor Colden ordered suits brought against intruders upon crown lands at Minisink. Even before the suits were filed, many of these squatters took out patents with a quit-rent of $2 \mathrm{~s} 6 \mathrm{~d}$. This incident shows what might have been done had the survey been completed. Colden to Board of Trade, June 7, 1765, Colden Papers, II, 13-14.

4 This rent roll was made out by counties, New York City also being given a section. In many cases the names of present possessers of patents were omitted. Also, in many patents the number of acres was not specified, the tract being indicated by the vaguest possible natural boundaries. One large grant in Westchester County, which was patented in 1668, was described as "extending twenty miles" "into the woods." Colden to Board of Trade, April 14, 1765, Colden Papers, II, 1; N. Y. Land Grants, 16661755, and 1761-1765, C. O. 5: 1134. 
the province. But he too found the task impossible. ${ }^{1}$ Without an adequate rent roll, the work of collection was very difficult, and the quit-rent act of 1755 did not prove to be especially helpful. Unless the clause in this act requiring joint landholders to pay one another's quitrent were abolished, Governor Moore believed that settlement on the frontier would cease, while the provisions for enforcing arrears proved so faulty that collections were invariably from four to six months behind. But when the governor caused a new measure to be drawn up that would remedy these defects, the assembly refused to act upon his recommendations. ${ }^{2}$ Two years later it renewed the act of $1755 .^{3}$ The only other act of any real benefit to the quit-rents was that which broke up the great Oblong Patent in Dutchess County, and doubtless the chief motive of the assembly in passing this measure was a desire to advance settlement rather than to further the interests of the crown. ${ }^{4}$

The best proof of the general collapse of the quit-rent system in New York is the comparatively small sum that was collected from this source. Owing to the loss of much valuable material, it is impossible to make an accurate estimate either of the nominal value, or of the actual revenue that was received from the quit-rents. ${ }^{5}$ From the scanty sources that are available, it is evident that this income was far less than it should have been.

1 Governor Moore to Earl of Dartmouth, April 30, 1766, N. Y. Col. Docs., VII, 826.

2 Governor Moore to Earl of Shelburne, February 20, 1767, C. O. 5: 112, pp. 111-114.

3 N. Y. Col. Laws, IV, 1036-1038.

4 N. Y. Col. Laws, V, 669-670; Proceedings, N. Y. Assembly, February 8, 1774, Proceedings, 1766-1776, p. 42.

5 T'he quit-rent accounts for New York were practically complete until the fire of 1911 rendered them illegible. See list in Osgood, Report on the Public Archives of New York, pp. 20-21. 
For the first two decades of the eighteenth century, the annual collections averaged between $£ 75$ and $£ 300 .{ }^{1}$ By 1721 the net revenue was not over $£ 400$, in spite of all the efforts that had been made to enforce the quit-rents. ${ }^{2}$ Only a slight improvement was shown during the vigorous administration of Archibald Kennedy as receivergeneral. ${ }^{3}$ By persistent efforts he increased the annual quit-rent revenue to at least $£ 800$ in $1761,{ }^{4}$ but this sum was far short of the nominal value, inasmuch as Governor Moore estimated the entire rent roll in 1767 at $£ 1,8067 \mathrm{~s}$ $7 \mathrm{~d}$. As the arrears at this time, according to the governor, were $£ 18,88816 \mathrm{~s} 10 \mathrm{~d}$, it is clear that in actual results the quit-rent system was a virtual failure in New York. $^{5}$

Although the amount was small, the value of the quitrent as a royal revenue was unmistakable during the long struggles between the governor and the assembly over

1 As far as the records show, the revenue from the quit-rents amounted in 1699 to $£ 16514 \mathrm{~s} 9 \mathrm{~d}$, in 1704 to $£ 2853 \mathrm{~s}$, and in $1708-1709$ to $£ 1766 \mathrm{~s} 6 \mathrm{~d}$. Blathwayt's Journal, II, 86, 323; Treas. 1: 114, f. 91.

2 Statement, Governor Hunter to Board of Trade, August 29, 1721, N. Y. Col. Docs., V, 561 .

3 For 1731 and 1732 collections were $£ 8189 \mathrm{~s}$, and for 1735 , $£ 55211 \mathrm{~s} 5 \frac{1}{4} \mathrm{~d}$. New York Quit-Rent Accounts, 1730-1735, Treas. 1: 284, ff. 148-155.

* Account of American Revenues, about 1761, C. O. 5: 216, f. 9.

5 This estimate, Governor Moore stated, included, as nearly as could be given, the commodity as well as the money rents, although "the prices of wheat, skins, lambs and pease", varied each year. This statement gives an additional insight into the difficulties of the quit-rent situation. Moore to Earl of Shelburne, February 20, 1767, C. O. 5: 112, f. 123. Among the items offered at the Phillipps sale in 1913 was a large folio volume entitled, "The General Accounts of His Majesty's Quit-Rents and Fines for the Province of New York, stated by the Receivers-General constituted thereto by his Majesty's Letters Patent for the Years 1763 to 1773.', Among the names of the receivers-general, deputy auditors, and others are Oliver De Lancey, Richard Nicolls, Archibald Kennedy, Cadwallader Colden, Andrew Elliot, Moore, Banyer, etc. The volume was purchased by Sabin, the bookseller, but since his death it has been either lost or mislaid and cannot now (1918) be found. C. M. A. 
appropriations. In 1709 Lieutenant Governor Ingoldesby pointed out the necessity of retaining the quit-rent "for several unavoydable exigencies." ${ }_{1}$ The importance of this advice was shown when the assembly refused to renew the revenue bill, and the quit-rent revenue became temporarily almost the only available fund for the support of the royal government in New York. ${ }^{2}$ As the struggles with the assembly continued, its value increased. The auditor-general, Horatio Walpole, characterized the action of the assembly in assuming the management of the revenue as a serious encroachment upon the royal prerogative which, if continued, "must make the colony of New York . . . independent of the crown in the most essential feature." As a means of asserting the royal power, he called attention to the quit-rent, which would produce a considerable revenue if it were properly administered. ${ }^{3}$ In 1747 Governor Clinton graphically presented the revenue situation in New York. For want of a fixed support for the officers of the royal government, he said, the "power of faction" was constantly increasing in the colony. If "ordinary" expenses were assured, "extraordinary" ones could be met only by a quit-rent upon all lands "equally rated," which would be "the most equitable and least burthensome of any method so far proposed." The 2s $6 \mathrm{~d}$ per 100 acres, if it should be extended to all lands in the colony, would produce, he estimated, $£ 4,000$ annually. This sum would increase in the future, and would be far in excess of what

1 Ingoldesby to Board of Trade, July 5, 1709, N. Y. Col. Docs., IV, 83.

2 Reports of William Blathwayt, December 15, 1713, and April 10, 1714, Blathwayt's Journal, III, 126-128; Treas. 1: 174, ff. 210-211; Governor Hunter to Earl of Stair, November 8, 1714, N. Y. Col. Docs., V, 454.

3 Memorial of $H$. Walpole to the Treasury, June 9, 1719, Treas. 1: 221, f. 191 . 
any assembly had granted. ${ }^{1}$ Lieutenant Governor Colden also, in 1766, showed his appreciation of the possibilities in the quit-rents, when, citing the examples of Maryland and Pennsylvania, he believed that if these charges were properly enforced in New York they would suffice for the entire civil list. ${ }^{2}$

Even the small revenue that was actually realized proved of great aid to the royal government. Customarily this fund was used, as in other royal colonies, to pay the salaries of officials who were of special service to the royal administration, but for whom the assembly either refused to provide, or else did so under conditions that would place them under local control. Among the officers who received allowances from the quit-rents were the secretary for Indian affairs, the deputy auditor and the receiver-general. ${ }^{3}$ A grant from the same source was also made to the secretary of the province after the assembly had arbitrarily reduced his salary. But often these allowances were not paid, and under Thomas Byerley, "an old and infirm man," practically nothing was left for salaries after the expenses of collection had

1 Clinton to Duke of Neweastle, September 27, 1747, N. Y. Col. Docs., VI, 395.

2 Colden to Sir Jeffrey Amherst, June 24, 1766, Colden Papers, II, 112 113.

3 The petition of the first secretary for Indian affairs, Robert Livingston, for a grant from the quit-rents as the only means of securing his salary, does not seem to have been allowed at first. Under his suceessor, Philip Livingston, the allowance for this office became a regular charge upon the quit-rents. Cal. Treas. Papers, III, 314, 512; Report of H. Walpole, January 17, 1745, Treas. 1: 316. The regular allowances from the quit-rents in 1767 were in sterling:

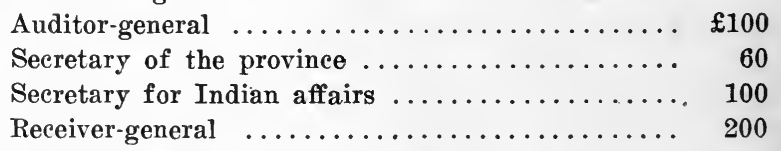

In addition there was a 5 per cent. allowance for auditing accounts. Moore to Earl of Shelburne, February 20, 1767, C. O. 5: 112, pp. 111-114. 
been settled. ${ }^{1}$ Gradually conditions improved until in 1766 the receiver-general paid off all the arrears due on the salaries that had regularly been allowed from the quit-rents. ${ }^{2}$

In addition to the regular allowances, special grants were occasionally made to meet the exigencies caused by the constant struggles with the assembly over the revenue. The value of the quit-rents in this respect is illustrated in the case of Richard Bradley, the attorneygeneral, who conducted the celebrated Zenger case and was consequently most unpopular throughout the province, and whose fees and other perquisites, amounting to $£ 900$, the assembly withheld "to the great misfortune of said attorney-general's numerous family." The governor and council recommended that Bradley be paid out of the royal civil list, "in consideration of the very great hardships under which the said attorney-general labors for want of a suitable provision," and of the great damages that might come to the royal government if so necessary an official were not suitably supported. The Board of Trade, also, held that the attorney-general, as the official specially charged with the enforcement of the laws of trade and navigation, should be independent of the assembly, and should receive his salary either from the quit-rents or the civil list. ${ }^{3}$ Following these recommendations, the Treasury ordered that the attorneygeneral should receive a part of the arrears due him from the quit-rents, and that in the future his salary should be paid from the civil list. ${ }^{4}$

1 Petition from George Clarke, Septemker 16, 1725, Treas. 1: 253, ff. 208-209.

2 Moore to Earl of Shelburne, February 20, 1767, C. O. 5: 112, pp. 111 114.

3 Report of Board of Trade, December 10, 1730, Treas. 1: 266, ff. 109-111.

4 Report of Board of Trade, December 10, 1731, and Treasury Minute, 
The value of the quit-rents was shown even more strikingly when, as a climax to the struggle over the control of judges, the assembly refused to grant the salaries of these necessary officials for more than a year, and then only on condition that their commissions last during good behavior. All the judges thereupon retired from office except Chief Justice Prat who, as Lieutenant Governor Colden pointed out, by serving without a regular salary prevented a total collapse in the administration of justice in New York. In consideration of this service, the governor recommended that Prat should receive a salary from the quit-rents. By this means, he pointed out, the chief justice would be assured of the independence from control by the assembly that was absolutely necessary if the rights of the crown were to be enforced in New York. Unless some such provision were made from the quit-rents, Colden asserted, it would be necessary either to appoint an interested person, or else to leave the province without a chief justice. ${ }^{1}$ To meet this pressing need the Treasury granted an allowance from the quit-rents, which was to continue until the assembly came to a sense of their duty, but was not to serve as a precedent for the future. ${ }^{2}$ This allowance continued while Chief Justice Prat held office, but the plea to renew the grant in favor of his successor does not appear to have been conceded. ${ }^{3}$

A number of other special grants were made from the quit-rents, and most of them were probably paid only in June 5, 1733, Cal. Treas. Papers, VIII, 106-107, 383; Account of American Revenues, about 1761 , C. O. 5 : 216, f. 25.

1 Acts, Privy Coun. Col., IV, 550-551; Colden to Board of Trade, January 11, 1762, to Earl of Egremont, January 12, 1762, and September 14, 1763, and to Secretary Pownall, February 6, 1761, Colden Papers, I, 150, 153, 162, 230-231.

2 Acts, Privy Coun. Col., December 15, 1762, IV, 550-551.

3 Colden to Board of Trade, July 8, 1763, N. Y. Col. Docs., VII, 529. 
part, if at all. ${ }^{1}$ All of these allowances, and especially those to the attorney-general, Richard Bradley, and the chief justice, Benjamin Prat, illustrate the importance of the quit-rents in New York as the source of a fund that was wholly at the disposal of the royal government. The political possibilities of such an income are obvious. If a revenue comparable to the one received in Virginia had been secured in New York, the quit-rents would have practically assured the financial independence of the royal government. Probably the assembly was fully aware of this possibility, for its persistently hostile attitude toward acts to enforce the quit-rents was scarcely due entirely to the influence of the landholding class.

The general indifference with which the quit-rents were regarded in New York was reflected in the failure of the assembly to abolish these feudal dues after independence was declared. ${ }^{2}$ The right to collect the quitrents was vested in the Commonwealth of New York as the successor to the crown. But there is little evidence

1 Of especial interest is a grant to Governor Clinton, in 1742 , of $£ 1,200$ from the quit-rents, "as the King's free gift and royal bounty.' In 1775 his sons were allowed a warrant on the same fund for $£ 3,7614 \mathrm{~s} 8 \mathrm{~d}$ in payment of what was still owed on account of their father's salary. Royal Warrant, April 27, 1742, Cal. Treas. Papers, XI, 173; Report of Horatio Walpole, January 17, 1745, and N. Y. Quit-Rent Accounts, October 2, 1776, Treas. $1: 525$, ff. 87-88.

2 Probably the chief influence that was responsible for the failure to abolish the quit-rents was that of the owners of great manorial estates. If the land had been freed from the quit-rents, the manorial rents would also doubtless have disappeared. While these latter rents were strikingly similar, they should not be classified with the quit-rents. Like the quit-rents, most of them were grants in perpetuity with the reservation of an annual payment, and they also conferred a right of distress and reëntry in case the conditions of the grant were not fulfilled. Unlike the quit-rents, they were paid to the lord of the manor rather than the crown, and involved many feudal obligations from which the tenant who owed quit-rents was freed by the mere payment of his annual dues. Cheyney, Anti-Rent Agitation in New York, 1839-1846, pp. 7-9, 14 et seq. 
of any actual steps to enforce them. When the settlers upon the New Hampshire grants complained that the quit-rents were an "innovation upon the rights of mankind," the provincial congress of New York offered the petitioners a permanent commutation of these dues. ${ }^{1}$ An act passed by the assembly in 1786 extended this offer of commutation to all landholders in New York, and remitted all arrears up to September 29, 1783. ${ }^{2}$ This law was typical of a long series of acts which provided either for the outright purchase of the quit-rent, or else for the postponement of the payment of arrears. ${ }^{3}$ Occasionally the assembly made appropriations for the public benefit from the quit-rents, but probably these grants were never paid. ${ }^{4}$ Finally, the constitution of 1846 abolished the quit-rents by a provision that all lands should be held by an allodial tenure, and that the title should be vested in the owner subject only to escheat. ${ }^{5}$

The very meager results secured by the quit-rent system in New York were in large measure due to the failure to institute a vigorous policy when royal control was first established. The proprietary régime left the quitrents in a disorganized and unsatisfactory condition, but had the royal government undertaken at the outset to deal with the situation in a vigorous fashion, these feudal dues might have been placed upon a firm basis. Unfortu-

1 Report of N. Y. Provincial Congress, May 10, 1777, and Proclamation, February 23, 1778, New York Documentary History, IV, 938-939, 954.

2 Gaine, Laws of New York, I, 250-253.

3 Laws of New York, 1787-1846, passim.

4 In 1815, $\$ 5,000$ was appropriated from the quit-rents arising in the towns of Athol, Hadley, Johnsonburg, and Warrenburg, in order to build a bridge over the middle branch of the Hudson River at Hadley Landing. In 1819 all proceeds from the quit-rents were appropriated to the "literature" fund; one-half to be invested in canal stock "for the benefit of the State University," one-half to be held in trust by the comptroller for the school fund. Statutes of New York, 1815, 187-188; 1819, 291-292.

5 Thorpe, Constitutions and Charters, 5, 2655. 
nately the British government, failing to appreciate the necessities of the case, continued many of the proprietary mistakes. As a result, the enforcement of the quit-rents became so hopelessly involved in the tangled land system that when a more vigorous policy was attempted, it was practically impossible to carry out reforms in face of the popular opposition that was aroused. Moreover, the failure to organize an effective system of collection had very injurious results. Had it been possible to collect a uniform quit-rent from all grants, both the land problem and the question of revenue might have been solved to a great extent. Even the small revenue that was realized from the quit-rents proved to be of great importance in the course of the struggles between the governors and the assembly. An appreciation of this fact was probably one of the chief causes of the strong opposition displayed by the assembly to any measures of real value for the collection of the quit-rents. Probably, too, the collapse of these feudal dues in East Jersey, and the hostility with which they were regarded in New England, influenced the inhabitants of New York. Certainly there was a strong feeling of antagonism toward the quit-rents in that province, which would probably have caused serious trouble if the crown had undertaken to enforce these charges in a really vigorous fashion. 


\section{CHAPTER X}

\section{ROYAL QUIT-RENTS: IN NORTH CAROLINA.}

Is the Carolinas, as in New York, the royal government faced the problem of reorganizing a quit-rent system that had fallen into a somewhat chaotic condition, though the situation in both the southern provinces was far more favorable than in the northern colony. In the south it was not necessary to reckon with the antagonistic influence of neighboring colonies, nor with any special class of landholdings, such as the Dutch grants, that were exempted from feudal dues. More efficient than the representatives of the Duke of York, the proprietary officials in the Carolinas had already organized a system of collection, and had placed the enforcement of the quit-rents upon the secure foundation of an act of assembly. Yet the outlook was not wholly favorable. The Carolina assemblies displayed a noticeable desire to control the quit-rents, and had already set a precedent by deciding that the income from this source should be employed to provide salaries for local officials, while, as a result of a long series of disorders, the collection of the quit-rents had been greatly neglected in both colonies for a number of years. Up to this point, the quit-rent situation was practically the same in North and South Carolina when the crown assumed the status of feudal overlord, but so diverse were the interests, and so numerous the problems in the two colonies, that it is necessary to consider separately the details of the quit-rent system in each.

In North Carolina the land and the quit-rent systems 
were inseparably connected. The Grand Deed to Albemarle, under which the inhabitants claimed that their lands should be held upon the same terms as those customary in Virginia, had never been interpreted in an authoritative fashion by the proprietaries. Again, after the closing of the land-office in 1712 many patents had been issued, the validity of which was seriously questioned. If the crown confirmed these grants, the quitrent upon them would be only $2 \mathrm{~s}$ per 100 acres, but if they were set aside the patentees must pay whatever amount the royal government chose to reserve. The collection of quit-rents from landholders who had not paid these dues for many years was not likely to be an easy task. Under these conditions a tactful policy was imperative, but as in the case of New York, the British government seems to have had little appreciation of the demands of the situation.

The instructions to Governor Burrington authorized him to remit all arrears, if the assembly would pass an act settling the land question, requiring the registration of grants, and stipulating in future patents that the lard would be forfeited unless the quit-rents were paid. In disregard of Governor Burrington's advice, these instructions increased the quit-rents to $4 \mathrm{~s}$ per 100 acres, and insisted that all payments should be made in proclamation money rather than in the customary commodities. ${ }^{1}$

1 Instructions to Governor Burrington, December 14, 1730, N. C. Col. Rec., III, 95-102. Governor Burrington had pointed out that the customary rate in North Carolina was $2 \mathrm{~s}$, the same as in Virginia. To increase it, he considered, would greatly retard settlement. Governor Burrington to Board of Trade, March, 1730, N. C. Col. Rec., III, 78.

In the colonies generally, "proclamation money", was silver at six shillings to the Spanish dollar and stood to sterling in the ratio of four to three, but in North Carolina the term was applied also to the bills of credit of 1748 and following years, because at issue they were made legal tender at the proclamation rate. Bills issued before 1748 were frequently known 
When the governor laid these instructions before the assembly, he met with immediate opposition. Declaring that the remission of arrears was no great favor in view of the small amount involved, the lower house expressed its willingness to pass an act for registration, although it considered the payment of the quit-rents in proclamation money an impossibility. Finally it passed a bill which, though remitting the arrears, made inadequate provision for registration and permitted payments of the quit-rents in three forms, proclamation money, commodities at fixed prices, or paper money. ${ }^{1}$ The council proved to be equally unmanageable, asserting that it was impossible to pay the quit-rents in gold and silver. When Governor Burrington asked if they would grant an equivalent, the representatives vouchsafed no answer, being, he alleged, too far gone in a "spirit of opposition." Finally he prorogued so stiff-necked a body. ${ }^{2}$

as "Old Proc.", Thus "Old Proc." and "Proc." in North Carolina corresponded to "Old Tenor", and "New Tenor", in New England. The usage is confusing, because bills of credit were constantly depreciating and never remained long at the proclamation rate. Thus in 1759, "Proclamation Bills" stood to sterling in the ratio of two to one and to proclamation money in the ratio of one and a half to one. In 1739 "Old Proc." stood to sterling in the ratio of ten to one and to proclamation money in the ratio of seven and a half to one. Bullock, in his Monetary History of the United State, is confusing and contradictory on this point. In some cases he considers proclamation money the same as barter or commodity currency (pages 131 note 1,144 note 4,146 note 7,174 note 6,182 note 5 ) which is quite wrong. Elsewhere he defines the term correctly (pages 152, 153 note 1, $161,164)$, but fails to make clear its application also to the paper money of the colony. C. M. A.

1 Legislative Journals, April to July, 1731, N. C. Col. Rec., III, 96-294, passim. A law which required the registration of all grants had been passed in 1715, but its provisions were practically nullified by a series of acts that relieved persons who failed to comply, from all penalties. Raper, North Carolina, p. 123; N. C. State Rec., XXIII, 49-52, 169, 185-186, 432-434.

2 Governor Burrington to Duke of Neweastle, July 2, 1731, N. C. Col. Rec., III, 143 et seq. 
After the failure of the quit-rent act, there was urgent need for the appointment of energetic officials who would devote a large part of their time to the work of collection. But the British government merely appointed a receiver-general, a deputy auditor, and an inspector in charge of the quit-rents of both the provinces. ${ }^{1}$ As all of these officials lived in South Carolina, they could pay little attention to the quit-rent system in North Carolina. To add to the difficulties of the situation, the British government insisted that the quit-rents be paid in proclamation money rather than in the customary commodities. $^{2}$ Consequently collections became almost nominal, and as the quit-rent revenue was the only fund which was available to meet the salaries of royal officials, the results threatened to become serious. But the assembly refused to grant a settled revenue, alleging that the quit-rents should be sufficient for this purpose, just as they had been under proprietary rule. Even though the governor was obliged to sell crown lands as the only means of meeting these salaries ${ }^{3}$ the Board of Trade still insisted upon the payment of the quit-rents in proclamation money, claiming that the Grand Deed to Albemarle which permitted the use of commodities was void. ${ }^{4}$ It also continued to demand $4 \mathrm{~s}$ per 100 acres, though it must have known that little land would be taken up at a rate which was double

1 Acts, Privy Coun. Col., III, 247; Cal. Treas. Papers, VIII, 450; Memorial of Horatio Walpole, about June, 1731, and Treasury to John Hammerton, June 30, 1731, Treas. 54: 31, pp. 398-400; Instructions to James St. John, May 12, 1731, Treas. 54: 31, pp. 375-376.

2 Governor Burrington to Duke of Neweastle, and Report, July 2, 1731, and January 1, 1732, N. C. Col. Rec., III, 143 et seq., 431.

3 Governor Burrington to Duke of Newcastle, July 2, 1731, and Legislative Journals, August 21, 1731, N. C. Col. Rec., III, 149, 294-295.

4 Alured Popple to Governor Burrington, August 16, 1732, N. C. Col. Rec., III, 354. The contention of the board regarding the Grand Deed was supported by the former proprietary secretary. The proprietaries, he declared, had never signed this concession, and had constantly given the 
that in force in Virginia. This policy was all the more reprehensible since most of the good land was already settled, and many tracts that paid a quit-rent of $6 \mathrm{~d}$ per 100 acres could be bought for less than $£ 10$ sterling per 1,000 acres. $^{1}$

This arbitrary policy of the Board of Trade bore fruit when Governor Burrington in 1733 brought before the assembly the question of an act to enforce the quit-rents. Again the lower house refused to require payment in proclamation money, asserting that, "our principals throughout the province" have "recommended nothing more earnestly to us than that we should not consent to burden them with such payments as it is impossible for them to make." Insisting that the Grand Deed to Albemarle was irrevocable, it concluded its address with caustic allusions to the governor's failure for two years to call them together, although other matters besides the quit-rents demanded attention. ${ }^{2}$ In reply, the governor insisted that the brisk border trade with Virginia in live-stock and other products brought more gold and silver into North Carolina than was needed to pay the quit-rents. But the lower house denied the truth of this statement, and having submitted three bills, all of them worthless in the governor's opinion, was dissolved with bitter reproaches for its unobliging conduct. ${ }^{3}$

governors instructions to ignore its provisions. Board of Trade Journal, August 8, 1734, C. O. 391: 44, p. 134.

1 Governor Burrington to Duke of Neweastle, July 2, 1731, N. C. Col. Rec., III, 144-150, 151. The number of patents taken out had decreased to such an extent that the fees of the secretary's office fell from $£ 600$ to $£ 400$ in a single year. But great tracts that had already been surveyed remained unpatented, owing to the fear that the higher quit-rents would be demanded. Forster to Governor Burrington, August 8, 1731, and Governor Burrington to Board of Trade, February 20, 1732, N. C. Col. Rec., III, 200, 337.

2 Legislative Journals, July 11, 1733, N. C. Col. Rec., III, 548-551.

3 Legislative Journals, July 17-18 and November 8, 1733, N. C. Col. Rec., III, 598-599, 606-611, 621-622. 
Governor Gabriel Johnston, who succeeded Governor Burrington in 1734, immediately attacked the quit-rent problem with characteristic energy. Adopting first a conciliatory attitude, he endeavored to secure a satisfactory law to enforce payment. The council cheerfully consented to consider "so just and equitable a matter," but the lower house merely promised to pass a measure that would "consist with the abilities of His Majesty's poor tenants." The two houses failed to agree upon such essential details as the place of payment and the values at which commodities would be accepted, and the council finally rejected the measure proposed by the lower house. ${ }^{1}$ Governor Johnston now resorted to an arbitrary policy in order to force the lower house to consent to an act in accordance with his ideas. Claiming that the Grand Deed to Albemarle had been revoked, he declared that all patents made out since it was issued must pay a quitrent of a penny and a half per acre, and on the pretext that the law to accept commodities had never been ratified, he insisted upon payments in specie. Lastly, he gave warning to all persons who held land without patents that they must take them out or be dispossessed. ${ }^{2}$ In order to enforce these orders, he erected a court of exchequer, but this move stirred up so much ill feeling that it became necessary to call out the militia to protect from insult the officials engaged in the collection of the quit-rents. Nevertheless, the general results were excellent. Within less than a year almost $£ 1,200$ was collected and, as Johnston himself said, the people were reminded that the king had rights not controlled by the assembly, "which is a very new sort of doctrine to them." The only

1 Legislative Journals, January 17-21 and February 10-12, 1735, N. C. Col. Rec., IV, 77-134, passim; N. C. State Rec., XXV, 215-219.

2 Legislative Journals, March 1, 1735, and Council Journal, March 6, 1735, N. C. Col. Rec., IV, 42-43, 110-113. 
additional measure, he thought, that was necessary to quiet the colony was a definite decision as to the validity of the many blank patents issued under the proprietaries. ${ }^{1}$

Governor Johnston also undertook to reorganize the official force in charge of the quit-rents, by appointing two receivers in each precinct to make actual collections and to report to the receiver-general. This arrangement lasted until 1754 when the collection of the quit-rents was assigned to the sheriffs. ${ }^{2}$ Another excellent reform was his appointment of a separate receiver-general for North Carolina. Finding that John Hammerton, the joint receiver-general who lived in South Carolina, was neglecting the quit-rents, Johnston, with the unanimous consent of the council, summarily removed him from his office in North Carolina, and appointed in his place Eleazer Allen, to whom the crown gave a commission in 1741. ${ }^{3}$ Henceforward, adequate supervision of the quitrent system was assured, and as the system of collection had also been organized, the payment of the quit-rents seemed certain of enforcement.

But the arbitrary policy adopted by Governor Johnston soon had its due effect, and in 1736 the lower house loudly protested against the unlawful acts of the royal officials who had been collecting the quit-rents. With sardonic humor the governor replied that only a quit-rent law could remedy these complaints, and that, he added, "lies entirely in your breasts." " This reply apparently was

1 Governor Johnston to Board of Trade, May 25, July 10, and December 5, 1735, N. C. Col. Rec., IV, 8-9, 15, 24-25; Governor Johnston to Lord Wilmington, December 5, 1735, Wilmington Papers.

2 The deputy collectors, and later the sheriffs, were allowed a commission of 5 per cent. The receiver-general received 10 per cent. Letter from Governor Tryon, July 16, 1767, C. O. 5: 112, pp. 289-290.

3 See Papers relating to Hammerton's case, 1735, Treas. 1: 289, ff. 177181; Commission to Eleazer Allen, April 2, 1741, Treas. 52: 41, pp. 202-203.

4 Legislative Journals, October 7, 1736, N. C. Col. Rec., IV, 236-238. 
not without result, for the lower house soon passed a quit-rent act which was, nevertheless, by no means satisfactory to the royal government. Its one concession that forfeiture should take place if the rents were not paid for five years was more than offset by the many restrictions that hedged in the recovery of these charges by distraint. After the council had summarily rejected this unsatisfactory measure, ${ }^{1}$ the lower house showed its hand by attempting to take into custody the royal offi cials who had distrained for the rents. Governor Johnston promptly met this defiant act by adjourning the assembly. ${ }^{2}$ The attitude displayed by the lower house was altogether in accord with the hostility that was shown toward Governor Johnston because of his diligence in enforcing the quit-rents, ${ }^{3}$ and was forcibly illustrated in 1737 , when a man who had insulted a court officer was imprisoned at Edenton. Upon the mere rumor that this individual had been seized for neglecting to pay his quitrents, the men of Bertie and Edgecombe precincts, who lived near the border and had been loud in their complaints against the collectors, marched to the rescue, five hundred strong, "cursing His Majesty and uttering many rebellious speeches." Before this mutinous array arrived within five miles of the town, the prisoner was released with a fine, but the mob threatened to take summary vengeance upon any person who dared demand quit-rents from them. This incident showed what might

1 The provisions limiting distraint had evidently been copied from a similar clause in the South Carolina quit-rent act passed in 1731. N. C. Col. Rec., IV, 188-189. See also p. 322, note 1.

2 Governor Johnston to Secretary of Board of Trade, March 11, 1737, N. C. Col. Rec., IV, 242-243.

3 Up to October 15, 1736, he had collected over $£ 4,200$ in arrears. Governor Johnston to Board of Trade, October 5 and November 9, 1736, N. C. Col. Rec., IV, 176-177, 203. 
be expected, if the enforcement of the quit-rents was pushed too far. ${ }^{1}$

Before the reorganization of the quit-rents could be completed, Governor Johnston declared that it would be necessary to straighten out the land system in North Carolina. Among the questionable grants were those which had been taken out under the Grand Deed to Albemarle and those which had been made after the proprietaries had closed their land-office. There were also blank patents for fully 500,000 acres that had been issued before the crown assumed control. These blank patents called for a quit-rent of either $6 \mathrm{~d}$ or $1 \mathrm{~s}$ per 100 acres, and it was customary to use them in order to evade a higher rate. ${ }^{2}$ At first Governor Johnston proposed to refer these blank patents to a court of exchequer, but the Board of Trade overruled this plan. ${ }^{3}$ Ultimately the entire land situation was referred to the attorney-general in England, who after due consideration ruled that practically all patents issued before the purchase by the crown were valid, but that those granted in the following years up to 1734, when the land-office was reopened, were void. He also decided that the Grand Deed to Albemarle was revocable, except for the grants that were issued directly in accordance with its provisions, and that the blank patents were valid, provided the proprietaries had given their tacit consent to them. Lastly, he maintained that the quit-rents could be demanded in sterling, and were payable either on the land, or at the place of the

1 Governor Johnston to Board of Trade, October 6, 1737, N. C. Col. Rec., IV, 267.

2 Many of these patents were issued by Sir Richard Everard in 1728.

3 Governor Johnston to Board of Trade, May 22, July 10 and August 2, 1735, Board of Trade to Governor Johnston, September 12, 1735, and Board of Trade Journal, October 14, 1735, N. C. Col. Rec., IV, 8-9, 14, 16-17, 30, 298. 
crown's general receipt. ${ }^{1}$ This opinion was of the utmost importance, since it settled the most pressing problems of the land system, and thus afforded an authoritative basis upon which to draw up a quit-rent act.

After he had received the attorney-general's opinion, Governor Johnston again endeavored to secure a quitrent act. This time he was successful in inducing the assembly to pass a bill that far surpassed his expectations. The act, passed in 1738 , provided that commodities should be accepted in payment of the quit-rents, but as it purposely undervalued them, it raised the presumption that everyone who could secure gold or silver would pay in that medium. This excellent law, Governor Johnston wrote the Board of Trade, ought to increase the quit-rents by at least $£ 1,800,{ }^{2}$ but unfortunately his recommendations were not heeded in England. Henry McCulloh, lately appointed special commissioner to settle the land and quit-rent problems in the Carolinas, advanced minor objections to the bill, and when the Board of Trade in its representation opposed certain unimportant details, the Privy Council disallowed the act. ${ }^{3}$ This disallowance was a grave error of policy and was especially discouraging to Governor Johnston, who after long effort had secured a bill that should have solved the quit-rent problem. There was now little prospect of

1 Opinion of Attorney-General, February, 1738, N. C. Col. Rec., IV, 290, 318-321.

2 The commodities, which were chosen purposely to stimulate trade, included inspected tobacco, hemp, flax, deerskins, and beeswax. Governor Johnston to Board of Trade, January 28, 1740, and Legislative Journals, February 28, 1739, N. C. Col. Rec., IV, 373, 415-417. Unfortunately the contents of the bill are not available, as it was only printed by title. $N$. C. State Rec., XXIII, 122.

3 Board of Trade to Governor Johnston, June 26, 1740. Observations of Henry McCulloh, and Minute, Privy Council, July 31, 1740, N. C. Col. Rec., IV, 420-435; Acts, Privy Coun. Col., III, 679. 
another act, and without the support of the assembly, he did not see how in the future the quit-rents could be collected. ${ }^{1}$

Probably the true reason for the disallowance of the act of 1738 was the desire of the British government to give a free hand to Henry McCulloh, a merchant of London, who was commissioned in 1739 as a special representative of the crown to inspect and adjust the land and quit-rent systems of the two Carolinas. ${ }^{2}$ His instructions with regard to North Carolina were based upon the opinion given by the attorney-general. They authorized him to confirm all proprietary grants with the original quit-rent, to exact $4 \mathrm{~s}$ per 100 acres from all grants issued after the purchase by the crown, and to recognize all blank patents paying $6 \mathrm{~d}$ or $1 \mathrm{~s}$ per 100 acres, provided the patentees paid a purchase price of $£ 10$ per 100 acres in addition. These instructions also required that the quitrents should be paid in sterling, or in commodities of an equivalent value, and empowered McCulloh to secure the passage of an act for the better collection of these charges, provided he considered such a measure necessary. $^{3}$

With the full dignity of a royal commissioner, McCulloh came to North Carolina in September, 1741, and gave a number of orders in fulfilment of his instructions. To the speaker of the assembly, he outlined the quit-rent act that he required, and to the deputy auditor he sent

1 Governor Johnston to Board of Trade, December 17, 1740, N. C. Col. Rec., IV, 424.

2 As most of McCulloh's activities were confined to South Carolina, see pages 331-341 for a more complete account of his powers. MeCulloh and his associates held patents to $1,200,000$ acres in the Piedmont section of North Carolina. Report, Board of Trade, August 15, 1735, N. C. Col. Rec., V, pp. xxxiii-xxxiv.

3 Instructions to Henry MeCulloh, May 16, 1739, N. C. State Rec., XI, $35-41$. 
a prescribed form of rent roll. He threatened the inhabitants in general with prosecution if they failed to pay their quit-rents in the manner indicated, and at the same time informed them of the terms upon which he would confirm their patents. ${ }^{1}$ But he soon discovered that a royal commissioner was by no means an omnipotent person in North Carolina. The assembly refused to consider his proposed bill until it found out what action would be taken in South Carolina; the royal officials, although they did not openly refuse him their aid, did not disguise their hostility to his mission; and the people paid little heed to his threats. After he had sternly reproved the governor for grants of land to persons who had no "manner of title thereto," McCulloh left for South Carolina. He had accomplished little more in the northern province than to arouse the bitter antagonism of all classes toward himself and his mission. ${ }^{2}$

Making occasional visits from his headquarters in South Carolina, McCulloh now devoted his energies, as far as North Carolina was concerned, chiefly to faultfinding. He went so far as to accuse the receiver-general, Eleazer Allen, of numerous discrepancies in his accounts, and even intimated that he had been dishonest. ${ }^{3}$ Allen in reply appealed to the council. McCulloh, refusing to obey a summons to appear before that body, retaliated by calling for copies of all receipts for quit-rents since 1716 and for all the books and papers of former

1 Petition, MeCulloh to Horatio Walpole, about 1747, Treas. 1: 330, f. 144; Address of MeCulloh to People of North Carolina, November 12, 1741, and March 20, 1742, N. C. State Rec., XI, 44-48, 68-72.

2 MeCulloh to Board of Trade, August 19, 1742, N. C. State Rec., XI, 73; Petition of McCulloh to Horatio Walpole, about 1747, Treas. 1: 330, ff. 144-145.

3 MeCulloh to Thomas Hill, February 16, 1744, N. C. State Rec., XI, 73; Petition, MeCulloh to Horatio Walpole, about 1747, Treas. 1: 330, ff. 144-145. 
receivers. ${ }^{1}$ He pointed out that arrears of fully $£ 10,000$ to $£ 12,000$ were due, and that the receiver-general had not been called to account for twelve or thirteen years. ${ }^{2}$ Again was McCulloh summoned before the council, and was threatened with a suit for $£ 10,000$ for his slanders against Allen. Actually in danger of imprisonment, he was cleared through the intervention of the auditorgeneral, Horatio Walpole, and July 16, 1746, he abandoned his mission and left the province. ${ }^{3}$

McCulloh's mission had been altogether fruitless in settling the quit-rent question in North Carolina, since the real cause of the difficulties encountered in enforcing these charges was, as Governor Johnston pointed out, the disallowance of the act passed in $1738 .{ }^{4}$ His appointment was a serious error of policy, for a special commissioner fresh from London was scarcely qualified to adjust a situation that had presented the utmost perplexities to a governor who was thoroughly conversant with local conditions. McCulloh by his tactless and arbitrary attitude only succeeded in making a bad matter worse and in stirring up additional discord. ${ }^{5}$ The irritation thus aroused was increased by the Granville grant in 1744 which handed over the northern district, already the

1 Memorial from Eleazer Allen, April 5, 1745, and MeCulloh to Governor Johnston, 1744, N. C. Col. Rec., IV, 762-763, 1129-1134.

2 Memorial of McCulloh, February 22, 1751, N. C. Col. Rec., IV, 1106.

3 Petition, McCulloh to Horatio Walpole, about 1747, Treas. 1: 330, f. 146.

4 Governor Johnston to Board of Trade, June 27, 1750, N. C. Col. Rec., IV, 1084, 1088.

5 James Abercrombie to Treasury, June 21, 1751, N. C. Col. Rec., IV, 1096-1097. The antagonism that was stirred up by MeCulloh was shown later in the settlement of his salary. Of his claims, £2,584 was to be credited to the quit-rents on his lands in North Carolina. Although by special order this land was exempt until 1760, the local officials reckoned these quit-rents from 1757, and the Privy Council was obliged to rebuke sharply this display of personal feeling. Eventually MeCulloh's heirs were only held responsible for the quit-rents on lands that were actually settled. 
scene of considerable confusion, to a proprietary. Besides the loss in revenue which this grant involved, the new propriety became a source of much disorder, and presented one of the greatest obstacles to the successful enforcement of the royal quit-rents in the remainder of the province. ${ }^{1}$

Meanwhile, the collection of the quit-rents that were due the crown became an increasingly difficult task. In 1741 Governor Johnston tried in vain to induce the assembly to pass another quit-rent act. Lacking legal sanction, other than the English common law, for the enforcement of the quit-rents, he was at his wit's end to devise some effective means of collection. ${ }^{2}$ The Treasury in England favored a court of exchequer, but past experience had shown the danger of this expedient. The mere issue of the usual proclamation for the payment of the quit-rents had little effect, nor was universal distraint possible. $^{3} \quad$ The popular attitude toward the quit-rents was reflected in a bold resolution which the lower house adopted, declaring that the refusal of the crown to accept commodities or paper money, except at an excessive discount, was a violation of the Grand Deed to Albemarle and the law of the province, and a "very just grievance."

Finally in 1748, after he had disfranchised the representatives from the northern district who had proved specially refractory, Governor Johnston secured the act desired. ${ }^{5}$ This law provided for the registration of all grants and the payment of the quit-rents either in proc-

1 See pp. 76-82.

2 Governor Johnston to Board of Trade, December 21, 1741, N. C. Col. Rec., IV, 584-585.

3 Council Journal, November 17, 1743, N. C. Col. Rec., IV, 649; Cal. Treas. Papers, XI, 70.

4 Legislative Journal, November 29, 1744, N. C. Col. Rec., IV, 744.

5 N.C. Col. Rec., V, p. vi. 
lamation money or in inspected tobacco at a penny a pound. ${ }^{1}$ An additional act required that each tenant should either show his last receipt for quit-rents in order to determine the arrears due, or else make oath that he had lost it. These acts should have accelerated the process of levying distress, ${ }^{2}$ but again the Privy Council failed to realize the importance of the local situation, and disallowed both acts on comparatively trifling grounds. ${ }^{3}$ This failure to confirm the quit-rent acts, in addition to the numerous local controversies, naturally affected the revenue. Accounts were so inaccurately and loosely kept that the nominal value of the rent roll is uncertain. Yet it is clear that the annual returns were far less than was due, and after the grant to Lord Granville they decreased still further. ${ }^{4}$ This loss in revenue from the quit-rents

1 Payments in proclamation money were to be made at the court house, but tobaceo must be paid at a convenient wharf, or at an inspection house. Indigo was also allowed, but was later removed from the optional payments. N. C. State Rec., XXIII, 301-302, 340, 350-351.

2 The only exemptions made from distraint were in favor of a "negro or negroes, ox or oxen, horse or horses of the plough, or any necessary utensil for husbandry where other sufficient distress is produced." $N$. C. State Rec., XXIII, 310-312.

3 Board of Trade to the King, March 14, 1754, N. C. Col. Rec., V, 93 et seq.; C. O. $5: 323$.

4 The following table shows the steady decline in collections, especially after the Granville grant in 1744. Proclamation money, either as silver or as paper at its par value, was worth 75 per cent. in sterling value.

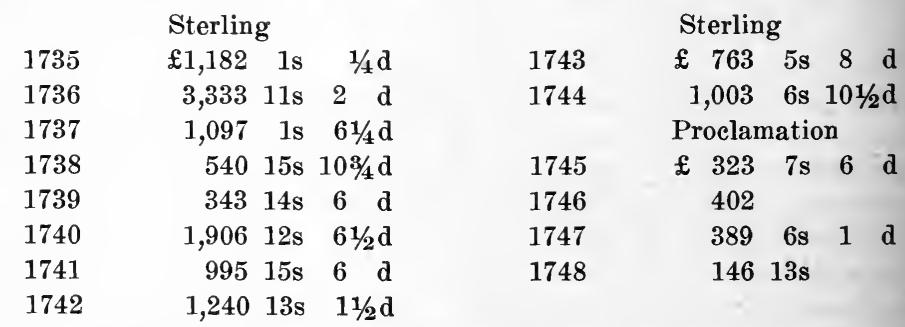

See Report of Horatio Walpole to Treasury, May 30, 1749, Treas. 1: 335, ff. 160-161. 
had a serious effect upon the salaries of the royal officials, which were already greatly in arrears. ${ }^{1}$

The arrival of Governor Dobbs in 1754 was the signal for a renewed effort to collect the quit-rents. Dobbs's instructions, which were similar to those given to McCulloh, provided for the adjustment of all questionable patents upon the basis that had already been outlined in the opinion submitted by the British attorney-general. In order to avoid difficulty in enforcing the quit-rents, these instructions required the insertion of a clause in all future patents, fixing forfeiture of the land as the penalty for failure to make prompt payments. They repeated the offer to remit all arrears that had accrued during the proprietary period, in case the assembly passed a satisfactory act providing for registration and

1 The annual allowances to the royal officials included $£ 1,000$ to the governor, $£ 100$ to the auditor, $£ 70$ to the chief justice, $£ 40$ to the baron of the exchequer, $£ 40$ to the surveyor-general, $£ 70$ to the secretary, $£ 80$ to the attorney-general, £25 to the elerk of the erown, and $£ 30$ for the expenses of the court of exchequer, or a total of $£ 1,455$. See N.C. Col. Rec., V, 20-21. These meager allowances remained as regular charges upon the quit-rents throughout the colonial era, except the $£ 1,000$ to the governor which later was paid from another source. The salary of the secretary was increased to $£ 100$. Letter from Governor Tryon, July 16, 1767, C. O. 5: 112, pp. 289-290. MeCulloh estimated that the arrears due on these salaries, up to 1735 , the first year in which the quit-rents were regularly collected, amounted to $\$ 3,52815 \mathrm{~s}$. These arrears were probably settled in part by the proceeds from the sale of crown lands, but whatever balance was due must have been paid from the quit-rents, even though collections were not adequate to meet the annual allowances. Henry McCulloh to Henry Pelham, November 8,1752 , N. C. Hist. Commission MSS. An instance of the results of the failure to pay the salaries of the royal officials in North Carolina was brought to the attention of the Board of Trade in 1753. When Thomas Child was asked why he did not return to America to carry on his duties as attorney-general of North Carolina, he replied that as he had received no salary since his appointment in 1745 , he had come to England to press his claims, leaving his office in charge of a deputy. Thomas Child to Board of Trade, January 8, 1753, N. C. Col, Rec., V, 15-16. Upon the death of Governor Johnston, in 1752, arrears of $£ 13,46219 \mathrm{~s} 2 \mathrm{~d}$ were owing on his salary as governor. Acts, Privy Coun. Col., IV, 238-239. 
the payment of the quit-rents in proclamation money, but declared that the provisions of this act must not extend to Granville's lands. ${ }^{1}$ Armed with these instructions, Governor Dobbs soon represented to the assembly the necessity of passing a quit-rent act in order to provide salaries for the crown's officials. ${ }^{2}$ The disallowance by the Privy Council of the act of 1746, by which the northern section of the colony had lost its representatives, paved the way for a more conciliatory attitude on the part of the lower house, ${ }^{3}$ which now promptly passed an act requiring the registration of grants, the issue of patents for surplus lands, and the payment of the quitrents upon all landholdings. This act allowed commodity payments of the quit-rents either in inspected tobacco or in indigo, and permitted distraint for arrears upon "any slaves, goods or chattels," although it prohibited the seizure by a sheriff of "unreasonable" distress, or of a slave, if other personal property were available. Despite the instructions to the contrary, the act failed to exempt Granville's lands from its provisions. ${ }^{4}$

When the act reached London, it was met with numerous criticisms. The attorney-general objected to the failure to fix forfeiture as the penalty for neglect to register patents, to the optional payments that were allowed in tobacco or indigo, and to the clauses regarding distress. ${ }^{5} \quad$ Granville's agent, also, protested against the act

1 Instructions to Governor Dobbs, June 17, 1754, N. C. Col. Rec., V, 1128-1133.

2 The situation had been somewhat relieved by an order in 1754 that Governor Dobbs's salary, $£ 1,000$, should be paid out of the royal Exchequer from some other source than the quit-rents. Acts, Privy Coun. Col., IV, 189-190, 238-239; Legislative Journals, December 14, 1754, N. C. Col. Rec., $\mathrm{V}, 213-214$.

3 N. C. Col. Rec., V, p. vi.

4 N. C. State Rec., XXV, 304-309.

5 Board of Trade to Treasury, November 27, 1755, and Report of Sir Matthew Lamb, June 17, 1755, Treas. 1: 360, ff. 227-240; 361, ff. 182-184. 
in a long-drawn-out elaboration of the attorney-general's report. ${ }^{1}$ In order to meet these objections, Robert Jones, Jr., the agent for North Carolina, defended the provisions of the act, opposing forfeiture as a penalty for neglect to register grants, and supporting the optional payment in tobacco or indigo by the time-worn argument that there was not sufficient gold and silver in the colony to pay the quit-rents. Indigo, he said, would probably be little used, as it was not a profitable crop, but tobacco payments would be made upon the same terms as in Virginia. He insisted that the exemption of slaves, where any other distress was available, was necessary in order that the landholders might be able to work their plantations. Although Jones plainly showed that these features of the act were necessary on account of local conditions in the colony, the Board of Trade would not recommend the confirmation of the bill. Once more the British government failed to take advantage of an opportunity to establish the quit-rent system in North Carolina upon a firm basis. ${ }^{2}$

The refusal of the crown to confirm the quit-rent act left Governor Dobbs in a difficult position. If the quitrents were to be collected, a rent roll was a necessity, but before such a list could be drawn up, the many problems presented by the land system must be adjusted. Especially objectionable in its effect upon the quit-rents was the "processioning"' act passed in 1723 , which, by placing all surveys under the control of the local vestries, allowed many persons to hold larger areas of land than their patents called for. Governor Dobbs recommended that this act should be repealed, and that the questionable

1 Thomas Child to Board of Trade, about June, 1755, Treas. 1: 361, ff. 159-168.

2 Remarks of Robert Jones, Jr., 1755, Treas. 1: 500, ff. 111-113; Acts, Privy Coun. Col., IV, 402. 
titles to surplus lands should be submitted to the council, sitting as a court of claims, with an appeal allowed to London. In addition, he proposed a complete survey of the colony as a necessary measure in order to adjust the land situation. But the auditor-general, Walpole, held that a court of claims was unknown to English law, and that the entire question of surplus lands should be submitted to the crown's attorney-general, rather than to a body, such as the council of North Carolina, with personal interests at stake. ${ }^{1}$ But no definite steps were taken at this time to adjust the problem of surplus lands, although a warrant was granted in 1757 to defray from the quit-rents the cost of a complete survey of the crown lands in North Carolina. ${ }^{2}$ This project, however, does not seem to have been completed, probably because a sufficient allowance could not be spared from the quitrent fund. Meanwhile Governor Dobbs, without an adequate rent roll, attempted by arbitrary measures to straighten out the quit-rent system, although he was not very successful. ${ }^{3}$

1 Governor Dobbs reported that one grant for 640 acres on the Neuse River was, by careless surveys, made to include fully 1,000 acres. Of course no quit-rents were paid upon the surplus land. This instance is typical. John Pownall to Treasury, January 13, 1757, and Report of Robert Cholmondeley, July 14, 1757, Treas. 1: 372, ff. 173-177, 196-197; Thomas Child to John Pownall, April 6, 1755, and Governor Dobbs to Board of Trade, October 29, 1756, N. C. Col. Rec., V, 339, 643.

2 Board of Trade to Governor Dobbs, March 10, 1757, N. C. Col. Rec., $\mathrm{V}, 749$.

3 The bond of Daniel Rees, receiver for Carteret County, illustrates the methods used by Governor Dobbs. The bond, for $£ 1,000$, required the collection of the quit-rents, the account to be handed in annually, March 25, to the receiver-general. The collector was authorized to make full inquiries with regard to land that paid no quit-rents, and to report to the receivergeneral. If anyone refused to produce or to take out a patent, the attorneygeneral should eject him by law, and his lands would be granted to the first claimant that appeared. See bond, dated September 4, 1755, N. C. Col. Rec., V, 422-423. 
The difficulties encountered by Governor Dobbs in enforcing the quit-rents were vastly increased by the insubordination and the generally inefficient work of the receiver-general, John Rutherfurd. ${ }^{1}$ Soon after his arrival Governor Dobbs directed the receiver-general to make out full accounts of the quit-rents, ${ }^{2}$ but Rutherfurd, who seems to have resented any supervision by the governor, ignored this request, and represented directly to the Board of Trade the deplorable condition of the quitrents in North Carolina. ${ }^{3}$ Actually, this situation was partly due to Rutherfurd's own careless methods. In his accounts, Rutherfurd was accustomed merely to give the gross amount of the quit-rents, with a haphazard statement of the various payments he had made, many of them without a royal warrant. He had made no effort to draw up a rent roll, although the records were available in the secretary's office. He was equally careless in collections, turning over this work to deputy collectors, over whom there was no adequate supervision. The climax was reached when he was accused of dishonest practices. Under the authority of an order from the receiver-general, the sheriff of Craven County had taken out of the quit-rents $£ 56817 \mathrm{~s} 91 / 4 \mathrm{~d}$, claimed to be due from the crown to the estate of the late attorney-general, William Anderson, and part of this sum Rutherfurd appropriated to himself. It was alleged also that Rutherfurd had allowed the promissory notes which had been issued in payment of the salary of James Murray, as secretary and clerk of the council, to be received on

1 The name is Rutherfurd, not Rutherford, as given in the printed records and elsewhere.

2 Governor Dobbs to Board of Trade, November 9, 1754, N. C. Col. Rec., $\mathrm{V}, 145$.

3 John Rutherfurd to Board of Trade, June 19, 1756, N. C. Col. Rec., $\mathrm{V}, 587-588$. 
account of the quit-rents. After a full investigation of these irregularities, the governor, in 1757, with the approval of the council suspended Rutherfurd from the receivership and both Rutherfurd and Murray from the council. In a letter to the Treasury he urged that board to uphold his action, for "unless misdemeanors are properly punished," he said, "and I be supported in doing my duty, I can't expect to do His Majesty justice in the receipt of His quit-rents and preserving His just prerogative here.'" $\mathrm{He}$ also sent a full statement of the case to the Board of Trade. ${ }^{2}$

At first the Board of Trade upheld the governor, especially as Murray and Rutherfurd had headed a faction against him in the colony. ${ }^{3}$ But Rutherfurd displayed unwonted energy. Going to England to answer personally the charges against him, he drew a melancholy picture of the quit-rent situation in North Carolina, declaring that he had incurred the displeasure of Governor Dobbs who owed large arrears of quit-rents, "and which your petitioner has been obliged by the duties of his office several times to demand payment of.' As to the charges against himself, he claimed that the sum due the late attorney-general, William Anderson, had been properly reserved, ${ }^{4}$ and that in honoring Murray's notes, he was

1 Altogether, Murray had issued $£ 320$ in promissory notes of 20 s each, which had been received in payment of the quit-rents all over the province. The governor issued a proclamation which forbade any further circulation of the notes. Council Journal, December 1, 12 and 14, 1757, Proclamation of Governor Dobbs, December 5, 1757, and Answer of John Rutherfurd, N.C. Col. Rec., V, 821-823, 826-828, 935-959; Representation of Governor Dobbs, December 26, 1757, Treas. 1: 372, ff. 190-193.

2 N. C. Col. Rec., V, 957.

3 Report of Board of Trade, July 28, 1758, N. C. Col. Rec., V, 959-960.

4 Altogether, $£ 8815 \mathrm{~s} 4 \mathrm{~d}$ on the account due Anderson had been taken out for Rutherfurd, who claimed that $£ 2011 \mathrm{~s} 4 \mathrm{~d}$ of this amount had been overpaid, and that he had charged it out in order to prevent confusion. The balance, $£ 684 \mathrm{~s}$, was a debt owed Sir Samuel Fludyer of London which 
merely following a common practice of the receivers of North Carolina in paying salaries. Therefore, he claimed, he should first have been admonished before he was deprived of his office. In his opinion, the reasons alleged were not of sufficient weight to suspend a man of "unimpeachable integrity" who had held office for years, "with the good liking of the inhabitants of the colony." "1

The issue thus raised between Rutherfurd and Governor Dobbs was typical of many similar controversies in the crown colonies. While undoubtedly much personal animosity was involved, Rutherfurd had been exceedingly careless in his accounts, and had neglected his duties as receiver-general. The specific charges brought against him did not convict him of actual dishonesty, but rather of such careless business methods as to unfit him for his office. ${ }^{2}$ Furthermore, he had displayed an attitude of insubordination that could not be tolerated if the governor were to exercise actual supervision over the quit-rents. Under these circumstances, Governor Dobbs should have been sustained, as was done in Virginia in the case of William Byrd, II. ${ }^{3}$ But under the influence of the Board of Trade, the Privy Council reinstated Rutherfurd in 1761, and deferred Murray's case for a more complete investigation. ${ }^{4}$ This belated action was doubly harmful. By the delay in the settlement of the controversy, the important office of receiver-general was

Anderson had collected, but for which he had not remitted. The truth of this latter statement was confirmed by the auditor-general. R. Cholmondeley to John Rutherfurd, August 16, 1758, and to Treasury, July 21, 1759, Treas. 1: 388, ff. 174-176; 397, f. 205.

1 Petition and Defense of John Rutherfurd, August, 1758, and Memorial

to Treasury, May 22, 1758, Treas. 1: 388, ff. 177-178, 201.

2 Rutherfurd's Answer to Governor Dobbs, about 1758, Treas. 1: 383.

3 See pp. 231-232.

4 Acts, Privy Coun. Col., IV, 477. 
left for four years without a properly authorized incumbent, while by the terms of that settlement the small amount of supervision which the governor had exercised over the receiver-general was destroyed. The actual effect upon the quit-rent system was illustrated when a rent roll was proposed in 1761. Rutherfurd, now firmly established in his office, became more careless than ever. He sent to Benjamin Heron, the deputy auditor, a rent roll consisting of fourteen leather-bound folios and two others that were merely stitched together. Heron refused to accept this roll as satisfactory, but as the weather was threatening, he took the folios, which lay exposed in an open cart, into his house. Upon examination they proved to be far from complete, and the council gave an order that another roll should be prepared. ${ }^{1}$ Although a complete list of land grants was available in the secretary's office, Rutherfurd seems to have paid little attention to this order. ${ }^{2}$

During the suspension of Rutherfurd the quit-rent system fell into great confusion, and an intense opposition to collections, which occasionally broke out into open hostility, began to be displayed. ${ }^{3}$ Frequently the sheriffs refused point-blank to collect the quit-rents, and the council found that it was a very difficult task to secure deputies. ${ }^{4}$ The rapid depreciation of North Carolina paper money, the usual medium of payment, also de-

1 Council Journal, April 25, 1764, and October 21-22, 1766, N. C. Col. Rec., VI, 1074-1075; VII, 524-526.

2 N. C. Land Grants, 1707-1768, C. O. 5: 319; Governor Tryon to Board of Trade, July 16, 1767, C. O. 5: 112, pp. 251-253.

3 In Johnston County, where the draft of men for the crown's service had already caused trouble, the people, taking advantage of imperfect rolls, refused to pay their rents and threatened "to take the law" of the sheriff if he dared enforce them. Deposition of Stephen Cade, December 12, 1757, N. C. Col. Rec., V, 938.

4 Council Journal, March 3, 1759, N. C. Col. Rec., VI, 78. 
creased the revenue from the quit-rents, but to refuse to receive this provincial currency would mean, in Governor Dobbs's estimation, the entire cessation of all payments for quit-rents and taxes. Moreover, if distress were levied for these charges, it was probable that the few owners of gold and silver in the colony would organize a monopoly to purchase all goods that were seized. In this event, the governor believed, so great a "flame" would run through the province that the royal administration, lacking a regular force, could not quench it. ${ }^{1}$ By 1760 , he declared, the province had become so demoralized that mobs assembled unmolested and the courts were held in general contempt. ${ }^{2}$ In consequence of these disturbances the quit-rents inevitably suffered, and in 1761 hardly a sixth of the rent roll was collected. ${ }^{3}$

A cause of further trouble at this time was the boundary dispute with South Carolina. Many settlers in the border territory refused to pay quit-rents to either colony until the line was definitely established, and one receiver asserted that he could levy distraint only at the risk of his life. ${ }^{4}$ In 1762 nearly a hundred and fifty families seized certain lands on Sugar and Reedy creeks which they claimed to hold under the jurisdiction of South Carolina. Organizing their own militia, they refused absolutely to recognize the authority of North Carolina. ${ }^{5}$ Unfortunately the zeal of Governor Dobbs only increased the general ferment. At his direction writs of ejectment were served upon persons who had

1 Governor Dobbs to Board of Trade, January 19, 1760, N. C. Col. Rec., VI, 218.

2 Legislative Journals, May 23, 1760, N. C. Col. Rec., VI, 414-416.

3 The estimated value of the quit-rents by 1761 was $£ 3,000$ sterling, but not more than $£ 455$ was collected. Answer to Queries of Board of Trade, about 1761, N. C. Col. Rec., VI, 618.

4 Deposition of John Hamer, December 5, 1757, N. C. Col. Rec., V, 938.

5 Council Journal, December 10, 1762, N. C. Col. Rec., VI, 794-795. 
long considered themselves inhabitants of South Carolina. Also, surveys were made and lines drawn through the hunting grounds and the burial places of the Catawbas, "to the great alarm and disquiet" of those friendly Indians. The Privy Council finally succeeded in settling these disputes, but not until after there had been much discord with a consequent loss in the quit-rents. ${ }^{1}$ Still another disturbing factor at this period was the unrest that prevailed in the Granville Grant. The hostility toward all feudal claims that arose in this propriety naturally found echo in the other part of the province where the quit-rents were payable to the crown. According to Governor Martin in 1772 the only possible means of removing this source of discord was the purchase of the Granville Grant. ${ }^{2}$

The continued failure to secure a quit-rent law that would meet the approval of the British government made the collection of quit-rents a very difficult matter. Governor Tryon said that the only remedy was a court of exchequer, an institution which, according to the crown lawyers, could be set up by the royal prerogative without any reference to the colonial legislature. ${ }^{3}$ But legal right was compelled to give place to expediency, since to establish an arbitrary court in this fashion would destroy without hope of recovery the small vestiges of royal authority that still remained in North Carolina.

1 Acts, Privy Coun. Col., IV, 552-553. For the expense of drawing the boundary line, a warrant for $£ 742 \mathrm{Ts}$ was allowed out of the quit-rents of North Carolina. Council Journal, December 18, 1769, N. C. Col. Rec., VIII, 162.

2 Governor Martin to Lord Hillsborough, Mareh 6, 1772, and to Lord Dartmouth, November 28, 1772, N. C. Col. Rec., IX, 261, 358. See also above, p. 81.

3 Governor Tryon to Earl of Shelburne, July 7, 1767, and Report of (probably) Law Lords, February 4, 1768, N. C. Col. Rec., VII, 498-499, 684-685. 
The so-called Regulators' War, which was provoked by the attempt to collect taxes in specie, soon showed how impossible was the vigorous enforcement of the quitrents. ${ }^{1}$

At the request of the Earl of Hillsborough, the newly appointed secretary of state for the colonies, Governor Tryon in 1769 outlined the measures he considered necessary to place the quit-rents of North Carolina upon a firm basis. First he proposed that all titles should be confirmed and all arrears remitted in order to induce the assembly to pass a quit-rent act. Next, he indicated the method by which a complete rent roll could be secured and kept up. Of even greater importance was his plan for greater coöperation between the receiver-general and the deputy collectors. He suggested that a list of the quit-rents due in his county should be given annually to each of these deputies, who should be required either to return the account in full or else make up the deficiency. As an inducement to good work, the receiver-general and the deputy collectors, upon whom fell the brunt of the work of collection, should receive commissions of ten per cent. and twenty per cent. respectively, and sufficient compensation should be allowed the secretary and the deputy auditor for keeping up the rent rolls. Enforcement of the quit-rents could be secured by allowing forfeiture after these charges had been in arrears for three years, and all slaves, goods, and chattels should be liable to distraint. $^{2}$

In drawing up his scheme of collection, which was strikingly similar to that employed in Maryland, Gov-

1 Governor Tryon to Lord Hillsborough, June 16, 1768, N. C. Col. Rec., VII, 791; Bassett, "'Regulators of North Carolina,', Report, Amer. Hist. Asso., 1894, pp. 141-212.

2 Governor Tryon to Earl of Hillsborough, May 27, 1769, N. C. Col. Rec., VIII, 46-47. 
ernor Tryon showed that he had carefully analyzed the situation in North Carolina. ${ }^{1}$ In 1771 he induced the lower house to frame a quit-rent bill based upon his recommendations. Unfortunately, on the third reading, the house insisted upon an amendment that would practically have nullified the provisions for the collection of arrears, and the council refused to pass the bill in this form. But the governor hoped to secure a satisfactory act in the near future, inasmuch as many members of the lower house desired to consult their constituents before they voted upon so important a measure, and the chief opposition had come from representatives living in Granville's propriety which would not be affected by the act. ${ }^{2}$ These expectations were defeated at the next session when the lower house definitely rejected the quit-rent bill. ${ }^{3}$

Following the example set by his predecessors, Governor Martin in 1773 proposed a quit-rent act that provided for the enforced registration of all titles and conveyances, and for the remission of the arrears up to 1771. In order to induce the assembly to accept the act, he proposed to include the Granville Grant within its scope. Either the assembly must pass some such act, he declared, or a court of exchequer would have to be established, if the quit-rents were to be enforced in North Carolina. ${ }^{4}$ The Treasury approved his recommendations, but the outbreak of the Revolution put an

1 Governor Tryon to Earl of Hillsborough, July 3, 1769, and February 20, 1770, N. C. Col. Rec., VIII, 53, 175-177.

2 Legislative Journals, January 10, 23 and 26, 1771, and Governor Tryon to Lord Hillsborough, March 9, 1771, N. C. Col. Rec., VIII, 418, 454-456, 479.

3 Legislative Journals, December 19, 1771, N. C. Col. Rec., IX, 195.

4 Governor Martin to Earl of Dartmouth, July 18, 1773, Treas. 1: 502, ff. 71-72. 
end to this last attempt to secure a quit-rent act in North Carolina that would prove acceptable to the crown. ${ }^{1}$

During this later colonial period, the revenue from the quit-rents showed little improvement. John Rutherfurd, the receiver-general, continued to file irregular and confused accounts, some of which had to be made out a second time before they could be sent to England. ${ }^{2}$ Although the council condoned such work upon the pretext of Rutherfurd's "ill state of health," this loose system of accounting so interfered with the work of the attorneygeneral that he was unable to secure sufficient evidence to push suits for the quit-rents. ${ }^{3}$ Rutherfurd, in spite of his carelessness, must have been a likable sort of individual, for Governor Martin, as well as the council, excused his conduct upon the score of his "distressed circumstances" and "extreme good nature." Yet even personal good will had its limitations when confronted with evidences of utter inefficiency. Strudwick, the secretary, in trying to secure the arrears of his own salary, collected $\$ 500$ more from the quit-rents in one county than Rutherfurd had received from the rest of the royal domain in North Carolina. Nevertheless, Rutherfurd refused Strudwick's offer to collect the quit-rents for a year, and the governor, his patience exhausted, recom-

1 Treasury Minute, July 22, 1774, Treas. 29: 44, pp. 13-14.

2 Rutherfurd presented an account March 25, 1766, which showed collections of $£ 3,23612 \mathrm{~s} 81 / 4 \mathrm{~d}$ in proclamation money. The period covered by these collections is not stated. The next account, filed June 23, 1768, showed collections of $£ 3,13013 \mathrm{~s} 61 / 2 \mathrm{~d}$, and presumably covered the period since 1766. But so fragmentary are the two accounts that it is impossible to tell whether the sums indicated were collected during any fixed period. Expenditures, too, were set down in similarly haphazard fashion. Council Journal, December 18, 1769, N. C. Col. Rec., VIII, 162-164.

3 Governor Martin to Lord Hillsborough, March 6, 1772, and Council Journal, Mareh 13, 1773, N. C. Col. Rec., IX, 260-261, 601-605. 
mended the appointment of the latter as receivergeneral. ${ }^{1}$

The failure to make full collections of the quit-rents continued to interfere with the efficiency of the royal government, for the little that was received from this source was absorbed by the regular charges of collection and the accumulated arrears of salary and nothing was left for the current allowances to the colonial officials. ${ }^{2}$ The members of the council, especially, suffered. Living, as many of them did, a hundred miles from the colonial capital, New Bern, they were at considerable expense in attending assemblies, courts and other public meetings. As their sole allowance was a per diem of $7 \mathrm{~s} 6 \mathrm{~d}$, they frequently offered excuses for non-attendance. On at least three occasions they presented petitions for an adequate allowance, such as was given in Virginia. None of these petitions was granted, probably because there were no funds to meet such demands. ${ }^{3}$ But the effect upon the council of the lack of an adequate allowance shows how close was the connection between the failure to enforce the quit-rents, and the notoriously weak royal administration in North Carolina toward the close of the colonial period. ${ }^{4}$

1 Governor Martin to the Treasury, July 29, 1774, Treas. 1: 505, ff. 317, 321. Rutherfurd's accounts for the period March 25, 1773, to March 25, 1774 , show the justice of Governor Martin's complaints. Altogether, quitrent collections of $£ 1,4173 \mathrm{~s} 4 \% / 4 \mathrm{~d}$ were reported. But of this sum $£ 991 \mathrm{ss}$ $101 / 2 \mathrm{~d}$ was merely a credit for quit-rents on McCulloh's account. The balance was collected from six counties, with nothing at all reported from ten of them. As the entire rent roll was roughly estimated at this time as from $£ 7,000$ to $£ 8,000$, it is obvious that only an insignificant part of the quit-rents was being accounted for. N. C. Quit-Rent Accounts, 1773-1774, Treas. 1: 505, f. 320 .

2 All the revenue from the quit-rents for 1773-1774 was used to pay the charges of collection. N. C. Quit-Rent Accounts, 1773-1774, Treas. 1: 505, f. 320 .

3 N. C. Col. Rec., V, 763; VII, 484, 800; IX, 375, 646-647.

${ }_{4}$ Up to March 25, 1773, the arrears due various royal officers in North 
As elsewhere in the American colonies, the quit-rents were abolished in North Carolina at the outbreak of the Revolution. Among the resolutions passed by the Mecklenburg Committee was one that called upon all collectors to pay over for public purposes their receipts from these feudal dues. ${ }^{1}$ Even more significant were the instructions given the Mecklenburg delegates to the provincial congress at Halifax, requiring them to see that men should "be quieted in their titles and possessions, and that provision [should] be made to secure men from being disturbed by old and foreign claims against their landed possessions." "2 These instructions were followed in the declaration of rights, which confirmed the titles of individuals, "holding or claiming to hold" under laws made by the crown or the proprietaries, and stipulated that the property in the soil should belong to the people collectively. The incorporation of this declaration of rights in the state constitution, and the prohibition of perpetuities marked the final overthrow of the quit-rent system in North Carolina. ${ }^{3}$ Any future claims for arrears were precluded by an act passed in 1777 which continued suits that had been brought under the royal government, but excepted those which had been instituted, "in the name of the king of Great Britain, when this territory was under his government and owed alle-

Carolina were estimated at $£ 11,3686 \mathrm{~s} 3 \mathrm{~d}$. Governor Martin proposed to offset these arrears by credits upon the quit-rents of the several officers. Governor Martin to Earl of Dartmouth, May 27, 1773, and List of Arrears due March 25, 1773, to royal officers, N. C. Col. Rec., IX, 646, 653-655.

1 Resolutions, Mecklenburg Committee, May 31, 1775, N. C. Col. Rec., IX, 1284.

2 Instructions to Mecklenburg Delegates, N.C. Col. Rec., X, 870 et seq.

3 Declaration of Rights, December 17, 1776, and State Constitution, December 18, 1776, N. C. Col. Rec., X, 1004-1006, 1013. 
giance to him for quit-rents and arrears of quit-rents said to be due for lands held of the said king."

The very slight measure of success that attended the quit-rent system in North Carolina was primarily due to the ill-advised policy pursued by the British officials in London. At the beginning of royal control they made grave mistakes in demanding a quit-rent that was double the usual rate, and in attempting to force payments in proclamation money rather than in the usual form of commodities. Had the Privy Council confirmed the Grand Deed to Albemarle, and accepted a rate of $2 \mathrm{~s}$ per 100 acres, together with payments in commodities, it is possible that the quit-rents might ultimately have been enforced as successfully in North Carolina as in Virginia. Had the land system been properly adjusted at the time the crown assumed control of North Carolina something might have been accomplished, but the British government insisted on conditions that the assembly would not accept, and so failed to secure the quit-rent act that was absolutely necessary. Meanwhile the local representatives of the crown, lacking the support of the assembly, found that the quit-rents could not be enforced by arbitrary measures. Another serious mistake of the British government was the grant of a part of the province to Lord Carteret, afterwards the Earl of Granville. This grant provoked the usual hostility to a propriety, and seriously interfered with the enforcement of the quitrents in the remaining part of North Carolina. The long and inefficient administration of John Rutherfurd as receiver-general must also be taken into account, while the failure of the Privy Council to sustain the governor in dismissing so incompetent an official, put an end to any effective supervision of the quit-rents in the colony.

1 Act of the Assembly, 1777, N. C. State Rec., XXIV, 62. 
The mission of Henry McCulloh was a mistake. Temperamentally, McCulloh was unfitted for his position, and even had he been a more tactful individual, better results would have been secured if Governor Johnston, who was thoroughly conversant with local conditions, had been left unhampered in the work of settling the quit-rents.

In spite of the discord that was stirred up by the many mistakes in royal policy, the people of North Carolina made no protest during the colonial period against the principle of paying a quit-rent, but accepted this feudal due as a customary charge. ${ }^{1}$ Their opposition was aroused by arbitrary methods of enforcement, and by what they conceived to be unjust terms, both in the rate and the medium of payment. They could scarcely be expected to submit tamely to a quit-rent that was twice as large as that paid across the border in Virginia and collected in a much more burdensome fashion. The failure of the British government to appreciate this situation was typical of many similar mistakes that were everywhere made through a lack of accurate knowledge of local conditions in the colonies. In North Carolina so obtuse a policy had a serious effect, for, aside from the discord aroused by the quit-rents, the small sum that was collected did not provide a sufficient allowance for the local officials. To this cause must be ascribed in large measure the weak administration that characterized the period of royal control.

1 That the principle of a quit-rent was generally accepted was shown when it was included in the conditions of settlement for the colony of Transylvania, where Richard Henderson reserved 2s per 100 acres to himself as proprietary. Had the quit-rent itself been obnoxious, it would scarcely have been included in terms that were drawn up in order to attract new settlers. Governor Martin to Earl of Dartmouth, March 10, 1775, and Minutes, Proprietors of Transylvania, September 25, 1775, N. C. Col. Rec., IX, 1155; X, 258-260. 


\section{CHAPTER XI}

\section{ROYAL QUIT-RENTS: IN SOUTH CAROLINA}

Is South Carolina, as in North Carolina, the royal government inherited a disorganized system of quit-rents from the proprietary period and found the difficulties of collection vastly increased because of the unsettled problems of the land system. But some of the other disturbing factors in North Carolina were absent from the neighboring colony. The influence of the Virginia quitrent system, which had resulted in the much disputed Grand Deed to Albemarle, was not felt to any appreciable extent; the crown never set off a propriety, such as the Granville Grant, to become a perennial source of discord; and the medium of payment, likewise, never aroused serious irritation. Accordingly, the quit-rent system in South Carolina was far more successful during the royal period than that in North Carolina, and by the end of the colonial era had become comparatively well organized and established.

Yet the royal policy was little wiser in the one colony than in the other. At the very beginning of royal control the British government made a serious mistake in proposing a prohibitive rate, one penny an acre, upon all future grants. Governor Johnson protested in memorials to the Treasury, saying that he believed any advance made in the customary rate of 1 s per 100 acres with $£ 2$ purchase money would force many who had received dormant patents for baronies of 12,000 to 48,000 acres to take up these grants, since they bore a quit-rent 
often of a nominal character. ${ }^{1}$ In accordance with this advice, the Board of Trade fixed the quit-rent for new patents at first at $2 \mathrm{~s}$ per 100 acres, a rate that would probably have proved satisfactory, inasmuch as the additional one shilling would have been counterbalanced by the waiving of purchase money. But upon the receipt of information, "to be depended on," that the land would bear a higher rate, the board finally decided upon a minimum quit-rent of $4 \mathrm{~s}$ per 100 acres which should be payable in proclamation money. ${ }^{2}$ As most of the proprietary grants reserved only one shilling, the adjustment of the quit-rents, in case the original patent had been lost, now became a matter of much importance, and, as Governor Johnson had predicted, many dormant patents were revived in order to take advantage of the lesser rate. This final decision to reserve four shillings rather than two shillings became, therefore, one of the chief causes of a bitter controversy over land titles that greatly decreased the efficiency of the quit-rent system in South Carolina.

A similar lack of wisdom characterized the measures adopted for the collection of the quit-rents. In order to insure the payment of these charges, the Board of Trade proposed a patent in the form of an indenture, which provided that if the quit-rents remained unpaid for three

1 Memorials of Governor Johnson, March 7 and 18, 1730, C. O. 5: 361. These dormant grants were those to territorial magnates. They usually called for 12,000 to 48,000 acres, and did not specify an exact location. As most of them carried a quit-rent of a peppercorn, a shilling, or else 1s per 100 acres, they formed a convenient medium to take up land, should the quit-rent be advanced. Smith, South Carolina as a Royal Province, pp. 34-35.

2 Instructions to Gorernor Johnson, September 17, 1730, C. O. 5: 192 , p. 88; Board of Trade Report, June 10, 1730, S. C. Public Rec. (MS.), XIV, 141-145; Thomas Lowndes to Sir Orlando Bridgman, June 12, 1733, C. O. 5 : 362. 
years, the land should revert to the crown. The assembly objected that so rigid a patent would render landholding altogether too precarious, and that five, rather than three years, was a more reasonable period. The British attorney-general, after a careful examination of the usual form of patents in other colonies, opposed an indenture, but supported the three years' limit before reversion. A patent in accordance with this opinion was finally adopted. ${ }^{1}$ In contrast with this strict contract for the payment of the quit-rent stands the system of actual collection which was very imperfectly managed by the receiver-general, John Hammerton. As no provision was made for deputies, and as North Carolina was included in the same jurisdiction as South Carolina, the burden of collection proved to be altogether too heavy for a single official. ${ }^{2}$ This defect was partly corrected by the appointment of a new officer, James St. John, as inspector and controller of quit-rents, whose duty it was to keep up a complete roll of each of the Carolinas, to report all frauds, and to transmit to the Treasury in England observations for the improvements of the quitrents. $^{3} \quad$ But even with the check afforded by this official, the inadequate means of collection proved detrimental to the quit-rent system.

The next important step was to secure a satisfactory

1 The special objection of the assembly was directed against the clause for the payment of the quit-rent, in which the phrase, "yielding and paying," had been altered to read, "on condition." Governor Johnson to Board of Trade, and to Duke of Newcastle, February 10, 1732, and Francis Fane to Board of Trade, October 7, 1735, C. O. 5: 388, ff. 38-42, 365.

2 Commission to John Hammerton, September 16, 1730, Treas. 52: 37, pp. 73-75.

3 A salary of $£ 400$ was allowed, and the first incumbent, James St. John, was also made surveyor-general and deputy auditor of South Carolina. Commission and Instructions to St. John, March 22 and May 15, 1731, Treas. 52: 37, pp. 179-180; Treas. 54: 31, pp. 375-377. 
quit-rent act. The instructions to Governor Johnson contained the same terms as in North Carolina, including especially the remission of arrears-provided the quit-rents were paid in the future in proclamation money -and the registration of all grants. ${ }^{1}$ Soon after the receipt of these instructions, Governor Johnson secured the introduction of a quit-rent bill in the assembly. But before the bill was taken up, the attorney-general of South Carolina, Benjamin Whittaker, pointed out that if the clause in the proposed act for the confirmation of all grants were allowed, it would validate the titles to great tracts of land that had been taken up under dormant proprietary grants, either at a nominal rate or at one much lower than the four shillings established by the royal government. To validate such titles, he asserted, would seriously interfere with the development of the province, and would cause an annual loss of fully $£ 1,200$ from the rent rolls. ${ }^{2}$ This opinion Governor Johnson transmitted to the assembly with a statement that he would not confirm these questionable grants without further instructions from England. ${ }^{3}$ A long series of messages now went back and forth between the council and the lower house. In half-hearted fashion the council upheld the royal instructions, but the lower house generally prevailed in the joint conference. ${ }^{4}$ The act as

1 Doubtless in order to prevent the passage of such acts as those that Governor Archdale had been compelled to sign, the governor was forbidden to assent to any bill of an "unsound and extraordinary nature," in which the crown's prerogative "or the property of Our subjects" was affected, unless its execution was suspended awaiting the royal pleasure. Instructions to Governor Johnson, September 17, 1730, C. O. 5: 192; Abstract of Commissions and Instructions, Brit. Mus., Addit. MSS. 30372, f. 8; Board of Trade Report, June 10, 1730, S. C. Public Rec. (MS.), XIV, 141-143.

2 Observations of Benjamin Whittaker, March, 1731, C. O. 5: 362.

3 Journal of S. C. Assembly, March 4, 1731, C. O. 5 : 432.

4 Journal of S. C. Assembly, March 24 to May 28, 1731, C. O. 5: 432. 
finally passed was altogether unsatisfactory from the standpoint of the crown. In return for the remission of arrears, it required that all grants should be registered within eighteen months, and despite Whittaker's opinion and the supposed opposition of Governor Johnson, it coolly proceeded to validate all titles, including the questionable ones that dated from the proprietary period. It also repealed an earlier measure passed under Governor Archdale which permitted a commodity payment, and provided henceforth that all quit-rents should be settled in proclamation money. If such were not promptly paid, the act permitted distraint, and if they were not settled within five years, it declared that the land should revert to the crown. ${ }^{1}$

In sending this bill to the Board of Trade, Governor Johnson apologetically represented that it was the best he could secure, and called special attention to the requirement for the payment of the quit-rents in proclamation money. Confirmation of the questionable proprietary patents, he declared, was necessary, for after the closing of the land-office many persons had secured land under them, and unless their titles had been recognized,

1 The available distress was so limited that this remedy was really a useless one. The act provided that "No rice, corn, or other grain, whilst in the sheaf or ear, either in the field or barn, shall be liable to any distress for quit-rents-till threshed out, nor negroes or any other slaves, nor waggons, earts, or carriages, loaden or unloaden, going in the king's high road, or private path, to or from a landing, nor oxen or horses drawing the same, nor the loading so carried or drawn, nor any goods in boats, periagoes, or other vessels on the water; nor oxen or horses of the plow on any plantation where any other horses or cattle are shown and delivered, nor mills or other plantation tools, or utensils, or canoes, boats, or periagoes, belonging to the owner or any other person, when other sufficient distress is shown or produced." The places fixed for collection of the quit-rents, which were evidently chosen for the convenience of the tenants, and seem to have been retained throughout the colonial period, were Port Royal in Granville County, Winyaw in Craven County, and Charlestown for Berkeley and Colleton counties. S. C. Statutes at Large, III, 289-304. 
it would have been impossible to secure this act which was "absolutely necessary for the peace and tranquillity of the province." Johnson's defense of the proprietary patents was not without a personal bias, since the crown's attorneys had already held that a patent for 24,000 acres issued in 1686 to his father, Sir Nathaniel Johnson, was void. As this had been a test case, inferentially the other questionable patents were invalid. ${ }^{2}$ James St. John, inspector and controller of the quit-rents, pointed out that Governor Johnson had assented to the act confirming these "bad" patents with a full knowledge of this opinion. Nor was St. John satisfied with the attitude of the council and the commons with regard to registration, inasmuch as a bill to extend the time limit was being considered. This proposed delay, he believed, was intentional, for "the country in general seem to join in the sense of the bill [and] if the crown will not confirm the quit-rent act, he will get no account of the rents." As to the provisions for distress, St. John considered that they would have little real effect in a country where there were no markets and only one settled town. ${ }^{3}$ In his opposition to the bill he was supported by the Treasury which held that it encroached upon the royal prerogative and was contrary to instructions. ${ }^{4}$

The Board of Trade, too, made an unfavorable report, asserting that the act had been supposedly passed "under colour" of the instructions to the governor, although actually, "it is very far from answering the intent of them." It was, the board believed, "a very partial act, calculated for the interest of some particular inhabitants

1 Governor Johnson to Board of Trade, November 14, 1731, C. O. 5 : 362.

2 Smith, South Carolina as a Royal Province, p. 35.

3 Memorial from St. John to Board of Trade, September 6, 1732, S. C. Public Rec. (MS.), XV, 149 et seq.

4 J. Scrope to Board of Trade, October 6, 1732, C. O. 5: 362. 
of South Carolina to the prejudice of Your Majesty's just rights and claims in that province," and should it be put in force, "the value even of the ancient quit-rents [would be] diminished, the lawful powers and rights of the crown invaded and neglected, and both the establishment and collection of Your Majesty's quit-rents so ill settled and regulated as to be left impracticable, or at least very precarious." For these reasons it recommended that the crown disallow the act. ${ }^{1}$ Notwithstanding these adverse representations, the Privy Council took no definite action at this time, and the act came to be regarded as the legal basis for the quit-rent system in South Carolina. ${ }^{2}$

Meanwhile, Governor Johnson was unwearied in his efforts to prevent the repeal of the quit-rent act. First he asked that such action be delayed twelve months, in order that registration might be completed. ${ }^{3}$ Three months later he sent a personal agent to impress upon the Board of Trade the merits of the act, of which the beneficial effects, he claimed, were now becoming apparent, since many patents had been registered, and the tenants were paying their quit-rents in proclamation money. ${ }^{4}$ Later, he even defended the clause that confirmed all grants, asserting that as much land had been taken up under the questionable proprietary patents, many innocent purchasers would be "left in the lurch" unless these titles were upheld. ${ }^{5}$ These persistent efforts

1 Report of Board of Trade, November 1, 1732, S. C. Public Rec. (MS.), $\mathrm{XV}, 240-246$.

2 Proclamation, April 3, 1734, C. O. 5 : 363.

3 Governor Johnson to Board of Trade, January 8, 1733, C. O. $5: 364$.

4 Governor Johnson to Board of Trade, April 6, 1733, C. O. 5: 364.

5 Governor Johnson claimed that as his father's patent had not even mentioned the province in which the land lay, the decision with regard to it could not influence other titles. Governor Johnson to Board of Trade, September 28, 1734, C. O. 5: 364. 
of Governor Johnson to secure confirmation of the quitrent act, were not, according to Benjamin Whittaker, altogether disinterested. After the land-office was closed, he asserted, the dormant proprietary patents "began to rear up their heads," fully 80,000 acres being taken up under them between 1720 and 1731, including 12,000 acres surveyed for the governor under the patent that had been issued to the latter's father, and had been declared void. The confirmation of such claims with a one shilling rather than a four shilling quit-rent was, Whittaker declared, the real object of the act. ${ }^{1}$

That these charges of official connivance were not without foundation appears from the persistent attempts of the governor and council to discredit St. John and Whittaker. Under cover of a trumped-up charge of insubordination and hostility to royal officials, the council asked that St. John should be suspended from his offices. ${ }^{2}$ Governor Johnson characterized him as, "the most vain and weakest of men," whose official conduct was filled with "corruption, partiality, and an open defiance of the powers of the legislature, as well as disrespect and disobedience" to the instructions of the crown and the governor. Whittaker, he declared, was "a most active fellow in stirring up contention" and one who "ran" St. John, and he expressed the hope that his own representations would have more weight with the Board of

1 Benjamin Whittaker to Duke of Neweastle, July 12, 1733, C. O. 5 : 388, ff. 203-210. The agent for South Carolina denied as "utterly false", the statement that Governor Johnson had taken up land upon the basis of questionable proprietary patents. But the weight of testimony tends to prove that the governor was by no means disinterested in his efforts to secure the confirmation of the act that was passed in 1731. See Board of Trade Journal, December 10, 1734, C. O. 391: pp. 44, 214.

2 Representations of South Carolina Council, December 15, 1732, C. O. 5 : 388 , ff. 25 et seq. 
Trade than the libels of Whittaker, "filled up with false facts, allegations, and crafty insinuations." 1

This official dislike was soon manifested toward St. John in even more pointed fashion. A copy of the observations on the quit-rent act which he had sent to the Board of Trade, was privately forwarded to South Carolina and was laid before the assembly by the governor. But some other pretext than the mere fact that he had done his duty as a crown official was necessary if punishment were to be justified. Consequently he was charged with having made, in a private conversation, remarks that were vaguely described as "very insolent and highly affronting" to the honor of the assembly, and he was committed to the custody of "John Brown, gentleman," messenger of the commons. After three months' imprisonment, he was discharged with a public reprimand by the speaker for the "insolence and indignity" of his conduct. ${ }^{2}$ This tardy release seems to have been due to the orders of the Board of Trade, which had taken swift measures to correct such unjust treatment of a royal official. $^{3}$ But St. John had learned his lesson, and was not inclined thereafter to expose the designs of the official coterie of land speculators in South Carolina.

Determined to enforce the quit-rents in the province, the Board of Trade now proposed to establish a court of exchequer, although such a step was regarded with little favor in the colony. Nevertheless, the crown's attorney suggested such a court in 1737 as the central feature of a quit-rent bill. ${ }^{4}$ The court was to be endowed

1 Governor Johnson to Board of Trade, January 29, 1733, C. O. 5 : 364.

2 Minutes, South Carolina Assembly, February 10 and May 10, 1733, C. O. 5: 433 ; Benjamin Whittaker to Walpole, September 21, 1732, C. O. 5 : 362, and to Duke of Newcastle, July 29, 1733, C. O. 5: 388, ff. 210-211.

3 St. John to Board of Trade, 1733, C. O. 5: 362; Board of Trade Journal, June 5, 1733, C. O. 391 : 43, pp. 74-75.

4 Governor Johnson to Board of Trade, November 21, 1732, C. O. 5: 364 . 
with ample powers, and with authority to make final decisions, unless an appeal were taken to the Privy Council. The proposed act also provided for the registration of all grants, but confirmed only those proprietary patents that had actually been taken up and settled before the crown purchased the colony. In addition, the act remitted all arrears accruing from the proprietary period, prescribed exact regulations for the payment of quit-rents in proclamation money, "or the value thereof in silver or current money," and made ample provisions for distress, allowing reversion of the land to the crown upon the nonpayment of the quit-rents for a fixed period. ${ }^{1}$

Had it been possible to secure the passage of this act, the quit-rents would have been placed upon a satisfactory basis. The titles to lands that had been taken up under the dormant proprietary patents after the crown purchased the Carolinas would have become invalid, and speculators would have been forced either to surrender their uncultivated tracts, or else to pay the quit-rents. But through their agent in London, the landholders of South Carolina immediately protested against the proposed act, insisting especially that all patents taken up prior to December 31, 1731, rather than July 25, 1729, the date of the royal purchase; should be allowed. The motive for this proposed change was obvious, for it would have confirmed the large tracts that had been taken up by the governor and his friends upon the basis of the dormant proprietary patents. Also, the landholders opposed the creation of a court of exchequer, and asserted that as the act of 1731 had already secured a rent roll and the payment of the quit-rents in proclamation money, the people, exasperated by its repeal, might be unwilling

1 J. Wittes to Alured Popple, November 1, 1734, C. O. 5 : 364. 
to pass a new law. ${ }^{1}$ In face of this local opposition, the passage of the proposed act was not urged at this time.

Without the sanction of the assembly, it was impossible to establish a court of exchequer in South Carolina. In 1736, when Governor Johnson attempted to open a court of this type, the persons summoned for the jury refused to appear, alleging that there was no provincial law to compel them to serve under such conditions. ${ }^{2}$ An attempt was now made to induce the assembly to pass an act that would set up a court of exchequer with full jurisdiction over the royal revenues, and with the same power and rules as in England. ${ }^{3}$ Though the council urged this bill upon the commons as a matter of justice to the crown's interest, scant attention was paid to its plea. Then the British government attempted, in accordance with an opinion of the crown lawyers, to establish the court by act of prerogative. ${ }^{5}$ Instructions to Governor Horsey required him to call a court of exchequer, whenever it became necessary, in order to secure speedy justice in cases relating to the quit-rents, and to report upon the advisability of founding such an institution upon a permanent basis in South Carolina. ${ }^{6}$ But these instructions accomplished nothing, for even with the best intentions, the governor could not carry out a proposed measure in face of the opposition of practically an entire province.

Meanwhile, popular hostility toward the crown's quit-

1 Remarks of Mr. Yonge, about 1734, and Mr. Yonge to Alured Popple, February 18, 1734, C. O. 5: 364.

2 Representations of sundry officers in charge of the South Carolina quit-rents, 1737, C. O. 5: 366.

3 Message of Council to Commons, February 25, 1737, C. O. $5: 366$.

4 Message of Council to Commons, March 2, 1737, C. O. 5: 366.

5 Opinion of D. Ryder and J. Sharpe, June 12, 1738, C. O. 5 : 366.

6 Minutes of Privy Council, July 31, 1738, and Commission to Governor Horsey, 1738, C. O. 5: 366. 
rents was becoming more manifest. By advertisements in the South Carolina Gazette and in public places, St. John gave notice that his office in "Charlestown" would be open for the registration of all grants, but though he published "the very words" of the quit-rent act, in order "to prevent all doubt and scruples, and to the end that no person may plead ignorance of the law," the response was far from satisfactory. ${ }^{1}$ The efforts of the receivergeneral, John Hammerton, to collect the quit-rents met .an equally discouraging reception. In numerous advertisements he called upon the people to pay their quitrents, threatening them with suits in case they did not comply. ${ }^{2}$ Aside from the general disinclination to pay the quit-rents, he found that the burden of collection was a most arduous one, and that occasionally, owing to the difficulties of travel, he was compelled to rely upon the rather unsatisfactory work of deputies in the outlying districts. ${ }^{3}$ Moreover, when many persons insisted upon the settlement of their quit-rents in provincial currency rather than in proclamation money as was required by law, Hammerton felt that he was obliged to accept such payment at the current rate of exchange. ${ }^{4}$ With

1 The diligence with which St. John administered his office was shown by his attendance in Charleston every day, "from the hours of nine till twelve in the forenoon, and from two to five in the afternoon, Sundays and holidays only excepted.', South Carolina Gazette, November 17, 1731, to July 1, 1732, passim. Copies of the act were offered for sale at the stores, as "very proper for everyone that has lands." Ibid., March 15, 1735.

2 South Carolina Gazette, April 1, 1732, and following.

3 On a trip to Winyaw to collect the rents of Craven County, Hammerton was taken "ill of a fever," and as his "ill state of health" would prevent any personal attendance, he called upon the people of Craven County to pay their quit-rents to Peter Gaudett, collector of the Port of Georgetown. South Carolina Gazette, July 12, September 2 and especially October 14, 1732.

4 A typical instance of the difficulties that Hammerton encountered was the case of one Sirre, a justice of the peace, who settled a part of his quitrents in currency, but absolutely refused to pay the remainder. Such con- 
a like consideration for public opinion, he warned the people to pay their quit-rents or he would be obliged to distrain. Very considerately he added that he hoped "no person will take it amiss after this publication." With the aid of St. John, Hammerton was able to effect such improvement that by 1740 the annual returns from the quit-rents amounted to more than $£ 1,500$, or about half of what was due. In view of the practical breakdown of the quit-rent system under the proprietary régime, this showing was an exceedingly encouraging. one. It had been accomplished, too, in spite of the obstacles presented by the great uncultivated areas upon which no distress could be levied, and of the continued failure of the government to adjust the many questionable patents. ${ }^{2}$

The revenue from the quit-rents continued to be spent, as during the proprietary period, for administrative purposes. At first under the royal government the expenses

duct, Hammerton asserted, had a bad effect upon " unguarded people." $\mathrm{He}$ was obliged to use a public advertisement as the only possible means of reaching this obdurate tenant. South Carolina Gazette, December 23, 1732.

1 South Carolina Gazette, December 16, 1732.

2 The following table shows the steady increase in the collections of the quit-rents which were made in proclamation money:

\section{Years}

July 25, 1729, to March 25, 1732

March 26, 1732, to March 25, 1735

March 25, 1735, to March 25, 1736

March 25, 1736, to March 25, 1737

March 26, 1737, to March 26, 1738

March 26, 1738, to March 25, 1739

March 26, 1739, to March 25, 1740
Amount

$$
\begin{array}{rrrr}
389 & 5 \mathrm{~s} & 1 & \mathrm{~d} \\
973 & 2 \mathrm{~s} & 63 / 4 & \mathrm{~d} \\
1,184 & 13 \mathrm{~s} & 11 & \mathrm{~d} \\
940 & 11 \mathrm{~s} & 61 / 4 & \mathrm{~d} \\
1,367 & 12 \mathrm{~s} & 10 & \mathrm{~d} \\
902 & 19 \mathrm{~s} & 1 / 2 \mathrm{~d} \\
1,584 & 15 \mathrm{~s} &
\end{array}
$$

S. C. Quit-Rent MSS., 1733 to 1742 ; S. C. Quit-Rent Account, February 23, 1741 , C. O. 5: 368 . By 1740 the rent rolls showed quit-rents of $£ 1,6756 \mathrm{~s}$ $81 / 4 \mathrm{~d}$ sterling due on grants under the crown at $4 \mathrm{~s}$ per 100 acres. Together with the quit-rents from the proprietary period, the total roll was $£ 2,626$ $11 / 2 \mathrm{~d}$ sterling, or $£ 3,14418 \mathrm{~s} 2 \% / 12 \mathrm{~d}$ proclamation money. S. C. Quit-Rent Account, February 23, 1741, C. O. 5 : 368. 
of collection absorbed the entire revenue, ${ }^{1}$ but as the situation improved, the crown began to accumulate a fund that was available for allowances to those royal officials in South Carolina whose duties made them unpopular in the colony, including especially the attorneygeneral, the clerk of the crown, and the provost marshal. ${ }^{2}$ The need for such allowances is illustrated by the case of George Morley, the provost marshal, who, when the assembly refused to allow him a salary, had been obliged to fit up the jail at his own expense. ${ }^{3}$ Yet as most of the royal officials in South Carolina received salaries from other sources, the quit-rents were not as vitally important as in North Carolina. However, their value to the royal government in South Carolina was strikingly shown in 1733 when, chiefly as a result of his stand against the land frauds, the assembly reduced by twothirds the salary of Chief Justice Wright.. ${ }^{4}$ In this crisis, as in the similar case of Chief Justice Prat in New York, the Treasury recommended that the chief justice should be made independent of the assembly. Accordingly, Chief Justice Wright received an allowance of $£ 200$ which was payable from the quit-rents. ${ }^{5}$

In view of the continued difficulties in adjusting the

1 These charges included, in proclamation money, the following salaries: inspector and controller of the quit-rents $£ 100$, auditor-general $£ 140,5$ per cent. on all receipts to the deputy auditor and 10 per cent. to the receivergeneral, and to the clerk of the receiver-gèneral £20. Also, an eighth of the gross revenue was retained to pay the share of Lord Granville, until the settlement made with him in 1744. S. C. Quit-Rent MSS., 1733-1742.

2 In sterling money these allowances were: to the attorney-general $£ 80$, to the clerk of the crown $£ 25$, and to the provost marshal $£ 40$. Royal Warrant, etc., March 7, 1738, Treas. 52: 40, pp. 10-13.

3 Minutes of Privy Council, October 27, 1735, and May 13, 1736, C. O. $5: 365$.

4 Smith, South Carolina as a Royal Province, pp. 43-46.

5 Quit-Rent Accounts, 1733-1744; Report of Treasury Board, 1735, Treas. 1: 286, ff. 19-22, 50 . 
land and quit-rent systems, together with the "great exertions of power' on the part of the governors, the British government finally decided, as we have already seen, to send Henry McCulloh as a special representative to the Carolinas. ${ }^{1}$ Aside from the attempt to solve the special problems involved, McCulloh's mission becomes of general interest as illustrating the means available to the British government of meeting official intrigue in the colonies. McCulloh's instructions required that he proceed to Carolina with "convenient speed," and there make a full investigation of the quit-rent and land systems. He was to inspect all accounts since 1716, and where the quit-rents had not been collected or the conditions of cultivation fulfilled, was to summon before him the delinquent landowners. He was also to examine the existing system and to draw up the necessary rules for the speedy collection and accounting of the quit-rents and the detection of concealments. He was to confirm all proprietary patents up to 1727 , but none after that date, and to allow no lost grants or surplus lands, without the reservation of a quit-rent of $4 \mathrm{~s}$ per 100 acres. All local officials were required to furnish McCulloh with the necessary aid in his mission, and he was empowered to apply to the assemblies for the passage of suitable quitrent acts. He was given an ample allowance from the quit-rents, and as a special commissioner he was subject, not to the local authorities, but to the Treasury and the Board of Trade. ${ }^{2}$

1 Petition of Henry MeCulloh to Treasury, February 10, 1748, Treas. 1: 330, f. 169; Commission to Henry MeCulloh, May 16, 1739, Treas. 52: 40, pp. 281-284.

2 McCulloh was allowed a salary of $£ 600$, and $£ 200$ annually for clerk's hire, " out of our revenue of quit-rents that shall be recovered and improved in our said provinces, or either of them," after paying the salaries of the officials already chargeable to this revenue. Commission and Instructions to Henry 
Even these ample powers, McCulloh considered, were not sufficient to cope with the great difficulties of his mission. There should be, he held, an outright repeal of the quit-rent act of 1731. He asked, further, that his instructions regarding the method of granting land should be brought to the attention of the governors of the two Carolinas, that they might give him protection in case of need, and he expressed a desire to be made a member of the councils in the two provinces. ${ }^{1}$ Governor Glen of South Carolina, who was still in London awaiting passage to America, did not favor an increase of McCulloh's powers, as he thought there was no need of repeating rules already in force and saw no reason why McCulloh should be afraid provided he maintained a "just" observance of his instructions. Glen ended his remarks with the sarcastic comment that only men were appointed to the council whose "character and interests" in the province qualified them for that "honorable" body." The Privy Council, however, ruled that in view of the constant evasion of the prescribed method for granting land, McCulloh's instructions should be brought to the attention of the governors of both Carolinas, who would be required to use "special care" in his protection and to lend him every possible assistance. ${ }^{3}$ But this halfhearted compliance with McCulloh's requests hampered rather than aided his mission. Unless the quit-rent act of 1731 were actually repealed, there was not much chance of his settling the land situation in South Carolina, and

McCulloh, May 16, 1739, Treas. 52: 40, pp. 281-284; N. C. State Rec., XI, 35-40.

1 Memorial of Henry MeCulloh, 1739, C. O. 5: 367; Minute of Privy Council, July 31, 1739, C. O. 5 : 367.

2 Governor Glen's remarks on MeCulloh's Petition, August 1, 1739, C. $0.5: 367$.

3 Minutes of Privy Council, August 14, 1740, C. O. $5: 368$. 
without a seat in the council he was likely to have little influence in the colony. ${ }^{1}$

McCulloh arrived in South Carolina, March 3, 1741, fully convinced, from the attitude already displayed by Governor Glen, that he could expect little aid from the royal officials. ${ }^{2}$ Under such conditions it would have been wise had he adopted, at least openly, a conciliatory policy, but with a characteristic lack of tact, he turned to the popular assembly, explaining the purposes of his mission and bespeaking its aid. ${ }^{3}$ In an address to the people of South Carolina he made a similar appeal for popular support, although underlying his appeal was a covert threat of legal proceedings if they failed to observe the terms granted for landholding and refused to pay their quit-rents. ${ }^{4}$ By these two direct appeals, McCulloh ranged himself in open opposition to the members of the council, who, accepting the challenge, exhibited a hostility that constantly baffled his efforts to carry on his mission. Following the tactics already used in the case of St. John, they again attempted to intimidate an official who was proving overzealous in the interests of the crown. Their opportunity came when McCulloh ordered a warrant for 250 acres of land that had been signed by the governor to be stopped, on the ground that it was not drawn up in accordance with the royal instructions. Resolving that in this instance McCulloh had assumed

1 For details as to the conduct of McCulloh in North Carolina, see above, pp. 296-299.

2 Henry McCulloh to Board of Trade, November 8, 1741, C. O. 5: 368, and to Horatio Walpole, about 1747, Treas. 1: 330, ff. 142 et seq.

3 Henry McCulloh to Speaker of the Assembly, March, 1741, Treas. 1: 306 , f. 60 .

$4 \mathrm{McCulloh}$ drew attention to the fact that taxes were paid on fully 2,500,000 acres, but that the average quit-rent, since the purchase by the crown, had been only $£ 753$ sterling annually. McCulloh's Proclamation to Gentlemen and Freeholders, C. O. 5: 368. 
undue authority and had acted in contempt of its authority, the council ordered the warrant to be carried out, and sent its "hipstaff" to demand an explanation. But this time the council was confronted with an antagonist of sterner mold than the pliable St. John. McCulloh positively refused to reply, asserting that he did not answer to the governor and council for his official conduct and that the council would not dare press its highhanded demands against a special representative of the crown. The incident marked a McCulloh victory, but it openly revealed the hostility from official quarters that McCulloh was certain to encounter-in carrying on his mission. ${ }^{1}$

McCulloh now worked with redoubled zeal to obtain the support of the assembly and soon reached an agreement with it regarding the preliminary draft of a quit-rent bill. In addition to the registration of grants, and the confirmation of patents in accordance with his instructions, this draft made provision for a rent roll and enforcement of the conditions of cultivation. It avoided any question of legal status, such as had arisen with regard to the quit-rent act passed in 1731, by adding a suspending clause, which prevented the measure from going into effect until actually confirmed by the crown. ${ }^{2}$ McCulloh, now in a conciliatory frame of mind, pointed out to the governor and council the advantages of the proposed act, ${ }^{3}$ but the grand jury at its October session condemned the bill as, "of a dangerous nature to the property of His

1 McCulloh to Board of Trade, November 8, 1741, Council Proceedings, April 3, 1741, and Declinatory Plea of Henry McCulloh, April 8, 1741, C. $0.5: 368$.

2 MeCulloh to Thomas Hill, June 4, 1741, and Proposals of MeCulloh, 1741 , C. O. 5 : 368.

3 MeCulloh to Governor Bull, and to Thomas Hill, 1741, C. O. 5: 368. 
Majesty's subjects in this province,"'1 and though McCulloh insisted that this presentment had been obtained through the influence of the council, he was probably wrong, for the commons soon came to oppose the quitrent act even more than did the upper house. ${ }^{2}$ At the very next session of the legislature, when the council urged the passage of such an act, the commons refused to comply, alleging lack of time, although probably their purpose was to postpone for the time being any settlement of the quit-rents and the land problem. ${ }^{3}$

The consistent hostility of the royal officials in South Carolina was not wholly due to motives of self-interest, since by unreasonable demands and accusations, McCulloh needlessly increased the jealousy that inevitably manifested itself toward a special commissioner. A notable instance of his methods was his treatment of John Hammerton, the receiver-general and secretary of the province, who was, he insinuated, guilty of dishonesty. He complained that Hammerton had failed to make out copies of all accounts, and that almost all of the crown officials in South Carolina were banded together to thwart his mission, either because they were guilty of land frauds, or because they feared lest, by a restriction of the land-office, their fees would be greatly diminished.* These charges are hardly capable of proof. Although Hammerton was careless in his work, he can

1 MeCulloh to Horatio Walpole, about 1747 , Treas. 1: 330, f. 142; Commons House Journal, December 3, 1741, pp. 86-87.

2 The charge of the grand jury was placed upon the minutes of the commons, and was referred to a committee. Commons House Journal, December 3, 1741, pp. 86-87.

3 Commons House Journal, March 1 and 2, 1742, pp. 264-268.

$4 \mathrm{MeCulloh}$ found that Hammerton actually owed the crown $£ 1,283 \mathrm{ss}$ $10 \mathrm{~d}$ on March 25, 1738, and that various irregularities appeared in his accounts, such as the failure to produce vouchers for a number of payments. Actually, Hammerton was probably careless rather than dishonest. McCulloh to Board of Trade, November 8 and 12, 1741, C. O. 5: 368. 
scarcely be blamed for failing to meet McCulloh's demand for copies of all grants since 1718, since, as he said in his reply, he had no funds from which to pay the necessary costs. ${ }^{1}$ The case of Alexander Gordon, clerk of the crown, is much the same, for McCulloh asked him to prepare copies of all land warrants between 1738 and $1742 .{ }^{2}$ In both instances McCulloh put an unfair interpretation upon the clause in his commission which required the local officials to furnish whatever documents he needed. With the small and irregular salaries allowed them, these men had no means of meeting the expense of such extensive copying as he demanded. The lack of coöperation between McCulloh and the royal officers, which was partly due to these unreasonable requests, was forcibly illustrated after the death of the provincial treasurer, when, in order to aid the collection of the quit-rents, McCulloh suggested that this office should be combined with that of receiver-general. ${ }^{3}$ This sensible suggestion let loose a storm of indignation, and the council passed a resolution scoring McCulloh's presumption. The governor haughtily announced that he would choose officials, as in the past, with the aid of the council. Disclaiming any motive other than that of making suggestions, according to his instructions, McCulloh sarcastically thanked the council for its resolution, which "so admirably" displayed its "real attitude" toward himself. ${ }^{4}$

1 Minutes of South Carolina Couneil, March 24, 1743, C. O. 5: 444, pp. 63-64.

2 Minutes of Soụth Carolina Council, March 24, 1743, C. O. 5: 444, pp. $65-68$.

3 This suggestion was a specially pertinent one, since all persons were required to give the treasurer under oath an annual account of their lands. In 1742 there were $2,349,129$ acres upon this tax list, but quit-rents were being paid on only 930,000 acres. George Saxby to Benjamin Whittaker, June 13, 1744, and Whittaker to Board of Trade, June 25, 1744, C. O. 5: 370.

4 See, various official documents, March, 1743, C. O. 5: 369. 
Undaunted by this official hostility, McCulloh proposed to enforce the crown's rights by lawsuits, until Benjamin Whittaker, now chief justice of South Carolina, pointed out the difficulties of such a course. McCulloh then decided to refer the entire situation in South Carolina to the crown. ${ }^{1}$ First warning the governor and council of his purpose, he called their attention to the hindrances that had been thrown in the way of his mission. He was helpless, he said, without the governor's aid, while the prestige of his office had suffered from the summons he had received to appear before the council. Their failure to respect his instructions, and their general official indifference endangered the very existence of the royal government, for he was certain that the quit-rent bill had been defeated by the "unreasonable opposition that issued from those who considered it was to their interest" to continue the rent rolls in their present confusion. ${ }^{2}$ Later McCulloh suggested that all persons, in giving account of their lands to the tax collector, should be required to include full information regarding the quitrents they owed, but the assembly rejected this proposal, owing to the trouble that it would cause the local officials. ${ }^{3}$

McCulloh's determined stand had its effect. Fearing the results of the royal displeasure if $\mathrm{McCulloh}$ carried out his threat and appealed to the crown, the council secured the passage of a quit-rent bill at the next session of the assembly. In many of its features this act was similar to that passed in 1731 , but it specifically stated that the purchaser, rather than the original owner of a tract, should be held responsible for the quit-rents that

1 MeCulloh to Whittaker, January 20 and 23, 1743, and Whittaker to MeCulloh, January 21, 1743, C. O. $5: 370$.

2 McCulloh to Governor Bull, February 16, 1743, and to Council of South Carolina, February 12, 1743, C. O. 5: 369, ff. 441, 586-596.

3 McCulloh to Governor Bull, February 21, 1743, and Benjamin Whittaker to Board of Trade, June 25, 1744, C. O. 5: $369,370$. 
were due upon it. The act made provision also for the surrender of surplus land, and permitted the owners of uncultivated tracts to give up their holdings, provided they paid all arrears of quit-rents, and had not wasted their lands by the manufacture of pitch, tar, or turpentine. ${ }^{1}$ Though the governor recommended this act, the chief justice, Benjamin Whittaker, opposed it, claiming that it made no provision for collecting the quit-rents from the many large uncultivated areas which had been granted out upon "head"' rights, and of which the owners were unknown. Whittaker did not approve of the proposed surrender of surplus lands, and thought that the shifting of responsibility for the quit-rents from the original owners to the purchasers constituted an undue assumption of the royal prerogative. In fact, he considered the whole quit-rent situation as lamentable, and was inclined to believe that the efforts to remedy it had been foiled by interested landowners in official position. ${ }^{2}$ McCulloh, too, opposed the act as "likely to open a door for new frauds to be practiced upon the crown," for whereas in former times the planters had been accustomed to rid themselves of unprofitable lands by disposing of them to transients, they would now be able to evade their obligations by law. ${ }^{3}$ Although the South Carolina agent in England called attention, not very convincingly, to the features of the bill that he considered advantageous, he did not succeed in having it confirmed. ${ }^{4}$

1 One of the chief reasons for taking this action was the need of the colony for military aid from the crown. Minutes, S. C. Council, March 2, 1743, C. O. 5: 444, ff. 13-14. See act, passed May 29, 1744, C. O. 5: 370.

2 Benjamin Whittaker to Board of Trade, June 25, 1744, C. O. 5: 370.

3 Henry MeCulloh to Board of Trade, (probably) January 16, 1745, C. O. $5: 371$ :

4 Peregrine Fury to Board of Trade, Norember 12, 1747, and Francis Fane to Board of Trade, September 1, 1746, C. O. 5: 371; Smith, South Carolina as a Royal Province, pp. 68-69. 
The truth probably is that the bill had been passed merely to counteract any representations that McCulloh might make regarding the indifference of the crown officials toward the quit-rents, and no one really expected that its provisions would prove acceptable.

The failure to secure a quit-rent bill embodying his ideas put an end to McCulloh's hopes, especially as he felt that the British government had given him little real support. ${ }^{1}$ Borrowing money in order to defray his expenses, he first went to the "Appelation" Mountains in order to secure information of the French in Louisiana, and then, under a rather broad interpretation of his instructions, he traveled northward, looking into the general conduct of colonial affairs from Virginia to New Hampshire, and sailed from Boston for Bristol, October 2, 1747. His work in South Carolina had not been wholly without results, for he had thoroughly alarmed the official ring of land speculators and had helped to bring about a notable increase in the revenue from the quitrents. ${ }^{2}$ But he had signally failed in the chief ends of his mission, the adjustment of land titles and the reorganization of the quit-rent system. While this failure was due primarily to the opposition he encountered from interested officials, he had exhibited little tact in dealing with a very delicate situation. In appealing directly to the commons at the outset of his mission, he had openly antagonized the officials upon whom he was compelled to rely for help, and before his departure had aroused so much hostility that any settlement of the problems he

1 MeCulloh to Treasury, February 10, 1748, Treas. 1: 330, f. 169.

2 After McCulloh's arrival, the quit-rents increased sufficiently to pay off $£ 2,000$ in arrears of salaries, besides $£ 1,200$ by special warrant to Governor Glen. When he left South Carolina, the receiver-general had a balance on hand of almost $£ 4,600$, and all salaries except McCulloh's had been paid practically in full. MeCulloh to Horatio Walpole, about 1747, Treas. 1: 330, ff. 146-147. 
had undertaken to solve was certain to prove more diffcult than ever. He would have accomplished much more had the British authorities, adopting a more conciliatory policy, compromised upon the $4 \mathrm{~s}$ per 100 acres, and employed the local royal officials, rather than a special representative, to reorganize the quit-rent and the land systems. ${ }^{1}$

An excellent step was taken, probably upon McCulloh's advice, when the receiver-general, John Hammerton, was retired in 1742. His successor, George Saxby, who had been deputy-receiver in 1739 , had already displayed much energy in collecting the quit-rents, repeatedly warning delinquents that he would proceed against them, "without favour or affection to any person whatsoever." That his threats were no mere idle words subsequent events proved. $^{2}$ They stand in strong contrast to the mild exhortations of Hammerton, who called upon the people to pay their quit-rents and arrears, in order that he might make collections "without any further trouble." But such complacency did not injure Hammerton's reputation in the eyes of South Carolina officials, who had little liking for Saxby's methods. Upon quibbling objections the council caused a delay of several months

1 The hostility which McCulloh's mission aroused is illustrated by the difficulty he experienced in securing the payment of his salary. After the receiver-general had refused to make payments from the South Carolina quit-rents, McCulloh appealed to the erown, but he did not secure a settlement for several years, and his unfortunate mission practically ruined him, both in reputation and fortune. MeCulloh to Treasury, about 1754, and MeCullolı's Release, July 6, 1758, Treas. 1: 369, ff. 38-39; 388, f. 71; Minutes of Privy Council, June 16, 1758, C. O. 5: 376; Royal Warrant, March 2, 1752, Treas. 1: 330, f. 135.

2 South Carolina Gazette, April 26 and June 30, 1739, and October 30, 1740. In one advertisement Saxby offered for sale four negroes that had heen seized in distraint for quit-rents. South Carolina Gazette, March 8, 1740 .

3 South Carolina Gazette, especially March 26, 1741, and May 29, 1742. 
before admitting Saxby into his office, ${ }^{1}$ while Hammerton refused to account to anyone but the auditor-general. ${ }^{2}$ Once established in his office, Saxby energetically went to work, and warned the inhabitants of South Carolina that they must pay their quit-rents according to law or he would bring suit against them in the courts. Those who neglected to give notice of the sale of their lands, he declared, would continue to be charged with the quitrents, and no one could plead ignorance of the law. In order to make collections, he announced that he would come to Craven County for twenty days in January, and that delinquents in that distant region would meet the same fate as elsewhere, "for I am determined not to leave the country until I get in the rents." 3 By similarly vigorous advertisements and other public notices, Saxby continued to call upon the people of South Carolina to appear and pay their quit-rents. ${ }^{4}$

But Saxby was not properly supported, for the policy of the British government toward the quit-rent problem in South Carolina, after the failure of McCulloh's mission, was an apathetic one. This became evident after the death of James St. John in 1743, when Lieutenant Governor Bull gave temporary commissions to a deputy auditor and an inspector of quit-rents. Neither appointment was confirmed, nor were commissions for these important offices given to other persons. ${ }^{5}$ This neglect was

1 Royal Warrant appointing George Saxby, February 9, 1742, Treas. 52: 41, pp. 485-486; Council Minutes, August 5, 1742, C. O. 5: 441, ff. 209-210.

2 Memorial of St. John, Hammerton's answer, and Council Minutes, September 16 and November 18 and 25, 1742, C. O. $5: 441$.

3 South Carolina Gazette, August 16, 1742.

4 South Carolina Gazette, passim, especially June 6, 1766, and March 30, 1770.

5 Council Minutes, April 9 and May 5, 1743, C. O. 5: 444, ff. 80, 103; Governor Bull to Board of Trade, May 6, 1743, C. O. 5: 370 . 
especially unfortunate in the case of George Hunter, who, as inspector of the quit-rents, had proved to be an energetic and efficient official. Though both the Board of Trade and the Treasury recommended that he be confirmed in his office, nothing was done, and Hunter was unable to collect any salary after six years of faithful service. ${ }^{1}$ Equally disastrous to the quit-rents was the delay in settling the boundary disputes between North Carolina and South Carolina, ${ }^{2}$ which dragged along for years, causing great confusion, especially in payments of the quit-rents and taxes. ${ }^{3}$ When a boundary line was finally run, it extended through only a part of the region in dispute, and as jurisdiction over a populous frontier district remained uncertain, numerous quarrels arose between the inhabitants and the officials of the two provinces. ${ }^{4}$ Another source of trouble in collecting the quit-rents was the custom of waiving payments for a fixed period, usually for ten years, upon grants to soldiers, to Protestant refugees, and to settlers on township lands. ${ }^{5}$ As these grants led to many disputes over the

1 George Hunter to Governor Bull, August 23, 1743, and to Board of Trade, October 31, 1743, May 4, 1747, June 20, 1748, and August 12, 1749, C. O. 5 : $370,371,372$.

2 North Carolina claimed that the Waccamaw River, which was thirty miles from the Cape Fear at its source and eighty at its mouth, constituted the boundary. South Carolina claimed that the dividing line should be thirty miles south of, and parallel to, the Cape Fear. Governor Glen to Board of Trade, July 19, 1749, and Charles Pinckney to Board of Trade, June 29, 1754, C. O. 5 : $372,374$.

3 Charles Garth to Board of Trade, 1762, C. O. 5 : 377, ff. 291-293.

4 Governor Boone to Board of Trade, November 24, 1763, and Governor Bull to Board of Trade, July 18, 1768, C. O. 5: 377, ff. 829-830; 379, ff. 20-21; Acts, Privy Coun. Col., IV, 742.

5 Acts, Privy Coun. Col., IV, 279, 539; S. C. Land Grants, 1764-1765, and 1767-1773, C. O. 5: 398, 399. 
exact time when the quit-rents were due, they became a source of annoyance in making collections. ${ }^{1}$

But the chief obstacle to the general enforcement of the quit-rents in South Carolina was the continued failure to adjust the many problems of the land system. In 1751 Governor Glen drew a melancholy picture of the situation, and declared that as a result of frauds in the past many persons held far more land than they were entitled to. The only remedy he could suggest was for the governors, in the future, to stick "immovably" to their instructions, but the "great obstacles" he himself had met with "from the public officials here" rendered impracticable a clear and concise statement either of the lands granted or of the quit-rents. ${ }^{2}$ Still more discouraging was a report by Governor Montagu in $\mathbf{1 7 6 6 ,}$ which represented that the receiver-general claimed he could make no estimate of the arrears, since he had never had a rent roll, and it would be impossible to make one out under present conditions. Furthermore, as a record of transfers had not been kept, there could be no distress until the new owners of land charged themselves with the quit-rents in the office of the deputy auditor, a proceeding they took care not to go through with. According to the governor, the receiver-general confessed that had he not held office for many years and thus known most of the people in the province, he could not have collected the quit-rents at all. ${ }^{3}$ Such methods seem hardly

1 The policy was summarized by the Treasury when, upon consideration of a proposal to settle French Protestants in South Carolina, it agreed that, "the general rule of subjecting all lands granted by the crown in America to the payment of quit-rents"' should never be departed from. Jenkinson to Mr. Pownall, August 3, 1763, C. O. 5: 377, f. 445.

2 Governor Glen to Board of Trade, 1751, C. O. $5: 373$.

3 Governor Montagu to Board of Trade, about 1767, C. O. 5: 112, ff. 297-299. 
necessary, since the list of grants which was drawn up for the Board of Trade shows that it would have been possible to make out a fairly complete rent roll, although the indifferent attitude of the British government furnished little incentive for undertaking such a difficult task. ${ }^{1}$ Much good might have been accomplished by the instructions issued in $\mathbf{1 7 7 4}$, which were designed to establish a uniform system of granting land in all the colonies. But these orders came too late to be of any real benefit to the quit-rent system in South Carolina. ${ }^{2}$

In spite of the many hindrances to the work of collection, the quit-rent revenue in South Carolina showed marked improvement under the able administration of George Saxby. Between 1735 and 1740 the average annual return was scarcely a third of the rent rolls, but from 1746 to 1751 it was fully one-half. By 1770 , approximately three-fourths of the rent roll was being collected, and in $\mathbf{1 7 7 2}$ the revenue from the quit-rents was over $£ 1,000$ more than was actually due, showing that a large sum in arrears, as well as the current charges, was being received. With the agitation that preceded the Revolution, there was a marked decrease in this revenue until, after July 19, 1774, no quit-rents seem to have been collected. But the steady growth in this revenue up to the revolutionary period was a sufficient proof of a gradually increasing effectiveness in the quit-rent system. Such success was the more noteworthy in view of the collapse of the proprietary system, which had necessitated practically a fresh start under the royal régime. Had the land frauds been adjusted, and had the numerous

1 The list of land grants is somewhat incomplete, as the proprietary records up to 1692 have been destroyed by fire, but the great bulk of patents is available, together with the quit-rents due on each one. S. C. Land Grants, 1674-1765, and 1767-1773, C. O. 5: 398, 399.

2 See below, pp. 437-438. 
questionable grants been brought upon the rent rolls, even better results might have been secured. ${ }^{1}$

The chief expenditures from the quit-rents of South Carolina covered the salaries of royal officials for whom the assembly would not provide, and the expenses of collection, including especially numerous small items for printing handbills and advertisements, "to send to the country, requiring persons to pay arrears of quit-rents.", But these regular charges by no means exhausted the fund, and on March 26, 1751, there was a balance on hand of $£ 4,55415 \mathrm{~s} 11 \mathrm{~d}$ which, on March 26,1761 , had decreased to $£ 3,64410$ s $2 d$. This large annual balance was absorbed chiefly by the arrears of salary due McCulloh and by a

1 The following table gives the average annual returns and the rent rolls, in proclamation money, for the periods indicated:

\section{Period}

March 25, 1735, to March 25, 1740

March 26, 1745, to March 26, 1751

March 26, 1760, to March 26, 1766

March 26, 1765, to March 26, 1770

March 26, 1770, to March 26, 1771

March 26, 1771, to March 26, 1772

March 26, 1772, to March 26, 1773

March 26, 1773, to June 24, 1774

June 24, 1774, to July 19, 1774

Period

1740

1765
Average annual returns $£ 1,200$

$\begin{array}{rrll}1,660 & 4 \mathrm{~s} & 9 & \mathrm{~d} \\ 300 & 9 \mathrm{~s} & 5 \% \mathrm{~d} \\ 2,355 & 2 \mathrm{~s} & 53 / 5 & \mathrm{~d} \\ 2,417 & 18 \mathrm{~s} & \\ 3,104 & 7 \mathrm{~s} & & \\ 5,139 & 19 \mathrm{~s} & 7 & \mathrm{~d} \\ 1,336 & 15 \mathrm{~s} & 7 & \mathrm{~d} \\ 491 & 4 \mathrm{~s} & 4 & \mathrm{~d}\end{array}$

Rent Roll

$£ 3,14418 \mathrm{~s} 27 / 12 \mathrm{~d}$

$4,115 \quad 7 \mathrm{~s}$

Report on South Carolina Quit-Rent Accounts to House of Commons, February 23, 1741, C. O. 5: 368; Accounts, South Carolina Quit-Rents, 1745-1751, Treas. $1: 347$, f. 79 ; S. C. Quit-Rent MSS., 1733-1742, and 1760-1774.

2 The salaries were: to the attorney-general $£ 80$, to the commander of Castle Johnson $£ 200$, to the secretary $£ 70$, to the provost marshal $£ 40$, to the elerk of the crown $£ 25$, to the auditor-general $£ 100$, to the receivergeneral $£ 70$, or altogether $£ 585$ sterling, equivalent in 1767 to $£ 861$ in proclamation money. The chief justice received $£ 1,000$ currency equal to $£ 200$ proclamation money, and the deputy auditor and the receiver-general were allowed fees of 5 per cent. and 10 per cent. respectively. For advertisements, $£ 3$ was allowed in 1768 , and $£ 116$ s in 1765 . S. C. Quit-Rent MSS., 1760-1774, especially March 26, 1766, to March 26, 1768. 
warrant of $£ 12,000$ in favor of the heirs of Governor Johnston of North Carolina. Both these payments illustrate the value of the quit-rents as the source of a fund at the disposal of the crown, which could be expended, if necessary, upon objects for which the assembly would make no provision. But there is no evidence that the quit-rent revenue in South Carolina was ever remitted to the royal exchequer, as was done in Virginia. The constant struggles with the assembly over the revenue, especially in North Carolina, prevented the accumulation of a surplus in these provinces that might have been sent overseas. ${ }^{1}$

Nor were extraordinary grants from the quit-rents often permitted, although the Treasury in England was besieged with requests for such allowances. A typical petition was one from John Hammerton, who, claiming that fully $£ 500$ was due him in arrears of his salary as secretary, represented in support of his plea the "great care and fidelity" with which he had carried on the office of receiver-general. ${ }^{2}$ But Horatio Walpole, the auditorgeneral, after making sarcastic allusions to the "insuperable obstacles" that had been thrown in the way of St. John, disclaimed any knowledge of "extraordinary services" on Hammerton's part, which the latter seemed to discover only after he found that he owed the crown $£ 3000^{3}$ Undismayed, Hammerton pressed his petition, this time urging his general devotion to the interests of the crown, and the losses he had suffered when he was taken prisoner by the French. ${ }^{4}$ His request does not 1 Accounts, S. C. Quit-Rents, 1745-1751, Treas. 1: 347, f. 79; S. C. QuitRent MSS., 1760-1774.

2 Memorial, John Hammerton to Treasury Board, referred November 18, 1746, Treas. 1: 323 , f. 86 .

3 Horatio Walpole to Treasury Board, December 24, 1746, Treas. 1: 323 , ff. $88-89$.

4 Hammerton to Treasury Board, about 1746, Treas. 1: 323, f. 84 . 
seem to have been granted, a fate that befell a number of other petitions for special allowances from the quitrent revenue in South Carolina. ${ }^{1}$

With the outbreak of the Revolution the quit-rents were allowed to lapse, and, in contrast especially with North Carolina, the several resolutions and constitutions passed in South Carolina after independence was declared, do not mention these charges. ${ }^{2}$ This failure specifically to abolish the quit-rent was probably due to the comparatively small degree of actual hostility that had been aroused toward this feudal due in South Carolina, in contrast with the corresponding attitude in North Carolina. Opposition in South Carolina was directed chiefly against the enforcement of the quit-rents upon the great uncultivated areas that were held, often fraudulently, for speculative purposes, and against the payment of the higher quit-rents demanded by the crown upon questionable proprietary patents. As far as the lands were listed in the rent rolls, the quit-rents were collected in South Carolina with a considerable' degree of success, although the revenue thus secured was much less important in this colony than in North Carolina, where it constituted the chief support of the royal officials.

In South Carolina, as in North Carolina, the British government failed at the beginning to adopt the firm and tactful policy in enforcing the quit-rents that was neces-

1 A petition for a salary to Governor Boone was refused upon the ground that the assembly should make an appropriation. Thomas Boone to Treasury, November 25, 1765, and Report of Board of Trade, C. O. 5: 378, ff. 29-33, 71. A grant from the quit-rents was also refused the surgeon to the royal garrison at Charleston. Report of Treasury, January 13, 1772, C. O. $5: 145$, f. 9 .

2 Thorpe, Constitutions and Charters, 6, 3241-3269; Extracts from Journal of Provincial Congress, 135-153; Journal of General Assembly of South Carolina, September 17 to October 20, 1776, 136-137. 
sary, in view of the practical collapse of the system under proprietary control. The demand for an increased rate in all new patents was a serious error which gave the owners of many dormant proprietary patents a strong incentive to secure the confirmation of their titles. As many of these claimants held official positions in the colony, their influence continually obstructed the attempts that were made to adjust the land situation. The long continued struggle that thus arose illustrates both the difficulty of carrying out royal orders that conflicted with local interests, and the intimate connection that existed between the enforcement of the quit-rents and the regulations for granting lands. Moreover, the ill-starred mission of McCulloh, while accomplishing few permanent results, stirred up much antagonism toward the British government. In spite of such mistakes in policy, the quit-rents were ultimately enforced in South Carolina more successfully than in any other royal colony except Virginia. 


\section{CHAPTER XII}

\section{ROYAL QUIT-RENTS : IN GEORGIA}

Though the problem of enforcing the quit-rents in Georgia, after the surrender by the trustees in 1751, would seem, at first sight, to have been very much the same as that which arose in the Carolinas after the purchase by the crown, a careful analysis reveals noteworthy differences. By the end of the proprietary period, the quit-rents had become practically a nominal charge in the Carolinas, though at least a method of enforcement had been devised and collections had been made in a more or less irregular fashion. But in Georgia, the quit-rents were never collected under the trustees, and there was neither precedent nor legislative warrant to support the royal government in its policy of enforcement. This situation was not altogether unfavorable to the crown, inasmuch as the quit-rents had as yet aroused no hostility in Georgia, comparable with that which existed in North Carolina under the proprietors, and the land system was in good working order. A firm and tactful policy on the part of the crown would probably have met the problem of establishing a quit-rent system under comparatively favorable conditions.

But at the very beginning, the British government made the same mistake in Georgia, as in the Carolinas, of demanding too high a quit-rent. In surrendering the colony to the crown, the trustees recommended that the quit-rents should be reduced from $4 \mathrm{~s}$ to $2 \mathrm{~s}$ per 100 acres, and that all arrears should be remitted, since the diffi- 
culties of early settlement had prevented most persons from cultivating their lands. ${ }^{1}$ Unfortunately this sensible advice was not fully accepted, for in 1755 the crown offered the people of Georgia terms that were very similar to those extended to the landholders of the Carolinas, after these colonies passed under the royal control, promising that all arrears would be remitted, provided a quit-rent of $4 \mathrm{~s}$ per 100 acres were paid in the future. ${ }^{2}$ That the British government was determined to collect the quit-rents became evident when the Board of Trade, in preparing plans for the civil government, inquired whether some establishment would not be necessary in order to manage this and other royal revenues. ${ }^{3}$ In 1757 Sir Patrick Hunter qualified as register and as receiver of the quit-rents, although the latter office absorbed little if any of his time. ${ }^{4}$

An important feature of the policy of enforcement was an attempt to draw up a rent roll. This project proved to be a difficult one, chiefly because of the common practice of taking out warrants without securing grants, in order to avoid registration and the payment of quit-rents. To end this custom, the governor in 1756 ordered that grants be secured within seven months after a warrant had been made out, and registered within seven months of the date of issue. ${ }^{5}$ Notwithstanding this order, the surveyor-general reported a year later that he had surveys for 20,000 acres, for which no patents had been taken out, although the time limit had long since expired.

1 Journal of Trustees, January 8, 1752, Ga. Col. Rec., I, 570.

2 Jones, History of Georgia, I, 487.

3 Board of Trade to James Wise, May 17, 1753, Treas. 1: 352, f. 173.

4 Minutes of Council, February 17, 1757, Ga. Col. Rec., VII, 489; Acts, Privy Cour. Col., IV, 179.

5 Though numerous warrants had been secured, up to 1756 only 84 grants had been registered since the crown took over the colony. Minutes of the Couneil, May 3, 1756, Ga. Col. Rec., VII, 337-338. 
His advertisement, to the effect that unless grants were taken out within six months these lands would become vacant and would be regranted, seems temporarily to have secured satisfactory results, ${ }^{1}$ but the multiplicity of orders that were given with regard to the taking out and registering of grants caused so much confusion that the council finally had to regulate the exact progress of all patents through the various offices. ${ }^{2}$ Other measures, such as the attempt to secure the listing of all grants, preliminary to the collection of the quit-rents, had little effect. $^{3}$ In 1766 the surveyor-general complained that there were nearly three hundred certified plots for land in his office, upon which the time limit for registration had expired, many of them being for pine lands which, according to the custom of neighboring provinces, had been surveyed merely for the purpose of cutting off the timber. Thereupon, the council ordered that all these tracts should be declared vacant, unless the claimants paid all the back taxes and the quit-rents from the time the land had been granted. ${ }^{4}$ By persisting in such measures the council finally secured the enrollment of at least the greater number of the grants issued in Georgia, but this achievement came too late to be of any real aid in collecting the quit-rents. ${ }^{5}$

The passage of a satisfactory quit-rent act was of first importance if full collections were to be made. The council recommended such an act in 1760, but the assembly

1 Council Minutes, May 27, 1757, Ga. Col. Rec., VII, 571; VIJI, 8 et seq.

2 Council Minutes, October 6, 1761, ibid., VIII, 577, 578.

3 Council Minutes, September 6, 1763, and January 3, 1764, ibid., IX, 90, 110 ; Acts of the Assembly, March 25, 1766.

4 Council Minutes, September 2, 1766, ibid., IX, 634-637.

5 By 1765 grants had been registered in Georgia for a total of 546,770 acres, in addition to 89,400 acres, on the boundary, which had been granted by the governor of South Carolina. Ga. Land Grants, 1755-1765, C. O. 5: 112, pp. 313-349. 
did not pass it for two years. ${ }^{1}$ Although this act of 1762 was sent immediately to the Board of Trade, the Privy Council took no action upon it, and after a second copy had met the same fate, Governor Wright bitterly complained of the delay. The auditor-general, he declared, had considered the act the best of its kind that had been passed in the American colonies, and unless it were confirmed, there would be no possibility of collecting the quit-rents in Georgia. ${ }^{2}$ Though the Treasury fully appreciated the necessity for such an act, it held that the measure of 1762 merely enforced registration by penalties, while that enacted in North Carolina in 1754 declared that all patents or conveyances not enrolled in the prescribed manner should become void. ${ }^{3}$ This criticism had sufficient weight to prevent confirmation, and as no second act was ever passed, the collection of quit-rents in Georgia does not appear to have been even attempted under the royal government. ${ }^{4}$

Popular opposition to the quit-rent, as a source of revenue for the crown, was shown in 1780 when the loyal assembly, acknowledging the promise of the British government to remit all arrears of quit-rents, voted that in the future this revenue, together with other royal emoluments, should be appropriated to the use of the colony. ${ }^{5}$ But the people of the state, like their compatriots in South Carolina, evidently did not consider the quit-rents worth the trouble of any formal action, and ignored these feudal charges in the constitutions of

1 Upper House Journal, February 4, 1760, Ga. Col. Rec., XVI, 428; Lower House Journal, February 26, 1762, Ga. Col. Rec., XIII, 687.

2 Governor Wright to Board of Trade, May 15, 1767, C. O. 5: 112, pp. 304-305.

3 Treasury Board Minutes, July 22, 1744, Treas. 29: 44, p. 14.

$4 \mathrm{Up}$ to March 25, 1767, the arrears were estimated at $£ 2,08115 \mathrm{~s}$. Governor Wright to Board of Trade, November 15, 1767, C. O. 5: 112, p. 309.

5 Lower House Journal, May 9, 1780, Ga. Col. Rec., XV, 552. 
1777 and 1789. In the constitution of 1808, however, there is the significant declaration that, "the property of the soil in a free government" is "one of the essential rights of a free people." 1 The truth is that the quitrents, never having been enforced, were really ignored by the people of Georgia. The collapse of the system was primarily due to the failure of the royal government to take prompt measures in enforcing collections. The long delay in making out a rent roll, together with the refusal to confirm the quit-rent act, put an end to all possibilities of collection, and the history of this feudal charge in Georgia during the colonial period is important chiefly as an illustration of the usual custom of reserving such dues in the colonies over which the crown assumed the status of a proprietary.

1 Thorpe, Constitutions and Charters, 2, 777-802, and especially 794. 


\section{CHAPTER XIII}

\section{ROYAL QUIT-RENTS: IN OTHER BRITISH COLONIES IN AMERICA}

Tночgн the British government ultimately resumed control of all the proprieties that were established in the West Indies and the outlying islands during the seventeenth century, it did not succeed in organizing a system of quit-rents in any one of them. In Jamaica, on the other hand, and in the territories acquired by treaty in 1713 and 1763, the quit-rent became an important feature of the land and financial systems from the beginnings of royal ownership, but the results in the two cases were very different. In Jamaica the quit-rents were successful because the royal authority exercised continuous control from the date of conquest and the preceding Spanish customs were of negligible importance, while in the territories ceded by treaty the earlier French or Spanish land systems had become so firmly established as to give rise to a double form of tenure, in many respects similar to the dual Dutch and English tenures of New York, which rendered a consistent quit-rent system impossible. The very fact, however, that quit-rents were reserved in these acquired territories is a proof of their importance as a customary feature of the British land system.

Of the proprieties created in the West Indies and the outlying islands, the most conspicuous was that founded by the Earl of Carlisle in Barbadoes and the Leeward Islands, which the crown resumed after the Restoration. 
Though the inhabitants of Barbadoes had already agreed with the proprietary to hold their lands subject to an annual acknowledgment of one peppercorn for each grant, the royal government proposed at once to reserve quitrents payable to the crown. ${ }^{1}$ But the people were unwilling to submit to such a charge, and as the land system was in great confusion, the governor, Lord Willoughby, induced the assembly to pass an act reaffirming the proprietary terms for land tenure. In compensation for the loss of the quit-rents, the crown was granted a perpetual export duty of four and a half per cent. on all "dead commodities," such as sugar and the like, of which a part was to be used to defray the expenses of the local government, and the remainder to be expended at the royal pleasure. ${ }^{2}$ A similar arrangement was effected later in the Leeward Islands. ${ }^{3}$ With the development of the sugar plantations in Barbadoes and the Leeward Islands, this four and a half per cent. ultimately became one of the most important colonial revenues of the crown, and was far more lucrative than the income that would have been received had the quit-rents been retained. Moreover, the four and a half per cent. proved as acceptable to the people as to the crown, and the sporadic attempts to restore a system of quit-rents failed completely. ${ }^{4}$

1 Petition from President and Council of Barbadoes, July 10, 1661 Letters Patent and Instructions to Lord Willoughby, November 18, 1662 , and June 16, 1663, Cal. State Pap. Col. 1661-1668, pp. 45-46, 114-115, 142 143.

2 Bryan Edwards, History of the West Indies, I, 334, 338-339.

3 Queries and Answers relating to the Leeward Islands, 1774, C. 0. 152: 54.

4 Revenue Receipts and Issues, 1710-1753, Brit. Mus., Addit. MSS. 36731. 36734. Governor Codrington proposed in 1691, and again in 1696, that quit-rents should be substituted for the $41 / 2$ per cent. in the British portion of St. Christopher, but this proposed change was not made. Governor Codrington to Board of Trade, February 12, 1691, and May 6, 1696, 
In the outlying islands too, Bermuda and the Bahamas, the British government failed to establish quit-rents after the crown resumed the proprieties that had been created in these colonies. At first in Bermuda (1686) instructions were given to reserve quit-rents, but eventually sixty "shares" of land were set aside instead, from which quitrents were paid to the crown in order to defray the expenses of the government. ${ }^{1}$ When the income from this source proved insufficient, the auditor-general, William Blathwayt, proposed that parliament pass a bill to raise whatever additional revenue was needed, but no definite steps seem subsequently to have been taken in order to establish a general quit-rent in Bermuda. ${ }^{2}$ Also, in the Bahamas, there was an annual quit-rent of three pence an acre (later reduced to a penny) nominally in force under the proprietors, but the charge does not appear to have been continued during the royal period. ${ }^{3}$

In contrast with the failure to establish quit-rents in the proprieties was the comparative success with which these dues were enforced in Jamaica. At first in 1661 the Council for Plantations recommended the granting of land with the proviso that in lieu of the quit-rents there should be imposed an export duty of five per cent. after the first seven years. ${ }^{4}$ This condition, which is

Cal. State Pap. Col. 1689-1692, p. 540; 1693-1696, pp. 680-681; 1702-1703, $\oint 536$.

1 Instructions to Sir Robert Robinson, October 31, 1686, Cal. State Pap. Col. 1685-1688, 270; Report of William Blathwayt, April 10, 1714, Treas. 1: 187, f. 211; Accounts, 1732-1735, Treas. 1: 296, ff. 20-25; Cal. State Pap. Col. 1700, p. $659 ; 1702-1703$, $\$ 536$.

2 Report of William Blathwayt, April 10, 1714, Treas. 1: 187, f. 212.

3 Acts, Privy Coun. Col., III, pp. 373-374.

4 The government proposed that each grantee should agree to pay the 5 per cent. duty, upon penalty of twenty times the value of any goods that were smuggled out of Jamaica. This offer is worth noting, as indicating, perhaps, a general intention at this time to substitute throughout the West Indies an export duty similar to the $41 / 2$ per cent., which was established 
similar to the four and a half per cent. agreement late made in Barbadoes and the Leeward Islands, does no appear to have been carried out, for in 1662 Governo Windsor was instructed to reserve a "fit rent" to th king. ${ }^{1}$

Just when the quit-rents were first introduced we d not know, but in 1670 Governor Modyford reported tha 213,746 acres had been granted and a penny an acre re served on all such as were "under manurance.", Elate over so excellent a showing Modyford believed that afte 250,000 acres had been granted, the king might impose three pence an acre alienation fine in addition to a quit rent of a penny, and after 250,000 more had been grante might raise the amounts to six pence and two pence $r \epsilon$ spectively. He asked for authority to fix the rates ac cordingly, confident that the yearly revenue from thi source would be sufficient to meet all the charges of gov ernment. He was undoubtedly too optimistic in hi claims, since for the two years previous to 1670 the $\mathrm{re}$ ceiver-general reported that he did not consider the quit rents of Jamaica worth the trouble of collection. ${ }^{3}$ I 1671 Sir Thomas Lynch said that fully 100,000 acres ha been granted without a farthing of quit-rent, while 300 , 000 acres, upon which the penny an acre had been $\mathrm{r} \epsilon$

two years later in Barbadoes in lieu of the quit-rents. The latter dut? however, was granted by act of the assembly and not by fiat of th crown, and its payment was not a condition of the land grants. Act Privy Coun. Col., I, 312.

1 Instructions to Windsor, March 21, 1662, /Cal. State Pap. Col. 166 1668 , p. 81. The terms offered to the people of New Haven in 1655, $t$ induce them to settle in Jamaica, included a quit-rent of a penny an acr Ibid., 1574-1660, pp. 429-430.

2 Modyford to Lord Arlington, ibid., 1669-1674, p. 95.

3 The last collection, which had brought in only $£ 1519 \mathrm{~s}$, including large proportion of arrears, showed how meager were the returns from th quit-rents. Report of Governor of Jamaica, September 23, 1670, Cal. Stat Pap. Col. 1669-1674, p. 104. 
served, did not bring in over $£ 150$ annually where there should have been a revenue of $£ 1,250 .^{1}$ Obviously any increase in the rate was an impossibility, and upon the representation of the council and the assembly that the people could not pay any more, Governor Lynch assented to an act which reduced all quit-rents in Jamaica to a half-penny an acre. Although, in his opinion, this act would greatly increase the returns from the quit-rents, the crown refused to confirm it. $^{2}$ Soon there was an appreciable improvement in collections as a result of a number of measures, among which was an order that patents should be forfeited if they were not taken out of the land-office within twelve months after they had been issued. ${ }^{3}$ This order was intended especially to break up the large plantations, practically unimproved and sparsely populated, of from 10,000 to 20,000 acres each in the southern part of the island. Were the owners of these tracts, it was believed, compelled to take out patents, they would be unable to evade the quit-rents and would then be obliged either to cultivate their lands or to sell them. ${ }^{4}$ Though this object was probably not fully realized, the revenue from the quit-rents improved to such an extent that in $1679, £ 9183 \mathrm{~s} 5 \mathrm{~d}$, or almost a third of the public income in Jamaica, was collected from this source. $^{5}$

1 Sir Thomas Iynch to Earl of Sandwich, October 14, 1671, Cal. State Pap. Col. 1669-1674, p. 265.

2 Sir Thomas Lynch to Council for Plantations, July 5, 1672, and Lord Arlington to Sir Thomas Lynch, 1672 (?), Cal. State Pap. Col. 1669-1674, pp. 385, 455.

3 Minute, Council of Jamaica, August 4, 1672, Cal. State Pap. Col. 16691674 , p. 398.

4 Mr. Nevil to Earl of Carlisle, about 1677, Brit. Mus., Addit. MSS. 12429 , f. 77.

5 As the total revenue was only $£ 3,35314 \mathrm{~s} 9 \mathrm{~d}$, the quit-rents formed an important item. Brit. Mus., Addit. MSS. 17019, f. 37. 
One of the tasks undertaken by William Blathwayt after he had been appointed auditor-general, was to develop and systematize the quit-rents of Jamaica. As the governors had often neglected to exercise adequate supervision over this revenue, ${ }^{1}$ Blathwayt issued orders that a rent roll should be drawn up and exact accounts of the rents transmitted to England ${ }^{2}$ and in 1681 he appointed for the colony a deputy auditor, Reginald Wilson, as he was doing at this time for other colonies also. ${ }^{3}$ Unfortunately, official jealousy interfered with the success of Blathwayt's plans. The deputy auditor refused to submit his back account for the governor's inspection, and the receiver-general, who held a life patent, proved to be an "eternal obstacle" in the way of a rent roll. The governor and council represented to the receiver that, with many planters living as far from either Port Royal or Saint Jago as one hundred to one hundred and fifty miles, it was necessary to appoint a deputy in each province to make out a rent roll, "which noe one man can ever doe." The only answer they received was that the receiver-general would take care of his patent and would consult his lawyer. Finally, Governor Lynch appealed to the Treasury at home, roundly scoring the receivergeneral, as "the most impracticable fellow I ever met

1 Report of William Blathwayt, October 4, 1680, Blathwayt's Journal, I, 63-64.

2 Duplicates of surveys were to be sent in to the Treasury in order that they could keep an account of all grants. The receiver was to send Blathwayt a ledger containing the full quit-rent accounts, and to take care "for the more effectual charging", of all persons in default. King and Treasury to various officials of Jamaica, June 30, 1680, Blathwayt's Journal, I, 21-32.

3 Deputation to Reginald Wilson, October 18, 1681, Blathwayt's Journal, I, 121. 
with, and soe confounded, now he is prest to give an account, that he knows not what he does."

After having heard the arguments that the receivergeneral had to offer in his own defense, the Treasury upheld the governor and council, and empowered them to appoint deputy receivers who should make out a rent roll and collect the quit-rents in Jamaica. As compensation these sub-collectors were allowed one-half of the receiver-general's commission of ten per cent., a deduction that readily explained the opposition of this official to such appointments. ${ }^{2}$ But no one was willing to undertake the duties of a deputy receiver with a commission of only five per cent., and the receiver-general still delayed his accounts, upon the plea that he had been "discomposed." With the aid of the attorney-general, he attempted to collect the quit-rents by sending out notices of distress upon personal goods, although Governor Lynch was sure that such a procedure would have no effect. ${ }^{3}$ Two years later the Lord Treasurer ${ }^{4}$ urged upon Governor Molesworth the necessity of giving an "effectuall order" for a complete rent roll, in order that the receiver-general might compel each person to pay the quit-rents that he owed. ${ }^{5}$ This rent roll probably was not made out, but these repeated admonitions finally secured a marked improvement in the quit-rent revenue which amounted, in 1691 , to $£ 1,97219 \mathrm{~s} 9 \mathrm{~d}^{6}$

1 Sir Thomas Lynch to Treasury, September 16, 1682, Blathwayt's Journal, I, 154-156.

2 Treasury to Sir Thomas Lynch, May 5, 1683, Blathwayt's Journal, I, 159-160.

3 Sir Thomas Lynch to Treasury, February 25, 1684, Blathwayt's Journal, I, 194-195.

4 The Earl of Rochester was Lord Treasurer from 1685 to 1687, when the office was again put in commission.

5 Lord Treasurer to Colonel Molesworth, June 15, 1686, Blathwayt's Journal, I, 317.

6 Blathwayt's report, August 15, 1692, Blathwayt's Journal, I, 620. 
Meantime, an act passed in 1683 completely transformed the status of the quit-rents in Jamaica, for it set aside the receipts from this source together with other revenues, for twenty-one years, as a fund for the support of the local government and to provide for other public needs. The act made material reductions in the rate, requiring that upon land granted prior to June 25,1671 , the quit-rent should be 1 s per 50 acres or $2 \mathrm{~s} 6 \mathrm{~d}$ per 100 acres and so on. Tracts patented between June 25, 1671, and March 12, 1674, and presumably thereafter, were to carry a rate of a half-penny an acre, and for "foot"' lands a half-penny a square foot. ${ }^{1}$ As this act transformed the quit-rent into merely a local tax, which was under the control of the assembly, its confirmation by the crown is remarkable, especially in view of the strenuous resistance that was made to a similar proposal in Virginia. The truth probably is that such a concession was necessary in order to secure a permanent revenue in Jamaica. The members of the assembly in this colony had proved far more successful in driving a bargain with the crown than their fellow legislators in Virginia. Thereafter, the quit-rent fund in Jamaica was merged in the general revenue account of the colony, ${ }^{2}$ although the royal gov-

1 Report of William Blathwayt, March 22, 1703, Treas. 1: 85, f. 70. The crown had originally proposed to surrender the quit-rent for public purposes, in return for a perpetual revenue, but the act was limited to twentyeight years. Besides the quit-rents, the act levied impost duties on spirituous liquors and required licenses for taverns. The surrender of the quitrents to local control shows the value of this feudal due in the negotiations for a permanent revenue. Beer, The Old Colonial System, Part 1, Vol. I, 213-217.

2 The local control of the quit-rents in Jamaica is emphasized by the fact that neither this revenue nor the other income of the colony is mentioned among the general colonial receipts. Yet the large revenue from the $41 / 2$ per cent. export duty collected in Barbadoes was regularly included among the revenues at the disposal of the crown. Revenue Receipts and Issues, 1710 to 1753 , Brit. Mus., Addit. MSS. 36731-36734. 
ernment still exercised a general supervision, and required the reservation of this charge in all grants. ${ }^{1}$ As collections continued to be far from satisfactory, even with the quit-rents under local control, an act was passed in 1696 relieving landholders temporarily of all claims for arrears, provided they gave security for future payments as they became due. The act also required nonresident landowners to settle for their rents within ten years or forfeit their lands, and it permitted anyone who wished to give up a part of his holdings after all arrears had been paid. Had this law been enforced, it would have cleared away all uncertainties regarding arrears and afforded a quit-rent roll. ${ }^{2}$ But it had little effect, and the quit-rent revenue steadily decreased, until in 1702 collections were scarcely one-ninth of what had been realized in $1691 .^{3}$

In order to improve the condition of the quit-rents, the assembly passed an act in 1703 that contained a number of excellent features. It put an end to fraudulent attempts to pay quit-rents upon only a part of a holding, by requiring that new surveys should be made upon the request of either the royal officials or the patentee. ${ }^{4}$

1 For example, in 1751 a Mr. Price, in applying for a grant of several thousand acres, asked for exemption from the quit-rents and from the usual conditions of settlement. Although his plan to drain and improve the lands was held to be of benefit to the colony, the Privy Council refused to waive the quit-rents. Acts, Privy Coun. Col., IV, 121-122.

2 As simply the oath of a landholder was sufficient to determine the arrears, the law would seem at first sight somewhat lenient. But the very fact that the landholder swore to the amount of his quit-rents established the sum due from him in the future. Acts of the Assembly, Jamaica, 1681. $1769, \mathrm{I}, 57$.

3 The exact revenue from the quit-rents of Jamaica amounted in 1700 to $£ 4233 \mathrm{~s} 91 / 4 \mathrm{~d}$. In 1702 it was $£ 2306 \mathrm{~s} 101 / 2 \mathrm{~d}$. Blathwayt's Journal, II, $146,325$.

4 The act required the receiver-general or his deputy to attend twice annually at Saint Jago, and at Kingston for one month, from eight to eleven 
Furthermore, as a great earthquake had destroyed the receiver-general's records and the tenants had lost many valuable papers by this calamity and by hostile attacks, the act relieved all persons of arrears up to Michaelmas, 1692 , but ordered that quit-rents must be settled by May 1, 1704. In case non-resident landholders failed to settle in this fashion by August 1, 1704, they forfeited their lands. Other delinquents lost all benefit of the act, and became liable to suits to compel them to pay their quitrents from the date of the patent. Further clauses of the act required the receiver-general to attend twice each year at Saint Jago and at Kingston, and provided for the registration of all alienations. ${ }^{1}$ The effect of this act, as measured in actual revenue, cannot be accurately stated, since the quit-rents were usually merged in the general public funds of Jamaica, but the royal government made a mistake in allowing the receiver-general a commission of only five per cent. and in making no local allowance at all for the deputy auditor. ${ }^{2}$ Consequently, there was little inducement for effective work on the part of these important officials. Yet they seem to have enforced the quit-rents with a severity that occasionally gave rise to complaints of unjust treatment. ${ }^{3}$ Indeed, a number of

in the morning, and from two to five in the afternoon. Acts of the Assembly, Jamaica, 1681-1769, I, 72; Acts, Privy Coun. Col., III, 414-415.

1 A minor clause guarded against future catastrophes by requiring that duplicates of all quit-rent books and papers must be kept at Saint Jago. Acts of the Assembly, Jamaica, 1681-1769, I, 71-74.

2 The auditor-general received $£ 150$ annually from the general revenues of Jamaica, out of which was to come whatever allowance was made to the deputy auditor. Blathwayt's report, September 13, 1711, Blathwayt's Journal, II, 445 ; III, 66, 69, 71.

3 Captain Samuel Jones complained in 1708 that, even though he had sufficient property upon which distraint might be levied, his estate of about 1,000 acres had been seized, by an agent's mistake, for arrears. When he tendered payment for what he owed, the receiver-general refused to accept 
instances of forfeiture for non-payment of these charges show that the quit-rents were not at this time merely a nominal levy upon the lands of Jamaica. ${ }^{1}$

Local control of the quit-rents was again asserted in 1728 when the assembly settled upon the royal government a perpetual revenue of $£ 8,000$. Included in this fund were the quit-rents, which were now estimated as worth $£ 1,460$ annually. The royal right of supervision was not ignored, since the act required that the receivergeneral should collect the quit-rents and that all accounts should be submitted to the auditor-general or "such other person as the crown sees fit to appoint."' Since by continued evasions and delays, the quit-rent revenue had been so reduced that heavy taxes were found necessary to make up the annual sum promised the crown, the assembly ordered delinquent landholders to pay their arrears at Saint Jago or at Kingston, on or before the March 25th following the passage of the act. All persons who neglected this order were to be charged an interest of twelve per cent. on their arrears. For the future, the act provided that if the quit-rents were not paid within three years, the twelve per cent. interest should be charged from the date of the last payment. Also, in order to "encourage the further settling of the island," and to prevent any question as to the titles to the estates of non-residents that had been forfeited for failure to pay the quit-rents, it declared that all grants of these lands were legal, provided due proclamation had been made and the judgment of the court confirmed, and as an aid to the discovery of land that had been forfeited,

it, and his estate was bestowed upon another person to whom the governor had promised it. Acts, Privy Coun. Col., II, 549-550.

1 Acts, Privy Coun. Col., November 2, 1710, II, 626-627.

2 Acts of the Assembly, Jamaica, 1681-1769, I, 125; Bryan Edwards, History of the West Indies, I, 181. 
it gave to any informer who was willing to pay the quitrent and to fulfill the terms of settlement the right to receive a grant. ${ }^{1}$ This act should have greatly aided the collection of the quit-rents in Jamaica, but the clause for the payment of interest upon arrears led to so many abuses that, in 1743 , the assembly was obliged to rule that the twelve per cent. should only be assessed at the end of three years upon the quit-rents that had become due in that period, and that all persons who had paid an overcharge should receive a discount from their future dues. $^{2}$ Doubtless this interpretation helped to clear the situation, and large sums were collected from the quitrents in the next few years. ${ }^{3}$

As interest continued to accumulate under the provisions of the act passed in 1733, the assembly enacted another measure in 1783. Ostensibly this act was designed to relieve landholders from the burden of interest, but doubtless an equally important motive was the desire to carry out the lenient policy that was being followed at this time with regard to the loyal colonies. As the act is one of the most comprehensive that was ever passed in any of the colonies, its provisions require a detailed analysis. The basis was laid for a rent roll by requiring that all persons must give an account upon oath, the "people called Quakers to affirm," before the parish officers as to the exact extent of their respective holdings. The claimants to surplus land must pay the

1 Acts of the Assembly, Jamaica, 1689-1769, I, 144-147.

2 Ibid., I, 181-182.

3 In 1747, in order to meet the exigencies of government, the assembly offered for public sale the lands that had been entered upon, probably under the law of 1733, for the payment of the quit-rents. Acts of the Assembly, Jamaica, 1689-1769, I, 216-217. The results of the act were shown in the quit-rent books, by which it appeared that in 1754 the quit-rents were being collected from 1,671,569 acres in Jamaica. List of Jamaica Landholders, 1754, C. O. 142 : 31. 
quit-rents specified in the original grant, but for tracts held otherwise than by a patent they should be charged the customary rate. As an inducement to secure compliance with these various provisions, the act remitted all arrears up to January 1, 1760, together with interest payments to November 1, 1784, and accepted, in lieu of the quit-rents since the former date, bonds that were due in twelve months and bore interest at six per cent. These benefits of the act were not to be extended to persons who failed to give in an account of their lands. The measure also provided for the collection of the quitrents, requiring the vestrymen of each parish annually to issue a summons to every landholder to make out a sworn statement of his lands. Thirty days after these accounts were handed in, the clerks of the vestries were to deliver to the constable lists of the quit-rents that were due from each person. The constables would then collect these dues and hand the proceeds to the receivergeneral. The act subjected the constables to severe penalties if they failed to return to the receiver-general the amount that was due upon the rent roll, and allowed them as compensation a commission of one shilling in the pound, or six pence in the towns of Saint Jago and Kingston. These means of enforcing collection were strengthened by clauses that conferred ample power to distrain upon the "goods chattels or slaves" of landholders who failed to pay their full quit-rents. ${ }^{1}$

This act asserted the full right of local control over the quit-rents, and henceforth determined their status as that of a general property tax. The comparative success that had attended these feudal charges was primarily due to the continuous royal control over the colony, which permitted a steady development of the 1 Acts of the Assembly, Jamaica, 1770 to 1783, pp. 368-382. 
quit-rents, with no sudden transition owing to a change in administration, such as had taken place when the neighboring proprieties passed under the control of the crown. Moreover, Jamaica was unique as the only colony in which the crown permitted the quit-rents to pass under local control, and this concession was doubtless made in order to secure from the assembly a perpetual revenue. Such concession is noteworthy in view of the zealous care with which the British government guarded its right of control elsewhere, especially in Virginia.

The reservation of quit-rents was also a feature of the land systems devised for the territories that were acquired from the French in 1713. In that portion of St. Christopher which was confirmed to the British at this time, a quit-rent for the support of the government was at first proposed by Governor Codrington, but eventually the customary four and a half per cent. export duty was established throughout the island. ${ }^{1}$ In Nova Scotia the royal government made a much more determined effort to reserve a quit-rent on the lands that were granted after the colony came under British control. The numerous projects to settle retired officers in this region provided for a quit-rent, ${ }^{2}$ which was fixed at twelve pence, or else three pounds of hemp per 50 acres. This became the usual quit-rent, although occasional attempts

1 Governor Codrington to Board of Trade, March 26, 1697, Cal. State Pap. Col. 1696-1697, p. 416; Treas. 1: 162, ff. 202 et seq.; 209, f. 34; 282, f. 239 .

2 A typical plan is the one presented in 1721 by a company which proposed to settle all pensioners that were "burthensome" to the kingdom in Nova Scotia and Maine. These colonists, it was planned, should raise hemp, flax, and other naval stores, and should pay an annual quit-rent of 28 pounds of hemp per 100 acres for the use of the royal navy. If the crown would remit this quit-rent for ninety-nine years, the company undertook to defray the cost of transporting and settling all half-pay officers on these lands. Such a plan would, it was asserted, help the nation and also the officers who could "live therein in greater plenty with their families" than 
were made to increase it. ${ }^{1}$ In 1764 the British government granted an exemption from the payment of the quit-rents for two, and later for ten years after a grant had been issued. ${ }^{2}$ These terms were carried out in practically all grants, with the exception of those for town lots of from one to eight acres and for public commons, upon which no quit-rents at all were reserved. ${ }^{3}$

Though quit-rents were reserved in most of the grants that were made in Nova Scotia, actual collection proved to be a difficult task. One great mistake of the British government was the failure to collect the feudal dues that had already been imposed under the French. In 1753 the French inhabitants of Cobequid represented that for years the receiver of their rents had refused to accept payments, alleging that as fast as he received them the Indians robbed him. Consequently, the landholders owed great arrears and were in an exceedingly distressed condition. ${ }^{4}$ The Board of Trade, to whom this petition was referred, reported that these rents, which were considerable, had never been legally collected, and that the

at home on half-pay. Fortunately for the officers, the scheme was given scant consideration. Unsigned Memorial to Lord Carleton, June 25, 1721, C. 0. 5 : 752 , f. 25 .

1 Instructions, 1728 and 1729, Brit. Mus., Addit. MSS. 30372, ff. 24, 25. 2 Acts, Privy Coun. Col., IV, 660, 755.

3 After 1765 patents were issued for a number of tracts of from 20,000 to 150,000 acres, with an exemption from quit-rents of one-half the land for five years, and of the remainder for ten years. A typical example of these grants is that of October 15, 1765, to Alexander MeNutt and his associates. The grant included 150,000 acres upon which the quit-rent, of one farthing per acre, was payable on one-half the grant after five years, and on the remainder after ten years. Extracts from Register of Land Grants, Nova Scotia, 1749-1767, C. O. 324: 54, I, passim. Among these grants of town commons was one of 2,000 acres in 1761 to the people of Lunenburg, and another in $\mathbf{1 7 6 3}$ of 325 acres to trustees, for the use of the town of Halifax. Register of Land Grants, Nova Scotia, C. O. 324 : 54, I.

4 Governor Hopson to Board of Trade, May 26, 1753, and Council Minute, May 10, 1753, Treas. 1 : 353, ff. 227-228. 
few payments made had been in the form of corn and live-stock for the use of the commandant at Annapolis. They recommended, therefore, that the governor of Nova Scotia should have discretionary power to remit these rents as a reward, whenever he might wish "to animate or engage these inhabitants in some public undertaking," although this means of stimulating the loyalty of the French inhabitants was not to involve any permanent waiving of the right to collect the rents, if necessity arose. ${ }^{1} \quad$ This order, which virtually abandoned the dues from at least a part of the French inhabitants, rendered collections from landholders under the later British grants all the more difficult. So negligible were the returns that they were not included in 1766 in a summary of the regular revenues of the province. The report of the receiver-general, John Collier, showed collections from 1762 to 1768 of only $£ 2712$ s $11 / 2 \mathrm{~d}$, of which the greater part was for arrears up to 1764 . Fully $£ 123$ 11s $8 \mathrm{~d}$ was still owing. ${ }^{2}$ Collections did not improve under the next receiver of Nova Scotia, James Woodmass, inasmuch as the apparent balance due the crown from actual receipts, on September 23, 1773, was only $7 \mathrm{~s} 31 / 2 \mathrm{d.}^{3} \quad$ As there were numerous grants of large tracts, upon many of which the quit-rents had long been due,

1 Board of Trade to Treasury, July 4, 1753, Treas. 1: 353, f. 226 . Under the seigniorial régime in Canada, the payment corresponding to the quit-rent was the cens, which has been defined as "a moderate annual tax imposed in recognition of the seignior's direct authority." The cens, however, differed in many important respects from the quit-rent and retained its feudal eharacteristics much longer and more completely in Canada at this time than did the quit-rent in the older British eolonies. The corn and live-stock mentioned in the text were probably the rentes, payable in kind or in money and kind by the "habitant," who was also charged with the lods et ventes, or alienation fines. For a discussion of the subject see Munro, The Seignorial System in Canada, ch. V, and below, pp. 375-379.

2 Report on Expenses and Revenue of Nova Scotia, C. O. 325 : 1, no. VII.

3 Return of American Revenue, October 2, 1776, Treas. 1: 525, no. 87. 
such collections were merely nominal. Finally, a petition in 1774 asked that the payment of the quit-rents should be remitted, in view of the youth of the colony, the absence of roads, and similar untoward conditions. ${ }^{1}$

In 1774 Governor Legge made an enlightening report upon the quit-rents, and incidentally upon the general land situation in Nova Scotia, asserting that upon investigation he had found that fully $5,000,000$ acres had been granted, upon which the quit-rents should have been $£ 5,000$. But the accounts showed that only a small part of this amount had been received, and of this sum the receiver had actually kept a part for his own use. ${ }^{2}$ With respect to the quit-rents, Governor Legge divided the settlers in Nova Scotia into three classes. First, there were the inhabitants of towns, including Annapolis, Onslow, Cumberland, and Sackville, who had been granted lands that had been improved by the French. These persons were prosperous, supplying the market at Halifax and even exporting to other colonies, and they were well able to pay their quit-rents, which amounted to about $£ 800$ annually. Secondly, there were many settlers along the seacoast who had rescued their lands from the wilderness and were now prosperous. They also were able to pay the quit-rents. Thirdly, there were the holders of numerous large estates upon which the conditions of settlement had not been fulfilled, and from which no quitrents could be collected, as there was "neither principal nor tenant." Many of these grants, most of which had been to non-resident soldiers and officers, had been de-

1 Henry Newton and others to Richard Cumberland, March 24, 1774, Eleventh Report, Historical MSS. Commission, V, Dartmouth Papers, p. 350.

2 Two hundred and sixty pounds had been collected from 1771 to 1773 , but only $£ 150$ was turned in to the governor. The remainder was retained by the receiver-general, James Woodmass, who had no other office or employment to provide for the "necessitous circumstances of his family." Governor Legge to Treasury, March 23, 1774, Treas. 1: 505, f. 62. 
clared forfeited and others might be. In view of all these facts, Governor Legge concurred in a petition from the council that little could be expected from Nova Scotia in the way of quit-rents. On unimproved lands, he recommended that the crown should waive these dues for seven years in order to promote settlement, since the only possible means of collection under existing conditions was forfeiture of the land. Where it was possible to pay the quit-rents, Governor Legge believed that they might be collected, if only a sufficient force of officials was appointed and the revenue employed for at least seven years in order to build roads between the different settlements. ${ }^{1}$ From this statement, it is clear that the quit-rent system in Nova Scotia had hardly become established at all before the American Revolution.

In spite of the difficulties that were encountered in Nova Scotia, the British government undertook to reserve the quit-rents in the American colonies acquired in 1763. A precedent had already been set in the Ohio Valley, possession of which was confirmed in 1763 by the Treaty of Paris. As early as 1754 the king instructed the governor of Virginia to grant land west of the Alleghanies with the usual two shillings quit-rent, but with an exemption for ten years and without the purchase money of $5 \mathrm{~s}$ per 50 acres. $^{2}$ In the main these conditions were consistently followed in the numerous grants made or proposed after Great Britain had secured undisputed possession. Indeed Lord Shelburne, in presenting recommendations for the settlement of the western lands, considered that a quit-rent was the most available form of revenue there. ${ }^{3}$ In his scheme for founding three colonies between the Ohio and the Mississippi, he proposed that

1 Governor Legge to Treasury, March 23, 1774, Treas. 1: 505, ff. 61-64.

2 Alvord, Mississippi Valley in British Politics, I, 89, footnote.

3 Ibid., I, 347. 
at the end of fifteen years the landholders should pay annually 2 s per 100 acres, which was to be "altogether applied to the contingencies of the government." A quitrent, after a stated period of exemption, was also included in the various proposals of the Mississippi Company, and of the Grand Ohio or the Walpole Company as it was more commonly known. ${ }^{2}$ From all of these schemes it is evident that, in accordance with precedent and the avowed policy of Shelburne, the quit-rent was determined upon as the chief means by which the crown could secure a revenue from these lands. Of especial interest was the project of the Walpole Company to found the colony of Vandalia, as a propriety. The company undertook to pay the crown $£ 10,4607 \mathrm{~s} 3 \mathrm{~d}$, and a quit-rent of $2 \mathrm{~s}$ for every 100 acres of cultivated land after the expiration of twenty years. In turn, the company, as proprietary, proposed to secure a large profit by charging prospective tenants $£ 10$ sterling purchase money for each 100 acres, and a quit-rent of a half-penny an acre. ${ }^{3}$ This elaborate plan for quit-rents in these western lands was of course involved in the general collapse of these feudal dues after 1783 , when this region reverted to the United States.

Attempts were made also to establish quit-rents in Prince Edward Island, then known as St. John. At first the island was included under the same administrative jurisdiction as Nova Scotia, but in 1764 the soil was granted to the Earl of Egmont and a large number of officers, upon condition that a quit-rent of $3 \mathrm{~s}$ per 100 acres should be paid after ten years. ${ }^{4}$ The collection of this charge was provided for in 1770 by the appointment of the governor, Walter Patterson, as receiver of St. John,

1 Carter, Illinois Country, 1763-17ry4, pp. 129-130.

2 Alvord, Mississippi Valley in British Politics, I, 348-349; II, 93, 173.

3 Ibid., II, 104, 151.

4 Acts, Privy Coun. Col., IV, 657-658. 
with a salary of $£ 50$ to be paid out of the quit-rents. ${ }^{1}$ The instructions to Patterson directed him to employ all possible means in order to collect the quit-rents, and to use the resulting revenue for the salaries of public officials, applying the surplus, if there was any, to the construction of good roads on the island. ${ }^{2}$ As an inducement for prompt payment, the Treasury in 1783 remitted one-half of the quit-rents due from all landholders in St. John who settled for the balance by May $1,1784 .^{3}$ This concession probably had little effect in securing actual collections, and just as in the nearby province of Nova Scotia, the quit-rent system in St. John was practically a complete failure.

In the remaining American territories acquired in 1763 , the royal proclamation defining the administrations of Quebec, East and West Florida, and Grenada authorized that the lands at the disposal of the crown be granted with the usual quit-rent, but with an exemption for ten years in favor of all soldiers. ${ }^{4}$ In carrying out these orders in Quebec, the British government encountered a serious difficulty in the large areas already granted under the French form of tenure. Here, as in the parallel case of New York, the crown confirmed existing grants subject to the original conditions, but ordered the reservation in all new patents of a quit-rent of 2 s sterling per 100 acres, to be paid annually after two years upon penalty of forfeiture. At the same time the governor was instructed to have the quit-rents collected. These directions, which were repeated in 1768, established in Quebec a twofold tenure of land with all the attendant difficulties that,

1 Commission to Walter Patterson, June 28, 1770, C. O. 5: 204, pp. 1-2.

2 Extract from Treasury Minutes, August 7, 1776, Treas. 1: 521, f. 253.

3 Ibid., July 11, 1783.

4 Proclamation of the Crown, Annual Register, 1763, pp. 208-212. Cf. Acts, Privy Coun. Col., IV, pp. 593, 595, 607. 
judging from experience in New York, were to be expected. ${ }^{1}$

The royal instructions were carried out with the reservation of $2 \mathrm{~s}$ per 100 acres in all grants of country land, although no exemptions for a limited period were conceded except in patents to soldiers. On town lots the quit-rents varied from one shilling or two shillings upon unimproved, to as high as fifty shillings upon improved tracts, while a number of these holdings were subject to a lease that was limited to ninety-nine years, rather than a quit-rent. In all these grants there were strict conditions that unless the quit-rent were paid annually, the land would be forfeited. ${ }^{2}$ But these careful provisions for a quit-rent system proved merely nominal, as far as Quebec was concerned. Between August 9 and December 30,1766 , the total sum collected from the quit-rents was only five shillings two and one-half pence, and up to 1776 there was no really persistent effort to enforce these charges. ${ }^{3}$ Realizing that quit-rents in Quebec were a failure, the British government issued instructions in 1771 that the remainder of the land should be granted according to French law, with the omission of the seign-

1 Each master or mistress was entitled to 100 acres, and to 50 acres additional for every member of the family. All extra land must be purchased at 5s per 100 acres in addition to the quit-rents. Instructions to the Governor of Quebec, December 7, 1763, C. O. 5: 201, pp. 37-38, 45-46; Ordinance of November 6, 1764, Draft of Ordinance, 1768, and Instructions to Governor Carleton, 1768, Canadian Archives, III, 166, 204-205, 218-219; Munro, The Seignorial System in Canada, pp. 194-195.

2 A lot containing 11,680 feet on Palace Street, Quebec, was granted in perpetuity with a quit-rent of $50 \mathrm{~s}$, which was to be paid annually at the Feast of the Nativity or else the grant would become void. This strict condition for the payment of the quit-rent is typical of other grants at this time in Quebec. Grant, December 21, 1765, Quebec Land Grants, 1765-1767, C. O. $324: 54$, II.

3 Report of Receiver-General for the period, August 9 to December 30, 1766, C. O. 5: 112, p. 25; Return of American Revenues, October 2, 1776, Treas. $1: 525$, f. 87 . 
ior's judicial rights. ${ }^{1}$ Although this measure complied with the desires of the people of Quebec, it was tantamount to an admission that the quit-rent system had completely collapsed. ${ }^{2}$ But with characteristic tenacity, the crown explicitly retained the rather empty right to reserve quit-rents whenever such a policy should be deemed expedient. ${ }^{3}$

The restoration of the French system of land tenure aroused many protests from the American Loyalists who fled to Canada after the outbreak of the Revolution. In a petition to the crown in 1785, these immigrants cited the onerous terms of the French tenure as one of the chief reasons for the setting off of Upper Canada as a separate province. The French land system, they declared, with its "rigorous rules, homages, and reservations, . . . which are so different from the mild tenures to which they have ever been accustomed, and which continue to be enjoyed by the rest of Your Majesty's subjects, has occasioned a general discontent." Many persons would have abandoned the settlements in Canada, the petitioners represented, but for the expectation that they would be permitted to obtain grants upon the same "terms and tenures"' and under the same laws as those which they had formerly enjoyed under the royal control. ${ }^{4}$ Of much the same tenor was a petition from the magis. trates of Cataraqui (Kingston), which protested especially against the conditions of land tenure, and asked for the same privileges as were enjoyed by their fellow sufferers who had fled to Nova Scotia and New Brunswick.

1 Instructions to Lord Carleton, July 2, 1771, Canadian Archives, III, 295.

2 Masères to Lord Chancellor, April 30, 1774, Canadian Archives, III, 373.

3 Quebec Act, 1774, and Instructions to Governor Carleton, January 3, 1775, Canadian Archives, III, 403, 429.

4 Petition of Sir John Johnston and Others, April 11, 1785, Canadian Archives, III, 525. 
Another petition, from the magistrates of New Oswegatchee (New Oswego), asked that they might have their lands free from "any other encumbrance whatever, the king's quit-rent excepted."' It is significant that all of these Loyalist petitions, either tacitly or openly, accepted the quit-rent as a customary feature of the British land system.

To meet these protests, the crown at first offered a compromise by which fiefs and seigniories according to French custom should be granted to the Loyalists, but the land should be held directly under the crown with a quitrent of a half-penny an acre to be paid after ten years. ${ }^{2}$ But such a half way measure was not acceptable, inasmuch as British subjects were unwilling to submit to the vexatious terms of the French tenure, even though they held under the crown. Finally, the merchants of Quebec proposed that, in order to encourage the settlement of the American Loyalists, these newcomers should have township grants in free and common socage, as was customary in New Brunswick, Nova Scotia, and the American states. A land system of this type was the only one, the merchants considered, to which British subjects would be reconciled. The French feudal tenure, they believed, was "inimical to a free commerce, and together with the constitution of the government, has greatly tended to prevent the settlement of lands and the improvement of the province hitherto, and will still have the same evil tendency until the lands to be granted are actually conceded, or declared to be intended to be so, on a more liberal tenure, for not only the desires, but even the prejudices of the people ought to be considered." Nor did

1 Magistrates of Cataraqui and New Oswegatchee to Sir John Johnston, December 18 and 22, 1786, Canadian Archives, III, 642-643, 645.

2 Instructions to Lord Dorchester, August 23, 1786, Canadian Archives, III, 561. 
the petitioners consider that the proposed change would affect old rights, since different tenures of land existed without ill consequences in many of the crown's dominions. The report ended with the significant statement that, "measures like these, we are confident, will soon give this province the form and figure of a British colony, bring forth its resources and raise it into consequence."'

Lord Dorchester (Sir Guy Carleton), governor of Quebec, was even more emphatic in urging the necessity for a change of policy with respect to land grants in Canada. In view of the "late changes," he considered that a policy adapted to the corresponding situation in the neighboring states, and suited to the temper of the people, had become "indispensably necessary." Therefore he recommended that grants should be limited to 1,000 acres, that they should be in free and common socage, and that quit-rents should be abolished in Canada, Nova Scotia, and New Brunswick. Similar measures, he considered, should be taken in order to meet American aggression by the extension of English settlement along the Lakes. The Canadians at Detroit, who were under strong military control, were charged rents, ${ }^{2}$ while their

1 Merchants of Quebec to Council Committee on Commercial Affairs, January 5, 1787, Canadian Archives, III, 616-617.

2 The lands at Detroit were held under a complicated French tenure, which readily explains the persevering efforts of the Loyalists to secure a return to the far simpler British land system. Lots within the fort at Detroit were granted upon the condition of carrying on the necessary work of enclosing the stronghold without charge to the king, and of paying two sols rent for each front foot. These lots were also subject to an alienation fine of one-twelfth upon sale or exchange. For country land, the quit-rent was one sol for each front foot, and one-quarter bushel of wheat per acre. The same alienation fine, one-twelfth the value, seems to have been imposed on country land, but one-third was waived in case it was promptly paid. Account of Revenue and Land Conditions at Detroit, about 1761-1768, C. O. 5: 216 , pp. 60-61. 
friends on the "Wabache," who paid nothing, believed that if they came under British control, they would be compelled to meet similar charges. The resulting hostility to the royal authority had been increased by the American promise that they should hold their lands free of all quit-rents. In conclusion, Lord Dorchester pointed out that "the quit-rents in the English colonies were not one-sixth of the burthen of the lands en roture, and yet I understand the government was never able to collect them; but, after the revolt had taken place, offered to relinquish the claim; from all which $\mathrm{I}$ am convinced that these dues never will be paid, and will only prove a perpetual cause of discontent, and afford the means of alienating the minds of the people from the king's service." ${ }_{1}$

Lord Dorchester's recommendations were only partly incorporated in a measure, proposed by Secretary Sydney, that from the territory west of the Cateau Rapids, where most of the Loyalists had settled, a new province should be formed, and that all persons in this region should hold their lands upon the same terms as settlers in Nova Scotia and New Brunswick. ${ }^{2}$ The first draft of the bill to carry out this scheme proposed that in both of the provinces into which Quebec was to be divided lands which were not held in free and common socage might be surrendered to the crown and regranted under the English form of tenure. ${ }^{3}$ But Lord Dorchester, who was determined to secure the abolition of the quit-rents, except upon tracts of 1,000 acres or more, was not satisfied

1 Earl Dorchester to Lord Sydney, June 13, 1787, Canadian Archives, III, 646-647.

2 Lord Sydney to Lord Dorchester, September 3, 1788, Canadian Archives, III, 646-647.

3 Grenville to Dorchester, October 20, 1789, Canadian Archives, III, $666,672$. 
with the proposed act. Whatever quit-rents were reserved upon large tracts, he considered, should be used for the support of the government, in order that "all seeds of discord between Great Britain and her colonies may be prevented," and to obviate "the necessity of sending money abroad, rather than to bring home any from quit-rents or duties of any kind." 1 These views finally prevailed in the Constitutional Act of 1791, which provided that all future grants in Upper Canada should be in free and common socage as in Great Britain, and that persons who already held their land under certificates of occupation might receive patents in accordance with the new form of tenure. The act permitted land to be granted in Lower Canada, also, on the same terms, if the patentee so desired. The quit-rents were not specifically mentioned, but as the act forbade any alterations in the terms prescribed for grants, except with the consent of the council and the assembly, the reservation of such a feudal due was an improbable contingency. ${ }^{2}$ While this measure was really an acknowledgment of Lord Dorchester's indictment of the quit-rent system as a source of discontent in the pre-Revolutionary period, it also constituted a tribute to the strong influence of the American system of free tenure of land. With feudal dues practically abolished in the United States, it would have been a suicidal policy to have insisted upon a system of quit-rents in Canada, especially in face of the efforts that were being made to detach the colony from Great Britain.

The policy of reserving a quit-rent, which had at first been carried out in Quebec, was upheld by the British government in organizing the Floridas. In these colonies

1 Dorchester to Grenville, February 8, 1790, Canadian Archives, III, 676.

2 Constitutional Act of 1791, Canadian Archives, III, 706. 
the Privy Council fixed the quit-rent at a half-penny sterling per acre, with an exemption for two years, ${ }^{1}$ which was later extended to five years for one-half of each grant, and ten years for the remainder. ${ }^{2}$ Upon these conditions numerous grants were made in both East and West Florida. In West Florida the wording of the patents was especially rigid, and required that the quitrent shoúld be paid within fourteen days of the time it became due, or else the land would be forfeited to the crown. This stringent condition was omitted in patents to town lots, which usually included a tract for building purposes, and one to serve as a pasture or a garden, with a quit-rent of six pence sterling upon the entire grant. ${ }^{3}$ In East Florida at least sixty grants were made between June 20, 1765, and June 22, 1767, including altogether 120,475 acres, upon which the usual quit-rent of a halfpenny per acre was reserved. ${ }^{4}$

The quit-rents in both of the Floridas constituted a merely nominal charge during the twenty years of British control, for as late as $\mathbf{1 7 6 7}$ no definite steps for

1 Acts, Privy Coun. Col., IV, 668-669.

2 Ibid., IV, Appendix, 813-815.

3 A typical grant was the one issued to James Elliott, February 24, 1777, for a town lot, 100 by 200 feet and a pasture lot of 5 acres in Harwich. Land Grants, West Florida, 1777-1779, C. O. 5: 610, I. Another grant to a lot in Harwich prescribed that the patentee "shall and do, within two years from the date hereof, on the said town lot hereby granted, erect and build one good and sufficient tenantable house, at least of the dimensions of 30 feet and 85 feet in depth, with one or more brick chimnies.' If this condition was not met, the patentee paid 20 s annually until it was fulfilled, and after ten years' non-payment the land was forfeited. Land Grants, West Florida, 1777-1779, C. O. 5: 610, p. 49. Upon a lot granted in Pensacola to William Southworth, "merchant," there was an even more interesting condition, providing that, "the free liberty of fishing, drawing, and lowering of seines and nettes" 'in front of the said lot shall be reserved to the inhabitants of Pensacola. Land Grants, West Florida, 1777-1779, C. O. 5: 610, pp. 141-142 and passim.

4 Patents, East Florida, June 20, 1765, to June 22, 1767, C. O. 5: 54, V. 
collection had been taken in either colony. ${ }^{1}$ Though a receiver-general was appointed in East Florida, the situation showed little improvement, and finally the landowners of this colony petitioned that the collection of the quit-rents should be stayed, "in consideration of the difficulties and disappointments" they had met in making. their settlements. ${ }^{2}$ The Treasury, to whom this petition was referred, consented to remit one-half of the quitrents due from East Florida for ten years, provided the other half was punctually paid. ${ }^{3}$ But there is no evidence that the quit-rents were ever paid in either of the Floridas during the few years of British control, for in 1776 the auditor-general reported "no accounts"' of this revenue from either province, and it is not probable that collections were enforced during the few stormy years that followed. ${ }^{4}$

In Grenada, St. Vincent, Dominica, and Tobago, the remaining territories acquired in 1763 , the quit-rent system was only slightly more successful than in Canada and in the Floridas. The crown ordered that cleared land in these new possessions should be sold to the highest bidder, but that unimproved tracts should bear merely a purchase price, and that in both instances a quit-rent of six pence per acre should be reserved. ${ }^{5}$ This order

1 Governor Browne to Board of Trade, and Governor Grant to Board of Trade, about 1767, C. O. 5: 112, pp. 367-368, 387.

2 Pownall to John Robinson, April 3, 1772, C. O. 5: 145, f. 13.

3 Treasury Board to Lord Hillsborough, July 16, 1772, C. O. $5: 145$, f. 21.

4 Report of Auditor-General Cholmondeley, October 2, 1776, Treas. 1: 525, ff. 87-88. Information regarding land allotments and tenures in East Florida can be obtained from the papers of the Commission on East Florida Claims, Treasury 77, and from a volume among the papers of the Commission on American Loyalist Claims (Vol. 60 of transeripts in the New York Public Library).

5 Acts, Privy Coun. Col., IV, pp. 593-596. For the quit-rent from St. Vincent, St. Lucia, and Tobago, reserved in the proposed grant to the Duke of Montagu in 1722 and 1728, see Acts, Privy Coun. Col., VI, $\$ 401$. 
was partly rescinded by another instruction which extended the four and a half per cent. export duty to Grenada, upon the pretext that according to the articles of capitulation the inhabitants of the Ceded Islands should enjoy their properties and privileges, and pay taxes, "in like manner as the rest of His Majesty's subjects of the other British Leeward Islands." "The people of Grenada strongly opposed this four and a half per cent. duty, and in 1774 Chief Justice Mansfield held that the imposition of the tax was illegal. ${ }^{2}$ As this decision applied with equal force to St. Vincent, Dominica, and Tobago, as well as to Grenada, it cleared the way for carrying out the original plan of reserving quit-rents.

But the attempt to enforce the quit-rents in the Ceded Islands did not prove altogether successful. ${ }^{3}$ Having rid themselves of the four and a half per cent. export duty, the inhabitants were not favorably disposed toward the alternative, a quit-rent, and in this attitude they seem to have received the support of a number of the local officials. The receivers-general of Dominica, St. Vincent, and Tobago represented that unless their powers were increased, they could not collect the quit-rents or any other royal revenues. Therefore, they asked that the governors should receive orders to aid them in this work, and that courts of exchequer should be established. Also, they considered that the rate of exchange for foreign money

1 Bryan Edwards, History of the West Indies, I, 357, 359.

2 This decision was based essentially upon a proclamation of October 7 , 1763 , in which the crown guaranteed to the inhabitants of the Ceded Islands the rights of Englishmen, including those of legislation. Thereafter, the decision held, the crown could not arbitrarily levy taxes such as the export duty of $4 \frac{1}{2}$ per cent., but could confirm the inhabitants in their lands upon any terms that the British government chose to require. This decision, which accented the right of the crown to reserve a quit-rent, carefully distinguished between such a feudal charge and a tax which could only be levied by legislative authority. Bryan Edwards, History of the West Indies, I, 359-362.

3 Report of the Auditor-General, October 2, 1776, Treas. 1: 525, f. 87. 
should be fixed, and that they themselves should receive appointments as treasurers in their respective jurisdictions. $^{1}$ The Treasury paid little attention to these requests, although it gave instructions to the governors to render every possible assistance to the receivers-general. ${ }^{2}$ So completely were these instructions ignored that when these latter officials attempted to collect the quit-rents, it became necessary to hire an attorney to institute suits against delinquent landholders in St. Vincent and Grenada. ${ }^{3}$

A tactless policy soon increased the hostility towards the quit-rents in the Ceded Islands. The Treasury granted landholders in Dominica and St. Vincent the privilege of converting their leaseholds at two shillings per acre into a fee-simple tenure with a quit-rent of six pence per acre. ${ }^{*}$ But by a mere instruction, the board required that the purchase money, as well as the quit-rents, should be paid at an exchange of $£ 318 \mathrm{~s} 3 \mathrm{~d}$ per ounce of foreign gold, although the current rate was $£ 71 \mathrm{~s}$. Such an arbitrary increase in exchange was contrary to law, and led to much agitation. ${ }^{5}$ When the receiver-general of St. Vincent, Archibald Ingram, insisted upon payments of the quit-rents at the higher rate of exchange he became, as he himself complained, so obnoxious to men of character and property that, "I am in a measure excluded their society." As an instance of the temper of the people, he wrote that he had been spending the evening with a friend and his family, "all women," when he was attacked by a mob, of which three of the ring-

1 Treasury Minutes, July 20, 1774, Treas. 29 : 44, p. 6.

2 Treasury Minutes, August 5, 1774, Treas. 29: 44, p. 53.

3 Memorial of James Greene, March 2, 1775, Treas. 1: 515, ff. 14, 15.

4 Treasury Minutes, January 24 and August 3, 1774, Treas. 29: 43, p. $277 ; 44$, pp. 48-49.

5 Archibald Ingram to Treasury, August 29 and 30, 1776, Treas. 1: 521, ff. 259-260, 264-265. 
leaders were members of the assembly and two were justices of the peace. Coming into the house, the mob demanded that he either resign his commission or quit the island. After he refused to take either step, some soldiers of the Sixth Regiment rescued him from being carried into the streets, whether to be tarred and feathered, "as has been said," or for other purposes the conspirators alone knew. Much abuse and many "infamous opprobrious names"' ended the affair, which, in Ingram's opinion, indicated that, "the affray from the northward" was kindling in the tropics. ${ }^{1}$ Despite such bitter opposition, Ingram persisted, and collected over $£ 2,300$ sterling from the quit-rents of St. Vincent, most of it from arrears. $^{2}$

Ingram's successor, Johnathan Atkinson, who was more tactful but less successful, reported that the revenue from the quit-rents was little more than sufficient to pay the cost of collection. ${ }^{3}$ To encourage the people to pay their rents and to disarm their hostility, he accepted payments at the usual exchange, rather than at the advanced rate fixed by the Treasury. In spite of these conciliatory measures, Atkinson found that many hindrances were thrown in his way. Of the suits he brought for enforcing the quit-rents, two came to trial but "were cast." One defendant paid his rent, while the other, supported by many of the inhabitants of the island, appealed the case. Moreover, Atkinson complained that in investigating the affairs of his office, he suffered much annoyance from Ingram's deputy who, besides refusing to allow him to

1 Archibald Ingram to John Robinson, September 24, 1776, Treas. 1: 521, f. 257 .

2 The total collections were $£ 2,3893 \mathrm{~s} 6 \mathrm{~d}$, of which a part was collected from leasehold land that paid $1 \mathrm{~s} 6 \mathrm{~d}$ per acre. All the quit-rents at $6 \mathrm{~d}$ per acre were paid up to June 1,1776 , while a considerable sum had been received from town lots. Ingram's Accounts, Treas. 1: 554, f. 92.

3 Account of the Quit-Rents for St. Vincent, 1778, Treas. 1: 554, f. 91. 
see the instructions from the British government, retained possession of the books kept by the receivergeneral. ${ }^{1}$

In Tobago also, the attempt to establish quit-rents aroused petty jealousies and local hostility. Peter Frankleyne, who had been appointed receiver-general of the island in 1773 , complained that by act of the assembly he was compelled personally to collect all payments. Though he had petitioned for a repeal of this clause, offering to give personal security, the council and the assembly even denied his right to receive any taxes whatever. Finally he was appointed treasurer of the island, but before he could enter upon his office the governor died, and his successor appointed another person. Frankleyne then appealed to the Treasury to consider the difficulties of his situation, and to take the necessary measures to enable him to carry out his commission. ${ }^{2}$ That the collection of the quit-rents in Tobago, as elsewhere, proved to be a difficult task, became manifest, when in 1778 the receiver-general denied that such charges were due. The only crown revenue, according to his statement, was a capitation tax which had been surrendered about 1769. Rather tartly he added, "I have given this information twice to the auditor-general, on being so often called on by him to account for His Majesty's quit-rents."

The failure to enforce the quit-rents in Grenada and the other Ceded Islands was typical of the situation in Barbadoes and the proprieties acquired in the eighteenth century, where the crown made a fatal mistake, as far as the quit-rents were concerned, of first granting these

1 Johnathan Atkinson to Treasury, January 10, 1779, Treas. 1 : 554, f. 93.

2 Peter Frankleyne to Treasury, received February 28, 1779, Treas. 1: 554 , f. 16 .

3 Richard Burke to John Robinson, October 10, 1778, Treas. 1: 545, f. 23. 
possessions to proprietaries. When, after being administered in a notoriously weak fashion, these proprieties finally came under royal control, the quit-rents had become merely nominal charges, and the crown was obliged either to accept the four and a half per cent. duty as a substitute, or abandon them altogether. Only in Jamaica was the quit-rent system firmly established, though even there the crown surrendered the control of this fund in order to secure a perpetual revenue for the local government. In the territories ceded by treaty in the eighteenth century the results were even less successful. Settlement was so sparse in Nova Scotia and the Floridas that it would have been difficult to enforce the quit-rents under the most favorable conditions, but in both colonies the necessity of conciliation, and of securing as large an English population as possible, rendered altogether undesirable the employment of coercive measures in order to collect these dues. A similar situation was presented in Quebec where, in addition, the widespread existence of the French tenure of land was especially unfavorable to the development of the quit-rents. With the coming of the Loyalists, the demand for the British land system, with the quit-rent as a customary feature, proved to be one of the chief reasons for the division of the province into Upper and Lower Canada. But the success of the American Revolution, together with the establishment in the former colonies of a land tenure that was free from all feudal dues, marked the doom of the quit-rents in Canada. In broad-minded fashion the British government bowed to the inevitable, and consented to the abandonment of the quit-rents, although these charges had been a usual feature of the land system from the very beginnings of American colonization. 


\section{CHAPTER XIV}

\section{BRITISH CONTROL OF THE QUIT-RENTS}

As the quit-rents paid to the crown constituted a royal revenue, the British government was obliged to develop a system of control that strikingly illustrates in its evolution the opportunist and dilatory methods, whereby problems of colonial administration were so often met. In an analysis of this system of control, it will be necessary to call attention to many details that have already been noted in the preceding chapters, but such repetition is essential in order to afford a composite view. The status of the quit-rents, as a revenue that was altogether at the disposal of the crown, was emphasized by the strict prohibition, except in Jamaica, of any expenditure from this fund, unless authorized by a royal warrant. ${ }^{1}$ Since collections, also, were in charge of officials who were responsible directly to the royal officials, and only indirectly to the governors of the respective colonies, an effective and centralized system of oversight became a necessity. This need was all the more pressing in view of the inevitable opposition in the colonies to a tenurial charge, such as the quit-rents, which was payable to an external power. But British control of the quit-rents was exceedingly

1 In Jamaica the quit-rents were soon absorbed in the general publie revenue. In Virginia, after 1684, the governor was ordered to permit expenditures from the quit-rents only upon a royal warrant. That this precedent, which was followed in other erown colonies, was effective is illustrated by a warrant upon the Virginia quit-rents, noted as, "given at Our Camp at Banques, the 7th. Day of September, N. S. 1695.' Blathwayt's Journal, I, 190-191, 287, 698-699; Treas. 1: 35, f. 70. 
loose prior to 1667 , when the newly organized Treasury Board assumed the supervision of all the royal revenues in America. In 1680 the board delegated the supervision of the quit-rent system in the crown colonies to an auditor-general, but as the quit-rent was only one of several revenues under the control of the Treasury and the auditor-general, their functions will be considered, as far as possible, with reference to the quit-rents alone.

The office of surveyor and auditor-general of all the royal revenues in the American plantations, or simply auditor-general according to the usual designation, was inaugurated May 19, 1680, with the appointment of William Blathwayt. The avowed purpose of creating the new office was to ensure the proper supervision and audit of the revenues from the American colonies. ${ }^{1}$ The patent to Blathwayt conferred general powers, "by all lawful ways and means," to recover and have paid to the proper officers all such "rents, duties and profits" in the American colonies as should become due to the crown. But the auditor-general was not uncontrolled in the exercise of his powers, for his audits were subject to the approval of the Lord High Treasurer, the First Lord of the Treasury, or the Chancellor of the Exchequer. ${ }^{2}$ At one time or another these officials exercised authority over the office and within the terms of the commission controlled the auditor-general as far as seemed necessary. From time to time the auditor-general reported to them

1 The patent set forth that the office was created in order to settle the revenues of the American plantations, and "for the due and orderly taking, examining and stating the accounts of all and every the collectors, receivers, ete." of "the summes of money growing or arising, and due and payable unto us" from the American plantations. Patent, May 19, 1680, Blathwayt's Journal, I, 5-15.

2 There were but six Lord High Treasurers after 1667 and none after 1714; the Chancellor of the Exchequer was a member of the Treasury Board. 
upon the accounts he received from local officials in the colonies, and in addition laid before them such observations and proposals as he considered would tend to the betterment of the revenue under his care. These terms practically made the auditor-general a deputy of the Treasury, charged with the general oversight and audit of all colonial revenues including the quit-rents. ${ }^{1}$ As compensation for his work he received a salary of $£ 500$, payable from the colonial revenues. ${ }^{2}$ This salary never seems to have been regularly paid, and certainly under Blathwayt the office was by no means a lucrative one. ${ }^{3}$ As additional colonies were brought under the royal control, an annual allowance was made in each for the auditorgeneral, so that by the close of the colonial period, the office was nominally worth at least $£ 950$ annually, although deductions for clerical work, in addition to irregular payments, materially reduced this compensation. ${ }^{4}$

1 Patent to William Blathwayt, May 19, 1680, Blathwayt's Journal, I, 5-15. Printed in Mass. Col. Rec., V, 521-526.

2 This salary was payable from the royal revenues as follows: $£ 100$ from Virginia, $£ 150$ from Barbadoes, $£ 100$ from the Leeward Islands, and $£ 150$ from Jamaica. Patent to William Blathwayt, May 19, 1680, Blathwayt's Journal, I, 8-9 ; Patent to Horatio Walpole, October 15, 1716, Patent Rolls, 3511, no. 28; Reversionary Patent to Robert Cholmondeley, November 20, 1751, Patent Rolls, 3634, no. 20.

3 In 1711 Blathwayt reported that the arrears in his salary amounted to $£ 2,300$, including $£ 1,300$ due from Barbadoes, $£ 800$ from the Leeward Islands, and $£ 200$ from Virginia, "with little expectation of due payment." Report to Commissioners of Accounts, September 13, 1711, Blathwayt's Journal, III, 63-70.

4 In his report to the Claims Commission in 1787, Cholmondeley asserted that his office was worth $£ 1,886$ annually, with a deduction of $£ 468$ for deputies and clerical expenses. But this statement cannot be relied upon, for the commission of 5 per cent. on all accounts audited, which he included in his summary, was more probably paid to the deputy auditors in the respective colonies. See reference, p. 423 , note 2 . The $£ 450$ above the regular $£ 500$ salary of the auditor-general included $£ 100$ from New York, $£ 150$ from Virginia, $£ 100$ from North Carolina and $£ 100$ from South Carolina. Me- 
Subject to the approval of his superiors, the auditorgeneral was authorized to appoint deputies as his personal representatives in the colonies, and he usually named a deputy auditor in each crown colony. ${ }^{1}$ These deputies received full powers to audit all accounts of the royal revenues in the colonies to which they were assigned. At regular intervals they were to report to the auditor-general, and always were subject to his authority, their commissions being vacated at his pleasure. Every six months they were to send to him such accounts as they had examined in the interim, to be "fairly written and duly attested," ${ }^{2}$ which before transmission to England, were to be examined and approved in each case by the governor and council. ${ }^{3}$ As a reward for this work they received a commission of five per cent. on all the accounts they audited, an arrangement that should have spurred them on to greater efforts in securing the enforcement of quit-rents. ${ }^{4}$

morial, Robert Cholmondeley to American Loyalist Claims Commission, 1787, Audit Office Transeripts, N. Y. Public Library, 45, pp. 433 et seq.

1 The office of auditor, which had already been established in Virginia, was soon brought under the control of the auditor-general. Blathwayt's Journal, I, 11; Va. Mag. of Hist., XIII, 227-231.

2 Deputation to Reginald Wilson, April 18, 1681, Blathwayt's Journal, I, 97-101. The deputation to Randolph, October 15, 1681, is in Mass. Col. Rec., V, 526-529.

3 Commission to George Clarke, January 29, 1702, Blathwayt's Journal, II, 128-129.

4 No separate allowance was made at first to the deputy auditor in New York, but by 1731 he received a commission of 5 per cent. as in the other colonies. Cholmondeley claimed that this 5 per cent. formed part of the perquisites of his office, but the evidence from the detailed accounts shows that this fee was the customary allowance made to the deputy auditor in each crown colony, except Jamaica where $£ 50$ was paid him annually by the auditor-general. Memorial of Robert Cholmondeley to the American Loyalist Claims Commission, 1787, Audit Office Transeripts, 45, ff. 433 et seq.; S. C. Quit-Rent MSS., 1733-1741, and 1756-1774; Blathwayt's Journal, III, 69 ; Treas. 1 : 187 , f. 14 ; 303 , f. 205 ; 503, f. 114 ; 505, f. 320 ; Treas. 54: 31, pp. 398-399. 
The most important local official in charge of the royal quit-rent system was the receiver-general, whom the crown appointed in each colony. Originally this office was filled in rather a casual fashion, as in Virginia where, in the early days, the treasurer collected such quit-rents as were received. ${ }^{1}$ With the reorganization of colonial finances in 1680 the importance of the receiver-general, as the chief officer in charge of the royal revenues in the crown colonies, steadily increased. His chief duty was to collect the royal revenues, including of course the quitrents, in the colony to which he was assigned. Where these dues were not promptly paid, he was authorized to levy by distress or otherwise, "according to the laws of our kingdom or the laws of our said colony and dominion." From the funds collected in payment of the quitrents, the receiver-general was to allow expenditures only upon the express authority of a royal warrant, and as an incentive to faithful work he received a commission of five per cent. in Virginia and ten per cent. in the Carolinas, on all receipts, while the proper performance of his duties was secured by a bond. ${ }^{2}$ At first the receivergeneral was wholly free of supervision by the Treasury

1 No regular accounts of the Virginia quit-rents seem to have been kept, or at least sent to England before 1684, when the crown purchased from Culpeper the land-rights in all but the Northern Neck. Treasury to Colonel Norwood, November 17, 1681, Blathwayt's Journal, I, 128-129.

2 The patent issued October 19, 1705, to William Byrd, as receivergeneral of Virginia, directed him to make grants out of the quit-rents, " according to such especial warrants or orders as shall be given by us to our said governor or commander-in-chief, or to him the said William Byrd, in that behalf and not otherwise." This patent allowed a commission of 3 per cent., afterward increased to 5 per cent., and required a bond for $£ 6,000$ in both England and Virginia. Treas. 52: 22, pp. 500-501. Later, in the Carolinas, the commission allowed the receiver-general was increased to 10 per cent., but it remained fixed at 5 per cent. in Virginia. Virginia Quit-Rent Accounts, 1713-1714, and following, Treas. 1: 187, f. 14 et seq.; Patent to John Hammerton, September 16, 1730, Treas. 52: 37, pp. 73-75. 
and the auditor-general, inasmuch as he held his office by royal patent and was thus responsible to the crown alone. A slight measure of control was afforded by the requirement that the Treasury approve the bond of the receivergeneral and that this official should make an annual report to the auditor-general of all receipts and expenditures. ${ }^{1}$ Later patents to receivers-general ordered them to give security, according to "the good liking of our governor and council," although this change does not appear to have strengthened British control in the colonies. $^{2}$

There were many defects in the system, as it was finally worked out. The most obvious was the fact that the receivers-general in the colonies and the auditorgeneral in England were practically coördinate officers, each holding directly under the crown. To secure effective work the receivers-general should have been placed upon the same basis as the deputy auditors in their relations with the auditor-general. The need for reform in this particular was apparent in the actual working of the quit-rent system, since the auditor-general was obliged to make representations to the crown in order to secure the removal of a dilatory receiver-general. ${ }^{3}$ This obligation was a cause of much trouble, for the receivers, ignoring the admonitions of the auditor-general, conducted their offices almost as they pleased. Another defect was the rather anomalous relation of the receiver-general and the deputy auditor to the governor of the colony. Much better results would have been secured had the governor received more actual power over both these officials. As it was, friction was inevitable, since the governor was

1 Patent to John Hammerton, September 16, 1730, Treas. 52: 37, pp. 73-75.

2 Patent to George Saxby, February 9, 1742, Treas. 52: 41, pp. 485-486.

3 See especially the case of Eleazer Allen, pp. 414-415. 
naturally more loyal to the royal interests than the receiver-general and the deputy auditor, who were often chosen from the colonial gentry and were apt to side with local interests in case of a conflict. Another defect was the extended scope of the auditor-general's duties. With numerous other revenues under his supervision, he was unable to give the attention to the quit-rents that these important feudal dues demanded. A similar condition existed in the offices of deputy auditor and receivergeneral. The ideal system would have been to create a special staff of officials in the crown colonies, whose sole duty was the enforcement of the quit-rents.

These defects in the organization prevented the really excellent system established for the control of the quitrents from attaining its full efficiency. Of all the crown colonies, Virginia was the one in which, owing to a combination of fortuitous circumstances, the system was at its best. Here the quit-rents were regularly collected, either every six months or annually, by the receivergeneral, who made expenditures upon the authority of royal warrants. His accounts were inspected every year by the deputy auditor, passed by the governor and council, and then sent to the auditor-general. With much less regularity, the same procedure was observed in South Carolina, ${ }^{1}$ but in other colonies such a systematic accounting of the quit-rents was not customary. Though often badly administered, the British system was well contrived to do the work required, and capable of expansion, if necessary, in order to meet further demands, as additional colonies came under the royal control.

Occasionally special officers supplemented the usual force, as when Francis Nicholson, sent to the colonies in

1 Accounts, Virginia Quit-Rents for various years, Treas. 1: 323, f. 92; 348, f. 254 et seq.; Accounts, S. C. Quit-Rents, C. O. 5 : 512, III, etc. 
1712 primarily as military governor of Nova Scotia, was instructed to make a general report on all standing revenues. His mission, however, produced no results as far as the quit-rents were concerned. ${ }^{1}$ More important was the appointment, after the crown purchased the Carolinas, of James St. John as inspector and controller of the quit-rents of Carolina. Though he held his offices under a royal patent, St. John was subject to the directions of the Treasury and the Board of Trade. ${ }^{2}$ He was also appointed a deputy auditor by Walpole, and thus had entire control of the quit-rents in the Carolinas with the exception of the actual work of collection. ${ }^{3}$ His instructions from the Treasury ordered him to proceed to Carolina and get the best available information regarding the quit-rents and other royal revenues that he could. After securing these details he was to make out a rent roll, delivering copies to the receiver-general, to the auditor-general and to the Treasury Board. He was to "use his utmost endeavors" to detect any frauds and to report them to the Treasury and the Board of Trade, while from time to time he was to notify the auditorgeneral of any measures he considered practicable in order to improve the quit-rents. Thus, his mission was that of a special officer who was endowed with an unusual combination of powers in order to put the quit-rents of Carolina upon a firm footing, ${ }^{4}$ and inevitably he came

1 Commission to Francis Nicholson, October 14, 1712, and his report, March 8, 1719, Treas. 1: 227, ff. 103-105, 106.

2 Beside the regular fees allowed the surveyor-general, St. John received a salary of $£ 100$ proclamation money of South Carolina, which was payable out of the quit-rents, in compensation for his work as inspector and controller of the quit-rents. Patent to St. John, March 22, 1731, Treas. 52: 37, pp. 179-180.

3 Deputation to St. John, May 15, 1731, Treas. 54: 37, p. 377.

4 The instructions to St. John were inclusive and definite. He was to get, "the best information he can, either by inspecting land grants or other 
into conflict with the local officials who stood for colonial interests. In this conflict he was completely worsted. ${ }^{1}$

Determined to enforce the quit-rents in the Carolinas, the British government in 1739 sent Henry McCulloh, not as an officer endowed with a combination of local powers, but rather as the personal representative of the crown to bring into order the land system and the quitrents. As special commissioner for the supervision, inspection, and control of all the royal revenues and land grants in both North and South Carolina, McCulloh was granted much ampler powers than had been given St. John. He was to examine all necessary records, and to conduct what was really a court of inquiry into the general condition of the quit-rents and land grants. His office was rather inquisitorial than administrative in character, as he was required to report all cases of fraudulent practice to the attorneys-general of the Carolinas for legal action. He was also to fix the proper rules, "to be observed for the more speedy collecting, receiving, and accounting for our quit-rents, and detecting and prosecuting any persons concealing or detaining the same," and was subject to the instructions of the Treasury and the Board of Trade, to whom he reported. To encourage his work, his salary was to be paid from the quit-rents. ${ }^{2}$

public records, or by any other lawful means,' of the quit-rents and other revenues. The form of rent roll was carefully specified, and was to include the names of the patentees or possessors, the number of acres, and the district or county in which the different tracts lay. Instructions to James St. John, May 12, 1731, Treas. 54: 31, pp. 375-376.

1 See pp. 323-326.

2 The importance attached to MeCulloh's mission was shown by the rery ample powers he was granted, as compared with those of St. John. He was empowered "to examine and inquire into all frauds, concealments, neglects, delays, and abuses with respect to the grants of land there and the quitrents payable thereupon, and towards preventing and determining all disputes relating to the premises, to inspect into the records and registers of the said provinces, and to summon or cause to be summoned before him all 
He also was unsuccessful in his mission, for, like St. John, he was balked by the opposition of colonial officials who represented local interests. ${ }^{1}$

Though the special missions of St. John and McCulloh failed in their objects, the operation of the quit-rent systems in Virginia and the Carolinas was not without results. Especially in Virginia, and to a lesser extent in South Carolina, satisfactory enforcement was secured under the three auditors-general: William Blathwayt who held office from 1680 to 1717 , Horatio Walpole from 1717 to 1757, and Robert Cholmondeley from 1757 to the Revolution. The development of the colonial quit-rent system under their care can best be taken up in detailed accounts of their separate administrations. ${ }^{2}$

Under William Blathwayt excellent work was done in the systematization and upbuilding of all the royal revenues from America. During his administration, the royal authority was asserted over the quit-rents, and notably in Virginia important steps were taken to establish and enforce these feudal dues. In accomplishing these ends Blathwayt personally played an important part. From the very first he was supported by the British

such persons as he shall judge capable of giving him any information relating to the premises, and also where our said commissioner finds, after due examination, that lands are claimed there under irregular titles as exempted from quit-rents, or as liable to pay less quit-rents than those preseribed by our royal instructions, or that any greater quantities of land are claimed or held by particular persons than what they pay rent for, or that lands are not regularly settled according to the conditions of the regular grants,' he should report all such cases for legal procedure. The patent required the colonial officials, including especially the treasurer, to give McCulloh full aid, especially by making all books and records available for his inspection. Patent to McCulloh, May 16, 1737, Treas. 52: 40, pp. 281-284.

1 See for details of both St. John's and MeCulloh's official conduct, pp. 296-299, 323-326, 331-341.

2 For an interesting account of the three auditors-general and the details of their office, see Andrews, Guide to the British Public Record Office, II, 142-148. 
government, which issued orders that the governors should give him and his assistants all necessary help and that all persons who were concerned with, "or intermeddle[d] with," the revenues should obey his orders. Additional instructions strengthened his position by requiring that all accounts of receipts and expenditures should be sent to him every six months. Still another important order, and one that set a precedent for other colonies, required the auditor of Virginia to send him a ledger of all quit-rents and similar payments due upon the land, so that he might the more effectually inspect accounts. ${ }^{1}$

In true businesslike fashion, Blathwayt organized his force of subordinates by appointing a deputy auditor in each crown colony, except Virginia. ${ }^{2}$ Continuing this energetic policy, he promptly appointed a deputy auditor in New York after the accession of the Duke of York brought that province under the royal control. ${ }^{3}$ Virginia, too, soon came under his jurisdiction when Nathaniel

1 See specimens of circular letters, King and Treasury to the Governor of Virginia, June 30 and July 15, and Treasury to Auditor of Virginia, July 5, 1680, Blathwayt's Journal, I, 43-51.

The Library of Congress has recently acquired "The Accounts of Her Majesties Revenues in America, as brought in and presented to the Honorable Commissioners of Accompts by William Blathwayt, Esquire, Surveyor and Auditor General thereof,' covering the period 1701 to 1712, and containing the accounts of New York, Massachusetts, New Hampshire, Jamaica, Virginia, Barbadoes, and Bermuda. It originally formed part of the Phillipps Collection, sold at Sotheby's in 1913.

2 Blathwayt appointed deputy auditors in Jamaica, New England, except New Hampshire, and Barbadoes. Blathwayt's Journal', I, 121. The quitrents, of course, formed only a part of the revenues under the care of the auditor-general and these deputies. The returns from the $4 \frac{1}{2}$ per cent. export duty in Barbadoes were far more important from the royal standpoint, while in other colonies there were numerous other revenues to be audited, as for example the $2 \mathrm{~s}$ per hogshead in Virginia. Blathwayt's Journal, I, 2, 3 and passim.

3 Commission to Stephen Courtland, Norember 7, 1687, Blathwayt's Journal, I, 446-452. 
Bacon, who held his office as auditor of Virginia by virtue of a royal patent, was induced to step out, "by reason of his great age and indisposition of health," and William Byrd, of the council of Virginia, was appointed as his successor. ${ }^{1}$ After Colonel Byrd's death, Blathwayt strongly opposed the practice of appointing the same person as both receiver-general and deputy auditor of Virginia, and the final separation of the two offices, certainly a wise move in the interest of the quit-rents, was due in large part to his influence. ${ }^{2}$

A number of instances show that the supervision exercised by Blathwayt over his subordinates was tactful and energetic. An example of his good judgment was the recommendation that Alexander Graham, who had acted as temporary receiver of New York, should be allowed due compensation as "a further encouragement." ${ }^{3}$ As the Treasury allowed him much latitude in the matter of appointments he was always prompt to fill vacancies in the ranks of the deputy auditors. ${ }^{4}$ Thus, soon after the death of Dudley Diggs, deputy auditor for Virginia, he recommended as his successor Philip Ludwell, a member of the council, of whom he had "a very good character," and this nomination was immediately confirmed by the Treasury, ${ }^{5}$ but soon after for good reason he revoked this deputation and appointed John

1 Blathwayt's Journal, I, 472-473.

2 Governor Nicholson to Treasury, August 24, 1700, and Blathwayt's report, February 11, 1701, Blathwayt's Journal, II, 60-61, 66-69. Blathwayt showed his business acumen by insisting that the Treasury make an immediate decision regarding the separation of the two offices, so that word might be sent to Virginia by the ships that were about to sail. Blathwayt to Lord Treasurer, July 12, 1705, Blathwayt's Journal, II, 376-379.

3 Report of William Blathwayt, March 3, 1692, Treas. 1: 17, f. 220.

4 Blathwayt's Journal, I, 2, 3 and passim.

5 Blathwayt to William Lowndes, April 18, 1711, Blathwayt's Journal, III, 49-50. 
Grymes to the vacant place. $^{1}$ These incidents illustrate the personal watch that Blathwayt kept over the administration of the royal revenues in the different crown colonies.

Occasionally Blathwayt influenced the appointments of the receivers-general, as in the case of William Byrd, II, whose petition to succeed his father was referred to him for an opinion. He reported in favor of the petitioner, who was, he pointed out, "now possest of one of the most considerable estates in Virginia," and had "an education answerable to this employment,", and his recommendation was favorably considered. But later, when upon the expiration of Byrd's commission at the death of Queen Anne, he again reported favorably upon Byrd's petition for a reappointment, as that of one who had efficiently performed his duties, ${ }^{3}$ the Treasury refused to follow his recommendation and appointed James Roscow, ${ }^{4}$ the nominee of Governor Spotswood.

Next in importance to the oversight of his subordinates was the work of the auditor-general in auditing accounts, the quit-rents receiving his special attention. Soon after his appointment Blathwayt endeavored to secure a systematic accounting for the quit-rent fund, and called upon Colonel Norwood, who had collected the quit-rents of Virginia up to 1669 , for his accounts. ${ }^{5}$ Norwood evaded

1 The language of the recall emphasized the authority of Blathwayt. As Ludwell had been appointed to the office of auditor of Virginia, "so long as by him, the said William Blathwayt shall be thought fit, the said William Blathwayt doth hereby revoke etc."' these powers. Revocation of Deputation to Philip Ludwell, July 2, 1716, Blathwayt's Journal, III, 144-145.

2 Report of Blathwayt, October 12, 1705, Blathwayt's Journal, II, 391392.

3 Report of Blathwayt, March 17, 1715, Treas. 1: 189, f. 16.

4 Patent to James Roscow, April 21, 1716, Blathwayt's Journal, III, 141144.

5 Blathwayt's Journal, I, 1-100, passim. 
a direct answer, claiming that as "Cleybourne". and other former treasurers had not been held accountable for the quit-rents, neither should he. Blathwayt promptly met such an excuse with a reminder that "Cleybourne" was still responsible, and proposed to charge Colonel Norwood with all the profits from Virginia for which he had not accounted. ${ }^{1}$ Though the Treasury supported this rather strenuous policy with a threat of legal proceedings, the refractory colonel paid little attention to the repeated warnings and apparently no final steps were ever taken. But at least Blathwayt had served notice that the old slipshod manner of administering colonial finances had come to an end. ${ }^{2}$

The energy with which Blathwayt supervised the audit of accounts was illustrated when William Byrd, Sr., receiver-general and deputy auditor of Virginia, died in 1704 , owing the crown a large balance. The adjustment of this account was considered so pressing a matter that Lord Treasurer Godolphin, lending Blathwayt his personal support, ordered that Byrd's son, who was his executor, should go before the governor and council of Virginia with his father's accounts, and should give full security for any balance that was owing to the erown from the estate. When urging the governor of Virginia to send full particulars of these accounts by the first ship, Blathwayt cannily suggested that the appointment of a successor would be materially influenced by the result of this investigation. Such a hint was well timed, inas-

1 Norwood, who had been appointed treasurer of Virginia in 1650, made no report of the quit-rents. He was liable for the revenues up to 1669 when the rights of the patentees under the royal grant began. As nothing could have been collected during the Puritan interim, he was held accountable only for the nine years, 1660-1669. Blathwayt's reports, October 13, and about November, 1681, Blathwayt's Journal, I, 120, 130-132.

2 Blathwayt's report, October 4, 1680, and Treasury to Colonel Norwood, November 17, 1681, Blathwayt's Journal, I, 60-65, 128-129. 
much as William Byrd, II, was a candidate to succeed his father. ${ }^{1}$ By means of a minute examination, the governor and council discovered that Colonel Byrd's accounts were complete for all receipts of the quit-rents from the date he assumed office, June 20, 1688, till his death, December 4,1704 . These accounts they verified by a comparison with the rent rolls of the different counties. Also, they found that all payments from the quit-rents had been made in due legal form, upon the basis of royal warrants. ${ }^{2}$ So ably did Blathwayt direct this settlement that within two years of Colonel Byrd's death, the entire balance due from his estate was remitted to the royal exchequer. ${ }^{3}$ To guard against future loss under similar circumstances, the Lord Treasurer required that before receivers-general should be allowed to assume office, they must give ample security in England as well as in the colonies, to cover any possible balance that was left in their hands. ${ }^{4}$

Closely connected with the audit of the quit-rents were Blathwayt's persistent attempts to collect the acknowledgments due from the proprietaries of American col-

1 The balance in the hands of William Byrd at the time of his death was $£ 7,6989 \mathrm{~s} 10 \mathrm{~d}$, of which $£ 5,7529 \mathrm{~s} 4 \mathrm{~d}$ was on account of the quit-rents. To seeure this sum, his son, William Byrd the younger, gave security for $£ 10,000$. Godolphin to Governor Nott, June 4, 1705, and William Blathwayt to Governor Nott, June 8, 1705, Blathwayt's Journal, II, 357-361. Cf. Cal. State Pap. Col. 1704-1705, p. 739. Godolphin was Lord High Treasurer from 1702 to 1710 . The office was not permanently put in commission and a “Treasury Board", permanently established until 1714.

2 Report to Council of Virginia, August 29, 1706, Blathwayt's Journal, II, $463-467$.

3 William Blathwayt to Lord Treasurer, December 11, 1705, and November 22, 1706, Blathwayt's Journal, II, 399-401, 451.

4 The total security required from the next receiver-general of Virginia was $£ 12,000$, one-half to be given in England, the other half in Virginia. This covered all possible losses. Similar double security was ordered in other colonies. Godolphin to Governor Nott, October 29, 1705, and Blathwayt to receiver-general of Jamaica, June 6, 1705, Blathwayt's Journal, II, $359,406$. 


\section{BRITISH CONTROL OF QUIT-RENTS 403}

onies. ${ }^{1}$ He repeatedly called the attention of the Treasury to their failure to pay these dues, and at the same time reminded the different proprietaries of their obligations. The proprietaries paid so little attention to these admonitions that in 1705 Blathwayt was asked to make out a report of all these acknowledgments for the Queen's Remembrancer, ${ }^{2}$ in order that processes for recovery might be issued. ${ }^{3}$ Finally, the proprietaries of the Carolinas settled their account, but nothing was ever secured from the other delinquents. ${ }^{4}$ Of similar interest was the half of the quit-rents and profits due from the Lower Counties, which was involved in the failure of William Penn to collect these charges in that region. ${ }^{5}$ These unpaid dues gave rise to an incident that illustrates the frequent attempts that were made at this period to raid the royal treasury under the plea of supposed services. Pretending to have discovered that Penn owed the crown $£ 3,000$, due from the Lower Counties, one Oliver Hill petitioned that he be allowed one-third of this sum for his alleged labors in bringing the debt to light, together with an additional sum as compensation for all injuries and damages he had incurred in making the discovery.

1 These annual dues included chiefly, for East and West Jersey, 10 nobles each; for Pennsylvania, two beaver skins; for Neweastle, 5s; for the Lower Counties, one-half of all quit-rents and other profits ; for Carolina, 20 marks; for Hudson Bay, two black beaver skins; and for Mount Hope in New England, seven beaver skins. Report of John Povey, August 26, 1701, and Blathwayt to William Lowndes, August 9, 1703, Blathwayt's Journal, II, 88-89, 204-205.

2 An official of that part of the exchequer known as the exchequer of account, whose duties were to recover the king's debts and regular revenues. Seargill-Bird, Guide to the Public Record Office, 3d ed., p. 87; Report on the Exchequer, Parliamentary Papers, 1797, X, 447; Thomas, The Ancient Exchequer of England, pp. 109-111.

3 William Lowndes to Blathwayt, May. 1, 1703, Blathwayt's Journal, II, 202, 204-205.

4 Blathwayt's Journal, I, 132-133; II, 142, 319.

5 Ibid., II, 205. 
John Povey, then acting as Blathwayt's deputy, objected that Hill's claim for compensation was altogether baseless. With a grim sarcasm that showed a sense of humor was not lacking in the prosaic office of the auditor-general, he added that, upon the return of Mr. Penn's moiety, he could see no objection to the payment of the petitioner's losses. ${ }^{1}$

In addition to auditing the accounts, Blathwayt sent numerous detailed reports to the commissioners of accounts and to the Treasury Board. These reports show that under his supervision the colonial revenues, and especially the quit-rents, were gradually being systematized to such an extent that accounts were coming in at stated intervals. Of the quit-rent accounts reported by Blathwayt, by far the largest returns were from Virginia. In New York this revenue was a mere trifle, and in Jamaica it was included in the general public funds. Up to 1700 , while the office of auditor-general was being placed upon a firm basis, Blathwayt submitted two general reports. After 1700 he filed numerous reports in response to requests from the Treasury and the commissioners of accounts. ${ }^{2}$ The evident policy of these two

1 Report of John Povey, December 9, 1701, Blathwayt's Journal, II, 91-93. This John Povey, who was acting as Blathwayt's assistant or deputy in the auditor-general's office at this time, may have been his uncle, the half-brother of his mother, and one of the elerks of the Privy Council. But the identification is uncertain, since the genealogy of the Povey family is at present almost hopelessly obscure. Blathwayt had other uncles and probably many cousins and one of them may have been this John. The Thomas Povey, who was lieutenant governor of Massachusetts from 1702 to 1706 , may also have been one of these cousins, and in that case his appointment may have been due to Blathwayt, who was at this time at the height of his political influence. C. M. A.

2 Report of William Blathwayt, August 15, 1692, Blathwayt's Journal, I, 618-622. The second report showed that Blathwayt was receiving accounts semiannually from Jamaica, annually from Virginia, and quarterly from New York. Commissioners of Accounts to Blathwayt, June 30, 1696, and Blathwayt's report, August, 1696, Blathwayt's Journal, I, 715-718. 
boards was to require from Blathwayt regular reports, and for a time he seems to have complied. A report filed with the Treasury in 1701, in answer to a request for a detailed statement of plantation accounts, emphasized the importance of the Virginia quit-rents as a fund that was altogether at the disposal of the crown, and one that was available to meet such emergencies as Bacon's Rebellion. The frequency with which Blathwayt called attention to the value of the quit-rents shows that he fully appreciated the importance to the crown of this revenue. ${ }^{1}$ The next report was in response to a request from the commissioners of accounts for a detailed statement of all plantation revenues from about 1695 . The report, which was presented only a month after the request had been made, was a proof of the constant supervision that Blathwayt exercised over the quit-rents, together with the other revenues in the colonies. ${ }^{2}$

Blathwayt continued to make out general reports, all of which revealed a masterly grasp of the details of the colonial quit-rents, and a steady hand in enforcing their payment where possible. ${ }^{3}$ The diligence with which he secured the material upon which all these accounts were based is shown by a letter in which he asked the

1 This report was made out by John Povey, "in the absence of Mr. Blathwayt," at this time also secretary of war. But most of the reports were probably made out by Blathwayt personally, showing that he did not customarily neglect his duties. Treasury to Blathwayt or his Deputy, July 2, 1701, and John Povey's report, August 26, 1701, Blathwayt's Journal, II, 77-89.

2 The accounts filed included complete statements of the Virginia quitrents, 1695 to 1700 , of the New York quit-rents from Michaelmas, 1695, to Midsummer, 1701, and of the Jamaica revenues, which included quit-rents in the general summary, Michaelmas, 1694, to March 25, 1700. Commissioners of Accounts to William Blathwayt, May 21, 1702, and Blathwayt's report, June 20, 1702, Blathwayt's Journal, II, 103-115.

3 See various reports for 1703 , also accounts, Blathwayt's Journal, II, 130-147, 202-209, 233; Treas. 1: 87, ff. 6-7, 254, 373. 
receiver-general of Jamaica to send in certain accounts that had been omitted, and called especial attention to the instruction to report every six months. ${ }^{1}$ But either his zeal flagged, or, more probably, the duties of his many offices became so heavy and the clerical assistance that he needed so insufficient, owing to the meager allowances made, that it became impossible to continue regular reports. Whatever the reason, the frequent reports ceased. A report filed January 31, 1705, with Lord Treasurer Godolphin is notable for its detail and exactness, but another for New York was so poor that Blathwayt apologized for his failure to secure accurate statements prior to June 9, 1702, owing to the "backwardness and negligence" of the persons who were security for Weaver, the displaced collector. In a report on the accounts for Virginia, Blathwayt dwelt upon the necessity of requiring the receiver-general to give bond for the large balances that were customarily retained in the colony. This general account was probably the last filed by Blathwayt before $1711 .^{2}$

The general report of the plantation revenues made by Blathwayt in 1711 is especially important, as showing the results he had accomplished by his careful supervision of accounts. The commissioners of accounts had required him to make out, in one month's time, a detailed account of all the colonial revenues from 1701 to 1711, together with a list of the officers under his care and their salaries. Although the report required two months, rather than the one month limit set by the commissioners,

1 Blathwayt to Leonard Campear, October 17, 1704, Blathwayt's Journal, II, 283-285.

2 The balance on hand of the quit-rents of Virginia at the end of 1703 , was $£ 5,7439 \mathrm{~s} 4 \mathrm{~d}$. This sum, which was not an unusual balance, showed the force of Blathwayt's suggestion that ample security should be required. Blathwayt to Lord 'Treasurer, January 31, 1705, Blathwayt's Journal, II, $313-325$. 
it fully met these rather extensive demands, and was a proof of the general efficiency of the office of the auditorgeneral. The commissioners also asked for quarterly accounts of the colonial revenues up to the expiration of their commission on March 25, 1712, but Blathwayt's journal does not show that this request was complied with. After the comprehensive report already filed, further work of this sort was probably impossible, because of the want of sufficient clerical assistance. ${ }^{1}$ Another, and an even more significant report, especially in its bearing upon the quit-rent, was that which Blathwayt made in 1714 in reply to a request from the Treasury for an account of all colonial revenues, with a "view to rendering the colonies self-supporting." The report mentioned the quit-rents in Virginia and Jamaica only. In the report upon New York, Blathwayt entered fully into the financial troubles of the colony, showing that there had been practically no regular revenue since May 18, 1709. In commenting upon the revenues of New York, he upheld the plan already proposed in the Privy Council, of bringing a bill into parliament to secure "suffcient" revenue, except for garrisons, "without charge to the crown." He did not specify the exact method of raising this revenue, but in view of the efforts in New York at this time to extend and enforce the quit-rents, he probably had the quit-rent revenue in mind. He noted also the necessity of devising some means to support the forts in St. Christopher, Nova Scotia, Newfoundland,

1 The report included the annual accounts of the quit-rents for Jamaica, March 25, 1702, to March 25, 1709, and for Virginia, April 25, 1701, to April 25, 1710. The lists of officials show that the offices of receivergeneral and deputy auditor were filled at this time in New York, Jamaica, and Virginia, so that the quit-rents should have been properly enforced in these colonies. Commissioners of Accounts to William Blathwayt, July 9, 1711, and Blathwayt's report, September 13, 1711, Blathwayt's Journal, III, 61, 76 . 
and Hudson Bay, which had lately been acquired from the French, and from what we know of later attempts to establish the quit-rent system in Nova Scotia we may infer that he had in mind the quit-rents of these colonies also. The report of 1714 is the last general report which he filed during his official term, and it shows very forcibly his comprehensive view of colonial finance, and, by implication, his appreciation of the true nature of the quitrents. ${ }^{1}$

Blathwayt concerned himself also with the important question of the expenditures to be allowed from the quitrents, especially in Virginia. Many applications for grants from this fund were referred to him, and throughout his reports may be traced a consistent and broadminded policy, which was exceedingly important in fixing the exact status of the quit-rents. Usually he favored expenditures that were likely to promote the welfare of the colony, and reported unfavorably on requests for individual needs, thus protecting the quit-rents from a horde of special claimants who would soon have depleted the fund had they not been warned off. Fully appreciating the importance of the quit-rents as a royal fund for sudden emergencies, Blathwayt constantly endeavored to keep a large balance on hand. His policy is illustrated by his report upon the petition for aid in founding the College of William and Mary. Without passing upon the merits of the case, he called attention to the fact that the sum first asked for constituted the entire balance of the quit-rents of Virginia, which was "intended as a fund to answer the exigencies of that government." 2 That he

1 Report of William Blathwayt, April 10, 1714, Treas. 1: 174, ff. 209-213.

2 Blathwayt recommended that, with the exception of the quit-rents, the crown should grant all the aid petitioned for, including certain tracts of land, all escheats, and the duty of $1 \mathrm{~d}$ per pound on all tobacco exported to other colonies. The office of surveyor-general he did not mention. Peti- 
was influenced by zeal for the royal interests rather than by opposition to the college appears from his answer to the petition of the board of visitors in 1709, which asked, after the college with all its books and furniture had been burned, for additional royal aid from the quit-rents, to erect a "moderate building" in place of the one that had been destroyed. This time Blathwayt reported that the balance of the quit-rents was ample to allow such a grant, and he added that if more aid were necessary the crown might increase this bounty in the future, provided "regard to the produce of the quit-rents" permitted." With a like appreciation of local needs, Blathwayt reported favorably upon a petition asking the crown to make an appropriation from the quit-rents to aid in the erection and support of two schools for the Indians of Virginia. He believed that such an undertaking, by cementing friendship with the Indians, would help to protect the frontiers from the French and promote the general welfare of the colony, and he recommended an immediate appropriation for building the schools and an annual allowance for their support. ${ }^{2}$

In other reports on proposed expenditures from the quit-rents, Blathwayt emphasized the nature of this revenue as one that should be employed for such extraordinary expenditures as were not likely to receive the sanc-

tion of Virginia Assembly, and report of William Blathwayt, February 22, 1692, Blathwayt's Journal, I, 574-579, 582.

1 Reports of William Blathwayt, February 11, 1709, and February 28, 1710, Blathwayt's Journal, II, 557-561; III, 30-33.

2 The farsightedness of this report is remarkable. Blathwayt considered the proposal, for which the coöperation of the Society for the Propagation of the Gospel had been promised, an excellent one, especially as, "securing and establishing a firm friendship with those bordering nations by such an intercourse and dependence as such a further settlement may procure." Also, he believed that such friendship would tend to protect the fur trade. Blathwayt's report, November 8, 1712, Blathwayt's Journal, III, 114-116. 
tion of the colonial assemblies. In his report on the application for aid from Colonel Hunter, who, after being appointed governor of Virginia, was captured by the French while on his way to the colony, he pointed out that the only available revenue from which to recompense Hunter for his losses was that from the quit-rents of Virginia, and of this fund there was at the time a sufficient balance on hand. ${ }^{1}$ Later he recommended a further grant to Colonel Hunter, in view of the "suffering and great zeal he has displayed." ${ }^{2}$ With a similar appreciation of colonial needs, he recommended that the expenses of the commissioners for drawing the boundary line between Virginia and North Carolina should be borne by the quit-rents. ${ }^{3}$ But on the other hand, he was equally ready to protect the quit-rents if necessary, even from an expenditure that was eminently just. For example, in his report upon the petition of Lady Lovelace for the payment of money due her late husband, the governor of New York, while not denying the validity of the claim, he asserted that the only available revenue in New York was the quit-rent, and all of it was necessary for the support of the present governor. Here as elsewhere he considered that the royal interests should be paramount to all others. ${ }^{4}$

1 Blathwayt again showed that a balance was necessary in case of sudden emergencies. Exactly what he had in mind is elearly explained by a reference to Bacon's Rebellion which, he declared, could have been prevented had any such reserve sum as the quit-rent been available. The constant reference by Blathwayt to this value of the quit-rent is most significant. Blathwayt's report, February 17, 1707, Blathwayt's Journal, II, 531-534.

2 Blathwayt's report, January 11, 1710, Blathwayt's Journal, III, 16-17.

3 Blathwayt's report, February 2, 1709, Treas. 1: 112, f. 114.

4 The report showed Blathwayt's full appreciation of the value of the quit-rents in New York, if they could have been completely enforced. There was, he said, no revenue in New York to meet the elaims of Lady Lovelace, except " what arises to Her Majesty by quit-rents, which are made use of towards the maintenance of the present governor, and which hitherto 
As a part of his manifold duties, Blathwayt was called upon to make a number of reports upon questions of general policy. These reports were characterized by a spirit of broad-minded justice which regarded the interests of the colonies as well as those of the crown. Apparently he was one of the few British officials who appreciated the strength of the local opposition to grants of settled lands as proprieties for royal favorites. Thus, while admitting that Lord Culpeper had a valid title to the Northern Neck of Virginia, ${ }^{1}$ he saw the dangers of perpetuating such a claim, and when Lord Fairfax offered to exchange this propriety for an estate in England, he recommended that this offer be accepted, since in his opinion, "nothing would be more acceptable to Her Majesty's subjects" in the colony than for the crown to reassume control of these lands. ${ }^{2}$ He displayed a similar opposition to proprietary grants when in a report upon the petition of Governor Dongan for a grant of Staten Island, he maintained that a concession of this sort would be extremely prejudicial to the frontier province of New York, especially if a right of free trade were included. ${ }^{3}$ The careful supervision which he exercised over the quitrents was further emphasized by an exhaustive report that he compiled in 1705 upon the Virginia revenue from this source. The practical suggestions he included for the reform of certain defects in the system of collection, were later put into effect with excellent results. ${ }^{4}$

The insight displayed by Blathwayt in dealing with have not amounted to above $£ 300$ per annum, one year with another." Blathwayt's report, December 15, 1713, Blathwayt's Journal, III, 126-128.

1 Blathwayt's report, July 20, 1686, Blathwayt's Journal, I, 512-513.

2 Blathwayt's report, January 22, 1709, Blathwayt's Journal, II, 543-548.

3 Blathwayt's report, 1795, Blathwayt's Journal, I, 707-709.

4 Lord Treasurer to Governor of Virginia, April 2, 1705, Blathwayt's memorial and report, February 21, 1706, Blathwayt's Journal, II, 347-355, 434. 
matters of general policy was characteristic of his entire attitude toward the quit-rents. As his recommendations were usually approved by the Treasury, his position was that of a valued adviser, who played an exceedingly important part in shaping British policy with respect to the quit-rents and in establishing precedents for the system of control. By organizing the official force, by constantly supervising its personnel, and by auditing the accounts, he placed the royal revenues in the American colonies upon probably as substantial a basis as was possible under the circumstances. Taking office at a time of transition, he permanently fixed the exact nature of the quitrent as a royal revenue, and shaped the details of collection and accounting. The work of his successors consisted merely in enforcing and pushing forward the system of control that he established and in extending the quit-rents as new colonies were acquired.

For the work of Horatio Walpole as auditor-general, 1717 to 1757 , the records are far less numerous than in the case of Blathwayt. But there is sufficient evidence to show that Walpole was not as efficient as Blathwayt had been. ${ }^{1} \quad$ Having already received a reversionary grant of the office, he became auditor-general upon the death of Blathwayt in 1717, and was invested with powers and emoluments similar to those enjoyed by his predecessor. ${ }^{2}$

1 Walpole, like Blathwayt, doubtless kept a journal, but so far it has not been discovered. The sources for his administration are necessarily incomplete, and are found chiefly in the different files of the Treasury Papers. His 'proper name is variously spelled, "Horatio," and "Horace." The former has been adopted in this study for the sake of muniformity. Walpole had too many irons in the fire to pay much attention to his duties as auditor-general. During the period from 1717 to 1757 he was a member of parliament, secretary to the Lord-Lieutenant of Ireland, secretary to the Treasury, cofferer of the royal household, a privy councillor, and a diplonat serving in many capacities. Dictionary of National Biography.

2 Patent to Horatio Walpole, October 15, 1716, Patent Rolls, 3511, no. 28. 
His chief duties with respect to the quit-rents consisted in the examination of accounts, for the Treasury now assumed a stricter oversight of the plantation revenues, though applications for expenditures continued to be referred to the auditor-general. Perhaps the growing business of the auditor-general's. office was largely responsible for this change. The important and increasing four and a half per cent. duty from the West Indies absorbed much of its time, while the increase in the royal revenues from the colonies, after the purchase of the Carolinas and the conquests from the French, increased the work of audit. The larger degree of control by the Treasury was not advantageous to the system, for that body, too, found its duties greatly increased, and necessarily relaxed its supervision. Thanks to the efficient work of Blathwayt, the quit-rents of Virginia were already upon a sound basis, though in New York and the Carolinas a strict and constant attention was needed in order to develop the system. This attention would have been secured had a special official been appointed in general charge of the entire quit-rent system in the American colonies, and to this lack of effective supervision must be ascribed many of the defects of execution.

As far as the records show, Walpole audited all the accounts that were transmitted from the colonies. The quit-rent accounts of Virginia were submitted with tolerable regularity, but there were few reports from New York, and the Treasury made few, if any, demands for the general reports on colonial revenues that Blathwayt had so frequently prepared. Indeed, Walpole filed but few accounts of any sort and those that he sent in related to the separate colonies. ${ }^{1}$ One of the most important

1 The Virginia accounts, each covering a year as was customary, included the quit-rents with expenditures from April 25, 1739, to April 25, 1740; 
accounts that he drew up was an elaborate report which he submitted to the House of Commons in 1741, covering the receipts and expenditures from the South Carolina quit-rents, during the eleven years from the purchase by the crown, July 25, 1729, to March 25, 1740. It also gave summaries of a number of rent rolls, and showed that for the years reported on, the accounts of South Carolina had been regularly filed in the prescribed form, but that collections had not amounted to over a third of what was due. ${ }^{1}$ From North Carolina, Walpole reported that he had received no rent rolls or accounts, nor, owing to the generally unsatisfactory condition of the quit-rents in that colony, did he offer any hope that this situation was likely to be remedied in the near future. ${ }^{2}$ Later, in presenting an imperfect account of the quit-rents collected in North Carolina between 1735 and 1748, he complained of the difficulty of securing even this bare statement. After sending Eleazer Allen, the receiver-general, "fre-

from April 25, 1745, to April 25, 1746, and for the year 1751. The second account Governor Gooch sent directly to the Treasury, and the others were probably sent in by the auditor-general. As all of these reports are endorsed in the proper manner, and as other evidence shows that Walpole kept close watch over the Virginia quit-rents, it is probable that this revenue was reported annually during Walpole's terms as auditor-general, as had been the custom under Blathwayt. Reports of Virginia Accounts, Treas. 1: 303, ff. $205-206$; 323, ff. 90-92; 348, ff. 253-254. The accounts for New York included receipts and expenditures of the quit-rents from September 29, 1730 , to September 29, 1733. These reports show that annual accounts of the New York quit-rents were not customarily filed and that, as under Blathwayt, the local officials in New York managed this revenue in a very loose fashion. See Report, Treas. 1: 284, ff. 148-155.

1 Report of Horatio Walpole to House of Commons, February 23, 1741, C. O. 5: 368. A later account of the South Carolina quit-rents covers the period from March 26, 1745, to March 26, 1751. It is not full in details, nor is it drawn up in the preseribed form. Accounts, S. C. Quit-Rents, 17451751, Treas. 1: 347 , f. 79 .

2 Report of Horatio Walpole to House of Commons, February 23, 1741, C. $0.5: 368$. 
quent duplicates" of a letter requesting a full statement of the royal revenues of North Carolina, he received an account so incomplete that the deputy auditor refused to pass it. As appeals to the governor to have the quitrents of North Carolina collected proved of no avail, he begged the Treasury to compel Allen to fulfill the duties of his office, but this request met with little, if any, consideration. ${ }^{1}$

The close watch that Walpole endeavored to keep over the revenue from the quit-rents is illustrated by two incidents, one in Virginia, the other in New York. In Virginia, John Grymes, the receiver-general, found that in remitting the quit-rents for 1745 and 1746 it was necessary to allow a higher rate of exchange than was customary. Though both the governor and the council gave Grymes a "sufficient testimonial of his good disposition," Walpole only grudgingly allowed the claim, intimating that such leniency should not be taken as a precedent. Emphasizing the British control of the quit-rents, he declared that the governor and council had no right to allow a higher rate of exchange, since such allowance really constituted a grant from the quit-rents. ${ }^{2} \mathrm{He}$ showed a similar care to secure the full amount of the quit-rents when Dixon, formerly receiver for New York,

1 The difficulty under which the Treasury labored in dealing with so careless and inefficient a colonial officer as Allen is illustrated by the endorsement upon the back of Walpole's letter; "My lords will be pleased to hear from Mr. Auditor Walpole in what manner their lordships may proceed in this matter.', Walpole to Treasury, May 30, 1749, Treas. 1: 335, ff. $160-161$.

2 The entire trouble arose from the fact that it was necessary to fix the rate of exchange for the Spanish silver in which the quit-rents were usually paid. For the future, Walpole stipulated that the rate of exchange should be sufficient to cover all possible losses in transmitting the quit-rents. Petition of John Grymes, October 20, 1747, and Report of H. Walpole, August 22, 1748, Treas. 1 : 328, ff. 96-97; 330, ff. 48-53. 
called the attention of the Treasury to the great land frauds and the neglect of the quit-rents in that colony. Adding his own testimony to this statement of the utter confusion into which the quit-rents of New York had fallen, Walpole believed that if they were put under proper regulation, they would produce a considerable sum, and he proposed to find out upon what terms Dixon would undertake the improvement of this revenue. It is rather significant that in the same letter Walpole complained that the assembly had assumed complete control of the revenues in New York. ${ }^{2}$ Had it been possible to enforce the quit-rents in New York, as a revenue under British control, the royal government would have been free from the long-continued struggles with the assembly over the finances, and doubtless Walpole was fully aware of this aspect of the case.

As a part of his duties, Walpole undertook the general supervision of the officials charged with the collection of the quit-rent, but the available records do not show that his control was as effective as that of Blathwayt. Walpole sent in at least one report with lists of these officers, ${ }^{3}$ and another which noted the compensations that were allowed the receivers of the quit-rents, including five per cent. in Virginia and Jamaica, and a salary of $£ 200$ in New York. ${ }^{*}$ Nor was he unmindful of the necessity of making a sufficient compensation to the deputy auditors also, for when the crown purchased Carolina he asked that the same fee as in Virginia should be allowed for

1 Dixon to Treasury Board, June 2, 1718, Treas. 1: 214, ff. 97-99.

2 Report of H. Walpole, June 9, 1719, Treas. 1: 221, f. 191.

3 Of the officials charged with the collection of the quit-rents, the report shows that there was a receiver-general and also a deputy auditor in Jamaica, Virginia, and New York. Lists of Auditors, Governors, and Receivers-General, 1718-1722, Treas. 1: 216, f. 191.

4 Report of H. Walpole, January 10, 1718, Treas. 1: 213, f. 37. 
auditing the accounts of the new province. This request the Treasury granted. ${ }^{1}$

Walpole, as well as Blathwayt, was frequently requested to pass upon the advisability of granting allowances from the quit-rents to different royal officials in the colonies. His general policy was to pay such salaries when he considered them helpful to the royal interests, and not unreasonable charges against the fund. ${ }^{2}$ Thus, when the attorney-general, the clerk of the crown, and the provost marshal of South Carolina made application for allowances from this source, he recommended that as they were of great importance to the royal government in South Carolina, they should receive their salaries from the time they assumed their offices, but with due regard to future applications, he cautiously added that this action should not be "drawn into a precedent for granting the same allowance to any like officers out of His Majesty's quit-rents there for the future." ${ }_{3}$ That this warning was not merely an idle statement, is evident from his treatment of the request of John Hammerton that as secretary he should receive an allowance upon

1 The fees allowed included a commission of 5 per cent. on all accounts and $£ 100$ annually. Similar fees were allowed in North Carolina, when the financial administration of the two Carolinas was separated. In actual practice, the 5 per cent. was given to the deputy auditor, while the auditorgeneral retained the $£ 100$ allowance. Treasury to John Hammerton, June 30, 1731, and Memorial of Horatio Walpole, June, 1731, Treas. 54: 37, pp. 398-400.

2 For example, Walpole considered that there was no reason why Philip Livingston, secretary for Indian affairs in New York, should receive his salary of $£ 100$ in sterling, when other allowances were being paid in proclamation money. Nor should he receive preference above other claimants upon the quit-rents of New York. The arrears due Livingston, Walpole held, should be paid, since the quit-rents afforded a sufficient proportion for other claimants. Report of Horatio Walpole, January 17, 1745, Treas. 1: 316.

3 Walpole to Treasury Board, February 11, 1738, Treas. 52: 40, pp. 12-13. 
similar conditions. Hammerton made a rather pitiful plea, claiming that he had experienced great losses in traveling up and down the whole province in the interest of the quit-rents and that through the remissness of his solicitor he had not obtained the arrears of his salary as had the other officials. Walpole sharply denied this claim, asserting that not until Hammerton was charged with a shortage of $£ 300$ had he presented any claims for such extraordinary services. Despite this adverse report, the Treasury was moved ultimately to grant his petition ${ }^{1}$ by another plea from Hammerton, who seems to have been an expert in playing upon a sympathetic chord. This action was ill advised, as after events in South Carolina proved, especially as it tended to discredit the authority of the auditor-general.

On the other hand Walpole was less fair to McCulloh, when the latter appealed for redress, after the receivergeneral of South Carolina had refused to pay his salary from the quit-rents. In a detailed statement McCulloh enumerated the losses he had incurred in going to South Carolina, and believing that the receiver-general had a sufficient amount on hand to pay his claims, petitioned Walpole to represent his case favorably to the Treasury. ${ }^{2}$ In his report on this petition, Walpole commented favorably upon the recommendations that McCulloh had made with respect to land grants and showed an appreciation of the difficulties under which the latter had labored, but

1 Walpole to Treasury, December 24, 1746, and petition of John Hammerton, November 18, 1746, with his reply to Walpole, Treas. 1: 323 , ff. 84-86, 88-89.

2 Petition of Henry McCulloh, February 10, 1748, Treas. 1: 330, f. 169. Before going to the Carolinas, McCulloh declared, he had been worth fully $£ 5,400$ sterling, and for the eight preceding years he had cleared an average of $£ 600$ annually. Since then he had experienced heavy losses, and actually owed $£ 4,000$ as a result of his mission. Memorials, Henry MeCulloh to $\mathrm{H}$. Walpole, about 1747, and May 2, 1748, Treas. 1: 330, ff. 7-9, 142-147. 
as he had already authorized the issue of a warrant for $£ 1,400$ from the quit-rents in favor of McCulloh, and as the improvements in the quit-rents, out of which McCulloh's salary was to come, had not materialized, he could not pass upon the matter of fact, but must leave to the Treasury the question of an additional allowance. ${ }^{1}$ Eventually, the question of McCulloh's salary was referred to the British attorney-general, who considered that Walpole's reluctance to pass the account was not well founded, because there had been such an increase in the quit-rents since McCulloh went to South Carolina, that even after the payment of all arrears of salary to crown officials, a surplus would exist out of which McCulloh's salary might be paid. Furthermore, the attorney-general maintained, McCulloh had entered on his office according to warrant, and had executed it with care, as far as "the circumstances of the case, and the difficulties and obstructions he had met with would permit, and this at a very great expense of time, labour and money." Therefore, the arrears of his salary should be paid after the regular allowances to South Carolina officials had been satisfied. ${ }^{2}$ In this opinion the attorneygeneral took a much more liberal view than Walpole had done, for McCulloh was already deeply plunged into debt as a result of the mission he had undertaken in behalf of the crown, and if his salary were left unpaid owing to mere technicalities, the example was likely to prove exceedingly embarrassing in any future attempts to secure special officials to undertake similar missions. Such overruling of Walpole's decisions is rare, and the scanty records show that in most instances he used excellent judgment and exercised a careful oversight over the quit-

1 Report of Horatio Walpole, September 19, 1748, Treas. 1: 330, ff. 1-4.

2 Memorial, Henry MeCulloh to Treasury, June 15, 1749, and report of Attorney-General Ryder, October 28, 1749, Treas. 1: 330, f. 5; 342, ff. 95-99. 
rents, although his supervision was confined chiefly to the audit of accounts and receipts.

Under the Reverend Robert Cholmondeley, who succeeded Walpole as auditor-general, British control over the quit-rents was greatly relaxed. This was not unexpected, since Cholmondeley looked upon his office as a life annuity which he inherited from his grandfather, ${ }^{1}$ and consequently he paid little attention to its duties. Such an attitude on the part of the auditor-general was well-nigh fatal, not only to a vigorous enforcement of the quit-rents in the colonies where they had already been established, but also to any effective extension of the system to the new territories that came under the control of the crown at this period. No journal of Cholmondeley's administration as auditor-general has been discovered, and it is doubtful if he ever kept one. Even the few papers that he filed with the Treasury show that he did not take his position very seriously, as far as thoroughness and efficiency were concerned, though it is probable that the routine of the office, as established under Blathwayt and Walpole, was maintained with tolerable faithfulness, probably by subordinates.

The need of firmness and energy on the part of the

1 September 6, 1718, George I granted the office of auditor-general, with all its fees, to George, Earl of Cholmondeley, during his lifetime and that of his sons, Samuel and George Cholmondeley, subject of course to the prior rights of Horatio Walpole. This reversionary right the Earl of Cholmondeley bequeathed to his grandsons, Robert and Frederick Cholmondeley, the younger sons of George, afterwards the Earl of Cholmondeley. In 1751, in consideration of the surrender of the reversionary grant by the executors of the Earl of Cholmondeley, the crown granted the office of auditor-general of the plantation revenues to Robert Cholmondeley, grandson of the original grantee, subject to the rights of Horatio Walpole. It was under this last grant that Robert Cholmondeley assumed the office of auditorgeneral. See Reversionary Grant to Robert Cholmondeley, November 20, 1751, Patent Rolls, 3634; no. 20; Andrews, Guide to the British Public Record Office, II, 145-147. 
auditor-general is forcibly illustrated by the few accounts of the quit-rents that were filed with the Treasury during Cholmondeley's term. Among them are at least three accounts of the Virginia quit-rents, but none of New York and only one of South Carolina. ${ }^{1}$ Accounts for North Carolina from 1773 to 1774 were filed, but they are incomplete and were in so unsatisfactory a condition that the deputy auditor refused to pass them. ${ }^{2}$ Besides these accounts of the separate colonies, there exist two reports on colonial revenues in general, drawn up in Cholmondeley's office. The first was prepared in $1761{ }^{3}$ and the second, containing a general summary of the accounts of the several colonies, was submitted to the Treasury, October 2, 1776, by George Gillio, deputy. This report shows that the quit-rent accounts had been kept up in a fashion, and had been sent, at least occasionally, to the auditor-general. It also includes numerous details as to the balances on hand, though it shows also that in many colonies collections of the quit-rents were far less than they should have been. ${ }^{4}$

In the rare instances in which Cholmondeley exercised

1 Accounts, Virginia Quit-Rents, 1756, 1757 and 1771, Treas. 1: 370, ff. $125-126$; 376, ff. 214-215; 503, ff. 113-114. The accounts for South Carolina, found in the Board of Trade papers, cover the period from 1761 to 1763 , and were probably made out in the office of the auditor-general. C. O. $5: 512$, III.

2 Accounts, N. C. Quit-Rents, March 25, 1773, to March 25, 1774, Treas. 1: 505 , f. 320 .

3 Report, about 1761, C. O. 5: 216, pp. 8-9.

4 The report shows that accounts of the quit-rents had been filed for Virginia to 1773 , for South Carolina to 1774 , for Georgia to 1770 , for New York to 1773, for Nova Seotia to 1773, and for North Carolina to 1776. Later accounts for North Carolina had been returned as unsatisfactory. No quit-rent accounts, the report states, had been filed for Quebec, East and West Florida, St. Vincent, Tobago, Dominica, and Grenada. The report gives merely the balances of the quit-rents without making any attempt to show how full and accurate were the accounts. Report from the office of Auditor-General, October 2, 1776, Treas. 1: 525, ff. 87-88. 
a personal supervision over the quit-rents, he exhibits some knowledge at least of the particular questions involved. Thus, in the case of John Rutherfurd, receivergeneral of North Carolina, whom Governor Dobbs had suspended for alleged irregularity in his accounts, he sent the accused official a long list of questions, which shows that he had carefully investigated the character of the charges. ${ }^{1}$ Though apparently satisfied with Rutherfurd's explanations, he instructed him to make certain corrections in his accounts and forbade him to pay out any money from the quit-rents in the future without the authority of a royal warrant. He also inquired what steps Rutherfurd had taken toward drafting a rent roll for the benefit of future receivers-general. ${ }^{2}$ Again, in a report upon a letter from Governor Dobbs of North Carolina, he showed excellent judgment and knowledge of the situation. For instance, when Governor Dobbs represented the evils resulting to the quit-rents from certain land frauds, Cholmondeley, though conceding the need of resurveys, considered that the legality of the grants cited should first be passed upon by the crown's attorneys, and that a court of claims should be adopted with the greatest caution, inasmuch as it was an institution unknown to English law. Furthermore, he questioned whether the council of North Carolina, as an interested party, was qualified to sit as a court of claims to consider land frauds in the colony. ${ }^{3}$

But Cholmondeley was not always prompt to adjust matters relating to the quit-rents. A glaring example of

1 Answer of John Rutherfurd to Governor Dobbs, about 1758, Treas. 1: 383 ; answer to Auditor-General's Queries, Treas. 1 : 360, ff. 275-277.

2 Cholmondeley to John Rutherfurd and to Treasury, August 16, 1758, and July 21, 1759, Treas. 1: 358, f. 174; 397, f. 205.

3 Report of Robert Cholmondeley, July 14, 1757, and John Pownall to Treasury, January 13, 1757, Treas. 1: 372, ff. 173-177, 196-197. 
neglect was his treatment of two memorials from the governor and council of Virginia, who petitioned for leave to return to the two shillings per hogshead fund the sum of $£ 3,0974 \mathrm{~s} 3 \mathrm{~d}$, which had been advanced in 1744 and 1756 to make up deficiencies in the quit-rents. Although the memorials showed that the colony stood in great need of this fund for use in sudden emergencies, Cholmondeley does not appear to have made any report upon this petition. ${ }^{1}$ Such negligence in so important a matter was inexcusable, and only serves to illustrate the evil resulting from the conversion of the auditor-generalship into a sinecure, as a pension for a royal favorite. If the office had not been so firmly established under Blathwayt and Walpole, the colonial revenues would inevitably have fallen into great confusion during the loose administration of Cholmondeley. The general routine of the office was maintained, but the vigorous oversight that was so necessary in order to keep up the quit-rent system at this junction was wholly lacking. ${ }^{2}$

1 Memorial, Governor and Council of Virginia, July 23, 1759, and January 3, 1759 (probably), Treas. 1: 389, ff. 107, 110.

2 That the office of auditor-general was coming to be regarded as a sinecure, was shown by a reversionary grant in 1770 to a Mr. Bradshaw for his own life, and that of his two sons. After the Revolution, Cholmondeley petitioned for compensation owing to the loss of the income from his office, and he eventually received a pension of $£ 400$. Memorial, Robert Cholmondeley to American Loyalist Claims Commission, 1787, Audit Office Transcripts, N. Y. Pub. Library, 45, ff. 433 et seq.; Andrews, Guide to the British Public Record Office, II, 146.

Cholmondeley was still serving as auditor-general in 1798. On April 19 of that year he reported to the Commissioners of Accounts that no revenues had been received from America since the beginning of the Revolutionary War, and no accounts of any kind except one from the receiver-general of the Island of St. John, which stated that the quit-rents received in that colony between September 22, 1780, and November 5, 1789, had amounted to $£ 1,139$, of which $£ 1,016$ had been spent chiefly for salaries on the island, leaving for the crown $£ 122$. He said further, "The Officers employed in 
The Treasury never entrusted the entire supervision of the quit-rents to the auditor-general, but itself settled directly many matters relating to this revenue. Its right to exercise this superiority was, of course, unquestioned, although the Board of Trade occasionally took up matters of general quit-rent policy. Sometimes its reports and those of the Board of Trade were referred to the Privy Council for a final decision, but for the most part the Treasury was the final authority on all matters connected with the quit-rents paid to the crown. Even where such questions were referred to the auditor-general, it rendered the final verdict. Its frequent reversal of the auditor-general's decisions, especially with regard to expenditures, proved that its control was not merely nominal.

The Treasury exercised its control most vigorously during the early years of Blathwayt's administration, when precedents were being established, and when the quit-rents, notably in Virginia, were being placed upon a firm basis. Upon the recommendation of the Board of Trade, it formulated the plan for the enforcement of the quit-rents in Virginia ${ }^{1}$ and later upheld Blathwayt in every effort that the latter made to establish his authority over obdurate colonial officials. For example, when the auditor-general failed to secure any answer from Colonel Norwood, who had been treasurer of Virginia, the Treas-

collecting and receiving His Majesty's American Quit-Rents are in England one Auditor-General and in each province one Deputy Auditor and one Receiver-General. Their Emoluments, whether arising from poundage or from a fixed salary, being chargeable in the Quit-Rents, have except in the Island of St. John's produced nothing since the separation of the American States.' What Cholmondeley's profits from the office were at this time is not clear. Contemporary accounts of the $4 \frac{1}{2}$ per cent. export duty show that $£ 250$ from that fund were allowed the auditor-general, but of other receipts we hear nothing definite. c. M. A.

1 Blathwayt's Journal, I, 122-123. 
ury reminded the latter that he was still accountable for all collections and threatened him with a legal process if he did not send in his accounts. ${ }^{1}$ More successful was its support of the auditor-general when he decided to permit no grants from the quit-rents except upon the authority of a royal warrant-a support that took practical form when a special grant was considered necessary to make up from the quit-rents in Virginia the deficit in the regular two shillings per hogshead fund. ${ }^{2}$ Governor Howard of Virginia acknowledged the authority of the Treasury over the quit-rents when he begged the board to purchase the interests of Culpeper in the Northern Neck. ${ }^{3}$ In New York it directed Lucas Santen, the receiver, to send Blathwayt a complete rent roll, and to keep a careful watch over all accounts, ${ }^{4}$ and when the governor of Jamaica, Sir Thomas Lynch, complained of the difficulty of securing either a rent roll or effective collections and recommended the appointment of a collector in each district, ${ }^{5}$ it authorized the appointment of these collectors. ${ }^{6}$ Later, when it became impossible to fill these positions with capable men at a commission of five per cent., it ordered an increased allowance of seven and a

1 Treasury to Colonel Norwood, November 17, 1681, and Treasury Minute, May 22, 1682, Blathwayt's Journal, I, 128-129, 135.

2 Lord Treasurer Rochester to Lord Howard, December 21, 1685, Blathwayt's Journal, I, 286.

3 Lord Howard to Treasury, February 20, 1685, Blathwayt's Journal, I, 294-295. Rochester was not sworn in as Lord High Treasurer until February 19, so Howard addressed his letter to the commissioners as he could not have known of Rochester's appointment.

4 Lord Treasurer Rochester to Lucas Santen, June 10, 1686, Blathwayt's Journal, I, 306-308.

5 Letter from Sir Thomas Lynch, September 16, 1682, Blathwayt's Journal, I, 154-156.

6 Treasury to Sir Thomas Lynch, May 5, 1683, Blathwayt's Journal, I, 159-160. 
half per cent., ${ }^{1}$ and urged the necessity of a rent roll. ${ }^{2}$ By such attention to details, the board afforded Blathwayt much needed assistance during the difficult period when the quit-rent system was being organized and its operation made effective in America.

After the quit-rents had become established and precedents had been fixed, the Treasury customarily referred to Blathwayt all questions of detail and usually adopted his recommendations. Toward the close of his term of office, that is, after 1710 when he gave up active official life and retired to the country, the board again began to exercise a more direct control, a policy which was continued, even more noticeably, under his successors. The zealous care with which the Treasury guarded the royal right to control the quit-rents, finds illustration when in 1714 the council of Virginia applied to the crown for a grant to supplement the deficiency in the two shillings per hogshead fund. The Privy Council referred the address to the Board of Trade, which recommended that it should be granted and that the revenue from the quitrents should be lodged in Virginia, for use as an emergency fund by the governor and council with strict accounting to the crown. The Privy Council sent this report to the Treasury, ${ }^{3}$ but that board, more farseeing than the Board of Trade, was unwilling to permit such local control of the quit-rents. Though Governor Spotswood said that owing to the scanty tobacco crops there was a considerable decrease in the revenue from the two shillings per hogshead, the Treasury merely ordered the

1 Treasury to Sir Thomas Lynch, June, 1684, Blathwayt's Journal, I, 193-194.

2 Lord Treasurer Rochester to Governor Molesworth, June 15, 1686, Blathwayt's Journal, I, 317.

3 Acts, Privy Coun. Col., II, $\$ 1234$. The report of the Board of Trade, September 2, 1715, is in C. O. 5: 1364, pp. 239-244. The reference to the Treasury was ordered September 9. 
accounts of the Virginia quit-rents to be transmitted for its inspection. ${ }^{1}$ Another illustration is found in a resolution which the board adopted in 1740, requiring a careful inspection of the instructions and commissions of the receivers of the royal revenues in the colonies in order to ascertain whether the directions had been fully complied with, and ordering, in case these directions had not been obeyed or had been neglected, that new and stricter instructions should be issued. It also directed that lists of the receivers, with their respective jurisdictions and estimates upon their conduct, should be prepared for its use. $^{2}$

Many questions relating to the Virginia quit-rents were brought to the attention of the Treasury, either by the Board of Trade or directly by colonial officials, among the most important of which were those relating to the disposal of the quit-rent fund. The board's usual policy was to permit only expenditures that would in one way or another strengthen the royal government and were not likely to be met from the local revenues. It approved allowances for such purposes as to recompense Thomas Lee, a magistrate in Virginia whose house had been burned by transported felons in revenge for the arrest of one of their number; to defray the expense of a commission to settle the boundary between Virginia and Carolina; and to make out a complete map of Virginia. It authorized grants from the quit-rents in order to increase the salary of the attorney-general of Virginia and to meet the expenses of commissioners to the Indians. ${ }^{3}$

1 Report of Board of Trade, September, 1715, and Governor Spotswood to Treasury, July 15, 1715, Treas. 1: 192, ff. 29-32, 34-35.

2 Treasury Minute, February 19, 1740, Treas. 29: 27, p. 292.

3 Report, Board of Trade, June 4, 1729, Governor Gooch to Treasury, July 17, 1732, and Governor Dinwiddie to Peter Leheup, December 10, 1752, Treas. 1: 272 , f. $186 ; 279$, ff. $98-99,102-103 ; 348$, f. 230. 
When in 1716 Governor Spotswood made complaints against the deputy auditor, Colonel Ludwell, the board authorized the removal of Ludwell from his office, ${ }^{1}$ but later in the controversy over the pistole fee, demanded by Governor Dinwiddie for affixing his seal to patents, when owing to the refusal to pay this fee, many thousands of acres, which had been surveyed, were not brought upon the rent rolls, with a corresponding loss in the quit-rents, the Treasury apparently refused to act and left the settlement of the dispute to the Board of Trade. ${ }^{2}$

The interest taken by the Treasury in the quit-rents of New York is shown by a rather inadequate rent roll that was begun about 1704 and filed among its papers, and by a memorial from Governor Cosby in 1733 that sets forth the difficulties of collecting the quit-rents in the province. ${ }^{3}$ The board also received a number of memorials for allowances to officials of New York, including one in 1725 from George Clarke, the secretary, who asked that the arrears of his salary should be paid out of the quit-rents which had, he claimed, begun to show considerable improvement. ${ }^{*}$ Later it adopted a recommendation of the Board of Trade that the salary of Richard Bradley, the attorney-general of New York and a necessary crown official, should be paid partly from the quit-rents and partly from the civil list. ${ }^{5}$ But with so many varied duties, it could not spare the time that would

1 Governor Spotswood to Treasury Board, May 23, 1716, Treas. 1: 199, ff. 76-80.

2 Governor Dinwiddie to Treasury, December 29, 1752, and Board of Trade to Robert Dinwiddie, January, 1755, Treas. 1: 353, ff. 240-241; 360, ff. $82-85$.

3 Quit-Rent Roll of New York, and Governor Cosby to Treasury, December 15,1733 , Treas. 1 : 87 , ff. 556-563; 284, f. 146.

${ }^{4}$ George Clarke to Treasury, September 16, 1725, Treas. 1: 253, ff. 208209.

5 Report of Board of Trade, December 10, 1730, Treas. 1: 266, ff. 109-111. 
have been necessary in order to carry out a firm policy for the enforcement of the quit-rents in New York.

After the purchase of the Carolinas, the Treasury showed how important it deemed the quit-rents there by its personal supervision of the important task of enforcing them. The Board of Trade had called attention to their value by proposing that Chief Justice Wright of South Carolina, who for three years had not been paid his salary by the assembly, should be recompensed from this source. Though believing that the assembly should pay the chief justice the arrears due him, the Treasury thought it would be "more to the dignity of his station and conducive to a more steady and equal distribution of justice" if this important officer were paid either out of the quit-rents or otherwise as the crown should direct. ${ }^{1}$ The interest which the board took in the appointment of McCulloh as special commissioner to the Carolinas is shown by the numerous documents bearing upon his mission that are filed among its papers. ${ }^{2}$ Evidently the board had a favorable opinion of McCulloh's character and conduct, since it aided him in his efforts to collect his salary. ${ }^{3}$

The general control which the Treasury exercised over the quit-rents of the Carolinas embraced all matters relating to their enforcement. After the passage of the quit-rent bill in North Carolina in 1755, it received from the Board of Trade a long list of documents upon which to base a report as to the advisability of allowing the act. ${ }^{*}$ It also received the draft of a quit-rent bill sub-

1 Reports of Board of Trade and Treasury, 1735, Treas. 1: 289, ff. 19, 21.

2 Memorial of Henry MeCulloh, November 8, 1744, and accompanying papers, Treas. 1: 306, ff. 53 et seq.

3 Warrant, March 24, 1752, and Memorial of MeCulloh, about 1754, Treas. 1: 350, f. $135 ; 369$, ff. 38-39.

4 These documents include the observations of the Board of Trade, the 
mitted by Governor Martin of North Carolina in 1773 and in reply recommended that this act, which it considered superior to the one passed in 1762 in Georgia, should be allowed with a few minor alterations. ${ }^{1}$ It considered many questions regarding the personnel of the officials in charge of the quit-rents in the Carolinas, as in the case of John Hammerton, who in 1730 was appointed receivergeneral for both North Carolina and South Carolina, and against whom, as an absentee official, a number of protests were received from the northern province. Hammerton was displaced by Governor Dobbs and Eleazer Allen was appointed in his stead. Although Hammerton vigorously protested against this action, the Treasury made no move to rebuke Governor Dobbs, and eventually Allen was confirmed. ${ }^{2}$ Another instance is that of John Rutherfurd regarding whom many papers are to be found in the Treasury files, which show that the final decision to reinstate this very troublesome receivergeneral was not taken by the board without a due examination of the evidence. ${ }^{3}$ Probably the Treasury in this case was guilty of an error of judgment, particularly in view of the continued complaints of Rutherfurd's inefficiency. ${ }^{4}$

The expansion of the quit-rent system that took place about the middle of the eighteenth century greatly inreport of Sir Matthew Lamb, the arguments of Mr. Child, agent for the Earl of Granville, those of Mr. Abercrombie, agent of North Carolina, and the answer of Robert Jones to Sir Matthew Lamb, Treas. 1: 360, ff. 237240,242 ; 361, ff. 159-168, 182-184; 500, ff. 111-113.

1 John Pownall to Grey Cooper, November 11, 1773, and Governor Martin to Earl of Dartmouth, July 18, 1773, Treas. 1: 502, ff. 71-72, 74; Treasury Minute, July 22, 1774, Treas. 29: 44, pp. 13-14.

2 Memorial from John Hammerton, June 25, 1735, Treas. 1: 289, ff. 177-181.

3 Proclamation of Governor Dobbs, December 5, 1757, and Memorial from John Rutherfurd, May 22, 1758, Treas. 1 : 378, f. 194 ; 388, ff. 177-178, 201.

4 Governor Martin to Treasury, July 29, 1774, Treas. 1: 505, ff. 317, 321. 
creased the number of questions which were referred to the Treasury. Soon after Georgia became a royal colony, the Board of Trade inquired of the Treasury what steps were necessary to promote the quit-rents and the other royal revenues in the colony. ${ }^{1}$ Again, in 1753, the Board of Trade recommended to the Treasury that the appeal of the French inhabitants of Nova Scotia to be released from their quit-rents should be granted. ${ }^{2}$ Later Governor Legge prayed that the quit-rents should be remitted on unimproved land in Nova Scotia for several years, in order to stimulate settlement, and that those collected from cultivated tracts should be employed during a like period to construct good roads on the island. ${ }^{3}$ The attempt to establish the quit-rents in the West Indies that were ceded in 1763 , led to many difficulties which were referred to the Treasury as the body in general charge of this revenue. In response to a number of memorials, the board drew up the conditions upon which leaseholds might be converted into fee-simple property with a quitrent. ${ }^{4}$ When the receivers in Dominica, Tobago, and St. Vincent complained of the local opposition they encountered, the Treasury took steps to support them, and ordered the creation of courts of exchequer. ${ }^{5}$ Occasionally it seems to have been overzealous in its measures, for Richard Burke rather testily complained of repeated orders to account for the quit-rents of Grenada, before these dues had even been established there. ${ }^{6}$

Usually the Board of Trade referred all questions relat-

1 Board of Trade to Treasury, May 17, 1753, Treas. 1: 352, f. 173.

2 Board of Trade to Treasury, July 4, 1753, Treas. 1: 353, f. 226.

3 Governor Legge to Treasury (probably March 23, 1774), Treas. 1: 505, ff. 61-64.

4 Treasury Minutes, January 25, 1774, Treas. 29: 43, p. 276.

5 See above, pp. 383-384.

6 Richard Burke to John Robinson, October 10, 1778, Treas. 1: 545, f. 23. 
ing to the quit-rents to the Treasury, but sometimes it took upon itself to decide matters of supreme importance. After the first decade of the eighteenth century the quitrent accounts of Virginia were annually sent to the board with a fair degree of regularity, but no similar reports appear to have been made from the other royal colonies. ${ }^{1}$ Occasionally there were general reports, one especially, that filed in 1761, in which the quit-rent was the only royal revenue entered from New York, North Carolina and South Carolina. This report also included the quit-rents among the revenues of Jamaica and Virginia, and emphasized the value of these feudal dues in paying the salaries of crown officials, especially in North Carolina and South Carolina. ${ }^{2}$ After 1763, in accordance with the general policy of increasing British control over colonial officials, the board displayed greater activity than ever. On December 11, 1766, the Earl of Shelburne sent a circular letter to the governors of all the British colonies in America, asking for an account of the annual charges of their respective governments and the income available. He wanted also a full statement of the methods of levying the quit-rents in each colony and complete reports of the arrears due, the number of patents, the names of the patentees, and the date of each grant. ${ }^{3}$ Shelburne's purpose in making this inquiry was to secure a better organization of the quit-rent and land systems. Opposing Townshend's plans for an immediate revenue from the American colonies, he thought that the quit-rents and the sales of crown lands should provide a sufficient fund, if they were properly managed, to support the "exigencies" of government in the colonies. Apparently he did not

${ }_{1}$ C. O. 5: 1313, 1315-1316, 1319-1321, 1323-1329.

2 Report to Board of Trade, about 1761, C. O. 5: 216.

3 Circular Letter from Lord Shelburne, December 11, 1766, C. O. 5: 112, pp. 1-2. 
favor a rigorous collection of the arrears, although he seems to have appreciated fully the usefulness of the quitrents, if properly enforced, in putting an end to the custom of holding for speculative purposes vast areas of uncultivated lands. ${ }^{1}$

The responses to Secretary Shelburne's letter afford an insight into the success of the quit-rent system in the different crown colonies. The most optimistic report came from Virginia where the quit-rent system was well organized and in successful operation. ${ }^{2}$ Elsewhere the situation was less hopeful. In New York, as Governor Moore pointed out, the laws were not enforced and the collections extremely meager. ${ }^{3}$ Conditions were equally unsatisfactory in North Carolina, where the lack of both a rent roll and a quit-rent law presented a formidable obstacle to the collection of this revenue. ${ }^{4}$ For South Carolina Governor Montagu drew a melancholy picture of the difficulties that stood in the way of adequate enforcement. $^{5}$ Reports from Quebec, Nova Scotia, and Georgia told the same or a worse tale, while in East and West Florida the quit-rents had not as yet become due. ${ }^{6}$ From the proprieties the responses were vague. The governor of New Jersey asserted that he knew nothing with regard to the quit-rents, as they were altogether under the management of the proprietaries, and "the

1 Alvord, Mississippi Valley in British Politics, I, 281-282, 334.

2 Reports of John Blair, Deputy Auditor of Virginia, and of Governor Fauquier, May 20, 1768, C. O. 5: 112, pp. 194-198.

3 Report of Governor Moore of New York, February 20, 1767, C. O. 5 : 112, pp. 111-114.

4 Reports of Governor Tryon of North Carolina and of John Rutherfurd, May 6, 1767, C. O. 5: 112, pp. 251-253, 260-261, 289-290.

5 Report of Governor Montagu of South Carolina, undated, C. O. 5: 112, pp. 297-299.

6 Report of Governors of Georgia, Quebec, Nova Scotia, East Florida and West Florida, 1767, C. O. 5: 112, pp. 5-6, 55-56, 304-309, 367-369, 387. 
government has no more knowledge of their transactions than it has of any other private persons in the province." The reply from Pennsylvania was equally non-committal. As the deputy governor was not permitted to answer any queries regarding the proprietary estates, Shelburne's letter was referred to Thomas Penn, who in reply mentioned the usual conditions for granting land but gave no detailed account of the quit-rents. ${ }^{2}$ Governor Sharpe of Maryland, on the other hand, made a report that showed the flourishing condition of the quitrents, as they had been developed under the Calverts. ${ }^{3}$

More important than the accounts of the quit-rents were the lists, sent in response to Shelburne's letter, of land grants in all the crown colonies. In many of these the quit-rent paid on each tract was noted, and all of them gave a detailed summary of grants. ${ }^{4}$ With these lists available, it was but a short step to the drafting of separate rent rolls which were absolutely necessary if the quit-rents were to be enforced. When once this had been accomplished and the collecting of the quit-rents assured, the next logical measure was to take over the proprieties, in order to establish a uniform system everywhere. There is reason to believe that some such project was in the mind of the British government at this time, as part of the plan suggested anew after 1763 of bringing the

1 Report of Governor Franklin of New Jersey, February 21, 1767, C. O. 5: 112, pp. 99-100.

2 Report of Thomas Penn, April 11, 1767, C. O. 5: 112, pp. 181-182.

3 Report of Governor Sharpe of Maryland, May 14, 1767, C. O. 5: 112, pp. 155-164.

4 The lists of grants included: Quebec, 1767; Nova Scotia, from 1749; township grants in New Hampshire, 1722-1764; New York, 1666-1755; North Carolina, 1707-1768; South Carolina, 1674-1765; Georgia, 1730-1749 and 1755-1765; East Florida, 1765-1767; and West Florida, 1769-1770. See C. O. 5: 112, pp. $313-349 ; 319 ; 398 ; 606 ; 670 ; 929$; and $1134 ;$ C. O. 324: 54, I, II. 
proprietary and corporate governments directly under the control of the crown. Shelburne's various circular letters, addressed to all the colonies without distinction and making inquiry regarding many other matters than quit-rents and land grants, would seem to point in that direction.

There is no doubt but that the British government at this time contemplated radical changes in the system of enforcing the quit-rents, as part of its general policy to reform land conditions in the colonies, and it had under consideration a number of suggestions with this end in view. Specially interesting is the scheme presented by John Gordon, "of Charlestown in South Carolina, merchant," which is remarkable for its keen analysis of the difficulties met in enforcing the quit-rents. Gordon said that the chief reasons for the great losses in this revenue were the want of an accurate and complete rent roll, the failure on the part of local officials to enforce the quitrents, and the lack of adequate laws in the different colonies to secure the collection of this legal debt to the crown. He thought that courts of exchequer could not be set up owing to the local popular dislike of prerogative methods, but he favored the passing of an act of parliament authorizing governors and councils to issue processes against all defaulters, which would remain in force until the colonies adopted suitable laws of their own. As "a matter of grace and favor to the people," he recommended that the quit-rents be remitted for a stated period to those who had regularly paid them, and in case this action were conditioned upon the entry of lands with the receiver-general, he believed that the record thus obtained, with the aid of the tax lists, exact plats of each parish or county made out by the surveyorgeneral, and the prompt entry of all transfers, would 
practically solve the problem of a rent roll. In order to enforce the payment of quit-rents by non-residents, who owned large uninhabited tracts upon which there were no goods to distrain, he proposed that the governor and council should be authorized, after a stated period of nonpayment of the quit-rents, to offer such lands for sale to the highest bidder. A striking feature of his scheme is the suggested appointment of two deputy surveyorsgeneral of the American revenues, one for the Northern, the other for the Southern district. As deputies of the auditor-general, these officers would aid in keeping a close watch over the accounts of the quit-rents within their respective districts. Other features of the scheme included the enforcement of the quit-rent laws that had already been passed, and the careful and prompt fulfilment of their duties by the receiver-general and the deputy auditor. By the adoption of these measures, Gordon believed there would be not only a considerable increase in the quit-rents, but also the owners of large tracts in the older provinces would be compelled to divide and to dispose of their estates to actual settlers. ${ }^{1}$

Another scheme, proposed by one Williamos, himself a candidate for the suggested office, involved the appointment of an inspector in general charge of all the crown's lands and quit-rents in the American colonies. To this official the surveyor-general of each colony should be required to send a map, with full details as to the original patentees and the quit-rents due. The clerks of the councils also should furnish lists with complete details of all the patents that had been granted, while the receiver-

1 Gordon's purpose, in presenting this scheme, was apparently to point out a means of raising the necessary revenue, in order to compensate him for certain losses he had suffered through the purchase of land in East Florida. Memorial, John Gordon to Lord North and to the Board of Trade, Dartmouth MSS. 1059, 1060. 
general should send an exact account of the quit-rents and the purchase money he had collected. No new patents should be allowed in the future without the endorsement of the inspector. Lastly, the inspector should receive lists of surplus lands with the quit-rents due upon them. After a comparison of all these accounts, the inspector would be in a position to make out a yearly report, which he could send to the Treasury and the Board of Trade, together with any alterations or improvements he wished to propose. He would also serve as a medium to keep a check upon every office connected with the quitrent and land systems in the American colonies, and would be able at any time to prepare a statement as to the exact condition of these revenues and lands. ${ }^{1}$

These two schemes, involving special officials in charge of the quit-rents and the crown lands, are significant. A necessary remedy for the quit-rent situation was some plan which would take the oversight of this important revenue from the already overburdened shoulders of the auditor-general and the Treasury, and place it under the control of a special appointee. Though the Board of Trade did not adopt either of the elaborate plans thus proposed, it did give instructions in $\mathbf{1 7 7 4}$ for a thoroughgoing reform in the system of granting the lands that were still at the disposal of the crown. All previous instructions were annulled, and a uniform system was established for all the royal colonies. In each colony the governor, the lieutenant governor, the surveyor-general for North America, the secretary, the surveyor-general

1 Included in the scheme was a proposal that in the contemplated sale, the crown lands should be offered in townships of 20,000 acres each. After the first townships were sold and settled, later and adjacent ones, it was claimed, would bring higher purchase prices and quit-rents. The originator of this scheme, also, was a candidate for an office, applying for the post of inspector. Mr. Williamos to Lord Dartmouth, November 18, 1773, Dartmouth MSS. 743 . 
and the receiver-general, or any three of them, were directed to set apart and have surveyed such portions of the crown lands as they considered most available, and to divide each tract into lots of not less than 100 or more than 1,000 acres. These lots were to be offered for public sale, with a purchase price of not less than six shillings and a quit-rent of a half-penny per acre. ${ }^{1} \mathrm{Had}$ these instructions been carried out, the next step logically would have been the establishment in all the royal colonies of a uniform and centralized system for collecting the quit-rents, which in turn would have led to the realization of Shelburne's plans to secure, from the sale of lands and from the quit-rents, a permanent revenue that would be in large measure free from the control of the assemblies. Undoubtedly the Board of Trade had some such purpose in mind, but this reform of the system of granting lands came too late to secure results.

1 Journal of Council, S. C., April 19, 1774, S. C. Hist. MSS. 36, ff. 23-29; Dartmouth MSS. 772. 


\section{CHAPTER XV}

\section{THE SIGNIFICANCE OF THE QUIT-RENTS}

The supreme importance of the quit-rent system in the American colonies arises from its significance as a means of asserting the feudal position of the crown. Scarcely less important were the possibilities of the quit-rent as the source of a royal revenue which in its expenditure should be altogether free from local control. From either point of view the attempt to enforce the quit-rents, in face of the local opposition to such external exploitation, was really an important phase of the larger question of the extent to which British control might be carried, in opposition to the forces that favored the development of local self-dependence. In short, the establishment of quit-rents in the American colonies inaugurated a struggle of external against internal interests, in which the latter conquered. Also, the institutional evolution of the quit-rent, with the petty struggles and animosities it aroused, is of much interest. Closely connected with the problem of enforcing this feudal due was the larger one of adjusting the land system, the two being interdependent in many colonies.

During the colonial era the quit-rents were more firmly established in Pennsylvania and the colonies to the southward than in those to the northward. The free tenure of land early set up in Massachusetts Bay and Plymouth checked attempts to found a quit-rent system elsewhere in New England. This Puritan influence made itself felt in East Jersey, and perhaps to a lesser degree in 
other colonies. In somewhat similar fashion the Dutch form of land tenure proved to be a stumbling-block in New York and the Jerseys. The necessity of recognizing Dutch grants, as a measure of conciliation, led to a twofold form of land tenure in these colonies. Part of the land was held under Dutch grants without quit-rents, the remainder under British grants with quit-rents. Such a situation, added to the influence of the land speculators in New York and the Puritans in East Jersey, naturally made the enforcement of quit-rents a difficult matter. In Canada and Nova Scotia a like problem was presented by the necessity of recognizing the French grants. In Jamaica the quit-rents were reserved from the days of early settlement, but were soon merged in the general revenue. In others of the West Indies they were surrendered in favor of the more lucrative four and a half per cent. export duty.

Pennsylvania and the colonies to the southward presented a more favorable field in which to develop the quit-rents than did the Jerseys, New York, or New England. South of Mason and Dixon's line existed practically a virgin soil where, with the unimportant exception of a few Dutch and Swedish grants, there was no extraneous form of land tenure to be reckoned with. In all of these colonies the quit-rent was reserved from the earliest English settlement. Thus, the essential elements of successful enforcement were present, and the chief problem was to formulate a tactful and wellbalanced policy. It is in these colonies, therefore, that the weakness and strength of the quit-rent, as it was established under British rule, may be fairly determined.

Apparently the British government at first failed to realize the importance of the quit-rents. The crown issued charters to proprietaries, and corporations over 
whom it retained but an undefined right of feudal lordship. Under the legal theory which gave them full control of the soil, these patentees could reserve and collect quit-rents for their own private use. The charters of Virginia, New England, Maryland, the Carolinas, New York, and Pennsylvania were all held on these terms. Such lack of foresight on the part of the British authorities made it possible for the Puritan to apply his theory of the free tenure of land with its disastrous effect upon the quit-rents. A policy of this kind might be justified if the charters had been issued only to the actual founders of colonies, but the crown granted proprietary rights over the Northern Neck in 1649 and over all Virginia in 1669, to royal favorites, and though the second grant was afterwards withdrawn, both grants betrayed a signal failure to appreciate not only the great importance of the quit-rents as a royal revenue, but also the very welfare of the colony itself.

From the standpoint of the quit-rents, the grants to proprietaries were a fundamental mistake in policy. In Maryland alone were the proprietaries able to enforce the quit-rents in really successful fashion, and to retain and exercise their rights of government until the Revolution. In other proprieties, where there was a lesser degree of executive control, the quit-rents suffered from the general weakening of authority. This was especially true in the Carolinas, where the royal administration inherited from the proprietary régime an ineffective quit-rent system which it was never able to bring into successful working operation. Where the proprietaries had only a title to the soil and lacked the prestige enjoyed by control of the government, the situation was almost hopeless. The royal officials hesitated to enforce such rights in the face of strong popular opposition, while 
the people could see no justification for the payment of feudal dues to private claimants. In East Jersey these influences were partly responsible for the complete collapse of the proprietary demands, and in other similar instances much friction developed. Even when they controlled the government, the proprietaries often allowed great arrears of quit-rents to accumulate, thus clouding the titles to land and arousing constant apprehension lest payment should be demanded. Finally, the proprieties presented a formidable obstacle to any governmental scheme for developing the quit-rents in the different colonies as a unified whole. A system of quitrents, which was controlled partly by the crown and partly by proprietaries, was foredoomed to failure.

In the last two decades of the seventeenth century the British government showed a greater appreciation of the importance of the quit-rents, and the violent opposition aroused by the proprietary grants to royal favorites in Virginia had its due effect. All private grants of the quit-rents in the future were forbidden, and even the creation of proprieties over vacant lands was put under the ban. Systematic efforts to enforce the quit-rents as a royal revenue in the crown colonies and as an important feature of the general policy to strengthen British control, found application first in New England under the Andros régime. But Puritan opposition proved too strong, and with the overthrow of Andros, the plan of establishing quit-rents in Massachusetts came to an end. Then the British government attempted, where possible, to bring the proprietary governments directly under the crown. Only Penn's illness and death prevented the realization of this aim in Pennsylvania and the Lower Counties. It succeeded, however, in the Carolinas and the Bahamas, where the crown took over the rights in 
the soil as well as the government, and in Georgia, where under the charter both land and government came into royal hands in 1752. The only private grant in the eighteenth century, that to Lord Granville in 1744, was merely an adjustment of a perfectly legal proprietary right, which had been granted eighty years before. Towards the close of the colonial era there was an unmistakable tendency to strengthen the quit-rents in the colonies, as a part of the general reform of the land system, and to place them all on a uniform basis. It is not impossible that in order to carry out this plan the crown would have taken over the remaining proprieties had not the Revolution intervened, for the British authorities were coming to realize the actual value of the quit-rents in stabilizing the royal administration in America.

This importance of the quit-rents, as a royal revenue, had been demonstrated in many ways. In Virginia especially, the large sum that was annually collected became of great value to the royal government. In spite of persistent efforts to assert local control, the quit-rents there were definitely recognized as a fund to be expended only with the express permission of the royal authorities. The tenacity with which this policy was upheld shows the importance that was ascribed to this source of income. As there was a permanent revenue in the province for the support of the regular administration, a fortunate aspect of the situation which saved Virginia from the quarrels over finance that took place in some of the other colonies, the income was kept as a contingent fund, to be expended for purposes closely connected with the royal interests, and for which the assembly could not be expected to provide. Virginia used this fund to aid New York in its struggle with the French and the Indians, and remitted large sums to the royal exchequer, 
to be employed wholly for purposes outside the colony. In New York and North Carolina, and to a lesser degree in South Carolina, the importance of the quit-rents to the royal administration was even more apparent. During the revenue struggles in New York, it was used to provide a salary for the chief justice, after the assembly had refused such an allowance except upon its own terms, and in North Carolina, where the assembly steadfastly refused to grant a permanent revenue, it became the one source from which to provide whatever recompense was given the officials of the royal establishment.

As an aid to the strengthening of the royal control over the colonies the quit-rents were of vital importance. The rent rolls of the crown and proprietary colonies on the mainland, exclusive of Nova Scotia, Quebec, and the Floridas, amounted at the Revolution to fully $£ 37,500$, while collections averaged at least $£ 19,0000^{1}$ As both these estimates are conservative, it is obvious that if the quit-rents had been successfully reserved in New England, and the crown had carried out the policy of purchasing all the proprietary rights, a very considerable

1 These estimates, which are only approximate, are derived chiefly from the tables given in the preceding chapters. Owing to the shifting ratio of currency to proclamation money, and the frequently careless fashion in which the rent rolls were made out, it is impossible to give exact figures. The estimate of the rent rolls includes only those of New York, Virginia, North Carolina, and South Carolina among the crown colonies, and of Pennsylvania, Maryland, the Granville Grant, and the Northern Neck among the proprieties. No estimate is possible of the rent rolls in Georgia, East Jersey, or the Lower Connties. For the annual returns, the estimate includes only those from New York, Virginia, North Carolina, and South Carolina of the crown colonies, and from Pennsylvania and Maryland of the proprieties. The annual returns from Georgia, the Granville Grant, the Northern Neck, East Jersey, and the Lower Counties cannot be stated eren approximately. In view of these facts, it is clear that both the rent rolls and the annual returns from the quit-rents were much greater than the amounts indicated. 
revenue would have been realized. Thus, one of the greatest obstacles to arbitrary rule, the control exercised by the assemblies over the public funds, would have been removed. With a permanent revenue, the expenditure of which was altogether free of local control, the governors would have occupied a place of great independence in dealing with the assemblies, and the representatives of the people would no longer have been in a position to wring from their governors a reluctant consent to measures that strongly favored local independence. Moreover, the royal authorities, possessed of a large independent revenue, could have quickly suppressed any incipient outbreak. The policy of strengthening the quit-rents, especially in connection with an administration such as that of Andros in New England, shows that the importance of the quit-rents from this point of view. was probably understood. ${ }^{1}$ The failure in this and other similar cases to obtain such an independent income means that the British government was never able to obtain that lạrger degree of imperial control which might in the end have made the Revolution impossible or have rendered it at least a much more difficult matter.

Aside from its revenue characteristics, the quit-rent was an effective aid in untangling the troublesome land problem in the colonies. Had the rules for its enforcement been actually carried out, the holding of great tracts for speculative purposes would have been impossible. This would have meant the throwing open to settlement

1 In connection with this value of the quit-rents, it is interesting to note a scheme of Governor Dinwiddie's to raise a fund for the defense of the colonies. He proposed that parliament should lay a tax of $2 \mathrm{~s}$ per 100 acres, similar to the Virginia quit-rent, on all the colonies. This tax would be collected by the sheriffs in the same fashion as the quit-rents. By such a measure, Governor Dinwiddie estimated, at least $£ 60,000$ annually could be secured. Governor Dinwiddie to Board of Trade, February, 1756, Dinwiddie Papers, II, 340-342. 
of great areas embracing fertile and well-situated land, and the creation of large numbers of small holdings and cultivable farms. There is no doubt but that this phase of the situation was understood and became a factor in shaping quit-rent policy, for settlement and the enforcement of the quit-rents were often closely bound up together. The failure to enforce the conditions of settlement in New York was closely connected with the very lax system of quit-rents. On the other hand, in both Maryland and Virginia, where the quit-rents were enforced, land speculation was held within bounds. In the Carolinas also the payment of quit-rents and the breaking up of the speculative holding of vast tracts of land were inseparable problems, and Henry McCulloh in coming to the Carolinas had both objects in view. The drafting of a rent roll, which was necessary in any wellorganized quit-rent system, was also a great aid in simplifying the land problem. By compulsory registration a complete list of grants was made possible, while questions of the validity of titles and of the right to hold surplus land were the more easily settled. The enforcement of the quit-rents came, therefore, to be an integral part of the general policy of carrying out the conditions of settlement and of solving the land problem.

When it came to enforcing the payment of quit-rents, the task proved to be difficult but not altogether hopeless. Once quit-rents had been reserved, it was largely a question of adequate official organization and a tactful policy which paid careful attention to local demands. The effective quit-rent system worked out in Maryland under the Calverts is a proof of what could be accomplished. Its most noticeable feature is the organization of a special group of officials whose sole business was the supervision and collection of the quit-rents and other dues from the 
land. Not having their attention diverted by a multitude of other duties, and with a fair recompense, these officials turned their attention to the quit-rents with gratifying results. Then, too, under such a system it was possible to keep closely in touch with local needs and to meet each crisis as it arose. To this close supervision, in connection with the tactful and broad-minded policy of the proprietaries, the success of the quit-rent system in Maryland was due. Unfortunately the crown did not profit by the example of Maryland, and made little effort in the royal colonies to improve the inadequate organization of the officials in charge or to correct the injudicious attitude of these officials towards local demands, which in varying degrees proved serious obstacles to effective enforcement. Of the crown colonies Virginia showed the best results. In South Carolina also collections were fairly satisfactory, especially in view of the numerous problems that were handed over by the weak proprietary régime. But in none of the other crown colonies was the quit-rent system at all successful. The causes of this comparative failure of the imperial administration, as contrasted with the proprietary rule in Maryland, are instructive as throwing light upon the whole system of British control in America.

In the first place the British system of supervision was altogether inadequate. When the office of auditorgeneral was founded, its duties were not so burdensome as to preclude a careful control of the quit-rents, and consequently in Virginia, the chief royal colony of the time, the system became firmly established. But as the colonial revenues increased in variety and amount, the auditor-general was unable, even with such aid as the Treasury could give, to spare sufficient time to attend 
properly to the details of the quit-rents. When the royal control was extended to New York and the Carolinas, and later to other colonies, the situation became inevitably worse. Had it been possible to watch the quitrents in these colonies as closely as had been done in Virginia during the critical period of reorganization, the outcome might have been far more satisfactory. But in the press of business, important questions that demanded prompt and vigorous action were not decided for months, or years, or at times at all. The Treasury and the auditor-general, lacking the necessary leisure or inclination to go into details, occasionally made hasty decisions that were based on incomplete or partial evidence. The ultimate deterioration of the auditor-general's office into a sinecure for a royal pensioner was the last straw. Plainly the British government failed to appreciate the demands of the situation, for had it appointed a special royal official, competent and diligent, to confine his attention to the quit-rents only and to watch much more closely the details of the system in the different colonies, it would have obtained far better results.

The same lack of wisdom was shown in organizing the official force to which was intrusted the actual charge of collection. The example of Maryland, where special officials were selected for that purpose, was not imitated in the crown colonies. Both the receiver-general and the deputy auditor had entire oversight of all the royal revenues, of which the quit-rents usually formed only a part, and the sheriff had charge of collections as but one of his manifold duties. None of these officials could give the quit-rents the necessary attention. A special official force in charge of the quit-rents would have been more expensive, but at the same time more effective. With a 
really adequate compensation men might have been secured who would have carried on their duties in a conscientious and thorough fashion. Another defect was the lack of coördination in the official force. The receiver-general should have been placed definitely under the control of the auditor-general, while the governor should have had unquestioned authority over the receivergeneral and the deputy auditor. With so loose an organization, the wonder is that these officials, distracted by numerous other duties and interests, should have supervised and collected the quit-rents as well as they did.

In the measures taken for the enforcement of the quitrents, the British government, with singular fatuity, pinned its faith to legal forms and precedents. Time and again, it issued arbitrary orders that were founded upon unquestionably legal rights, but even the sacred principles of the British common law did not always win the respect of obdurate colonials, and such orders proved altogether futile. As a last resort it frequently sought to erect in the colonies a court of exchequer, but every attempt to set up such a court ended in dismal failure. Apparently the officials in control of British policy were unable to comprehend that British judicial precedent was of little avail against the opposition of a determined people separated by three thousand miles from the source of authority. With singular lack of insight, they failed to see that the one possible means of securing any effective enforcement of the quit-rents was a local act of assembly, based upon popular approval, for both Board of Trade and Privy Council too often refused to make even slight concessions, whereby laws that had been laboriously secured by the colonial governors should receive the confirmation of the crown. The evil results 
of such an ill-advised policy were most strikingly shown in North Carolina, where law after law was passed only to be rejected as undesirable by the Board of Trade and the committee of the Council. Sometimes these rejections were justifiable, but in many instances they were due to objections that were trifling in comparison with the fact that the laws represented local needs and preferences. Such an adherence to a strict and somewhat arbitrary policy affected the successful operation of the quit-rent system in many of the royal colonies.

One of the most difficult problems confronting the British government was how to overcome the influence of land speculators upon the colonial assemblies. This problem was especially serious in South Carolina. The first royal governor there, in order to obtain a rent roll, secured an act for the registration of all titles. This act manifestly favored the landholding class, for should it be allowed many fraudulent titles would become valid. It soon became obvious, however, that only by favoring this class could registration be secured and the quit-rents enforced. A similar situation presented itself in New York. In both instances a compromising attitude on the part of the British government might have helped to smooth out the difficulties. Certainly the method determined upon for the Carolinas, of sending a special royal commissioner who was ignorant of local conditions, was as unwise a measure as could have been adopted. If the quit-rents were to be placed upon any sure basis, a rent roll was absolutely necessary, and such a roll could be secured only by an act which had the popular consent. By its stubborn refusal to recognize this fact, the British government only made a bad matter worse.

In fixing the annual amount of the quit-rent, the government at home was for the most part fair and eminently 
tactful. In this respect it stood in strong contrast with the proprietaries of Pennsylvania, and of the Carolinas during the earlier years, whose attitude was both selfish and grasping. It reserved a moderate rate in the crown colonies and one that was practically uniform for all grants, and it never demanded the constant and irritating increases that were insisted on in the proprietary colonies, though toward the end of the colonial era it showed an inclination to increase the quit-rent on new grants. Its policy toward North Carolina was, however, an exception to this rule. Here the British government, failing to grasp the demands of the situation, attempted to exact a higher quit-rent than was customary across the border in Virginia, and refused to recognize as binding the so-called Grand Deed to Albemarle. Nothing was gained by this irritating refusal, for the quit-rents paid in North Carolina were upon the lower basis claimed as a right by the inhabitants. In South Carolina also, the insistence upon a rather high quit-rent was one of the chief causes of the struggle to validate many questionable grants. In both colonies the British attitude gained little and aroused needless hostility. A more considerate policy was carried out in the numerous exemptions that were granted for a limited time along the frontier, though perhaps even there better results might have been secured if a smaller quit-rent than the one reserved in older and better settled regions had been granted permanently. On the whole, however, the royal policy was decidedly more successful in fixing the rate than in dealing with the other local problems that arose.

One difficult matter concerned the medium of payment. The usual custom was to specify in the grant that the quit-rent should be paid in English money, but owing to the lack of hard money in the colonies, it was usually im- 
possible to meet this requirement. The various expedients that were adopted to settle the quit-rents afford an interesting insight into the very troublesome problem of securing an acceptable medium of exchange during the colonial period. In the seventeenth century and the first decades of the eighteenth century, wheat was the commodity in general use for payments of the quit-rents in New York, Pennsylvania, and the Lower Counties. In Maryland tobacco was the usual medium, although wheat was sometimes used, especially on the Eastern Shore. In Virginia and North Carolina tobacco was the universal medium of payments during this early period, and in South Carolina it became necessary to accept such native products as cotton, indigo, silk, rice, pork, and English peas. In Maryland and Virginia the assemblies legalized payments of the quit-rents in a variety of grains, in order to stimulate a diversified agriculture, but these measures do not appear to have. been very successful. The use of commodities caused much confusion, and often aroused ill-feeling. The values at which they should be received, the proper grading, the cost of transportation, and the places of payment were the subjects of much controversy between the governors and the assemblies. The royal officials were obliged to keep a sharp lookout for the interests of the crown, and were disposed to issue arbitrary orders with regard to the different points at issue. The assemblies also, in their zeal to protect the interests of their constituents, were frequently unfair to the crown.

After the first two decades of the eighteenth century when Spanish silver began to circulate in the colonies, there was a marked tendency to require payments of the quit-rents in specie rather than in commodities. In the Carolinas the insistence upon payment in proclamation 
money, after the crown purchased the proprietary rights, aroused much antagonism. This was especially true in North Carolina, where act after act failed to receive the royal confirmation, largely because the assembly insisted upon a continuance of the payments in commodities. By the middle of the eighteenth century Spanish silver was in general use in Maryland and Virginia for paying the quit-rents. But the question of the rate of exchange caused much controversy, especially in Virginia, and with regard to this problem also both the proprietary and the royal agents often adopted an arbitrary and exacting course. The acceptance of the issues of paper money in payment of the quit-rents was also a cause of much agitation, notably in Pennsylvania. The refusal to receive this currency was economically sound, but in the eyes of amateur colonial financiers it was an arbitrary debasement of their much-vaunted panacea for all monetary ills. In the end, the proprietary or the crown, as the case might be, was usually obliged to accept the paper money, although the rate of discount became an additional source of controversy. The entire question of the medium of payment was handled, especially in the crown colonies, in a rather petty fashion that inevitably aroused antagonism toward the quit-rents. Had there been a more effective organization of the official force in charge of the quit-rents, there would probably have been a keener appreciation of the local economic situation, with a consequent avoidance of many irritating incidents.

The need of more efficient officials in charge of the quitrents became apparent in connection with the penalties for non-payment. While distress and ultimate forfeiture were permitted by the common law, the colonial assemblies very early showed themselves inclined to modify these penalties. In the Carolinas they attempted to 
hedge distraint with so many restrictions that it could have had but little effect as a method of execution. On many great tracts of vacant land, where there was no personal property, forfeiture was the one available means of enforcing the quit-rents, but the influence of interested landholders was sufficiently strong to prevent in many instances the actual use of such a penalty. The assembly in New York passed an act vacating certain notoriously extravagant grants, only to repeal it a few years later. Even in Virginia where the royal authority met with the least resistance, forfeiture of the land as a penalty for non-payment of the quit-rents was expressly forbidden. Confronted by such a determined refusal to adopt the usual penalties, the royal officials were almost helpless in dealing with the quit-rents on vacant land, for an arbitrary stand upon the crown's rights, though under the ægis of the common law, was clearly impossible. Perhaps a more conciliatory policy toward the medium of payment would have induced a softening of heart on the part of the assemblies, and it is also probable that had officials been appointed, as in Maryland, whose sole jurisdiction was over the quit-rents, better results would have been secured. In New York and the Carolinas a vigorous use of the penalties that were available was not without effect. But the British authorities did not appreciate the need of closer supervision, nor did they always support officials who were zealous in their work. Too often they lent a favorable ear to the representations of interested landowners, in preference to royal officials who had, from the local standpoint, proved too faithful to the interests of the crown.

The difficulties that confronted the royal officials in enforcing the quit-rents were present also in the proprieties, often in magnified form. Only in Maryland under 
the Calverts were these problems met in a fair and businesslike spirit. In strong contrast was the proprietary quit-rent system in Pennsylvania, where a niggardly and grasping policy resulted in only a half-hearted enforcement of these dues. Conditions were even worse in the Lower Counties. Proprietary control in the Jerseys was so slight that the quit-rents soon became a mere nominal charge. In the Carolinas the proprietary period was marked by a continual surrender to local demands that greatly complicated the problems of the quit-rents and the closely allied land system. The trustees of Georgia, too, during their brief tenure of power, managed to entangle the quit-rents in a well-nigh hopeless snarl. The effect of such weak proprietary control upon the quitrent system in the royal colonies was doubtless far from beneficial.

The controversies provoked by so many mistakes in policy inevitably aroused opposition to the quit-rents in both the proprietary and the crown colonies. Except where large arrears were allowed to accumulate, this antagonism was not due to the amount of the quit-rent. In transferring this feudal due from England to the colonies, both the crown and the proprietaries established rates that were much less than those customary in the mother country. Such a reduction was necessary. If as high a rate had been demanded for lands that were rescued from the primeval wilderness as for those that had long been settled and under cultivation, there would have been no inducement to come to the New World. ${ }^{1}$

1 The quit-rents in the American colonies varied between 1d per acre and 1s per 100 acres. Occasional attempts to reserve a higher rate failed, while such nominal acknowledgments as were reserved in a number of the eolonies may be ignored. The usual rate was $2 \mathrm{~s}$ or $4 \mathrm{~s}$ per 100 acres. This may be compared with the quit-rents of the manor of Eltham in Kent. The manor included 2,166 acres, and had an annual quit-rent roll amounting to £23 5s $21 / 2 \mathrm{~d}$. If this quit-rent were uniform on all the land, the annual rate 
With this necessary condition met, it would seem that so customary a charge in England as the quit-rents would have been accepted in the colonies without question.

But opposition soon developed to the very principle of paying such a feudal due as a quit-rent. The underlying cause of this attitude in New England was the free tenure of land which the Puritans established in the early days of Massachusetts. After being accustomed, as a result of opportunity rather than through any premeditated royal policy, to freedom from feudal dues, the New England colonists developed a theory of free tenure of the soil. This theory was altogether in accordance with the spirit of independence from external control that characterized the New England colonies, and its strength was shown in the vigorous resistance to the attempts that were made under Andros to reëstablish the quit-rent system. From the protests uttered at the time, it is clear that this intense hostility was due, not to the amount of the quit-rent, which was merely nominal in comparison with the value of the land, but to the Puritan belief that the land should be free from all payment to an overlord. This New England theory of a free tenure cropped out wherever the New Englander settled, as in Elizabethtown in East Jersey, which became a center of opposition to the claims of the Jersey proprietors.

Opposition to the principle of paying a quit-rent developed in all the proprietary colonies. Though to a less extent than in New England, a spirit of hostility manifested itself openly in Pennsylvania, where many move-

would be $21 / 2 \mathrm{~d}$ per acre, a much higher amount than was reserved in any American colony. If a quit-rent were not reserved in all grants, the annual rate would be even higher. The annual allowance to the bailiff for collecting the quit-rents was $£ 613 \mathrm{~s} 4 \mathrm{~d}$, or over 25 per cent., a much higher commission than was allowed colonial receivers. Survey of the Manor of Eltham in Kent, 1750, Crown Lease Book, Treas. 55: 8, pp. 115-121. 
ments were set on foot to secure local control, and persistent and successful efforts were made to tax the quit-rents as private property. In Maryland there was a feeble and fruitless echo of this latter move. In all the proprietary colonies, except Maryland, objections to paying feudal dues to a proprietary were intensified by the weak and irritating policy of these overlords. The accumulation of great sums of arrears and an insistence upon petty rights, bore an abundant fruit of controversy.

Prior to the Revolution no outward evidences of hostility toward the principle of a quit-rent appeared in the crown colonies. With the recognition of the crown ownership of the land went an acceptance, without question, of the quit-rents as the customary sign of this superior right to the soil. Such controversies as arose were directed rather against the measures taken to enforce the quit-rents, for though the inhabitants of Virginia bitterly opposed any subjection to proprietaries, they made no outward complaint against paying quitrents to the crown. But the numerous errors of policy committed by the British government, and especially its rigid insistence upon legal rights in such matters as the medium of payment and measures for enforcement, were the chief causes of the opposition to the quit-rents that appeared in the royal colonies. Even interested landowners directed their efforts, not so much toward the overthrow as toward the evasion of the quit-rents. Upon a superficial view, the attempts in Virginia to secure local control of expenditures from the quit-rent fund might be considered as a protest against this rent, but a careful analysis shows that in reality these moves were dictated by financial needs, and were in no sense a denial of the royal right to reserve the rent. 
One interesting phase of the opposition aroused by the quit-rents is the intercolonial influence of such dues. This influence, though often subtle, was in fact very real. Thus, considerable discontent was caused in Maryland by the more vigorous enforcement of the quit-rents and the higher rate there than that which prevailed across the border in Pennsylvania. One cause of the scanty population and slow growth of North Carolina may have been the turmoil excited in that colony by excessive demands regarding the quit-rents, in contrast with the peaceful situation in Virginia. But to estimate the actual effect of the various phases of the quit-rent system of any one colony upon its neighbors is a difficult matter. Such influences are usually so obscure, and so slow in producing an outward effect, that conclusions at best can be only tentative. It is obvious that the Puritan influence spread to East Jersey and New York, and there are evidences that the struggles against the proprietaries in Pennsylvania were not unnoticed in Maryland, but to what extent these practices had weight in other colonies, it is impossible to say. As intercourse and familiarity increased, the tenures of New England must have become known to the leaders in the southern colonies, but that these tenures affected in any way the southern attitude toward the quit-rents there is nothing to show.

The difficulty of ascertaining the sentiments of the people in the various colonies makes it almost impossible to furnish any accurate estimate of the extent to which the quit-rents constituted one of the main causes of the American Revolution. While not brought prominently to the front in the enumeration of grievances that preceded the final struggle, there is no doubt that the quitrents had been a source of great irritation. ${ }^{1}$ Conse-

1 Jeremy Belknap queried in 1767 whether it would not be of great service to the cause of the colonies if some plan were laid to withhold from the 
quently this feudal due may be considered as one at least of the causes of that growing discontent, which culminated in revolt from the mother country. It is at any rate significant that with the outbreak of the Revolution, all the latent antagonism toward the quit-rents that existed in both crown and proprietary colonies was converted into open hostility. Coincident with the overthrow of royal authority was the collapse of the quitrents, the outward sign of an absentee ownership of the soil. Only in New York were they retained as a nominal charge due the state. In South Carolina, Delaware and the Jerseys they were allowed simply to lapse with all other vestiges of royal control. In the remaining continental colonies which declared for independence and in which quit-rents had been established, the inhabitants repudiated these feudal dues in no uncertain terms. The different measures that were passed prove conclusively that the quit-rent, as a feudal charge and the source of a permanent royal revenue, was deemed incompatible with the land tenure of an independent people.

The history of the colonial quit-rent illustrates the futility of the attempt to transplant to fresh soil a feudal charge upon the land that even in the home country was outgrowing its original justification. As a payment that had great possibilities, especially in affording a permanent revenue, it was of vital importance in any scheme of strong royal control. But failure at first to appreciate its real value and later to adopt a well-balanced policy of management and supervision aroused such strong opposition as to defeat the royal aims. Furthermore, as a token of overlordship and a source of income

crown the quit-rents in America. Such action, he believed, would be of as much importance as stopping the trade to Great Britain. Common Grant Book, B, p. 6, Massachusetts Historical Society MSS. 
for absentee proprietaries, the quit-rent was altogether out of keeping with the increasing spirit of individual freedom. The British authorities acknowledged the failure of the quit-rents after the American Revolution, when they gave up these charges in Canada, and adopted towards them elsewhere a much more conciliatory policy. 


\section{BIBLIOGRAPHY}

\section{I}

\section{GENERAL}

\section{PRINTED MATERIAL}

Alvord, C. W., The Mississippi Valley in British Politics, Two Volumes. Cleveland, 1917.

Andrews, C. M., Narratives of the Insurrections, 1675-1690. In series, Original Narratives of Early American History. New York, 1915.

Beer, G. L., The Origins of the British Colonial System, 15781660. New York, 1908.

The Old Colonial System, 1660-1754, Part I, The Establishment of the System, 1660-1668, Two Volumes. New York, 1912.

Blackstone's Commentaries, Wendell's edition, Four Volumes. New York, 1859-1862.

British Official Publications:

Acts of the Privy Council, Colonial Series, Six Volumes, 16131766. Hereford and London, 1908-1912.

Calendar of Treasury Papers, Vols. I-XI, 1557-1745. London, 1868-1903.

Calendar of State Papers, Colonial Series, 1574-1708, Vols. I-

XXII. London and Hereford, 1880-1916.

Reports of the Royal Commission on Historical Manuseripts, Eleventh Report, Appendix V, Dartmouth Papers. London, 1881 .

Canadian Archives, Vol. III. Documents relating to the Constitutional History of Canada, 1759-1791, 6-7, Edward VII, Sessional Paper, No. 18. Ottawa, 1907. 
Carter, C. E., Great Britain and the Illinois Country, 1763-1774. Washington, 1910.

Channing, Edward, History of the United States, Vols. I-III. New York and London, 1905-1912.

Edwards, Bryan, History, Civil and Commercial, of the British Colonies in the West Indies, Vol. I. London, 1793.

Finlayson, W. F., History of the Law of Tenures of Land in England and Ireland. London, 1870.

Gilbert, Sir Jeffrey, On Rent. Dublin, 1792.

Gow, Neil, Report of Cases at Nisi Prius in the Court of Common Pleas. London, 1828.

Jamaica, Acts of Assembly, 1681-1769, Two Volumes, ed. Arkman. Kingston, 1787.

Jamaica, Acts of Assembly, 1770-1783, Kingston, 1786.

Lapsley, G. T., The County Palatinate of Durham. In Harvard Historical Studies. New York, 1900.

Osgood, H. L., The American Colonies in the Seventeenth Century, Three Volumes. New York, 1904-1907.

Thorpe, Francis N., Federal and State Constitutions, Charters and Other Organic Laws, 1492-1908, Seven Volumes. Washington, 1909.

Victoria History of the Counties of England. Bedford, Vol. II. London, 1908. Berkshire, Vol. II. London, 1907. Buckingham, Vol. II. London, 1908. Cumberland, Vol. I. Westminster, 1901. Derby, Vol. II. London, 1907. Dorset, Vol. II. London, 1908. Durham, Vol. II. London, 1907. Essex, Vol. II. London, 1907. Lancaster, Vol. II. London, 1908. Lincoln, Vol. II. London, 1906. Oxford, Vol. II. London, 1907. Rutland, Vol. I. London, 1908. Stafford, Vol. I. London, 1908.

Vinogradoff, Paul, Villainage in England. Oxford, 1892.

\section{MANUSCRIPTS}

The following manuscript sources in the British Museum and in the Public Record Office have been examined. In many cases the exact contents of the volumes are here omitted, as they have already been fully described elsewhere. See Guide to the Manu- 
script Materials for the History of the United States to 1783 in the British Museum, in Minor London Archives, and in the Libraries of Oxford and Cambridge, by C. M. Andrews and F. G. Davenport, Washington, 1908; Guide to the Materials for the History of the United States to 1783 in the Public Record Office of Great Britain, by C. M. Andrews, Two Volumes, Washington, 1912, 1914.

IN THE BRITISH MUSEUM, LONDON

Stowe MSS., Vol. 317, Particular State of the Revenue, 16881710.

Additional MSS., 4152, 12429, 14285, 36731-36734 (Revenue Receipts and Issues, 1710-1753), 37047.

IN THE PUBLIC RECORD OFFICE, LONDON

Treas. 1, Bundles 13 to 623, Treasury Board Papers, Original Correspondence.

Treas. $29:$ 27, 43, 44, Treasury Minute Books.

Treas. 52 : 10, 22, 37, 40, 41, 42, 63, King's Warrants.

Treas. $54: 17,18,19,31,34,37$, Warrants not Relating to Money. Treas. 55 : 8, Crown. Lease Book, Warrants for Crown Lands.

Patent Rolls, 3634, No. 20.

Colonial Office Papers :

C. 0. 5: 112, 145, America and West Indies.

192, 201, Plantation Entry Books.

204, Patents.

216, Instructions, Reports, and Various.

286-292, Carolina, Propriety.

319-322, North Carolina.

$358-380,383,387,388,398,399,406,408,432,433$,

441-447, 450, 512, South Carolina.

606-610, West Florida.

670, Georgia.

752, Massachusetts.

904, New England.

929, New Hampshire.

1124-1125, 1134, New York. 
1233, Pennsylvania.

$1341,1344,1356,1371,1376,1407,1408,1411,1413$ 1416, Virginia.

C. O. $76: 9$, Dominica.

C. O. $142: 31$, Jamaica.

C. O. $152: 54$, Leeward Islands.

C. O. $324: 2,26,29,31,32,36,54$, Plantations General.

C. O. $325: 1$, Miscellaneous.

C. O. $391: 10,11,43,44$, Board of Trade Journal.

IN THE ILLINOIS HISTORICAL SOCIETY LIBRARY, SPRINGFIELD Transcripts, Dartmouth MSS., 743, 772, 1059-1060.

\section{IN THE LIBRARY OF CONGRESS}

Fairfax, Thomas, Lord, Estate, Executors' Account, 1781-1798. Fairfax, Thomas, Lord, Papers relating to, 1739-1751.

Fairfax MSS., Miscellaneous.

Wilmington Papers, 1675-1736.

Transcripts, British Museum, Additional MSS. :

22357. Letters Patent to William Blathwayt.

30372. America, Abstract of Commissions, Governors of American Plantations.

33029. Newcastle Papers, America and West Indies, 17441758.

35908. Hardwicke Papers, Law Officers' Opinions on American Trade and Plantations, 1720-1733.

35909. Hardwicke Papers, American Plantations, Papers relating to, 1710-1758.

37047. Correspondence of R. Long, Secretary of State, 16491661, and Grant to Virginia.

Transcripts, Colonial Office Papers :

C. O. $5: 192$, Commissions and Instructions to Governors, May 30, 1725, to November 29, 1731.

C. 0.5 : $1313,1315-1317,1319-1321,1323-1329$, Virginia, 1702 1760 . 
Transcript, Journal of Proceedings in Pursuance of Letters Patent, dated the 19th of May, 1680, constituting William Blathwayt, Esquire, Surveyor and Auditor-General of all his Majestie's Revenues in America, 1680-1717, cited as Blathwayt's Journal.

Transcript, British Museum, King's MSS., 206. State of Manufacturing and Mode of Granting Land, Fees of Officers, etc., in America. Answers to Circular Letter from Lords of Trade, August 1, 1766.

Transcript, Patent Roll, 3511, 2 George I, No. 28, Letters Patent to Horatio Walpole as Auditor-General, 1716.

IN THE NEW YORK PUBLIC LIBRARY, NEW YORK CITY

Transcripts, Public Record Office, Audit Office, 45.

\section{II}

\section{INDIVIDUAL COLONIES}

\section{GEORGIA}

Banks, E. M., Economics of Land Tenure in Georgia, Columbia University Studies, Vol. 23, No. 1. New York, 1905.

Georgia, Acts of the Assembly, 1755-1770. Savannah, 1755-1770. Georgia, Colonial Records:

Vol. I. Journal of the Trustees, 1732-1752. Atlanta, 1904.

Vol. II. Minutes of the Common Council of Trustees, 17321752. Atlanta, 1904.

Vol. III. Accounts, Monies and Effects, 1732-1751. Atlanta, 1905.

Vol. VI. Proceedings of the President and Assistants, 17411754. Atlanta, 1906.

Vols. VII-XII. Proceedings and Minutes of the Governor and Council, 1754-1782. Atlanta, 1906-1907.

Vols. XIII-XV. Journal of the Commons House of the Assembly, 1755-1782. Atlanta, 1907. 
Vols. XVI-XVII. Journal of the Upper House of the Assembly, 1755-1774. Atlanta, 1908.

Vol. XVIII. Statutes enacted by the Royal Legislature, 17541768. Atlanta, 1911.

Vol. XIX. Statutes, Colonial and Revolutionary, 1768-1773. Atlanta, 1911.

Georgia, Digest of the Laws, 1755 to 1800, ed. Marbury and Crawford. Savannah, 1802.

Georgia Historical Collections, Vol. 2. Savannah, 1842.

Jones, C. C., Jr., History of Georgia, Two Volumes. Boston, 1883.

\section{$M A R Y L A N D$}

Bacon, T., Laws of Maryland, 1683-1763. Annapolis, 1765. Gould, C. P., The Land System in Maryland, 1720-1765. Johns Hopkins University Studies, Series XXXI, No. 1. Baltimore, 1913.

Kilty, John, The Landholder's Assistant. Baltimore, 1808.

Mayer, Lewis, Ground Rents in Maryland. Baltimore, 1883.

Mereness, N. D., Maryland as a Proprietary Province. New York, 1901.

Maryland, Acts of the Assembly, 1732, and 1742-1780. Annapolis, 1732-1780.

Maryland Fund Publications, No. 34, Calvert Papers, No. 2. Baltimore, 1894.

Maryland, Votes and Proceedings of Senate, 1785. No imprint. Maryland Archives. Baltimore, 1883-1915.

Vols. I, II, VII, XIII, XIX, XXII, XXIV, XXVI, XXVII, $\mathrm{XXIX}, \mathrm{XXX}, \mathrm{XXXIII-XXXV}$, Assembly Proceedings, 1638-1726.

Vols. III, V, VIII, XV, XVII, XX, XXIII, XXV, XXVIII, XXXI, XXXII, Council Proceedings, 1636-1770.

Vols. VI, IX, XIV, Governor Sharpe, Correspondence, 17531771.

Vol. XXXI, Letters to Governor Sharpe, 1754-1765.

Vol. XXXII, Minutes of the Board of Revenue.

Vols. IV, X, Provincial Court, 1637-1657. 
IN" THE MARYLAND HISTORICAL SOCIETY, BALTIMORE

Calvert Papers, Lord Baltimore's Account Books, 1733, 1748, 1752-1761.

Correspondence, Miscellaneous, 1719-1760.

Council Proceedings, 1753-1771, Libers 19-20.

Dulany Papers.

Land Office Accounts, 1735-1761.

Lower House Journal, 1728-1758, Libers 45-50.

Miscellaneous Papers, Portfolios 2, 13.

Proprietary Papers; Miscellaneous, Nos. 2, 3, 1703-1769.

Rent Rolls and Debt Books, Miscellaneous, 1650-1759.

Upper House Journal, 1715-1754. Libers 31-35.

IN THE LAND COMMISSIONER'S OFFICE, ANNAPOLIS

Miscellaneous Rent Rolls and Debt Books, 1735-1773.

\section{NEW ENGLAND}

Belknap, Jeremy, History of New Hampshire, Farmer's edition. Dover, 1831.

Burrage, Henry S., The Beginnings of Colonial Maine, 16021658. Portland, 1914.

Connecticut, Colonial Records of, 1636-1665. Hartford, 1850.

Council for New England, Records of, in American Antiquarian Society Proceedings for April 24, 1867. Cambridge, 1867. Maine Historical Society Collections:

1st Series, Vol. V. Portland, 1857.

2d Series, Vols. VII, VIII. Farnham Papers. Portland, 1901-1902.

2d Series, Vol. X, Baxter MSS. Portland, 1907.

Massachusetts, Colonial.Laws of, Reprint from edition of 1660 , with Supplement to 1672 . Boston, 1889.

Massachusetts Historical Society Collections. 4th Series, Vol.

II, Vol. X, Aspinwall Papers. Boston, 1854 and 1871. 5th Series, Vol. IX, Trumbull Papers. Boston, 1885. 
Massachusetts, Temporary Acts and Laws of the Province of, ed. Kneeland and Green. Boston, 1742.

New Hampshire, Provincial Papers of:

Vol. I, 1623-1686. Concord, 1867.

Vol. V, 1738-1749. Nashua, 1871.

Palfrey, John G. History of New England, Vols. I-III. Boston, 1859-1864.

Prince Society Publications:

Sir William Alexander and American Colonization. Boston, 1873.

Andros Tracts, Three Volumes. Boston, 1868-1874.

Sir Ferdinando Gorges and his Province of Maine, Vols. 1-3. Boston, 1890.

Captain John Mason, Papers. Boston, 1877.

Edward Randolph, Seven Volumes. Boston, 1898-1899.

Rhode Island, Records of, Vol. III, 1678-1706. Providence, 1858.

Williamson, W. D., History of Maine, Two Volumes. Hallowell, 1832.

IN THE CONNECTICUT HISTORICAL SOCIETY, HARTFORD

Transcript, Barrington Letters, British Museum, Egerton, 2648.

IN THE MASSACHUSETTS HISTORICAL SOCIETY, BOSTON

Belknap, Commonplace Book, B, p. 6 (Furnished by Professor Andrews).

\section{NEW JERSEY}

Fisher, E. J., New Jersey as a Royal Province, 1738-1776. Columbia University Studies, Vol. XLI. New York, 1911.

Hatfield, E. F., History of Elizabeth, N.ew Jersey. New York, 1868.

Lee, Francis B., New Jersey as a Colony and a State, Four Volumes. New York, 1902.

Mulford, Isaac S., History of New Jersey. Camden, 1848. 
New Jersey Archives:

1st Series :

Vols. I-IV, Documents relating to the Colonial History of New Jersey, 1631-1720. Newark, 1880-1882.

Vols. XIII-XVIII, Journal of the Governor and Council, 1682-1775. Trenton, 1890-1893.

Vols. XI-XII, XIX-XX, XXIV-XXVII, Newspaper Extracts, 1704-1776. Paterson, 1894-1905.

2d Series :

Vols. I-III, Newspaper Extracts, 1776-1779. Trenton, 19011906.

New Jersey, Acts of the Assembly of, Vol. I, 1703-1752, ed. Samuel Nevil. Printed by William Bradford, 1752.

New Jersey, Grants, Concessions, and Original Constitutions of, ed. Aaron Leaming and Jacob Spicer. Philadelphia, 1758. New Jersey Historical Society Collections:

Vol. I, Whitehead, W. A., East Jersey under the Proprietary Government. New York, 1846.

New Jersey, Journal and Votes of the House of Representatives of the Province of New Cesarea or New Jersey, 1703-1709. Jersey City, 1872.

Tanner, E. P., The Province of New Jersey. Columbia University Studies, Vol. XXX. New York, 1908. .

Yard, J. S., Old Times in Old Monmouth. Freehold, 1887.

IN THE NEW JERSEY HISTORICAL SOCIETY, NEWARK

Tracts and Broadsides:

Answer to a Bill in the Chancery of New Jersey at the Suit of John, Earl of Stair and Others, commonly called Proprietors of the Eastern Division of New Jersey, against Benjamin Bond and others claiming under the Original Proprietors and Associates of Elizabethtown. New York, 1752.

Answer to Council of Proprietors' two publications as set forth at Perth Amboy, March 25, 1746, and March 25, 1747; also observations on Mr. Nevil's speech to the House of Assembly regarding a petition presented May, 1746. Published by order of the Committee. New York, 1747. 
Bill in the Chancery of New Jersey at the Suit of John, Earl of Stair, and others, Proprietors of the Eastern Division of New Jersey, against Benjamin Bond and some other Persons of Elizabethtown, distinguished by the Name of the Clinker Lot Right Men. To which is added, the Publications of the Council of Proprietors of East Jersey and Mr. Nevil's speech to the General Assembly concerning the Riots committed in New Jersey and the Pretences of the Rioters and their Seducers. New York, 1747.

The Claim of the Inhabitants of the Town of Newark, in virtue of the Indian Purchases made by the first settlers in Newark, in 166\%, stated and considered. Woodbridge in New Jersey, 1766.

\section{Manuseripts}

Paris Papers, Elizabethtown, Vols. O, P, R.

Miscellaneous MSS., Mr. Lewis Morris' Account of Money received and paid to the West New Jersey Society, from 15, May, 1704, to 23, July, 1730.

IN OFFICE OF SECRETARY OF STATE, TRENTON

New Jersey Colonial Documents :

East Jersey Deeds, etc., Libers D, E, G.

West Jersey Records, Liber B, Part 2.

Deeds, Patents, etc., Liber 1.

IN OFFICE OF SURVEYOR-GENERAL FOR EAST JERSEY, PERTH AMBOY Minutes, Council of Proprietors, Eastern Division of New Jersey, Books A and B, 1725-1794.

Miscellaneous Papers, Liber A, 1682-1688.

Book of Land Grants, IV, A, B, 1718-1761.

IN OFFICE OF SURVEYOR-GENERAL FOR WEST JERSEY, BURLINGTON Minutes, Council of Proprietors of West Jersey, 1-5, 1688-1751; Books A-C, 1751-1782. 


\section{NEW YORK}

Cheney, E. P., Anti-Rent Agitation in New York, 1839-1846. University of Pennsylvania Publications, No. 2. Philadelphia, 1887.

New York, Calendar of Historical MSS., Four Volumes, Part

II. Albany, 1865-1866.

New York, Colonial Laws of, 1664 to the Revolution. Albany, 1894.

New York, Documentary History of the State of, ed. E. B. O'Callaghan, Vol. 4. New York, 1887.

New York, Documents relative to the Colonial History of the

State of, ed. E. B. O'Callaghan, Vols. III-VIII, 1614-1782.

Albany, 1853-1857.

New York Historical Society Collections:

Colden Papers, Vols. I-II, 1760-1775. New York, 1876-1877.

Clarendon Papers. New York, 1869.

Journal of Assembly, Two Volumes, 1691-1765, printed by $\mathrm{H}$.

Gaine. New York, 1764-1766.

Journal of Assembly, 1766-1776. Reprint. Albany, 1820.

Journal of Legislative Council, Two Volumes, 1691-1775, ed.

E. B. O'Callaghan. Albany, 1861.

New York, Laws of, Vols. II-V, 1785-1806. Printed by H. Gaine.

Reprint. Albany, 1886.

Minutes of the Executive Council of the Province of New York, 1668-1673, Two Volumes, ed. Victor H. Paltsits. Albany, 1910.

New York State Library, History Bulletin 6, Calendar of Council Minutes, 1668-1783. Albany, 1902.

New York, Statutes of, 1814-1853. Albany and Troy, 1814-1853. Osgood, H. L., Report on the Archives and Public Records of the State of New York, and of New York City. Reprint from the First Report of the Public Archives Commission of the American Historical Association, 1900. Washington, 1901. Pemaquid, Papers relating to, ed. F. B. Hough. Albany, 1856. 
IN THE NEW YORK STATE LIBRARY, ALBANY

Minutes, Executive Council of New York, Vols. 5-31, 1683-1776. New York Colonial MSS., Vols. 28, 34 (Part I), 35, 40, 41, 49, $50,51,54,63,81,86$.

IN THE OFFICE OF THE SECRETARY OF STATE, ALBANY

New York Land Papers, 1643-1776, and especially Vols. III-V. Translation, Book of Dutch Patents, C. G. Vol. 26, 1630-1649. Translations from the Dutch, 1654-1655; Patents, 1654-1666. Dutch Patents and Transports, 1652-1674.

Patent Book Series, Nos. 1-16, 1664-1775.

\section{NORTH CAROLINA}

Connor, Henry G., The Granville Estate and North Carolina, in University of Pennsylvania Law Review, Vol. 62, No. 9. Philadelphia, October, 1914.

Coulter, E. M., The Granville District. James Sprunt Historical Collections, Vol. 13, No. 2. Durham, 1913.

North Carolina, Colonial Records, 1662-1776, Vols. I-X. Raleigh, 1886-1890.

North Carolina, State Records:

Vol. XI, 1777, and Supplement, 1730-1776. Winston, 1895.

Vols. XXIII-XXV, Laws, 1669-1790. Goldsboro, 1904-1906. North Carolina, Historical and Genealogical Register, Vol. 3, January-July, 1903. Edenton, N. C.

Raper, C. L., North Carolina, A Study in English Colonial Government. New York, 1894.

Swann, Samuel, Collection of Public Statutes, North Carolina, 1715-1752. Newbern, 1752.

IN NORTH CAROLINA HISTORICAL COMMISSION LIBRARY, RALEIGH

Various papers from the manuscript files, relating to the Granville Grant and other subjects, furnished by Professor Andrews. 
PENNSYLVANIA AND THE LOWER COUNTIES

Browning, Charles H., Welsh Settlement of Pennsylvania.

Philadelphia, 1912.

Cadwalader, R. M., A Practical Treatise on the Law of Ground Rents in Pennsylvania. Philadelphia, 1879.

Delaware, Laws of. Printed by B. Franklin, Philadelphia, 1752. Delaware, Laws of, 1700-1797, Two Volumes. Neweastle, 1797.

Pennsylvania Archives:

First Series :

Vols. I-IV, Miscellaneous Documents and Papers, 1664-1776.

Philadelphia, 1852-1853.

Second Series :

Vol. V, Papers relating to the Colonies on the Delaware, 1614-1682. Harrisburg, 1877.

Vol. VII, Papers relating to Provincial Affairs, 1682-1750. Harrisburg, 1878.

Vol. XIX, Minutes of Board of Property, 1685-1739. Harrisburg, 1893.

Third Series :

Vol. I, Minutes of Board of Property, 1733-1791. Harrisburg, 1894.

Vols. VIII-X, Provincial Commissions, 1733-1790. Harrisburg, 1896.

Fourth Series :

Vols. I-III, Papers of the Governors, 1682-1785. Harrisburg, 1900.

Pennsylvania Colonial Records:

Vols. I-X, Minutes of the Provincial Council, 1683-1776.

Harrisburg, 1838-1852.

Pennsylvania Gazette, Files 1752-1775 (In Library of Congress). Pennsylvania, Laws of, 1700-1852, ed. Jas. Dunlop. Philadelphia, 1853.

Pennsylvania, Statutes at Large, Vols. I-X, 1682-1781. Harrisburg, 1896.

Root, W. T., The Relations of Pennsylvania with the British Government, 1696-1765. New York, 1912. 
Shepherd, W. R., History of Proprietary Government in Pennsylvania. Columbia Studies, Vol. VI. New York, 1896.

IN THE PENNSYlVANIA HISTORICAL SOCIETY, PHILAdELPHIA

Logan Papers :

Quit-Rents, Governor John Blackwell's Roll, 1684-1689.

Receipt Book of Lynford Lardner, 1743-1750.

Three Lower Counties, Quit-Rents.

Miscellaneous Papers :

Chester County, 1684-1847.

Three Lower Counties, Delaware, 1655-1805.

Penn MSS. :

Accounts, Vol. I.

Additional Miscellaneous Letters, Vols. I-II.

Official Correspondence, Vols. I-X, 1683-1771.

Papers relating to the Three Lower Counties, 1629-1774.

Vol. VII, Philadelphia Land Grants.

Vol. IX, Pennsylvania Land Grants, 1681-1706.

Penn-Physick MSS. :

Accounts of Quit-Rents, from 1701 to about 1776.

Vol. VI, Bonds, Surveys, Powers of Attorney, etc., 1681-1769.

Vol. IV, Land Grants and Surveys, Miscellaneous, 1676-1801. Penn-Physick Papers :

Correspondence, Vol. I, 1682-1788.

Letter Book, Vol. III, 1769-1804.

James Steele's Letter Book, 1719-1730.

Taylor Papers, Vols. 14 and 15, Correspondence, 1683-1750.

IN THE FRIENDS' REFERENCE LIBRARY, DEVONSHIRE HOUSE, LONDON Penn MSS., Vols. I and II.

IN PENNSYlVANIA LAND-OFFICE, HARRISBURG

Patent Books, Series A, Nos. 1-6 and following.

Miscellaneous Proprietary Papers. 


\section{SOUTH CAROLINA}

McCrady, Edward, The History of South Carolina under Proprietary Government, 1670-1719. New York and London, 1897.

McCrady, Edward, The History of South Carolina under the Royal Government, 1719-1776. New York and London, 1899. Smith, W. Roy, South Carolina as a Royal Province. New York and London, 1903.

South Carolina, Acts of the Assembly, May 29, 1744. No imprint. Journal of the Commons House of the Assembly, September 20October 15, 1692, 1693, January 30-March 17, 1796, and November 24-December 5, 1696, ed. A. S. Salley, Jr. Columbia, 1907-1912.

Journal of the General Assembly, March 26, 1776-April 11, 1776, and September 17, 1776-October 20, 1776, ed. A. S. Salley, Jr. Columbia, 1906 and 1909.

Journal of the Grand Council, August 25, 1671-June 24, 1680, April 11, 1692-October 15, 1692, ed. A. S. Salley, Jr. Columbia, 1907.

Extracts from the Journal of the Provincial Congress of South Carolina, 1775-1776. Charlestown, 1776.

Warrants for Lands, 1672-1692, ed. A. S. Salley, Jr. Columbia, 1910 and 1911.

South Carolina Gazette, January 8, 1732, to August 9, 1742 (In Library of Charleston Library Society).

South Carolina and American Gazette, 1766-1776 (In Library of Charleston Library Society).

South Carolina, Statutes at Large, 1682-1786, Four Volumes. Columbia, 1836-1838.

IN THE SOUTH CAROLINA HISTORICAL COMMISSION LIBRARY, COLUMBIA

Quit-Rent MSS., Accounts, 1733-1741 and 1756-1774. Public Records, Transcripts, Vols. XIV, XV, XXXVI. Commons House Journal of South Carolina, 1741-1742. 


\section{VIRGINIA}

Bassett, J. S., Writings of Colonel William Byrd of Westover in Virginia. New York, 1901.

Beverley, Robert, History of Virginia, Reprint, ed. Charles Campbell. Richmond, 1855.

Bruce, Philip A., Economic History of Virginia in the Seventeenth Century, Two Volumes. New York, 1896.

Bruce, Philip A., Institutional History of Virginia in the Seventeenth Century, Two Volumes. New York and London, 1910.

Burk, John D., History of Virginia from its earliest Settlement to the present Day, Four Volumes. Petersburg, 1804-1816. Cartmell, T. K., A History of Frederick County, Virginia. Winchester, 1909.

Dinwiddie, Robert, Official Records of, Vols. I-II, Virginia Historical Society Collections. Vols. III-IV, new series. Richmond, 1883-1884.

Filson Club Publications, No. 27, Petitions of the Early Inhabitants of Kentucky to the General Assembly of Virginia, 1769-1792, ed. J. R. Robertson. Louisville, 1914.

Flippin, Percy S., The Financial Administration of the Colony of Virginia, Johns Hopkins University Studies, Series XXXIII, No. 2. Baltimore, 1915.

Flippin, Percy S., Royal Government in Virginia, 1624-1775, Columbia University Studies, 1919.

Hening, W. W., Statutes at Large, 1619-1792, Thirteen Volumes. Richmond, etc., 1819-1823.

House of Burgesses of Virginia, Journal of, 1619-1776, ed. Jno.

P. Kennedy and H. R. MeIlwain. Richmond, 1905-1915.

Palmer, W. P., Calendar of Virginia State Papers, Vol. I, 16521781. Richmond, 1875.

Ripley, W. Z., Financial History of Virginia, 1609-1776. Columbia University Studies, Vol. IV. New York, 1893.

Spotswood, Alexander, Official Letters of, Two Volumes. Virginia Historical Society Collections. Richmond, 1882 and 1885. 
Virginia Magazine of History and Biography, Vols. I-XXIII. Richmond, 1893-1915.

Wertenbaker, T. J., Virginia under the Stuarts. Princeton, 1914.

IN THE VIRGINIA HISTORICAL SOCIETY, RICHMOND

Letter Book of.Richard Corbin, Transcript, Vols. I and II, 17581768.

Ludwell MSS.

Transcripts and Autographs, M. (Furnished by Professor Andrews).

IN THE VIRGINIA STATE LIBRARY, RICHMOND

MeDonald Transeripts.

Sainsbury Abstracts.

William Allason's Letter Book, 1770-1789 (Furnished by Professor Andrews). 



\section{INDEX}

Albany, city of, as proprietor, 256 (note 3)

Albemarle, Grand Deed to, a source of dispute, $77,113,116,287$, $289,290,291,294,299,316$, 318,451

Alexander, James, receiver-general,

- East Jersey, 97, 98

Alexander, William, Lord, claims to Long Island, 260 (note 2)

Alienation fines, 176 (note 1), 179, $182,191,193,216$ (note 2), 358

Allen, Eleazer, receiver-general, North Carolina, 292, 297, 298, 414, 415, 430

Allen, Samuel, proprietary claims of, in New Hampshire, 59-60

American Revolution, quit-rents as cause of, 11, 458-459

Andros, Sir Edmund, 44-50, 442, 445, 456 ; proposed revival of quitrents in New England, 44-45, 442, 445; attempt to establish quit-rents in Massachusetts, 4550 ; overthrow of, 49,456

Archdale, John, governor, South Carolina, quit-rent laws passed under, 120-121, 321

Arrears, as source of anti-quit-rent agitation, 102-103, 123-125, 138, $166-171,262,265-266,442,455$

Ashfield, Richard, receiver-general, East Jersey, 98, 99

Atkinson, Johnathan, receiver-general, St. Vincent, 385-386

Auditor-general of the Plantation Revenues, office of, 389-391, 393-
394, 397 (note 2), 424, 447-448; powers, 389; duties, 389-390; compensation, 390

Bacon, Nathaniel, treasurer and auditor, Virginia, 226

Bacon's Rebellion, partly caused by proprietary grant, 63, 64; an illustration of need for an independent royal revenue, 233 , 240,405

Bahamas, quit-rents in, 131, 357

Baltimore, Lord, boundary disputes of, with Penn family, 162, 164, 167,170

Baltimore, Lords, proprietaries of Maryland, 175, 176, 177, 180, $181,182,184,185,186,188$, $189,194,198,199,200,209,210$

Barbadoes, quit-rents in, 131, 355356,386

Barclay, John, receiver-general, East Jersey, 96, 97

Bellomont, Lord (Richard Coote), governor, New York, 255, 262; attempt to annul extravagant grants of land, 258-259

Berkeley and Carteret, proprietaries, New Jersey, 84-87

Bermuda, quit-rents in, 131, 357

Blathwayt, William, auditor-general, $68,94,164,224,226,261,357$, $360,389,397-412,413,416,417$, 420, 424, 425, 426; administration as auditor-general, 397-412; supported by British govern. ment, 397-398; supervision over 
subordinates, 398-400; audit of accounts, 400-404; reports on quit-rent revenue, 404-408; reports on expenditures, 408-410; general reports, 411; summary, 411-412

Board of Property, Pennsylvania, 136, 137, 144, 163, 166; control of quit-rents, 136-137

Board of Proprietors, East Jersey, vs. Associates of Elizabethtown, Bill in Chancery, 101-103, 106

Board of Proprietors, East Jersey, attempts to enforce quit-rents, $90,91,92,98-100$; quarrel with Lord Cornbury, 95-96

Board of Proprietors, West Jersey, quit-rent policy, 88

Board of Revenue, Maryland, in general control of quit-rents, 211214

Board of Trade, quit-rent policy, 60 , $66,129,240,244,260,268,269$, $281,289,290,294,295,303,305$, $306,307,319,322,323,326,332$, $343,345,351,353,369,395,424$, $426,428,429,431-435,437,449$, 450 ; direct supervision over the quit-rents, 431-435; general supervision, 431-432; circular letter, Earl of Shelburne to governors, 432-433; responses to Earl of Shelburne's letter, 433434 ; lists of land grants sent to, 434-435

Boston, town of, as proprietor, 23 (note)

Boundary disputes, 68-71, 117, 162, 163-164, 167, 170, 237, 250, 309$310,343,410,427$

Bradley, Richard, attorney-general, New York, salary from quitrents, 281, 283, 428

Burrington, George, governor, North
Carolina, 287, 288, 290, 291; instructions regarding quit-rents, 287 ; efforts to secure quit-rent law, 288, 290

Byerley, Thomas, receiver-general, New York, 263

Byrd, William, deputy auditor and receiver-general, Virginia, 226, $399,401.402$

Byrd, William, II, receiver-general, Virginia, 226, 231, 232, 240, 307, 400, 402

Calvert, Benedict, opinion regarding commutation of quit-rents in Maryland, 185-186

Calvert family, proprietary policy of, 133, 174, 201-204, 217-218, 454-455

Canada, Lower, 380, 387; see also under Canada

Canada, quit-rents in, 374-380, 387; French tenures, 374, 375, 376, 378 ; rate, 374,375 ; revenue, 375 ; opposition to French tenure, 376-378; separation of Upper and Lower Canada, 376$378,379-380,387$; abolition, 378-380

Canada, Upper, 376, 380, 397; see also under Canada

Carolinas, propriety of, sale of, 118, 125 ; causes of quit-rent situation in, 286, 455; failure of quit-rents in, 125-126, 441; rate of quit-rent, 451

Carteret, Lord, proprietary, East Jersey, 88

Ceded Islands, quit-rents in, 382386,431 ; rate, 382 ; futile attempts to substitute four and one-half per cent., 383 ; opposition, $383-386$; revenue, 385

Charters, proprietary, right to reserve quit-rents under, 31-32 


\section{INDEX}

Cholmondeley, Reverend Robert, auditor-general, 397, 420-423; administration as auditor-general, 420-423; general supervision over quit-rents, 420, 421423 ; reports on quit-rent revenue, 420-421 ; summary, 423

Clinker Lot Men, 102, 108; see also under Elizabethtown, associates of

Clinton, George, governor, New York, report on quit-rents, 279 280

Commodities, in payment of quitrents, $79,114-115,119,120,128$, 175, 178, 223, 266 (note 4), 278 (note 5) , 287, 288, 289, 291, 295, 299, 302, 303, 322, 368, 370,452

Connecticut, quit-rents in, 22 (note), $39-42$; quit-rents proposed at Saybrook, 39 ; opposition to, $39-40$; quit-rents prohibited, 40 ; opposition to Hamilton claim, 40-42

Corbin, Richard, receiver-general, Virginia, 242

Cornbury, Lord (Edward Hyde), governor, New Jersey, controversies with proprietaries, East Jersey, 95-97

Cranfield, Edward, governor, New Hampshire, attempt to establish quit-rents, 56-59

Crown colonies, advantages and disadvantages of quit-rent system in, 219-221, 227

Culpeper, Lord, proprietary claims of, $62,74-76,224,234$; claim to all Virginia, 62, 64-65, 224; claim to the Northern Neck, 66-76, 234

Delaware, quit-rents in, 161-173, see also under Lower Counties
Delaware Bay, special rates for land on, 176

Deputy auditor, office of, 226, 391, 393, 398, 399-400, 416, 417, 423, 448-449; powers, 391 ; duties, 391 ; compensation, 391, 416 417

Diggs, Dudley, deputy auditor, Virginia, 227, 299

Dinwiddie, Robert, governor, Virginia, 244, 251, 428; requests grant from quit-rent fund for local needs, 251

Distress, as penalty for non-payment of quit-rents, 29-30, 74-75, 86, $89,91,115,116,117-118,120$, $137,139,170,177,205,206$, 222, 228, 233, 272, 293, 299, $300,302,303,309,311,322,323$, $327,330,344,361,367,453-454$

Dixon, Thomas, receiver-general, New York, 263, 267, 268, 415, 416

Dobbs, Arthur, governor, North Carolina, 301, 302, 303, 304, 305, 306, 307, 309, 422, 430 ; instructions regarding quitrents, 301-302; failure to secure confirmation of quit-rent act, 302-304; controversy with John Rutherfurd, 305-308

Dominica, quit-rents in, 382, 383, 384, 431; see also under Ceded Islands

Dorchester, Lord (Sir Guy Carleton), proposes abolition of quitrents in Canada, 378-380

Duke of York, proprietary, New York, 110, 111, 112, 113, 254, 257, 261, 286

Dulany, Daniel, proprietary agent in Maryland, 192, 194, 198

Durham, Palatinate of, quit-rents in, 27-28 
Dutch tenure, 110-111, 112-113, 254, 286,440

East Jersey, quit-rents in, 84, 88108, 433-434, 442; influences against quit-rents, 84, 85-86; quit-rents under Carteret, 88; quit-rents under proprietaries, 89-95; rate, 89 ; measures for enforcement, 89-91, 98-101; revenue, 91,99 (note 5); problems encountered, 91-92; popular opposition, 92-93, 97-98; proposed sale of quit-rents, 9394 ; uncertainty of proprietary title, 94-95; transfer of government to the crown, 95 ; controversies between the proprietaries and the governor, Lord Cornbury, 95-97; gross value, 97 ; suit against associates of Elizabethtown, 101-103, 106; proprietary and anti-proprietary views, 103-106; summary, 107 108

Eastern Shore vs. Western Shore, Maryland, 187, 195, 196-197

Elizabethtown, associates of', suit against, 101-103, 106

Elizabethtown patents, a source of discord, 85-87, 89, 90-91, 95, 97, 100

Exchange, rate of, in payments of quit-rents, 142-143, 189, 205, 207, 246-248, 329, 383-384, 415, 453

Exchequer, court of, as means of enforcing quit-rents, 264, 268$269,273,291,299,310,312$, $326,327,328,383,431,435$, 449

Extortion in collecting quit-rents, 78-79, 180-181, 205-207
Fairfax, Thomas, Lord, proprietary, Northern Neck, 69-76; boundary controversy with Virginia, 69-71; suit brought by Joist Hite against, 71-74; proprietary claims annulled, 75-76

Fenwick, George, proposes propriety at Saybrook, 39-40

Fletcher, Benjamin, governor, New York, grants of land under, 258-259

Florida, East and West, quit-rents in, $374,380-382,387,433$; rate, 381 ; measures for enforcement, 381 ; method of collection, 381 382 ; revenue, 382

Forfeiture, as penalty for non-payment of quit-rents, $29-30,88$, $120,127,144,177,228,230,273$, $274,291,293,301,302,303,311$, $319-320,322,327,352,359,363$, $364-365,372,374,375,381,436$, 453-454

Four and one-half per cent. export duty, as substitute for quitrents, 33, 356, 357-358, 368, 383, 387,413

Frankleyne, Peter, receiver-general, Tobago, 386

French tenure, 355, 369-370, 374, $375,376,378$ (note 2), 379, 387,440

Frontier lands, quit-rents on, 119, $136,157-158,188,193,194,197$ $198,206-207,244-245$

Georgia, erown colony, quit-rents in, $350-354,431,433$; favorable conditions for, 350 ; rate, 350 351 ; method of collection, 351 ; measures for enforcement, 351353,431 ; opposition, 353 ; abolition, 353-354; summary, 354

Georgia, propriety, quit-rents in, 32 , $126-130,350,431,455$; rate, 
126-128, 128-129; medium of payment, 127, 128; measures for enforcement, 128-129; method of collection, 129-130

Gilbert, Sir Humphrey, quit-rents proposed by, 31, 32

Gordon, John, proposed reform of quit-rent system, $4.35-436$

Gorges, Ferdinando, claimant to Maine, 52-53; sale of claims to Massachusetts; 53-54

Gorges, Sir Ferdinando, proprietary, Maine, 42, 51-54

Granville Grant, propriety of, 61, 66, 76-82, 298-299, 300, 302, 310, $312,316,318,443$; origin, $76-$ 77 ; a source of discord, 77-79, 81 , 310 ; rate, 78 ; method of collection, 78; gross value of quit-rents in, 81 ; abolished, 8182

Granville, Lord, proprietary, Carolinas, and Granville Grant, 76$82,125,129,331$ (note 1), 443

Grenada, quit-rents in, 382, 383, 384, 386,431 ; see also under Ceded Islands

Ground rents, 160 (note 4), 215 (note 2)

Grymes, John, deputy auditor and receiver-general, Virginia, 232, 242,415

Hamilton claims, Connecticut, 40-41, especially 41 (note 1)

Hammerton, John, receiver-general, South Carolina, 292, 320, 329, $330,336,341,342,347,417-418$, 430

Hawley, Jerome, treasurer, Virginia, 222

Higginson, Reverend, protest against quit-rents in New England, 4748
Hite, Joist, suit against Lord Fairfax, 71-74

Hockley, Richard, receiver-general, Pennsylvania, 148-156, 158, 159

Hunter, Robert, governor, New York, $237,260,266,410$; recompensed from quit-rent fund for losses, 237, 410

"Inch of candle," sale of quit-rent tobaceo by, $227-229$

Indians, special rate to, 176, 222

Ingram, Archibald, receiver-general, St. Vincent, 384, 385

Jamaica, quit-rents in, 355, 357-368, $387,388,404,425-426$; proposed export duty, 357-358; rate, $358-359,362$; revenue, 359 . $361,363,404$; measures for en forcement, $359,361,363,363$ 365 , 365-366, 366-367 ; speculation in land, 359-363; method of collection, $360-361,365,367$, 425-426; local control, 362-363, 365 , 367 ; expenditures, 362 ; summary, 367-368

Jenkins, Griffith, anti-proprietary pamphlet, East Jersey, 105-106 Johnson, Robert, governor, South Carolina, 125, 318, 319, 321, 322. $323,324,325,328$; instructions regarding quit-rents, 318-319, 321 ; efforts to secure quit-rent law, 319-325

Johnston, Gabriel, governor, North Carolina, 291, 292, 293, 294, $295,299,345$; arbitrary enforcement of quit-rents, 291-295

Kennedy, Archibald, receiver-general, New York, 257, 263, 267, 278

King's College, New York, quit-rent on grant to, 255 -256 
Land, price of, 68 (note 2), 89, 114, $119,120-121,127,134,176$ (note 1), 223 (note 4), 290, $296,318,372,373,438$

Land speculation, influence of quitrents upon, 188, 218, 228-229, 244, 254, 257-261, 270, 275-276, 285,290 (note 1), 340, 359, 363, 445-446, 450

Land system, 78-79, 92, 116, 117, $122,175,187,188,204-205,228$, 243-244, 258-261, 268, 287, 294, 303-304, 332, 333, 334, 340-341, $344,345,349$, 351-352, 359, 371 $372,374-380,416,432,434,435-$ 438, 445-446

Lardner, Lynford, receiver-general, Pennsylvania, 147, 148

Leeward Islands, quit-rents in, 355356

Legge, Francis, governor, Nova Scotia, report on quit-rents in Nova Scotia, 371-372, 431

Lloyd, Edward, receiver-general, Maryland, 202, 203, 204

Logan, James, receiver-general, Pennsylvania, 137, 140, 143, 144, 164, 166, 167

London Company, quit-rents under, 32, 109-110, 131, 221, 254

Lower Counties, quit-rents in, 161173, 403-404; Penn title to, 161$162,164-165,403-404$; rate, 162 ; medium of payment, 162 ; opposition aroused, 162-163, 169-171; method of collection, 163-172; boundary dispute, 164, 167,170 ; accumulation of arrears, 166-171; gross value, 170 ; abolition, 171; summary, 171173

Loyalists, American, opposition to French tenure in Upper Canada, 376-377
Ludwell, Thomas, deputy auditor, Virginia, 231, 232, 399, 428

Lynch, Sir Thomas, governor, Jamaica, 358, 359, 360, 361, 425

McCulloh, Henry, 79-80, 295, 296299 , 316, 331-341, 345, 349, 396$397,418-419,429,446$; agreement with Lord Granville for quit-rents, 79-80; mission to North Carolina, 295, 296-299, 317; instructions regarding North Carolina, 296; official conduct in North Carolina, 296298; hostility of local officials in North Carolina, 297-298; result of mission to North Carolina, 298-299; mission to South Carolina, 331-341, 349; instructions regarding South Carolina, 332 ; official conduet in South Carolina, 333-340; hostility of local officials in South Carolina, $333-335,336,340$; result of mission to South Carolina, 340341 ; controversy over salary, $345,418-419$, 429; special royal commissioner to the Carolinas, 396-397; powers, 396; duties, 396 ; compensation, 396 .

McKean, Chief Justice, Pennsylvania, opinion on quit-rents, 160

Maine, quit-rents in, 22 (note), $35,42,51-54$; see also under Gorges, Sir Ferdinando, and Gorges, Ferdinando

Manorial rents, New York, 283 (note 2)

Maryland, quit-rents in, 174-218, 434, 441 ; periods, 174 ; rate, $174-176$, 180 , 188-189, 197-198, 198-199, 217 ; method of collection, 176 $177,188,189-190,200-201,201$ 204, 210-213, 217, 446-447; medium of payment, $175,178-179$, 
$180,185-186,189,191,192,193$, 194 ; measures for enforcement, 177-178, 180, 204-205, 213-214; commutation by tobacco duty, 179-187; extortions by proprietary agents, 180-181, 205-207; lease of quit-rents, 181, 182183 ; attempt to renew commutation, 190-197; gross value, 192, 215-216; revenue, 195, 215-216; charges on land in comparison with Pennsylvania and Virginia, 198-199; taxation of quit-rents, 207-210; opposition, 209-210, 214-215, 217-218; supervision by Board of Revenue, 211-214; abolition, 214-215 ; summary, 216-218

Mason, Captain John, proprietary, New Hampshire, 42, 51-52, 5460

Mason, Robert, proprietary claims in New Hampshire, 54-56; opposition aroused by claims, 56-59; claims abandoned, 59-61

Massachusetts, quit-rents in, 2223 (note), 38-39, 42-50, 442; abolished, 38-39; proposed by Edward Randolph, 42-43; attempt to establish quit-rents under Sir Edmund Andros, 4347,445 ; opposition' aroused, 45$46,47-49,442$; overthrow of Andros, 49; free tenure of land established, 49-50; defeat of scheme to found propriety on the Kennebec, 50

Mather, Increase, protest of, against quit-rents in Massachusetts, 4546

Mecklenburg Committee, resolution against quit-rents, 315

Mississippi Company, quit-rent proposed by, 373
Monmouth Patents, a source of discord, 85-86

Montagu, Lord (Charles Greville), governor, South Carolina, report of, on quit-rent system in South Carolina, 344, 433

Montgomery, Sir Robert, grant of Azalia, 20

New England, quit-rents in, 14, 15, 22-23 (note), 35-50, 51-61, 440; importance of free tenure in, 38 $39,42,50,84,85,107,285,439$ $440,456,458$; see also under separate colonies

New England Council, quit-rents under, 32, 35-37

New Hampshire, quit-rents in, 35, 42, 51-52, 54-61; proposed by Captain John Mason, 51-52; revived by Robert Mason, 54-59; opposition aroused by revival of Mason claims, 56-59; Mason claims sold and abandoned, 5960 ; quit-rents on frontier lands, 60-61

New Hampshire grants, quit-rents on, 284

New Jersey, quit-rents in, under Berkeley and Carteret, 84-87; rate, 84-85; method of collection, 85 ; opposition, $85-87$; measures for enforeement, $86-87$; see also under East Jersey and West Jersey

New York, crown colony, quit-rents in, 254-285, 404, 407, 410, 416, $420,433,444$; unfavorable conditions for quit-rents, 254 ; rate, 254, 254-255, 257-258, 259-260; method of collection, 254, 261264, 271-272; land speculation, 254, 257-258, 258-261, 270, 275$276,416,450$; medium of payment, 255, 266 (note 4), 278 
(note 5) ; measures for enforcement, 259-260, 264-277, 407, 425 ; opposition, 262,266 ; revenue, 266, 277-278, 404, 416; gross value, 278 ; expenditures, 278-283, 410, 428, 444 ; struggles between governor and assembly over revenue, 278-280, 282-283, $285,416,444$; abolition, 283, 284 ; summary, 284-285

New York, propriety, quit-rents in, 110-113, 284; conditions of settlement, 110-111; Dutch patents, 110-111, 112-113; rate, 111-112; medium of payment, 111 ; measures for enforcement, 112

New York, state, quit-rents in, 283 284

Nicholson, Francis, governor, Virginia, 224-226, 229; proposed reforms of quit-rent system, 229 ; special officer of crown, 394-395

Nicolls, Richard, governor, New York, uncertain status of patents issued by, in New Jersey, $88,90,91,100-101$

North Carolina, crown colony, quitrents in, 286-317, 414-415, 422, $429-430,433,444,451,458$; rate, 287-288, 289-290, 294, 296, $433,451,458$; land system, 287, 294, 303-304; measures for enforcement, $287-288,290,292$ 293, 295-296, 296-298, 299-300, 301-304, 310-313, 429-430; medium of payment, 287-288, 289, $290,291,294,295,296,299$, 299-300, 302, 303, 308, 309 ; method of collection, 289, 292, 311-312, 430; revenue, 289, 291, 300, 313, 414-415; expenditures, $289,301,304,314$, 444; ques- tionable patents, 287, 291-292, 294, 296, 422 ; opposition, 293 294, 299, 308-309; mission of Henry McCulloh, 296-298, 317; creation of Granville Grant, 298299 ; controversy between Gov- ernor Dobbs and John Rutherfurd, 305-308, 422, 430; gross value, 314 (note 1), 414 ; abolition, 315-316 ; summary, 316317

North Carolina, propriety, quit-rents in, 113-118, 451; rate, 113-114, 451 ; medium of payment, 114 115; method of collection, 115; measures for enforcement, 115 117, 117-118; questionable patents, 116-117; revenue, 118; expenditures, 118 ; sale to crown, 118

Northern Neck, propriety of, 61, 66 76, 224, 234, 249, 411, 425, 441; opposition to, 66-67; Culpeper claim confirmed, 67; rate, 68; method of collection, 68 ; proposed exchange for an estate in England, 68, 411; boundary controversy, 68-71; suit brought by Joist Hite, 71.74; measures for enforcing quit-rents, 74-75; medium of paying quit-rents, 75 ; abolished, 75-76; summary, 76

Norwood, Henry, treasurer, Virginia, $225,400-401,424-425$

Nova Scotia, quit-rents in, 368-372, $387,431,433$; rate, $368-369$; medium of payment, 368-369; French tenures, 369-370 ; exemptions, 369-370, 431; revenue, $370-371$; report of Governor Legge, 371-372, 431; gross value, 371 
Officers, local, salaries to, from quitrents, 44-45, 56, 118, 122, 180, $235,249,280-282,289,301,314$, $330-331,346-348,410,417-418$, 428, 429, 432, 444

Ohio Company, grant to, 245

Ohio Valley, quit-rents in, $372-373$

Paper money, in payment of. quitrents, 114, 142, 144-146, 156, $192,193,247-248,288,299,308$ 309,453

Patents to land, questionable, 116, 121, 287, 291-292, 294, 296, 318319 , 321, 322-323, 325, 327, 332, $340,344,422$

Peirce, John, proprietary grant to Plymouth, 37

Pemaquid, quit-rents in, 54 (note 2), 112

Penn family, proprietary policy, 133$134,136,171-173,174,217,455$

Penn, Thomas, proprietary, Pennsylvania and Lower Counties, 150, 152,434

Penn, William, proprietary, Pennsylvania and Lower Counties, $136,138,139,160,161,162,163$, 164,403

Penns, boundary dispute of, with Lord Baltimore, 163-164, 166167

Pennsylvania, quit-rents in, 133-161, $171-173,434,451,453$; rate, 134-135, 451; method of collection, 136-138, 139-141, 147$149,156-160,172$; medium of payment, 136, 142-143, 144-146, 156 ; opposition, 138, 141-142, 149 ; measures for enforcement, 138-139, 143-144; controversies over paper money, 142, 144-146, 156,453 ; taxation of quit-rents, 149-155; abolition, 160; gross value, 161 ; revenue, 161 ; summary, 171-173

Physick, Edmund, receiver-general, Peunsylvania, 148, 159

Plymouth, quit-rents in, 22 (note), 36, 37-38

Prat, Chief Justice, New York, salary to from quit-rents, 282 283, 331

Prince Edward Island, see under St. John

Privy Council, quit-rent policy, 59, $60,66,155,222,226,244,245$, $246,247,256,273,295,300,302$, $307,310,316,324,327,333$, $353,381,407,424,426,449,450$ Proclamation money, definition of, 287 (note 1)

Proprietaries, agitation against, 56 $59,62-67,78-79,100-101,103$ $107,123-125,138,141-142,149$. 155, 166-171, 209-210, 224, 442

Proprietary dues to crown, 17, 9495, 161-162, 164-165, 402-404

Proprietary grants, discouraged, 65 $66,260-261,411,442-443$

Proprieties, advantages and disadvantages of quit-rent system in, $82-83,109,131-132, \quad 219-221$, 386-387, 441-442

Proprieties, in crown colonies, 51-83; under Mason and Gorges, 51-52; Gorges claims in Maine, 52-54; Mason claims in New Hampshire, 54-61; unpopularity of proprietary grants, 61-62; Northern Neck in Virginia, 6176; Granville Grant in North Carolina, 76-82; summary, 82 83

Quebec, merchants of, protest against French tenure, 377-378

Quebec, quit-rents in, 374-376, 387, 433 ; see also under Canada 
Quit-rents, abolition, 75-76, 81-82, $87-88,107,160,171,214-215$, 252, 283-284, 315-316, 348, 353$354,378-380,459$

Quit-rents, an aim in proprietary grants, $18-20$

Quit-rents, British control of, 388438 ; system of control, 388397 ; office of auditor-general, 389-391; office of deputy auditor, 391 ; office of receiver-general, 392-393; defects in system of control, 393-394; actual working of system of control, 394; special officers to supervise quit-rents, 394-397; William Blathwayt as auditor-general, 397-412, see also under Blathwayt, William; Horatio Walpole as auditor-general, 412 420, see also under Walpole, Horatio; Reverend Robert Cholmondeley as auditor-general, 420-423, see also under Cholmondeley, Reverend Robert; direct supervision by the Treasury, 424-431, see also under Treasury, British; direct supervision by the Board of Trade, 431-435, see also under Board of Trade; reforms proposed by John Gordon, 435-436; reforms proposed by Williamos, 436-437; reforms instituted in the granting of lands, 437-438

Quit-rents, colonies without, 35-50; under New England Council, 3537; Plymouth, 37-38; Connecticut, 39-42; Rhode Island, 40; Massachusetts, 42-50

Quit-rents, commutation of, in Maryland, 179-187, 190-197; partial commutation, 179-182 ; full commutation, 183-184; public senti- ment regarding commutation, 184-185; opinion of Governor Benedict Calvert on commutation, 185-186; commutation abolished, 186-187; attempts to revive commutation, 190-197

Quit-rents, definition of, 15-16, 17 $18,25,30$

Quit-rents, exemptions from, 92, 110 111,119 (note 3), 114 (note 3 ), 136 (note 1), 221 (note 3 ), 256, $343-344,369,370,373,431$

Quit-rents, gross value, 81, 97, 103, 161,170 (note 2), 192, 215-216, 223, 278, 314 (note 1), 330 (note 2), 345-346, 371, 414, 444

Quit-rents, importance as a royal revenue, 43, 44, 233-234, 252, 253, 278-283, 285, 331, 405, 408, 410 (note 1), 416, 432-433, 443445

Quit-rents, in American colonies, 20 21, 31-33

Quit-rents, in England and Ireland, 20-21

Quit-rents, intercolonial influence, 50, 141-142, 198-199, 218, 285, $317,318,440,456,458$

Quit-rents, lease of, Maryland, 181, 182-183

Quit-rents, legal status, 28-30, 160, 210

Quit-rents, legislative control of, 114115 , 120-121, 122-123, 222-223, 224-225, 233-234, 237-241, 286, $362-363,365,367,368,426-427$

Quit-rents, measures for enforcement, 28-30, 74-75, 86-87, 89-90, 98$101,112,115-118,120-121,126-$ $128,129,138-139,143-144,177-$ 178, 180, 204-205, 213-214, 222, 228-229, 232-233, 241-244, 259$260,264-277,287-288,290,292$ 293, 295-296, 296-298, 299-300, 
301-304, 310-313，319-320，320325, 326-328, 338-340, 341-342, 351-353, 359, 361, 363-365, 365366, 366-367, 381, 424-425, 429$430,431,435$, 436, 449-450, 453454

Quit-rents, medium of payment, 17$18,75,78,111,114-115,119-$ $120,127,128,136,142-143,144-$ $146,156,162,175,178-179,180$, 185-186, 189, 191, 192, 193, 194, 223, 224-225, 245-248, 255, 266 (note 4), 278 (note 5), 287-288, $289,290,292-293,294,295,296$, 299-300, 302, 303, 308-309, 319, $321,327,329,368,369,451-453$

Quit-rents, method of collection, 68, $78,85,87,115,121-122,129$ 130, 136-138, 139-141, 147-149, $156-160,163,172,176-177,188$, 189-190, 200-201, 201-204, 210 213, 217, 222-223, 225-227, 230233, 254, 261-264, 271-272, 289, 292, 311-312, 320, 329, 342-343, 344-345, 351, 360, 361, 365, 367, 373-374, 381-382, 425-426, 430, $436,437,446-449$

Quit-rents, opposition to, 39-42, 45$50,57-59,85-87,88,92-93,103$ $106,138,141-142,149,162-163$, 169-171, 209-210, 214-215, 217 $218,262,266,293-294,299,308$ $309,317,328,329-330,348,353$, $383-386,455-457$

Quit-rents, origin of, 15-17, 25-28

Quit-rents, proprietary, expenditures from, 62, 118, 122-123, 286, 441

Quit-rents, proprietary, taxation of, 149-155, 207-210, 457-458

Quit-rents, rate in American colonies in comparison with that in England, 455 (note 1)

Quit-rents, rate of, 17, 18, 32, 36, 37, $44,47,52,55,60,68,78,84-85$,
$87,88,89,109-110,111-112,113$ $114,118-119,120,126-128,128-$ 129, 134-135, 162, 174-176, 180, 188-189, 197-198, 198-199, 217, 221, 254-255, 257-258, 259-260, 287-288, 289-290, 294, 296, 318319 , 332, 350-351, 357, 358, 359, $362,368-369,372,373,374,375$, $381,382,438,450-451,455-456$

Quit-rents, revenue from, 18, 91, 99 (note 5), 118, 122, 161, 195, 215-216, 223-224, 232, 234-235, $248,266,277-278,289,291,300$, $313,330,340,345-346,359,361$, $363,370-371,375,382,385,404$, $406,414-415,416,421,444$

Quit-rents, royal, British control of revenue from, 234, 241, 388, 443

Quit-rents, royal, expenditures from, 224, 233-234, 235-237, 238, 241, 248-252, 278-283, 289, 301, 304, 314, 330-331, 346-348, 362, 388, 408-410, 414, 417-419, 423, 425, 426-427, 428, 429, 443-444

Quit-rents, significance of, 439-460; general importance, 439; more firmly established in Pennsylvania and Southern colonies, 439-440; effect of proprietary grants upon quit-rents, 440-443; importance as a source of royal revenue, 443-445; influence upon land system, 445-446; organization of method of collection, 446449 ; proprietary method of collection in Maryland a success, 446-447; defects of method of collection in crown colonies, 447 . 449 ; measures for enforcement, 449-450, 453-454; tactless policy of British government, 449-450; hostile influence of land speculators, 450; determination of rate, $450-451$; medium of pay- 
ment, $452-453$; proprietary problems, 454-455; opposition, 455457; opposition not due to amount, 455-456; influence of free tenure in New England, 456; opposition in proprietaries, 456-457; opposition in crown colonies, 457; intercolonial influence, 458; as a cause of the American Revolution, 450-459; final failure of, $459-460$

Quit-rent system, general problems of, 33-34

Randolph, Edward, proposal for quit-rents in New Fngland, 42. 43

Receiver-general, office of, 141, 226, 292, 307-308, 392-393, 394, 399, 400, 402, 406, 416, 427, 448-449; powers, 392-393; duties, 392; compensation, 392, 416

Revenue struggle in New York, importance of quit-rents in, 278$280,283-285,416,444$

Rhett, Colonel, receiver-general, South Carolina, 121

Rhode Island, quit-rents in, 22 (note), 40

Roscow, James, receiver-general, Virginia, 232

Rutherfurd, John, receiver-general, North Carolina, 305, 306, 307, $308,313,316,422,430$; controversy with Governor Dobbs, 305-308, 422, 430

Santen, Lucas, receiver-general, New York, 425

Saxby, George, receiver-general, South Carolina, 341, 342, 345

Saybrook, propriety proposed at, 3940

Sharpe, Horatio, governor, Maryland, 188, 198, 199, 200, 201,
202, 203, 204, 207, 434; tactful policy with regard to quit-rents, 198-201

Smith, William, objections to quitrent bill in New York, 274-275

Shelburne, Earl of, scheme for settlement of Ohio Valley, 372-373; circular letter to governors, and answers, 432-434

Sonmans, Peter, receiver-general, East Jersey, 96, 97

South Carolina, erown colony, quitrents in, 318-349, 414, 417-419, 429 , 430, 451; rate, 318-319, 332,451 ; questionable patents, $318-319$, 321, 322-323, 325, 327, $332,340,344,450$; medium of payment, 319, 321, 327, 329; measures for enforcement, 319 . 320 , 320-325, 326-328, 338-340, $341-342$; method of collection, $320,329,342-343,344-345,430$; local hostility to St. John and MeCulloh, 325-326, 333-335, 335336 , 336-337, 338; opposition, $328,329-330,348$; revenue, 330 , $340,345-346,414$; expenditures, 330-331, 346-348, 414, 417-419, 429 ; gross value, 330 (note 2), 345-346, 414; mission of Henry MeCulloh, 331-341, 349; abolition, 348 ; summary, $348-349$

South Carolina, propriety, quit-rents in, 118-126; rate, 118-119; medium of payment, 119-120; measures for enforcement, 120 121; legislative control, 120 121 ; method of collection, 121 122 ; revenue, 122 ; expenditures, 122-123; arrears, a source of anti-proprietary agitation, 123125; sale to crown, 125

Spanish tenure, 355

Spotswood, Alexander, governor, 
Virginia, 224, 230, 231, 232, 233, $240,248,400,426,428$; reforms instituted in quit-rent system, 230-233

St. Christopher, quit-rents in, 368

St. John, James, inspector and controller of quit-rents, South Carolina, 320, 323, 325, 326, 334, 342, 347, 395-397; powers, 395 ; duties, 395 ; compensation, 395 (note 2); controversy with Governor Johnson of South Carolina, 325-327

St. John, quit-rents in, 373-374; rate, 373 ; method of collection, 373-374

St. Vincent, quit-rents in, 382, 383, $384,385,431$; see also under Ceded Islands

Steele, James, receiver-general, Pennsylvania, 140, 143, 147

Stilemon, Elias, protest against quit-rents in New Hampshire, 55-57

Surplus land, effect of quit-rents upon, 188, 204-205, 230 (note 1), 243-244, 302, 303-304, 332, 339,366

Sutherland, Earl of, petition for grant of Lower Counties, 165. 166

Swedish tenure, 162, 440

Tobacco, export duty on, as commutation for quit-rents in Maryland, 179-187, 19.2, 194, 195, 196

Tobacco, in payment of quit-rents, $65,75,178-179,180,181,182$, $223,224,225,245-246,300,302$, 303,452

Tobacco, value of, $178-179, \quad 225$ (note 4)

Tobago, quit-rents in, $382, \cdot 383,386$,
431; see also under Ceded Islands

Town lots, quit-rents on, 119 (note

3 ) $127,135,180,197,221$ (note

$3), 369,375,381$

Transylvania, claims of, 245 ; quitrents reserved in, ,317 (note 1 )

Treasury, British, quit-rent policy, $164,229,235,238,240,250$, $251,260,281,282,299,312$, 318 , 320, 323, 332, 343, 353 $360,361,374,382,385,386$, $389,390,392,395,399,400$, $401,404,405,407,412,413$, $415,416,418,421,424-431,432$, $437,447,448$; direct supervision of quit-rents, 424-431, 447 , 448 ; usually the final authority, 424 ; control during early years of Blathwayt's administration, 424-426; later control, 426-427; supervision over quit-rents of Virginia, 427-428; supervision over quit-rents of New York, 428-429; supervision over quitrents of the Carolinas, 429-430; supervision over quit-rents of other crown colonies, 430-431

Trinity Church, New York, quit-rent on grant to, 255

Tryon, William, governor, North Carolina, reforms proposed in method of collection, 311-312

Virginia, crown colony, quit-rents in, 219-253, 404, 411, 423, 425, 426$427,433,443-444$; rate, 221 ; periods, 221 ; method of collection, 222-223, 225-227, 230-233, $253,411,428$; measures for enforcement, 222 , $228-229$, 232 233, 241-244, 424-425 ; medium of payment, 223, 224-225, 245 248 ; legislative control of, 222 223, 224-225, 233-234, 237-241, 


\section{INDEX}

426-427, 457; gross value, 223 ; revenue, 223-224, 232, 234-235, 248, 404; proprietary grants, 224 ; reforms in quit-rent system by Governor Spotswood, 230233 ; expenditures, 233-234, 235237, 238, 241, 248-252, 410, 423, 425, 426-427, 443-444; abolition, 252 ; summary, 252-253

Virginia, propriety, quit-rents in, 62-66, 109-110, 224, 441, 442; propriety established, 62-63, 441 ; local opposition to propriety, 62-65, 224, 442; propriety abolished except in Northern Neck, 65.66; propriety under London Company, 109-110

Walpole Company, quit-rent proposed by, 373

Walpole, Horatio, auditor-general, $130,246,268,279,298,304$, $347,395,397,412-420$; administration as auditor-general, 412 420 ; effect of less supervision of quit-rents, 413 ; reports on quit-rent revenue, $413-416$; supervision of subordinates, 416 -
417; reports on expenditures, 417-419; summary, 419-420

Weare, Nathaniel, agent for $\mathrm{New}$ Hampshire, protest against quitrents, 58

West Indies, quit-rents in, 130, 132, 355,356 ; see also under separate islands

West Jersey, quit-rents in, 84, 8788, 108; influences against, 84; rate, 87 ; abandoned, $87-88,108$ Wheat, in payment for quit-rents, 134 (note 3 ) , 137, 162, 175, 255, 452

Whittaker, Benjamin, attorneygeneral and chief justice, South Carolina, 321, 322, 325, 326, 338,339 ; opposes schemes of land speculators, 321,325

William and Mary, College of, aid from quit-rents, 235-236, 408 409

Williamos, proposed reforms of, for quit-rent system, 436-437

Winthrop, Fitz-John, protest against Hamilton claims in Connecticut, 40-41

Wright, Chief Justice, South Carolina, salary to from quit-rents, 331,429 




\section{PLeAse do NOt Remove}

\section{CARDS OR SLIPS FROM THIS POCKET}

\section{UNIVERSITY OF TORONTO LIBRARY}




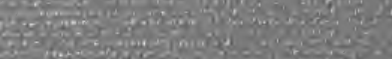

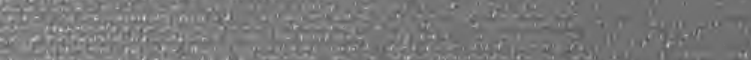

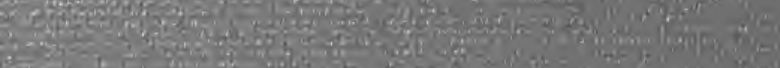

2.

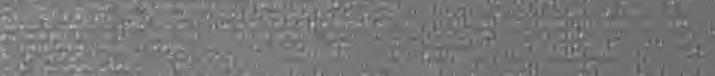

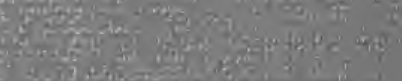

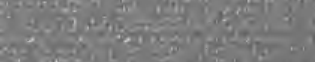

Q

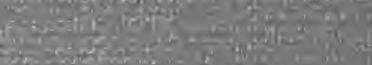

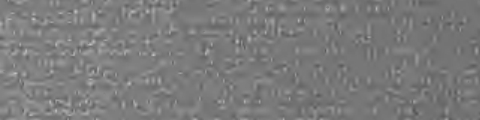

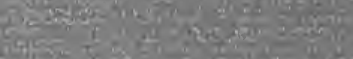

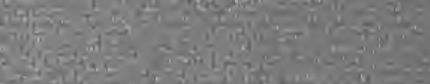

(x)

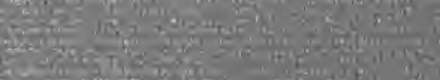

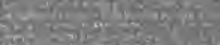

(5)

-

-

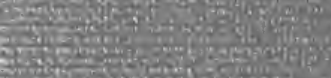

and

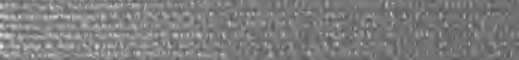

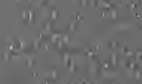

$3 y^{2}=$ a 